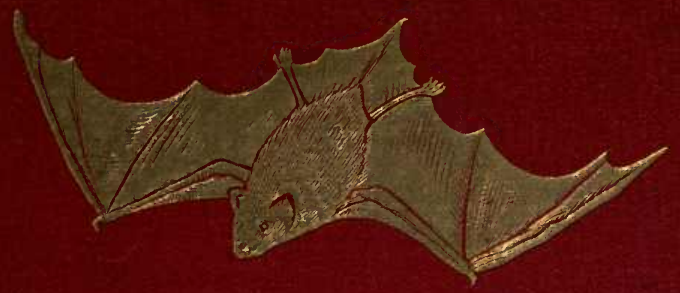

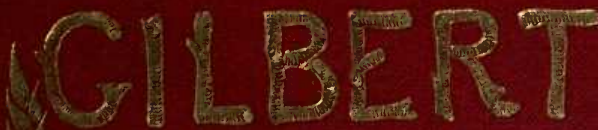

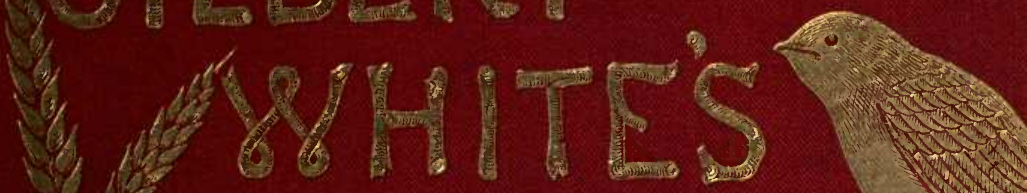

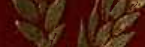

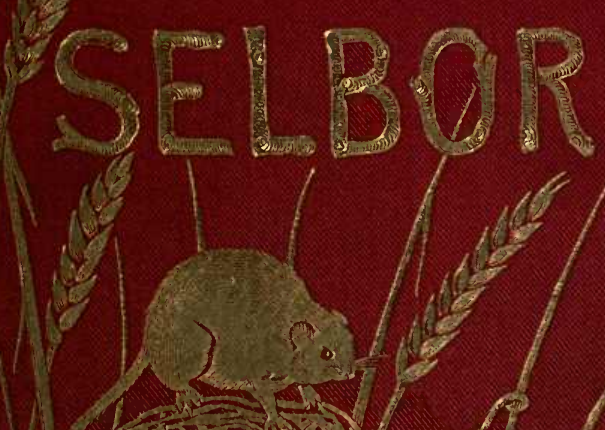

3. (1) 
PRIVATE LIBRARY

\section{OF}

HARLES A. KOFOID.

1.4.

Cost.a.r.n

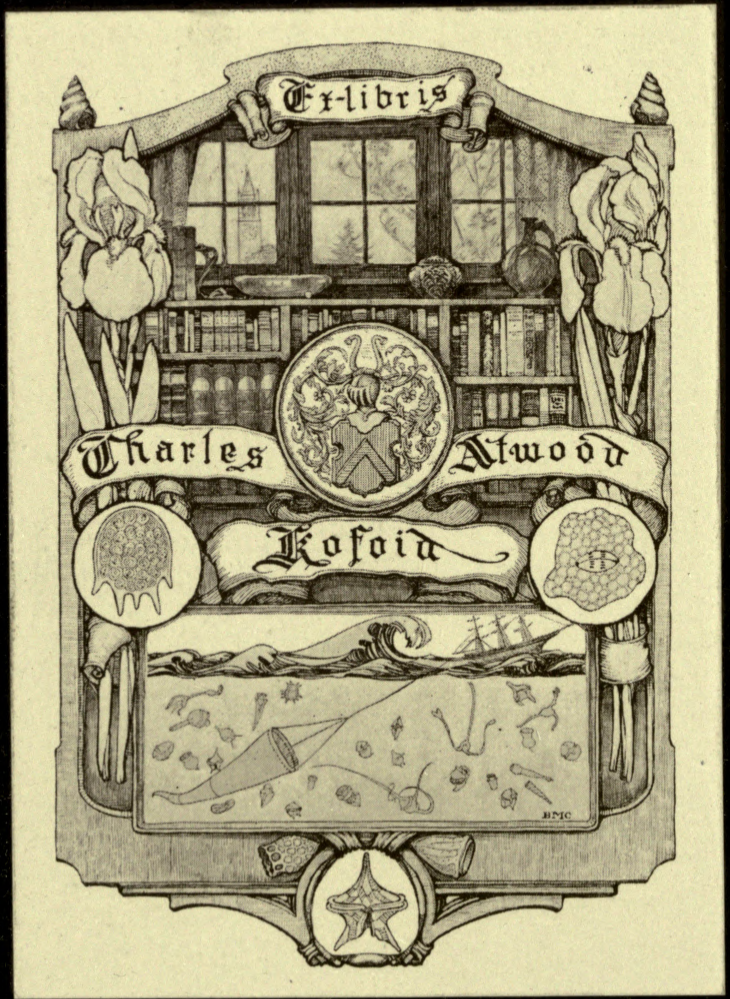




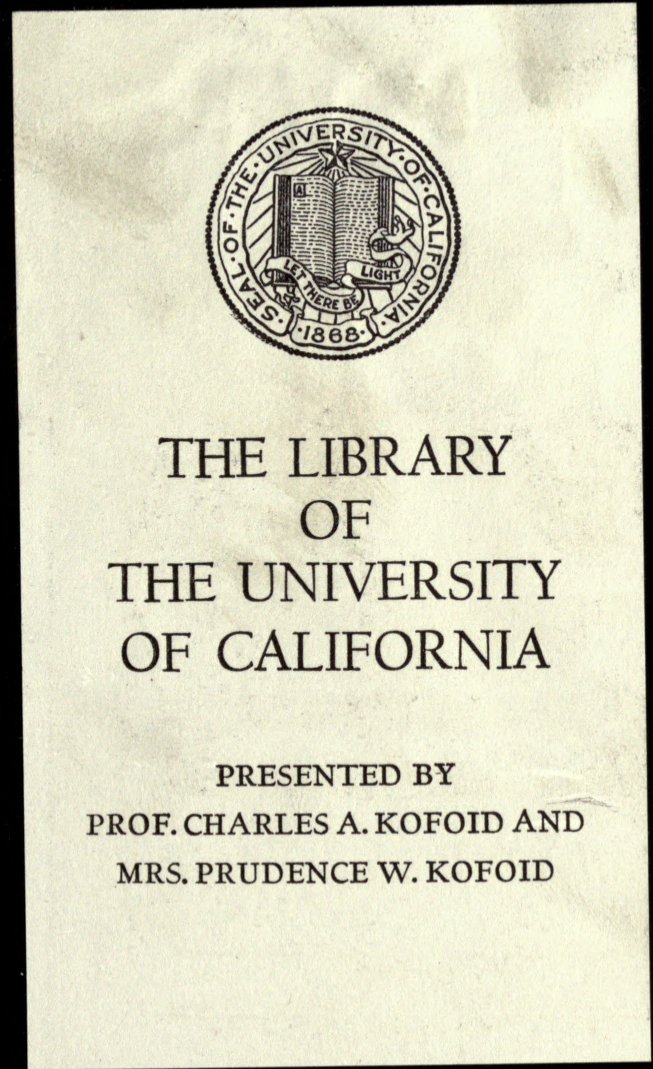





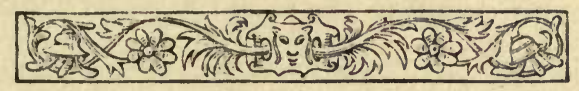

\section{THE NATURAL HISTORY OF SELBORNE.}

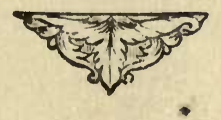




\title{
THE NATURAL HISTORY
}

\author{
AND
}

A N T I Q U I T I ES

$\mathrm{OF}$

\section{S E L B O R N E,}

IN THE COUNTY OF SOUTHAMPTON.

BY THE REV. GILBERT WHITE, M.A.

THE STANDARD EDITION BY E. T. BENNETT.

Thoroughly revised, with additional Notes.

BY JAMES EDMUND HARTING, F.L.S., F.Z.S.

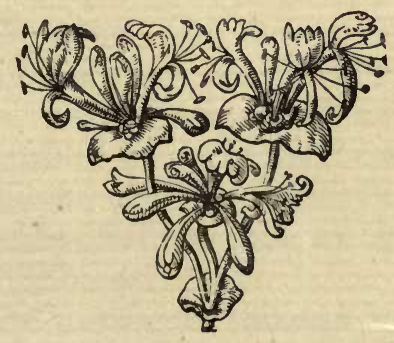

FIFTH EDITION.

WITH TEN LETTERS NOT INCLUDED IN ANY OTHER EDITION OF THE WORK.

ILLUSTRATED WITH ENGRAVINGS BY THOMAS BEWICK AND OTHERS.

Sgle

LONDON :

SWAN SONNENSCHEIN, LOWREY \& CO., PATERNOSTER SQUARE.

1887. 
Printed by Hazell, Watson, \& Viney, Ld., London and Aylesbury 


\section{S4W5 \\ 1887 Bul. dile}

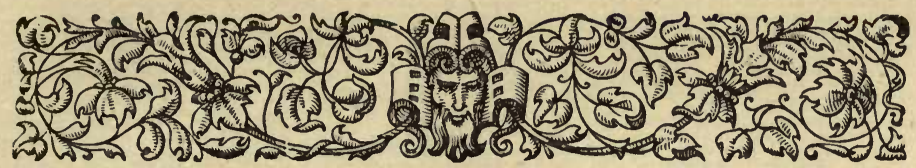

\section{PUBLISHERS' PREFACE TO THE FOURTH EDITION.}

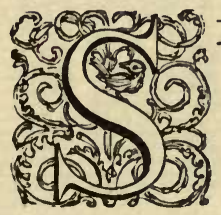

INCE the publication of our first edition of this work, in the autumn of 1875, there has appeared in the "Transactions of the Norfolk and Norwich Naturalists' Society" a series of ten recently discovered letters from Gilbert White to Robert Marsham, with the corresponding replies.

The extreme interest which attaches to these new letters, and the fact of their having been edited for the Society by Mr. Harting has enabled us to reprint them in an appendix to our present edition, and thus lay before the reader in one volume all that has hitherto come to light from the pen of the historian of Selborne.

Those who desire to possess Marsham's replies to these letters, must be referred to the volume of the Society's "Transactions" for 1875-76, in which the entire correspondence is published.

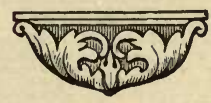





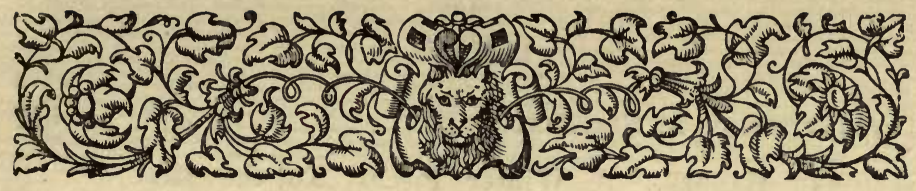

\section{CONTENTS.}

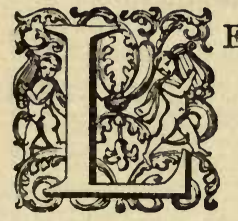

PAGE

etTers to Thomas Pennant, Esquire

Letters to the Honourable Daines

Barrington . . . .

136

OBSERVATIONS ON VARIOUS PARTS OF NATURE.

QuAdRUPEDS . . . . . . . . . 317

BIRDS • • • . . . . . 319

INSECTS AND VERMES • • . • • • • 341

VEgetables $\quad$ • • • • • • • 355

Meteorological Observations . • . . . 363

Summary of the Weather. $. \quad . \quad . \quad . \quad 367$

A NATURALIST'S CALENDAR.

Dr. Aikin's Advertisement • . • . . 379

Preface to the Naturalist's Calendar • • • 383

A Comparative View of White's and Markwick's

Calendars . $\quad . \quad . \quad . \quad . \quad . \quad$. 385

THE ANTIQUITIES OF SELBORNE.

LetTers . . . . . . . . . 405 
POEMS.

The Invitation to Selborne • . • . .

Selborne Hanger. A Winter Piece. To the Miss Batties . . . . . . . 520

ON the Rainbow . . . . . . . 521

A Hartest Scene . . . . . . . . . 522

On the Dark, Still, Dry, Warm Weather, occasionally happening in the Winter months . . . 523

Appendix. Ten Letters from the Rev. Gilbert White to Robert Marsham, F.R.S., 1790-1793 • . . 525

[NDEX • . . . . . , 56 ]

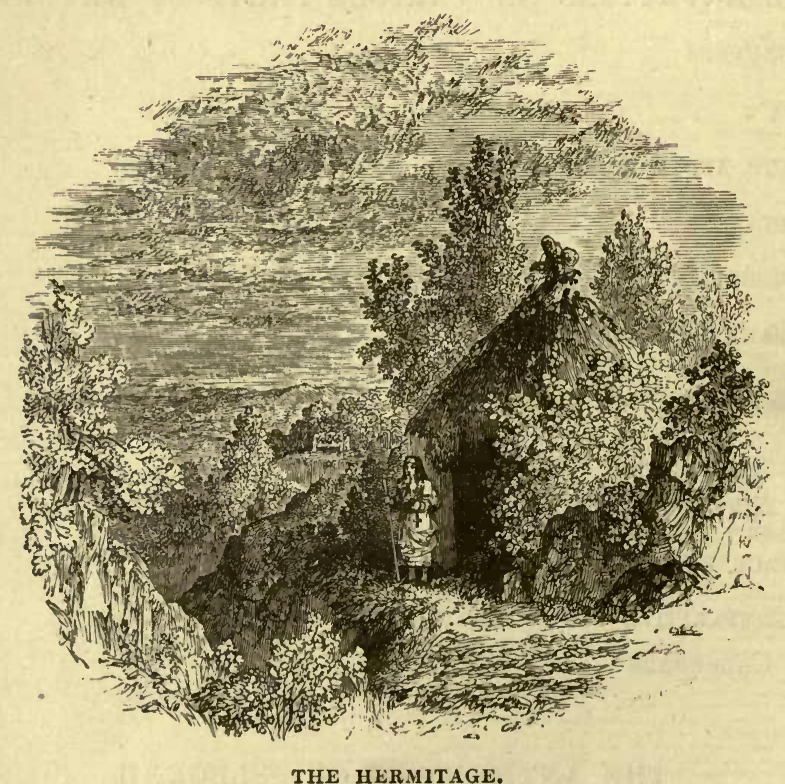

THE HERMITAGE. 


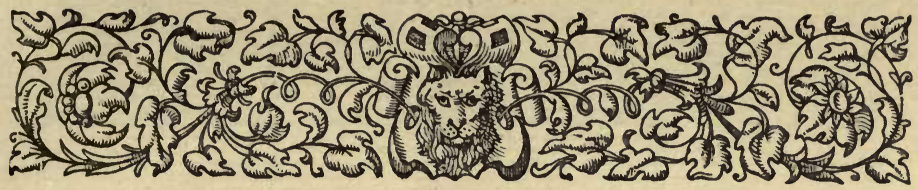

\section{LIST OF ILLUSTRATIONS.}

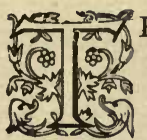

HE Hermitage . Back view of the residence, at Selborne, of the Rev. Gilbert White

Selborne, from Dorton . .

Raven . . . . .

Ostrea carinata . . . .

Hollow Lane and Bridge, near Norton .

Approach to the village.

Partridge . . . . .

Black grouse . . . . 20

Dog and hind . . . . 24

Fallow deer . . . . . 31

Hoopoe . • • • . 38

Crossbill . . . . . 39

Harvest mouse . . . . 42

Chaffinch . . . . . 46

Wheatear . . . . . 48

Weasel . . . . . 53

Quill-feathers of the wood wren . . . .

Quill-feathers of the willow wren. . . . .

Quill-feathers of the chiffchaff.

Jackdaw

Swallow

Melolontha fullo

Eagle owl . . . . .

Hedgehog . . . . .

Otter

Stone curlew . . . . 105

Peacock . . . . . 110

Fern-owl . . . . . 114
Page

Redbreast - $\quad$ - $\quad 123$
Nest of the whitethroat. $\quad$ - 125

Sparrow-hawk . . . . 131

Nest of the willow wren . 135

Bustard . . . . 143

Cuckoo. . . . . . 147

Skylark. . . . . . 165

Sand martins' colony at Oak-

hanger • . • . . 198

Sand martin's nest . . . 199

Missel-thrush . . . . 210

Hog. • . . . . 231

Hawkley Slip . . . . 263

Field cricket . . . . . 265

House cricket . . . . 269

Mole cricket and nest . . 271

Black-winged stilt . . 275

The shell of Gilbert White's tortoise . . . . . 277

Peregrine falcon . . . 292

Cat . . . . . 318

Magpie. . . . . . 322

Mallard. . . . . . 323

Hen partridge. . . . 325

Ranatra linearis . . . 346

Sphinx stellatarum . . 348

The grindstone oak, in the Holt Forest . . . 357

South view of Selborne church . . . . . 411

The vicarage house . . . 419

Temple, in the parish of Selborne. . . . 438

The Plestor . . . . 440

Way leading to Gracious

Street . . . . 



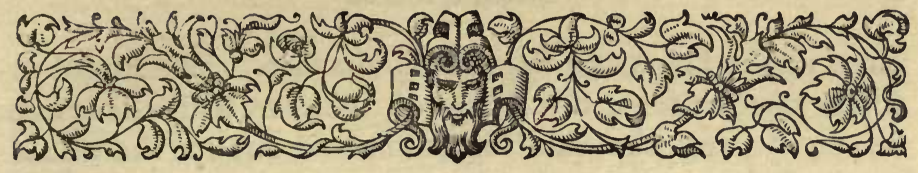

\section{PREFACE.}

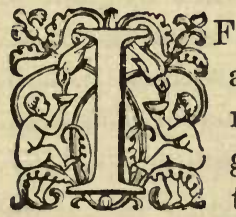

F any apology be deemed necessary for the appearance of a new edition of one of the most delightful books in the English language, the reader need only be reminded of the physical changes which have taken place since Gilbert White's day in the district of which he wrote, and of the vast additions which are daily being made to our knowledge in almost every branch of natural history.

Wolmer Forest, which eighty years ago was " without one standing tree in the whole extent" (p. 18), is now partly enclosed, and planted to the extent of several hundred acres with oak, larch, and Scotch fir. Bin's Pond, a " considerable lake," which at one time " afforded a safe and pleasing shelter to wild ducks, teals, and snipe" (p. 26), has long since been drained, and cattle now graze on its bed. The covert in which foxes and pheasants formerly abounded (p. 27) has almost entirely disappeared.

The village church at various times having undergone repairs, has sustained in consequence considerable alteration. Ancient tombs have disappeared (p. 413), and the interior of the edifice has been entirely remodelled.

The curious bridge at Oakhanger, "of considerable antiquity and peculiar shape" (p. 504), has given place to a more modern structure of greater convenience though of less interest, while of the ancient manor-house, called Temple, "with its massive thick walls and narrow windows" (p. 439), not a vestige now remains.

No less remarkable are the changes which have taken 
place in the fauna and flora of the district. The Red-deer, which once roamed the Forest of Wolmer, and which were driven "along the vale" in a herd of 500 for the amusement of Queen Anne (pp. 21-22), have long since become extinct. Black game, which " abounded much before shooting flying became so common" (p. 20), though thought by Gilbert White to have been exterminated, have yet maintained their footing, and are now to be found in not inconsiderable numbers.

Those noble birds the Bustards, which once frequented the downs (pp. 143, 156), and which when seen in flocks at a distance were thought to resemble Fallow-deer (p. 156, note 2), have entirely vanished as denizens of England. The Honey-buzzard has deserted Selborne Hanger (p. 130), and the Raven is extinct on Blackmoor (p. 6). The Chough, which formerly bred on Beachy Head and on all the cliffs of the Sussex coast (p. 117), has long since disappeared.

On the other hand, birds which were unknown to Gilbert White, or were possibly overlooked by him, have since been met with in the neighbourhood of Selborne; while others, which he regarded as rare, or at least as accidental visitants to his parish, have since been found to be not uncommon there. In the former class may be instanced the Cirl bunting (p. 47, note 3) and the Garden warbler (p. 59, note) ; in the latter, the Landrail (p. 328) and the Teal (p. 177). Woodcocks, which in his day were not supposed to breed in England (pp. 159, 161), now do so regularly in Hants and Sussex, to say nothing of other localities.

In regard to the botany of the district, allusion has already been made to the changes which have taken place since White's day in the aspect of the forest-land. To this may be added that while some few plants of interest have been included in the "Flora Selborniensis" since Gilbert White described it, others, as the Toothwort, Lathroea squamaria, and the Marsh Cinquefoil, Comarum palustre, have never since been met with in the neighbourhood. Under these circumstances, and having regard to the time which has elapsed since any edition of White's "Selborne" 
nas appeared, it need be no matter of surprise that steps should once more be taken to add, if possible, to the popularity of a favourite author, and render his work still more instructive by bringing the information which he has imparted so agreeably to a par with the knowledge of the present day.

Of the many editions of this work which have been published since 1789, when the original quarto appeared, it will only be necessary to refer to one.

Messrs. Sonnenschein \& Co. having acquired the copyright of what has long been admitted to be the stand.rd edition of the work, namely, that which was prepared by the late Mr. Edward Turner Bennett, a well-known naturalist and former secretary to the Zoological Society, an opportunity presented itself for thoroughly revising his notes, which, written in 1837, had grown somewhat out of date; while the unexpected acquisition of a number of Bewick's engravings suggested the happy idea of illustrating the work of a favourite author with the designs of an equally renowned engraver. With this object in view, they invited my cooperation as editor, and I need hardly say that I acceded to their request with a considerable degree of pleasure.

The book is one in which I have long delighted; the neighbourhood of Selborne I know well; and Gilbert White's favourite theme, ornithology, I have made my special study for years. The task, therefore, has been undertaken con amore; how far I have succeeded I must leave to critics to determine. Suffice it to say that my aim has been two-fold; to present the reader with the original text as issued by White himself (to which end the proof sheets have been carefully collated with the first quarto), and to supply such editorial notes only as are necessary to bring the subject matter on a level with our information at the present day.

In this respect I have ventured to differ materially from my worthy predecessor, Mr. Bennett, whose notes, though generally of interest and value, are occasionally somewhat irrelevant and ofttimes unpardonably long.

Commencing with four pages of notes on the geological 
features of Selborne, notwithstanding a chapter on the subject by the author, we find the same number of pages devoted to a note on bats, and as many more to the subject of migration. The author had only to allude to the infraorbital cavities in the heads of deer to suggest to his editor a dissertation upon deer and antelopes, illustrated by an engraving of two heads of an Indian species to which, it is needless to say, no reference is made by the historian of Selborne. An equally long note, concluding with a description and figure (p. 178) of a bird which Gilbert White never saw and does not even mention, is quite as irrelevant and out of place.

But if four pages of notes be considered an unduly long commentary upon a single passage, what is to be thought of fifteen pages (pp. 119-213), the majority of them appended to only two lines of text, upon the treatment of birds in confinement, and suggested, apparently, by a casual remark of the author that a blackcap and sedge bird "would require more nice and curious management in a cage than he should be able to give them"? These cannot but be regarded as errors of judgment. However entertaining a note may be, it should never be introduced at the expense of the author. Long notes, moreover, weary the reader, distract his attention, and ofttimes cause him to lose sight of his author altogether. While I have retained, therefore, in the present edition, many valuable notes by Mr. Bennett and his coadjutors, the late Hon. and Rev. W. Herbert and Professor Rennie, it has seemed desirable, for the reasons stated, to eliminate much that they have supplied, and either to refrain altogether from dwelling on passages which in point of fact require no comment, or to substitute, where such is needed, a more modern interpretation than was offered to the reader five and thirty years ago.

The original foot-notes by Gilbert White have been scrupulously reproduced, and are in every case distinguished by the initials, "G. W."

As the reader may expect, not unnaturally, to have presented to him some brief memoir of the author, it may be 
well to reproduce here the "few Biographical Records" which have been handed down to us by his nephew John; at the same time it may be desirable to add some little account of the eminent naturalists as well those to whom his letters were addressed, as those who have furnished a worthy supplement to his work in the "Observations" and "Calendar."

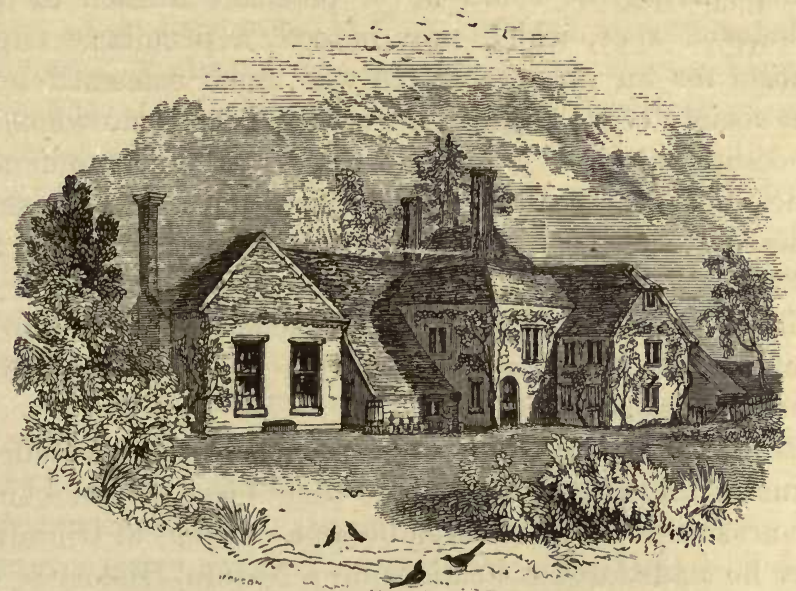

BACK VIEW OF THE RESIDENCE, AT SELBORNE, OF THE REV. GILBERT WHITE.

"Gilbert White was the eldest son of John White, of Selborne, Esq., and of Anne the daughter of Thomas Holt, rector of Streatham in Surrey. He was born at Selborne on July 18, 1720 ; and received his school-education at Basingstoke, under the Rev. Thomas Warton, vicar of that place, and father of those two distinguished literary characters, Dr. Joseph Warton, master of Winchester School; and Mr. Thomas Warton, poetry-professor at Oxford. He was admitted at Oriel College, Oxford, in December, 1739, and took his degree of bachelor of arts in June, 1743. In March, 1744, he was elected fellow of his college. He became master of arts in October, 1746, and was admitted one of the senior proctors of the University in April, 1752. Being of an unambitious temper, and 
strongly attached to the charms of rural scenery, he early fixed his residence in his native village, where he spent the greater part of his life in literary occupations, and especially in the study of nature. This he followed with patient assiduity, and a mind ever open to the lessons of piety and benevolence which such a study is so well calculated to afford. Though several occasions offered of settling upon a college living, he could never persuade himself to quit the beloved spot, which was, indeed, a peculiarly happy situation for an observer. He was much esteemed by a select society of intelligent and worthy friends, to whom he paid occasional visits. Thus his days passed, tranquil and serene, with scarcely any other vicissitudes than those of the seasons, till they closed at a mature age on June 26, 1793."

Gilbert White lived and died a bachelor, and it is to be regretted that no portrait remains to preserve a record of his personal appearance.

His brother John, to whom frequent reference is made in the succeeding pages, was at one time Vicar of Blackburn, in Lancashire. He afterwards became resident at Gibraltar, where he made large collections for a Natural History of the place, from the unpublished manuscript of which an extract is given at page 282. He is honourably mentioned by Pennant in his "Literary Life," as having rendered him material assistance in connection with the birds and fishes of Gibraltar.

Another brother, Thomas (to whose observations, made at his house at South Lambeth, our author occasionally refers), was a wholesale ironmonger in London; but quitting business with an ample fortune; devoted much of his time to literary pursuits, especially on subjects connected with meteorology and natural history. He was a Fellow of the Royal Society, and author of numerous essays which appeared in the "Gentleman's Magazine" between the years 1780 and 1790, under the signature of T. H. W. Among these a series of articles on the trees of Great Britain are particularly deserving of notice, for the extensive information, good taste, and variety of reading which they display. 
A third brother, Benjamin, the publisher of the first edition of the present work, was during much of the latter half of the past century the principal publisher of English books on Natural History. On the death of Gilbert he succeeded to the estate at Selborne, and transferred his business to his second son, John, who continued it until within a few years of the present time. From this establishment emanated, among many other important publications, most of the works of Ellis, Pennant, Montagu, Latham, Donovan, Andrews, the elder Sowerby, Curtis, Lightfoot, and other well-known naturalists. The house in which the business was carried on was originally distinguished, according to the fashion of the times, by the sign of the Horace's Head, a misreading of which gave rise to a whimsical mistake on the part of Scopoli, who, in dedicating the several plates of his "Deliciæ Floræ et Faunæ Insubricæ" to various patrons of natural history, inscribed one of them as published "Auspiciis DD. DD. Beniamini White, et Horatii Head, Bibliopol. Londinensium." It may be added, that in his "Vitæ suæ Vices," published at the end of the third and last part of the work just quoted, the same writer enumerates among the " eruditi viri cum quibus commercium litterarium colui," the name of "D. White, ex Gibraltariâ." Many passages in the present work prove how highly Scopoli was esteemed by our author, with whose family these circumstances, trivial as they are, serve in some degree to connect his name.

In Gilbert White's diaries mention is also made of a "brother Harry." He too was in the ehurch, and rector of Fyfield, near Andover, in the county of Hants, whence one of the letters to Daines Barrington is dated, and where, as appears by various references in the course of the volume, a series of meteorological observations were made for comparison with those registered at Selborne, South Lambeth, and Lyndon, in the county of Rutland.

In the commencement of his tenth letter to Pennant, the earliest in date of the entire series, Gilbert White laments the want of neighbours whose studies led them towards the pursuit of natural knowledge. But from his continued cor- 
respondence with the relatives just enumerated, from his occasional visits to most of them, and from the return of those visits to himself, (for his house, although that of a bachelor, was always open to his family and friends,) he must, in his latter years, have felt this want much less sensibly than at the period when it was noted as an apology for the slender progress which he then conceived himself to have made in the science. Few men have had the good fortune to possess so many near connexions engaged in pursuits so congenial with their own.

Thomas Pennant, the correspondent for many years of Gilbert White and the esteemed friend to whom the first series of his Letters on the Natural History of his native place were addressed, was among the most active of the scientific and literary characters of his day. At the commencement of his correspondence with White, he was busily engaged in the preparation of the octavo edition of his British Zoology: the first edition of that work had preceded it but a few years; and it was quickly followed by others ; and by other works on zoology, and on antiquities, and by tours, topographies, and other productions; all of which were deservedly popular. For more than forty years his pen was never idle. Industrious himself, he was the cause also of industry in others; and the enumeration which he gives of the services he did to the professors of the art of engraving by the multitude of plates executed by them for his several works, while it furnishes a list of the principal of his productions, will also afford some idea of the extent and variety of his labours.

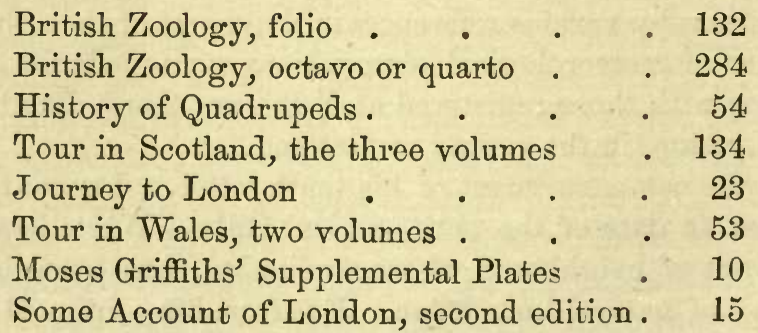


Indian Zoology $\quad \cdot \quad$ • $\quad$ • 17

Genera of Birds . . . . . 16

Arctic Zoology, two volumes . • . 26

Systematic Index to De Buffon . . 1

Lightfoot's Flora Scotica, two volumes . 37

Of many of these works several editions were required, and the superintendence of them added to the demands on him for continual devotion to literary pursuits. Many minor works were also published by him, including numerous papers in the "Philosophical Transactions." He maintained too an active correspondence both at home and abroad throughout the whole of his life; and numbered among his friends the most distinguished men in the several branches of knowledge which he cultivated. Linnæus was among his earliest correspondents; and with Pallas he was in frequent communication.

"I am often astonished," he says, in his Literary Lifo of himself, "at the multiplicity of my publications, especially when I reflect on the various duties it has fallen to my lot to discharge, as father of a family, landlord of a small but numerous tenantry, and a not inactive magistrate. I had a great share of health during the literary part of my days. Much of this was owing to the riding exercise of my extensive tours, to my manner of living, and to my temperance. I go to rest at ten; and rise winter and summer at seven, and shave regularly at the same hour, being a true misopogon. I avoid the meal of excess, a supper; and my soul rises with vigour to its employs, and, I trust, does not disappoint the end of its Creator."

Pennant died in 1798, in the seventy-third year of his age; having survived for more than seven years the literary death which he had anticipated for himself in 1791.

DAINES BARRINGton, honourable by birth and respected for his talents, was well suited, by the pursuits to which from choice he had devoted himself, to become the favourite 
correspondent of an observer like Gilbert White. The legal studies which he had originally cultivated as a professional duty, and in which he had been so successful as to have merited the office of recorder of Bristol, and to have become subsequently a Welsh judge, were eventually laid aside by him, although not until after they had fostered in him an attachment to antiquarian pursuits which he retained through life so strongly as to entitle him to be distinguished among his fellow-students in that department of knowledge as a vice-president of the Society of Antiquaries. To the "Transactions" of that body he was a frequent contributor. $\mathrm{He}$ also made numerous communications to the Royal Society, which were printed in the "Philosophical Transactions." Many of them were afterwards republished by himself in a separate form, under the title of "Miscellanies ;" a work alluded to with satisfaction by our historian in his Letter LI. In his essays Barrington availed himself freely of the information imparted to him by White, whose authority he repeatedly quotes, and whose merits as a "well read, ingenious, and observant" naturalist he is ever ready to acknowledge.

A large proportion of the essays in the "Miscellanies" are on subjects of natural history; and in many of them Daines Barrington was the advocate of views directly opposed to those of our author's other correspondent, Pennant. Thus, for instance, while Pennant felt a full conviction as to the migration of many birds, Barrington was most sceptical on the subject; and it is scarcely to be doubted that his letters to Gilbert White tended to keep alive and to increase the suspicions which the historian of Selborne always entertained that the little creatures whose presence delighted him during the summer, were still at hand, though hidden from him, in the winter. Another point on which his two correspondents disagreed was as to the authority which they attributed to Ray and to Linnæus; and White was evidently quite aware of the difference of their feelings on this subject, humouring them so far as to accommodate himself to the wishes of each when addressing him in particular. When sending to Pennant, in his Letter XVI., 
a list of the summer birds of passage, the Latin names which he uses are "Linnæi nomina;" in his correspondence with Barrington, Letter I. and elsewhere, he designates his birds, scientifically, by "Raii Nomina." Barrington argued so warmly against the deficiencies of the Linnæan characters, and advocated so strongly the excellences of our countryman, John Ray, that he is carried on by the discussion in which he was engaged to inquire, no doubt in his estimation triumphantly, "After this comparison can there be a doubt whether the English botanist should consult Ray or Linnæus for an English plant?"

William MaRKwick, who afterwards took the name of Eversfield, derived from his residence in the country opportunities of observing nature, which he embraced with a readiness worthy of a pupil of Gilbert White. His "Naturalist's Calendar" affords ample evidence of his perșeverance in attending to and noting occurrences in both the organized kingdoms of the creation; and the remarks subjoined by him, in numerous instances, to our author's "Observations on various Parts of Nature," show him to have been a sensible as well as a diligent observer. He communicated to the Linnean Society various essays on subjects of interest to zoologists, which were published in the earlier volumes of the "Transactions" of that body; the first of them, "On the Migration of certain Birds, and on other Matters relating to the Feathered Tribes," included a table of the annual appearance and disappearance of certain birds, which was continued to the end of 1794 in a subsequent communication, entitled "Aves Sussexienses; or, a Catalogue of Birds found in the County of Sussex, with Remarks." His last paper consisted of "Observations on the Clover Weevil," and was published in 1801. His death took place in 1813 .

DR. JoHn AIKIN is known both as the author of numerous and popular productions, and as one of an eminently literary and scientific family. He dedicated his "Calendar of Nature" to his sister, Mrs. Barbauld, referring to her 
children's books as having raised the character of such publications. "Had it been designed," he says, speaking of own work, "for a different class of readers, a larger compass might have been taken, and a more learned and elevated character of writing have been aimed at, yet it must still have remained essentially the same; and its merit must still have been that of compilation. The plan itself is a borrowed one; and you must certainly recollect its model in one of your own little books, where, in a very entertaining manner, you give a brief description of the several months, formed of some of the most striking circumstances attending each. What you have done for a child three or four years old, I have attempted for young people from ten to fourteen."

In editing from the MSS. of White, he carried yet higher his desires of extending acquaintance with natural history; the work compiled by him from that source being adapted to students of adult powers, and embodying many facts which were altogether new, at the time of their publicaticn, to naturalists generally. Founded on the observation of nature their interest is calculated to endure.

\section{James Edmund Harting.}

Lincoln's Inn Fields, Sept. 1874.

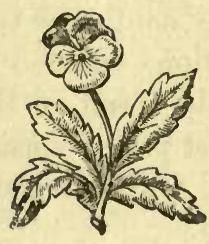




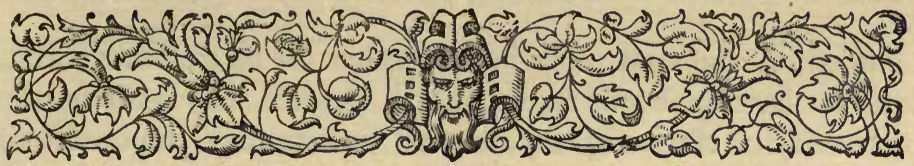

\section{ADVERTISEMENT TO THE FIRS'T EDITION.}

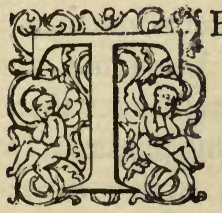

HE author of the following letters takes the liberty, with all proper deference, of laying before the public his idea of parochial history, which, he thinks, ought to consist of natural productions and occurrences as well as antiquitios. He is also of opinion that if stationary men would pay somo attention to the districts on which they reside, and would publish their thoughts respecting the objects that surround them, from such materials might be drawn the most complete county-histories, which are still wanting in several parts of this kingdom, and in particular in the county of Southampton.

And here he seizes the first opportunity, though a late one, of returning his most grateful acknowledgments to the reverend the president and the reverend and worthy the fellows of Magdalen College in the university of Oxford, for their liberal behaviour in permitting their archives to be searched by a member of their own society, so far as the evidences therein contained might respect the parish and priory of Selbornc. To that gentleman also, and his assistant, whose labours and attention could only be equalled by the very kind manner in which they were bestowed, many and great obligations are also due.

Of the authenticity of the documents above mentioned there can be no doubt, since they consist of the identical deeds and records that were removed to the college from the Priory at the time of its dissolution; and, being carefully 
copied on the spot, may be depended on as genuine; and, never having been made public before, may gratify the curiosity of the antiquary, as well as establish the credit of the history.

If the writer should at all appear to have induced any of his readers to pay a-more ready attention to the wonders of the creation, too frequently overlooked as common occurrences; or if he should by any means, through his researches, have lent an helping hand towards the enlargement of the boundaries of historical and topographical knowledge; or if he should have thrown some small light upon ancient customs and manners, and especially on those that were monastic; his purpose will be fully answered. But if he should not have been successful in any of these his intentions, yet there remains this consolation behind-that these, his pursuits, by keeping the body and mind employed, have, under Providence, contributed to much health and cheerfulness of spirits, aven to old age; and, what still adds to his happiness, have led him to the knowledge of a circle of gentlemen whose intelligent communications, as they have afforded him much pleasing information, so, could he flatter himself with a continuation of them, would they ever be deemed a matter of singular satisfaction and improvement.

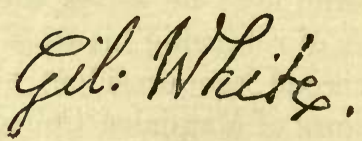

Selborne.

January 1st, 1783. 


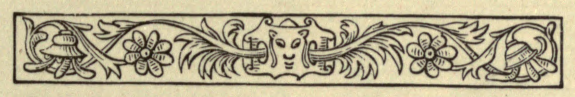

\section{THE NATURAL HISTORY OF SELBORNE.}

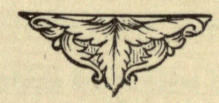




\section{THE NATURAL HISTORY OF SELBORNE.}

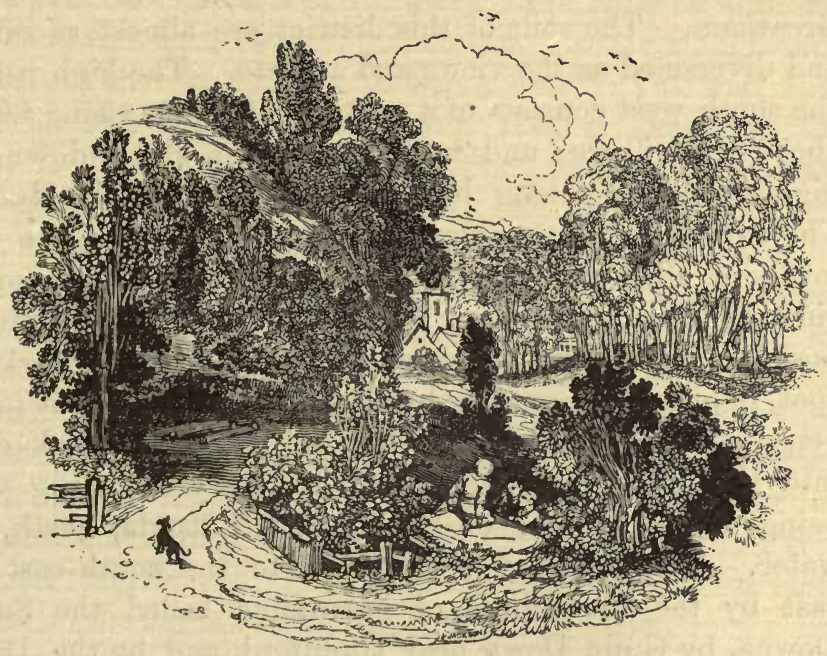

SELBORNE, FROM DORTON.

See, Selborne spreads her boldest beauties round, The varied valley, and the mountain ground,

Wildly majestic! What is all the pride

Of flats, with loads of ornament supplied ?-

Unpleasing, tasteless, impotent expense,

Compared with Nature's rude magnificence. WHIte.

\section{LETTER I.}

TO THOMAS PENNANT, ESQUIRE.

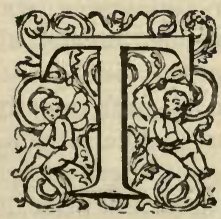

HE parish of Selborne lies in the extreme eastern corner of the county of Hampshire, bordering on the county of Sussex, and not far from the county of Surrey; is about fifty miles south-west of London, in latitude 51, and near midway between the towns of Alton and Peters- 
field. Being very large and extensive, it abuts on twelve parishos, two of which are in Sussex, viz. Trotton and Rogate. If you begin from the south and proceed westward, the adjacent parishes are Emshot, Newton Valence, Faringdon, Harteley Mauduit, ${ }^{1}$ Great Ward le ham, ${ }^{2}$ Kingsley, Hedleigh, Bramshot, Trotton, Rogate, Lysse, and Greatham. The soils of this district are almost as various and diversified as the views and aspects. The high part to the south-west consists of a vast hill of chalk, rising $300 \mathrm{ft}$. above the village; and is divided into a sheep down, the high wood, and a long hanging wood called The Hanger. (The covert of this eminence is altogether beech, the most lovely of all forest trees, whether we consider its smooth rind or bark, its glossy foliage, or graceful pendulous boughs. The down, or sheep-walk, is a pleasing park-like spot, of about one mile by half that space, jutting out on the verge of the bill country, where it begins to break down into the plains, and commanding a very engaging view, being an assemblage of hill, dale, woodlands, heath, and water. The prospect is bounded to the south-east and east by the vast range of mountains called the Sussex Downs, by Guild Down near Guildford, and by the Downs round Dorking and Ryegate in Surrey, to the north-east; which, altogether, with the country beyond Alton and Farnham, form a noble and extensive outline.

$1 \mathrm{Mr}$. Bennett, in a foot-note to this passage, which appeared in his cdition of the present work, published in 1837, states that in the parochial registers the orthography is Harteley Maudytt. Mauduit, used by Gilbert White, is, however, a more usual reading of Malduith, the name of the earliest Norman lord, which was used subsequently to the Conquest as an adjunct to the Saxon appellation, for the purpose of distinguishing this Harteley from the other Hartleys in the same county to the north of it.-ED.

2 The orthography in the text, though formal in appearance, was deliberately adopted by the author, who, in his first edition, inserted all deviations from it as errata; it is, consequently, preserved throughout. Wordlam, according to Mr. Bennett, is a pronunciation not unfrequently used in the neighbourhood: but Worldham is the more ordinary name. And in this case he suspects that the vulgar are right; Werildeham, the oldest name which he could find for it, belonging to an era prior to the erection in England of Norman castles.-ED. 
At the foot of this hill, one stage or step from the uplands, lies the village, which consists of one single straggling - Horthfir
street, three quarters of a mile in length, in a sheltered vale, and running parallel with The Hanger. The houses are divided from the hill by a vein of stiff clay (good wheat land), yet stand on a rock of white stone, little in appearance removed from chalk; but seeming so far from being calcareous, that it endures extreme heat. Yet that the freestone still preserves somewhat that is analogous to chalk, is plain from the beeches, which descend as low as those rocks extend, and no farther, and thrive as well on them, where the ground is steep, as on the chalks.

The cart-way of the village divides, in a remarkable manner, two very incongruous soils. To the south-west is a rank clay, that requires the labour of years to render it mellow; while the gardens to the north-east, and small enclosures behind, consist of a warm, forward, crumbling mould, called black malm, which seems highly saturated with vegetable and animal manure; and these may perhaps have been the original site of the town, while the woods and coverts might extend down to the opposite bank.

At each end of the village, which runs from south-east to north-west, arises a small rivulet: that at the north-west end frequently fails; but the other is a fine perennial spring, little influenced by drought or wet seasons, called Wellhead. ${ }^{1}$ This breaks out of some high grounds joining to Nore Hill, a noble chalk promontory, remarkable for sending forth two streams into two different seas. The one to the south becomes a branch of the Arun, running to Arundel, and so falling into the British Channel: the other to the north, the Selborne stream, makes one branch of the Wey; and, meeting the Black Down stream at Hedleigh, and the Alton and Farnham stream at Tilford Bridge, swells into a considerable river, navigable at Godalming; from whence it

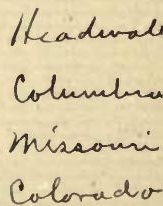

et. -

1 This spring produced, September 14, 1781, after a severe hot summer, and a preceding dry spring and winter, nine gallons of water in a minute, which is 540 in an hour, and 12,960, or 216 hogsheads, in twenty. four hours, or one natural day. At this time many of the wells failed, and all the ponds in the vales were dry.-G. W. 
passes to Guildford, and so into the Thames at Weybridge; and thus at the Nore into the German Ocean.

Our wells, at an average, run to about sixty-three feet, and when sunk to that depth seldom fail; but produce a fine limpid water soft to the taste, and much commended by

- I those who drink the pure element, but which does not lather well with soap. ${ }^{1}$

To the north-west, north, and east of the village, is a range of fair enclosures, consisting of what is called white malm, a sort of rotten or rubble stone, which, when turned up to the frost and rain, moulders to pieces, and becomes manure to itself. ${ }^{2}$

Still on to the north-east, and a step lower, is a kind of white land, neither chalk nor clay, neither fit for pasture nor for the plough, yet kindly for hops, which root deep into the freestone, and have their poles and wood for charcoal growing just at hand. This white soil produces the brightest hops.

As the parish still inclines down towards Wolmer Forest, at the juncture of the clays and sand, the soil becomes a wet him, Q. - sandy loam, remarkable for timber, and infamous for roads. The oaks of Temple and Blackmoor stand high in the estimation of purveyors, and have furnished much naval timber; while the trees on the freestone grow large, but are what workmen call shaky, and so brittle as often to fall to pieces in sawing.

Beyond the sandy loam the soil becomes a hungry lean sand, till it mingles with the forest, and will produce little without the assistance of lime and turnips. ?

${ }^{1}$ Although this water is said to be soft to the taste, it is nevertheless what would be usually called hard, the test of which, as pointed ont by Mr. Rennie, is its not producing a lather with soap, or with soap dissolved in spirit of wine, because it contains sulphate of lime, the sulphuric acid in which, uniting with the soda in the soap, sets free the tallow, composed of the margaric and oleic acids ; and these acids, uniting with the lime thus set free, form a soap that will not dissolve in water.-ED.

2 This soil produces good wheat and clover.-G.W. 


\section{LETTER II.}

TO THOMAS PENNANT, ESQUIRE.

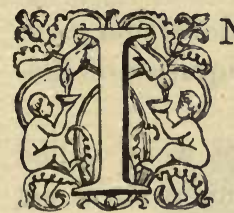

the court of Norton farm-house, a manor farm to the north-west of the village, on the white malms, stood within these twenty years a broad-leaved elm, or wych hazel, Ulmus folio latissimo scabro of Ray, ${ }^{1}$ which, though it had lost a considerable leading bough in the great storm in the year 1703, equal to a moderate tree, yet, when felled, contained eight loads of timber; and, being too bulky for a carriage, was sawn off at seven feet above the butt, where it measured near eight feet in the diameter. This elm I mention to show to what a bulk planted elms may attain, as this tree must certainly have been such from its situation.

In the centre of the village, and near the church, is a square piece of ground surrounded by houses, and vulgarly called The Plestor. ${ }^{2}$ In the midst of this spot stood, in old times, a vast oak, with a short squat body, and huge horizontal arms extending almost to the extremity of the area. This venerable tree, surrounded with stone steps, and seats above them, was the delight of old and young, and a place of much resort in summer evenings; where the former sat in grave debate, while the latter frolicked and danced before

1 Ulmus montanus of modern botanists, and the common elm of the north of England and Scotland. It is a valuable timber tree, and of very different growth from that which is generally termed the common elm, Ulmus campestris, seldom presenting so fine a bole as the latter, or attaining so large a size.-ED.

2 The Plestor, originally called Pleystow, or play-place, was granted, as it subsequently appears, to the prior and convent of Selborne, in 1271, by $\mathrm{Sir}$ Adam Gurdon and wife, as " all his right and claim to a certain place ( $p l a c e a)$ called 'la Pleystow' in the village aforesaid, 'in liberam, puram, et perpetuam elemosinam.'" It is still used as a place for recreation by the village children.-En.

.


them. Long might ithave stood, had not the amazing tempest in 1703 overturned it at once, to the infinite regret of the inhabitants, and the vicar, who bestowed several pounds in setting it in its place again: but all his care could not avail; the tree sprouted for a time, then withered and died. This oak I mention to show to what a bulk planted oaks also may arrive: and planted this tree must certainly have been, as will appear from what will be said further concerning this area when we enter on the antiquities of Selborne. ${ }^{1}$

On the Blackmoor estate there is a small wood called Losel's, of a few acres, that was lately furnished with a set of oaks of a peculiar growth and great value; they were tall and taper like firs, but, standing near together, had very small heads, only a little brush, without any large limbs." About twenty years ago the bridge at the Toy, near Hampton Court, being much decayed, some trees were wanted for the repairs that were fifty feet long without bough, and would measure twelve inches diameter at the little end. Twenty such trees did a purveyor find in this little wood, with this advantage, that many of them answered the description at sixty feet. These trees were sold for twenty pounds a piece.

In the centre of this grove there stood an oak, which, though shapely and tall on the whole, bulged out into a large excrescence about the middle of the stem. On this a pair of ravens had fixed their residence for such a series of

1 The Plestor, as it subsequently appears, measured about forty-four yards by thirty-six, and the oak, whose branches nearly overshadowed this large space, is conjectured by Gilbert White to have been, at the time when it was blown down, four hundred and thirty-two years old. -ED.

2 We have here a hint at the different effects of shelter and exposure on the growth of trees. Those in the interior of woods generally have their stems upright, their bark glossy, their tops small and thinly prorided with branches, and their roots, in the same way, spare and scanty, but in due proportion to the tops. Those, on the other hand, in exposed situations, have their stems stout and short, their bark thick and coarse, their tops spreading, and their roots in the same way throwing themselves out in every direction.-ED. 
years, that the oak was distinguished by the title of The Raven Tree. Many were the attempts of the neighbouring youths to get at this eyry: the difficulty whetted their inclinations, and each was ambitious of surmounting the arduous task. But, when they arrived at the swelling, it jutted out so in their way, and was so far beyond their grasp, that the most daring lads were awed, and acknowledged the undertaking to be too hazardous. So the ravens built on, nest upon nest, in perfect security, till the fatal

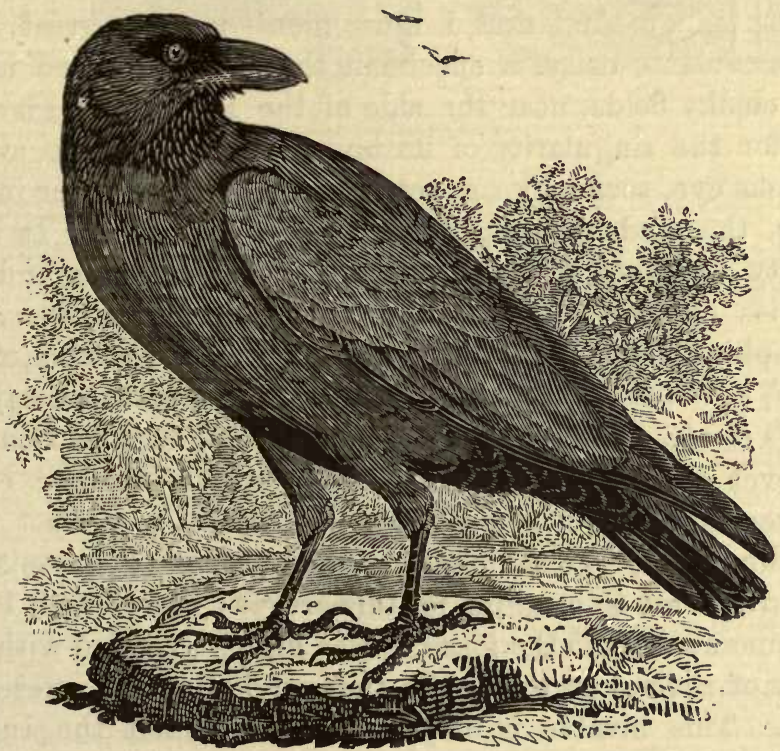

THE RAVEN.

day arrived in which the wood was to be levelled. It was in the month of February, when those birds usually sit. The saw was applied to the butt, the wedges were inserted into the opening, the woods echoed to the heavy blows of the beetle or mallet, the tree nodded to its fall; but still the dam sat on. At last, when it gave way, the bird was flung from her nest; and, though her parental affection deserved a better fate, was whipped down by the twigs, which brought her dead to the ground. 


\section{LETTER III.}

\section{TO THOMAS PENNANT, ESQUIRE.}

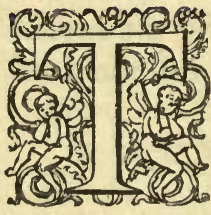

HE fossil shells of this district, and sorts of stone, such as have fallen within my observation, must not be passed over in silence. And first I must mention, as a great curiosity, a specimen that was ploughed up in the chalky fields, near the side of the Down, and giren to me for the singularity of its appearance, which, to an incurious eye, seems like a petrified fish of about four inches long, the cardo passing for a head and mouth. It is in reality a bivalve of the Linnæan genus of Mytilus and the species of Crista galli; called by Lister, Rastellum; by Rumphius, Ostreum plicatum minus ; by D'Argenville, Auris porci, s. Crista galli; and by those who make collections, cock's comb. Though I applied to several such in London, I never could meet with an entire specimen; nor could I ever find in books any engraving from a perfect one. In the superb museum at Leicester House, ${ }^{1}$ permission was given me to examine for this article; and though I was disappointed as to the fossil, I was highly gratified with the sight of several of the shells themselves in high preservation. This bivalve is only known to inhabit the Indian ocean, where it fixes itself to a zoophyte, known by the name Gorgonia. The curious foldings of the suture the

1 This was originally the property of Sir Ashton Lever, and long known as the Leverian Museum. Pennant characterized it as "the most astonishing collection of the subjects of natural history ever collected, in so short a space, by any individual." The specimens of natural history and of art, which it contained, were exhibited for many years, but were finally disposed of by auction, in 1806. Some idea may be formed of the extent of the collection at that time by the duration of the sale, which lasted for sixty-five days, and by the number of the lots, which amounted to 7879.-ED. 
one into the other, the alternate flutings or grooves, and the curved form of my specimen being much easier expressed

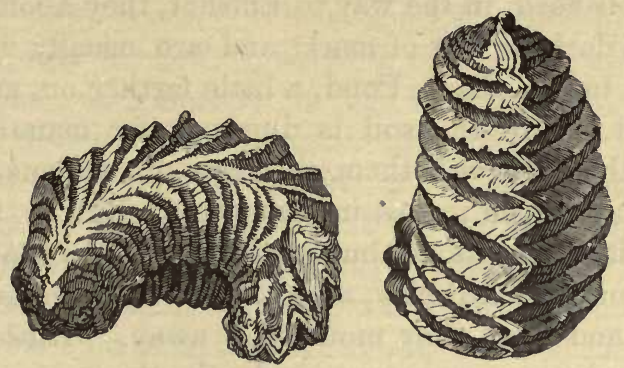

OSTREA CARINATA.

by the pencil than by words, I have caused it to be drawn and engraved. ${ }^{1}$

Cornua Ammonis are very common about this village. ${ }^{2}$

1 This is not the analogue of the cock's comb oyster, but belongs to a different species which has not any living analogue, so far as is known. The figures given above, which are copied from those of the original edition, represent a shell of the Ostraa carinata of Lamarck, so called on account of the strong ridge or keel along the middle of each of its valves. Though both are plaited oysters, the plaits or folds in each are disposed in a different manner: in the cock's comb oyster they are in the longitudinal direction of the shell, which, moreover, is rounded in its general outline; in the keeled oyster they pass transversely on each side from the ridge or keel.

The statement in the text, that White's specimens were obtained in chalky fields, renders it necessary, as Mr. Bennett has judiciously remarked, to caution the reader against regarding it as a chalk fossil. The fields below the chalk downs at Selborne, though white in the appearance of their soil-locally termed white malm-belong in truth to the formation known to geologists by the singularly inappropriate name of green sand. To this formation the keeled oyster is peculiar; and it appears even to be limited, as a fossil, to the upper green sand, the stratum on which the village of Selborne is built, and of which the immediately adjacent enclosures consist.-ED.

2 The Rev. J. Mitford has said the same thing of Keynsham, between Bath and Bristol, adding that "This has given rise to a fabulous legend, which says that St. Keyna, from whom the place takes its name, resided here in a solitary wood, full of venomous serpents, and her prayers converted them into stones, which still retain their shape."-See Espriella's Letters from England, vol. iii. p. 362.-Ev. 
As we were cutting an inclining path up The Hanger, the labourers found them frequently on that steep, just under the soil, in the chalk, and of a considerable size. In the lane above Well-head, in the way to Emshot, they abound in the bank in a darkish sort of marl; and are usually very small and soft: but in Clay's Pond, a little farther on, at the end of the pit, where the soil is dug out for manure, I have occasionally observed them of large dimensions, perhaps fourteen or sixteen inches in diameter. But as these did not consist of firm stone, but were formed of a kind of terra lapidosa, or hardened clay, as soon as they were exposed to the rains and frost they mouldered away. These seemed as if they were a very recent production. ${ }^{1}$

In the chalk-pit, at the north-west end of The Hanger, large Nautili are sometimes observed.

In the very thickest strata of our freestone, and at conund Va siderable depths, well-diggers often find large scallops, or Pectines, having both shells deeply striated, and ridged and furrowed alternately. They are highly impregnated with, if not wholly composed of, the stone of the quarry.

\section{LETTER IV.}

\section{TO THOMAS PENNANT, ESQUIRE.}

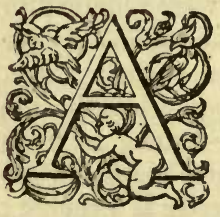

$\mathrm{S}$ in a former letter the freestone of this place has been only mentioned incidentally, I shall here become more particular.

This stone is in great request for hearthstones, and the beds of ovens; and in lining of lime-kilns it turns to good account: for the workmen use sandy loam instead of mortar ; the sand of which fluxes,

1 They were in all probability casts of the ammonites, and not the shells themselves.-Ev.

2 'There may probably be also in the chalk itself, that is burnt for lime, a proportion of sand; for few chalks are so pure as to have none. -G. W. 
and runs by the intense heat, and so cases over the whole face of the kiln with a strong vitrified coat like glass, that it is well preserved from injuries of weather, and endures thirty or forty years. When chiselled smooth, it makes elegant fronts for houses, equal in colour and grain to the Bath stone; and superior in one respect, that, when seasoned, it does not scale. Decent chimney-pieces are worked from it of much closer and finer grain than Portland; and rooms are floored with it; but it proves rather too soft for this purpose. It is a freestone, cutting in all directions; yet has something of a grain parallel with the horizon, and therefore should not be surbedded, but laid in the same position that it grows in the quarry. ${ }^{1}$ On the ground abroad this firestone will not succeed for pavements, because, probably, some degree of saltness prevailing within it, the rain tears the slabs to pieces." Though this stone is too hard to be acted on by vinegar, yet both the white part, and even the blue rag, ferment strongly in mineral acids. Though the white stone will not bear wet, yet in every quarry, at intervals, there are thin strata of blue rag, which resist rain and frost, and are excellent for pitching of stables, paths and courts; and for building of dry walls against banks, a valuable species of fencing, much in use in this village ; and for mending of roads. This rag is rugged and stubborn, and will not hew to a smooth face; but is very durable: yet, as these strata are shallow and lie deep, large quantities cannot be procured but at considerable expense. Among the blue rags turn up some blocks tinged with a stain of yellow, or rust colour, which seem to be nearly as lasting as the blue; and every now and then balls of a friable substance, like rust of iron, called rust balls.

In Wolmer Forest I see but one sort of stone, called by

1 "To surbed stone is to set it edgewise, contrary to the posture it had in the quarry," says Dr. Plot, Oxfordsh. p. 77. But surbedding does not succeed in our dry walls; neither do we use it so in ovens, though he says it is best for Teynton stone.-G. W.

2 Firestone is full of salts, and has no sulphur: must be closegrained, and have no interstices. Nothing supports fire like salts ; saltstone perishes exposed to wet and frost.-Plot's Staff. p. 152. G. W. 
the workmen sand, or forest, stone. This is generally, of the colour of rusty iron, and might probably be worked as iron ore; is very hard and heavy, and of a firm compact texture, and composed of a small roundish crystalline grit, cemented together by a brown, terrene, ferruginous matter; will not cut without difficulty, nor easily strike fire with steel. Being often found in broad flat pieces, it makes good pavement for paths about houses, never becoming slippery in frost or rain; is excellent for dry walls; and is sometimes used in buildings. In many parts of that waste it lies scattered on the surface of the ground; but is dug on Weaver's Down, a vast hill on the eastern verge of that forest, where the pits are shallow, and the stratum thin. This stone is imperishable.

From a notion of rendering their work the more elegant, and giving it a finish, masons chip this stone into small fragments about the size of the head of a large nail ; and then stick the pieces into the wet mortar along the joints of their freestone walls : this embellishment carries an odd appearance, and has occasioned strangers sometimes to ask us pleasantly, "whether we fastened our walls together with tenpenny nails?"

\section{LETTER V.}

TO THOMAS PENNANT, ESQUIRE.

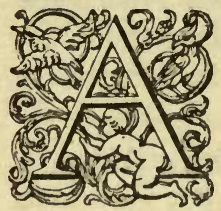

MONG the singularities of this place, the two rocky hollow lanes, the one to Alton, and the other to the forest, deserve our attention. These roads, running through the malm lands, are, by the traffic of ages and the fretting of water, worn down through the first stratum of our freestone, and partly through the second; so that they look more like water-courses than roads; and are bedded with naked rag for furlongs together. In many 
places they are reduced sixteen or eighteen feet beneath the level of the fields; and after floods, and in frosts, exhibit very grotesque and wild appearances, from the tangled roots that are twisted among the strata, and from the torrents rashing down their broken sides; and especially when those cascades are frozen into icicles, hanging in all the fanciful shapes of frost-work. These rugged gloomy scenes affright the ladies when they peep down into them

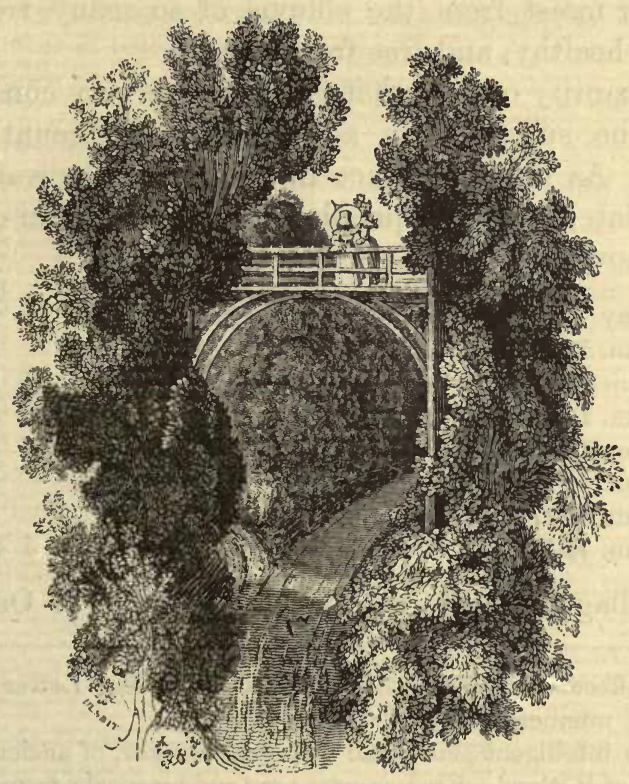

HOLLOW LANE AND BRIDGE, NEAR NORTON.

from the paths above, and make timid horsemen shudder while they ride along them; but delight the naturalist with their various botany, and particularly with the curious Filices with which they abound.

The manor of Selborne, was it strictly looked after, with all its kindly aspects, and all its sloping coverts, would swarm with game; even now, hares, partridges, and pheasants abound; and in old days woodcocks were as plentiful. There are few quails, because they more affect 
open fields than enclosures: after harvest some few landrails are seen.

The parish of Selborne, by taking in so much of the forest, is a vast district. Those who tread the bounds are employed part of three days in the business, and are of opinion that the outline, in all its curves and indentings, does not comprise less than thirty miles.

The village stands in a sheltered spot, secured by The Hanger from the strong westerly winds. The air is soft, but rather moist from the effluvia of so many trees ; ${ }^{1}$ yet perfectly healthy, and free from agues.

The quantity of rain that falls on it is very considerable, as may be supposed in so woody and mountainous a district. As my experience in measuring the water is but of short date, I am not qualified to give the mean quantity. ${ }^{2}$ I only know that

From May 1, 1779, to the end of the year, there fell Inch. Hnnd.

From Jan. 1, 1780, to Jan. 1, 1781

From Jan. 1, 1781, to Jan. 1, 1782

From Jan. 1, 1782, to Jan. 1, 1783

From Jan. 1, 1783, to Jan. 1, 1784

From Jan. 1, 1784, to Jan. 1, 1785

From Jan. 1, 1785, to Jan. 1, 1786

From Jan. 1, 1786, to Jan. 1, 1787

2837 !

$27 \quad 32$

$30 \quad 71$

5026 !

3371

$33 \quad 80$

$31 \quad 55$

$39 \quad 57$

The village of Selborne, and large hamlet of Oakhanger,

1 This effect of trees is fully treated of in the Letter to Daines Barrington, numbered XXIX.-ED.

2 A very intelligent gentleman [Thomas Barker, of ancient family in the county of Rutland-Ev.] assures me (and he speaks from upwards of forty years' experience) that the mean rain of any place cannot be ascertained till a person has measured it for a very long period. "If I had only measured the rain," says he, "for the four first years, from 1740 to 1743 , I should have said the mean rain at Lyndon was $16 \frac{1}{2}$ in. for the year; if from 1740 to $1750,18 \frac{1}{2}$ inches. The mean rain before 1763 was $20 \frac{1}{4}$; from 1763 and since, $25 \frac{1}{2}$; from 1770 to 1780,26 . If only 1773 , 1774, and 1775, had been measured, Lyndon mean rain would have been called 32 in."-G. W.

Averaging fifty per cent. more than Lyndon, and upwards of fifty per cent. more than the neighbourhood of London, it may well be said that the quantity of rain that falls at Selborne is very considerable. The excess, as is stated in the text, is altogether attributable to local circumstances.-ED. 
with the single farms, and many scattered houses along the verge of the forest, contains upwards of 670 inhabitants. ${ }^{1}$

We abound with poor; many of whom are sober and industrious, and live comfortably in good stone or brick, cottages, which are glazed, and have chambers above 'i. bum stairs: mud buildings we have none. Besides the employment from husbandry, the men work in hop gardens, of which we have many; and fell and bark timber. In the

1 A State of the Parish of Selborne, taken Oct. 4, 1783.

The number of tenements or families, 136.

The number of inhabitants in the street is . . . 313

in the rest of the parish $\quad 363$

Total 676 ; near five inhabitants to each tenement.

In the time of the Rer. Gilbert White, vicar, who died in 1727-8, the number of inhabitants was computed at about 500 .

Average of Baptisms for Sixty Years.

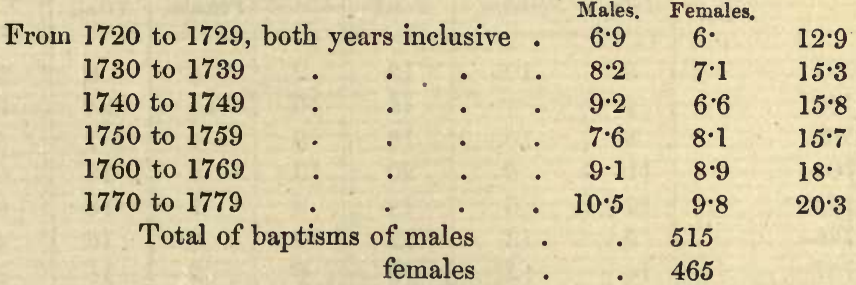

Total of baptisms from 1720 to 1779 , both inclusive, sixty years, 980 .

Average of Burials for Sixty Years.

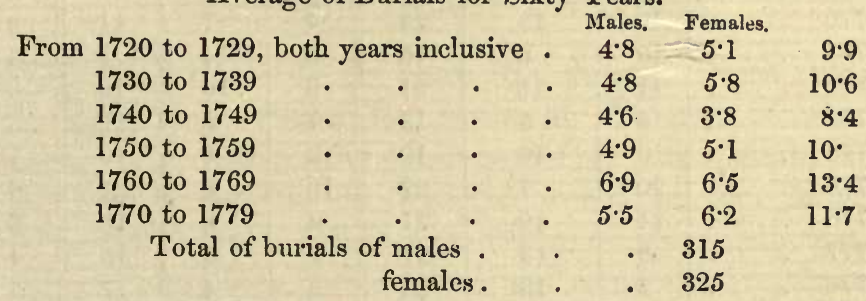

Total of burials from 1720 to 1779 , both inclusive, sixty years, 640 .

Baptisms exceed burials by more than one-third.

Baptisms of males exceed females by one-tenth, or one in ten.

Burials of females exceed males by one in thirty.

It appears that a child, born and bred in this parish, has an equal chance to live above forty years.

Twins thirteen times, many of whom dying young have lessened the chances for life.

Chances for life in men and women appear to be equal. 
spring and summer the women weed the corn; and enjoy a second harvest in September by hop-picking. Formerly, in the dead months they availed themselves greatly by spinning wool, for making of barragons, a genteel corded stuff, much in vogue at that time for summer wear; and chiefly manufactured at Alton, a neighbouring town, by some of the people called Quakers : but from circumstances this trade is at an end. ${ }^{1}$

The inhabitants enjoy a good share of health and longevity; and the parish swarms with children.

A Table of the Baptisms, Burials, and Marriages, from January 2, 1761, to December 25, 1780, in the Parish of Selborne.

\begin{tabular}{|c|c|c|c|c|c|c|c|c|c|}
\hline & & & \multicolumn{3}{|c|}{ BAPTISMS. } & \multicolumn{3}{|c|}{ BURIALS. } & \multirow{2}{*}{$\begin{array}{c}\text { MARRI- } \\
\text { AGES. }\end{array}$} \\
\hline & & & Males. & Females. & Total. & Males. & Females. & Total. & \\
\hline 1761 & • & . & 8 & 10 & 18 & 2 & 4 & 6 & 3 \\
\hline 1762 & • & . & 7 & 8 & 15 & 10 & 14 & 24 & 6 \\
\hline 1763 & • & - & 8 & 10 & 18 & 3 & 4 & 7 & 5 \\
\hline 1764 & . & . & 11 & 9 & 20 & 10 & 8 & 18 & 6 \\
\hline 1765 & • & . & 12 & 6 & 18 & 9 & 7 & 16 & 6 \\
\hline 1766 & . & . & 9 & 13 & 22 & 10 & 6 & 16 & 4 \\
\hline 1767 & . & . & 14 & 5 & 19 & 6 & 5 & 11 & 2 \\
\hline 1768 & . & . & 7 & 6 & 13 & 2 & 5 & 7 & 6 \\
\hline 1769 & • & . & 9 & 14 & 23 & 6 & 5 & 11 & 2 \\
\hline 1770 & . & . & 10 & 13 & 23 & 4 & 7 & 11 & 3 \\
\hline 1771 & • & . & 10 & 6 & 16 & 3 & 4 & 7 & 4 \\
\hline 1772 & • & . & 11 & 10 & 21 & 6 & 10 & 16 & 3 \\
\hline 1773 & • & . & 8 & 5 & 13 & 7 & 5 & 12 & 3 \\
\hline 1774 & • & . & 6 & 13 & 19 & 2 & 8 & 10 & 1 \\
\hline 1775 & • & . & 20 & 7 & 27 & 13 & 8 & 21 & 6 \\
\hline 1776 & . & . & 11 & 10 & 21 & 4 & 6 & 10 & 6 \\
\hline 1777 & . & . & 8 & 13 & 21 & 7 & 3 & 10 & 4 \\
\hline 1778 & • & . & 7 & 13 & 20 & 3 & 4 & 7 & 5 \\
\hline 1779 & . & . & 14 & 8 & 22 & 5 & 6 & 11 & 5 \\
\hline 1780 & • & . & 8 & 9 & 17 & 11 & 4 & 15 & 3 \\
\hline
\end{tabular}

During this period of twenty years, the births of males exceeded those of females 10. The burials of each sex were equal. And the births exceeded the deaths $140 .-\mathrm{G}$. W.

${ }^{1}$ Since the passage above was written, 1 am happy in being able to say that the spinning employment is a little revived, to the no small comfort of the industrious housewife.-G. W. 


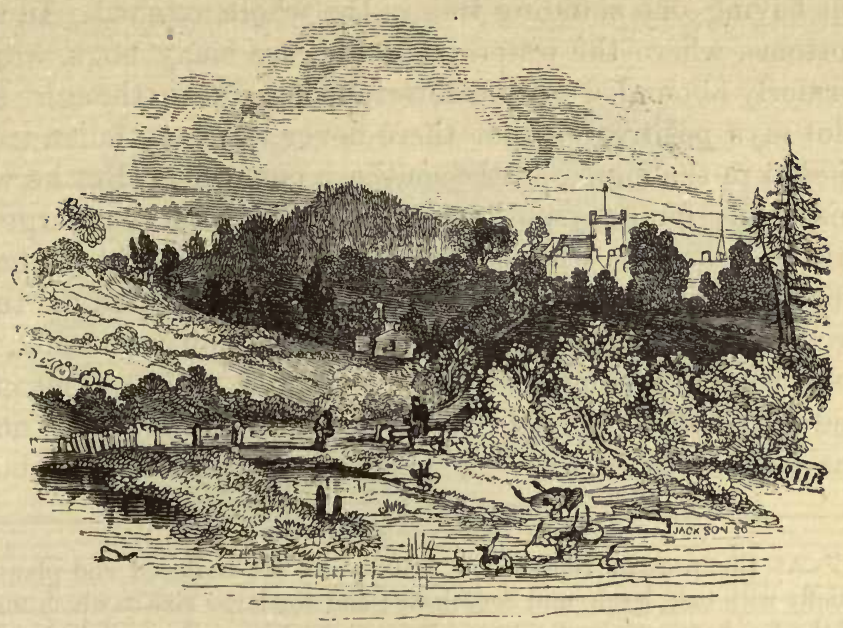

APPROACH TO THE VILLAGE.

\section{LETTER VI.}

TO THOMAS PENNANT, ESQUIRE.

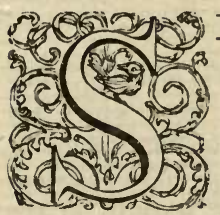

HOULD I omit to describe with some exactness the forest of Wolmer, of which three-fifths perhaps lie in this parish, my account of Selborne would be very imperfect; as it is a district abounding with many curious productions, both animal and vegetable; and has often afforded me much entertainment both as a sportsman and as a naturalist.

The royal forest of Wolmer is a tract of land of about seven miles in length, by two and a half in breadth, running nearly from north to south, and is abutted on, to begin to the south, and so to proceed eastward, by the parishes of Greatham, Lysse, Rogate, and Trotton, in the county of Sussex; by Bramshot, Hedleigh, and Kingsley. This 
royalty consists entirely of sand covered with heath and fern; but is somewhat diversified with hills and dales, without having one standing tree in the whole extent. ${ }^{1}$ In the bottoms, where the waters stagnate, are many bogs, which formerly abounded with subterraneous trees; though Dr. Plot says positively, ${ }^{2}$ that there never were any fallen trees hidden in the mosses of the southern counties. But he was mistaken; for I myself have seen cottages on the verge of this wild district, whose timbers consisted of a black hard wood, looking like oak, which the owners assured me they procured from the bogs by probing the soil with spits, or some such instruments ; but the peat is so much cut out, and the moors have been so well examined, that none has been found of late. ${ }^{3}$ Besides the oak, I have also been

1 At the present time nearly 1,500 acres are enclosed and planted, chiefly with oak, larch, and Scotch fir ; and the large size to which many of the firs have attained, proves how well adapted the soil is for that kind of timber. Outside the enclosures seedling firs are springing up rapidly; and year by year as the wind scatters the seeds, the area of the woodland increases, so that in time were the trees not felled or burned, they would extend over the whole of the district comprised in the "forest."

During the hot summer of 1864 , a terrible conflagration occurred, and was supposed to have been the work of incendiaries. 540 acres in Longmoor, and 170 in Brimstone Wood were destroyed before the fire burnt itself out. The amount of game destroyed, as may be supposed, was commensurate with the destruction of its haunts.-ED.

${ }^{2}$ See his History of Staffordshire.-G. W.

s Old people have assured me that, on a winter's morning, they have discovered these trees, in the bogs, by the hoar frost, which lay longer over the space where they were concealed than on the surxounding morass. Nor does this seem to be a fanciful notion, but consistent with true philosophy. Dr. Hales saith, "That the warmth of the earth, at some depth under ground, has an influence in promoting a thaw, as well as the change of the weather from a freezing to a thawing state, is manifest from this observation, viz. Nov. 29, 1731, a little snow having fallen in the night, it was, by eleven the next morning, mostly melted away on the surface of the earth, except in several places in Bushy Park, where there were drains dug and covered with earth, on which the snow continued to lie, whether those drains were full of water or dry : as also where elm-pipes lay under ground; a plain proof this, that those drains intercepted the warmth of the earth from ascending from greater depths below them : for the snow lav where the 
shown pieces of fossil wood of a paler colour, and softer nature, which the inhabitants called fir: but upon a nice examination, and trial by fire, I could discover nothing

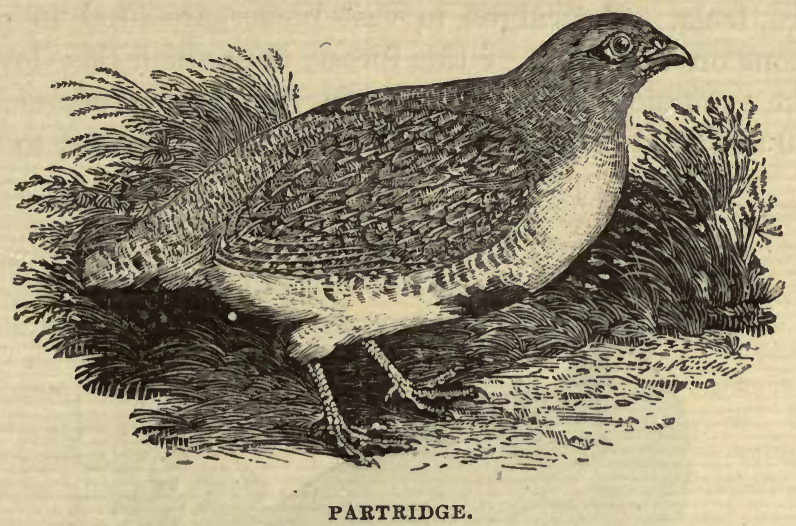

resinous in them; and therefore rather suppose that they were parts of a willow or alder, or some such aquatic tree. ${ }^{1}$

drain had more than four feet depth of earth over it. It continued also to lie on thatch, tiles, and the tops of walls." See Hule's Homastatics, p. 360.-Quere, Might not such observations be reduced to domestic use, by promoting the discovery of old obliterated drains and wells about houses; and, in Roman stations and camps, lead to the finding of parements, baths, and graves, and other hidden relics of curious antiquity ?-G. W.

See also the letter to Daines Barrington, numbered LXI.; in which the effects of the short but intense frost of 1768 are described.-ED.

1 A more recent instance of the occurrence of bog-oak is recorded in Letter LIX. to Daines Barrington : and probably the stock is by no means yet exhausted. In addition to the oak, fir and birch are also found. They are in various stages of carbonization, dependent on their position, or, in other words, on the length of time during which they have been subjected to the action of moisture and pressure. Above the peat is a layer of sand of eighteen inches or two feet in thickness. On the top of this rests a thick layer of turf ; consisting of the blended roots of many generations of heath and other plants, and approaching, in its lower part, to the character of the genuine bog. It is from this compact layer that the majority of the larger trunks are obtained. -ED. 
This lonely domain is a very agreeable haunt for many sorts of wild fowls, which not only frequent it in the winter, but breed there in the summer; such as lapwings, snipes, wild-ducks, and, as I have discovered within these few years, teals. Partridges in vast plenty are bred in good seasons on the verge of this forest, into which they love to make excursions: and in particular, in the dry summers of 1740 and 1741, and some years after, they swarmed to such

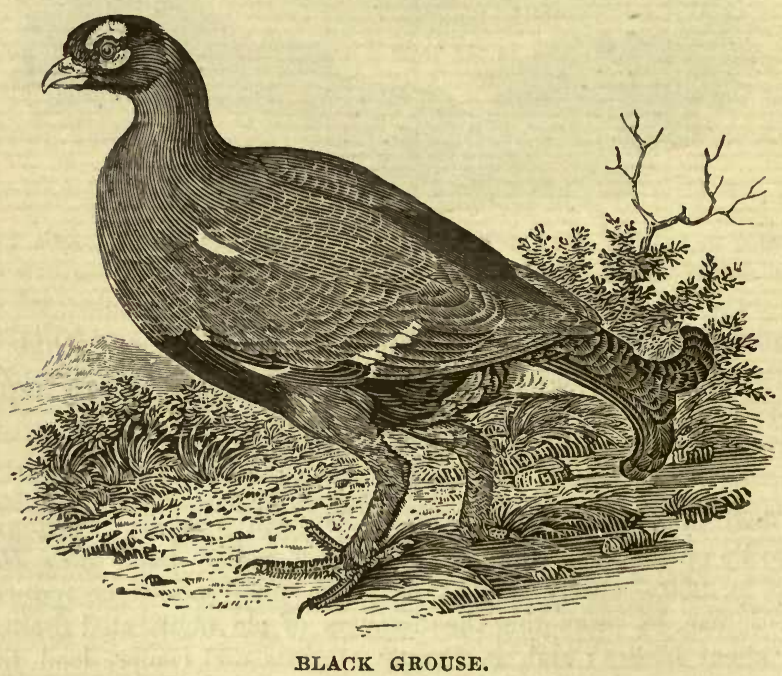

a degree, that parties of unreasonable sportsmen killed twenty and sometimes thirty brace in a day.

But there was a nobler species of game in this forest, now extinct, which I have heard old people say abounded much before shooting flying became so common, and that was the heath-cock, or black game. When I was a little boy I recollect one coming now and then to my father's table. The last pack remembered, was killed about thirty-five years ago ; and within these ten years one solitary gray hen was sprung by some beagles in beating for a hare. The sportsman cried out, "A hen pheasant;" but a gentleman 
present, who had often seen black game in the north of England, assured me that it was a gray hen.'

Nor does the loss of our black game prove the only gap in the Fauna Selborniensis; for another beautiful link in the chain of beings is wanting, I mean the red deer, which toward the beginning of this century amounted to about five hundred head, and made a stately appearance. There is an old keeper, now alive, named Adams, whose great

1 This fine game-bird, although it became extinct in Gilbert White's day, was reintroduced after the planting of the wood, by Sir Charles Taylor, then ranger of the forest, and for some time throve exceedingly well. The parent stock of the present race came from Cumberland, and in 1872 an old man who had brought the birds to Wolmer was still living in the neighbouring village of Liphook. A good sportsman and naturalist, Capt. Feilden, late of the 4th Regt., who visited Wolmer in 1872 , expressly with the intention of noting the changes which had taken place there since White's day, reported of the black game as follows: "That the ground is well adapted for black game is evident; but I think the disproportion between the sexes which now exists will, unless remedied, lead once more, and that ere long, to the destruction of the species on Wolmer. There must be as many as forty to fifty blackcocks on the ground, and I certainly have not seen above six or seven grey hens. If this polygamous species is to be kept up, the proportion of sexes ought to be reversed; as it now is, the hens are worried and driven off the ground by the importunities of a crowd of suitors, and the result is that for several years past the warders have not come across a nest or brood on the Government lands. I am aware that in some parts of Scotland, where black game abound, the old cocks are justly looked upon as detrimental to the general interest, and are killed off as vermin at any season of the year. If this were done at Wolmer, and a fair proportion produced between the sexes, we might hope to retain this noble game-bird as a denizen of Wolmer Forest for years to come." The species occurs sparingly upon the moorlands and heaths of many of the southern counties of England, and is reported as nesting occasionally in Cornwall, Devon, Somerset, Dorset, Hants, Sussex and Surrey. Its chief haunts, however, lie more to the north, upon the lower slopes of heathy and mountainous tracts, which are covered with a natural growth of willow, birch, and alder, and intersected by morasses. It subsists on a variety of food according to season, such as insects, wild berries, and the seeds of various rushes and other plants, but chiefly on the young and tender shoots of the heath, and in winter, when these are no longer procurable, upon the buds and tops of the birch and alder, and the embryo shoots of the different firs. These they can well obtain, since they readily perch on trees, and always roost at night on a horizontal bough like pheasants.-ED. 
grandfather (mentioned in a perambulation taken in 1635), grandfather, father, and self, enjoyed the head keepership of Wolmer Forest in succession for more than a hundred years. This person assures me, that his father has often told him that Queen Anne, as she was journeying on the Portsmouth road, did not think the forest of Wolmer beneath her royal regard. For she came out of the great road at Lippock, which is just by, and reposing herself on a bank smoothed for that purpose, lying about half a mile to the east of Wolmer-pond, and still called Queen's bank, saw with great complacency and satisfaction the whole herd of red deer brought by the keepers along the vale before her, consisting then of about five hundred head. A sight this, worthy the attention of the greatest sovereign! But he farther adds that, by means of the Waltham blacks, or, to use his own expression, as soon as they began blacking, they were reduced to about fifty head, and so continued decreasing till the time of the late Duke of Cumberland. It is now more than thirty years ago that his highness sent down a huntsman, and six yeomen-prickers, in scarlet jackets laced with gold, attended by the staghounds; ordering them to take every deer in this forest alive, and to convey them in carts to Windsor. In the course of the summer they caught every stag, some of which showed extraordinary diversion; but, in the following winter, when the hinds were also carried off, such fine chases were exhibited as served the country people for matter of talk and wonder for years afterwards. I saw myself one of the yeomenprickers single out a stag from the herd, and must confess that it was the most curious feat of activity I ever beheld, superior to any thing in Mr. Astley's riding-school. The exertions made by the horse and deer much exceeded all my expectations ; though the former greatly excelled the latter in speed. When the devoted deer was separated from his companions, they gave him, by their watches, law, as they called it, for twenty minutes; when, sounding their horns, the stop-dogs were permitted to pursue, and a most gallant scene ensued. 


\section{LETTER VII.}

TO THOMAS PENNANT, ESQUIRE.

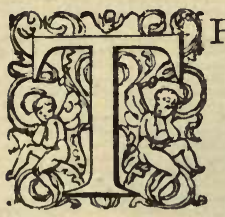

HOUGH large herds of deer do much harm to the neighbourhood, yet the injury to the morals of the people is of more moment than the loss of their crops. The temptation is irresistible; for most men are sportsmen by constitution, and there is such an inherent spirit for hunting in human nature, as scarce any inhibitions can restrain. Hence, towards the beginning of this century, all this country was wild about deer-stealing. Unless he was a hunter, as they affected to call themselves, no young person was allowed to be possessed of manhood or gallantry. The Waltham blacks at length committed such enormities, that government was forced to interfere with that severe and sanguinary act called the black act, ${ }^{1}$ which now comprehends more felonies than any law that ever was framed before. And, therefore, a late Bishop of Winchester, when urged to restock Waltham-chase, ${ }^{2}$ refused, from a motive worthy of a prelate, replying that "It had done mischief enough already."

Our old race of deer-stealers are hardly extinct yet: it was but a little while ago that, over their ale, they used to recount the exploits of their youth; such as watching the pregnant hind to her lair, and, when the calf was dropped, paring its feet with a penknife to the quick to prevent its escape, till it was large and fat enough to be killed; the shooting at one of their neighbours with a bullet in a turnipfield by moonshine, mistaking him for a deer; and the losing a dog in the following extraordinary manner:-Some fellows

1 Statute 9 Geo. I. c. 22.

2 This chase remains unstocked to this day: the Bishop was Dr. Hoadley.-G. W 
suspecting that a calf new-fallen was deposited in a certain spot of thick fern, went with a lurcher to surprise it, when the parent-hind rushed out of the brake, and, taking a vast spring with all her feet close together, pitched upon the neck of the dog, and broke it short in two.

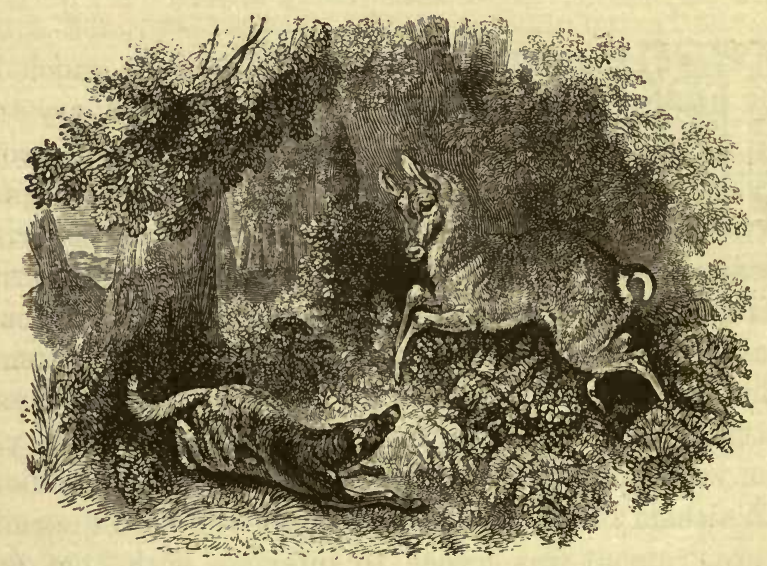

Another temptation to idleness and sporting was a number of rabbits, which possessed all the hillocks and dry places; but these being inconvenient to the huntsmen, on account of their burrows, when they came to take away the deer, they permitted the country people to destroy them all.

Such forests and wastes, when the all urements to irregularities are removed, are of considerable service to neighbourhoods that verge upon them, by furnishing them with peat and turf for their firing, with fuel for the burning their lime, and with ashes for their grasses, and by maintaining their geese and their stock of young cattle at little or no expense.

The manor farm of the parish of Greatham has an admitted claim, I see (by an old record taken from the Tower of London), of turning all live stock on the forest, at proper seasons, bidentibus exceptis. ${ }^{1}$ The reason, I presume, why

1 For this privilege the owner of that estate used to pay to the king annually seven bushels of oats.-G. W. 
sheep are excluded is because, being such close grazers, they would pick out all the finest grasses, and hinder the deer from thriving. ${ }^{1}$

Though (by statute 4 and 5 W. and Mary, c. 23), "to burn on any waste, between Candlemas and Midsummer, any grig, ling, heath and furze, goss or fern, is punishable with whipping and confinement in the house of correction ;" yet in this forest, about March or April, according to the dryness of the season, such vast heath-fires are lighted up, that they often get to a masterless head, and, catching the hedges, have sometimes been communicated to the underwoods, woods, and coppices, where great damage has ensued. ${ }^{2} \quad$ The plea for these burnings is, that when the old coat of heath, \&c. is consumed, young will sprout up, and afford much tender browze for cattle: but where there is large old furze, the fire, following the roots, consumes the very ground; so that for hundreds of acres nothing is to be seen but smother and desolation, the whole circuit round looking like the cinders of a volcano; and, the soil being quite exhausted, no traces of vegetation are to be found for years. These conflagrations, as they take place usually with a north-east or east wind, much annoy this village with

I In the Holt, where a full stock of fallow-deer has been kept up till lately, no sheep are admitted to this day.-G. W.

Sheep obtain the first pair of central permanent incisors when about fourteen months old, and are then occasionally referred to by the term bidentes. As remarked by Mr. Yarrell, it is singular that sheep with a single row of incisor teeth pressing against a cartilaginous pad, should be able to bite closer than a horse with a well matched double row of teeth; but it is a well known fact that a horse would be starved on downs where sheep thrive.-ED.

2 In Scotland where the extensive burnings of heath are common, the prohibited months have reference to the preservation of the eggs and young of grouse and other game, as little other inconvenience is apt to ensue when no woods are in the vicinity.

The Rev. J. Mitford has observed that the description of the conflagration arising from the heath-fires here mentioned reminds the scholar of the stubble-burning described in Virgil's Georgics, i. 84, and the commentary on the passage, by the elegant and learned Mr. Holdsworth, p. 52. Compare Virgilii AEn. ii. 304, Ovid. Epist. xv. 9, and Sil. Ital. vii. 365.-ED. 
their smoke, and often alarm the country; and once in particular, I remember that a gentleman, who lives beyond Andover, coming to my house, when he got on the downs between that town and Winchester, at twenty-five miles distance, was surprised much with smoke and a hot smell of fire, and concluded that Alresford was in flames; but when he came to that town, he then had apprehensions for the next village, and so on to the end of his journey.

On two of the most conspicuous eminences of this forest stand two arbours or bowers, made of the boughs of oaks; the one called Waldon-lodge, the other Brimstone-lodge: these the keepers renew annually on the feast of St. Barnabas, taking the old materials for a perquisite. The farm called Blackmoor, in this parish, is obliged to find the posts and brushwood for the former; while the farms at Greatham, in rotation, furnish for the latter, and are all enjoined to cut and deliver the materials at the spot. This custom I mention, because I look upon it to be of very remote antiquity.

\section{LETTER VIII.}

\section{TO THOMAS PENNANT, ESQUIRE.}

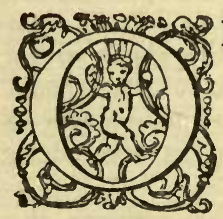

$N$ the verge of the forest, as it is now circumscribed, are three considerable lakes, two in Oakhanger, of which I have nothing particular to say; and one called Bin's or Bean's Pond, which is worthy the attention of a naturalist or a sportsman. For, being crowded at the upper end with willows, and with the Carex cespitosa, ${ }^{1}$ it affords such a safe and pleasing shelter to wild ducks, teals, snipes, \&c. that they breed there. In the winter this covert is also

1 I mean that sort which, rising into tall hassocks, is called by the foresters torrets-a corruption, I suppose, of turrets.-G. W. 
frequented by foxes, and sometimes by pheasants; and the bogs produce many curious plants. ${ }^{1}$ [For which, consult Letter XLI. to Mr. Barrington.]

By a perambulation of Wolmer Forest and The Holt, made in 1635, and in the eleventh year of Charles the First (which now lies before me), it appears that the limits of the former are much circumscribed. For, to say nothing of the farther side, with which I am not so well acquainted, the bounds on this side, in old times, came into Binswood; and extended to the ditch of Ward le ham Park, in which stands the curious mount called King John's Hill, and Lodge Hill; and to the verge of Hartley Mauduit, called Mauduit-hatch; comprehending also Short-heath, Oakhanger, and Oakwoods; a large district, now private property, though once belonging to the royal domain. ${ }^{2}$

It is remarkable that the term purlieu is never once mentioned in this long roll of parchment. It contains, besides the perambulation, a rough estimate of the value of the timbers, which were considerable, growing at that time in the district of The Holt $;^{3}$ and enumerates the officers, superior and inferior, of those joint forests, for the time being, and their ostensible fees and perquisites. In those days, as at present, there were hardly any trees in Wolmer Forest.

Within the present limits of the forest are three considerable lakes, Hogmer, Cranmer, and Wolmer ; ${ }^{4}$ all of

1 This pond has long since been drained, and cattle now graze in its bed. The covert in which wild ducks and foxes formerly abounded has almost entirely disappeared.-ED.

${ }^{2}$ In the beginning of the summer (1787), the royal forests of Wolmer and Holt were measured by persons sent down hy government.-G. W. Wolmer, with but two enclosures within its precincts, extended over 5,949 acres. The royal forest of The Holt, with its enclosures, was then found to comprehend 2,744 acres.-ED.

${ }^{3}$ At the date of the survey referred to in the preceding note, the timber of The Holt was valued at $£ 61,100$.-ED.

4 The name Wolmer is doubtless a corruption of Wolf-mere, or Wolvemere: and it is not a little remarkable that the three great meres of that district-Hogmer, Cranmer, and Wolmer-were named after wild animals, which are all now extinct in Britain, namely, the hog, or wild boar, the crane, and the wolf.-ED. 
which are stocked with carp, tench, eels, and perch: but the fish do not thrive well, because the water is hungry, and the bottoms are a naked sand.

A circumstance respecting these ponds, though by no means peculiar to them, I cannot pass over in silence; and that is, that instinct by which in summer all the kine, whether oxen, cows, calves, or heifers, retire constantly to the water during the hotter hours; where, being more exempt from flies, and inhaling the coolness of that element, some belly deep, and some only to mid-leg, they ruminate and solace themselves from about ten in the morning till four in the afternoon, and then return to their feeding. During this great proportion of the day they drop much dung, in which insects nestle; and so supply food for the fish, which would be poorly subsisted but from this contingency. Thus Nature, who is a great economist, converts the recreation of one animal to the support of another! Thomson, who was a nice observer of natural occurrences, did not let this pleasing circumstance escape him. He says, in his "Summer,"

"A various group the herds and flocks compose.

Some ruminating lie; while others stand

Half in the flood, and often bending, sip

The circling surface.'

Wolmer-pond, so called, I suppose, for eminence sake, is a vast lake for this part of the world, containing, in its whole circumference, 2,646 yards, or very near a mile and a half. The length of the north-west and opposite side is about 704 yards, and the breadth of the south-west end about 456 yards. This measurement, which I caused to be made with good exactness, gives an area of about sixty-six acres, exclusive of a large irregular arm at the north-east corner, which we did not take into the reckoning.

On the face of this expanse of waters, and perfectly secure from fowlers, lie all day long, in the winter season, vast flocks of ducks, teals, and widgeons, of various denominations; where they preen and solace and rest themselves, till towards sunset, when they issue forth in little parties 
(for in their natural state they are all birds of the night) to feed in the brooks and meadows; returning again with the dawn of the morning. Had this lake an arm or two more, and were it planted round with thick covert (for now it is perfectly naked), it might make a valuable decoy. ${ }^{1}$

Yet neither its extent, nor the clearness of its water, nor the resort of various and curious fowls, nor its picturesque groups of cattle, can render this mere so remarkable as the great quantity of coins that were found in its bed about forty years ago. But as such discoveries more properly belong to the antiquities of this place, I shall suppress all particulars for the present, till I enter professedly on my series of Letters respecting the more remote history of this village and district.

\section{LET'TER IX.}

\section{TO THOMAS PENNANT, ESQUIRE.}

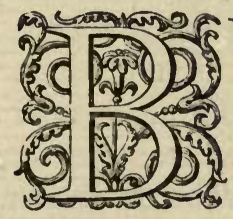

$Y$ way of supplement, I shall trouble you once more on this subject, to inform you that Wolmer, with her sister forest Ayles Holt, alias Alice Holt, ${ }^{2}$ as it is called in old records, is held by grant from the crown for a term of years.

The broad expanse of Wolmer Great Pond still affords a safe retreat to flocks of wild-fowl during the winter season; and wild-ducks and teal still breed in the forest; the ducks in the heath, at long distances from the swamp; the teal nearer to the water. But the numbers of both these species are yearly decreasing.-ED.

${ }^{2}$ In Rot. Inquisit. de statu forest. in Scaccar. $36 \mathrm{Ed}$. III. it is called Aisholt. In the same, "Tit. Woolmer \& Aisholt Hantisc. Dominus Rex habit unam capellam in haia suâ de Kingesle." " Haia, sepes, sepimentum, parcus: a Gall. haie and haye." Spelman's Glossary. Several additional documents relating to the earlier history of the forests, both that of Wolmer and The Holt, are given in a note to Letter $\mathrm{X}$. of the Anticui ties. - G. W. 
The grantees that the author remembers are BrigadierGeneral Emanuel Scroop Howe, and his lady, Ruperta, who was a natural daughter of Prince Rupert by Margaret Hughs; a Mr. Mordaunt, of the Peterborough family, who married a dowager Lady Pembroke; Henry Bilson Legge and lady; and now Lord Stawel, their son. ${ }^{1}$

The lady of General Howe lived to an advanced age, long surviving her husband; and, at her death, left behind her many curious pieces of mechanism of her father's constructing, who was a distinguished mechanic and artist," as well as warrior; and among the rest, a very complicated clock, lately in possession of $\mathrm{Mr}$. Elmer, the celebrated game-painter at Farnham, in the county of Surrey.

Though these two forests are only parted by a narrow range of enclosures, yet no two soils can be more different: for The Holt consists of a strong loam, of a miry nature, carrying a good turf, and abounding with oaks that grow to be large timber; while Wolmer is nothing but a hungry, sandy, barren waste.

The former, being all in the parish of Binsted, is about two miles in extent from north to south, and near as much from east to west; and contains within it many woodlands and lawns, and the great lodge where the grantees reside; and a smaller lodge called Goose Green; and is abutted on by the parishes of Kingsley, Frinsham, Farnham and Bentley; all of which have right of common.

One thing is remarkable; that, though The Holt has been of old well stocked with fallow-deer, unrestrained by any pales or fences more than a common hedge, yet they were never seen within the limits of Wolmer ; nor were the

1 On the expiration of the grant to Lord Stawel, the Commissioners of Woods and Forests resumed possession of The Holt. All the lands held by him, and two-thirds of the former open forest, were subsequently enclosed and planted. - ED.

2 This prince was the inventor of mezzotinto.-G. W. It would perhaps be more correct to say that he was the introducer only of this art into England. The invention it seems is due to Ludwig von Siegen, who about 1654 communicated the secret to Prince Rupert ( $c f$. Walpole's "Anecdotes of Painters and Engravers," Bohn's edition, vol. iii. p. 393).-ED. 
red deer of Wolmer ever known to haunt the thickets or glades of The Holt. ${ }^{1}$

At present the deer of The Holt are much thinned and

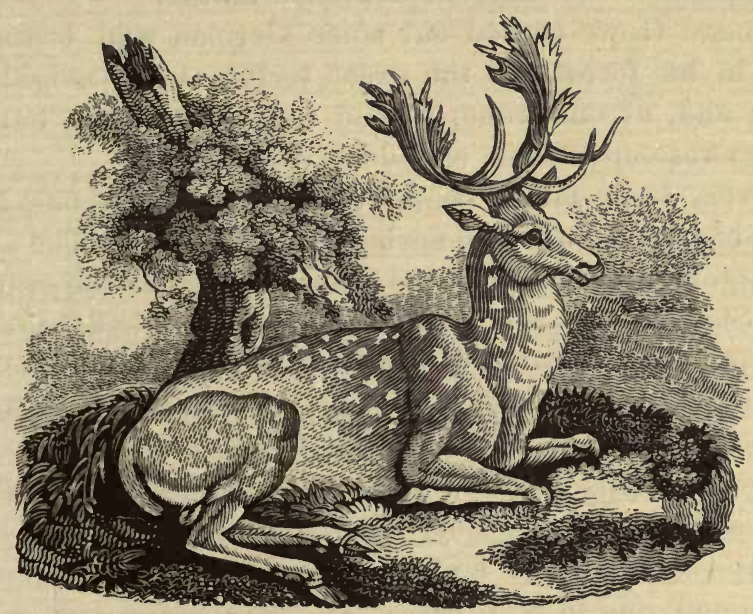

FALLOW DEER.

reduced by the night-hunters, who perpetually harass them in spite of the efforts of numerous keepers, and the severe penalties that have been put in force against them as often

1 Mr. Bennett has pointed out that there could scarcely be two situations more dissimilar than The Holt and Wolmer Forest. The Holt is on the gault, and has all the richness of meadow and nobleness of oak wood that distinguish that formation. It consequently offered to the fallow deer, while they remained on it, plentiful grazing, abundance of browzing, and open and sheltered glades; advantages suited to the habits of that half domesticated race, introduced into this country by man, and still requiring at his hands care and protection. Wolmer Forest, on the lean and hungry sand, scarcely affords any grass, and has no high covert; and the red deer attached to it would have been limited for their provender almost exclusively to the lichens, the heath tops, and the twigs of the very few stunted bushes that occur here and there on its surface : retirement could only have been obtained for them by plunging into the unfrequented hollows interposed between its ridges. The more tender and exotic deer was placed, and it might have seemed almost naturally, in the richer and more sheltered forest of The Holt; the hardier and native race subsisted on the coarse fare of the dreary and cheerless waste of Wolmer.-Ev. 
as they have been detected, and rendered liable to the lash of the law. Neither fines nor imprisonments can deter them : so impossible is it to extinguish the spirit of sporting, which seems to be inherent in human nature.

General Howe turned out some German wild boars and sows in his forests, to the great terror of the neighbourhood; and, at one time, a wild bull or buffalo: but the country rose upon them and destroyed them. ${ }^{1}$

A very large fall of timber, consisting of about 1,000 oaks, has been cut this spring (viz. 1784) in The Holt forest; one-fifth of which, it is said, belongs to the grantee, Lord Stawel. He lays claim also to the lop and top: but the poor of the parishes of Binstead and Frinsham, Bentley and Kingsley, assert that it belongs to them ; and, assembling in a riotous manner, have actually taken it all away. One man, who keeps a team, has carried home for his share forty sacks of wood. Forty-five of these people his lordship has served with actions. ${ }^{2}$ These trees, which were very sound, and in high perfection, were winter-cut, viz. in February and March, before the bark would run.

In old times The Holt was estimated to be eighteen miles, computed measure, from water-carriage, viz. from the town of Chertsey, on the Thames; but now it is not half that distance, since the Wey is made navigable up to the town of Godalming, in the county of Surrey. ${ }^{3}$

1 Charles the First also turned out in the New Forest German boars and sows, which bred and increased. An engraving of one will be found in Gilpin's "Forest Scenery," vol. ii. p. 118. - ED.

$2 \mathrm{Mr}$. Bennett ascertained that the defendants in these actions, though they made a show of resistance, suffered judgment to go by default. The question of right had, in fact, been tried in 1741, and determined against the claimants. Yet notwithstanding this, so soon after as 1788 , on the occasion of another fall of timber in The Holt, the people of Frinsham again assembled and carried off openly upwards of 6,000 faggots. So difficult is it to convince where interest opposes.-ED.

3 The formation of the Basingstoke Canal has again reduced the distance of The Holt from water-carriage; and it is now accessible, either at Odiham or at Bagman's Castle, within about seven miles.-ED. 


\section{LETTER X.}

TO THOMAS PENNANT, ESQUIRE.

August 4, 1767.

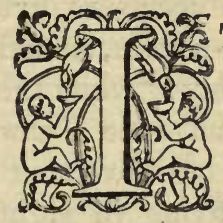

$\mathrm{T}$ has been my misfortune never to have had any neighbours whose studies have led them . towards the pursuit of natural knowledge; so that, for want of a companion to quicken my industry and sharpen my attention, I have made but slender progress in a kind of information to which I have been attached from my childhood.

As to swallows (Hirundines rustica) being found in a torpid state during the winter in the Isle of Wight, or any part of this country, I never heard any such account worth attending to. But a clergyman, of an inquisitive turn, assures me, that when he was a great boy, some workmen, in pulling down the battlements of a church tower early in the spring, found two or three swifts (Hirundines apodes ${ }^{1}$ ) among the rubbish, which were, at first appearance, dead; but, on being carried toward the fire, revived. He told me that, out of his great care to preserve them, he put them in a paper bag, and hung them by the kitchen fire, where they were suffocated.

Another intelligent person has informed me that, while he was a schoolboy at Brighthelmstone, in Sussex, a great fragment of the chalk-cliff fell down one stormy winter on the beach, and that many people found swallows among the rubbish; but, on my questioning him whether he saw any of those birds himself, to my no small disappointment, he answered $m e$ in the negative, but that others assured him they did.

Young broods of swallows began to appear this year on July the eleventh, and young martins (Hirundines urbica) - Mest im

1 Cypselus apus of modern ornithologists.-ED. 
were then fledged in their nests. Both species will breed again once; for I see by my Fauna of last year, that broods came forth so late as September the eighteenth. Are not these late hatchings more in favour of hiding than migration? Nay, some young martins remained in their nests last year so late as September the twenty-ninth; and yet they totally disappeared with us by the fifth of October.

How strange is it that the swift, which seems to live exactly the same life as the swallow and house-martin, should leave us before the middle of August invariably ! ${ }^{1}$ while the latter stay often to the middle of October; and once I saw numbers of house-martins on the seventh of November. The martins and redwing fieldfares were flying in sight together-an uncommon assemblage of winter birds $!^{2}$

A little yellow bird (it is either a species of the Alauda trivialis, or rather perhaps of the Motacilla trochilus) still continues to make a sibilous shivering noise in the top of tall woods. ${ }^{3}$

The Stoparola of Ray (for which we have as yet no name in these parts) is called, in your Zoology, the flycatcher. ${ }^{4}$ There is one circumstance characteristic of this bird, which seems to have escaped observation, and that is, it takes its stand on the top of some stake or post, from whence it springs forth on its prey, catching a fly in the air, and hardly ever touching the ground, but returning still to the same stand for many times together.

1 In quoting the above remark, under the head of Swift, in the second volume of his "British Zoology," 1768, p. 246, Pennant adds : "For these, and several other observations, we owe our acknowledgments to the Reverend Mr. White, of Selborne, Hampshire."-Ev.

${ }^{2}$ An uncommon assemblage for the time of year, no doubt, though it would not have been so in the Spring; for at that season redwings and fieldfares frequently stay with us for a month after the swallows and martins have arrived.-ED.

3 By Alauda trivialis White intended the grasshopper warbler, as will be seen by referring to his list of summer birds, in the 16th Letter to Mr. Pennant. His Motacilia trochilus was the willow wren; but the "little yellow bird," which he compared with these, was no doubt the woud wren, Ph. sibilatrix, of modern naturalists.-ED.

\$ The spotted flycatcher, Muscicapa grisola, of modern naturalists. -ED. 
I perceive there are more than one species of the Motacilla trochilus: Mr. Derham supposes, in Ray's "Philosophical Letters," that he has discovered three." In these there is again an instance of some very common birds that have as yet no English name.

Mr. Stillingfleet makes a question whether the blackcap (Motacilla atricapilla) be a bird of passage or not; I think there is no doubt of it, for in April, in the first fine weather, they come trooping all at once into these parts, but are never seen in the winter. ${ }^{2}$ They are delicate songsters. ${ }^{3}$

Numbers of snipes breed every summer in some moory ground on the verge of this parish. It is very amusing to see the cock bird on wing at that time, and to hear his piping and humming notes. ${ }^{4}$

I have had no opportunity yet of procuring any of those

1 Three are now well recognized, namely-the willow wren, the wood wren, and the chiff-chaff.-ED.

${ }^{2}$ It is now well known that the blackcap, as White surmised, migrates southwards at the approach of the cold weather, and spends the winter in Palestine, Egypt, Nubia, Abyssinia, and other parts of Africa, on the west coast, as well as on the east. Many eren spend the winter in Italy, Greece, and some of the islands of the Mediterranean.-ED.

${ }^{3}$ For a description of the song of the blackcap see the letter to. Mr. Pennant, numbered XL. This description was copied by Pennant, in the third edition of his "British Zoology," vol. i. p. 375.-ED.

${ }^{4}$ Amongst the many rural sounds which greet the ear of the vagrant naturalist in spring, none is more remarkable than that produced by the common snipe in pairing time. This peculiar sound, which is never heard except from a bird on the wing, has been variously termed "humming," "drumming," "neighing," and "bleating," according to the fancy of the auditor; and nothing has puzzled naturalists more, per. haps, than to discover how this noise is produced.

Among German ornithologists especially, this has been a favourite theme for discussion, and various have been the opinions expressed by eminent observers on the subject. Some, like Bechstein, have maintained that the sound is emitted through the bill; others, like Naumann, considered it to result from a vibratory movement of the wings : whilst the latest and most remarkable theory, that of Herr Meves, is that it is produced by the outer tail feather on each side as it is drawn rapidly through the air in the bird's descent. In an article on this subject, contributed to the Field, 27th April, 1872, we examined the various theories here referred to, and gave our reasons for believing that the view expressed by Naumann is probably the right one.-ED. 
mice which I mentioned to you in town, "The person that brought me the last says they are plenty in harvest, at which time I will take care to get more; and will endeavour to put the matter out of doubt, whether it be a nondescript species or not.

I suspect much there may be two species of water-rats. Ray says, and Linnæus after him, that the water-rat is webfooted behind. Now I have discovered a rat on the banks of our little stream that is not web-footed, and yet is an excellent swimmer and diver: it answers exactly to the Mus amphibius of Linnæus (see Syst. Nat.), which he says, "natat in fossis et urinatur." I should be glad to procure one "plantis palmatis." Linnæus seems to be in a puzzle about his Mus amphibius, and to doubt whether it differs from his Mus terrestris; which, if it be, as he allows, the "Mus agrestis capite grandi, brachyuros," of Ray, is widely different from the water-rat, both in size, make, and manner of life. ${ }^{1}$

As to the Falco, which I mentioned in town, I shall take the liberty to send it down to you into Wales; presuming on your candour, that you will excuse me if it should appear as familiar to you as it is strange to me. Though mutilated, qualem dices . . antehac fuisse, tales cum sint reliquioe!"

1 Willughby was the originator of the confusion alluded to, as pointed out by Mr. Bennett in a note to this passage. He described the water-rat as having its toes connected together by intervening webs; and his description was published by Ray in the "Synopsis Quadrupedum." Linnæus, believing that such authorities were to be relied on, admitted into several editions of his "Fauna Suecica" a ratlike animal, having its hinder feet webbed. Subsequently, however, he referred to it as of doubtful existence, as being perhaps inaccurately described, and as probably to be referred to his Mus terrestris. Willughby's error no doubt was occasioned by his having assumed from a certain habit that a certain structure which he regarded as indicated by it must necessarily be coexistent with it.

The Mus agrestis capite grandi, brachyuros, of Ray, is the shorttailed field mouse or vole, Arvicola agrestis, Lins.; the water rat, or rather water vole, being the Arv. amphibia, Desm. The hybernaculum, or winter nest of the water vole, is described later by White in his twenty-sixth letter to Pennant.-ED. 
It haunted a marshy piece of ground in quest of wild ducks and snipes; but, when it was shot, had just knocked down a rook, which it was tearing in pieces. I cannot make it answer to any of our English hawks; neither could I find any like it at the curious exhibition of stuffed birds in Spring Gardens. I found it nailed up at the end of a barn, which is the countryman's museum. ${ }^{1}$

The parish I live in is a very abrupt, uneven country, full of hills and woods, and therefore full of birds.

\section{LETTER XI. \\ TO THOMAS PENNANT, ESQUIRE.}

Selborne, September 9, 1767.

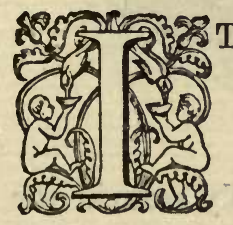

T will not be without impatience that I shall wait for your thoughts with regard to the Falco. As to its weight, breadth, \&c., I wish I had set them down at the time: but to the best of my remembrance, it weighed two pounds and eight ounces, and measured, from wing to wing, thirty-eight inches. Its cere and feet were yellow, and the circle of its eyelids a bright yellow. As it had been killed some days, and the eyes were sunk, I could make no good observation on the colour of the pupils and the irides."

The most unusual birds I ever observed in these parts were a pair of hoopoes (Upupa), which came several years ago in the summer, and frequented an ornamented piece of ground, which joins to my garden, for some weeks. They used to march about in a stately manner, feeding in the walks, many times in the day; and seem disposed to breed

1 The species proved to be the Peregrine, Falco peregrinus of naturalists.-ED.

2 The irides of all the true Falcons are brown.-ED. 
in my outlet; but were frighted and persecuted by idle boys, who. would never let them be at rest. ${ }^{1}$

Three gros-beaks (Loxia coccothraustes) ${ }^{2}$ appeared some years ago in my fields, in the winter; one of which I shot:

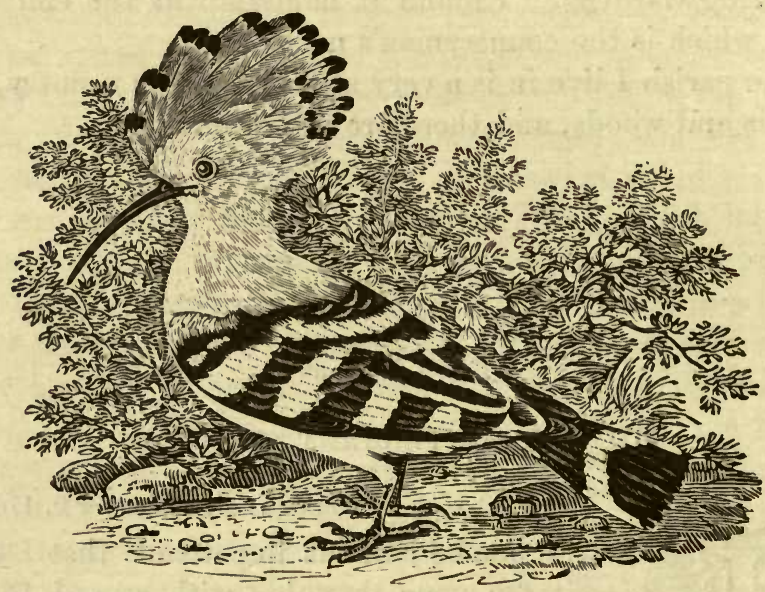

THE HOOPOE.

since that, now and then, one is occasionally seen in the same dead season.

1 The hoopoe is an irregular spring and autumn visitant to this country. It has occasionally nested here, and would do so, no doubt, more frequently if unmolested. Colonel Montagu states, in his "Ornithological Dictionary," that a pair of hoopoes began a nest in Hampshire, but being disturbed forsook it, and went elsewhere ; and Dr. Latham, in the Supplement to his "General Synopsis," has referred to a young Hoopoe in nestling plumage, which was shot in this country in May. A pair nested for several years in the grounds of Pennsylvania Castle, Portland ( $c f$. Garland, "Naturalist," 1852, p. 82), and according to Mr. Turner, of Sherborne, Dorsetshire, the nest has been taken on three or four occasions by the school-boys from pollard willows on the banks of the river at Lenthay. The birds were known to the boys as "hoops." Mr. Jesse, in a note to this passage in his edition of the present work, states that a pair of hoopoes bred for many years in an old ash tree in the grounds of a lady in Sussex, near Chichester.-ED.

2 Coccothraustes vulgaris of modern systematists. 
A cross-bill (Loxia curvirostra) was killed last year in this neighbourhood. ${ }^{1}$

Our streams, which are small, and rise only at the end of phimeloino the village, yield nothing but the bull's head or millers s. Commin thumb (Gobius fluviatilis capitatus), the trout (Trutta watem

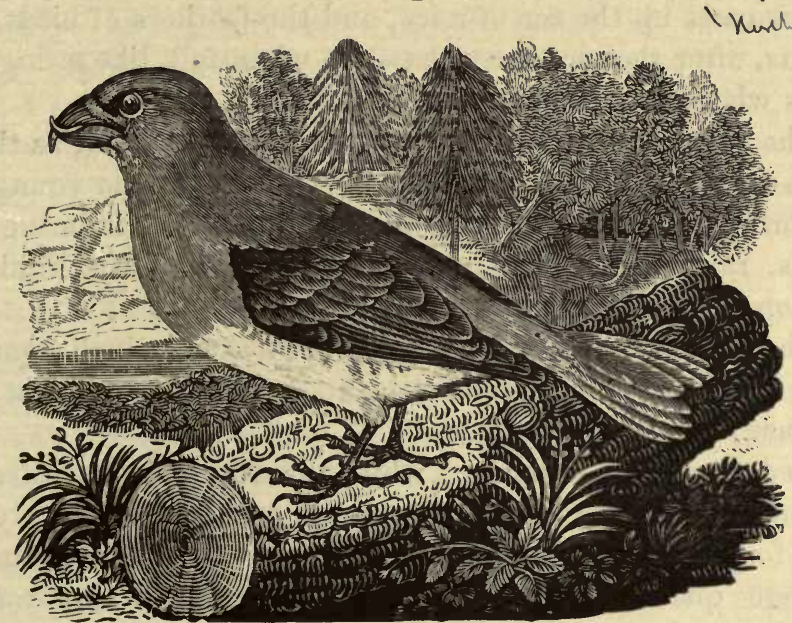

Crossbill.

fluviatilis), the eel (Anguilla), the lampern (Lampetra parva et fluviatilis), and the stickle-back (Pisciculus aculeatus). ${ }^{2}$ Sumal, opacies in aquasim Q.C.

We are twenty miles from the sea, and almost as many

1 In the fourth volume of the "Zoological Journal," and subsequently in the second volume of his "History of British Birds," Mr. Yarrell published an excellent account of the muscles by which the singular beak and tongue of the cross-bill are made to serve the peculiar purposes for which they are designed.-Ev.

2 These names were derived from Ray's "Synopsis Avium et Piscium." The more modern nomenclature, as adopted by Yarrell in his "History of British Fishes," is as follows :-The river bull-head or miller's-thumb, Cottus gobio; the trout, Salmo fario; of eel three species are admitted by Yarrell as indigenous to this country, the Sharp-nosed, Anguilla acutirostris, the Broad-nosed, A. latirostris, and the Snig, A. mediorostris; but the first and third are now regarded as identical, whilst the second is as much a marine as a fresh-water species; the Lampern, Petromyzon fuviatilis; and the Common Stickleback (there are several species), Gasterosteus aculeatus.--ED. 
from a great river, and therefore see but littie of seabirds. As to wild fowls, we have a few teams of ducks bred in the moors where the snipes breed; and multitudes of widgeons and teals in hard weather frequent our lakes in the forest.

Having some acquaintance with a tame brown owl, I find that it casts up the fur of mice, and the feathers of birds, in pellets, after the manner of hawks : when full, like a dog, it hides what it cannot eat.

The young of the barn-owl are not easily raised, as they want a constant supply of fresh mice: whereas the young of the brown owl will eat indiscriminately all that is brought; snails, rats, kittens, puppies, magpies and any kind of carrion or offal.

The house-martins have eggs still, and squab-young. The last swift I observed was about the twenty-first of August; it was a straggler.

Red-starts, fly-catchers, white-throats and Reguli non cristati, still appear ; ${ }^{1}$ but I have seen no blackcaps lately.

I forgot to mention that I once saw, in Christ Church College quadrangle in Oxford, on a very sunny warm morning, a house-martin flying about, and settling on the parapets, so late as the twentieth of November.

At present I know only two species of bats, the common Vespertilio murinus ${ }^{2}$ and the Vespertilio auritus. ${ }^{2}$

I was much entertained last summer with a tame bat, which would take flies out of a person's hand. If you gave it any thing to eat, it brought its wings round before the mouth, hovering and hiding its head in the manner of birds

1 By Reguli non cristati are intended the three species of "willowwrens," as they are generally called, and to which allusion has been already made.-ED.

2 The common pipistrelle and the long-eared bat. In giving to the former, however, the specific name murinus White fell into a mistake which many others have since made. $V$. murinus being the common bat of the Continent, it was assumed that the common bat of this country must be the same species, and Pennant having once stated such to be the case, every subsequent writer on bats copied the mistake. It was left to the Rev. Leonard Jenyns to correct this long established error, and he has done so most satisfactorily in a paper published in the 16th vol. of the "Linnean Society's Transactions."-Ev. 
ot prey when they feed. The adroitness it showed in shearing off the wings of the flies, which were always rejected, was worthy of observation, and pleased me much. Insects seemed to be most acceptable, though it did not refuse raw flesh when offered: so that the notion, that bats go down chimneys and gnaw men's bacon, seems no improbable story. While I amused myself with this wonderful quadruped, I saw it several times confute the vulgar opinion, that bats when down on a flat surface cannot get on the wing again, by rising with great ease from the floor. It ran, I observed, with more dispatch than I was aware of; but in a most ridiculous and grotesque manner.

Bats drink on the wing, like swallows, by sipping the surface, as they play over pools and streams. They love to frequent waters, not only for the sake of drinking, but on account of insects, which are found over them in the greatest plenty. As I was going some years ago, pretty late, in a boat from Richmond to Sunbury, on a warm summer's evening, I think I saw myriads of bats between the two places: the air swarmed with them all along the Thames, so that hundreds were in sight at a time.

\section{LETTER XII.}

TO THOMAS PENNAN'I, ESQUIRE.

November 4, 1767.

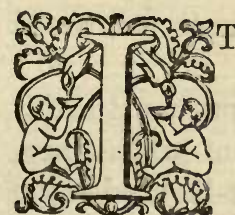

gave me no small satisfaction to hear that the Falco turned out an uncommon one. ${ }^{1}$ I must confess I should have been better pleased to have heard that I had sent you a bird that you had nover seen before; but that, I find, would be a difficult task.

I This hawk proved to be the Falco peregrinus; a variety.-G. W. It differed from the ordinary type in having the under parts of the 
I have procured some of the mice mentioned in my former letter, ${ }^{1}$ a young one and a female with young, both of which I have preserved in brandy. From the colour, shape, size and manner of nesting, I make no doubt but that the

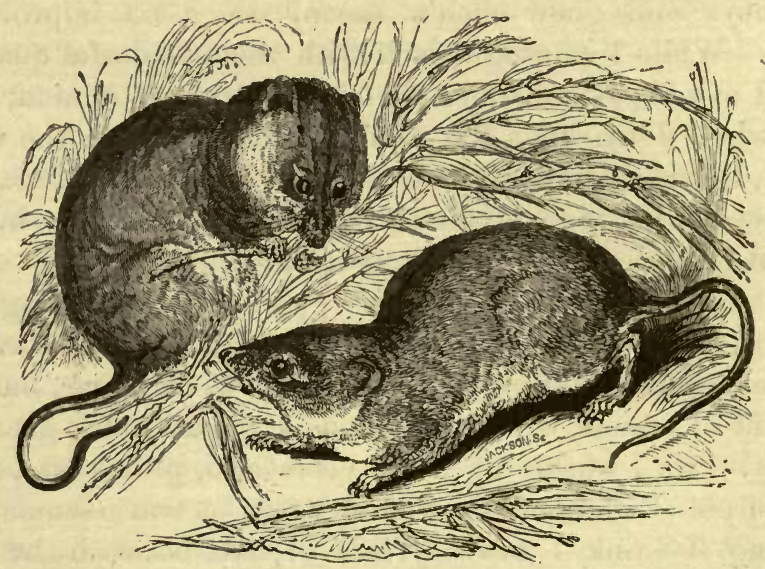

THE HARVEST MOUSE.

species is nondescript. They are much smaller, and more slender, than the Mus domesticus medius of Ray; and have more of the squirrel or dormouse colour: their belly is white; a straight line along their sides divides the shades of their back and belly. They never enter into houses, are carried into ricks and barns with the sheaves, abound in $q_{0}$ harvest, and build their nests amidst the straws of the corn above the ground, and sometimes in thistles. They breed as many as eight at a litter, in a little round nest composed of the blades of grass or wheat.

One of these nests I procured this autumn, most artificially plaited, and composed of the blades of wheat, perfectly round, and about the size of a cricket-ball, with the

body of a dirty yellow colour, but with the usual black bars. See Pennant, "Brit. Zool." 1768 , p. 560. It was shot in the adjoining parish of Faringdon.-ED.

1 Letter X. pp. 35, 36. 
aperture so ingeniously closed, that there was no discovering to what part it belonged. It was so compact and well filled, that it would roll across the table without being discomposed, though it contained eight little mice that were naked and blind. As this nest was perfectly full, how could the dam come at her litter respectively so as to administer a teat to each? Perhaps she opens different places for that purpose, adjusting them again when the business is over; but she could not possibly be contained herself in the ball with the young, which moreover would be daily increasing in bulk. This wonderful "procreant cradle," an elegant instance of the efforts of instinct, was found in a wheat.field suspended in the head of a thistle. ${ }^{1}$

A gentleman, curious in birds, wrote me word that his servant had shot one last January, in that severe weather, which, he believed, would puzzle me. I called to see it this summer, not knowing what to expect; but the moment I took it in hand, I pronounced it the male Garrulus Bohemicus, or German silk-tail, from the five peculiar crimson tags or points which it carries at the ends of five of the short remiges. It cannot, I suppose, with any propriety, be called an English bird; and yet I see, by Ray's Philosophical Letters, that great flocks of them, feeding on haws, appeared in this kingdom in the winter of $1685 .^{2}$

The mention of haws puts me in mind that there is a total failure of that wild fruit, so conducive to the support of many of the winged nation. For the same severe weather, late in the spring, which cut off all the produce of the more tender and curious trees, destroyed also that of the more hardy and common.

1 We are indebted to Gilbert White for the first published account of this beautiful little animal as indigenous to this country, although it appears to have been previously seen by Montagu in Wiltshire ( $c f$ Trans. Lin. Soc. vol. vii. p. 274). White communicated his discovery to Pennant, who published it in the second edition of his "British Quadrupeds;" and thence it has been copied, with but little addition, by almost every writer on the subject of British mammalia.-ED.

2 The waxwing, or Bohemian chatterer, as it is often called (Ampelis garrulus, Linnæus), may be regarded as an irregular winter visitant to this country, occasionally appearing in large flocks.-ED. 
Some birds, haunting with the missel-thrushes, and feeding on the berries of the yew-tree, which answered to the description of the Merula torquata, ${ }^{1}$ or ring-ouzel, were lately seen in this neighbourhood. I employed some people to procure me a specimen, but without success. ${ }^{2}$

Query - Might not canary birds be naturalized to this climate, provided their eggs were put, in the spring, into the nest of some of their congeners, as goldfinches, greenfinches, \&c.? Before winter, perhaps, they might be hardened, and able to shift for themselves.

About ten years ago, I used to spend some weeks yearly at Sunbury, which is one of those pleasant villages lying on the Thames, near Hampton Court. In the autumn, I could not help being much amused with those myriads of the swallow kind which assemble in those parts. But what struck me most was, that from the time they began to congregate, forsaking the chimneys and houses, they roosted every night in the osier-beds of the aits of that river. Now this resorting towards that element, at that season of the year, seems to give some countenance to the northern opinion (strange as it is) of their retiring under water. A Swedish naturalist is so much persuaded of that fact, that he talks, in his "Calendar of Flora," as familiarly of the swallow's going under water in the beginning of September as he would of his poultry going to roost a little before sunset. ${ }^{3}$

An observing gentleman in London writes me word, that he saw a house-martin, on the twenty-third of last October, flying in and out of its nest in the Borough. And I myself, on the twenty-ninth of last October (as I was travelling through Oxford) saw four or five swallows hovering round and settling on the roof of the county hospital.

Now, is it likely that these poor little birds (which, perhaps, had not been hatched but a few weeks) should, at that late season of the year, and from so midland a county,

1 Turdus torquatus, Linnæus.

2 See Letters XIII. and XX.

3 Stillingfleet's "Calendar of Flora," Swedish and English, made in 1755, and published in 1761.-ED. 
attempt a voyage to Goree or Senegal, almost as far as the equator ? ${ }^{1}$

I acquiesce entirely in your opinion - that, though most of the swallow kind may migrate, yet that some do stay behind and bide with us during the winter.

As to the short-winged soft-billed birds, which come trooping in such numbers in the spring, I am at a loss even what to suspect about them. I watched them narrowly this year, and saw them abound till about Michaelmas, when they appeared no longer. Subsist they cannot openly among us, and yet elude the eyes of the inquisitive; and, as to their hiding, no man pretends to have found any of them in a torpid state in the winter. But with regard to their migration, what difficulties attend that supposition! that such feeble bad fliers (who the summer long never flit but from hedge to hedge), should be able to traverse vast seas and continents, in order to enjoy milder seasons amidst the regions of Africa! ${ }^{2}$

1 See Adanson's Voyage to Senegal.-G. W.

The late Dean of Manchester, the Hon. and Rev. W. Herbert, furnished an interesting note to this passage for Mr. Bennett's edition of this work, to the effect that late broods of young swifts, as soon as they leave the nest, are often obliged to migrate at once (see White's observations in Letter LII. to the Hon. Daines Barrington); and that the various species of hirundines remain in their nests till they are more completely feathered than any other birds, so that when they come forth at last, they are ready for flight. Whether the same individuals of a species, amongst birds, ever cross the equator is a question upon which ornithologists are not unanimously agreed. Certain it is, however, that the same species is often found on both sides of the line, as in the case of the common swallow, which, spending the summer in Europe, passes some portion of the year also at the Cape of Good Hope. On this subject the reader may be referred to an interesting article "On some new or littleknown points in the Economy of the Common Swallow," by Messrs. Sharpe and Dresser, published in the "Proceedings of the Zoological Society," 1870, p. 244.--ED.

2 Some further observations on this subject, tending to a solution of the difficulties referred to, will be found in Letter XXXIII. to Pennant, and Letter IX. to the Hon. Daines Barrington.-ED. 


\section{LETTER XIII.}

TO THOMAS PENNANT, ESQUIRE.

Selborne, Jan. 22, 1768.

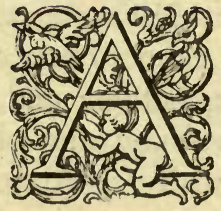

$\mathrm{S}$ in one of your former letters you expressed the more satisfaction from my correspondence on account of my living in the most southerly county; so now I may return the compliment, and expect to have my curiosity gratified by your living much more to the north.

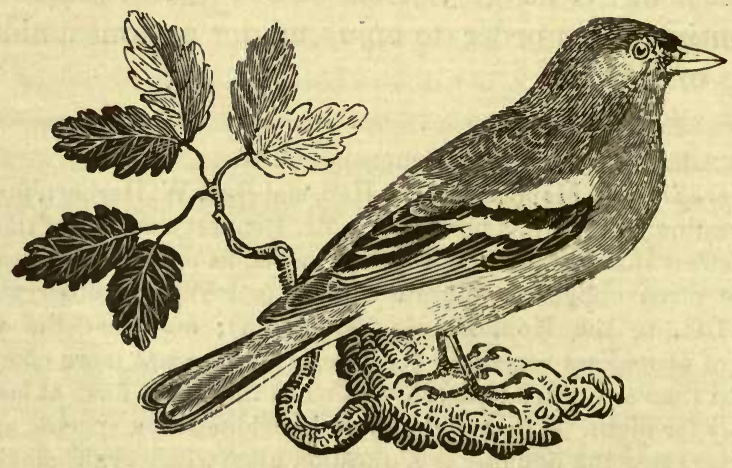

CHAFFinCH.

For many years past I have observed that towards Christmas vast flocks of chaffinches have appeared in the fields ; many more, I used to think, than could be hatched in any one neighbourhood. But, when I came to observe them more narrowly, I was amazed to find that they seemed to me to be almost all hens. I communicated my suspicions to some intelligent neighbours, who, after taking pains about the matter, declared that they also thought them all mostly females; at least fifty to one. This extraordinary occurrence brought to my mind the remark of Linnæus; 
that "before winter all their hen chaffinches migrate through Holland into Italy." Now I want to know, from some curious person in the north, whether there are any large flocks of these finches with them in the winter, and of which sex they mostly consist? For, from such intelligence, one might be able to judge whether our female flocks migrate from the other end of the island, or whether they come over to us from the continent. ${ }^{1}$

We have, in the winter, vast flocks of the common linnets ; more, I think, than can be bred in any one district. These, I observe, when the spring advances, assemble on some tree in the sunshine, and join all in a gentle sort of chirping, as if they were about to break up their winter quarters, and betake themselves to their proper summer homes." It is well known, at least, that the swallows and the fieldfares do congregate with a gentle twittering before they make their respective departure.

You may depend on it that the bunting, Emberiza miliaria, does not leave this county in the winter. In January, 1767, I saw several dozen of them, in the midst of a severe frost, among the bushes on the downs near Andover: in our woodland enclosed district it is a rare bird. ${ }^{3}$

Wagtails, both white and yellow, ${ }^{4}$ are with us all the

1 This separation of the sexes in winter has been noticed by other observers, but it is not universally the rule, for in some parts of the country inany individuals of both sexes remain throughout the winter and do not flock. - ED.

2 Linnets flock in September, and continue to congregate till March. -ED.

3 Since this remark was penned by Gilbert White, another species of bunting has been observed in his parish, namely, the cirl bunting, Emberiza cirlus. Not only have we seen this bird there in autumn, but Mr. Bell (the fortunate owner of Gilbert White's old house), informs us that it has nested there to his knowledge on several occasions, and successfully reared its young.-En.

4 By the yellow wagtail, White here means the winter yellow wagtail, or, as it is generally called, the grey wagtail ( $M$. boarula, Linn.) It is a local resident, breeding regularly in Scotland and the north of England, but is generally regarded in the south of England as a winter visitant. It has, however, been found nesting in many of the southern counties, as Sussex, Dorset, Gloucester, Devon and Cornwall.--Ev. 
winter. Quails crowd to our southern coast, and are often killed in numbers by people that go on purpose.

Mr. Stillingfleet, in his Tracts, says that, " if the wheatear (Enanthe $)^{1}$ does not quit England, it certainly shifts places ; for about harvest they are not to be found, where

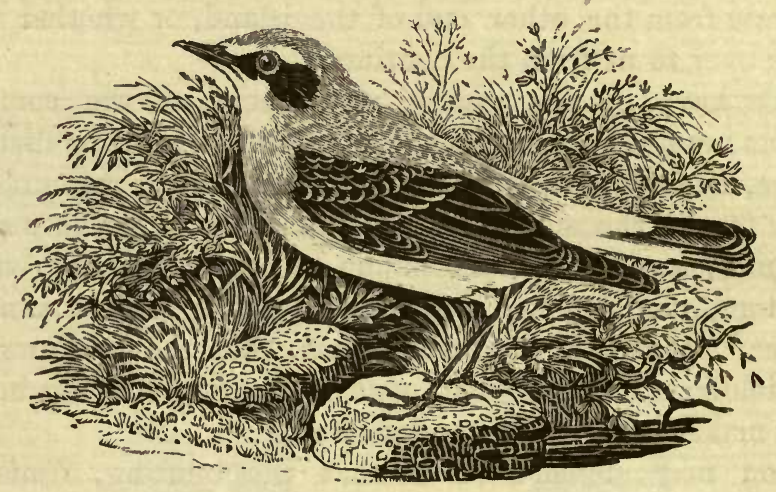

WHEATEAR.

there was before great plenty of them." This well accounts for the vast quantities that are caught about that time on the South Downs near Lewes, where they are esteemed a delicacy. There have been shepherds, I have been credibly

I Saxicola ænanthe (Linn.) The popular name "wheatear" appears to have been originally local and confined to the South Downs. Elsewhere it is called "fallow-chat" and "white-tail." Willughby, referring to this bird, calls it "the fallow-smick, in Sussex the wheatear, because the time of wheat-harvest they wax very fat." Many other derivations of the name, however, have been suggested, amongst others the following is perhaps as plausible as any. Those who are acquainted with the wheatear, know that the basal half of the tail is white, and that as the bird moves, this white patch is very conspicuous. "Wheat" may easily be a corruption of " whit" or "white," and as regards the "ear," if we affix the " $\mathrm{e}$ " instead of prefixing it, and insert a penultimate letter, we have the substantive by which our Saxon forefathers would have described that portion of the anatomy which is white. This view receives some support from the spelling adopted by the earlier English writers ( $c f$. Chaucer's "Miller's Tale"), and Mr. Bennett has suggester that "Hwitærs" may possibly have been its Saxon name. In France to this day the bird is called "cul-blanc."-ED. 
informed, that have made many pounds in a season by catching them in traps. And though such multitudes are taken, I never saw (and I am well acquainted with those parts) above two or three at a time: for they are never gregarious. They may perhaps migrate in general; and, for that purpose, draw towards the coast of Sussex in autumn; but that they do not all withdraw I am sure; because I see a few stragglers in many counties, at all times of the year, especially about warrens and stone quarries. ${ }^{1}$

I have no acquaintance, at present, among the gentlemen of the navy; but have written to a friend, who was a seachaplain in the late war, desiring him to look into his minutes, with respect to birds that settled on their rigging during their voyage up or down the Channel. What Hasselquist says on that subject is remarkable; there were little short-winged birds frequently coming on board his ship all the way from our Channel quite up to the Levant, especially before squally weather. ${ }^{2}$

What you suggest, with regard to Spain, is highly probable. The winters of Andalusia are so mild, that, in all likelihood, the soft-billed birds that leave us at that season may find insects sufficient to support them there.

Some young man, possessed of fortune, health, and leisure, should make an autumnal voyage into that kingdom; and should spend a year there, investigating the natural history of that vast country. Mr. Willughby ${ }^{3}$ passed through that kingdom on such an errand; but he seems to have skirted along in a superficial manner and an ill humour, being much disgusted at the rude dissolute. mm jom manners of the people.

I have no friend left now at Sunbury to apply to about the swallows roosting on the aits of the Thames; nor can I

1 On this subject the reader may be referred to Knox's "Ornithological Rambles in Sussex," p. 194 ; and Professor Newton's edition of Yarrell's " Hist. Brit. Birds," vol. i. pp. 350, 351.-ED.

2 This statement has been confirmed repeatedly by subsequent observers.-ED.

3 See Ray's "Travels," p. 466.-G. W. 
hear any more about those birds which I suspected were Meruloe torquatoe. ${ }^{1}$

As to the small mice, I have farther to remark, that though they hang their nests for breeding up amidst the straws of the standing corn, above the ground, yet I find that, in the winter, they burrow deep in the earth, and make warm beds of grass; but their grand rendezvous seems to be in corn-ricks, into which they are carried at harvest. A neighbour housed an oat-rick lately, under the thatch of which were assembled near a hundred, most of which were taken; and some I saw. I measured them; and found that, from nose to tail, they were just two inches and a quarter, and their tails just two inches long. ${ }^{2}$ Two of them, in a scale, weighed down just one copper halfpenny, which is about the third of an ounce avoirdupois ; so that I suppose they are the smallest quadrupeds in this island. A full-grown Mus domesticus medius weighs, I find, one ounce lumping weight, which is more than six times as much as the mouse above; and measures from nose to rump four inches and a quarter, and the same in its tail.

We have had a very severe frost and deep snow this month. My thermometer was one day fourteen degrees and a half below the freezing point, within doors. The tender evergreens were injured pretty much. It was very providential that the air was still, and the ground well covered with snow, else vegetation in general must have suffered prodigiously. There is reason to believe that some days were more severe than any since the year $1739-40 .^{1}$

1 See antea, p. 44.

2 It is perhaps not generally known that the tail of the harvest mouse is prehensile, and is in consequence of great service to the little animal when descending the wheat stalks amongst which its nest is usually suspended. In "The Zoologist" for 1843, p. 289, will be found a woodcut in illustration of this fact as observed by the Rev. Pemberton Bartlett.-ED.

3 A full account of the effects of this short but intense frost will be found in Letter LXI. to the Hon. Daines Barrington. 


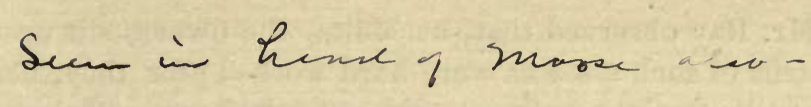

\section{LETTER XIV.}

TO THOMAS PENNANT, ESQUIRE.

Selborne, March 12, 1768.

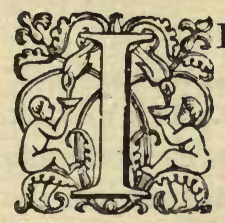

some curious gentleman would procure the head of a fallow-deer, and have it dissected, he would find it furnished with two spiracula, or breathing places, besides the nostrils; probably analogous tot he puncta lachrymalia in the human head. When deer are thirsty they plunge their noses, like some horses, very deep under water while in the act of drinking, and continue them in that situation for a considerable time; but, to obviate any inconveniency, they can open two vents, one at the inner corner of each eye, having a communication with the nose. Here seems to be an extraordinary provision of nature worthy our attention; and which has not, that I know of, been noticed by any naturalist. For it looks as if these creatures would not be suffocated, though both their mouths and nostrils were stopped. This curious formation of the head may be of singular service to beasts of chase, by affording them free respiration; and no doubt these additional nostrils are thrown open when they are hard run. ${ }^{1}$

1 In answer to this account, Mr. Pennant sent me the following ourious and pertinent reply. "I was much surprised to find in the antelope something analogous to what you mention as so remarkable in deer. This animal also has a long slit beneath each eye, which can be opened and shut at pleasure. On holding an orange to one, the creature made

- as much use of those orifices as of his nostrils, applying them to the fruit, and seeming to smell it through them."-G. W.

Both White and Pennant, however, were here misled by appearances, for it has since been shown by anatomical investigation, that there is no communication between those cavities and the nostrils, they being rather the site of a peculiar secretion. Dr. Jacob, in a paper "On the infraorbital cavities in deer and antelopes," published in the "Edinburgh 
Mr. Ray observed that, at Malta, the owners slit up the nostrils of such asses as were hard worked; for they, being naturally straight or small, did not admit air sufficient to serve them when they travelled, or laboured in that hot climate. And we know that grooms, and gentlemen of the turf, think large nostrils necessary, and a perfection, in hunters and running horses. Oppian, the Greek poet, by the following line, seems to have had some notion that stags have four spiracula.

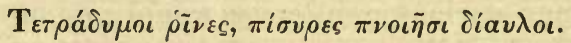

"Quadrifidæ nares, quadruplices ad respirationem canales."

Opr. Cyn. lib. ii. 1. 181

Writers, copying from one another, make Aristotle say that goats breathe at their ears; whereas he asserts just the

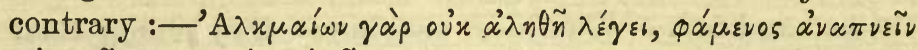
$\tau \alpha^{\prime} \varsigma$ a $\alpha^{\tau} \gamma \alpha \varsigma$ $x \alpha \tau \alpha^{\prime} \tau \alpha^{\prime} \omega^{\tau} \tau \alpha$. "Alcmæon does not advance what is true, when he avers that goats breathe through their ears."-History of Animals, Book I. chap. xi. ${ }^{1}$

Philosophical Journal" for October, 1835, says : "The passage of air through these cavities cannot take place, as they are perfectly impervious towards the nostril; but I have no doubt that the fact stated [by White] is correct; the air which escapes passing not through the infra-orbital sacs, but through the lachrymal passages, which are very large, consisting of two openings capable of admitting the end of a crow's quill, the entrance to a tortuous canal, which conducts the tears to the extremity of the nose. Introducing a pipe into the outlet of the nasal duct, at the extremity of the nose, I can without difficulty force a current of air or water through the nasal duct [Quare, lachrymal sinus.Ev.] and it therefore appears reasonable to admit that the effect observed [by White], arose from the animal forcing the air into the nostrils while the nose and mouth were immersed in water." - Ev.

${ }^{1}$ It is possible that this idea may have originated in the possession by the chamois of post-auditory sinuses; the openings of which behind the base of the ears may have been regarded as orifices for breathing, in the same manner as a similar function was erroneously ascribed to the suborbital sinuses. There is more reason in the supposition that the ears communicate with the nose, than that the suborbital sinus has any such communication; since in all animals that have a tympanic carity opening upon the surface by an external passage, there is another conduit termed the Eustachian tube, leading inwards from the tympanum to the nose, the use of which is to regulate the pressure of the atmosphere upon the membrana tympani, and to conrey superfluous moisture to the nose.-Ev. 


\section{LETTER XV.}

TO THOMAS PENNANT, ESQUIRE.

Selborne, March 30, 1768.

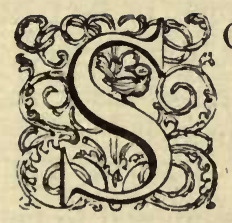

OME intelligent country people have a notion that we have in these parts a species of the genus mustelinum, besides the weasel, stoat, ferret, and polecat; a little reddish beast, not much bigger than a field mouse, but much longer, which they call a "cane." This piece of intelligence can be little depended on; but farther inquiry may be made. ${ }^{1}$

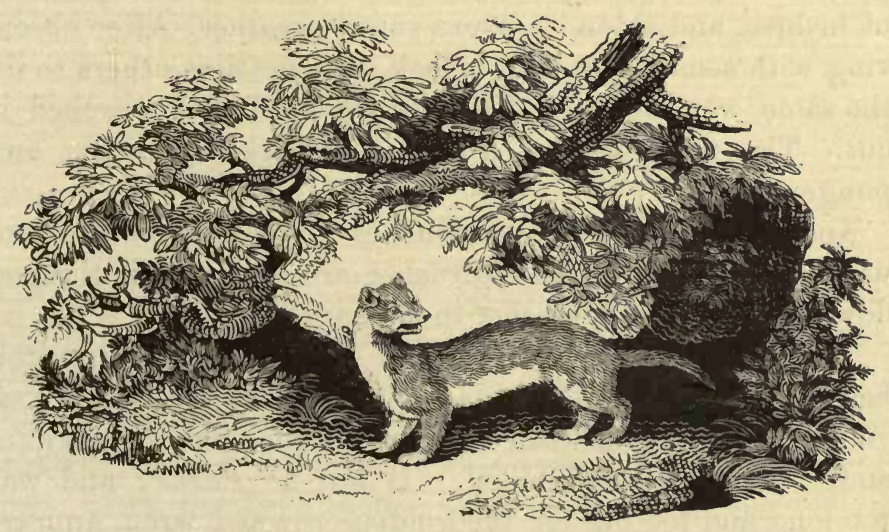

WEASEL.

A gentleman in this neighbourhood had two milk-white rooks in one nest. A booby of a carter, finding them before they were able to fly, threw them down and destroyed them, to the regret of the owner, who would have been glad to have preserved such a curiosity in his rookery. I saw the birds myself nailed against the end of a barn, and

\footnotetext{
1 Cane is a provincial name for the female of the common weasel, which is usually one-fourth smaller than the male.-ED.
} 
was surprised to find that their bills, legs, feet, and claws were milk-white.

A shepherd saw, as he thought, some white larks on a down above my house this winter: were not these the snowflake, the Emberiza nivalis of the British Zoology? No doubt they were.

A few years ago I saw a cock bullfinch in a cage, which had been caught in the fields after it was come to its full colours. In about a year it began to look dingy; and, blackening every succeeding year, it became coal-black at the end of four. Its chief food was hempseed. Such influence has food on the colour of animals! The pied and mottled colours of domesticated animals are supposed to be owing to high, various, and unusual food.

I had remarked, for years, that the root of the cuckoopint (Arum) was frequently scratched out of the dry banks of hedges, and eaten in severe snowy weather. After observing with some exactness, myself, and getting others to do the same, we found it was the thrush kind that searched it out. The root of the Arum is remarkably warm and pungent.

Our flocks of female chaffinches have not yet forsaken us. The blackbirds and thrushes are very much thinned down by that fierce weather in January.

In the middle of February I discovered, in my tall hedges, a little bird that raised my curiosity ; it was of that yellow-green colour that belongs to the Salicaria kind, ${ }^{1}$ and, I think, was soft-billed. It was no Parus; and was too long and too big for the golden-crowned wren, appearing most like the largest willow-wren. ${ }^{2}$ It hung sometimes with its back downwards, but never continuing one moment in the same place. I shot at it, but it was so desultory that I missed my aim.

1 By Salicaria, White evidently means the willow-wren group, and not the reed warblers, to which the generic term Salicaria is often applied.-Ev.

2 It was probably the Chiff-chaff, although the date mentioned would be an unusually early one at which to find this hardy little bird here. In 1872, the Chiff-chaff was seen at Torquay on the 2nd March, and at Chudleigh and Taunton on the 9 th of that month.-Eo. 
I wonder that the stone curlew (Charadrius oedicnemus ${ }^{1}$ ), should be mentioned by the writers as a rare bird; it abounds in all the campaign parts of Hampshire and Sussex, and breeds, I think, all the summer, having young ones, I know, very late in the autumn. Already they begin clamouring in the evening. They cannot, I think, with any propriety, be classed, as they are by Mr. Ray, among birds "circa aquas versantes ;" for with us, by day at least, they haunt only the most dry, open, upland fields and sheepwalks, far removed from water; what they may do in the night I cannot say. Worms are their usual food, but they also eat toads and frogs. ${ }^{2}$

I can show you some good specimens of my new mice. Linnæus perhaps would call the species Mus minimus.

\section{LETTER XVI.}

\section{TO THOMAS PENNANT, ESQUIRE.}

Selborne, April 18, 1768.

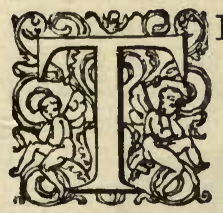

HE history of the stone curlew (Charadrius odicnemus) is as follows. It lays its eggs, usually two, never more than three, on the bare ground, without any nest, in the field; so that the countryman, in stirring his fallows, often destroys them. The young run immediately from the egg like partridges, \&c. and are withdrawn to some flinty field by the dam, where they skulk among the stones, which are their best security; for their feathers are so exactly of the colour of our grey spotted flints, that the most exact observer, unless he catches the eye of the young

1 Edicnemus crepitans, ТЕмм.

2 The stomachs of several stone curlews which we have examined at different times, were filled chiefly with the remains of beetles, but in one we found the remains of a long-tailed field mouse--ED. 
bird, may be eluded. The eggs are short and round; of a dirty white, spotted with dark bloody blotches. Though I might not be able, just when I pleased, to procure you a bird, yet I could show you them almost any day; and any evening you may hear them round the village, for they make a clamour which may be heard a mile. Edicnemus is a most apt and expressive name for them, since their legs seem swollen like those of a gouty man. ${ }^{1}$ After harvest I have shot them before the pointers in turnip-fields.

I make no doubt but there are three species of the willow wrens; two I know perfectly; but have not been able yet to procure the third..$^{2}$ No two birds can differ more in their

1 It is only the young of the year which have the upper part of the tarsus so much swollen. The same thing is observable, but less markedly, in the young of most other agallatorial birds. - Ev.

${ }^{2}$ Gilbert White clearly distinguishes three species of these little birds; and he seems to have had some idea of a fourth; but on this point there is a confusion in the entries in the Naturalist's Calendar, which has perhaps arisen from his having used different names for the same bird in noting down his observations in different years. Five different names are employed in the Calendar to designate some species of willow wren. The first named, i.e. the " small uncrested willow wren," appearing on the 19th of March, and called in the text "the chirper," is said to have black legs; th is is the Chiff-chaff, Ph. rufa. The second appearing on April 11, as the "middle yellow wren," the third on April 14, as the "second willow or laughing wren," and the fifth on April 17, as the "middle willow wren," must all be referred to one and

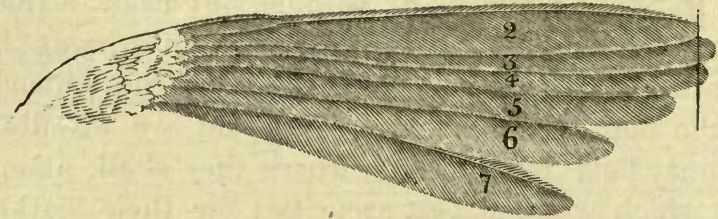

QUILL FEATHERS OF THE WOOD WREN.

the same species, namely the Willow wren par excellence Ph.trochilus of modern naturalists. The fourth, entered under date April 17, as the "large shivering willow wren," must be the Wood wren $P h$. sibilatrix.

The three British species of willow wrens may be thus distinguished. The Wood wren (Ph. sibilatrix) is the largest of the three, measuring in length about 5.2 inches, in wing 3 inches, and tarsus 0.7 inches. It has 
notes, and that constantly, than those two that I am acquainted with; for the one has a joyous, easy laughing note; the other a harsh loud chirp. The former is every way larger, and three-quarters of an inch longer, and weighs two drams and a half; while the latter weighs but two; so the songster is one-fifth heavier than the chirper. The chirper (being the first summer-bird of passage that is heard, the

comparatively the longest wings, the latter when closed covering threefourths of the tail, and the longest legs. In the wing the second primary is nearly equal in length to the fourth as shown in the cut opposite, while the third and fourth have their outer webs sloped off towards the extremity (this peculiarity seems to have been inadvertently overlooked by the artist). In colour it is much greener above, and of a purer white beneath than either of its congeners. The legs are flesh-coloured. The Willow wren (Ph.trochilus) measures in length as nearly as possible 5 inches, wing $2 \cdot 6$ and tarsus $0 \cdot 7$. The wing is thus comparatively shorter, the second primary being equal to the sixth, and the third, fourth and fifth with their outer webs sloped off towards the extremity.

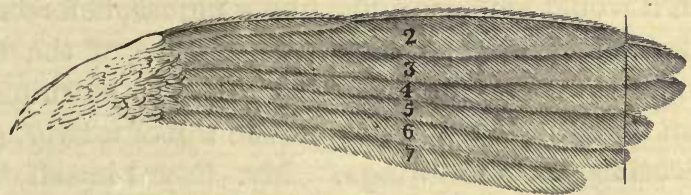

QUILL-FEATHERS OF THE WILLOW WREN.

In colour it is the yellowest of the three species, and this is particularly observable in young birds in the plumage of their first autumn. The legs are flesh-coloured.

The Chiff-chaff (Ph. rufa) is the smallest of the three, measuring in length about $4 \cdot 7$ inches, wing $2 \cdot 4$, and tarsus $0 \cdot 6$. The wing is re-

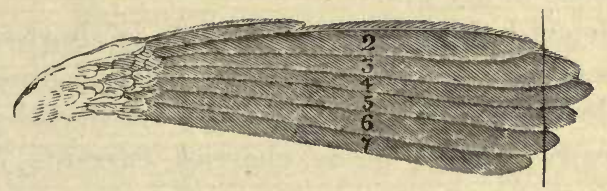

QUILL-FEATHERS OF THE CHIFF-CHAFF.

markably short, the second primary being about equal to or no longer than the seventh, and the third, fourth, fifth, and sixth have their outer webs sloped off towards the extremity.

In regard to colour, greenish brown is the prevailing tint above, white tinged with yellow beneath. The legs are hair brown.-ED. 
wryneck sometimes excepted) begins his two notes in the middle of March, and continues them through the spring and summer till the end of August, as appears by my journals. The legs of the larger of these two are fleshcoloured; of the less, black.

The grasshopper-lark ${ }^{1}$ began his sibilous note in my fields last Saturday. Nothing can be more amusing than the whisper of this little bird, which seems to be close by, though at a hundred yards distance; and when close at your ear, is scarce any louder than when a great way off. Had I not been a little acquainted with insects, and known that the grasshopper kind is not yet hatched, I should have hardly believed but that it had been a Locusta whispering in the bushes. The country people laugh when you tell them that it is the note of a bird. It is a most artful creature, skulking in the thickest part of a bush; and will sing at a yard distance, provided it be concealed. I was obliged to get a person to go on the other side of the hedge where it haunted; and then it would run, creeping like a mouse, before us for a hundred yards together, through the bottom of the thorns; yet it would not come into fair sight; but in a morning early, and when undisturbed, it sings on the top of a twig, gaping and shivering with its wings. Mr. Ray himself had no knowledge of this bird, but received his account from $\mathrm{Mr}$. Johnson, who apparently confounds it with the Reguli non cristati, ${ }^{2}$ from which it is very distinct. See Ray's Philosophical Letters, p. 108.

The flycatcher (Stoparola) has not yet appeared; it usually breeds in my vine.

The redstart begins to sing ; its note is short and imperfect, but is continued till about the middle of June.

The willow wrens (the smaller sort) are horrid pests in a garden, destroying the pease, cherries, currants, \&c. $;^{3}$ and are so tame that a gun will not scare them.

1 The grasshopper-warbler, Salicaria locustella (Latham).

2 The willow wrens.

3 This sentence has possibly led to the destruction of many of these little birds, which are in truth peculiarly the gardener's friends 
A List of the Summer Birds of Passage discovered in this Neighbour. hood, ranged somewhat in the Order in which they appear:

$\begin{array}{ll}\text { Smallest willow wren, } & \text { Minnai Nomina. } \\ \text { Wryneck, } & \text { Yunx torquilla: } \\ \text { House swallow, } & \text { Hirundo rustica: } \\ \text { Martin, } & \text { Hirundo urbica: } \\ \text { Sand martin, } & \text { Hirundo riparia: } \\ \text { Cuckoo, } & \text { Cuculus canorus: } \\ \text { Nightingale, } & \text { Motacilla luscinia: } \\ \text { Blackcap, } & \text { Motacilla atricapilla: }\end{array}$

The Rev. W. Herbert observed that his gardeners were in the habit of catching the hens on their nests in the strawberry beds, and killing them, under the impression that they made great havoc among the cherries; yet he affirmed that they never tasted the fruit, nor could those which were reared from the nest in confinement be induced to touch it. They merely peck off the Aphides which are injurious to the fruit trees.

- The birds which were mistaken for them are the young of the garden warbler (Sylvia hortensis), with which species apparently White was not acquainted, as it is not mentioned by him, nor does it appear in his list of summer birds. The young of this species have a strong tinge of yellow on the sides, which disappears after the moult, and gives them very much the appearance of the willow wren when seen upon the tree, thongh they are larger and stouter, and in habits more nearly resemble the blackcaps, with whom they are associated in the plunder of fruit.

Mr. Herbert remarks - " I could not persuade my gardener that the yellow wrens did not eat the cherries, till he had shot some of the pettychaps (garden-warbler) in the act of eating them, and compared them with the wrens, when he became satisfied of the error. In order to ascertain, beyond doubt, whether the yellow wrens ever eat fruit, I left some which had been reared tame from the nest, and of course were more likely to feed upon any new thing than the wild birds, without victuals, till they were very hungry, and I then offered them little bits of ripe cherry. They seized them with avidity, but immediately threw them down again, and it was evident that they would rather have starved than eat the fruit. I had no doubt of the fact, but I wished to set the question completely at rest; for I have seen them pulling the leaves of the cherry-trees so near the fruit, that any person might be deceived, and think they were eating it, and the young of the pettychaps (garden-warbler) look so like them, that I am not in the least surprised at their having got into bad repute with the gardeners."-ED.

1 White seems to have applied the Latin name Motacilla trochilus to three different birds in this list, probably because he was unable to identify them with the Latin names respectively bestowed on them by older authors. He therefore employed the expression Moiacilla trochilus as he would say " a kind of willow wren."-ED. 


$\begin{array}{ll}\text { Whitethroat, } & \text { Motacilla sylvia: } \\ \text { Middle willow wren, } & \text { Motacilla trochilus: } \\ \text { Swift, } & \text { Hirundo apus : } \\ \text { Stone Curlew ? } & \text { Charadrius codicnemus } \\ \text { Turtle-dove? } & \text { Turtur Aldrovandi? } \\ \text { Grasshopper lark, } & \text { Alauda trivialis : } \\ \text { Landrail, } & \text { Rallus crex: } \\ \text { Largest willow wren, } & \text { Motacilla trochilus: } \\ \text { Redstart, } & \text { Motacilla phonicurus : } \\ \text { Goatsucker or Fern-owl, } \text { Caprimulgus europaus: } \\ \text { Flycatcher, } & \text { Muscicapa grisola. }\end{array}$

My countrymen talk much of a bird that makes a clatter with his bill against a dead bough, or some old pales, calling it a jar-bird. I procured one to be shot in the very fact; it proved to be the Sitta europoea (the nuthatch). Mr. Ray says that the less spotted woodpecker does the same. This noise may be heard a furlong or more.

Now is the only time to ascertain the short-winged summer birds; for, when the leaf is out, there is no making any remarks on such a restless tribe; and, when once the young begin to appear, it is all confusion; there is no distinction of genus, species, or sex.

In breeding time snipes play over the moors, piping and humming; they always hum as they are descending. Is not their hum ventriloquous like that of the turkey? Some suspect it is made by their wings. ${ }^{1}$

This morning I saw the golden-crowned wren, whose crown glitters like burnished gold. It often hangs, like a titmouse, with its back downwards.

1 The "humming" of the snipe bas already been adverted to in Letter $\mathrm{X}$, and will be found again noticed in Letter XXXIX. See foot-note anteà, p. 35. In addition to the authorities there quoted, the reader may be referred on this subject to Stevenson's "Birds of Norfolk," vol. ii. p. 316, and Saxby's "Birds of Shetland," p. 204. The lastnamed author remarks: "The many years' intimate acquaintance with the bird and its habits which I have enjoyed, confirms me in the now generally received opinion that the 'drumming' is produced by the vibration of the wings alone."-ED. 


\section{LETTER XVII.}

TO THOMAS PENNANT, ESQUIRE.

Selborne, June 18, 1768.

$\mathrm{N}$ Wednesday last arrived your agreeable letter of June the 10th. It gives me great satisfaction to find that you pursue these studies still with such vigour, and are in such forwardness with regard to reptiles

and fishes.

The reptiles, few as they are, I am not acquainted with, so well as I could wish, with regard to their natural history. There is a degree of dubiousness and obscurity attending the propagation of this class of animals, something analogous to that of the Cryptogamia in the sexual system of plants; and the case is the same with regard to some of the fishes; as the eel, \&c. ${ }^{1}$

The method in which toads procreate and bring forth seems to be very much in the dark. Some authors say that they are viviparous; and yet Ray classes them among his oviparous animals $;^{2}$ and is silent with regard to the manner

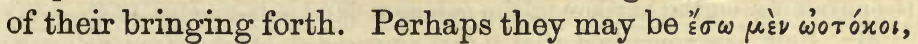

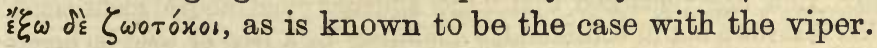

The copulation of frogs (or at least the appearance of itfor Swammerdam proves that the male has no penis intrans) is notorious to everybody; because we see them sticking upon each others' backs for a month together in the spring and yet I never saw or read of toads being observed in the same situation. ${ }^{3}$

1 Since this observation was published it has been demonstrated by Mr. Yarrell that eels deposit their spawn like other fishes.-ED.

2 Toads are oviparous.-ED.

3 In this respect toads do not differ from firogs.-ED. 
It is strange that the matter with regard to the venom of toads has not been yet settled. ${ }^{1}$ That they are not noxious to some animals is plain; for ducks, buzzards, owls, stone curlews, and snakes eat them, to my knowlege, with impunity. And I well remember the time, but was not eyewitness to the fact (though numbers of persons were), when a quack, at this village, ate a toad to make the country people stare; afterwards he drank oil.

I have been informed also, from undoubted authority, that some ladies (ladies you will say of peculiar taste) took a fancy to a toad, which they nourished, summer after summer, for many years, till he grew to a monstrous size, with the maggots which turn to flesh flies. The reptile used to come forth every evening from a hole under the garden steps; and was taken up, after supper, on the table to be fed. But at last a tame raven, kenning him as he put forth his head, gave him such a severe stroke with his horny beak as put out one eye. After this accident the creature languished for some time and died.

1 This question has since been set at rest. The old prejudice that they possess the power of communicating poison by their bite is wholly unfounded; and the fluid which they eject from the cloaca when frightened or handled is, in their case as in frogs, pure limpid water. The skin, however, has been ascertained by Dr. Davy to secrete an acid liquid, not perhaps poisonous, but capable of producing an uncomfortable sensation on the tongue; a secretion of somewhat similar qualities is poured out on the surface of the common land salamander of Europe.

Mr. Bell has remarked that " the aqueous fluid above mentioned, which is thrown out in considerable quantities by a frog or toad on being taken in the hand, is held in a double bladder which opens into the cloaca ; and this fact is connected with the absorbing power of the skin. The cutaneous surface of these animals is now known to serve the purposes of respiration; but in order to perform this function, it is necessary that it should be kept constantly in a moist condition. When placed in water or in a sufficiently damp situation, the surface of the body absorbs a considerable quantity of water, which is conveyed to the receptacle above mentioned, there to remain as in a reservoir for future use; and if the animal be exposed to a dry atmosphere, the fluid is re-absorbed, and again secreted on the surface of the skin, in order to keep up its respiratory function. This is the true history of the poisonous liquid of toads, as it is considered, which renders them the objects of dread and hatred to the ignorant of all parts of the country."-ED. 
I need not remind a gentleman of your extensive reading of the excellent account there is from Mr. Derham, in Ray's "Wisdom of God in the Creation" (p.365), concerning the migration of frogs from their breeding ponds. In this account he at once subverts that foolish opinion of their dropping from the clouds in rain; showing that it is from the grateful coolness and moisture of those showers that they are tempted to set out on their travels, which they defer till those fall. Frogs are as yet in their tadpole state; but, in a few weeks, our lanes, paths, fields will swarm for a few days with myriads of thoso emigrants, no larger than my little finger nail. Swammerdam gives a most accurate account of the method and situation in which the male impregnates the spawn of the female. How wonderful is the economy of Providence with regard to the limbs of so vile a reptile! While it is an aquatic it has a fish-like tail, and no legs; as soon as the legs sprout, the tail drops off as useless, and the animal betakes itself to the land ! ${ }^{1}$

Merret, I trust, is widely mistaken when he advances that the Rana arborea is an English reptile; it abounds in Germany and Switzerland.

It is to be remembered that the Salamandra aquatica of Ray (the water-newt or eft) will frequently bite at the angler's bait, and is often caught on his hook. I used to take it for granted that the Salamandra aquatica was hatched, lived, and died, in the water. But John Ellis, Esq., F.R.S., (the coralline Ellis), asserts, in a letter to the Royal Society, dated June the 5 th, 1766, in his account of the mud inguana, an amphibious bipes from South Carolina, that the water-eft,

1 Mr. Bell has pointed out that the whole of the typical Batrachia, the frogs, toads, newts, salamanders, \&c. undergo a complete metamorphosis. In the land species, which from their habits have no constant access to water, the aquatic portion of their existence, during which the gills remain attached, cannot be passed in that medium in the same manner as the frogs, \&c. They undergo the metamorphosis therefore in the oviduct, before they are excluded from the mother, and come forth in the perfect condition. But in the other forms, the change takes place in the water, and the young live there for a time in a fish-like state, as regards not only their respiration, but most of the other functions of life.-F. 
or newt, is only the larva of the land-eft, as tadpoles are of frogs. Lest I should be suspected to misunderstand his meaning, I shall give it in his own words. Speaking of the opercula, or coverings to the gills, of the mud inguana, he proceeds to say that "The form of these pennated coverings approaches very near to what I have some time ago observed in the larva, or aquatic state, of our English Lacerta, known by the name of eft, or newt; which serve them for coverings to their gills, and for fins to swim with while in this state; and which they lose, as well as the fins of their tails, when they change their state and become land animals, as I have observed, by keeping them alive for some time myself."

Linnæus, in his Systema Naturæ, hints at what Mr. Ellis advances, more than once.

Providence has been so indulgent to us as to allow of but one venomous reptile of the serpent kind in these kingdoms, and that is the viper. As you propose the good of mankind to be an object of your publications, you will not omit to mention common salad-oil as a sovereign remedy against the bite of the viper. ${ }^{1}$

As to the blind worm (Anguis fragilis, so called because it snaps in sunder with a small blow), I have found, on examination, that it is perfectly innocuous. ${ }^{2}$

A neighbouring yeoman (to whom I am indebted for some good hints) killed and opened a female viper about

1 We agree with Mr. Bell in thinking that the efficacy of oil as a remedy against the bite of the viper has probably been overrated. It is generally believed in those parts of the country where vipers abound to be very efficacious as an external application, as is also the fat of the reptile itself. The application of ammonia, however, both externally and internally, is recommended on much surer grounds.-ED.

2 A blindworm, which Mr. Daniel kept for some weeks in confinement, fed upon the little white slug (Limax agrestis, Linn.) so common in fields and gardens, eating six or seven of them one after the other; but it did not eat every day. It invariably took them in one position: elevating its head slowly above its victim, it would suddenly seize the slug by the middle, in the same manner that a ferret or dog will generally take a rat by the loins; it would then hold it thus sometimes for more than a minute, when it would pass its prey through its jaws, and swallow the slug head foremost. It refused the larger slugs, and would not touch either young frogs or mice.-ED. 
the 27th of May; he found her filled with a chain of eleven eggs, about the size of those of a blackbird; but none of them were advanced so far towards a state of maturity as to contain any rudiments of young. Though they are oviparous, yet they are viviparous also, hatching their young within their bellies, and then bringing them forth. Whereas snakes lay chains of eggs every summer in my melon beds, in spite of all that my people can do to prevent them; which eggs do not hatch till the spring following, as I have often experienced. Several intelligent folks assure me that they have seen the viper open her mouth and admit her helpless young down her throat on sudden surprises, just as the female opossum does her brood into the pouch under her belly, upon the like emergencies: and yet the London viper-catchers insist on it, to Mr. Barrington, that no such thing ever happens. ${ }^{1} \quad$ The serpent kind eat, I believe, but once in a year; or, rather, but only just at one season of the year. ${ }^{2}$ Country people talk much of a watersnake, but, I am pretty sure, without any reason; for the common snake (Coluber natrix) delights much to sport in the water, perhaps with a view to procure frogs and other food.

I cannot well guess how you are to make out your twelve

1 Upon this point Mr. Bell says :- I have been assured by a very honest and worthy gardener in Dorsetshire, that he had seen the young vipers enter the mouth of the mother when alarmed. I have never been able to obtain further evidence of the fact, though $I$ have made the most extensive inquiries in my power. If it be untrue, the popular error may have arisen from the circumstance of fully formed young having been found in the abdomen of the mother, ready to be excluded. The actions of the young which were emancipated from the oviduct by White on a subsequent occasion (see Letter XXXI. to Daines Barrington) do not appear necessarily to bear upon the question, as there are many instances of the young of animals manifesting the habits and instincts of their species immediately on coming into the world-as in the case of young ducks seeking the water, \&c.-ED.

2 The slow power of digestion possessed by serpents renders them capable of remaining a long time without food. If a snake swallows a frog, or a viper a mouse, it is several weeks before it is digested. It is probable, therefore, that they do not eat above three or four times in the course of a summer, and in winter not at all.-ED. 
species of reptiles, unless it be by the various species, or rather varieties, of our Lacertoe, of which Ray enumerates five. I have not had opportunity of ascertaining these; but remember well to have seen, formerly, several beautiful green Lacertoe on the sunny sandbanks near Farnham, in Surrey $;^{1}$ and Ray admits there are such in Ireland.

\section{LETTER XVIII.}

TO THOMAS PENNANT, ESQUIRE.

Selborne, July 27, 1768.

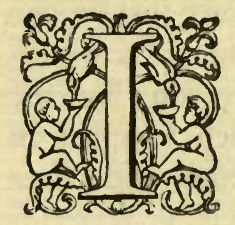

RECEIVED your obliging and communicative letter of June the $28 \mathrm{th}$, while I was on a visit at a gentleman's house, where I had neither books to turn to, nor leisure to sit down, to return you an answer to many queries, which I wanted to resolve in the best manner that I am able.

A person, by my order, has searched our brooks, but could find no such fish as the Gasterosteus pungitius; he found the Gasterosteus aculeatus in plenty. ${ }^{2}$ This morning, in a basket, I packed a little earthen pot full of wet moss, and in it some sticklebacks, male and female; the females big with spawn; some lamperns; some bulls-heads; but I could procure no minnows. The basket will be in Fleet Street by eight this evening; so I hope $\mathrm{Mazel}^{3}$ will have them fresh and fair to-morrow morning. I gave some

1 See Letter XXII.

2 G. pungitius, the ten-spined stickleback, although generally distributed, seems to be nowhere so abundant as the common stickleback, G. aculcatus.-Fi.

3 Peter Mazel, the engraver of the plates of Pennant's "British Zoology."-Ev. 
directions, in a letter, to what particulars the engraver should be attentive.

Finding, while I was on a visit, that I was within a reasonable distance of Ambresbury, I sent a servant over to that town, and procured several living specimens of loaches, which he brought safe and brisk in a glass decanter. They were taken in the gullies that were cut for watering the meadows. ${ }^{1}$ From these fishes (which measured from two to four inches in length) I took the following description : "The loach, in its general aspect, has a pellucid appearance; its back is mottled with irregular collections of small black dots, not reaching much below the linea lateralis, as are the back and tail fins; a black line runs from each eye down to the nose; its belly is of a silvery white; the upper jaw projects beyond the lower, and is surrounded with six feelcrs, three on each side; its pectoral fins are large, its ventral much smaller; the fin behind its anus small; its dorsal fin large, containing eight spines; its tail, where it joins to the tail fin, remarkably broad, without any taperness, so as to be characteristic of this genus; the tail fin is broad, and square at the end. From the breadth and muscular strength of the tail it appears to be an active nimble fish."”

In my visit I was not very far from Hungerford, and did not forget to make some inquiries concerning the wonderful method of curing cancers by means of toads. Several intelligent persons, both gentry and clergy, do, I find, give a great deal of credit to what was asserted in the papers; and I myself dined with a clergyman who seemed to bo persuaded that what is related is matter of fact; but, when I came to attend to his account, I thought I discerned circumstances which did not a little invalidate the woman's story of the manner in which she came by her skill. She says of herself, "that labouring under a virulent cancer,

$1 \mathrm{Mr}$. Bennett states that Ambresbury had become notorious for its loaches, on account of sportsmen there frequently, in frolic, swallowing one of them alive in a glass of white wine; but the fish is by no means a local one. It occurs generally throughout the country in brooks and rivulets, lurking under stones.-ED. 
she went to some church where there was a vast crowd; on going into a pew, she was accosted by a strange clergyman; who, after expressing compassion for her situation, told her that if she would make such an application of living toads as is mentioned, she would be well." Now is it likely that this unknown gentleman should expross so much tenderness for this single sufferer, and not feel any for the many thousands that daily languish under this terrible disorder? Would he not have made use of this invaluable nostrum for his own emolument; or, at least, by some means of publication or other, have found a method of making it public for the good of mankind? In short, this woman (as it appears to me) having set up for a cancerdoctress, finds it expedient to amuse the country with this dark and mysterious relation.

The water-eft has not, that I can discern, the least appearance of any gills; for want of which it is continually rising to the surface of the water to take in fresh air. ${ }^{1}$ I opened a big-bellied one, indeed, and found it full of spawn. Not that this circumstance at all invalidates the assertion that they are larvoe: for the larvo of insects are full of egg's, which they exclude the instant they enter their last state. The water-eft is continually climbing over the brims of the vessel, within which we keep it in water, and wandering away: and people every summer see numbers crawling out of the pools where they are hatched, up the dry banks. There are varieties of them, differing in colour; and some have fins up their tail and back, and some have not. ${ }^{2}$

1 This applies only to the adult; the young during the first months of their existence have external gills.-ED.

2 The appearance of fin-like expansions on the back and tail of the several species of Triton is confined to the male, and is only found in that sex at the season of reproduction.- En. 


\section{LETTER XIX.}

TO THOMAS PENNANT, ESQUIRE.

Sélborne, Aug. 17, 1768.

HAVE now, past dispute, made out three distinct species of the willow wrens (Motacilloe trochili) which constantly and invariably use distinct notes. ${ }^{1}$ But at the same time, I am obliged to confess that I know nothing of your willow lark." In my letter of April the 18th, I had told you peremptorily that I knew your willow lark, but had not seen it then : but, when I came to procure it, it proved, in all respects, a very Motacilla trochilus; only that it is a size larger than the two other, and the yellow green of the whole upper part of the body is more vivid, and the belly of a clearer white. ${ }^{3}$ I have specimens of the three sorts now lying before me; and can discern that there are three gradations of sizes, and that the least has black legs, and the other two flesh-coloured ones. The yellowest bird is considerably the largest, and has its quill feathers and secondary feathers tipped with white, which the others have not. This last haunts only the tops of trees in high beechen woods, and makes a sibilous grasshopper-like noise, now and then, at short intervals, shivering a little with its wings when it sings; and is, I make no doubt now, the Regulus non cristatus of Ray; which he says "cantat voce stridulâ locustoe." Yet this great ornithologist never suspected that there were three species.

1 See antea, pp. $56,57$.

2 Brit. Zool. edit. 1776, octavo, p. 381.-G. W.

3 This is evidently the Wood wren. Ph. sibilatrix.--ED. 


\section{LETTER XX.}

TO THOMAS PENNANT, ESQUIRE.

Selborne, Oct. 3, 1768.

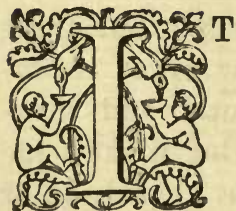

is, I find, in zoology, as in botany: all nature is so full, that that district produces the greatest variety which is the most examined. Several birds, which are said to belong to the north only, are, it seems, often in the south. I have discovered this summer three species of birds with us, which writers mention as only to be seen in the northern counties.

The first that was brought me (on the 14th of May) was the sandpiper (Tringa hypoleucos): it was a cock bird, and haunted the banks of some ponds near the village; and, as it had a companion, doubtless intended to have bred near. that water. Besides, the owner has told me since, that, on recollection, he has seen some of the same birds round his ponds in former summers.

The next bird that I procured (on the 21st of May) was a male red-backed butcher-bird (Lanius collurio). My neighbour, who shot it, says that it might easily have escaped his notice, had not the outcries and chatterings of the whitcthroats and other small birds drawn his attention to the bush where it was: its craw was filled with the legs and wings of beetles.

The next rare birds (which were procured for me last week) were some ring-ousels (Turdi torquati).

This week twelve months a gentleman from London, being with us, was amusing himself with a gun, and found, he told us, on an old yew hedge where there were berries, some birds like blackbirds, with rings of white round their necks : a neighbouring farmer also at the same time observed the same; but, as no specimens were procured, littlo 
notice was taken. I mentioned this circumstance to you in my letter of November the 4th, 1767: (you however paid but small regard to what I said, as I had not seen these birds myself :) but last week the aforesaid farmer, seeing a large flock, twenty or thirty, of these birds, shot two cocks and two hens : and says, on recollection, that he remembers to have observed these birds again last spring, about Ladyday, as it were, on their return to the north. Now perhaps these ousels are not the ousels of the north of England, but belong to the more northern parts of Europe; and may retire before the excessive rigour of the frosts in those parts; and return to breed in the spring, when the cold abates. If this be the case, here is discovered a new bird of winter passage, concerning whose migrations the writers are silent: but if these birds should prove the ousels of the north of England, then here is a migration disclosed within our own kingdom never before remarked. It does not yet appear whether they retire beyond the bounds of our island to the south; but it is most probable that they usually do, or else one cannot suppose that they would have continued so long unnoticed in the southern countries. The ousel is larger than a blackbird, and feeds on haws; but last autumn (when there were no haws) it fed on yew-berries: in the spring it feeds on ivy-berries, which ripen only at that season, in March and April.

I must not omit to tell you (as you have been so lately on the study of reptiles) that my people, every now and then, of late, draw up with a bucket of water from my well, which is sixty-three feet deep, a large black warty lizard with a fin tail and yellow belly. ${ }^{1}$ How they first came down at that depth, and how they were ever to have got out thence without help, is more than I am able to say.

My thanks are due to you for your trouble and care in the examination of a buck's head. As far as your discoveries reach at present, they seem much to corroborate my suspicions; and I hope Mr. —— may find reason to give his decision in my favour; and then, I think, we may

1 This is Triton palustris; as to the "fin-tail" see note, p. 68.-ED. 
advance this extraordinary provision of nature as a new instance of the wisdom of God in the creation.

As yet I have not quite done with my history of the Edicnemus, or stone-curlew; for I shall desire a gentleman in Sussex (near whose house these birds congregate in vast flocks in the autumn) to observe nicely when they leave him (if they do leave him), and when they return again in the spring: I was with this gentleman lately, and saw several single birds.

\section{LETTER XXI.}

TO THOMAS PENNANT, ESQUIRE.

Selborne, Nov. 28, 1768.

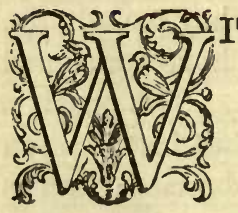

TH regard to the Edicnemus, or stonecurlew, I intend to write very soon to my friend near Chichester, in whose neighbourhood these birds seem most to abound; and shall urge him to take particular notice when they begin to congregate, and afterward to watch them most narrowly whether they do not withdraw themselves during the dead of the winter. When I have obtained information with respect to this circumstance, I shall have finished my history of the stone-curlew; which I hope will prove to your satisfaction, as it will be, I trust, very near the truth. ${ }^{1}$ This gentleman, as he occupies a large farm of his own, and is abroad early and late, will be a very proper spy upon the motions of these birds: and besides, as I have prevailed on him to buy the "Naturalist's Journal," (with which he is much delighted,) I shall expect that h3 will be very exact in his dates. ${ }^{2}$ It is very extraordinary,

1 This bird is again alluded to in Letter XXXIII. to Pennant.--ED.

2 The "Naturalist's Journal." Printed for W. Sandby, Fleet Strect, London; 1767. Price one shilling and sixpence.-ED. 
as you observe, that a bird so common with us should never straggle to you. ${ }^{1}$

And here will be the properest place to mentioa, while I think of it, an anecdote which the above mentioned gentleman told me when I was last at his house; which was that, in a warren joining to his outlet, many daws (Corvi moneduloe) build every year in the rabbit burrows under ground. The way he and his brothers used to take their nests, while they were boys, was by listening at the mouths of the holes; and, if they heard the young ones cry, they twisted the nest out with a forked stick. Some waterfowls (viz. the puffins)

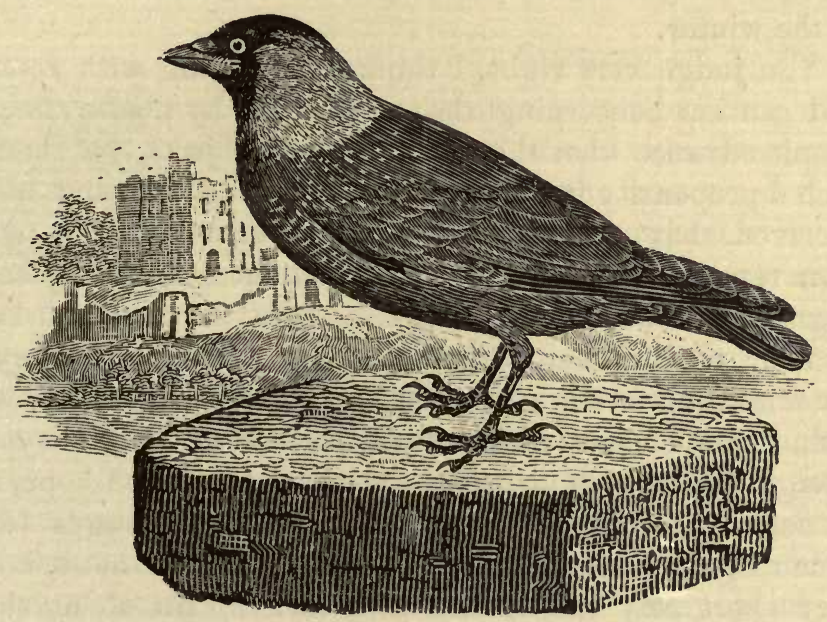

JACKDAW.

breed, I know, in that manner; but I should never have suspected the daws of building in holes on the flat ground. ${ }^{2}$

1 The Hon. and Rev. W. Herbert has observed that this bird is met with only on the chalk. He used to find it and its two eggs on the bare ground in September, at Highclere, in Hampshire, but only where there was a chalk subsoil. It never strayed to the sand or gravel, and consequently was not upon the heaths; but in the chalky turnip fields. This statement, though it may be true enough of the locality to which it refers, is not of universal application. See Stevenson's "Birds of Norfolk," vol. ii. pp. 51-64.-ED.

2 The stock-dove and the shell-drake may also be mentioned as species which make use of deserted rabbit-burrows to nest in.-ED. 
Another very unlikcly spot is made use of by daws as a place to breed in, and that is Stonehenge. These birds deposit their nests in the interstices between the upright and the impost stones of that amazing work of antiquity: which circumstance alone speaks the prodigious height of the upright stones, that they should be tall enough to secure those nests from the annoyance of shepherd boys, who are always idling round that place.

One of my neighbours last Saturday, November the 26th, saw a martin in a sheltered bottom: the sun shone warm, and the bird was hawking briskly after the flies. I am now perfectly satisfied that they do not all leave this island in the winter.

You judge very right, I think, in speaking with reserve and caution concerning the cures done by toads: for, let people advance what they will on such subjects, yet there is such a propensity in mankind towards deceiving and being deceived, that one cannot safely relate any thing from common report, especially in print, without expressing some degree of doubt and suspicion.

Your approbation, with regard to my new discovery of the migration of the ring-ousel, gives me satisfaction; and I find you concur with me in suspecting that they are foreign birds which visit us. You will be sure, I hope, not to omit to make inquiry whether your ring-ousels leave your rocks in the autumn. What puzzles me most, is the very short stay they make with us; for in about three weeks they are all gone. I shall be very curious to remark whether they will call on us at their return in the spring, as they did last year.

I want to be better informed with regard to ichthyology. ${ }^{1}$ If fortune had settled me near the seaside, or near some

1 At the time when White's remark was made, Pennant had in preparation the third volume of his "British Zoology," containing the fishes, which was published in the following year. This work, however, has naturally been superseded by others of more modern date and greater merit ; notably, Yarrell's "IIistory of British Fishes," Couch's "Fishes of the British Islands," and Günther's "Catalogue of Fishes in the British Museum."-Ev. 
great river, my natural propensity would soon have urged me to have made myself acquainted with their productions: but as I have lived mostly in inland parts, and in an upland district, my knowledge of fishes extends little farther than to those common sorts which our brooks and lakes produce.

\section{LETTER XXII.}

TO THOMAS PENNANT, ESQUIRE.

Selborne, Jan. 2, 1769.

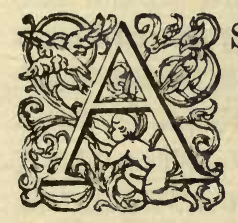

$\mathrm{S}$ to the peculiarity of jackdaws building with us under the ground in rabbit-burrows, you have, in part, hit upon the reason; for, in reality, there are hardly any towers or steeples in all this country. And perhaps, Norfolk excepted, Hampshire and Sussex are as meanly furnished with churches as almost any counties in the kingdom. We have many livings of two or three hundred pounds a year whose houses of worship make little better appearance than dove-cots. When I first saw Northamptonshire, Cambridgeshire, and Huntingdonshire, and the fens of Lincolnshire, I was amazed at the number of spires which presented themselves in every point of view. As an admirer of prospects, I have reason to lament this want in my own country; for such objects are very necessary ingredients in an elegant landscape.

What you mention with respect to reclaimed toads raises my curiosity. An ancient author, though no naturalist, has well remarked that "Every kind of beasts, and of birds, and of serpents, and things in the sea, is tamed, and hath been tamed, of mankind." 1

It is a satisfaction to me to find that a green lizard has actually been procured for you in Devonshire; because it 
corroborates my discovery, which I made many years ago, of the same sort, on a sunny sandbank near Farnham, in Surrey. I am well acquainted with the south hams of Devonshire; and can suppose that district, from its southerly situation, to be a proper habitation for such animals in their best colours. ${ }^{1}$

Since the ring-ousels of your vast mountains do certainly not forsake them against winter, our suspicions that those which visit this neighbourhood about Michaelmas are not English birds, but driven from the more northern parts of Europe by the frosts, are still more reasonable; and it will be worth your pains to endeavour to trace from whence they come, and to inquire why they make so very short a stay.

In your account of your error with regard to the two species of herons, you incidentally gave me great entertainment in your description of the heronry at Cressi Hall; which is a curiosity I never could manage to see. Fourscore nests of such a bird on one tree is a rarity which I would ride half as many miles to have a sight of. Pray be sure to tell me in your next whose seat Cressi Hall is, and near what town it lies. ${ }^{2}$ I have often thought that those vast extents of fens have never been sufficiently explored. If half a dozen gentlemen, furnished with a good strength of water-spaniels, were to beat them over for a week, they would certainly find more species.

There is no bird, I believe, whose manners I have studied more than those of the Caprimulgus (the goatsucker), as it is a wonderful and curious creature: but I have always found that though sometimes it may chatter as it flies, as I know it does, yet in general it utters its jarring note sitting on a bough : and I have for many a half hour watched it as it sat with its under mandible quivering, and particularly this summer. It perches usually on a bare

$1 \mathrm{Mr}$. Bell thinks these were probably unusually bright and large individuals of Lacerta stirpium, now ascertained to be indigenous to this country. See Jenyns, "Man. Brit. Vert. An." p. 291.-ED.

2 Cressi or Cressy Hall, situate near Spalding, in Lincolnshire, was the seat of a branch of the ancient family of Heron. The heronry there has been long since destroyed.-ED. 
twig, with its head lower than its tail, in an attitude well expressed by your draughtsman in the folio British Zoology. This bird is most punctual in beginning its song exactly at the close of day; so exactly that I have known it strike up more than once or twice just at the report of the Portsmouth evening gun, which we can hear when the weather is still. It appears to me past all doubt that its notes are formed by organic impulse, by the powers of the parts of its windpipe, formed for sound, just as cats purr. You will credit me, I hope, when I assure you that, as my neighbours were assembled in an hermitage on the side of a steep hill where we drink tea, ${ }^{1}$ one of these churn-owls came and settled on the cross of that little straw edifice and began to chatter, and continued his note for many minutes; and we were all struck with wonder to find that the organs of that little animal, when put in motion, gave a sensible vibration to the whole building! This bird also sometimes makes a small squeak, repeated four or five times; and I have observed that to happen when the cock has been pursuing the hen in a toying way through the boughs of a tree.

It would not be at all strange if your bat, which you have procured, should prove a new one, since five species have been found in the neighbouring kingdom. The great sort that I mentioned is certainly a nondescript: I saw but one this summer, and that I had no opportunity of taking.

Your account of the Indian grass was entertaining. I am no angler myself; but inquiring of those that are, what they supposed that part of their tackle to be made of? they replied, "Of the intestines of a silk-worm."

Though I must not pretend to great skill in entomology, yet I cannot say that I am ignorant of that kind of knowledge: I may now and then perhaps be able to furnish you with a little information.

The vast rains ceased with us much about the same time as with you, and since we have had delicate weather. Mr.

1 A vignette of this hermitage appears on the title-page.-ED. 
Barker, who has measured the rain for more than thirty years, says, in a late letter, that more has fallen this year than in any he ever attended to ; though, from July, 1763, to January, 1764, more fell than in any seven months of this year.

\section{LETTER XXIII.}

TO THOMAS PENNANT, ESQUIRE.

Selborne, Feb. 28, 1769.

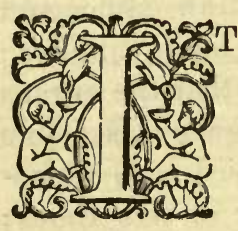

is not improbable that the Guernsey lizard and our green lizards may be specifically the same; all that I know is, that, when some years ago many Guernsey lizards were turned looso in Pembroke College garden, in the University of Oxford, they lived a great while, and seemed to enjoy themselves very well, but never bred. Whether this circumstance will prove anything either way I shall not pretend to say.

I return you thanks for your account of Cressi Hall; but recollect, not without regret, that in June, 1746, I was visiting for a week together at Spalding, without ever being told that such a curiosity was just at hand. Pray send me word in your next what sort of tree it is that contains such a quantity of herons' nests; and whether the heronry consist of a whole grove or wood, or only of a few trees.

It gave me satisfaction to find we accorded so well about the Caprimulgus : all I contended for was to prove that it often chatters sitting as well as flying; and therefore the noise was voluntary, and from organic impulse, and not from the resistance of the air against the hollow of its mouth and throat.

If ever I saw anything like actual migration, it was last Michaelmas-day. I was travelling, and out early in the morning : at first there was a vast fog ; but by the time 
that I was got seven or eight miles from home towards the coast, the sun broke out into a delicate warm day. We were then on a large heath or common, and I could disceru, as the mist began to break away, great numbers of swallows (Hirundines rusticae) clustering on the stunted shrubs and bushes, as if they had roosted there all night. As soon as the air became clear and pleasant they all were on the wing at once; and, by a placid and easy flight, proceeded on southward towards the sea: after this I did not see any more flocks, only now and then a straggler.

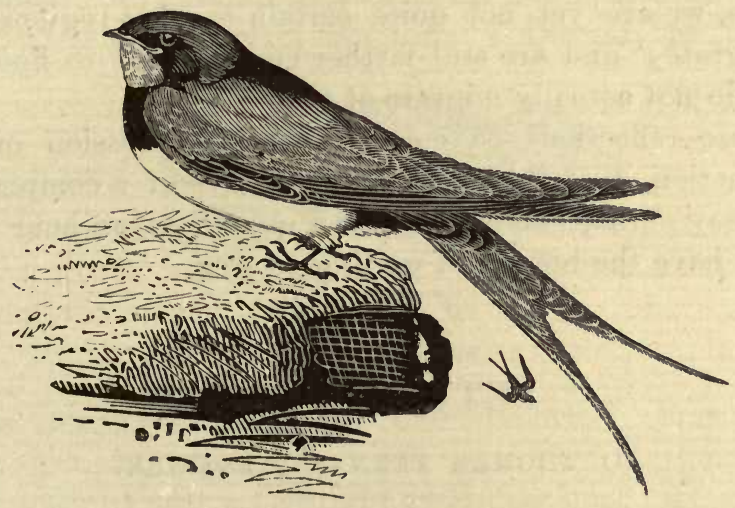

SWALLOW.

I cannot agree with those persons that assert that the swallow kind disappear some and some gradually, as they come, for the bulk of them seem to withdraw at once: only some stragglers stay behind a long while, and do never, there is the greatest reason to believe, leave this island. Swallows seem to lay themselves up, and to come forth in a warm day, as bats do continually of a warm evening, after they have disappeared for weeks. For a very respectable gentleman assured me that, as he was walking with some friends under Merton Hall on a remarkably hot noon, either in the last week in December or the first week in January, he espied three or four swallows huddled together on the moulding of one of the windows of that college. I have frequently remarked that swallows are seen later at Oxford 
than elsewhere: is it owing to the vast massy buildings of that place, to the many waters round it, or to what else?

When I used to rise in a morning last autumn, and see the swallows and martins clustering on the chimneys and thatch of the neighbouring cottages, I could not help being touched with a secret delight, mixed with some degree of mortification; with delight to observe with how much ardour and punctuality those poor little birds obeyed the strong impulse towards migration, or hiding, imprinted on their minds by their great Creator; and with some degree of mortification, when I reflect that, after all our pains and inquiries, we are yet not quite certain to what regions they do migrate $;^{1}$ and are still farther embarrassed to find that some do not actually migrate at all.

These reflections made so strong an impression on my imagination, that they became productive of a composition that may perhaps amuse you for a quarter of an hour when next I have the honour of writing to you.

\section{LETTER XXIV.}

\section{TO THOMAS PENNANT, ESQUIRE.}

Selborne, May 29, 1769.

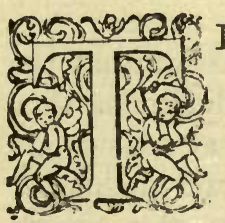

HE Scarabceus fullo ${ }^{2}$ I know very well, having seen it in collections; but have never been able to discover one wild in its natural state. Mr. Banks told me he thought it might be found on the seacoast. ${ }^{3}$

On the 13th of April, I went to the sheep-down, where

1 The winter haunts of the swallows are now well known to naturalists. See an article on swallows, in continuation of a series on "Our Summer Migrants," published by the writer in the "Field" of October 14th and October 21st, 1871, in which a detailed reply is given to the inquiries, "What do swallots feed upon?" and "Where do the swallows go in winter?"-ED.

2 Melolontha fullo, Fabr. an insect of the same genus as the better known cock-chafer Melolontha vulgaris.

$3 \mathrm{Mr}$. Bennett has remarked that all the specimens of this fixe chafer that have yet been captured in England, and they are very far from numer- 
the ring-ousels have been observed to make their appearance at spring and fall, in their way perhaps to the north or south; and was much pleased to see three birds about the usual spot. We shot a cock and a hen; they were plump and in high condition. The hen had but very small rudiments of eggs within her, which proves they are late breeders, whereas those species of the thrush kind that remain with us the whole year have. fledged young before that time. In their crops was nothing very distinguishable, but somewhat that seemed like blades of vegetables nearly digested. In autumn they feed on haws and yew-berries, and in the spring on ivy-berries. I dressed one of these

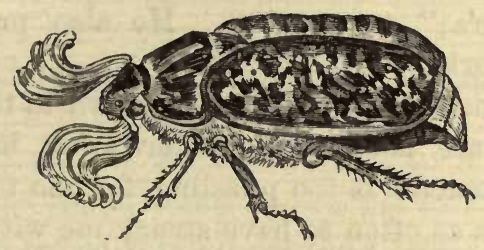

MELOLONTHA FULLO.

birds, and found it juicy and well-flavoured. It is remarkable, that they make but a few days' stay in their spring visit, but rest near a fortnight at Michaelmas. These birds, from the observations of three springs and two autumns, are most punctual in their return; and exhibit a new migration unnoticed by the writers who supposed they never were to be seen in any of the southern counties.

One of my neighbours lately brought me a new Salicaria, which, at first, I suspected might have proved your willow lark, ${ }^{1}$ but on a nicer examination, it answered much better

ous, have occurred on the coast of Kent. Dover seems to be the middle point of their range, from which they extend westward as far as Hythe, and northward to Sandwich. Mr. Stephens has recorded the capture, by a lady, of no less than eight specimens in one year, in the neighbourhood of Sandwich; a number probably nearly equal to all the others that are known to have been at any time taken in this country.-ED.

1 For this Salicaria, see Letter, August 30, 1769.-G. IV.

The birds to which White previously applied the generic term Salicaria were the willow wrens, as already pointed out in note 1, p. 54 , and Pennaat's willow lirk, as shown in note $3, \mathrm{p} .69$, was the wood wren, $P$. 
to the description of that species which you shot at Revesby, in Lincolnshire. ${ }^{1}$ My bird I describe thus: "It is a size less than the grasshopper lark; the head, back, and coverts of the wings, of a dusky brown, without those dark spots of the grasshopper lark; over each eye is a milkwhite stroke; the chin and throat are white, and the under parts of a yellowish white; the rump is tawny, and the feathers of the tail sharp pointed; the bill is dusky and sharp, and the legs are dusky; the hinder claw long and crooked."' The person that shot it says that it sung so like a reed sparrow that he took it for one; and that it sings all night: but this account merits farther inquiry. For my part, I suspect it is a second sort of Locustella, hinted at by Dr. Derham in "Ray's Letters;" see p. 108. He also procured me a grasshopper lark.

The question that you put with regard to those genera of animals that are peculiar to America, viz. how they came there, and whence? is too puzzling for me to answer; and yet so obvious as often to have struck me with wonder. If one looks into the writers on that subject, little satisfaction is to be found. Ingenious men will readily advance plausible arguments to support whatever theory they shall choose to maintain ; but then the misfortune is, every one's hypothesis is each as good as another's, since they are all founded on conjecture. The late writers of this sort, in whom may be secn all the arguments of those that have gone before, as I remember, stock America from the western coast of Africa, and the south of Europe; and then break down the isthmus that bridged over the Atlantic. But this is making use of a violent piece of machinery; it is a difficulty worthy of the interposition of a god! "Incredulus odi."

sibilatrix. But here he extends the term to include the sedge warblers, which really belong to a well marked and very distinct group. - En.

1 The seat of Sir Joseph Banks, where Pennant was staying on a visit in May, 1767.- Ev.

2 This is the serlge warbler, Salicaria phragmitis. The remark of White's informant that the bird he procured "sung so like a reed sparrow" is a mistake which a casual observer might easily make, since the sedge warbler often sings concealed in a patch of reeds or sedge, while the unmusical reed bunting (Emberiza schoniclus), sitting conspicuously on a reed top, gets all the credit for the song.-lid. 
TO THOMAS PENNANT, ESQUIRE.

THE

\section{NATURALIST'S SUMMER EVENING WALK.}

- equidem credo, quia sit divinitùs illis

Ingenium.

VırG. Georg. i. 415.

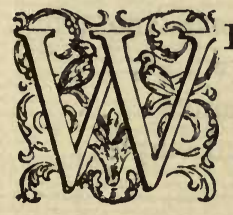

HEN day declining sheds a milder gleam, What time the May-fly haunts the pool or stream;

When the still owl skims round the grassy mead,

What time the timorous hare limps forth to feed;

Then be the time to steal adown the vale,

And listen to the vagrant cuckoo's ${ }^{2}$ tale;

To hear the clamorous curlew ${ }^{3}$ call his mate,

Or the soft quail his tender pain relate;

To see the swallow sweep the darkening plain

Belated, to support her infant train;

To mark the swift in rapid giddy ring

Dash round the steeple, unsubdued of wing :

Amusive birds! say where your hid retreat

When the frost rages and the tempests beat;

Whence your return, by such nice instinct led,

When spring, soft season, lifts her bloomy head?

1 The angler's May-fly, the Ephemera vulgata, Lisv. comes forth from its aurelia state, and emerges out of the water, about six in the evening, and dies about eleven at night, determining the date of its fly state in about five or six hours. They usually begin to appear about the 4 th of June, and continue in succession for near a fortnight. See Swammerdam, Derham, Scopoli, \&c.-G. W.

2 Vagrant cuckoo; so called because, being tied down by ro incu. bation or attendance about the nutrition of its young, it wanders without control.-G. W.

3 'The stone curlew, Edicnemus crepitans.-En, 
Such bafflcd searches mock man's prying pricio, The God of NATURE is your secret guide!

While deepening shades obscure the face of day

To yonder bench leaf-shelter'd let us stray,

Till blended objects fail the swimming sight,

And all the fading landscape sinks in night;

To hear the drowsy dorr come brushing by

With buzzing wing, or the shrill cricket ${ }^{1}$ cry;

To see the feeding bat glance through the wood;

To catch the distant falling of the flood;

While o'er the cliff th' awaken'd churn-owl hung

Through the still gloom protracts his chattering song;

While high in air, and poised upon his wings,

Unseen, the soft enamour'd woodlark ${ }^{2}$ sinks :

These, Nature's works, the curious mind employ,

Inspire a soothing melancholy joy:

As fancy warms, a pleasing kind of pain

Steals o'er the cheek, and thrills the creeping vein!

Each rural sight, each sound, each smell, combine;

The tinkling sheep-bell, or the breath of kine;

The new-mown hay that scents the swelling breeze,

Or cottage chimney smoking through the trees.

The chilling night dews fall :- away, retire;

For see, the glow-worm lights her amorous firo! ${ }^{3}$ 'Thus, ere night's veil had half obscured the sky, Th' impatient damsel hung her lamp on high:

True to the signal, by love's meteor led,

Leander hasten'd to his Hero's bed. ${ }^{4}$

1 Gryllus campestris.

2 In hot summer nights woodlarks soar to a prodigious height, aud hang singing in the air.- G. IV.

3 The light of the female glow-worm (as she often crawls up the stalk of a grass to make herself more conspicuous) is a signal to the male, which is a slenrler dusky Scarabaus.-G. W.

This is still the generally received notion, but the fact is that both sexes of the glow-worm are phosphorescent, not only in the perfect insect, but also in the larva and even pupa state.-F.v.

* See tlie story of IIcro and Leander.-G. II. 


\section{LETTER XXV.}

TO THOMAS PENNANT, ESQUIRE.

Selborne, Aug. 30, 1769.

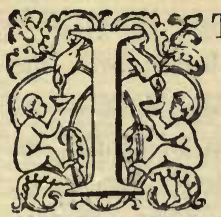

$\mathrm{T}$ gives me satisfaction to find that my account of the ousel migration pleases you. You put a very shrewd question when you ask me how I know that their autumnal migration is southward? Were not candour and openness the very life of natural history, I should pass over this query just as a sly commentator does over a crabbed passage in a classic; but common ingenuousness obliges me to confess, not without some degree of shame, that I only reasoned in that case from analogy. For as all other sutumnal birds migrate from the northward to us, to partake of our milder winters, and return to the northward again when the rigorous cold abates, so I coucluded that the ring-ousels did the same, as well as their congeners the fieldfares; and especially as ring-ousels are known to haunt cold mountainous countries: but I have good reason to suspect since, that they may come to us from the westward; because I hear, from very good authority, that they brecd on Dartmoor; and that they forsake that wild district about the time that our visitors appear, and do not return till late in the spring.

I have taken a great deal of pains about your Salicaria and mine, with a white stroke over its eye and a tawny rump. I have surveyed it alive and dead, and have procured several specimens; and am perfectly persuaded myself. (and trust you will soon be convinced of the same) that it is no more nor less than the Passer arundinaceus minor of Ray. This bird, by some means or other, seems to be entirely omitted in the "British Zoology;" and one reason probably was because it is so strangely classed in Ray, who ranges it among his Picis affines. It ought no doubt to lave gone among his Aviculoe caudâ unicolore, and among 
your slender-billed small birds of the same division. Linnæus might with great propriety have put it into his genus of Motacilla; and the Motacilla salicaria of his Fauna Suecica seems to come the nearest to it. It is no uncommon bird, haunting the sides of ponds and rivers where there is covert, and the reeds and sedges of moors. The country people in some places call it the sedge bird. ${ }^{1}$ It sings incessantly night and day during the breeding time, imitating the note of a sparrow, a swallow, a skylark; and has a strange hurrying manner in its song. My specimens correspond most minutely to the description of your fen salicaria shot near Revesby. Mr. Ray has given an excellent characteristic of it when he says, "Rostrun ct pedes in liâc aviculâ multò majores sunt quàm pro corporis ratione." See Letter, May 29, 1769.

I have got you the egg of an Edicnemus, or stonecurlew, which was picked up in a fallow on the naked ground: there were two; but the finder inadvertently crushed one with his foot before he saw them.

When I wrote to you last year on reptiles, I wish I had nut forgot to mention the faculty that snakes have of stinking se defendendo. I knew a gentleman who kept a tame snake, which was in its person as sweet as any animal while in good humour and unalarmed; but as soon as a stranger, or a dog or cat, came in, it fell to hissing, and filled the room with such nauseous effluvia as rendered it hardly supportable. Thus the squnck, or stonck, of Ray's "Synopsis Quadrupedum" is an innocuous and sweet animal; but, when pressed hard by dogs and men, it can eject such a most pestilent and fetid smell and excrement that nothing can be more horrible.

A gentleman sent me lately a fine specimen of the Lanius minor cinerascens cum maculâ in scapulis allî, RAII ; ${ }^{2}$ which is a bird that, at the time of your publishing your two first volumes of "British Zoology," I find you had not seen. You have described it well from Edwards's drawing.

1 Salicaria phragmitis, see note 2, p. 82.-Ev.

2 The woodchat, Lanius rutilus, Latham. This is one of the earliest British specimens noticed.-Ev. 


\section{IETTER XXVI.}

\section{TO THOMAS PENNANT, ESQUIRE.}

Selborne, Dec. 8, 1769.

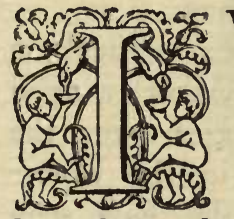

WAS much gratified by your communicative letter on your return from Scotland, where you spent, I find, some considerable time, and gave yourself good room to examine the natural curiosities of that extensive kingdom, both those of the islands, as well as those of the highlands. The usual bane of such cxpeditions is hurry; because men seldom allot themselves half the time they should do; but, fixing on a day for their return, post from place to place, rather as if they were on a journey that required dispatch, than as philosophers investigating the works of nature. You must have made, no doubt, many discoveries, and laid up a good fund of materials for a future edition of the "British Zoology;" and will have no reason to repent that you have bestowed so much pains on a part of Great Britain that perhaps was never so well examined before.

It has always been matter of wonder to me that fieldfares, which are so congenerous to thrushes and blackbirds, should never choose to breed in England: but that they should not think even the highlands cold and northeriy, and sequestered enough, is a circumstance still more strange and wonderful. The ring-ousel, you find, stays in Scotland the whole year round; so that we have reason to conclude that those migrators that visit us for a short space every autumn do not come from thence.

And here, I think, will be the proper place to mention that those birds were most punctual again in their migration this autumn, appearing, as before, about the 30th of September: but their flocks were larger than common, and 
their stay protracted somewhat beyond the usual time. If they came to spend the whole winter with us, as some of their congeners do, and then left us, as they do, in spring, I should not be so much struck with the occurrence, since it would be similar to that of the other winter birds of passage; but when I see them for a fortnight at Michaelmas, and again for about a week in the middle of April, I am seized with wonder, and long to be informed whenco these travellers come, and whither they go, since they secm to use our hills merely as an inn or baiting place.

Your account of the greater brambling, or snow-fleck, is very amusing; and strange it is, that such a short-winged bird should delight in such perilous voyages over the northern ocean! Some country people in the winter time have every now and then told me that they have seen two or three white larks on our downs; but, on considering the matter, I begin to suspect that these are some stragglers of the birds we are talking of, which sometimes perhaps may rove so far to the southward.

It pleases me to find that white hares are so frequent on the Scottish mountains, and especially as you inform me that it is a distinct species; for the quadrupeds of Britain are so few, that every new species is a great acquisition.

The eagle-owl, could it be proved to belong to us, is so majestic a bird, that it would grace our Fauna much. ${ }^{1}$

I never was informed before where wild geese are known to breed.

You admit, I find, that I have proved your fen salicaria to be the lesser reed sparrow of Ray: ${ }^{2}$ and I think you may be secure that I am right; for I took very particular pains to clear up that matter, and had some fair specimens; but, as they were not well preserved, they are decayed already. You will, no doubt, insert it in its proper place in your next edition. Your additional plates will much improve your work.

1 In the "Handbook of British Birds" (1872), pp. 94, 95, will be found enumerated at least a dozen instances of its occurrence in different parts of the British islands.-ED.

${ }^{2}$ See p. 82, note 2 , and p. 86 , note 1.-ED. 
De Buffon, I know, has described the water sinrew-mouse : but still I am pleased to find you have discovered it in Lincolnshire, for the reason I have given in the article of the white hare.

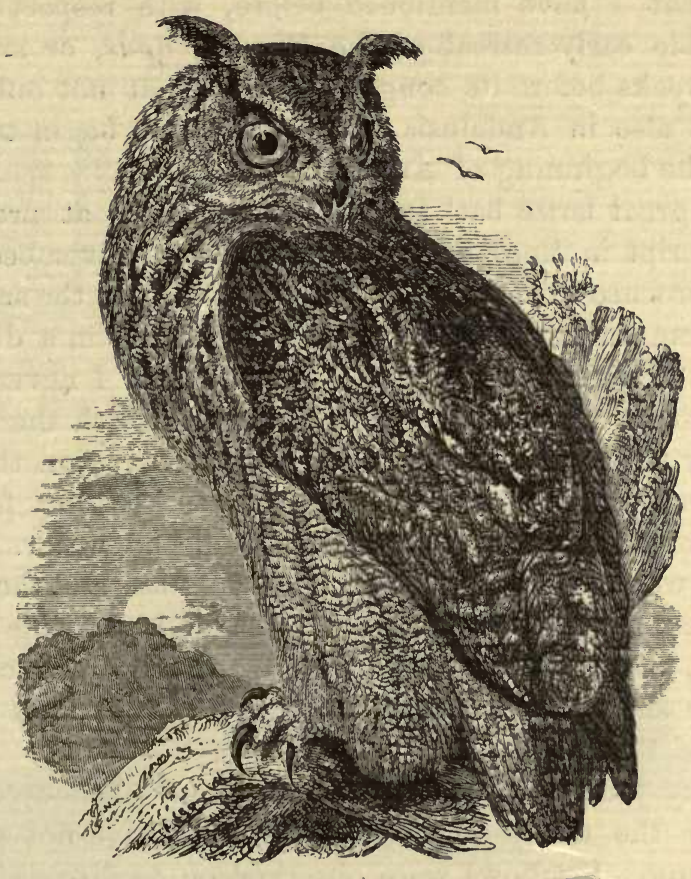

THE EAGLE OWL.

As a neighbour was lately ploughing in a dry chalky field, far removed from any water, he turned out a water-rat, that was curiously laid up in an hybernaculum artificially formed of grass and leaves. At one end of the burrow lay above a gallon of potatoes regularly stowed, on which it was to have supported itself for the winter. But the difficulty with me is how this amphibius mus came to fix its winter station at such a distance from the water. Was it determined in its choice of that place by the mere accident of finding the potatoes which were planted there; or is it the constant practice of the aquatic rat to forsake the neighbourhood of the water in the colder months? 
Though I delight very little in analogous reasoning, knowing how fallacious it is with respect to natural history; yet, in the following instance, I cannot help being inclined to think it may conduce towards the explanation of a difficulty that I have mentioned before, with respect to the invariable early retreat of the Hirundo apus, or swift, so many weeks before its congeners; and that not only with us, but also in Andalusia, where they also begin to retire about the beginning of August.

The great large bat ${ }^{1}$ (which by the by is at present a nondescript in England, and what I have never been able yet to procure) retires or migrates very early in the summer; it also ranges very high for its food, feeding in a different region of the air; and that is the reason I never could procure one. Now this is exactly the case with the swifts; for they take their food in a more exalted region than the other species, and are very seldom seen hawking for flies near the ground, or over the surface of the water. From hence I would conclude that these Hirundines, and the larger bats, are supported by some sorts of highflying gnats, scarabs, or Phalanoe, that are of short continuance; and that the short stay of these strangers is regulated by the defect of their food.

By my journal it appears that curlews ${ }^{2}$ clamoured on to October the thirty-first: since which I have not seen or heard any. Swallows were observed on to November the third.

1 The little bat appears almost every month in the year; but I have never seen the large ones till the end of April, nor after July. They are most common in June, but never in any plenty; are a rare species with us.-G. W.

2 Stone-curlews, OEdicnemus crepitans. The true curlew, Numenius arcuatus, was not observed at Selborne.-E. 


\section{LETTER XXVII.}

\section{TO THOMAS PENNANT, ESQUIRE.}

Selborke, Feb. 22, 1770.

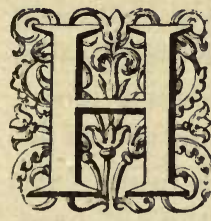
EDGEHOGS abound in my gardens and fields. The manner in which they eat the roots of the plantain in my grass walks is very curious: with their upper mandible, which is much longer than their lower, they bore under the plant, and so eat the root off upwards, leaving the tuft of leaves untouched. In this respect

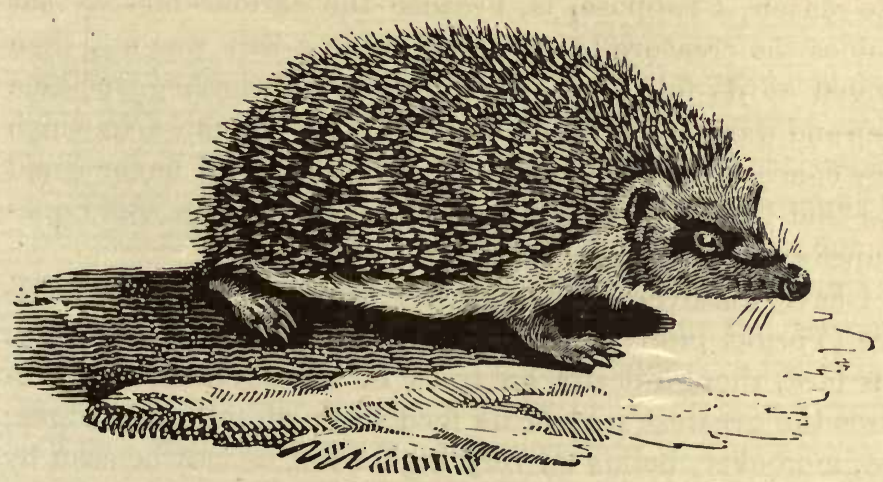

HEDGEHOG.

they are serviceable, as they destroy a very troublesome weed; but they deface the walks in some measure by digging little round holes. ${ }^{1}$ It appears, by the dung that

1 The author of the "Letters of Rusticus" discovered this to be a mistake. He found that it was not the hedgehog but a night-eating caterpillar. He says :- "In a grass walk I saw some flattened plants of the common plantain withering and half dead; by the side of each I found the hole bored, as White supposed, by the long upper mandible of 'Hoggy', but it was scarcely big enough to admit a lead pencil. and 
they drop upon the turf, that beetles are no inconsiderable part of their food. In June last I procured a litter of four or five young hedgehogs, which appeared to be about five or six days old: they, I find, like puppies, are born blind, and could not see when they came to my hands. No doubt their spines are soft and flexible at the time of their birth, or else the poor dam would have but a bad time of it in the critical moment of parturition: but it is plain that they soon harden; for these little pigs had such stiff prickles on their backs and sides as would easily have fetched blood, had they not been handled with caution. Their spines are quite white at this age ${ }^{\prime}$ and they have little hanging ears, which I do not remember to be discernible in the old ones. They can, in part, at this age draw their skin down over their faces; but are not able to contract themselves into a ball, as they do, for the sake of defence, when full grown. The reason, I suppose, is, because the curious muscle that enables the creature to roll itself up in a ball was not then arrived at its full tone and firmness. Hedgehogs make a deep and warm hybernaculum with leaves and moss, in which they conceal themselves for the winter: but I never could find that they stored in any winter provision, as some quadrupeds certainly do.

I have discovered an anecdote with respect to the fieldfare (Turdus pilaris), which I think is particular enough: this bird, though it sits on trees in the daytime, and procures the greatest part of its food from whitethorn hedges; yea, moreover, builds on very high trees, as may be seen by the Fauna Suecica; yet always appears with us to roost on the ground. They are seen to como in flocks just before it is dark, and to settle and nestle among the heath on our forest. And besides, the larkers, in dragging their nets by night, frequently catch them in the wheat-stubbles; while the bat-fowlers, who take many redwings in the hedges,

so round and smooth that I said directly to myself, "'tis the burrow of a night-eating caterpillar.' I got a trowel and in a trice the fellow was unearthed; and he afterwards turned to a 'ghost moth' or 'ycllow underwing,' I cannot say which, fur both came out in one cage."-ED 
never entangle any of this species. Why these birds, in the matter of roosting, should differ from all their congeners, and from themselves also with respect to their proceedings by day, is a fact for which $I$ am by no means ablo to account.

I have somewhat to inform you of concerning the moose deer; but in general foreign animals fall seldom in my way: my little intelligence is confined to the narrow sphere of my own observations at home.

\section{LETTER XXVIII.}

\section{TO THOMAS PENNANT, ESQUIRT.}

Selborne, March, 1770.

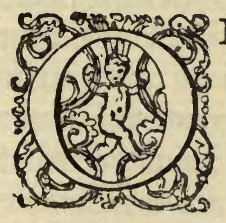

N Michaelmas-day, 1768, I managed to get a sight of the female moose belonging to the Duke of Richmond, at Goodwood; but was greatly disappointed, when I arrived at the spot, to find that it died, after having appeared in a languishing way for some time, on the morning before. However, understanding that it was not stripped, I proceeded to examine this rare quadruped. I found it in an old green-house, slung under the belly and chin by ropes, and in a standing posture; but though it had been dead for so short a time, it was in so putrid a state that the stench was hardly supportable. The grand distinction between this deer, and any other species that I have ever met with, consisted in the strange length of its legs, on which it was tilted up much in the manner of the birds of the Grallae order. I measured it, as they do a horse, and found that, from the ground to the wither, it was just five feet four inches; which height answers exactly to sixtcen hands, a growth that few horses arrive at: but then, with this length of legs, its neck was remarkably short, no more than twelve inches; so that, by straddling with one foot forward, and the 
other backward, it grazed on the plain ground, with the greatest difficulty, between its legs; the ears were vast and lopping, and as long as the neck; the head was about twenty inches long and ass-like, and had such a redundancy of upper lip as I never saw before, with huge nostrils. This lip, travellers say, is esteemed a dainty dish in North America. It is very reasonable to suppose that this creature sup. ports itself chiefly by browsing of trees, and by wading after water plants; towards which way of livelihood the length of legs and great lip must contribute much. I have read somewhere that it delights in eating the Nymphoea, or water-lily. From the fore-feet to the belly behind the shoulder it measured three feet and eight inches: thelength of the legs before and behind consisted a great deal in the tibia, which was strangely long; but, in my haste to get out of the stench, I forgot to measure that joint exactly. Its scut seemed to be about an inch long; the colour was a grizzly black; the mane about four inches long; the fore hoofs were upright and shapely, the hind flat and splayed. The spring before it was only two years old, so that most probably it was not then come to its growth. What a vast tall beast must a full grown stag be! I have been told some arrive at ten and a-half feet! This poor creature had at first a female companion of the same species, which died the spring before. In the same garden was a young stag, or red deer, between whom and this moose it was hoped that there might have been a breed; but their inequality of height must have always been a bar to this.' I should have been glad to have examined the teeth, tongue, lips, hoofs, \&c. minutely; but the putrefaction precluded all farther curiosity. This animal, the keeper told me, seemed to cnjoy itself best in the extreme frost of the former winter. In the house they showed me the horn of a male moose, which had no front antlers, but only a broad palm with some snags on the edge.

1 They belong, moreover, to very distinct genera of the Cervidee. In addition to the peculiarities of form described by Gilbert White, the moose has broadly palmated horns instead of a rounded stem and antlers as in the red deer.-Ev. 
The noble owner of the dcad moose proposed to mako a skeleton of her bones.

Please to let me hear if my female moose corresponds with that you saw; and whether you think still that the American moose and European elk are the same creature.

\section{LETTER XXIX.}

\section{TO THOMAS PENNANT, ESQUIRE.}

Selborne, May 12, 1770.

AST month we had such a series of cold turbulent weather, such a constant succession of frost, and snow, and hail, and tempest, that the regular migration or appcarance of the summer birds was much interrupted. Some did not show themselves (at least were not heard) till weeks after their usual time, as the blackcap and whitethroat; and some have not been heard yet, as the grasshopper lark and largest willow wren.' As to the flycatcher, I have not seen it: it is indeed one of the latest, but should appear about this time: and yet, amidst all this meteorous strife and war of the elements, two swallows discovered themselves as long ago as the 11th of April, in frost and snow; but they withdrew quickly, and were not visible again for many days. House martins, which are always more backward than swallows, were not observed till May came in.

Among the monogamous birds several are to be found, after pairing-time, single, and of each sex: but whether this state of celibacy is matter of choice or necessity, is not so easily discoverable. When the house sparrows deprive my martins of their nests, as soon as I cause one to be shot, the other, be it cock or hen, presently procures a mate, and so for several times following.

1 'The wood wren, Ph. sibilatrix. See note, p. 56.-ED. 
I have known a dove-house infested by a pair of white owls, which made great havoc among the young pigeons. One of the owls was shot as soon as possible; but the survivor readily found a mate, and the mischief went on. After some time the new pair were both destroyed, and the annoyance ceased. ${ }^{1}$

Another instance I remember of a sportsman, whose zeal for the increase of his game being greater than his humanity, after pairing-time he always shot the cock bird of every couple of partridges upon his grounds, supposing that the rivalry of many males interrupted the breed: he used to say, that, though he had widowed the same hen several times, yet he found she was still provided with a fresh paramour, that did not take her away from her usual haunt.

Again: I knew a lover of setting, an old sportsman, who has often told me that soon after harvest he has frequently taken small coveys of partridges, consisting of cock birds alone; these he pleasantly used to call old bachelors.

There is a propensity belonging to common house cats that is very remarkable; I mean their violent fondncss for fish, which appears to be their most favourite food. And yet nature in this instance seems to have planted in them an appetite that, unassisted, they know not how to gratify; for of all quadrupeds, cats are the least disposed towards

1 This is contrary to the experience of the late Charles Waterton, who, in his "Essays in Natural History," 1st series, p. 14, says :-

"When farmers complain that the barn owl destroys the eggs of their pigeons they lay the saddle on the wrong horse. They ought to put it on the rat. Formerly I could get very few young pigeons till the rats were excluded effectually from the dove cot. Since that took place it has produced a great abundance every year, though the barn owls frequent it, and are encouraged all around it. 'The barn owl merely resorts to it for repose and concealment. If it were really an enemy to the dove cot we should see the pigeons in commotion as soon as it begins its evening flight! but the pigeons heed it not; whereas if the sparrow hawk or hobby should make its appearance, the whole community would be up at once; proof sufficient that the barn owl is not lonked upon as a bad, or even a suspicious cuaracter by the inlabitants of the dove cot."-Eis. 
water, and will not, when they can avoid it, deign to wet a foot, much less to plunge into that element.

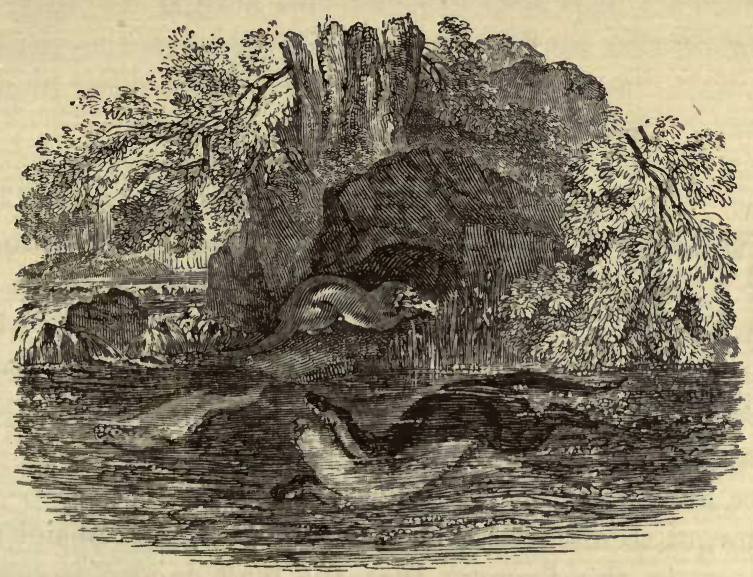

THE OTTER.

Quadrupeds that prey on fish are amphibious. Such is the otter, which by nature is so well formed for diving that it makes great havoc among the inhabitants of the waters. Not supposing that we had any of those beasts in our shallow brooks, I was much pleased to see a male otter brought to me, weighing twenty-one pounds, that had been shot on the bank of our stream below the Priory, where the rivulet divides the parish of Selborne from Harteley Wood. ${ }^{1}$

${ }^{1}$ It is generally supposed that otters live exclusively on fish, but such is not invariably the case. They are carnivorous as well as piscivorous, and have been known to eat ducks and teal, and, while in confinement, young pigeons. Frogs form part of their bill of fare, and even mussels at times furnish food to these animals. Numbers of mussel-shells have been found in an otter's haunt, with the ends bitten off, and evident marks of teeth upon the broken fragments, the position of the shells indicating that the otter, after having crunched off one end, had sucked or suooped out the mollusc, in much the same way as those who are partial to shrimps dispose of that esculent crustacean.-ED. 


\section{LETTER XXX.}

\section{TO THOMAS PENNANT, ESQUIRE.}

Selbornf, Aug. 1, 1770.

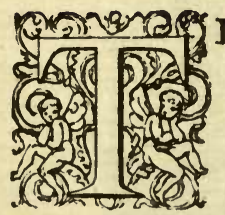

HE French, I think, in general are strangely prolix in their natural history. What Linnæus says with respect to insects, holds good in every other branch: "Verlositas proesentis sacculi, calamitas artis."

Pray how do you approve of Scopoli's new work? As I admire his "Entomologia," I long to see it.

I forgot to mention in my last letter (and had not room to insert in the former) that the male moose, in rutting time, swims from island to island, in the lakes and rivers of North America, in pursuit of the females. My friend, the chaplain, saw one killed in the water as it was on that errand in the river St. Lawrence. It was a monstrous beast, he told me; but he did not take the dimensions.

When I was last in town, our friend Mr. Barrington most obligingly carried me to see many curious sights. As you were then writing to him about horns, he carried me to see many strange and wonderful specimens. There is, I remember, at Lord Pembroke's, at Wilton, a horn room furnished with more than thirty different pairs; but I have not secn that house lately.

Mr. Barrington showed me many astonishing collections of stuffed and living birds from all quarters of the world. After I had studied over the latter for a time, I remarked that every species almost that came from distant regions, such as South America, the coast of Guinca, \&c., were thickbilled birds of the Loxia and Fringilla genera, and no Motacillae or Mfuscicapoe were to be met with. When I came to consider, the reason was obvious enough; for the hard-billed birds subsist on seeds which are casily carried on board; whilst the soft-billed birds, which are supportcd 
by worms and insects, or, what is a succedaneum for them, fresh raw meat, can meet with neither in long and tedious voyages. It is from this defect of food that our collections (curious as they are) are defective, and we are deprived of some of the most delicate and lovely genera.

\section{LETTER XXXI.}

\section{TO THOMAS PENNANT, ESQUIRE.}

Serborne, Sept. 14, 1770.

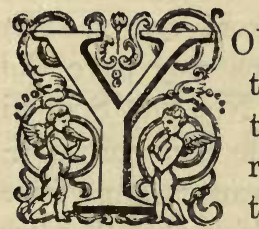
OU saw, I find, the ring-ousels again among thcir native crags ; and are farther assured that they continue resident in those cold regions the whole year. ${ }^{2}$ From whence then do our ring-ousels migrate so regularly every September, and make their appearance again, as if in their return, every April? They are more early this year than common, for some were seen at the usual hill on the fourth of this month.

An observing Devonshire gentleman tells me that they frequent some parts of Dartmoor, and breed there; but leave those haunts about the end of September or beginning of October, and return again about the end of March.

1 Since the foregoing remarks were penned, not only have the means of transport become much more rapid than was the ease in White's day, but greater attention having been paid to the importation of foreign birds and animals, and more consideration given to their food, enterprising individuals have succeeded in bringing alive and well to this country many more delicate species than those referred to by our anthor; and from much greater distances. If he regretted the inability in 1770 to procure a soft-billed bird from the coast of Guinea, how would he have marvelled to see alive in the Zoological Society's Gardens at the present day the insectivorous Australian Pied Grallina, Grallina australis, the Black-tailed Flower-bird, Anthornis melanura, from New Zealand, and the Wood swallow, Artamus superciliosus, from New South Wales.-Ev.

2 From our present knowledge of the habits of the ring-ousel, we may infer with little doubt that Pennant's informant must have confounded the dipper or water-ousel with the ring-ousel.-ED, 
Another intelligent person assures me that they breed in great abundance all over the Peak of Derby, and are called there Tor-ousels; withdraw in October and November, and return in spring. This information seems to throw some light on my new migration.

Scopoli's new work ${ }^{1}$ (which I have just procured) has its merit in ascertaining many of the birds of the Tyrol and Carniola. Monographers, come from whence they may, have, I think, fair pretence to challenge some regard and approbation from the lovers of natural history; for, as no man can alone investigate all the works of nature, these partial writers may, each in their department, be more accurate in their discoveries, and freer from errors, than more general writers; and so by degrees may pave the way to a universal correct natural history. Not that Scopoli is so circumstantial and attentive to the life and conversation of his birds as I could wish: he advances some false facts; as when he says of the Hirundo urbica that "pullos extra nidum non nutrit." This assertion I know to be wrong from repeated observation this summer; for house martins do feed their young flying, though it must be acknowledged not so commonly as the house swallow; and the feat is done in so quick a manner as not to be perceptible to indifferent observers. He also advances some (I was going to say) improbable facts; as when he says of the woodcock that "pullos rostro portat fugiens ab hoste." But candour forbids me to say absolutely that any fact is false, because I have never been witness to such a fact. I have only to remark that the long unwieldy bill of the woodcock is perhaps the worst adapted of any among the winged creation for such a feat of natural affection. ${ }^{2}$

1 "Annus Primus Historico-Naturalis."-G. W.

2 The fact that woodcocks carry their young has long been known to naturalists. Several instances are referred to by Yarrell in the third volume of his "History of British Birds." Others are recorded by Mr. Lloyd in his "Scandinavian Adventures" and "Game Birds and Wild Fowl of Sweden and Norway," in which latter work will be found a woodcut ( $p$. 194) illustrating a case witnessed by a friend of the author. Mr. St. John, in his "Natural History and Sport in Morav." 
p. 211, has some interesting remarks on this subject from his own obserration. He says: "That the old birds carried their young $I$ had long since ascertained, having often seen them in the months of April and May in the act of doing so, as they flew, towards nightfall, from the woods down to the swamps in the low grounds. From close observation, however, I found out that the old woodcock carries her young even when larger than a snipe, not in her claws, which seem quite incapable of holding up any weight, but by clasping the little bird tightly between her thighs, and so holding it tight towards her own body. In the summer and spring evenings the woodcocks may be seen so employed passing to and fro, and uttering a gentle cry on their way from the woods to the marshes. They not only carry their young to feed, but also, if the brood is suddenly come upon in the daytime, the old bird lifts up one of her young, flies with it fifty or sixty yards, drops it quietly, and flies silently on. The little bird immediately runs a few yards, and then squats flat on the ground amongst the dead leaves, or whatever the ground is covered with. The parent soon returns to the rest of her brood, and if the danger still threatens her, she lifts up and carries away another young bird in the same manner. I saw this take place on the 18th of May." This is confirmed by a correspondent who, writing from Rostrevor, Co. Down, in August, 1871, suys: "On the 2nd of this month I started a brace of wondcocks close to me. One of them had a young one pressed between its breast and feet; it lighted on the ground again after rising, apparently to get a better grasp of its young one, and then flew off with it. "They were near the edge of a wood, in the afternoon and during sunshine." Another correspondent, writing from Rohallion, Birnam, in "'The Field" of 26th August, 1871, says: "This spring (1871) I have been witness repeatedly to the ability of the woodcock to carry its young and fly off with them pressed to its body by its legs. This was in May and June." Some additional evidence will be found in Mr. Stevenson's "Birds of Norfolk," vol. ii. p. 292.

This curions habit has been noticed also in the North American woodcock, as testified by Audubon and others, while more recently the same thing has been observed in England of the common snipe. A well-known sportsman, who has adopted the pseudonym of "Idstone," writing in "The Field" of 30th May, 1874, says that, on the 22nd of the same month, when crossing a marsh on his way to a trout stream, a snipe rose almost at his feet, "and there was attached to it, mostly on its left or near side, a young snipe which it carried, or which clung to it, for about twenty-five yards." He could distinctly see the markings on the young one, and is therefore positive that he was not mistaken. The locality was close to Lawrence's Mill, Morden, Dorsetshire.

In the same number of "The Field," Mr. John Titterton, of Ely, Cambs., says that a similar thing was observed near Ely also in May of the same year.-ED. 


\section{LETTER XXXII. \\ TO THOMAS PENNANT, ESQUIRE.}

Selborne, Oct. 29, 1770.

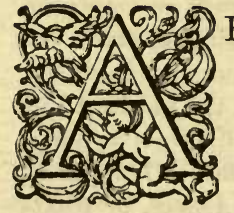

FTER an ineffectual search in Linnæus, Bris-. son, \&c., I begin to suspect that I discern my brother's Hirundo hyberna in Scopoli's new discovered Hirundo rupestris, p. 167. His description of "Supra murina, subtus albida; rectrices maculâ ovali albâ in latere interno; pedes nudi, nigri; rostrum nigrum; remiges obscuriores quam plumo dorsales; rectrices remigibus concolores; cauda emarginata nec forcipata;" agrees very well with the bird in question; but when he comes to advance that it is "statura Hirundinis urbico," and that "definitio Hir undinis riparioe Linvoei huic quoque convenit," he in some measure invalidates all he has said; at least he shows at once that he compares them to these species merely from memory: for I have compared the birds themselves, and find they differ widely in every circumstance of shape, size and colour. However, as you will have a specimen, I shall be glad to hear what your judgment is in the matter. ${ }^{1}$

Whether my brother is forestalled in his nondescript or not, he will have the credit of first discovering that they spend their winters under the warm and sheltery shores of Gibraltar and Barbary. ${ }^{2}$

I It seems highly probable that Gilbert White's suspicion of the identity of his brother's Gibraltar swallow with the Hirundo rupestris was correct; indeed, if the Gibraltar bird exhibited a white spot on the inner web of each of the tail feathers (except the two intermediate ones), it could have been no other than the bird first characterized by Scopoli, in his "Annus Primus," under the name quoted. According to M. Temminck the rock swallow is abundant along the shores of the Mediterranean.-ED.

2 "This remark," says Mr. Bennett, "is not to be understond as miting the residence of the rock swallow at Gibraltar to the winter 
Scopoli's characters of his ordines and gencra are clear, just, and expressive, and much in the spirit of Linnocus. These fow remarks are the result of my first perusal of Scopoli's "Annus Primus."

The bane of our science is the comparing one animal to the other by memory: for want of caution in this particular Scopoli talls into errors: he is not so full with regard to the manners of his indigenous birds as might be wished, as you justly observe: his Latin is easy, elegant, and expressive, and very superior to Kramer's. ${ }^{1}$

I am pleased to see that my description of the moose corresponds so woll with yours.

\section{LETTER XXXIII.}

\section{TO THOMAS PENNANT, ESQUIRE.}

Selnorne, Not 26, 1770.

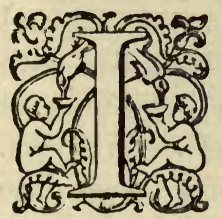

WAS much pleased to see, among the collection of birds from Gibraltar, some of those short-wingedEnglish summer birds of passage, concerning whose departure we have made so much inquiry. Now, if these birds are found in Andalusia to migrate to and from Barbary, it may easily be supposed that those that come to us may migrate back to the continent, and spend their winters in some of the warmer parts of Europe. This is certain, that many softbilled birds that come to Gibraltar appear there only in spring and autumn, seeming to advance in pairs torrards the northward, for the sake of breeding during the summer

inly; but merely as indicating that it does not quit the neighbourhood of that place, like the other swallows, during the colder months. It is, in fact, stationary throughout the year." M. Risso states it to be stationary also in the more northern locality of Nice; where all the other swallows are, as in England, birds of passage.-ED.

1 See his "Elenchus vegetabilium et animalium per Austriam inferiorem," \&c.-G. W. 
months; and retiring in parties and broods towards the south at the decline of the year: so that the rock of Gibraltar is the great rendezvous, and place of observation, from whence they take thcir departure each way towards Europe or Africa. It is therefore no mean discovery, I think, to find that our small short-winged summer birds of passage are to be seen spring and autumn ou the very skirts of Europe; it is a presumptive proof of their emigrations.

Scopoli seems to me to have found the Hirundo melbu, the great Gibraltar swift, in Tyrol, without knowing it. For what is his Hirundo alpina but the afore-mentioned bird in other words?. Says he, "Omnia prioris" (meaning the swift); "sed pectus album; paulo major priore." I do not suppose this to be a new species. It is true also of mella, that "nidificat in excelsis Alpium rupilus." Vid. Annum Primum.

My Sussex friend, a man of observation and good scnse, but no naturalist, to whom I applied on account of the stone curlew (Edicnemus), sends me the following account: "In looking over my Naturalist's Journal for the month of April, I find the stone curlews are first mentioned on the 17 th and 18th, which date seems to me rather late. They live with us all the spring and summer, and at the beginning of autumn prepare to take leave by getting together in flocks. They seem to me a bird of passage that may travel into some dry hilly country south of us, probably Spain, because of the abundance of sheep-walks in that country; for they spend their summers with us in such districts. This conjecture I hazard, as I have never met with any one that has seen them in England in the winter. ${ }^{2}$ I believe they are

I Cypselus melba, ILs. (Cyps. alpinus, Tемм.) Stragglers of this species, the large white-bellied swift, have occurred, in several instances, in the British islands. A score of such instances will be found enumerated in the "Handbook of British Birds," pp. 125, 126.-ED.

2 One of the most interesting facts in connection with Cornish ornithology is that the stone curlew, which is usually met with in other parts of England as a summer visitant, is never seen in the Lizard and Land's End districts except in winter, and in the opinion of Mr. Rodd ("List Brit. Birds," 2nd ed. 1860 , p. 5) the only way to account for this devia- 
not fond of going near the water, but feed on earth-worms, that are common on sheep-walks and downs. They breed on fallows and lay-fields abounding with gray mossy flints, which much resemble their young in colour; among which they skulk and conceal themselves. They make no nest, but lay their eggs on the bare ground, producing in common but two at a time. There is reason to think thcir young run soon after they are hatched; and that the old ones do not feed them, but only lead them about at the

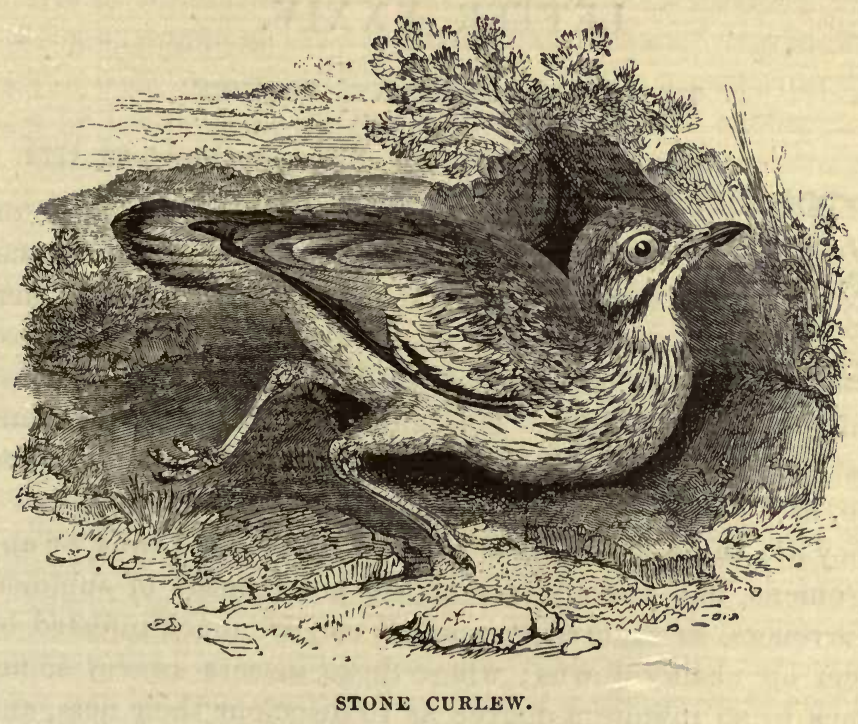

time of feeding, which, for the most part, is in the night." Thus far my friend.

In the manners of this bird you see there is something very analogous to the bustard, whom it also somewhat resembles in aspect and makc, and in the structure of its feet.

tion is to presume that a portion of the migratory party, in their southern flight in the antumn, hold a northern limit just reaching the Land's End and the Lizard lands (the most scuthern in the British isles), the corresponding northern migration in the spring just taking the whole number above the sonthern latitudes of the extreme western counties - F.D. 
For a long time I have desired my relation to look out for these birds in Andalusia; and now he writes me word that, for the first time, he saw one dead in the market on the 3rd of September. ${ }^{1}$

When the Edicnemus flies it stretches out its legs straight behind, like a heron.

\section{LETTER XXXIV.}

TO TIIOMAS PENNAN'T, ESQUIRE.

Selborne, March 30, 1771.

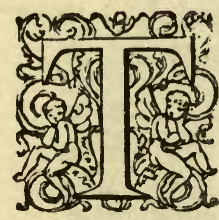

HERE is an insect with us, especially on chalky districts, which is very troublesome and teasing all the latter end of the summer, getting into people's skins, especially those of women and children, and raising tumours which itch intolerably. This animal (which we call a harvest bug) is very minute, scarce discernible to the naked eye, of a bright scarlet colour, and of the genus of Acarus. They are to be met with in gardens on kidney beans, or any legumens, but prevail only in the hot months of summer. Warreners, as some have assured me, are much infested by them on chalky downs; where these insects swarm sometimes to so infinite a degree as to discolour their nets, and to give them a reddish cast, while the men are so bitten as to be thrown into fevers.

There is a small long shining fly in these parts very troublesome to the housewife by getting into the chimneys and laying its eggs in the bacon while it is drying. These eggs produce maggots called jumpers, which, harbouring in the gammons and best parts of the hogs, eat down to the

1 Mr. Howard Saunders, in his "List of the Birds of Southern Spain" (Ibis, 1871, p. 386), includes the stone curlew as "cominon and resident, frequenting dry watercourses, and the most arid plains, where it deposits its eggs." - ED. 
bone and make great waste. This fly I suspect to be a variety of the Musca putris of Linnæus. It is to be seen in the summer in farm-kitchens on the bacon-racks, and about the mantlepieces and on the ceilings.

The insect that infests turnips and many crops in the garden (destroying often whole fields while in their seedling leaves) is an animal that wants to be better known. The country people here call it the turnip-fly and black dolphin, but I know it to be one of the Coleoptera; the "Chrysomela oleracea, saltatoria, femoribus posticis crassissimis." In very hot summers they abound to an amazing degree, and as you walk in a field or in a garden, make a pattering like rain by jumping on the leaves of the turnips or cabbages.'

There is an Estrus, known in these parts to every ploughboy; which, because it is omitted by Linnæus, is also passed over by late writers, and that is the curvicauda of old Mouffet, mentioned by Derham in his "Physico-Theology," p. 250, an insect worthy of remark for depositing its eggs as it flies in so dexterous a manner on the single hairs of the legs and flanks of grass horses. ${ }^{2}$ But then Derham is

1 On the subject of the Turnip-fly the reader may be referred to the "Letters of Rusticus," pp. 91-108, and to an excellent account published by Mr. Edward Newman in the "Field" of Nov. 20, 1869.

Against the attacks of the black caterpillar, or "black dolphin," as White terms it, no preventive has yet been suggested. The inost effectual means of keeping it under is by freely sprinkling the infested ficlds with lime, and renewing the sprinkling as often as the fine powder may happen to be carried away by the wind. The same process appears also to have been the most successful that has yet been resorted to against the attacks of the ordinary turnip-fly. It is strongly recommended in a report which was published in 1834 by the Doncaster Agricultural Society, as the result of a very extensive correspondence, instituted with the especial view of collecting, from all parts of England, information on a subject of so much importance to the agriculturist. Ev.

2 Gilbert White was mistaken in supposing that Linnæus had overlooked this insect. He described it both in the "Fauna Suecica" and in his "Systema," under the name of Estrus bovis, but the habitats which he assigned to it, namely, the stomach of the horse and the back of kine, show that he confounded together two distinct insects, the maggots of which infest the several situations referred to by him. The maggots of the one, known by the names of wormals or warbles, and 
mistaken when he advances that this Estrus is the parent of that wonderful star-tailed maggot which he mentions afterwards; for more modern entomologists have discovered

sometimes by that of bots, are found beneath the skin of cattle: these are the larvæ of the true $E$ Estrus bovis, the perfect fly of which was probably unknown to the great Swedish naturalist. The maggots of the other, known, in common with those of some other species, by the name of bots, are found with the larvæ of those other bot-flies in the stomachs of horses. The one whose habits are described by White. may be called the spotted-winged bot-fly.

Mr. Bracy Clark, who has well described the habits of these insects in his "Observations on the Genus CEstrus," published in the third volume of the "Linnean Society's Transactions," and subsequently in an "Essay on the Bots of Horses," says: "The female bot-fly approaching a horse on the wing, holds her body nearly upright in the air, and her tail, which is lengthened for the purpose, curved inwards and upwards : in this way she approaches the part where she designs to deposit the egg; and suspending herself for a few seconds before it, suddenly darts upon it, and leaves the egg adhering to the hair : she hardly appears to settle, but merely touches the hair with the egg held out on the projected point of the abdomen. The egg is made to adhere by means of a glutinous liquor secreted with it. She then leaves the horse at a small distance, and prepares a second egg, and, poising herself before the part, deposits it in the same way. The liquor dries, and the egg becomes firmly glued to the hair: this is repeated by various flies, till four or five hundred eggs are sometimes placed on one horse.

"'The inside of the knee is the part on which these flies are most fond of depositing their eggs, and next to this on the side and back part of the shoulder, and less frequently on the extreme ends of the hairs of the mane. But it is a fact worthy of attention, that the fly does not place them promiscuously abont the body, but constantly on those parts which are most liable to be licked with the tongue; and the ova therefore are always scrupulonsly placed within its reach. Whether this be an act of reason or of instinct, it is certainly a very remarkable one." Mr. Bracy Clark suspects, with Dr. Darwin, it cannot be the latter, as that ought to direct the performance of any act in one way only.

The eggs thus deposited are not, in Mr. Bracy Clark's opinion, removed from the hairs by the inoisture of the horse's tongue, aided by its roughness, in the act of licking, and thus conveyed to the stomach : but remain, he conceives, attached to the hairs for four or five days until they have become "ripe, after which time the slightest application of warmth and moisture is sufficient to bring forth in an instant the latent larva. At this time, if the tongue of the horse touches the egg, its operculum is thrown open, and a small active worm is produced, which readily adheres to the moist surface of the tongue, and is from thence conveyed into the stomach," For the manuer in which the larva affixes 
that singular production to be derived from the egg of the Musca chamoleon: $:^{1}$ see Geoffroy, t. 17, f. 4.

A full history of noxious insects hurtful in the field, garden, and house, suggesting all the known and likely means of destroying them, would be allowed by the public to be a most useful and important work. ${ }^{2}$ What knowledge there is of this sort lies scattered, and wants to be collected; great improvements would soon follow of course. A knowledge of the properties, economy, propagation, and in short, of the life and conversation of these animals, is a necessary step to lead us to some method of preventing their depredations.

As far as I am a judge, nothing would recommend entomology more than some neat plates that should well express the generic distinctions of insects according to Linnæus;

itself in the stomach by means of the two hooks with which it is furnished at its smaller extremity; its mode of growth; its detachment, when fully grown, from the stomach; its passage through the intestines to remain, during its pupa state, in some convenient spot of dung or earth ; some anatomical particulars respecting it; and many other facts relating to the fly in its various stages, as well as to other species; the reader is referred to the paper in the "Linnean Society's Transactions," from which the above extracts are taken. Interesting as they are, the explanation of them would extend this note to too great a length, and would carry it altogether away from the point to which it is chiefly directed,- the admirable provision adrerted to in the text for securing for the bots. the only habitation in which they could exist.-ED.

1 The singular larva of the Stratiomys chamaleon, D E GEer, has been repeatedly figured and described; and the use of the star-like circle of feathered hairs appended to its tail, as a means of suspending that part and the orifice of the respiratory tube in their centre, has been often explained : it is among the most beautiful as well as the most curious contrivances resorted to for such a purpose by ever-varying Nature. The eggs from which these larvæ are produced are affixed by the parent fly to plants living in the water in which the development of the maggot is to take place: those seen by Messrs. Kirby and Spence were "arranged like tiles on a roof, one laid partly over another, on the under side of the leaves of the water-plantain."-ED.

${ }^{2}$ Since this observation was penned, the labours of Messrs. Kirby and Spence, Curtis, Newman, and others have gone far to supply the want alluded to, and have placed in the hands of students a store of most valuable and interesting facts on the subject of entomology.-F. 
for I am well assured that many people would study insects, could they set out with a more adequate notion of those distinctions than can be conveyed at first by words alone.

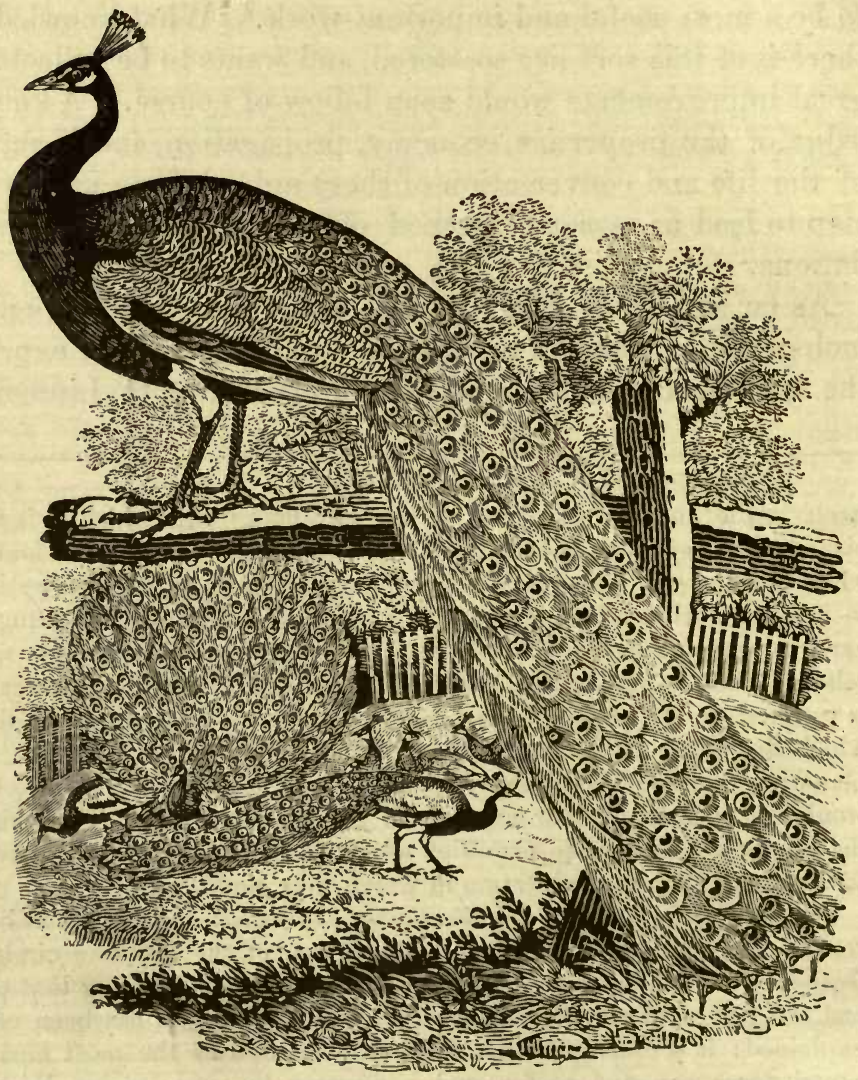

PEACOCK. 


\section{LETTER XXXV.}

\section{TO THOMAS PENNANT, ESQUIRE.}

\section{SELBORNe, 1771.}

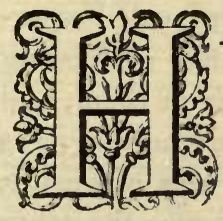

APPENING to make a visit to my neighbour's peacocks, I could not help observing that the trains of those magnificent birds appear by no means to be their tails; those long feathers growing not from their uropygium, but all up their backs. ${ }^{1} \quad$ A range of short brown stiff feathers, about six inches long, fixed in the uropygium, is the real tail, and serves as the fulcrum to prop the train, which is long and top-heavy, when set on end. When the train is up, nothing appears of the bird before but its head and neck; but this would not be the case were those long feathers fixed only in the rump, as may be seen by the turkey-cock when in a strutting attitude. By a strong muscular vibration these birds can make the shafts of their long feathers clatter like the swords of a sword dancer; they then trample very quick with their feet, and run back. wards towards the females.

I should tell you that I have got an uncommon calculus agagropila, taken out of the stomach of a fat ox; it is perfectly round, and about the size of a large Seville orange; such are, I think, usually flat.

1 The peafowl is not the only bird in which the feathers of different parts sometimes assume the appearance of a tail. Familiar instances of this peculiarity are found in some of the cranes, notably in the Stanley crane, and in the beautiful Trogon resplendens of Central America.E.D. 


\section{LETTER XXXVI.}

\section{TO THOMAS PENNANT, ESQUIRE.}

Sept. 1771.

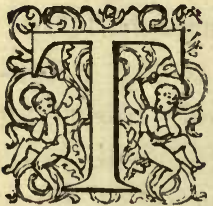

HE summer through I have seen but two of that large species of bat which I call Vespertilio altivolans ${ }^{1}$, from its manner of feeding high in the air: I procured one of them, and found it to be a male; and made no doubt, as they accompanied together, that the other was a female: but, happening in an evening or two to procure the other likewise, I was somewhat disappointed, when it appeared to be also of the same sex. This circumstance, and the great scarcity of this sort, at least in these parts, occasions some suspicions in my mind whether it is really a species, or whether it may not be the male part of the more known species, one of which may supply many females; as is known to be the case in sheep, and some other quadrupeds. But this doubt can only be cleared by a farther examination and some attention to the sex, of more specimens. All that I know at present is, that my two were amply furnished with the parts of generation, much resembling those of a boar.

In the extent of their wings they measured fourteen inches and a half; and four inches and a half from the nose to the tip of the tail : their heads were large, their nostrils bilobated, their shoulders broad and muscular; and their whole bodies fleshy and plump. Nothing could be more sleek and soft than their fur, which was of a bright chestnut colour; their maws were full of food, but so macerated that the quality could not be distinguished; their livers, kidneys, and hearts were large, and their bowels covered with fat. They weighed each, when entire, full one ounce and one drachm. Within the ear there was somewhat of a peculiar structure that I did

I This is the noctule bat, Vespertilio noctula, Linn.-ED. 
not understand perfectly; but refer it to the observation of the curious anatomist. ${ }^{1}$ These creatures sent forth a very rancid and offensive smeli.

\section{LETTER XXXVII.}

\section{TO THOMAS PENNANT, ESQUIRE}

Set.Borne, 1771.

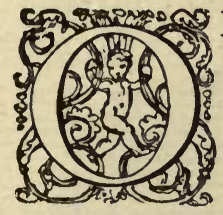

$\mathrm{N}$ the 12th of July I had a fair opportunity of contemplating the motions of the Caprimulgus, or fern-owl, as it was playing round a large oak that swarmed with Scaraboei solstitiales, ${ }^{2}$ or fern-chafers. The powers of its wing were wonderful, exceeding, if possible, the various evolutions and quick turns of the swallow genus. But the circumstance that pleased me most was, that I saw it distinctly, more than once, put out its short leg while on the wing, and, by a bend of the head, deliver somewhat into its mouth. If it takes any part of its prey with its foot, as I have now the greatest reason to suppose it does these chafers, I no longer wonder at the use of its middle toe, which is curiously furnished with a serrated claw.

Swallows and martins, the bulk of them I mean, have

1 This is termed the tragus; it is found in all our British bats except the greater and lesser horse-shoe bats. In man it exists only as a small lobe projecting in front over the auditory opening.

When White first wrote to Pennant on the subject of bats, he knew but two indigenous kinds; the long-eared, and that which he regarded as the short-eared: these, in fact, being all that were even known to Linnæus as European. White subsequently became acquainted with another; the great bat of the text. Pennant knew and described a fourth, the horse-shoe bat. Many years subsequently elapsed without the addition of another. The four indigenous species known in 1771 have now been increased to at least fourteen distinct species, so great have been the advances that have of late years been made in England in the search after animals and in the discrimination between them.-ED.

2 Amphimalla solstitialis, LATr. 
forsaken us sooner this year than usual; for on September the 22 nd they rendezvoused in a neighbour's walnut tree, where it seemed probable they had taken up their lodging for the night. At the dawn of the day, which was foggy, they rose all together in infinite numbers, occasioning such a rushing from the strokes of their wings against the hazy air, as might be heard to a considerable distance : since that no flock has appeared, only a few stragglers.

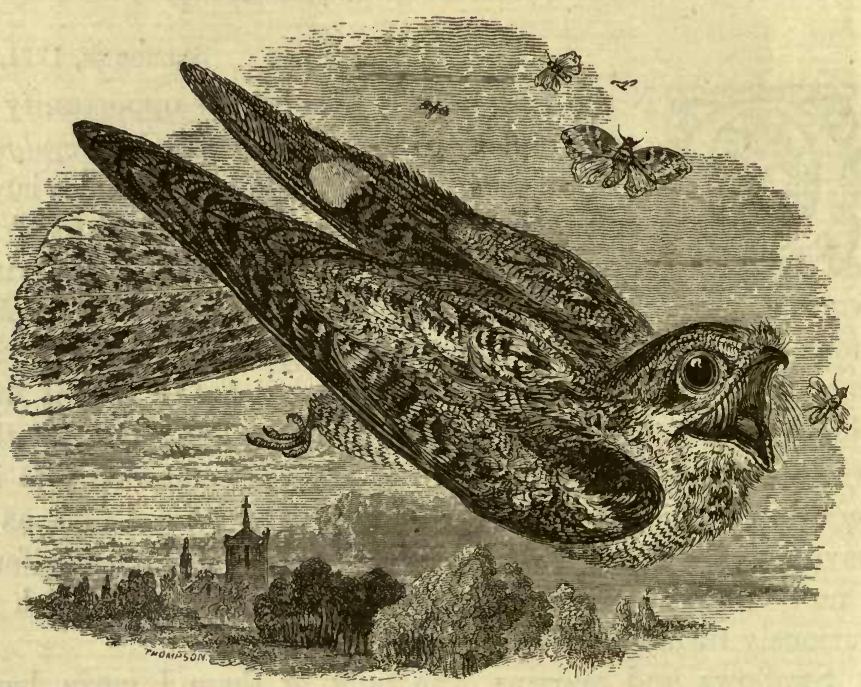

THE FERN-OWL.

Some swifts stayed late, till the 22nd of August-a rare instance! for they usually withdraw within the first week. ${ }^{1}$

On September the 24th three or four ring-ousels appeared in my fields for the first time this season: how punctual are these risitors in their autumnal and spring migrations!

1 See Letter LII. to Mr. Larrington.-G. W. 


\section{LETTER XXXVIII.}

\section{TIIOMAS PENNANT, ESQUIRE.}

Seldor Ne, March 15, 1773.

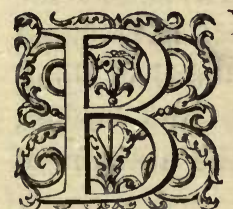

$Y$ my journal for last autumn it appears that the house martins bred very late, and stayed very late in these parts; for on the lst of October, I saw young martins in their nest nearly fledged; and again, on the 21st of October, we had, at the next house, a nest full of young martins just ready to fly; and the old ones were hawking for insects with great alertness. The next morning the brood forsook their nest, and were flying round the village. From this day I never saw one of the swallow kind till November the 3rd; when twenty, or perhaps thirty, house martins were playing all day long by the side of the hanging wood, and over my fields. Did these small weak birds, some of which were nestlings twelve days ago, shift their quarters at this late season of the year to the other side of the northern tropic? Or rather, is it not more probable that the next church, ruin, chalk cliff, steep covert, or perhaps sandbank, lake or pool (as a more northern naturalist would say), may become their hybernaculum, and afford them a ready and obvious retreat?

We now begin to expect our vernal migration of ringousels every week. Persons worthy of credit assure me that ring-ousels were seen at Christmas, 1770, in the forest of Bere, on the southern verge of this country. Hence we may conclude that their migrations are only internal, and not extended to the continent southward, if they do at first come at all from the northern parts of this island only, and not from the north of Europe. Come from whence they will, it is plain, from the fearless disregard that they show for men or guns, that they have been little accustomed to places of much resort. Navigators mention, that, in tho Isle of Ascension, and other such desolatio districts, birds 
are. so little acquainted with the human form that they settle on men's shoulders, and have no more dread of a sailor than they would have of a goat that was grazing. A young man at Lewes, in Sussex, assured me that about seven years ago ring-ousels abounded so about that town in the autumn, that he killed sixteen himself in one afternoon: he added further, that some had appeared since in every autumn; but he could not find that any had been observed before the season in which he shot so many. I myself have found these birds in little parties in the autumn cantoned all along the Sussex downs, wherever there were shrubs and bushes, from Chichester to Lewes; particularly in the autumn of 1770 ,

\section{LETTER XXXIX.}

\section{TO TIIOMAS PENNANT, ESQUIRE.}

Selborne, Nov. 9, 1773.

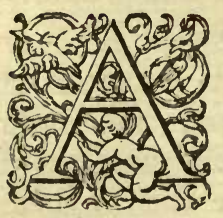

S you desire me to send you such observations as may occur, I take the liberty of making the following remarks, that you may, according as you think me right or wrong, admit or reject what $I$ here advance, in your intended new edition of the " British Zoology."

The osprey was shot about a year ago at Frinsham-pond, a great lake, at about six miles from hence, while it was sitting on the handle of a plough and devouring a fish. It used to precipitate itself into the water, and so take its prey by surprise.

A great ash-coloured butcher-bird was shot last winter in Tisted Park, and a red-backed butcher-bird at Selborne: they are raroe aves in this county. ${ }^{2}$

1 This was the third edition, which subsequently appeared in 1776, and contained many of the notes forwarded by Gilbert White in this and the succeeding letter.-ED.

2 Another butcher bird, or shrike, of which mention has been made 
Crows go in pairs the whole year round.

Cornish choughs abound, and breed on Beachy Head and on all the cliff's of the Sussex coast. ${ }^{1}$

The common wild pigeon, or stock dove, is a bird of passage in the south of England, seldom appearing till towards the end of November; is usually the latest winter bird of passage. Before our beechen woods were so much destroyed, we had myriads of them, reaching in strings for a mile together as they went out in a morning to feed. They leave us early in spring; where do thoy breed ? ${ }^{2}$

The people of Hampshire and Sussex call the missel-bird the storm-cock, because it sings early in the spring in blowing showery weather. Its song often commences with the year. With us it builds much in orchards.

A gentleman assures me he has taken the nests of ringousels on Dartmoor. They build in banks on the sides of streams.

Titlarks ${ }^{3}$ not only sing sweetly as they sit on trees, but

on p. 86, has also occurred at Selborne. Amangst the extracts from White's MS. diary published by Mr. Jesse ("Gleanings in Natural History," 2nd series, p. 161), is the following, under date May 22nd: "Farmer Hoare's son shot a hen Wood-chat, or small butcher-bird, as it was washing at Wellhead, attended by the cock. It is a rare bird in these parts. In its craw were insects."-ED.

1 The chough, unfortunately, is no longer to be found on the Sussex coast. Mr. A. E. Knox in his delightful "Ornithological Rambles in Sussex," (1st ed. p. 210,) thus refers to it in 1849:- " Late writers on British ornithology speak of this bird as a denizen of the cliffs of Beachy Head. I regret to say that it is to be found there no longcr. This was certainly its last stronghold, but it disappeared from the coast about twenty years ago. I have frequently examined the entire line of cliffs between Brighton and Eastbourne, but conld nerer-even with the assistance of a spy-glass-discover one, or procure a recent specimen in any part of Sussex." In 1865 the writer found choughs breeding in the limestone cliffs of the Dorsetshire coast, not far from Lulworth, and procured the eggs from two nests there in May of that year. The old birds were frequently seen, and scrupulously left uninolested. ( $C f$. "The Zoologist," 1865, p. 9668.) The following summer the writer was informed that they were still in their old quarters.-ED.

${ }^{2}$ See Letter XLIV. to Pennant, and the notes thereon.-ED.

${ }^{3}$ Gilbert White here applies the name titlark to the tree pipit, al though elsewhere he thus designates the meadow pipit.-Ev. 
also as they play and toy about on the wing; and particularly while they are descending, and sometimes as they stand on the ground.

Adanson's testimony seems to me to be a very poor evidence that European swallows migrate during our winter to Senegal. He does not talk at all like an ornithologist, and probably saw only the swallows of that country, which I know build within Governor O'Hara's hall against the roof. Had he known European swallows, would he not have mentioned the species?

The house swallow washes by dropping into the water as it flies. This species appears commonly about a week before the house martin, and about ten or twelve days before the swift.

In 1772 there were young house martins in their nest till October the 23rd.

The swift appears about ten or twelve days later than the house swallow, viz., about the 24th or 26th of April.

Whinchats and stonechats stay with us the whole year. ${ }^{1}$

Some wheatears continue with us the winter through.

Wagtails, all sorts, ${ }^{2}$ remain with us all the winter.

Bullfinches, when fed on hempseed, often become wholly black: ${ }^{3}$

We have vast flocks of female chaffinches ${ }^{4}$ all the winter, with hardly any males among them.

1 We know of no instance in which the whinchat has been found here in winter, although the stonechat occasionally passes that season with ns. It is possible that female stonechats may have been mistaken for whinchats, and may thus have given occasion to the above remark.-ED.

2 The pied wagtail, Motacilla Yarrellii, and the grey wagtail, M. boarula. As to the latter, which White elsewhere calls the yellow wagtail, see p. 47, note 4.-ED.

${ }^{3}$ Bullfinches are not the only birds which have been observed to turn black from feeding on hempseed, nor is hempseed the only seed which conduces to such a change of colour. Larks have been known to become black after being fed for some time on hempseed; and the late Mr. Blyth informed us that he had seen one of the little Amandavat finches which had become black, though fed entirely on canary seed.-ED.

4 "British Zoology," vol. ii. p. 306. See also Letter XIII. to Pennant, p. 46.-ED. 
When you say ${ }^{1}$ that in breeding time the cock snipes make a bleating noise, and I a drumming (perhaps I should have rather said a humming), I suspect v:e mean the same thing. However, while they are playing about on the wing, they certainly make a loud piping with their mouths; but whether that bleating or humming is ventriloquous, or proceeds from the motion of their wings, I cannot say; but this I know, that when this noise happens, the bird is always descending, and his wings are violently agitated. ${ }^{2}$

Soon after the lapwings have done breeding, they congregate, and, leaving the moors and marshes, betake themselves to downs and sheep-walks.

Two years ago last spring the little auk was found alive and unhurt, but fluttering and unable to rise, in a lane a few miles from Alresford, where there is a great lake; it was kept awhile, but died. ${ }^{3}$

- I saw young teals taken alive in the ponds of Wolmer

1 “ British Zoology," vol. ii. p. 358.

2 Reference has already been made to this curious sound, and to the mode in which it is supposed to be produced. See antea, p. 35, note 4.

The Hon. and Rev. W. Herbert, in a note to the above passage, has the following pertinent remarks :- "I have observed the drumming of snipes in bright days at the beginning of April, and I could very clearty discern the manner in which the sound is produced. After rising high, and crying peet, peet, peet, which is the snipe's vernal note, it lets itself drop obliquely through the air, keeping the wings motionless, but turning by some muscular contraction each individnal quill sideways in the same manner that the bars of a Venetian blind are turned to admit more light, and having descended to the customary point, it readjusts its feathers, and rises again obliquely without sonnd. They will continue for hours together amusing themselves in this manner upon a mild day, and when they are in this mood, the sportsnian has very little chance of getting near them. The cushat has a sportive movement a little similar, in the summer time, in the narrow wooded valleys amongst the hills; it is less observed in flat countries. It descends obliquely without any motion of the wings, and when it has dived to the usual point of descent, flaps its wings with a loud noisc, and towers again obliquely to the other side of the valley."

The rook, the peewit, and the black-headed gull all produce at times a loud humming sound with the wings.-Ev.

${ }^{3}$ Although the little auk is a sea-bird, many instances have been recorded of its having been found inland during or after stormy weather.-Ev. 
Forest in the beginning of July last, along with flappers, or young wild ducks.

Speaking of the swift (vol. iv. p. 15) that page says "its drink the dew," whereas it should be, "it drinks on the wing," for all the swallow kind sip their water as they sweep over the face of pools or rivers; like Virgil's bees, they drink flying, "flumina summa libant." In this method of drinking, perhaps this genus may be peculiar.

Of the sedge-bird be pleased to say it sings most part of the night. Its notes are hurrying, but not unpleasing, and imitative of several birds, as the sparrow, swallow, skylark. When it happens to be silent in the night, by throw. ing a stone or clod into the bushes where it sits, you immediately set it a singing, or, in other words, though it slumbers sometimes, yet as soon as it is awakened it reassumes its song.

\section{LETTER XL.}

TO THOMAS PENNANT, ESQUIRE.

Selborne, Sept. 2, 1774.

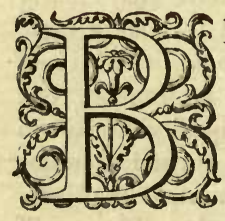

EFORE your letter-arrived, and of my own accord, I had been remarking and comparing the tails of the male and female swallow, and this ere any young broods appeared; so that there was no danger of confounding the dams with their pulli. And besiles, as they were then always in pairs, and busied in the employ of nidification, there could be no room for mistaking the sexes, nor the individuals of different chimneys the one for the other. From all my observations, it constantly appeared that eack sex has the long feathers in its tail that give it that forked shape, with this difference, that they are longer in the tail of the male than in that of the female.

Nightingales, when thcir young first come abroad, and are he'pless, make a plaintive and a jarring noise; and also 
a snapping or cracking, pursuing people along the hedges as they walk : these last sounds seem intended for menace and defiance.

The grasshopper-lark chirps all night in the height of summer.

Swans turn white the second year, and breed the third.

Weasels prey on moles, as appears by their being sometimes caught in mole-traps.

Sparrow-hawks sometimes breed in old crows' nests, and the kestril in churches and ruins.

There are supposed to be two sorts of eels in the island of Ely. ${ }^{1}$ The threads sometimes discovered in eels are perhaps their young; the generation of eels is very dark and mysterious. ${ }^{2}$

Hen-harriers breed on the ground, and secm never to settle on trees.

When redstarts shake their tails they move them horizontally, as dogs do when they fawn; the tail of a wagtail, when in motion, bobs up and down like that of a jaded horse.

Hedge-sparrows have a remarkable flirt with their wings in breeding time; as soon as frosty mornings come they make a very piping plaintive noise.

Many birds which become silent about Midsummer, reassume their notes again in September; as the thrush, blackbird, woodlark, willow wren, \&c.; hence August is by much the most mute month, the spring, summer, and autumn through. Are birds induced to sing again because the temperament of autumn resembles that of spring?

Linnæus ranges plants geographically; palms inhabit the tropics, grasses the temperate zones, and mosses and lichens the polar circles; no doubt animals may be classed in the same manner with propriety.

1 Three species of eels are described and figured in Yarrell's "History of British Fishes." But see antea, p. 39, note 2.-ED.

2 Eels are infested by sereral kinds of intestinal worms, which are doubtless the thread-like bodies referred to. The observations made by the late Mr. Yarrell on the reproduction of eels leave little doult that they spawn like other fishes.-Ev. 
House sparrows build under eaves in the spring; as the weather becomes hotter they get out for coolness, and nest in plum-trees and apple-trees. These birds have been known sometimes to build in rooks' nests, and sometimes in the forks of boughs under rooks' nests.

As my neighbour was housing a rick he observed that his dogs devoured all the little red mice that they could catch, but rejected the common mice; and that his cats ate the common mice, refusing the red.

Redbreasts sing all through the spring, summer, and autumn. The reason that they are called autumn songsters is, because in the two first seasons their voices are drowned and lost in the general chorus; in the latter their song becomes distinguishable. Many songsters of the autumn seem to be the young cock redbreasts of that year; notwithstanding the prejudices in their favour, they do much mischief in gardens to the summer fruits. ${ }^{1}$

The titmouse which early in February begins to make two quaint notes, like the whetting of a saw, is the marsh titmouse; the great titmouse sings with three cheerful joyous notes, and begins about the same time.

Wrens sing all the winter through, frost excepted.

House martins came remarkably late this year both in Hampshire and Devonshire; is this circumstance for or against either hiding or migration?

Most birds drink sipping at intervals; but pigeons take a long continued draught, like quadrupeds.

Notwithstanding what I have said in a former letter, no groy crows were ever known to breed on Dartmoor; it was my mistake.

The appearance and flying of the Scarabous solstitialis,

1 They eat also the berries of the ivy, the honeysuckle, and the Eunnymus europaus, or spindle-tree.-G. IV.

'The Hon. and liev. W. Herbert observed a robin feed its young entirely upon red currants. He thought they did not eat any other fruit, but were troublesorne in the hothouse. In one year they devoured every seed of Hamanthus multiflorus and Griffinia liyacinthina just as they were ripening; and it was very difficult to save the berries of any Daphne from them. Mr. Rennie found that a redbreast which he hacl in a cage greedily deroured the berrics of Solanum dulcamara, but would not touch those of privet.-Ev. 
or fern-chafer, commence with the month of July, and cease about the end of it. These scarabs are the constant food of Caprimulgi, or fern-owls, through that period. They abound on the chalky downs and in some sandy districts, but not in the clays.

In the garden of the Black Bear Inn in the town of Reading, is a stream or canal running under the stables and out into the fields on the other side of the road; in this

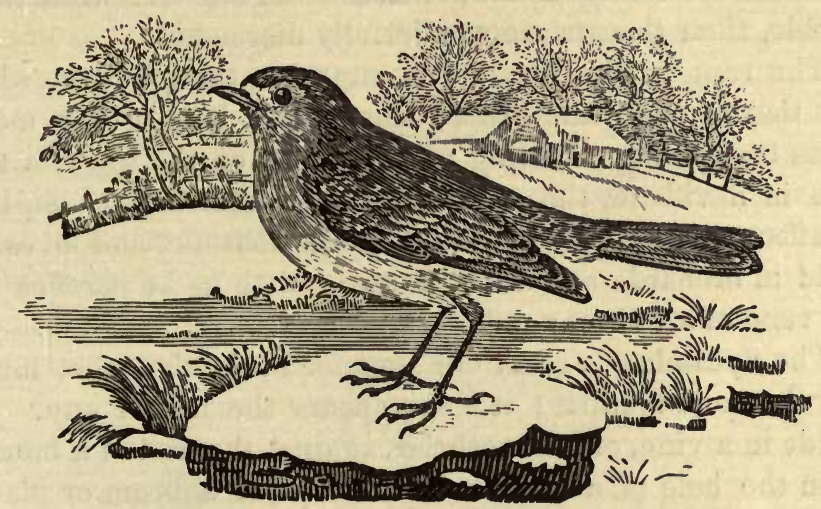

REDBREAST.

water are many carps, which lie rolling about in sight, being fed by travellers, who amuse themselves by tossing them bread; but as soon as the weather grows at all severe these fishes are no longer seen, becanse they retire under the stables, where they remain till the return of spring. Do they lie in a torpid state? if they do not, how are they supported?

The note of the whitethroat, which is continually repeated, and often attended with odd gesticulations on the wing, is harsh and displeasing. These birds seem of a pugnacious disposition; for they sing with an erected crest and attitudes of rivalry and defiance; are shy and wild in breeding time, avoiding neighbourhoods, and haunting lonely lanes and commons; nay, even the very tops of the Sussex Downs, where there are bushes and covert; but in July and 
August they bring their broods into gardons and orchards and make great havoc among the summer fruits. ${ }^{1}$

The blackcap has, in common, a full, sweet, deep, loud, and wild pipe; yet that strain is of short continuance, and his motions are desultory; but when that birds sits calmly and engages in song in earnest, he pours forth very sweet, but inward melody, and expresses great variety of soft and gentle modulations, superior perhaps to those of any of our warbiers, the nightingale excepted.

Blackcaps mostly haunt orchards and gardens: while they warble, their throats are wonderfully distended.

The song of the redstart is superior, though somewhat like that of the whitethroat; some birds have a fow more notes than others. Sitting very placidly on the top of a tall tree in a village, the cock sings from morning to night; he affects neighbourhoods, and avoids solitude, and loves to build in orchards and about houses; with us he perches on the vane of a tall may-pole.

The flycatcher is of all our summer birds the most mute and the most familiar; it also appears the last of any. It builds in a vine, or a sweetbriar, against the wall of a house, or in the hole of a wall, or on the end of a beam or plate, and often close to the post of a door where people are going in and out all day long. This bird does not make the least pretension to song, but uses a little inward wailing note when it thinks its young in danger from cats or other annoyances; it breeds but once, and retires early. ${ }^{2}$

1 The Hon. and Rev. W. Herbert thought the whole of this passage founded in error, since according to his experience there are no birds less shy and less pugnacious than whitethroats. And the late Mr. Daniel remarked on this passage that "so far from being wild and shy in the breeding season, the whitethroat frequents at that period the vicinity of London, and forms part even of the Fauna of St. Marylebone, covered as that parish now is with buildings. I have a nest taken by myself from a bramble-bush, by the side of a foot-path, just beyond the houses in the Avenue Road, Regent's Park." The fact is, Gilbert White seems to have mistaken the lesser whitethroat for the common whitethroat. The account which he gives of the habits of his bird will apply to the former, but not no well to the latter species.-En.

The spcttud flycatcher not unfrequently rears a second brood.-ED. 
Selborne parish alone can and has exhibited at times more than half the birds that are ever seen in all Sweden; the former has produced more than one hundred and twenty species, the latter only two hundred and twenty-one. Let me add also that it has shown near half the species that were ever known in Great Britain. ${ }^{1}$

On a retrospect, I observe that my long letter carries with it a quaint and magisterial air, and is very sententious; but, when I recollect that you requested stricture and anecdote, I hope you will pardon the didactic manner for the sake of the information it may happen to contain.

1 Sweden 221, Great Britain 252 species.-G. W.

The number of so-called British birds at the present time is about 395. Of these, in round numbers, 130 are residents, 100 periodical migrants, and 30 annual visitants, the remainder being rare and accidental visitants.-ED.

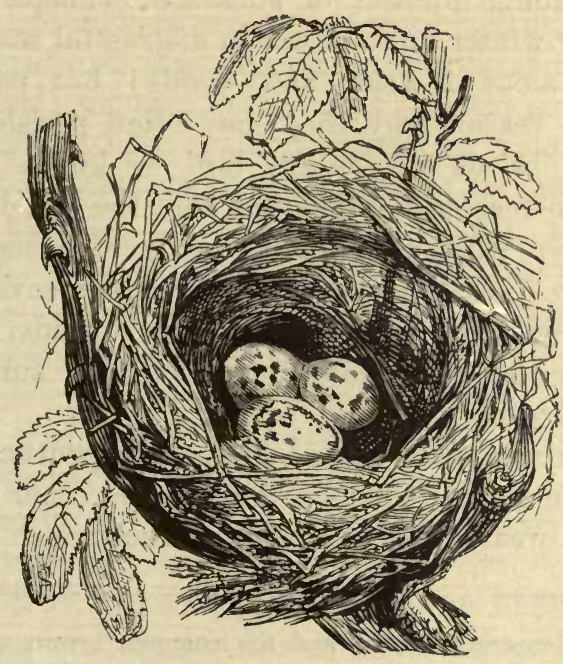




\section{LETTER XLI.}

\section{TO THOMAS PENNANT, ESQUIRE.}

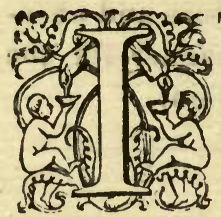

$\mathrm{T}$ is matter of curious inquiry to trace out how those species of soft-billed birds, that continue with us the winter through, subsist during the dead months. The imbecility of birds seems not to be the only reason why they shun the rigour of our winters; for the robust wryneck (so much resembling the hardy race of woodpeckers) migrates, while the feeble little golden-crowned wren, that shadow of a bird, braves our severest frosts without availing himself of houses or villages, to which most of our winter birds crowd in distressful seasons, while this keeps aloof in fields and woods; but perhaps this may be the reason why they may often perish, and why they are almost as rare as any bird we know. ${ }^{1}$

I have no reason to doubt but that the soft-billed birds, which winter with us, subsist chiefly on insects in their aurelia state. All the species of wagtails in severe weather haunt shallow streams near their spring-heads, where they never freeze; and, by wading, pick out the aurelias of the genus of Phryganco, \&c. ${ }^{2}$

Hedgo sparrows frequent sinks and gutters in hard weather, where they pick up crumbs and other sweepings: and in mild weather they procure worms, which are stirring

1 The golden-crested wren and the common brown wren are both very impatient of cold. In confinement, as observed by the Hon. and Rev. W. Herbert, the least frost is immediately fatal to them. In a wild state, they keep themselves warm by constant active motion in the day, and at night they secrete themselves in places where the frost cannot reach them; but numbers doubtless perish in severe winters.-ED.

2 See Derham's "Physico-I'heology," p. 235.-G. W. 
every month in the year, as any one may see that will only be at the trouble of taking a candle to a grass-plot on any mild winter's night. Redbreasts and wrens in the winter haunt out-houses, stables, and barns, where they find spiders and flies that have laid themselves up during the cold season. But the grand support of the soft-billed birds in winter is that infinite profusion of aureliæ of the Ordo Lepidoptera, which is fastened to the twigs of trees and their trunks; to the pales and walls of gardens and buildings; and is found in every cranny and cleft of rock or rubbish, and even in the ground itself.

Every species of titmouse winters with us; they have what I call a kind of intermediate bill between the hard and the soft, between the Linnæan genera of Fringilla and Motacilla. One species alone spends its whole time in the woods and fields, never retreating for succour in the severest seasons to houses and neighbourhoods; and that is the delicate long-tailed titmouse, which is almost as minute as the golden-crowned wren: but the blue titmouse, or nun (Parus corruleus), the colemouse (Parus ater), the great black-headed titmouse (Fringillago), ${ }^{1}$ and the marsh titmouse (Parus palustris), all resort, at times, to buildings; and in hard weather particularly. The great titmouse, driven by stress of weather, much frequents houses, and, in deep snows, I have seen this bird, while it hung with its back downwards (to my no small delight and admiration), draw straws lengthwise from out the eaves of thatched houses, in order to pull out the flies that were concealed between them, and that in such numbers that they quite defaced the thatch, and gave it a ragged appearance.

The blue titmouse, or nun, is a great frequenter of houses, and a gencral devourer. Besides insects, it is very fonc. of flesh; for it frequently picks bones on dunghills : it is a vast admirer of suet, and haunts butchers' shops. When a boy, I have known twenty in a morning caught with snap mousetraps, baited with tallow or suet. It will also pick holes in apples left on the ground, and be well entertained 
with the secds on the head of a sunflower. The bluc, marsh, and great titmice will, in very severe weather, carry away barley and oat straws from the sides of ricks.

How the wheatear and whinchat support themselves in winter cannot be so easily ascertained, since they spend their time on wild heaths and warrens $;^{1}$ the former especially, where there are stone quarries : most probable it is, that their maintenance arises from the aureliæ of the Ordo Lepidoptera, which furnish them with a plentiful table in the wilderness.

\section{LETTER XLII.}

\section{TO THOMAS YENNANT, ESQUIRE.}

Selborne, March 9, 1775.

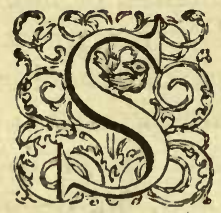

O.ME future Faunist, a man of fortune, will, I hope, extend his visits to the kingdom of Ireland; a new field, and a country little known to the naturalist. He will not, it is to be wished, undertake that tour unaccompanicd by a botanist, because the mountains have scarcely been sufficiently examined; and the southerly counties of so mild an island may possibly afford some plants little to be expected within the British dominions. A person of a thinking turn of mind will draw many just remarks from the modern improvements of that country, both in arts and agriculture, where premiums obtained long before they wore heard of with us. The manners of the wild natives, their superstitions, their prejudices, their sordid way of life, will

1 The stonechat may have been mistaken for the whinchat, since the former occasionally spends the winter here, but the latter never. The wheatear, from having been observed in March, may have been supposed to have passed the winter with us, but we know of no instance in which it has been met with in England between the end of November and the beginning of March. See note 1, p. 118.-Fid. 
extort from him many useful reflections. He shoulà also take with him an able draughtsman; for he must by no means pass over the noble castles and seats, the extensive and picturesque lakes and waterfalls, and the lofty stupendous mountains, so little known, and so engaging to the imagination when described and exhibited in a lively manner: such a work would be well received. ${ }^{1}$

As I have seen no modern map of Scotland, I cannot pretend to say how accurate or particular any such may be; but this I know, that the best old maps of that kingdom are very defective.

The great obvious defect that I have remarked in all maps of Scotland that have fallen in my way is, a want of a coloured line, or stroke, that shall exactly define the just limits of that district called the Highlands. Moreover, all the great avenues to that mountainous and romantic country want to be well distinguished. The military roads formed by General Wade are so great and Roman-like an undertaking, that they well merit attention. My old map, Moll's Map, takes notice of Fort William; but could not mention the other forts that have been erected long since: therefore a good representation of the chain of forts should not be omitted.

The celebrated zigzag up the Coryarich must not be passed over: Moll takes notice of Hamilton and Drumlanrig, and such capital houses; but a new survey, no doubt, should represent every seat and castle remarkable for any great event, or celebrated for its paintings, \&c. Lord Breadalbane's seat and beautiful policy are too curious and extraordinary to be omitted.

The seat of the Earl of Eglintoun, near Glasgow, is worthy of notice. The pine plantations of that nobleman are very grand and extensive indeed.

1 Since these lines were penned by Gilbert White, an excellent work on the "Natural History of Ireland," in four volumes, has been pub. lished by the late Mr. William Thompson, of Belfast.-ED. 


\section{LETTER XLIII.}

TO THOMAS PENNANT, ESQUIRE.

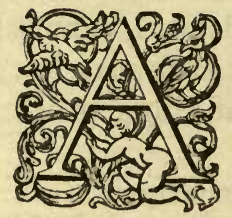

PAIR of honey buzzards, Buteo apivorus sive vespivorus, Rall, built them a large shallow nest, composed of twigs and lined with dead beechen leaves, upon a tall slender beech near the middle of Selborne Hanger, in the summer of 1780 . In the middle of the month of June a bold boy climbed this tree, though standing on so steep and dizzy a situation, and brought down an egg, the only one in the nest, which had been sat on for some time, and contained the embryo of a young bird. The egg was smaller, and not so round as those of the common buzzard; was dotted at each end with small red spots, and surrounded in the middle with a broad bloody zone.

The hen bird was shot, and answered exactly to Mr. Ray's description of that species; had a black cere, short thick legs, and a long tail. When on the wing this species may be easily distinguished from the common buzzard by its hawk-like appearance, small head, wings not so blunt, and longer tail. This specimen contained in its craw some limbs of frogs and many gray snails without shells. The irides of the eyes of this bird were of a beautiful bright yellow colour.

About the 10th of July in the same summer a pair of sparrow-hawks bred in an old crow's nest on a low beech in the same Hanger; and as their brood, which was numerous, began to grow up, became so daring and ravenous, that they were a terror to all the dames in the village that had chickens or ducklings under their care. A boy climbed the tree, and found the young so fledged that they all escaped from him; but discovered that a good house hav been kept: the larder was well stored with provisions; for he brought down a young blackbird, jay, and house-martin, 
all clean picked, and some half devoured. The old birds had been observed to make sad havock for some days among the new-flown swallows and martins, which, being but

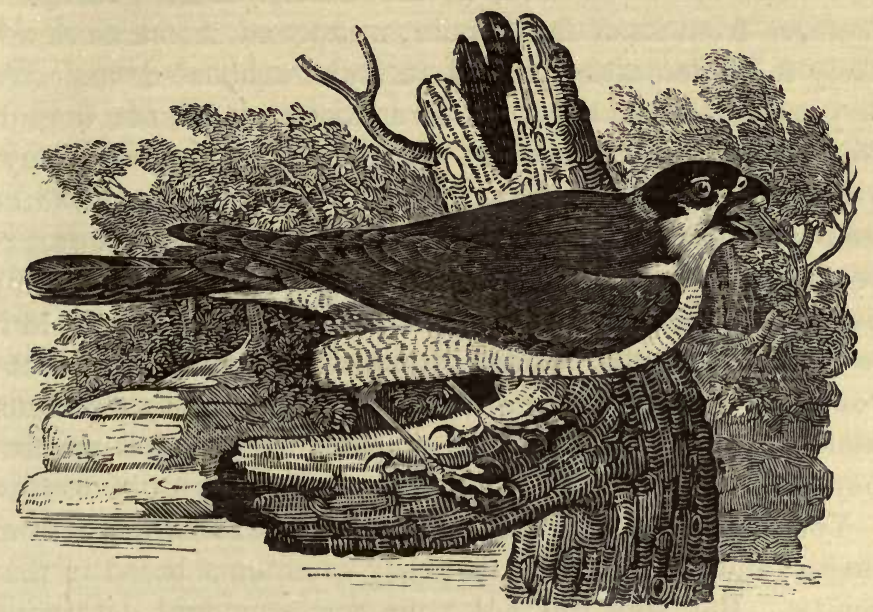

SPARROW-HAWK.

lately out of their nests, had not acquired those powers and command of wing that enable them, when more mature, to set such enemies at defiance.

\section{LETTER XLIV.}

TO THOMAS PENNANT, ESQUIRE.

Selborne, Nor. 30, 1780.

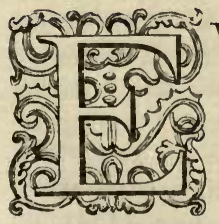

VERY incident that occasions a renewal of our correspondence will ever be pleasing and agreeable to me.

As to the wild wood-pigeon, the Enas or Vinago of Ray, ${ }^{1}$ I am much of your mind, and see no reason for making it the origin of the common house- 
dove; but suppose those that have advanced that opinion may have been misled by another appellation, often given to the Enas, which is that of stock-dove.

Unless the stock-dove in the winter varies greatly in manners from itself in summer, no species seems more unlikely to be domesticated and to make a house-dove. We very rarely see the latter settle on trees at all, nor does it ever haunt the woods; but the former, as long as it stays with us, from November perhaps to February, lives the same wild life with the ring-dove (Palumbus torquatus) $;^{1}$ frequents coppices and groves, supports itself chiefly by mast, and delights to roost in the tallest beeches. Could it be known in what manner stock-doves build, the doubt would be settled with me at once, provided they construct their nests on trees, like the ring-dove, as I much suspect they do. ${ }^{2}$

You received, you say, last spring a stock-dove from Sussex, and are informed that they sometimes breed in that county. But why did not your correspondent determine the place of its nidification, whether on rocks, cliffs, or trees? If he was not an adroit ornithologist, I should doubt the fact, because people with us perpetually confound the stock-dove with the ring-dove. ${ }^{3}$

For my own part, I readily concur with you in supposing that house-doves are derived from the small blue rock-

1 Columba palumbus, Lins.

2 The stock-dove, Columba onas, LinN., so called from its habit of building in stocks or pollards, nests also in deserted rabbit burrows, and even under thick furze bushes, where openings near the ground have been made by rabbits. Mr. Salmon, in his notice of Norfolk birds ("Loudon's Mag. Nat. Hist.," vol. ix. p. 520), says he has known the stock-dove to make its nest high up in a fir tree, like the ring-dove; but this was undoubtedly an exceptional case. It has fallen to the lot of the writer on different occasions to find stock-doves nesting in a church spire ( $c f$. "The Ibis," 1867, p. 379, and "Zoologist," 1867, p. 758) and even in limestone rocks facing the sea ( $c f$. "The Field," 14th April, 1866). In both instances the young were taken and reared, and the identity of the species thus placed beyond doubt.-Ev.

3 Pennant confounded the stock-dove with the rock-dove, Columba livia, Temm. and made one species of them.-ED. 
pigeon, for many reasons. ${ }^{1}$ In the first place, the wild stock-dove is manifestly larger than the common housedove, against the usual rule of domestication, which generally enlarges the breed. Again, those two remarkable black spots on the remiges of each wing of the stock-dove, which are so characteristic of the species, would not, one should think, be totally lost by its being reclaimed, but would often break out among its descendants. ${ }^{2}$ But what is worth a hundred arguments is, the instance you give in Sir Roger Mostyn's house-doves in Caernarvonshire, which, though tempted by plenty of food and gentle treatment, can never be prevailed on to inhabit their cote for any time, but, as soon as they begin to breed, betake themselves to the fastnesses of Ormshead, and deposit their young in safety amidst the inaccessible caverns and precipices of that stupendous promontory.

"Naturam expellas furcâ, tamen usque recurret."

I have consulted a sportsman, now in his seventy-eighth year, who tells me that fifty or sixty years back, when the beechen woods were much more extensive than at present, the number of wood-pigeons was astonishing; that he has often killed near twenty in a day; and that, with a long wildfowl piece, he has shot seven or eight at a time on the wing, as they came wheeling over his head. He moreover adds, which I was not aware of, that often there were among them little parties of small blue doves, which he calls rockiers. ${ }^{3} \quad$ The food of these numberless emigrants was beech mast and some acorns, and particularly barley, which they collected in the stubbles. But of late years, since the

1 This is now the generally received opinion, although formerly naturalists, misled by the signification of the word "stock," regarded the stock-dove as the progenitor of all the domestic breeds.-ED.

${ }^{2}$ A good argument, as illustrated by the fact that the two conspicuous black bars on the wing of the rock-dove may be observed in many individuals of the numerous domestic varieties. The fact also of the dove-cot pigeon never perching upon trees affords another proof of its relationship with the rock-dove, and not with the stock-dore.-ED.

${ }^{3}$ Although called "rockiers," these "small blue doves" must have been stock-doves.-ED. 
vast increase of turnips, that vegetable has furnished a yreat part of their support in hard weather, and the holes they pick in these roots greatly damage the crop. From this food their flesh has contracted a rancidness which occasions them to be rejected by nicer judges of eating, who thought them before a delicate dish. They were shot not only as they were feeding in the fields, and especially in snowy weather, but also at the close of the evening, by men who lay in ambush among the woods and groves to kill them as they came in to roost. ${ }^{1}$ These are the principal circumstances relating to this wonderful internal migration which with us takes place towards the end of November, and ceases early in the spring. Last winter we had in Selborne high wood about a hundred of these doves; but in former times the flocks were so vast, not only with us but all the district round, that on mornings and evenings they traversed the air like rooks, in strings, reaching for a mile together. When they thus rendezvoused here by thousands, if they happened to be suddenly roused from their roost trees on an evening,

"Their rising all at once was like the sound

Of thunder heard remote."

It will by no means be foreign to the present purpose to add that $I$ had a relation in this neighbourhood who made it a practice, for a time, whenever he could procure the eggs of a ring-dove, to place them under a pair of doves that were sitting in his own pigeon-house, hoping thereby, if he could bring about a coalition, to enlarge his breed, and teach his own doves to beat out into the woods, and to support themselves by mast. The plan was plausible, but something always interrupted the success, for though the birds were usually hatched, and sometimes grew to half their size, yet none ever arrived at maturity. I myself have seen these foundlings in their nest displaying a strange ferocity of nature, so as scarcely to bear to be looked at, and snapping with their bills by way of menace. In short, they always

1 Some old sportsmen say that the main part of these flocks user to withdraw as soon as the heavy Christmas frosts were over.-G. WV. 
died, perhaps for want of proper sustenance; but the owner thought that by their fierce and wild demeanour they frighted their foster-mothers, and so were starved.

Virgil, as a familiar occurrence, by way of simile, describes a dove haunting the cavern of a rock, in such engaging numbers, that I cannot refrain from quoting the passage: and John Dryden has rendered it so happily in our language, that without further excuse I shall add his translation also.

"Qualis speluncâ subitò commota Columba, Cui domus et dulces latebroso in pumice nidi, Fertur in arva volans, plausumque exterrita pennis Dat tecto ingentem - mox aëre lapsa quieto, Radit iter liquidum, celeres neque commovet alas." "As when a dove her rocky hold forsakes, Roused, in a fright her sounding wings she shakes; The cavern rings with clattering :- out she flies, And leaves her callow care, and cleaves the skies: At first she flutters:-but at length she springs To smoother flight, and shoots upon her wings."

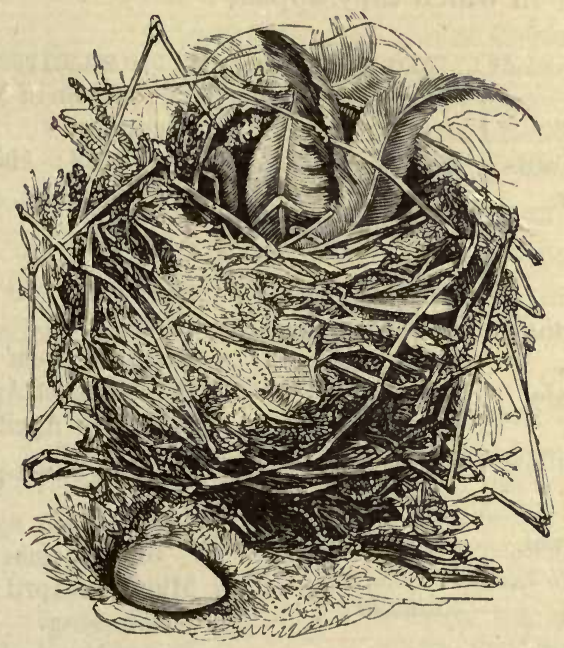




\section{LETTER I:}

\section{TO THE HONOURABLE DAINES BARRINGTON.}

Selborne, June 30, 1769.

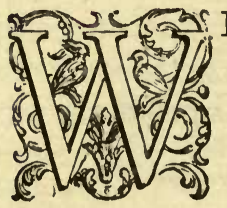

HEN I was in town last month I partly engaged that I would some time do myself the honour to write to you on the subject of natural history: and I am the more ready to fulfil my promise, because I see you are a gentleman of great candour, and one that will make allowances; especially where the writer professes to be an outdoor naturalist, one who takes his observations from the subject itself, and not from the writings of others.

The following is a list of summer birds of passage which I have discovered in this neighbourhood, ranged somewhat in the order in which they appear:

RAII NOMINA.

1. Wryneck, $\quad\left\{\begin{array}{c}\operatorname{Jyn} x \text { sive torquil- } \\ l a:\end{array}\right\} \begin{gathered}\text { The middle of March: harsh } \\ \text { note. }\end{gathered}$

2. Smallest wil- $\{$ Regutus low wren,

3. Swallow,

4. Martin,

5. Sand martin,

6. Blackcap,

7. Nightingale,

8. Cuckoo,

9. Middle willow wren,

10. Whitethroat,

11. Redstart,

12. Stone curlew

13. Turtle-dove
Ruticilla :

$\{$ Regulus non cris- $\}$ March 23: chirps till Sep$\left\{\begin{array}{c}\text { Hirundo domesti- } \\ \text { ca: }\end{array}\right\}$ April 13.

\section{Hirundo rustica: Ditto.}

Hirundo riparia: Ditto. Atricapilla :

Luscinia:

Cuculus :

Ditto: a sweet wild note.

Beginning of April.

Middle of April.

$\left\{\begin{array}{l}\text { Regulus non cris- } \\ \text { tatus: }\end{array}\right.$

Ficedula affinis :

CEdicnemus:

Turtur.
Ditto: a sweet plaintive note.

Ditto: mean note; sings on till September.

$\{$ Middle of April : mare agreeable song.

$\{$ End of March. loud nocturnal whistle. 
$\left.\begin{array}{l}\text { 14. Grasshopper } \\ \text { lark, }\end{array}\right\} \begin{gathered}\text { Alauda minima lo- } \\ \text { custe voce: }\end{gathered}\left\{\begin{array}{c}\text { Middle of April : a small si- } \\ \text { bilous note, till the end of } \\ \text { July. }\end{array}\right.$

15. Swift,

Hirundo apus: $\quad$ About April 27.

16. Less reed $\}$ Passer arundina- $\{$ A sweet polyglot, but hurry-

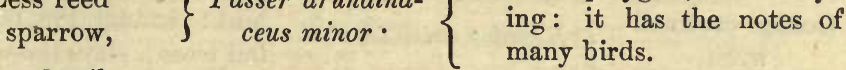

17. Land-rail, Ortygometra :

A loud harsh note, crex, crex. $\left.\begin{array}{l}\text { 18. Largest willow } \\ \text { wren, }\end{array}\right\} \begin{gathered}\text { Regulus non cris- } \\ \text { tatus: }\end{gathered}\left\{\begin{array}{c}\text { "Cantat voce stridulâ locus }- \\ \text { ta:" end of April, on the }\end{array}\right.$ tops of high beeches.

19. Goatsucker, or fern owl, $\}$ Caprimulgus:

Beginning of May : chatters

20. Flycatcher,

Stoparola : by night with a singular noise.

Cay 12. A very mute bird: this is the latest summer bird of passage.

This assemblage of curious and amusing birds belongs to ten several genera of the Linnæan system; and are all of the Ordo of Passeres, save the Jynx and Cuculus, which are Picoe, and the Charadrius (Edicnemus) and Rallus (Ortygometra), which are Gralloe.

These birds, as they stand numerically, belong to the following Linnæan genera :-

1.

$2,6,7,9,10,11,16,18$.

$3,4,5,15$.

8.

12.
Jynx:

Motacilla:

Hirundo:

Cuculus:

Charadius:
13. Columba:

17. Rallus :

19. Caprimulgus:

14. Alauda :

20. Muscicapa:

Most soft-billed birds live on insects, and not on grain and seeds; and therefore at the end of summer they retire; but the following soft-billed birds, though insecteaters, stay with us the year round:-

RAII NOMINA.

Redbreast,

Wren,

Hedge sparrow,

White wagtail, Yellow wagtail, Gray wagtail,
Rubecula :

$\{$ Passer troglodytes:

Curruca:

Motacilla alba: Motacilla flava: Motacilla cinerea:
These frequent houses; and haunt out-buildings in the winter : eat spiders.

f Haunt sinks for crumbs and other sweepings.

These frequent shallow rivulets near the spring heads, where they never freeze: eat the aureliæ of Phryganea. The smallest birds that walk. 


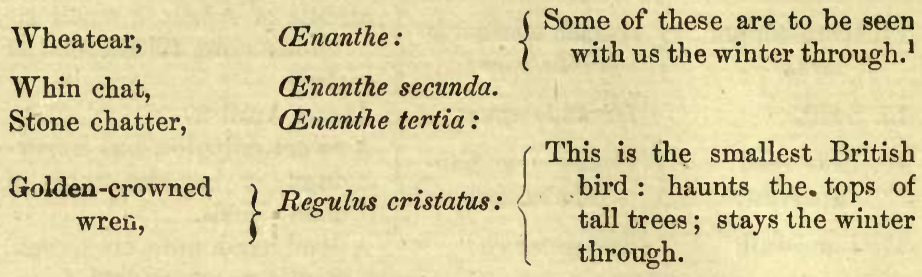

A list of the winter birds of passage round this neighbourhood, ranged somewhat in the order in which they appear:-

1. Ring-ousel,

2. Redwing,

3. Fieldfare,

4. Royston crow,

5. Woodcock,

6. Snipe,

7. Jack snipe,

8. Wood-pigeon,

9. Wild swan,

10. Wild goose,

11. Wild duck.

12. Pochard,

13. Wigeon,

14. Teal, breeds with us in Wolmer Forest,

15. Grosbeak,

16. Crossbill,

17. Silktail,
(This is a new migration, which I have lately discovered, Merula torquata: about Michaelmas week, and again about the fourteenth of March.

About old Michaelmas.

Turdus iliacus:

Turdus pilaris:

$\{$ Though a percher by day, roosts on the ground.

Most frequent on downs.

$\{$ Appears about old Michaelmas.

$\int$ Some snipes constantly breed with us.

Gallinagominima.

QEnas:

Cygnus ferus :

Anser ferus.

$\left\{\begin{array}{l}\text { Anas torquata mi- } \\ \text { nor: }\end{array}\right.$

Anas fera fusca:

Penelope

On our lakes and streams. $\left\{\begin{array}{c}\text { Seldom appears till late: not } \\ \text { in such plenty as formerly. } \\ \text { On some large waters. }\end{array}\right.$

These birds, as they stand numerically, belong to the following Linnæan genera:-
$1,2,3$.
Turdus:
$9,10,11,12,13,14$.
Anas :
4.
Corvus:
$15,16$.
Loxia:
$5,6,7$,
Scolopax:
17.
Ampelis.
8.
Columba:

${ }^{1}$ See note on page 128.-ED. 
Birds that sing in the night are but few. ${ }^{1}$

Nightingale, $\quad$ Luscinia: $\quad\{$ "In shadiest covert hid."
Mruton.

Woodlark, Alauda arborea: Suspended in mid air.

$\left.\begin{array}{l}\text { Less reed spar- }\left\{\begin{array}{c}\text { Passer arundina- } \\ \text { ceus minor: }\end{array}\right. \\ \text { row, }\end{array}\right\}$ Among reeds and willows.

$I$ should now proceed to such birds as continue to sing after midsummer, but as they are rather numerous, they would exceed the bounds of this paper; besides, as this is now the season for remarking on that subject, I am willing to repeat my observations on some birds concerning the continuation of whose song I seem at present to have some doubt.

\section{LETTER II.}

\section{TO THE HONOURABLE DAINES BARRINGTON.}

Selborne, Nov. 2, 1769.

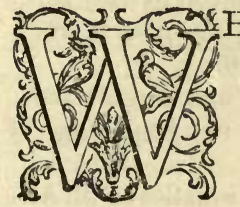

HEN I did myself the honour to write to you about the end of last June on the subject of natural history, I sent you a list of the summer birds of passage which I have observed in this neighbourhood; and also a list of the winter birds of passage; I mentioned besides those soft-billed birds that stay with us the winter through in the south of England, and those that are remarkable for singing in the night.

According to my proposal, I shall now proceed to such birds (singing birds strictly so called) as continue in full song till after midsummer; and shall range them somewhat

1 Some others might have been added, as the reed warbler, the grasshopper warbler, and the cuckoo. The sky-lark often sings very late, and the note of the corncrake may frequently be heard in May between 11 and 12 P.M. The "less reed sparrow," Passer arundaccus minor, above mentioned is the sedge warbler, Salicaria phragmitis (Bechstein).-Ev. 
in the order in which they first begin to open as the spring advances.

\section{RAII NOMINA.}

1. Woodlark, Alauda arborea: $\left\{\begin{array}{r}\text { In January, and continues to } \\ \text { sing through all the summer } \\ \text { and autumn. }\end{array}\right.$

2. Song-thrush, $\left\{\begin{array}{l}\text { Turdus simpliciter } \\ \text { dictus: }\end{array}\left\{\begin{array}{l}\text { In February, and on to } \\ \text { August, reassume their } \\ \text { song in autumn. }\end{array}\right.\right.$

3. Wren,

4. Redbreast, Passer troglodytes :

5. Hedge sparRubecula: row,

Curruca:

6. Yellowhammer,

7. Skylark,

Emberiza flava:

8. Swallow,

9. Blackcap,

10. Titlark, 1

11. Blackbird,

12. Whitethroat,

13. Goldfinch,

14. Greenfinch,

15. Less reed sparrow,

Alauda vulgaris : $\left\{\begin{array}{l}\text { Hirundo domesti- } \\ \text { ca: }\end{array}\right\}$ $\left\{\begin{array}{l}\text { All the year, hard frost ex- } \\ \text { cepted. }\end{array}\right.$

\section{Ditto.}

$\{$ Early in February, to July $\{$ the 10th.

f Early in February, and on through July to Aug. 21st. In February, and on to Oct. Atricapilla:

From April to September.

Beginning of April to July 13. Alauda pratorum: $\left\{\begin{array}{c}\text { From middle of April to July } \\ \text { the 16th. }\end{array}\right.$ \} Merula vulgaris: Sometimes in February and March, and so on to July $23 \mathrm{rd}$, reassumes in autumn. Ficedula affinis: In April, and on to July 23rd. Carduelis :

Chloris: $\left\{\begin{array}{l}\text { April, and through to Sep- } \\ \text { tember } 16 .\end{array}\right.$ On to July and August 2nd. \} Passer arundina- $\{$ May, on to beginning of ceus minor: $\quad$ July.

(Breeds and whistles on till $\mathrm{Au}$ -

$\left.\begin{array}{l}\text { 16. Common lin- } \\ \text { net, }\end{array}\right\}$ Linaria vulgaris : gust; reassumes its note when they begin to congregate in Octoker, and again early before the flocks separate.

1 Gilbert White, it would seem, did not clearly distinguish the tree pipit, Anthus arboreus, which he calls the titlark, from the meadow pipit, Anthus pratensis, which is the titlark of other authors. The former is a migratory bird, arriving in April and leaving in September, and a good songster (see p. 117); the latter is found here throughout the year, though many go southward for the winter, and is a very poor songster. The former, as its name implies, lives chiefly in trees; the latter lives almost entirely on the ground, and in its habits and mode or feeding closely resembles the wagtail.-ED. 


$$
\text { OF SELBORNE. }
$$

Birds that cease to bo in full song, and are usually silent at or before Midsummer:-

\section{RAII NOMINA.}

17. Middle wil- $\}$ Regulus non cris- $\{$ Middle of June: begins in low wren, $\}$ tatus: $\quad$ April.

18. Redstart, Ruticilla: Ditto: begins in May.

19. Chaffinch, Fringilla $\{$ Beginning of June: sings first $\{$ in February.

20. Nightingale, Luscinia: $\quad\left\{\begin{array}{c}\text { Middle of Junc: sings first } \\ \text { in April. }\end{array}\right.$

Birds that sing for a short time, and very early in the spring :-
21. Missel-bird,
Turdus viscivorus:
(January 2, 1770, in February. Is called in Hampshire and Sussex the storm-cock, be- Turdus viscivorus: cause its song is supposed
to forebode windy wet wea-
ther: is the largest sing-
ing bird we have.

$\left.\begin{array}{l}\text { 22. Great tit- } \\ \text { mouse or ox- } \\ \text { eye, }\end{array}\right\}$ Fringillugo:

( In February, March, April : reassumes for a short time in September.

Birds that have somewhat of a note or song, and yet are hardly to be called singing birds:-

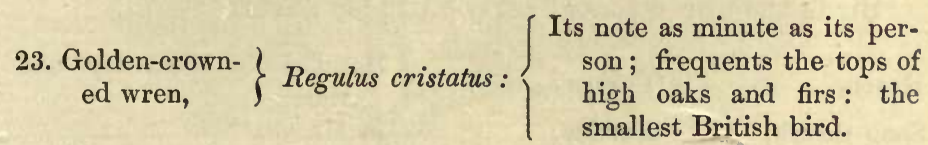

24. Marsh tit- $\left.\begin{array}{c}\text { mouse, }\end{array}\right\}$ Parus palustris: $\left\{\begin{array}{c}\text { Haunts great woods : two } \\ \text { harsh sharp notes. }\end{array}\right.$

25. Small willow- $\}$ Regulus non cris- $\{$ Sings in March, and on to Sepwren, $\}$ tatus: $\quad\left\{\begin{array}{l}\text { tember. } \\ \text { tem }\end{array}\right.$

26. Largest ditto, Ditto :

27. Grasshopper- $\left.\begin{array}{c}\text { Alauda minıma } \\ \text { lark, }\end{array}\right\} \begin{gathered}\begin{array}{c}\text { Chirps all night, from the } \\ \text { middle of April to the end } \\ \text { of July. }\end{array}\end{gathered}$

28. Martin, Hirundo agrestis: $\left\{\begin{array}{c}\text { All the breeding time; from } \\ \text { May to September. }\end{array}\right.$

29. Bullfinch, Pyrrhula.

30. Bunting, Emberiza alba: $\left\{\begin{array}{c}\text { From the end of January to } \\ \text { July. }\end{array}\right.$ All singing birds, and those that have any pretensions to 
song, not only in Britain, but perhaps the world through, come under the Linnæan Ordo of Passeres.

The above-mentioned birds, as they stand numerically, belong to the following Linnæan genera :-
$1,7,10,27$.
Alauda :
$8,28$.
Hirundo:
$2,11,21$.
Turdus:
13, 16, 19. Fringilla :
$3,4,5,9,12,15$.
$17,18,20,23,25,26$. 6,30 .
Motucilla: 22, 24.
Parus :
Emberiza: 14, 29.
Loxia.

Birds that sing as they fly are but few :RAII NOMINA.

Skylark,

Titlark, Alauda vulgaris: Rising, suspended, and falling.

Woodlark,

Blackbird,

Whitethroat,

Swallow,

Wren, Alauda prutorum: $\left\{\begin{array}{l}\text { In its descent; also sitting on } \\ \text { trees, and walking on the } \\ \text { ground. }\end{array}\right.$

Suspended; in hot summer Alauda arborea: $\left\{\begin{array}{r}\text { nuspts all night long. } \\ \text { night }\end{array}\right.$

Merula :

Sometimes from bush to bush Ficedula affinis : $\left\{\begin{array}{l}\text { Uses when singing on the } \\ \text { wing odd jerks and gesti- }\end{array}\right.$ culations.

Birds that breed most early in these parts : ${ }^{1}$

$\begin{array}{lll}\text { Raven, } & \text { Corvus : } & \text { Hatches in February and } \\ \text { March. } & \text { Turdus : } & \text { In March. } \\ \text { Song-thrush, } & \text { Merula: } & \text { In March. } \\ \text { Blackbird, } & \text { Cornix frugilega: } & \text { Builds the beginning of March. } \\ \text { Rook, } & \text { Alauda arlorea: } & \text { Hatches in April. } \\ \text { Woodlark, } & \begin{array}{l}\text { Palumbus torqua- } \\ \text { tus : }\end{array} & \text { Lays the beginning of April. }\end{array}$

All birds that continue in full song till after Midsummer appear to me to breed more than once.

Most kinds of birds seem to me to be wild and shy somewhat in proportion to their bulk; I mean in this island, where they are much pursued and annoyed; but in Ascen-

1 To this list might have been added the robin, since it not unfrequently nests in January during mild winters.-ED. 
sion Island, and many other desolate places, mariners have found fowls so unacquainted with a human figure, that they would stand still to be taken; as is the case with boobies, \&c. As an example of what is advanced, I remark that the golden-crested wren (the smallest British bird) will stand

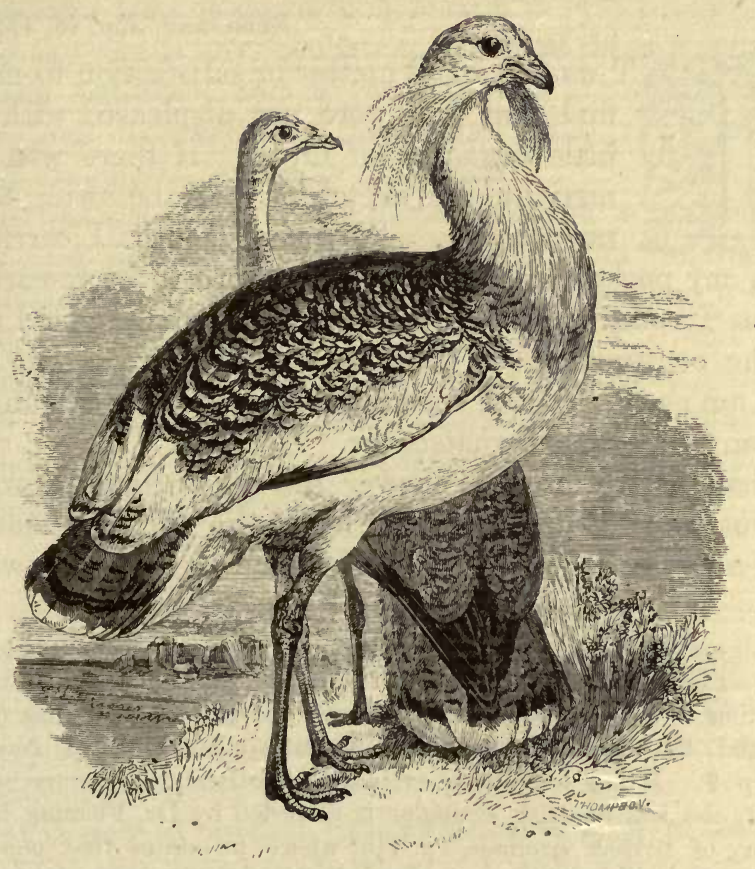

BUSTARD.

unconcerned till you come within three or four yards of it, while the bustard (Otis), the largest British land fowl, does not care to admit a person within so many furlongs. ${ }^{1}$

1 "Besides the barren 'brecks' of Norfolk and Suffolk, the great bustard, on good authority, appears in former times to have been extremely common on all the open parts of this island which were suited to its habits - the elevated moors of Haddingtonshire and Berwickshire, the desolate wolds of Yorkshire and Lincolnshire, Newmarket and Royston Heaths on the borders of Cambridgeshire, together with the downs of Berkshire, Wiltshire, Dorsetshire, Southampton, and Sussex 


\section{LETTER III.}

\section{TO THE HONOURABLE DAINES BARRINGTON.}

Selborne, Jan. 15, 1770.

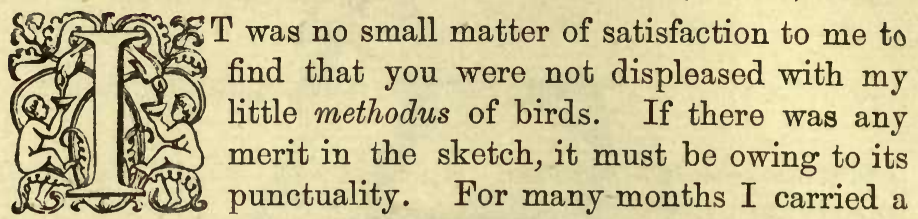
list in my pocket of the birds that were to be remarked, and, as I rode or walked about my business, I noted each day the continuance or omission of each bird's song; so that I am as sure of the certainty of my facts as a man can be of any transaction whatsoever.

I shall now proceed to answer the several queries which you put in your two obliging letters, in the best manner that I am able. Perhaps Eastwick, and its environs, where

being all more or less frequented by it; but in every one of these localities it had ceased to exist before the last of the race of British bustards fell victims to the advancement of agricultural enterprise in this (Norfolk) and the adjoining county."-Stevenson's Birds of Norfolk, vol. ii. p. 2. It has long been extinct in Scotland, the occurrence of probably the last Scottish straggler is recorded by Dr. Fleming in his "History of British Animals," p. 115, where he states that one was shot in 1803 in Morayshire. As regards Ireland, the great bustard is included by Smith, in his "History of Cork," as one of the birds of the county of Cork in 1749, but if ever it was really found in Ireland, it has long since become extinct there.

Our knowledge of the supposed gular pouch in the male bustard, originally due to a British anatomist, Dr. James Douglas, was first made known in 1740 by Albin, in his "Nat. Hist. Brit. Birds," iii. p. 36. Since that date many have been the contributions published, and various the opinions expressed, on this very curious subject. In the "Ibis" for 1862, pp. 107-27, will be found a very full and interesting account by Professor Newton of all that had been previously published on the matter, supplemented with observations of his own, and an important communication on the same subject by Dr. Cullen is given in the "Ibis," 1865, p. 143.-ED. 
you heard so very few birds, is not a woodland country, and therefore not stocked with such songsters. If you will cast your eye on my last letter, you will find that many species continued to warble after the beginning of July.

The titlark and yellowhammer breed late, the latter very late; and therefore it is no wonder that they protract their song: for I lay it down as a maxim in ornithology, that as long as there is any incubation going on there is music. As to the redbreast and wren, it is well known to the most incurious observer that they whistle the year round, hard frost excepted; especially the latter.

It was not in my power to procure you a blackcap, or a less reed-sparrow, or sedge bird, alive. As the first is undoubtedly, and the last, as far as I can yet see, a summer bird of passage, they would require more nice and curious management in a cage than I should be able to give them : they are both distinguished songsters. The note of the former has such a wild sweetness that it brings to my mind those lines in a song in "As You Like It."

\section{"And tune his merry note \\ Unto the wild bird's throat."}

\section{SHakspeare.}

The latter has a surprising variety of notes resembling the song of several other birds; but then it has also a hurrying manner, not at all to its advantage: it is notwithstanding a delicate polyglot.

It is new to me that titlarks in cages sing in the night; perhaps only caged birds do so. I once knew a tame redbreast in a cage that always sang as long as candles were in the room; but in their wild state no one supposes they sing in the night.

I should be almost ready to doubt the fact, that thero are to be seen much fewer birds in July than in any former month, notwithstanding so many young are hatched daily. Sure I am, that it is far otherwise with respect to the swallow tribe, which increases prodigiously as the summer advances: and I saw, at the time mentioned, many hundreds of young wagtails on the banks of the Cherwell, which almost covered the meadows. If the matter appears as you say in tho 
other species, may it not be owing to the dams being engaged in incubation, while the young are concealed by the lcaves?

Many times have I had the curiosity to open the stomachs of woodcocks and snipes, but nothing ever occurred that helped to explain to me what their subsistence might be: all that I could ever find was a soft mucus, among which lay many pellucid small gravels. ${ }^{1}$

\section{LETTER IV.}

\section{TO TIIE HONOURABLE DAINES BARRINGTON.}

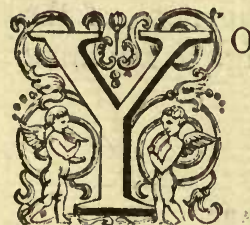

Serborne, Feb. 19, 1770.

young," is perfectly new to me, and struck me so forcibly, that I naturally fell into a train of thought that led me to consider whether the fact was so, and what reason there was

1 That good observer, Mr. Thompson, in his "Natural History of Ireland" (Birds, vol. ii. p. 239) states that on examination of the stomachs of thirteen woodcocks, killed at different periods and in every kind of weather, from Octuber to March, one was found to contain only small pebbles; ten vegetable matter, chiefly Conferva (in one instance an aquatic moss), and several of them worms of small or moderate size, insect larvæ and aquatic coleoptera, torrether with a few pebbles. The vegetable matter, of which there is often a considerable quantity, probably remains intact after the gastric juice has acted on the worms and other aninal food, and thus appears disproportionate to the other contents. As to the food of snipe, he says (tom. cit. p. 268), "The gontents of the stomach of seven of these birds, which were particularly exaxined, and all from different localities, were as fullows:-Of three shot in the month of January, two contained a few seeds, and the third was half filled with soft vegetable matter; two shot in March exlibited the remains of regetable food, which resembled Conferva ; of two killed 
for it. When I came to recollect and inquire, I could not find that any cuckoo had ever been seen in these parts, except in the nest of the wagtail, the hedge-sparrow, the titlark, the whitethroat, and the redbreast, all soft-billed insectivorous birds. The excellent Mr. Willughby mentions

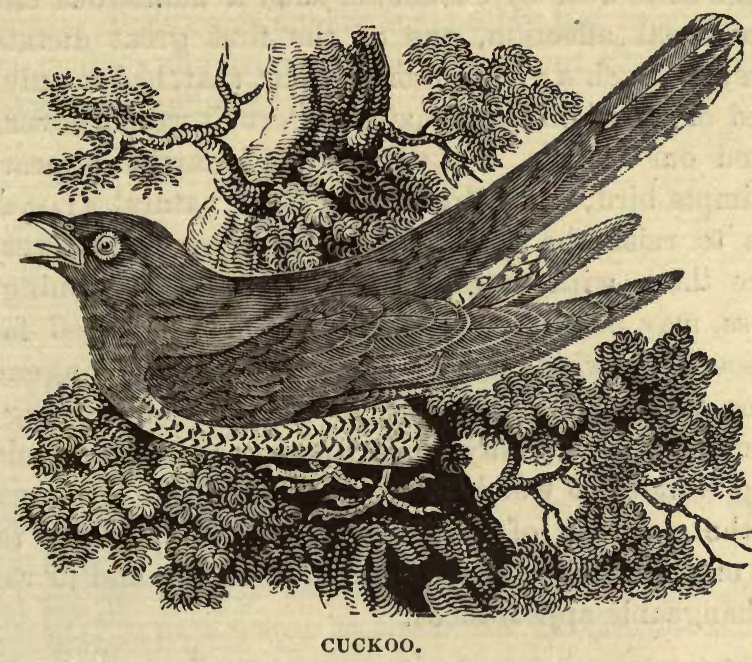

the nest of the ring-dove (Palumbus), and of the chaffinch (Fringilla), birds that subsist on acorns and grains, and such hard food; but then he does not mention them as of his own knowledge, but says afterwards that he saw himself: a wagtail feeding a cuckoo. It appears hardly possible

in October, one contained a large worm, and two or three seeds of different kinds; the other two, insect larvæ (Ascaris-like in form). Fragments of stone, of which some were the size of small peas, were found in all, the last-noted one being filled with them.

In almost all moist soils, and in cow-dung, peculiar small thm worms of a uniform deep red colour (not at all the same species found in uplands and gardens) occur, and during slight frosts they come up to the surface in thousands. During such weather, both woodcocks and, snipe make these their chief food, and are then in first-rate condition.--Ev.

1 In "The Ibis" for 1865, p. 178, Mr. Dawson Rowley, on the authority of continental as well as British authors, has published a list 
that a soft-billed bird should subsist on the same food with the hard-billed, for the former have thin membranaceous stomachs suited to their soft food; while the latter, the granivorous tribe, have strong muscular gizzards which, like mills, grind, by the help of small gravels and pebbles, what is swallowed. This proceeding of the cuckoo, of dropping its eggs as it were by chance, is such a monstrous outrage on maternal affection, one of the first great dictates of nature, and such a violence on instinct that, had it only been related of a bird in the Brazils or Peru, it would never have merited our belief. But yet, should it farther appear that this simple bird, when divested of that natural $\sigma \tau$ rop $\gamma^{\prime}$ that seems to raise the kind in general above themselves, and inspire them with extraordinary degrees of cunning and address, may be still endued with a more enlarged faculty of discerning what species are suitable and congenerous nursing-mothers for its disregarded eggs and young, and may deposit them only under their care, this would be adding wonder to wonder, and instancing in a fresh manner that the methods of Providence are not subjected to any mode or rule, but astonish us in new lights, and in various and changeable appearances. ${ }^{1}$

of thirty-seven European species of birds in whose nests the egg of the cuckoo has been found more or less frequently, and to this list the editor of "The Ibis" was able to add fifteen others. On different authority, another list of twenty-two species is given in "The Birds of Middlesex," p. 120.-ED.

1 Since the abore remarks were written by Gilbert White, so many extraordinary facts in relation to the habits of the cuckoo have been brought to light, mainly through the researches of modern ornithologists, that it would be impossible within the compass of a foot-note to mention half of them.

Commencing with the observations of Dr. Jenner (Phil. 'I'rars vol. lxxviii. p. 225), the rrader may be referred to what has been published by Cul. Montagu (Orn. Dict. Introd.), Mr. Blackwall (Manchester Memoirs, 2nd series), Mr. Durham Weir (Macgillivray's Hist. Brit. Birds, vol. iii. p. 128), Dr. Baldamus (Naumannia, 1853, pp. 307 326), a very remarkable paper translated and epitomized by the Rev. A. C. Smith and Mr. George Dawson Rowley respectively in the "Zoologist," 1868, pp. 1145-1166, and "The Ibis," 1865, p. 178; Herr Adolf Müller, in "Der Zoologische Garten," for Oct. 1868; 
What was said by a very ancient and sublime writer concerning the defect of natural affection in the ostrich, may be well applied to the bird we are talking of :

"She is hardened against her young ones, as though they wore not her's :

"Because God hath deprived her of wisdom, neither hath he imparted to her understanding." I

Qucry. Does each female cuckoo lay but one egg in a season, or does she drop several in different nests according as opportunity offers ? ${ }^{2}$

\section{LETTER V.}

\section{TO TIIE HONOURABLE DAINES BARRINGTON.}

Selborne, April 12, 1770.

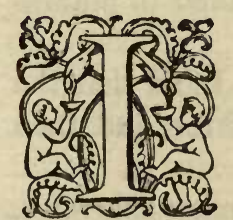

HEARD many birds of several species sing last year after midsummer; enough to prove that the summer solstice is not the period that puts a stop to the music of the woods. The yellowhammer, no doubt, persists with more steadiness than any other; but the woodlark, the wren, the redbreast, the swallow, the whitethroat, the goldfinch, the common linnct, are all undoubted instances of the truth of what I advanced.

If this severe season does not interrupt the regularity of the summer migrations, the blackcap will be here in two or three days. I wish it was in my power to procure you one of those songsters; but I am no birdcatcher; and so little

and Prufessor A. Newton, in "Nature" of Nov. 18, 1869, and his new edition of Yarrell's "History of British Birds." Reference should also be made to Mr. Stevenson's chapter on the cuckoo, in his "Birds of Norfolk," vol. i. p. 303, and, if the reader's patience is not then exhausted, to a couple of articles by the writer of this note, contributed to "Science Gussip" of May 1, 1870, and "The Field" of Nov. 22, 1873.-ED.

1 Job xxxix. 16, 17.

2 See p. 151, note 1.-ED 
used to birds in a cage, that I fear if I had one it would soon die for want of skill in feeding.

Was your reed sparrow, which you kept in a cage, the thick-billed reed sparrow of the Zoology, p. 320 ; or was it the less reed sparrow of Ray, the sedge-bird of $\mathrm{Mr}$ Pennant's last publication, p. 16 ?

As to the matter of long-billed birds growing fatter in moderate frosts, I have no doubt within myself what should be the reason. The thriving at those times appears to me to arise altogether from the gentle check which the cold throws upon insensible perspiration. The case is just the same with blackbirds, \&c.; and farmers and warreners observe, the first, that their hogs fat more kindly at such times, and the latter that their rabbits are never in such good case as in a gentle frost. But when frosts are severe, and of long continuance, the case is soon altered; for then w want of food soon over-balances the repletion occasioned by a checked perspiration. I have observed, moreover, that some human constitutions are more inclined to plumpness in winter than in summer.

When birds come to suffer by severe frost, I find that the first that fail and die are the redwing fieldfares, and then the song-thrushes.

You wonder, with good reason, that the hedge sparrows, \&c., can be induced at all to sit on the egg of the cuckoo without being scandalized at the vast disproportioned size of the supposititious egg; but the brute creation, I supposc, have very little idea of size, colour, or number. For the common hen, I know, when the fury of incubation is on her, will sit on a single shapeless stone instead of a nest full of eggs that have been withdrawn; and, moreover, a henturkey, in the same circumstances, would sit on in the empty nest till she perished with hunger.

I think the matter might easily be determined whether a cuckoo lays one or two eggs, or more, in a season, by opening a female during the laying-time. If more than one was come down out of the ovary, and advanced to a good size, doubtless then she would that spring lay more than ont. 
I will endeavour to get a hen, and to examinc.'

Your supposition that there may be some natural obstruction in singing birds while they are mute, and that when this is removed the song recommences, is new and bold; I wish you could discover some good grounds for this suspicion.

I was glad you were pleased with my specimen of the Caprimulgus, or fern owl; you were, I find, acquainted with . the bird before.

When we meet, I shall be glad to have some conversation with you concerning the proposal you make of my drawing up an account of the animals in this neighbourhood. Your partiality towards my small abilities persuades you, I fear, that I am able to do more than is in my power: for it is no small undertaking for a man unsupported and alone to begin a natural history from his own autopsia! Though there is endless room for observation in the field of nature, which is boundless, yet investigation (where a man endeavours to be sure of his facts) can make but slow progress; and all that one could collect in many years would go into a very narrow compass.

Some extracts from your ingenious "Investigations of the Difference between the present Temperature of the Air in Italy," \&c., have fallen in my way; and gave me great satisfaction: they have removed the objections that always arose in my mind whenever I came to the passages which you quote. Surely the judicious Virgil, when writing a didactic poem for the region of Italy, could never think of describing freezing rivers, unless such severity of weather pretty frequently occurred!

P.S. Swallows appear amidst snows and frost. ${ }^{2}$

' It has since been ascertained that cuckoos do lay more than one egg in a season, although Dr. Baldamus, to whose remarkable essay we have already referred, states that each hen bird lays but one egg in each nest; and adds that the same hen bird lays eggs of similar colouring, as a general rule, in the nests of the same species only.-ED.

2 We apprehend that allusion is here made to the fact that swallows which arrive early in this country occasionally get caught in late frosts, and vice versâ. - ED. 


\section{LETTER VI.}

TO TIIE HONOURABLE DAINES BARRINGTON.

Selborne, May 21, 1770.

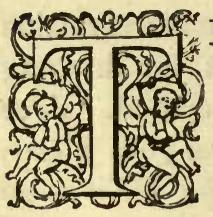

$\mathrm{HE}$ severity and turbulence of last month so interrupted the regular process of summer migration, that some of the birds do but just begin to show themselves, and others are apparently thinner than usual; as thowhitethroat, the blackcap, the redstart, the flycatcher. I well remember that after the very severe spring in the year $1739-40$, summer birds of passage were very scarce. They come probably hither with a south-east wind, or when it blows between those points; but in that unfavourable year the winds blowed the whole spring and summer through from the opposite quarters. And yet amidst all these disadvantages two swallows, as I mentioned in my last, appeared this year as early as the 11th of April, amidst frost and snow; but they withdrew again for a time.

I am not pleased to find that some people seem so little satisfied with Scopoli's new publication ; $^{1}$ there is room to expect great things from the hands of that man, who is a good naturalist: and one would think that a history of the birds of so distant and southern a region as Carniola would be new and interesting. I could wish to see that work, and hope to get it sent down. ${ }^{2}$ Dr. Scopoli is physician to the wretches that work in the quicksilver mines of that district.

When you talked of keeping a reed sparrow, and giving

1 This work he calls his "Annus Primus Historico-Naturalis."- G.IV.

2 Later in the same year the author procured the work here spoken of. His observations on it will be found in his Letters to Pennant, numbered XXXI. and XXXII., as well as incidentally in others. See also the following Letter.-ED. 
it seeds, I could not help wondering: because the reed sparrow which I mentioned to you (Passer arundinaceus minor, $\mathrm{R}_{\mathrm{AII}}{ }^{1}$ ) is a soft-billed bird, and most probably migrates hence before winter; whereas the bird you kept (Passer torquatus, $\mathrm{R}_{\mathrm{AII}}{ }^{2}$ ) abides all the year, and is a thickbilled bird. I question whether the latter be much of a songster; but in this matter I want to be better informed. ${ }^{3}$ The former has a variety of hurrying notes, and sings all night. Some part of the song of the former, I suspect, is attributed to the latter. We have plenty of the soft-billed sort; which Mr. Pennant had entirely left out of his "British Zoology," till I reminded him of his omission. See "British Zoology" last published, p. 16.

I have somewhat to advance on the different manners in which different birds fly and walk; but as this is a subject that I have not enough considered, and is of such a nature as not to be contained in a small space, I shall say nothing further about it at present. ${ }^{5}$

No doubt the reason why the sex of birds in their first plumage is so difficult to be distinguished is, as you say, " because they are not to pair and discharge their parental functions till the ensuing spring." As colours seem to be the chief external sexual distinction in many birds, these colours do not take place till sexual attachments begin to obtain. And the case is the same in quadrupeds; among whom, in their younger days, the sexes differ but little: but, as they advance to maturity, horns and shaggy manes, beards and brawny necks, \&c. \&c., strongly discriminate the male from the female. We may instance still farther in our own species, where a beard and stronger features are usually characteristic of the male sex : but this sexual diversity does not take place in earlier life; for a beautiful youth shall be

1 The sedge warbler, Salicaria phragmitis.-ED.

2 The reed bunting, Emberiza schoniclus.-Ev.

3 See Letter XXIV. to Pennant, p. 82, note 2. - ED.

4 See Letters XXIV. XXV. and XXVI. to Pennant.-ED.

5 See Letter XLII. to Daines Barrington.-Fin. 
so like a beautiful girl that the difference shall not be discernible;

"Quem si puellarum insereres choro,

Mirè sagaces falleret hospites

Discrimen obscurum, solutis

Crinibus, ambiguoque vultu."-Hor.

\section{LETTER VII.}

TO THE IIONOURABLE DAINES BARRINGTON.

Ringmer, near Lewes, Oct. 8, 1770.

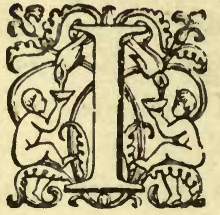

AM glad to hear that Kuckahn ${ }^{1}$ is to furnish you with the birds of Jamaica; a sight of the Hirundines of that hot and distant island would be a great entertainment to me.

The Anni of Scopoli are now in my possession; and I have read the Annus Primus with satisfaction: for though some parts of this work are exceptionable, and he may advance some mistaken observations; yet the ornithology of so distant a country as Carniola is very curious. Men that undertake only one district are much more likely to advance natural knowledge than those that grasp at more than they can possibly be acquainted with: every kingdom, every province, should have its own monographer.

The reason, perhaps, why he mentions nothing of Ray's Ornithology may be the extreme poverty and distance of his country, into which the works of our great naturalist may have never yet found their way. You have doubts, 1 know, whether this Ornithology is genuine, and really the work of Scopoli: as to myself, I think I discover strong tokens of authenticity; the style corresponds with that of his Entomology; and his characters of his ordines and

1 Kuckahn was the author of a paper in the "Philosophical Transactions" for 1770 on the preservation of dead birds.-ED. 
genera are many of them new, expressive, and masterly. IIe has ventured to alter some of the Linnæan genera with sufficient show of reason.

It might, perhaps, be mere accident that you saw so many swifts, and no swallows, at Staines; because, in my long observation of those birds, I never could discover the least degree of rivalry or hostility between the species.

Ray remarks that birds of the Gallince order, as cocks and hens, partridges and pheasants, \&c., are pulveratrices, such as dust themselves, using that method of cleansing their feathers, and ridding themselves of their vermin. As far as I can observe, many birds that dust themselves never wash : and I once thought that those birds that wash themselves would never dust; but here I find myself mistaken; for common house sparrows are great pulveratrices, being frequently seen grovelling and wallowing in dusty roads; and yet they are great washers. Does not the skylark dust?

Query. Might not Mahomet and his followers take one method of purification from these pulveratrices? because I find, from travellers of credit, that if a strict Mussulman is journeying in a sandy desert where no water is to be found, at stated hours he strips off his clothes, and most scrupulously rubs his body over with sand or dust.

A countryman told me he had found a young fern owl in the nest of a small bird on the ground; and that it was fed by the little bird. I went to see this extraordinary phenomenon, and found that it was a young cuckoo hatched in the nest of a titlark: it was become vastly too big for its nest, appearing

$$
\text { Majores pennas nido extendisse- }
$$

and was very fierce and pugnacious, pursuing my fing(r, as I teased it, for many feet from the nest, and sparring and buffeting with its wings like a gamn-cock. The dupe of a dam appeared at a distance, hovering about with meat in its month, and expressing the greatest solicitude.

In July I saw several cuckoos skimming over a large pond; and found, after sone observation, that they were 
feeding on the Libelluloe, or dragon flies; sume of which they caught as they settled on the weeds, and some as they were on the wing. Notwithstanding what Linnæus says, I cannot be induced to believe that they are birds of prey.

This district affords some birds that are hardly ever heard of at Selborne. In the first place considerable flocks of crossbeaks (Loxice curvirostroe) have appeared this summer in the pine-groves belonging to this house; the water-ousel is said to haunt the mouth of the Lewes river, near Newhaven; and the Cornish chough builds, I know, all along the chalky cliffs of the Sussex shore. ${ }^{1}$

I was greatly pleased to see little parties of ring-ousels (my newly discovered migrators) scattered, at intervals, all along the Sussex downs from Chichester to Lewes. Let them come from whence they will, it looks very suspicious that they are cantoned along the coast in order to pass the Channel when severe weather advances. They visit us again in April, as it should seem, in their return; and are not to be found in the dead of winter. It is remarkable that they are very tame, and seem to have no manner of apprehensions of danger from a person with a gun. There are bustards on the wide downs near Brighthelmstone. ${ }^{2}$ No doubt you are acquainted with the Sussex Downs: the prospects and rides round Lewes are most lovely!

As I rode along near the coast I kept a very sharp lookout in the lanes and woods, hoping I might, at this time of the year, have discovered some of the summer short-winged

1 'This is now no longer the case. See Letter XXXIX. to Pennant, p. 117 , note.-Ev.

2 The great bustard has long ceased to frequent the South Downs except as a rare and accidental visitant. Amongst various extracts from Gilbert White's MS. diary, published by Mr. Jesse in the second series of his "Gleanings in Natural History," is one (p. 164) wherein the author states that on Nov. 17, 1782, he spent three hours at a lone farm-house in the midst of the downs between Andover and Winton, where "the carter told us that about twelve years ago he had seen a flock of eighteen bustards at one time on that farm, and once since only two." Further on (p. 180) he adds: "Bustards when seen on the downs resemble fallow-deer at a distance."

Sec Letter II. to Daines Barrington, p. 143, note.-ED. 
birds of passage crowding towards the coast in order for their departure: but it was very extraordinary that I never saw a redstart, whitethroat, blackcap, uncrested wren, flycatcher, \&c. And I remember to have made the same remark in former years, as I usnally come to this place annually about this time. The birds most common along the coast at present are the stonechatters, whinchats, buntings, linnets, some few wheatears, titlarks, \&c. Swallows and house martins abound yet, induced to prolong their stay by this soft, still, dry season.

A land tortoise, which has been kept for thirty years in a little walled court belonging to the house where I now am visiting, retires under ground about the middle of November, and comes forth again about the middle of April. When it first appears in the spring it discovers very little inclination tuwards food; but in the height of summer grows voracious : and then as the summer declines, its appetite declines; so that for the last six weeks in autumn it hardly eats at all. Milky plants, such as lettuces, dandelions, sowthistles, are its favourite dish. In a neighbouring village one was kept till by tradition it was supposed to be a hundred years old. An instance of vast longevity in such a poor reptile!

\section{LETTER VIII.}

TO THE HONOURABLE DAINES BARRINGTON.

Selborne, Dec. 20, 1770.

Qreneras $\mathrm{HE}$ lirds that I took for Aberdavines were

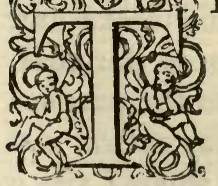
recd sparrows (Passeres torquati).

There are, doubtless, many home internal migrations within this kingdom that want to be better understood; witness those vast flocks of hen chaffinches that appear with us in the winter without hardly any cocks among them. Now, was there a 
duo proportion of each sex, it should seem very improbable that any one district should produce such numbers of these little birds; and much more when only one-half of the species appears: therefore we may conclude that the chaffinches (Fringilla calebes), for some good purposes, have a peculiar migration of their own in which the sexes part. Nor should it seem so wonderful that the intercourse of sexes in this species of birds should be interrupted in winter; since in many animals, and particularly in bucks and does, the sexes herd separately, cxcept at the season when commerce is necessary for the continuance of the hreed. For this matter of the chaffinches see "Fauna Suecica," p. 85, and "Systema Naturæ," p. 318. I see every winter vast flights of hen chaffinches, but none of cocks. ${ }^{1}$

Your method of accounting for the periodical motions of the British singing birds, or birds of flight, is a very probable one; since the matter of food is a great regulator of the actions and proceedings of the brute creation: there is but one that can be set in competition with it, and that is love. But I cannot quite acquiesce with you in one circumstance, when you advance that, "when they have thus feasted, they again separate into small parties of five or six, and get the best fare they can within a cortain district, having no inducement to go in quest of freshturned earth." Now, if you mean that the business of congregating is quite at an end from the conclusion of wheat-sowing to the season of barley and oats, it is not the case with us; for larks and chaffinches, and particularly linnets, flock and congregate as much in the very dead of winter, as when the husbandman is busy with his pluughs and harrows.

Sure there can be no doubt but that woodcocks and fieldfares leave us in the spring, in order to cross the seas, and to retire to some districts more suitable to the purpose of breeding. That the former pair before they retire, and that the hens are forward with egg, I myself, when I was a

1 See Letter XIII. to Penuant, p. 47, note 1.-ED. 
sportsman, have often experienced. It cannot indeed bc denied but that now and then we hear of a woodcock's nest, or young birds, discovered in some part or other of this island: but then they are always mentioned as rarition, and somewhat out of the common course of things: but as to redwings and fieldfares, no sportsman or naturalist has ever yet, that I could hear, pretended to have found the nest or young of those species in any part of these kingdoms. And I the more admire at this instance as extraordinary, since, to all appearance, the same food in summer as well as in winter might support them here which maintains their congeners, the blackbirds and thrushes, did they choose to stay the summer through. ${ }^{1}$ From hence it

1 Both the redwing and fieldfare are stated on some authority to have occasionally nested in the British Islands: see Mr. More's article on the "Distribution of Birds in Great Britain during the nesting season," published in "The Ibis" for 1865, p. 19. In "Charlesworth's Magazine of Natural History," the late Mr. Blyth reported that several instances of the redwing's nesting in Surrey were known to him; and in the same periodical (rol. i. p. 440) he quoted the statement of a dealer that a nest of this bird had been taken at Barnet. Yarrell instances a nest found at Godalming: and one taken in Leicestershire is recorded by Mr. J. H. Ellis in "The Zoologist" for 1864, p. 9248. In Shropshire Mr. Eyton has observed that some of these birds remain all the summer in his neighbourhood. In May, 1855, the late Dr. Saxby found a nest of the redwing at Maintwrog, North Wales. It was placed in a tall Portugal laurel; and he repeatedly observed the bird sitting on her eggs, which he afterwards took. The circumstance was recorded by him in "The Zoologist" or 1861, p. 7427 ; but a more detailed account, copied from his private journal, has since been published by his brother, the Rev. Stephen Saxby, in his recent work on the "Birds of Shetland," p. 384. 'In the Outer Hebrides Mr. Bullock, in a letter to Dr. Fleming, dated 23rd April, 1819, mentioned the circumstance of the redwing breeding in Harris, where he had observed it in the preceding summer. (Sec Fleming's Hist. Brit. An. p. 65.) In Orkney, Mr. Low says ("Fauna Orcadensis," p. 58) that he observed a pair of these birds in Hoy throughout the greatest part of the summer, and imagined that they built amongst the bushes there, though with the strictest search he could not discover the nest.

In like manner there are several reported instances of the fieldfare having remained to breed in this country. Mr. St. John in his "Tour in Sutherlandshire," vol. i. p. 206, says that he was shown a nest and eggs from near the Spey; and the bird is reported to have nested also 
appears that it is not food alone which determines some species of birds with regard to their stay or departure. Fieldfares and redwings disappear sooner or later according as the warm weather comes on earlier or later. For I well remember, after that dreadful winter, 1739-40, that cold north-east winds continued to blow on through April and May, and that these kinds of birds (what few remained of them) did not depart as nsual, but were seen lingering about till the beginning of June.

The best authority that we can have for the nidification of the birds above mentioned in any district, is the testimony of faunists that have written professedly the natural history of particular countries. Now, as to the fieldfare, Linnæus, in his "Fauna Suecica," says of it, that "maximis in arboribus nidificat:" and of the redwing he says, in the same place, that "nidificat in mediis arbusculis, sive sepibus: ova sex cur rulco-viridia maculis nigris variis." Hence we may be assured that fieldfares and redwings breed in Sweden. Scopoli says, in his "Annus Primus," of the woodcock, that "nupta ad nos venit circa oequinoctium vernale:" meaning in Tyrol, of which he is a native. And afterwards he adds, "nidificat in paludibus alpinis : ova ponit 3-5." It does not appear from Kramer that woodcocks breed at all in Austria: but he says, "Avis hoce septentrionalium provinciarum cestivo tempore incola est; ubi plerumque nidificat. Appropinquante hyeme, australiores provincias petit: hinc circa plenilunium mensis Octobris plerumque

in Selkirkshire (see Fairholme, "Mag. Nat. Hist." 1837, pp. 339 and 439). The late Mr. Blyth published an account of its having nested at Merton, in Surrey ("Mag. Nat. Hist." vol. iii. p. 467), but unfortunately he did not see the birds himself. Another supposerl instance. of the fieldfure breeding in the south of England was reported by $\mathrm{Dr}$. Bree in "Ihle Field" of June 12th and 19th, 1869. Mr. Blyth statel ("Mag. Nit. Hist." rol. vii. p. 242), that both the redwing and fieldfare had been repeatedly seen throughout the summer in a wood called the Wood of Logie, upon the estate of Sir John Forbes, at Fintry, in Aberdeenshire. On the 29th July, 1864, a fieldfare was shot in a garden near Kirby Muxloe, in Leicestershire, and forwarded to the editor of "The Ficld" for examination (see "Zoologist," 1864, p. 9248). It bad been observed about the garden all the summer.-ED. 
Austriam transmigrat. Tunc rursus circa pleniluniunn potissimum mensis Martii per Austriam matrimonio juncta ad septentrionales provincias redit." For the whole passage (which I have abridged) see Elenchus, \&c., p. 351. This seerns to be a full proof of the migration of woodcocks; though little is proved concerning the place of breeding. ${ }^{1}$

P.S.-There fell in the county of Rutland, in three weeks of this present very wet weather, seven inches and a half of rain, which is more than has fallen in any three weeks for these thirty years past in that part of the world. A mean quantity in that county for one year is twenty inches and a half.

\section{LETTER IX.}

\section{TO THE HONOLRABLE DAINES BARRINGTON.}

Frfiedd, ncar Andover, Feb. 12, 1771.

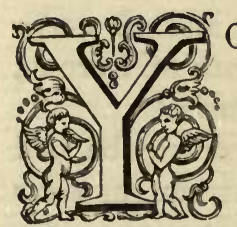
$\mathrm{OU}$ are, I know, no great friend to migration; and the well attested accounts from various parts of the kingdom seem to justify you in your suspicions, that at least many winter, but lay themselves up like insects and bats, in a torpid state, and slumber away the more uncomfortable months till the return of tho sun and fine weather awakens them.

But then we must not, I think, deny migration in general; because migration certainly does subsist in some places, as my brother in Andalusia has fully informed me. Of the motions of these birds he has ocular demonstration,

1 It is now well known that although a large proportion of the woodcocks which visit us in autumn leave again in the spring, numbers remain behind to breed here, and the reported instances of nests and eggs being found in different counties are becoming more and more rumerous every year.-Ev. 
for many weeks together, both spring and fall: during which periods myriads of the swallow kind traverse the Sitraits from north to south, and from south to north, according to the season. And these vast migrations consist not only of Hirundines, but of bee-birds, hoopoes, Oropendolas, ${ }^{1}$ or golden thrushes, \&c., \&c., and also of many of our soft-billed summer birds of passage ; and, moreover, of birds which never leave us, such as all the various sorts of hawks and kites. Old Belon, 200 years ago, gives a curious account of the incredible armies of hawks and kites which he saw in the spring-time traversing the Thracian. Bosphorus from Asia to Europe. Besides the above-mentioned, he remarks that the procession is swelled by whole troops of eagles and vultures.

Now, it is no wonder that birds residing in Africa should retreat before the sun as it advances, and retire to milder regions, and especially birds of prey, whose blood being heated with hot animal food, are more impatient of a sultry climate; but then I cannot help wondering why kites and hawks, and such hardy birds as are known to defy all the severity of Fngland, and even of Sweden and all north Europe, should want to migrate from the south of Europe, and be dissatisfied with the winters of Andalusia. ${ }^{2}$

It does not appear to me that much stress may be laid on the difficulty and hazard that birds must run in their

1 Oropendola is the Spanish name for the Golden Oriole.-ED.

2 The migration of the kites and hawks no doubt depends in a measure upon that of the smaller birds upon which they prey; in the same way that some of the latter are influenced by the appearance or disappearance of locusts and other insects, which form their chief food. In Lloyd's "Game Birds and Wild-fowl of Norway and Sweden," p. 370 , there is a wonderful picture by Wolf, entitled "The Birdcloud," in which, in illustration of the author's remarks, the artist has depicted a vast flock of wild fowl on migration harassed by birds of prey. In Andersson's "Birds of Damaraland," p. 264, a singular account is given of the way in which the pratincoles (Glareola melanoptera) attend the flying swarms of locusts in South Africa. The writer says:- "These birds come, I may say, in millions, attendant on the flying swarms of locusts; indeed, the appearance of a few of them is looked unon as a sure presage of the locust swarms being at hand."--ED. 
migrations, by reason of vast oceans, cross winds, \&c.; because, if we reflect, a bird may travel from England to the equator without launching out and exposing itself to boundless seas, and that by crossing the water at Dover, and again at Gibraltar. And I with the more confidence advance this obvious remark, because my brother has always found that some of his birds, and particularly the swallow kind, are very sparing of their pains in crossing the Mediterranean; for when arrived at Gibraltar, they do not,

" Ranged in figure wedge their way, and set forth

Their airy caravan high over seas

Flying, and over lands with mutual wing

Easing their flight."

Mriton.

but scout and hurry along in little detached parties of six or seven in a company; and sweeping low, just over the surface of the land and water, direct their course to the opposite continent it the narrowest passage they can find. They usually slope across the bay to the south-west, and so pass over opposite to Tangier, which, it seems, is the narrowest space.

In former letters we have considered whether it was probable that woodcocks in moonshiny nights cross the German ocean from Scandinavia. As a proof that birds of less speed may pass that sea, considerable as it is, I shall relate the following incident, which, though mentioned to have happened so many years ago, was strictly matter of fact:-As some poople were shooting in the parish of Trotton, in the county of Sussex, they killed a duck in that dreadful winter, 1708-9, with a silver collar about its neck, ${ }^{1}$ on which were engraven the arms of the king of Denmark. This anecdote the rector of Trotton at that time has often told to a near relation of mine; and, to the best of my remembrance, the collar was in the possession of the rector. ${ }^{2}$

1 I have read a like anecdote of a swan.-G. W.

2 We suspect that this bird was a cormorant, and that the recter of 
At present I do not know anybody near the seaside that will take the trouble to remark at what time of the mon woodcocks first come; if I lived near the sea myself, I would soon tell you more of the matter. One thing I used to observe when I was a sportsman, that there were times in which woodcocks were so sluggish and sleepy that they would drop again when flushed just before the spaniels, nay, just at the muzzle of a gun that had been fired at them; whether this strange laziness was the effect of a recent fatiguing journey, I shall not presume to say.

Nightingales not only never reach Northumberland and Scotland, but also, as I have been always told, Devonshire and Cornwall. In those two last counties we cannot attribute the failure of them to the want of warmth: the defect in the west is rather a presumptive argument that these birds come over to us from the continent at the narrowest passage, and do not stroll so far westward. ${ }^{1}$

Trotton and his friend mistook it for a duck on account of its webbed feet. Cormorants, as is well known, were formerly trained for fishing purposes, and wore collars, usually it is true of leather, but in the case of the king of Denmark, they may well have been of silver, or sufficiently ornamented with silver, to be spoken of as though made of that metal. Our own King James I., who was a great sportsman, made fishing with cormorants quite a fashionable amusement. He had a regular establishment for these birds on the Thames at Westminster, and, to meet the requirements of the day, created a new office, "Master of the Royal Cormorants." See "The Ornithology of Shakespeare," pp. 260-265. As to the use of the "collar" or "strap," the reader may be referred to Frecman and Salvin's "Falconry: its claims, history and practice," to which are added remarks on training the otter and cormorant. pp. 327-350.-ED.

1 In a note to this passage in his edition of the present work, the late Mr. Blyth observed that the nightingale "appears to migrate almost due north and south, deriating but a very little indeed either to the right or left. There are none in Brittany, nor in the Channel Islands (Jersey, Guernsey, \&c.); and the most westward of them probably cross the Channel at Cape La Hogue, arriving on the coast of Dorsetshire, and thence apparently proceeding northward rather than dispersing towards the west, so that they are only known as accidental stragglers beyond at most the third degree of western longitude, a line which cuts off the counties of Devonshire and Cornwall, together with all Wales and Ireland, and by far the greater portion of Scotland, in 
Let me hear from your own observation whether skyiarks do not dust. I think they do; and if they do, whether they wash also.

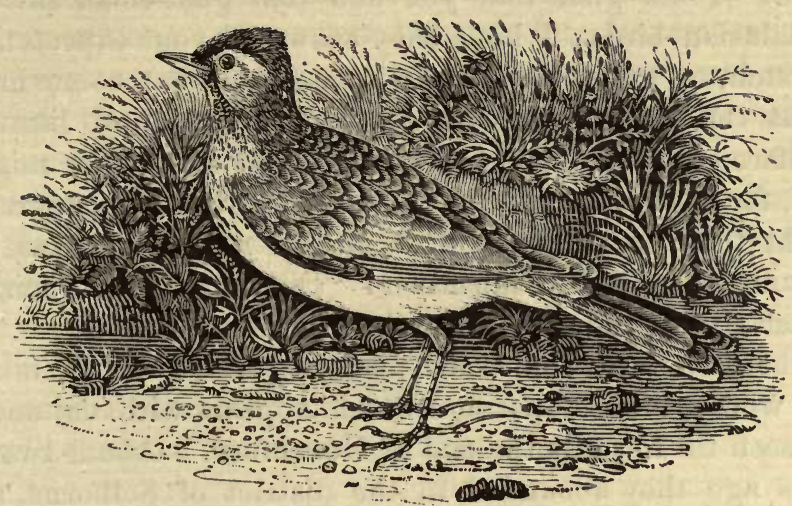

SKYLARK。

The titlark, ${ }^{1}$ or Alauda pratensis of Ray, was the poor dupe that was educating the booby of a cuckoo mentioned in my letter of October last.

which last-mentioned kingdom the species has once or twice occurred to the eastward only of this meridian." With regard to the distribution of the nightingale in the British Islands, we may quote the observations of Professor Newton, as set forth in his edition of Yarrell's " History of British Birds," now in course of publication, vol, i. pp. 315, 316. He says:- "In England the nightingale's western limit seems to be formed by the Valley of the Exe, though once, and once only, Montagu (on this point an unerring witness) heard it singing on the 4th May, 1806, near Kingsbridge, in South Devon, and it is said to have been heard at Teignmouth, as well as in the north of the same county at Barnstaple. But even in the east of Devon it is local and rare, as it also is in the north of Somerset, though plentiful in other parts of the latter. Crossing the Bristol Channcl, it is said to be not uncommon at times near Cowbridge in Glamorganshire. Dr. Bree states ('Zoologist,' p. 1211) that it is found plentifully on the banks of the Wye, near Tintern; and thence there is more or less good evidence of its occurrence in Herefordshire, Salop, Staffordshire, Derbyshire, and in Yorkshire to about five miles north of its chief city, but as Mr.

1 Elsewhere, White applies the name titlark to the tree pipit. See p. 117, note 2, and p. 140, note 1.-ED. 
Your letter came too late for me to procure a ring-ousel for Mr. Tunstal during their autumnal visit; but I will endeavour to get him one when they call on us again in April. I am glad that you and that gentleman saw my Andalusian birds; I hope they answered your expectation. Royston,'or gray crows, are winter birds, that come much about the same time with the woodcock: they, like the fieldfare and redwing, have no apparent reason for migration, for as they fare in the winter like their congeners, so might they, in all appearance, in the summer. Was not T'enant, when a boy, mistaken? Did he not find a misselthrush's nest, and take it for the nest of a fieldfare?

The stock-dove, or wood-pigeon ${ }^{1}$ (Einas, RAII), is the last winter bird of passage which appears with us, and is not seen till towards the end of November. About twenty years ago they abounded in the district of Selborne, and strings of them were seen morning and evening that reached a mile or more; but since the beechen woods have been greatly thinned, they are much decreased in number. ${ }^{2}$ The

Thomas Allis states, not further. Along the line thus sketched out, and inmediately to the east and south of it, the appearance of the nightingale, even if regular, is in most cases rare, and the bird local; but further away from the boundary it occurs yearly with great regularity in every county, and in some places is very numerous. Mr. More states that it is 'thought to have once bred near Sunderland, and it is said to have been once heard in Westmoreland and also in the summer of 1808 near Carlisle; but these assertions must be looked upon with great suspicion, particularly the last, which rests on anonymous authority only. Still more open to doubt are the statements of the nightingale's occurrence in Scotland, such as Mr. Duncan's (not on his own evidence, be it r'emarkell), published by Macgillivray ('British Birds,' ii. p. 334) respecting a pair believed to have visited Calder Wood in Mid Lothian in 1826; or Mr. Turnbull's ('Birds of East Lothian,' p. 39), of its being heard near Dalmeny Park, in the same county, in June, 1839. In Ireland there is no trace of this species." On the continent it may be observed that the nightingale has not been met with further north than Funen in Denuark, and the neighbourhood of Copenhagen.-Ev.

1 The name wood-pigeon is generally applied to the ring-dove, $\mathrm{Co}$ lumba palumbus.-ED.

2 This subject has been already noticed in Letter XLIV. to Pennant. The stock-dove breeds in parts of Hants and Sussex, although doubtless it is most numerous in these counties in winter. We 
ring-dove (Palumbus, RAII), stays with ws the whole year, and breeds several times through the summer.

Before I received your letter of October last, I had just remarked in my journal that the trees were unusually green. This uncommon verdure lasted on late into Nuvember; and may be accounted for from a late spring, a cool and moist summer, but more particularly from vast armies of chafers, or tree-beetles, which, in many places, reduced whole woods to a leafless, naked state. These trees shot again at Midsummer, and then retained their foliage till very late in the year.

My musical friend, at whose house I am now visiting, has tried all the owls that are his near neighbours with a pitchpipe set at concert-pitch, and finds they all hoot in B flat. He will examine the nightingales next spring.

\section{LETTER $\mathrm{X}$.}

\section{TO THE IIONOURABLE DAINES BARRINGTON.}

Selborne, Aug. 1, 1771.

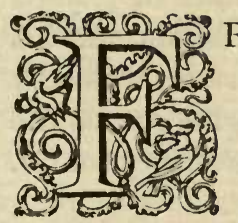

ROM what follows, it will appear that neither owls nor cuckoos keep to one note. A friend remarks that many (most) of his owls hoot in $\mathrm{B}$ flat, but that one went almost half a note below A. The pipe he tried their notes by was a common half-crown pitch-pipe, such as masters use for tuning of harpsichords; it was the common Lorsion pitch.

A neighbour of mine, who is said to have a nice ear, remarks that the owls about this village hoot in three different keys, in $G$ flat or $F$ sharp, in $B$ flat and A flat.

have seen pairs throughout the summer and have repeatedly found the nest in the neighbourhood of Uppark near Petersfield, which is at no great distance from Selborne.-Ev. 
He heard two hooting to each other, the one in A flat, and the other in B flat. Query: Do these different notes proceed from different species, or only from various individuals? The same person finds upon trial that the note of the cuckoo (of which we have but one species) varies in different individuals; for about Selborne Wood he found they were mostly in D. $\mathrm{He}_{\Theta}$ heard two sing together, the one in $\mathrm{D}$, the other in $\mathrm{D}$ sharp, who made a disagreeable concert. $\mathrm{He}$ afterwards heard one in D sharp, and about Wolmer Forest some in C. ${ }^{1}$ As to nightingales, he says that their notes are so short, and their transitions so rapid, that he cannot well ascertain their key. Perhaps in a cage and in a room, their notes may be more distinguishable. This person has tried to settle the notes of a swift, and of several other small birds, but cannot bring them to any criterion.

As I have often remarked that redwings are some of the first birds that suffer with us in severe weather, it is no wonder at all that they retreat from Scandinavian winters; and much more the Ordo of Grailoe, who all, to a bird, forsake the northern parts of Europe at the approach of winter. "Grallce tanquam conjuratoe unanimiter in fugam se conjiciunt; ne earum unicam quidem inter nos habitantem invenire possimus; ut enim cestate in australibus degere nequeunt ob defectum lumbricorum, terramque siccam; ita nec in frigidis ob eandem causam," says Ekmarck, the Swede, in his ingenious little treatise called Migrationes Avium, which by all means you ought to read while your thoughts run on the subject of migration. See Amonitates Academica, vol. iv. p. 565 .

Birds may be so circumstanced as to be obliged to migrate in one country and not in another; but the Gralloe (which procure their food from marshes and boggy grounds) must in winter forsake the more northerly parts of Europe, or perish for want of food.

I Dr. Arne in his music to the "Cuckoo's Song" in "Love's Labour's Lust" gives the note of the cuckoo as C natural and G: Gungl in his "Cuckoo Galop" gives it as B natural and G sharp. For some further particulars respecting the notes of owls and cuckoos, see "The Ornithology of Shakespeare," pp. 90 and 151.-ED. 
I am glad you are making inquiries from Linnæus concerning the woodcock. It is expected of him that he should be able to account for the motions and manner of life of the animals of his own Fauna.

Faunists, as you observe, are too apt to acquiesce in bare descriptions and a few synonyms: the reason is plain, because all that may be done at home in a man's study; but the investigation of the life and conversation of animals is a concern of much more trouble and difficulty, and is not to be attained but by the active and inquisitive, and by those that reside much in the country.

Foreign systematics are, I observe, much too vague in their specific differences, which are almost universally constituted by one or two particular marks, the rest of the description running in general terms. But our countryman, the excellent Mr. Ray, is the only describer that conveys some precise idea in every term or word, maintaining his superiority over his followers and imitators in spite of the advantages of fresh discoveries and modern information.

At this distance of years it is not in my power to recollect at what periods woodcocks used to be sluggish or alert when I was a sportsman; but upon my mentioning this circumstance to a friend, he thinks he has observed them to be remarkably listless against snowy foul weather. If this should be the case, then the inaptitude for flying arises only from an eagerness for food, as sheep are observed to be very intent on grazing against stormy wet evenings. ${ }^{1}$

1 Amongst the miscellaneous observations, published by Mr. Jesse from Gilbert White's MS. diary ("Gleanings Nat. Hist.," 2nd series, p. 177) occurs the following:- "When horses, cows, sheep, deer, \&c., feed in wind and rain, they always keep their heads down the wind and their tails to the weather; but birds always perch and choose to fly with their heads to the weather, to prevent the wind from ruffling their feathers, and the cold and wet from penetrating to their skins." -Ev. 


\section{LETTER XI.}

\section{TO THE HONOURABLE DAINES BARRINGTOÑ.}

Selborne, Feb. 8, 1772.

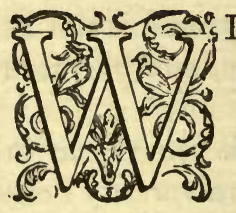

HEN I ride about in the winter, and see such prodigious flocks of various kinds of birds, I cannot help admiring at these congregations, and wishing that it was in my power to account for those appearances almost peculiar to the season. The two great motives which regulate the proceedings of the brute creation are love and hunger; the former incites animals to perpetuate their kind, the latter induces them to preserve individuals: whether either of these should seem to be the ruling passion in the matter of congregating is to be considered. As to love, that is out of the question at a time of the year when that soft passion is not indulged; besides, during the amorous season, such a jealousy prevails between the male birds, that they can hardly bear to be together in the same hedge or field. Most of the singing and elation of spirits of that time seems to me to be the effect of rivalry and emulation: and it is to this spirit of jealousy that I chiefly attribute the equal dispersion of birds in the spring over the face of the country.

Now as to the business of food: as these animals are actuated by instinct to hunt for necessary food, they should not, one would suppose, crowd together in pursuit of sustenance at a time when it is most likely to fail; yet such associations do take place in hard weather chiefly, and thicken as the severity increases. As some kind of selfinterest and self-defence is no doubt the motive for the proceeding, may it not arise from the helplessness of their state in such rigorous seasons; as men crowd together, when under great calamities, though they know not why? Perhaps approximation may dispel some degree of cold; 
and a crowd may make each individual appear safer from the ravages of birds of prey and other dangers.

If I admire when I see how much congenerous birds love to congregate, I am the more struck when I see incongruous ones in such strict amity. If we do not mucl: wonder to see a flock of rooks usually attended by a train of daws, yet it is strange that the former should so frequently have a flight of starlings for their satellites. Is it because rooks have a more discerning scent than their attendants, and can lead them to spots more productive of food? Anatomists say that rooks, by reason of two large nerves which run down between the eyes into the upper mandible, have a more delicate feeling in their beaks than other round-billed birds, and can grope for their meat when out of sight. Perhaps, then, their associates attend them on the motive of interest, as greyhounds when on the motions of their finders; and as lions are said to do on the yelpings of jackals. Lapwings and starlings sometimes associate.

\section{LETTER XII.}

\section{TO THE HONOURABLE DAINES BARRINGTON.}

March 9, 1772.

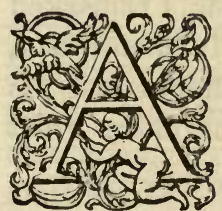

$S$ a gentleman and myself were walking on the 4th of last November round the seabanks at Newhaven, near the mouth of the Lewes river, in pursuit of natural knowledge, we were surprised to see three house swallows gliding very swiftly by us. That morning was rather chilly, with the wind at north-west; but the tenor of the weather for some time before had been delicate, and the noons remarkably warm. From this incident, and from repeated accounts which I meet with, I am more and more induced to believe that many of the swallow kind do not depart from this island; but lay themselves up in holes and 
caverns; and do, insect-like and bat-like, come forth at mild times, and then retire again to their latebra. Nor make I the least doubt but that, if I lived at Newhaven, Seaford, Brighthelmstone, or any of those towns near the chalk-cliffs of the Sussex coast, by proper observations, I should see swallows stirring at periods of the winter, when the noons were soft and inviting, and the sun warm and invigorating. And I am the more of this opinion from what I have remarked during some of our late springs, that though some swallows did make their appearance about the usual time, viz., the 13th or 14th of April, yet, meeting with a harsh reception, and blustcring cold north-east winds, they immediately withdrew, absconding for several days, till the weather gave them better encouragement. ${ }^{1}$

\section{LETTER XIII.}

\section{TO THE HONOURABIE DAINES BARRINGTON.}

April 12, 1772.

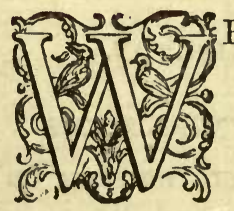

HILE I was in Sussex last autumn, my residence was at the village near Lewes, from whence I had formerly the pleasure of writing to you. On the 1st of November, I remarked that the old tortoise, formerly mentioned, began first to dig the ground in order to the forming its hybernaculum, which it had fixed on just beside a great

1 Writers on this subject do not as a rule distinguish between torpidity and hybernation. There are numerous instances of swallows becoming torpid, but none of their hybernating, none of their being aroused from a dormant state by unusually warm weather in early spring, which latter fact, says Mr. Blyth, cannot be too much impressed on those who still advocate the theory of the hybernation of a portion of these birds. It should be remembered also, he says, that the adults or one species, the chimney swallow, and the young of all, moult during the winter months.-FD. 
tuft of hepaticas. It scrapes out the ground with its fore feet, and throws it up over its back with its hind; but the motion of its legs is ridiculously slow, little exceeding the hour-hand of a clock; and suitable to the composure of an animal said to be a whole month in performing one feat of copulation. Nothing can be more assiduous than this creature night and day in scooping the earth, and forcing its great body into the cavity; but, as the noons of that season proved unusually warm and sunny, it was continually interrupted, and called forth, by the heat in the middle of the day; and though I continued there till the 13th of November, yet the work remained unfinished. Harsher weather, and frosty mornings, would have quickened its operations. No part of its behaviour ever struck me more than the extreme timidity it always expresses with regard to rain; for though it has a shell that would secure it against the wheel of a loaded cart, yet does it discover as much solicitude about rain as a lady dressed in all her best attire, shuffing away on the first sprinklings, and running its head up in a corner. If attended to, it becomes an excellent weather-glass; for as sure as it walks elate, and as it were on tip-toe, feeding with great earnestness in a morning, so sure will it rain before night. It is totally a diurnal animal, and never pretends to stir after it becomes dark. The tortoise, like other reptiles, has an arbitrary stomach as well as lungs; and can refrain from eating as well as breathing for a great part of the year. When first awakened it eats nothing; nor again in the autumn before it retires; through the height of the summer it feeds voraciously, devouring all the food that comes in its way. I was much taken with its sagacity in discerning those that do it kind offices: for, as soon as the good old lady comes in sight who has waited on it for more than thirty years, it hobbles towards its benefactress with awkward alacrity; but remains inattentive to strangers. Thus not only " the ox knoweth his owner, and the ass his master's crib," "but the most abject reptile and torpir of beings distinguishes 
the hand that feeds it, and is touched with the feclings of gratitude!

P.S. In about three days after I left Sussex the tortoise retired into the ground under the hepaticas.

\section{LETTER XIV.}

TO THE HONOURABLE DAINES BARRINGTON.

Selborne, March 26, 1773.

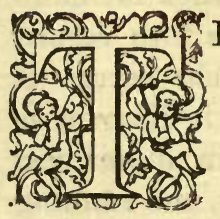

HE more I reflect on the $\sigma \tau$ ropyn of animals, the more $I$ am astonished at its effects. Nor is the violence of this affection more wonder. ful than the shortness of its duration. Thus every hen is in her turn the virago of the yard, in proportion to the helplessness of her brood; and will fly in the face of a dog or a sow in defence of those chickens, which in a few weeks she will drive before her with relentless cruelty.

This affection sublimes the passions, quickens the invention, and sharpens the sagacity of the brute creation. Thus a hen, just become a mother, is no longer that placid bird she used to be, but with feathers standing on end, wings hovering, and clucking note, she runs about like one possessed. Dams will throw themselves in the way of the greatest danger in order to avert it from their progeny. Thus a partridge will tumble along before a sportsman in order to draw away the dogs from her helpless covey. In the time of nidification the most feeble birds will assault the most rapacious. All the Hirundines of a village are up in arms at the sight of a hawk, whom they will persecute till he leaves that district. A very exact observer has often remarked that a pair of ravens nesting in the rock of Gibraltar would suffer no vulture or eagle to rest near their station, but would drive them from the hill with an amazing 
fury: $c$ ven the blue thrush at the season of breeding would dart out from the clefts of the rocks to chase away the kestril, or the sparrow hawk. If you stand near the nest of a bird that has young, she will not be induced to betray them by an inadvertent fondness, but will wait about at a distance with meat in her mouth for an hour together.

Should I farther corroborate what I have advanced above by some anecdotes which I probably may have mentioned before in conversation, jet you will, I trust, pardon the repetition for the sake of the illustration.

The flycatcher of the Zoology (the Stoparola of Ray) builds every year in the vines that grow on the walls of my house. A pair of these little birds had one year inadvertently placed their nest on a naked bough, perhaps in a shady time, not being aware of the inconvenience that followed. But a hot sunny season coming on before the brood was half fledged, the reflection of the wall became insupportable, and must inevitably have destroyed the tender young, had not affection suggested an expedient, and prompted the parent birds to hover over the nest all the hottcr hours, while with wings expanded, and mouths gaping for breath, they screened off the heat from their suffering offspring.

A farther instance I once saw of notable sagacity in a willow wren, which had built in a bank in my fields. This bird a friend and myself had observed as she sat in her nest; but were particularly careful not to disturb her, though we saw she eyed us with some degree of jealousy. Some days after, as we passed that way, we wore desirous of remarking how this brood went on; but no nest could be found, till I happencd to take up a large bundle of long green moss, as it were, carelessly thrown over the nest, in order to dodge the eye of any impertinent intruder.

A still more remarkable mixture of sagacity and instinct occurred to me one day as my people were pulling off the lining of a hotbed, in order to add some fresh dung. From out of the side of this bed leaped an animal with great agility that made a most grotesque figure; nor was it without great difficulty that it could be taken; when it 
proved to be a large white-bellied field mouse ${ }^{1}$ with three or four young clinging to her teats by their mouths and feet. It was amazing that the desultory and rapid motions of this dam should not oblige her litter to quit their hold, especially when it appeared that they were so young as to be both naked and blind!

To these instances of tender attachment, many more of which might be daily discovered by those that are studious of nature, may be opposed that rage of affection, that monstrous perversion of the $\sigma \tau$ opyn', which induces some females of the brute creation to devour their young because their owners have handled them too freely, or removed them from place to place! Swine, and sometimes the more gentle race of dogs and cats, are guilty of this horrid and preposterous murder. When I hear now and then of an abandoned mother that destroys her offspring, I am not so much amazed; since reason perverted, and the bad passions let loose, are capable of any enormity; but why the parental feelings of brutes, that usually flow in one most uniform tenor, should sometimes be so extravagantly diverted, I leave to abler philosophers than myself to determine.

\section{LETTER XV.}

TO THE HONOURABLE DAINES BARRINGTON.

Selborve, July 8, 1773.

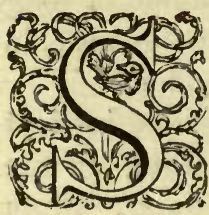

OME young men went down lately to a pond on the verge of Wolmer Forest to hunt flappers, or young wild-ducks, many of which they caught, and, among the rest, some very minute yet well fledged wild-fowls alive, which upon examination I found to be teals. I did not

1 The long-tailed field mouse, Mus sylraticus.-ED. 
know till then that teals ever bred in the south of England, and was much pleased with the discovery; this I look upon as a great stroke in natural history. ${ }^{1}$

We have had, ever since I can remember, a pair of white owls that constantly breed under the eaves of this church. As I have paid good attention to the manner of life of these birds during their season of breeding, which lasts the summer through, the following remarks may not perhaps be unacceptable:-About an hour before sunset (for then the mice begin to run) they sally forth in quest of prey, and hunt all round the hedges of meadows and small enclosures for them, which seem to be their only food. In this irregular country we can stand on an eminence and see them beat the fields over like a setting-dog, and often drop down in the grass or corn. I have minuted these birds with my watch for an hour together, and have found that they return to their nest, the one or the other of them, about once in five minutes; reflecting at the same time on the adroitness that every animal is possessed of as far as regards the well-being of itself and offspring. But a piece of address, which they show when they return loaded, should not, I think, be passed over in silence. As they take their prey with their claws, so they carry it in their claws to their nest; but, as the feet are necessary in their ascent under the tiles, they constantly perch first on the roof of the chancel, and shift the mouse from their claws to their bill, that the feet may be at liberty to take hold of the plate on the wall as they are rising under the eaves.

White owls seem not (but in this I am not positive) to hoot at all; all that clamorous hooting appears to me to come from the wood kinds. ${ }^{2}$ The white owl does indeed

1 The teal still breeds in the neighbourhood of Wolmer (sce p. 29, note 1), and the writer has repcatedly seen the nest eggs and young of this bird in the western portion of the adjoining county of Sussex. -ED.

2 Mr. Colquhoun, the author of "The Moor and the Loch," speaking of the white or barn owl, says:- "They do hoot, but very rarely. I heard one once six times in succession, and then it ceased." Sir William Jardine once shot a white owl in the very act of hooting; and 
snore and hiss in a tremendous manner ; and these menaces well answer the intention of intimidating: for I have known a whole village up in arms on such an occasion, imagining the churchyard to be full of goblins and spectres. White owls also often scream horribly as they fly along; from this screaming probably arose the common people's imaginary species of screech-owl, which they superstitiously think attends the windows of dying persons. The plumage of the remiges of the wings of every species of owl that I have yet examined is remarkably soft and pliant. Perhaps it may be necessary that the wings of these birds should not make much resistance or rushing, that they may be enabled to steal through the air unheard upon a nimble and watchful quarry.

While I am talking of owls, it may not be improper to mention what I was told by a gentleman of the county of Wilts. As they were grubbing a vast hollow pollard-ash that had been the mansion of owls for centuries, he discovered at the bottom a mass of matter that at first he could not account for. After some examination, he found that it was a congeries of the bones of mice (and perhaps of birds and bats) that had been heaping together for ages, being cast up in pellets out of the crops of many generations of inhabitants. For owls cast up the bones, fur, and feathers of what they devour, after the manner of hawks. $\mathrm{He}$ believes, he told me, that there were bushels of this kind of substance. ${ }^{1}$

Mr. W. Boulton, of Beverley, referring to a bird of this species. which he had reared from the nest, observed ("Zoologist," 1863, p. 8765) :"It does ' hoot' exactly like the long eared owl, but not so frequently. I use the term 'hoot' in contradistinction to 'screecl,' which it often does when irritated."-ED.

1 In order to ascertain the nature of the food of owls, a German naturalist, Dr. Altum, collected their "pellets" at different seasons of the year, and in different localities, and carefully examined them, with the following remarkable results. In 706 pellets of the white or barn owl he found the remains of the following animals: bats 16, rats 3 , mice 237, voles 693, shrews 1590, mole 1, sma.l birds 22 . In 210 pelle's of the tawny owl (S. aluco) he found remains of stoat 1, rats 6 , mice 12 , voles 296 , squirrel 1 , shrews 33 , moles 48 , small birds 18 . and 
When brown owls hoot, their throats swell as big as a hcn's egg. I have known an owl of this species live a full year without any water. Perhaps the case may be the same with all birds of prey. When owls fly they stretch out their legs behind them as a balance to their large heavy heads: for as most nocturnal birds have large eyes and ears they must have large heads to contain them. Large eyes I presume are necessary to collect every ray of light, and large concave ears to command the smallest degree of sound or noise.

It will be proper to premise here that the sixteenth, eighteenth, twentieth, and twenty-first letters have been published already in the "Philosophical Transactions:" but as nicer observation has furnished several currections and additions, it is hoped that the re-publication of them will not give offence; especially as these sheets would be very imperfect without them, and as they will be new to many readers who had no opportunity of seeing them when they made their first appearance.-G. W.

The Hirundines are a most inoffensive, harmless, entertaining, social, and useful tribe of birds: they touch no fruit in our gardens; delight, all except one species, in attaching themselves to our houses; amuse us with their migrations, songs, and marvellous agility: and clear our outlets from the annoyances of gnats and ither troublesome insects. Some districts in the South Seas, near Guayaquil, ${ }^{1}$ are desolated, it seems, by the infinite swarms of venomous mosquitoes, which fill the air, and render those coasts insupportable. It would be worth inquiring whether any

a large number of beetles belonging to seven or eight different genera, besides quantities of cock-chafers (Melolontha vulgaris). In pellets of the long-eared owl, he found remains of mice 14, voles 271, shrews 2 , and small birds 3 . Of the short-eared owl he examined only a few pellets, which were found to contain the remains of water voles only, but as these were obtained in a single locality where these animals were especially abundant, he reserved his remarks on the food of this owl until he could make further investigations. In the details, however, which he has furnished, we have abundant proof of the important services which owls render to the agriculturist.-ED.

1 See "Ulloa's 'Travels."-G. W. 
species of Hirundives is found in those regions. Whoevcr contemplates the myriads of insects that sport in the sunbeams of a summer evening in this country, will soon bo convinced to what a degree our atmosphere would be choked with them was it not for the friendly interposition of the swallow tribe.

Many species of birds have their peculiar lice; but the Hirundines alone seem to be annoyed with Dipterous insects, which infest every species, and are so large, in proportion to themselves, that they must be extremely irksome and injurious to them. These are the Hippobosca hirundinis, ${ }^{1}$ with narrow subulated wings, abounding in every nest; and are hatched by the warmth of the bird's own body during incubation, and crawl about under its feathers.

A species of them is familiar to horsemen in the south of England under the name of forest-fly; and to some of sidefly, from its running sideways like a crab. It creeps under the tails, and about the groins of horses which, at their first coming out of the north, are rendered half frantic by the tickling sensation; while our own breed little regards them. ${ }^{2}$

The curious Réaumur discovered the largo eggs, or rather pupce, of these flies, as big as the flies themselves, which he hatched in his own bosom. Any person that will take the trouble to examine the old nests of either species of swallows may find in them the black shining cases or skins of tho pupce of these insects: but for other particulars, too long for this place, we refer the reader to "L'Histoire de? Insectes" of that admirable entomologist, tom. iv. pl. 11.

\section{Craterina hirundinis, OLfers.}

2 In the New Forest, whence its name of forest fly, the Hippobosca equina, Lins., abounds in such profusion that Mr. Samouelle states, in his "Entomologist's Useful Compendium," that he has obtained from the flanks of one horse six handfuls, which consisted of upwards of a hundred specimens. He adds, "Mr. Bentley informs me, from observations he made in the summer of 1818 , wlile in Hampshire, that the Hippoboscce are found in a considerably greater abundance on white and light-coloured horses than on those of a black and dark colour; and this obserration was confurmed by the stable-keepers in the vicinity of the Forest."-ED. 


\section{LETTER XVI.}

\section{TO THE HONOURABLE DAINES BARRINGTON.}

Selborne, Nov. 20, 1773.

So $35 \mathrm{~N}$ obedience to your injunctions I sit down to give you some account of the house martin Q2 1 or martlet; and, if my monography of this 2.9. little domestic and familiar bird should happen isc bably soon extend my inquiries to the rest of the British Hirundines - the swallow, the swift, and the bank martin.

A few house martins begin to appear about the 16 th of April ; usually some few days later than the swallow. For some time after they appear, the Hirundines in general pay no attention to the business of nidification, but play and sport about either to recruit from the fatigue of their journey, if they do migrate at all, or else that their blood may recover its true tone and texture after it has been so long benumbed by the severities of winter. About the middle of May, if the weather be fine, the martin begins to think in earnest of providing a mansion for its family. The crust or shell of this nest seems to be formed of such dirt or loam as comes most readily to hand, and is tempered and wrought together with little bits of broken straws to render it tough and tenacious. As this bird often builds against a perpendicular wall without any projecting ledge under, it requires its utmost efforts to get the first foundation firmly fixed, so that it may safely carry the superstructure. On this occasion the bird not only clings with its claws, but partly supports itself by strongly inclining its tail against the wall, making that a fulcrum; and thus steadied, it works and plasters the materials into the face of the brick or stone. But then, that this work may not, while it is soft and green, pull itself down by its own weight, the pro- 
vident architect has prudence and forbearance enough not to advance her work too fast; but by building only in the morning, and by dedicating the rest of the day to food and amusement, gives it sufficient time to dry and harden. About half an inch seems to be a sufficient layer for a day. Thus careful workmen when they build mud walls (informed at first perhaps by this little bird) raise but a moderate layer at a time, and then desist; lest the work should become top-heavy, and so be ruined by its own weight. By this method in about ten or twelve days is formed an hemispheric nest with a small aperture towards the top, strong, compact, and warm; and perfectly fitted for all the purposes for which it was intended. But then nothing is more common than for the house sparrow, as soon as the shell is finished, to seize on it as its own, to eject the owner, and to line it after its own manner.

After so much labour is bestowed in erecting a mansion, as Nature seldom works in vain, martins will breed on for several years together in the same nest, where it happens to be well sheltered and secure from the injuries of weather. The shell or crust of the nest is a sort of rustic-work full of knobs and protuberances on the outside: nor is the inside of those that I have examined smoothed with any exactness at all; but is rendered soft and warm, and fit for incubation, by a lining of small straws, grasses, and feathers; and sometimes by a bed of moss interwoven with wool. In this nest they tread, or engender, frequently during the time of building; and the hen lays from three to five white eggs.

At first when the young are hatched, and are in a naked and helpless condition, the parent birds, with tender assiduity, carry out what comes away from their young. Was it not for this affectionate cleanliness the nestlings would soon be burnt up, and destroyed in so deep and hollow a nest, by their own caustic excrement. In the quadruped creation, the same neat precaution is made use of ; particularly among dogs and cats, where the dams lick away what proceeds from their young. But in birds there seems to be a particular provision, that the dung of nestlings is enveloped in a tough kind of jelly, and therefore is the easier 
conveyed off without soiling or daubing. ${ }^{1}$ Yet, as Nature is cleanly in all her ways, the young perform this office for themselves, in a little time, by thrusting their tails out at the aperture of their nest. As the young of small birds presently arrive at their $i \lambda_{6} x^{\prime} \alpha$, or full growth, they soon become impatient of confinement, and sit all day with their heads out at the orifice, where the dams, by clinging to the nest, supply them with food from morning to night. For a time, the young are fed on the wing by their parents; but the feat is done by so quick and almost imperceptible a slight, that a person must have attended very exactly to their motions before he would be able to perceive it. As soon as the young are able to shift for themselves, the dams immediately turn their thoughts to the business of a second brood: while the first flight, shaken off and rejected by their nurses, congregate in great flocks, and are the birds that are seen clustering and hovering on sunny mornings and evenings round towers and steeples, and on the roofs of churches and houses. These congregations usually begin to take place about the first week in August; and therefore wo may conclude that by that time the first flight is pretty well over. The young of this species do not quit their abodes all together, but the more forward birds get abroad some days before the rest. These, approaching the eaves of buildings, and playing about before them, make people think that several old ones attend one nest. They are often capricious in fixing on a nesting-place, beginning many edifices, and leaving them unfinished; but when once a nest is completed in a sheltered place, it serves for several scasons. Those which breed in a ready-finished house get

1 It is a very curious provision of nature, as remarked by the Hon. and Rev. W. Herbert, that the dung of all nestlings is enclosed in a thir membrane, which enables the old birds to carry it away in their bills, which they do regularly each time they bring food to the nest. The young instinctively, even before they can see, protrude their hind quarters to eject the dung from the nest; but if the parent did not carry it away, there would be a congeries of dirt under the nest, which would not only be uncleanly, but would attract attention and discover their retreat.-ED. 
the start, in hatching, of those that build new, by ten days or a fortnight. These industrious artificers are at their labours in the long days before four in the morning: when they fix their materials, they plaster them on with their chins, moving their heads with a quick vibratory motion. They dip and wash as they fly sometimes in very hot weather, but not so frequently as swallows. It has been observed that martins usually build to a north-east or northwest aspect, that the heat of the sun may not crack and destroy their nests: but instances are also remembered where they bred for many years in vast abundance in a hot stifled inn-yard, against a wall facing to the south.

Birds in general are wise in their choice of situation : but in this neighbourhood, every summer, is seen a strong instance to the contrary at a house without eaves in an exposed district, where some martins build year by year in the corners of the windows. But, as the corners of theso windows (which face to the south-east and south-west) are too shallow, the nests are washed down every hard rain; and yet these birds drudge on to no purpose from summer to summer, without changing their aspect or house. It is a piteous sight to see them labouring when half their nest is washed away, and bringing dirt-" generis lapsi sarcire ruinas." Thus is instinct a most wonderfully unequal faculty: in some instances so much above reason, in other respects so far below it! Martins love to frequent towns, especially if there are great lakes and rivers at hand; nay, they even affect the close air of London. And I have not only seen them nesting in the Borough, but even in the Strand and Fleet Street; but then it was obvious from the dinginess of their aspect that their feathers partook of the filth of that sooty atmosphere. Martins are by far the least agile of the four species; their wings and tails are short, and therefore they are not capable of such surprising turns and quick and glancing evolutions as the swallow. Accordingly they make use of a placid easy motion in a middle region of the air, seldom mounting to any great height, and never sweeping long together over the surface of the ground or water. They do not wander far for food, but affect 
sheltered districts, over some lake, or under some hanging wood, or in some hollow vale, especially in windy weather. They breed the latest of all the swallow kind: in 1772 they had nestlings on to October the 21 st, and are never without unfledged young as late as Michaelmas.

As the summer declines, the congregating flocks increase in numbers daily, by the constant accession of the second broods; till at last they swarm in myriads upon myriads round the villages on the Thames, darkening the face of the sky as they frequent the aits of that river where they roost. They retire (the bulk of them I mean) in vast flocks together, about the beginning of October: but have appeared of late years in a considerable flight in this neighbourhood, for one day or two, as late as November the 3rd and 6 th, after they were supposed to have been gone for more than a fortnight. They therefore withdraw with us the latest of any species. Unless these birds are very short-lived indeed, or unless they do not return to the district where they are bred, they must undergo vast devastations somehow, and somewhere; for the birds that return yearly bear no manner of proportion to the birds that retire.

: House martins are distinguished from their congeners by having their legs covered with soft downy feathers down to their toes. They are no scngsters; but twitter in a pretty inward soft manner in their nests. During the time of breeding, they are often greatly molested with fleas. ${ }^{1}$

1 Allusion has been already made to the parasites of awallows in the previous letter, p. 180, and some further remarks on the subject will be found later on in Letters XX. and XXI. Should the reader be curious to learn something more of these singular insects, reference may be made with advantage to Denny's "Monographia Anoplurorum Britanniæ," an essay on the Britisl species of parasitic insects.-ED. 


\section{LETTER XVII.}

TO THE HONOURABLE DAINES BARRLNGTON.

Ringmer, near Lewes, Dec. 9, 1773.

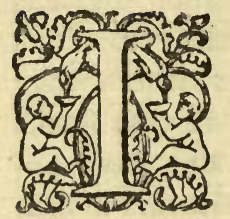

RECEIVED your last favour just as I was setting out for this place, and am pleased to find that my monography met with your approbation. My remarks are the result of many years' observation; and are, I trust, true in the whole: though I do not pretend to say that they are perfectly void of mistake, or that a more nice observer might not make many additions, since subjects of this kind are inexhaustible.

If you think my letter worthy the notice of your respectable society, you are at liberty to lay it before them; and they will consider it, I hope, as it was intended, as an humble attempt to promote a more minute inquiry into natural history; into the life and conversation of animals. Perhaps hereafter I may be induced to take the house swallow under consideration; and from that proceed to the rest of the British Hirundines.

Though I have now travelled the Sussex downs upwards of thirty years, yet I still investigate that chain of majestic mountains with fresh admiration year by year; and think I see new beauties every time I traverse it. This range, which runs from Chichester eastward as far as East-Bourn, is about sixty miles in length, and is called the South Downs, properly speaking, only round Lewes. As you pass along you command a noble view of the wild, or weald, on one hand, and the broad downs and sea on the other. Mr. Ray used to visit a family ${ }^{1}$ just at tho foot of these hills, and was so ravished with the prospect from Plumpton Plain, near Lewes, that he mentions those scapes

1 Mr. Courthope, of Danny.-G. W. 
in his "Wisdom of God in the Works of the Creation" with the utmost satisfaction, and thinks them equal to any thing he had seen in the finest parts of Europe.

For my own part, I think there is somewhat peculiarly sweet and amusing in the shapely figured aspect of chalk hills, in preference to those of stone, which are rugged, broken, abrupt, and shapeless.

Perhaps I may be singular in my opinion, and not so happy as to convey to you the same idea; but I never contemplate these mountains without thinking I perceive somewhat analogous to growth in their gentle swellings and smooth fungus-like protuberances, their fluted sides, and regular hollows and slopes, that carry at once the air of vegetative dilatation and expansion. Or was there ever a time when these immense masses of calcareous matter were thrown into fermentation by some adventitious moisture; were raised and leavened into such shapes by some plastic power; and so made to swell and heave their broad backs into the sky so much above the less animated clay of the wild below?

By what I can guess from the admeasurements of the hills that have been taken round my house, I should suppose that these hills surmount the wild, at an average, at about the rate of five hundred feet.

One thing is very remarkable as to the sheep: from the westward till you get to the river Adur all the flocks have horns, and smooth white faces, and white legs; and a hornless sheep is rarely to be seen: but as soon as you pass that river eastward, and mount Beeding Hill, all the flocks at once become hornless, or, as they call them, poll sheep; and have moreover black faces, with a white tuft of wool on their foreheads, and speckled and spotted legs : so that you would think that the flocks of Laban were pasturing on one side of the stream, and the variegated breed of his sonin-law Jacob were cantoned along on the other. And this diversity holds good respectively on each side from the valley of Bramber and Beeding to the eastward, and westward all the whole length of the downs. If you talk with the shopherds on this subject, they tell you that the caso 
has been so from time immemorial ; and smile at your simplicity if you ask them whether the situation of these two different breeds might not be reversed. However, an intelligent friend of mine near Chichester is determined to try the experiment; and has this autumn, at the hazard of being laughed at, introduced a parcel of black-faced hornless rams among his horned wostern ewes. The black-faced poll sheep have the shortest legs and the finest wool. ${ }^{1}$

As I had hardly ever before travelled these downs at so late a season of the year, I was determined to keep as sharp a look-out as possible so near the southern coast, with respect to the summer short-winged birds of passage. We make great inquiries concerning the withdrawing of the swallow kind, without examining enough into the causes why this tribe is never to be seen in winter; for entre nous, the disappearing of the latter is more marvellous than that of the former, and much more unaccountable. The Hirundines, if they please, are certainly capable of migration; and yet, no doubt, are often found in a torpid state: but redstarts, nightingales, whitethroats, blackcaps, \&c. \&c. are very ill provided for long flights ; have never been once found, as I ever heard of, in a torpid state; and yet can never be supposed, in such troops, from year to year to dodge and elude the eyes of the curious and inquisitive, which from day to day discern the other small birds that are known to abide our winters. But, notwithstanding all my care, I saw nothing like a summer bird of passage : and, what is more strange, not one wheatear, though they abound so in the autumn as to be a considerable perquisite

1 In a note to this passage, Mr. Bennett says :- "To assert that the black-faced, hornless race of sheep, known as South Downs, can exist westward of the river Adur, would be superfluous : they are not only to be seen on the downs to the west of Bramber, but everywhere throughout Enģland; so strongly have they been recommended to general favour by their short legs and their fine wool. The Dorsets, as they are called, the horned sheep with smooth white faces and white legs, now oecur much more rarely than the rival breed. Yet the observation in the text is cirious, as indicating the rapid advance that has taken place, in iitle more than half a century, in the knowledge and power of the agricuicurist." - Es. 
to the shopherds that take them; and though many are to be seen to my knowledge all the winter through in many parts of the south of England. The most intelligent shepherds tell me that some few of these birds appear. on the downs in March, and then withdraw to breed, probably, in warrens and stone-quarries: now and then a nest is ploughed up in a fallow on the downs under a furrow, but it is thought a rarity. At the time of wheat harvest, they begin to be taken in great numbers; are sent for sale in vast quantities to Brighthelmstone and Tunbridge; and appear at the tables of all the gentry that entertain with any degree of elegance. About Michaelmas they retire, and are seen no more till March. Though these birds are, when in season, in great plenty on the South downs round Lewes, yet at East-Bourn, which is the eastern extremity of those downs, they abound much more. One thing is very remarkable - that though in the height of the season so many hundreds of dozens are taken, yet they never are seen to flock; and it is a rare thing to see more than three or four at a time: so that there must be a perpetual flitting and constant progressive succession. It does not appear that any wheatears are taken to the westward of Houghton Bridge, which stands on the river Arun. ${ }^{1}$

I did not fail to look particularly after my new migration of ring-ousels; and to take notice whether they continued on the downs to this season of the year; as I had formerly remarked them in the month of October all the way from Chichester to Lewes wherever thero were any shrubs and covert: but not one bird of this sort came within my observation. I only saw a fow larks and whinchats, some rooks, and several kites and buzzards.

About Midsummer a flight of crossbills comes to the pinegroves about this house, but never makes any long stay.

1 This is a mistake. We have seen them frequently in spring on the downs above Chichester, and, in antumn, on the low-lying ground between Bognor and Selsea Bill. Several pairs breed annually on the dowris near Uppark, in the parish of Harting, which is within a few miles of the borders of Hants, and not very far from Selborne. This observation we have had an opportunity of verifying during the present summer.-ED. 
The old tortoise, that I have mentioned in a former letter, still continues in this garden; and retired under ground about the 20th of November, and came out again for one day on the 30th: it lies now buried in a wet swampy border under a wall facing to the south, and is enveloped at present in mud and mire!

Here is a large rookery round this house, the inhabitants of which seem to get their livelihood very easily; for they spend the greatest part of the day on their nest-trees when the weather is mild. These rooks retire every evening all the winter from this rookery, where they only call by the way, as they are going to roost in deep woods: at the dawn of day they always revisit their nest-trees, and are preceded a few minutes by a flight of daws, that act, as it were, as their harbingers.

\section{LETTER XVIII.}

\section{TO THE HONOURABLE DAINES BARRINGTON.}

SeLborve, Jan. 29, 1774.

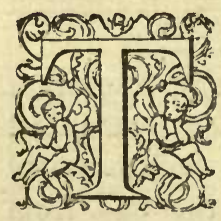

HE house swallow, or chimney swallow, is, unundoubtedly, the first comer of all the British Hirundines; and appears in general on or about the 13th of April, as I have remarked from many years' observation. Not but now and then a straggler is seen much earlier: and, in particular. when I was a boy, I observed a swallow for a whole day together on a sunny warm Shrove Tuesday; which day could not fall out later than the middle of March, and often happened early in February.

It is worth remarking that these birds are seen first about lakes and mill-ponds; and it is also very particular, that if these early visitors happen to find frost and snow, as was the case of the two dreadful springs of 1770 and 1771, they immediately withdraw ${ }^{1}$ for a time. A circumstance this,

1 It has been remarked by the Hon. and Rev. W. Herbert that it 
much more in favour of hiding than migration; since it is much more probable that a bird should retire to its hybernaculum just at hand, than return for a week or two only to warmer latitudes.

The swallow, though called the chimney-swallow, by no means builds altogether in chimneys, but often within barns and outhouses against the rafters; and so she did in Virgil's time:

Frarrula quàm tignis nidos suspendat hirundo."

In Sweden she builds in barns, and is called ladu suala, the barn-swallow. Besides, in the warmer parts of Europe there are no chimneys to houses except they are Englishlinilt: in these countries she constructs her nest in porches, and gateways, and galleries, and open halls.

Here and there a bird may affect some odd, peculiar place; as we have known a swallow build down the shaft of an old well, through which chalk had been formerly drawn up for the purpose of manure: but in general with us this Hirundo breeds in chimneys; and loves to haunt those stacks where there is a constant fire, no doubt for the sake of warmth. Not that it can subsist in the immediate shaft where there is a fire; but prefers one adjoining to that of the kitchen, and disregards the perpetual smoke of that funnel, as I have often observed with some degree of wonder.

Five or six or more feet down the chimney, does this little bird begin to form her nest about the middle of May, which consists, like that of the house martin, of a crust or shell composed of dirt or mud, mixed with short pieces of straw, to render it tongh and permanent; with this difference, that whereas the shell of the martin is nearly hemispheric, that of the swallow is open at the top, and like half a deep dish : this nest is lined with fine grasses, and feathers which are often collected as they float in the air.

is very doubtful whether the swallows which appear unseasonably for a few days do not perish when they are said to withdraw. "I do not see," he says, "how they are identified when they are supposed to reappear in due time."-ED. 
Wonderful is the address which this adroit bird shows all day long in ascending and descending with security through so narrow a pass. When hovering over the mouth of the funnel, the vibrations of her wings acting on the confined air occasion a rumbling like thunder. It is not improbable that the dam submits to this inconvenient situation so low in the shaft, in order to secure her broods from rapacious birds, and particularly from owls, which frequently fall down chimneys, perhaps in attempting to get at these nestlings.

The swallow lays from four to six white eggs, dotted with red specks; and brings out her first brood about the last week in June, or the first week in July. The progressive method by which the young are introduced into life is very amusing: first, they emerge from the shaft with difficulty enough, and often fall down into the rooms below: for a day or so they are fed on the chimney-top, and then are conducted to the dead leafless bough of some tree, where, sitting in a row, they are attended with great assiduity, and may then be called perchers. In a day or two more they become flyers, but are still unable to take their own food; therefore they play about near the place where the dams are hawking for flies; and, when a mouthful is collected, at a certain signal given, the dam and the nestling advance, rising towards each other, and meeting at an angle; the young one all the while uttering such a little quick note of gratitude and complacency, that a person must have paid very little regard to the wonders of Nature that has not often remarked this feat.

The dam betakes herself immediately to the business of a sccond brood as soon as she is disengaged from her first; which at once associates with the first broods of house martins ; and with them congregates, clustering on sunny roofs, towers, and trees. This Hirundo brings out her second brood towards the middle and end of August.

All the summer long is the swallow a most instructive pattern of unwearied industry and affection; for, from morning to night, while there is a family to be supported, she spends the whole day in skimming close to the ground, 
and exerting the most sudden turns and quick evolutions. Avenues, and long walks under hedges, and pasture fields, and mown meadows where cattle graze, are her delight, especially if there are trees intersporsed; because in such spots insects most abound. When a fly is taken a smart snap from her bill is heard, resembling the noise at the shutting of a watchcase; but the motion of the mandibles is too quick for the eye.

The swallow, probably the male bird, is the excubitor to house martins, and other little birds, announcing the approach of birds of prey. For as soon as a hawk appoars, with a shrill alarming note he calls all the swallows and martins about him; who pursue in a body, and buffet and strike their enemy till they have driven him from the village, darting down from above on his back, and rising in a perpendicular line in perfect security. This bird also will sound the alarm, and strike at cats when they climb on the roofs of houses, or otherwise approach the nests. Each species of Hirundo drinks as it flies along, sipping the surface of the water; but the swallow alone, in gencral, washes on the wing, by dropping into a pool for many times together : in very hot weather house martins and bank martins dip and wash a little.

The swallow is a delicate songster, and in soft sunny weather sings both perching and flying; on trees in a kind of concert, and on chimney tops : is also a bold flyer, ranging to distant downs and commons even in windy weather, which the other species seem much to dislike; nay, even frequenting exposed seaport towns, and making little excursions over the salt water. Horsemen on wide dewns are often closely attended by a little party of swallows for miles together, which plays before and behind them, sweoping around, and collecting all the skulking insects that are roused by the trampling of the horses' feet, when the wind blows hard; without this oxpedient, they are often forced to settle to pick up their lurking prey.

This species feeds much on little Coleoptera, as well as on gnats and flies; and often settles on dug ground, or 
paths, for gravels to grind and digest its food. Before they depart, for some weeks, to a bird, they forsake houses and chimneys, and roost in trees; and usually withdraw about the beginning of October; though some few stragglers may appear on at times till the first woek in November.

Some few pairs haunt the new and open streets of London next the fields, but do not enter, like the house martin, the close and crowded parts of the city.

Both male and female are distinguished from their congeners by the length and forkedness of their tails. They are undoubtedly the most nimble of all the species; and when the male pursues the female in amorous chase, they then go beyond their usual speed, and exert a rapidity almost too quick for the eye to follow.

After this circumstantial detail of the life and discerning

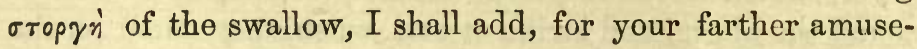
ment, an anecdote or two not much in farour of her sagacity:-

A certain swallow built for two years together on the handles of a pair of garden shears, that were stuck up against the boards in an outhouse, and therefore must have her nest spoiled whenever that implement was wanted: and, what is stranger still, another bird of the same species built its nest on the wings and body of an owl that happened by accident to hang dead and dry from the rafter of a barn. This owl, with the nest on its wings, and with eggs in the nest, was brought as a curiosity worthy the most elegant private museum in Great Britain. The owner, struck with the oddity of the sight, furnished the bringer with a large shell, or conch, desiring him to fix it just where the owl hung: the person did as he was ordered, and the following year a pair, probably the same pair, built their nest in the conch, and laid their eggs. ${ }^{1}$

The owl and the conch make a strange grotesque appear-

1 This anecdote is related, almost in the same words, and eviclently originally from the same pen, in Barrington's "Miscellanies," p. 240.-ED. 
ance, and are not the least curious specimens in that wonderful collection of art and nature. ${ }^{1}$

Thus is instinct in animals, taken the least out of its way, an undistinguishing, limited faculty; and blind to every circumstance that does not immediately respect self-preservation, or lead at once to the propagation or support of their species.

\section{LETTER XIX.}

\section{TO THE HONOURABLE DAINES BARRINGTON.}

Selborne, Feb. 14, 1774.

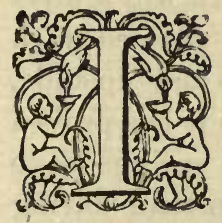

RECEIVED your favour of the eighth, and am pleased to find that you read my little history of the swallow with your usual candour: nor was I the less pleased to find that you made objections where you saw reason.

As to the quotations, it is difficult to say precisely which specios of Hirundo Virgil might intend in the lines in question, since the ancients did not attend to specific differences like modern naturalists; yet somowhat may be gathered, enough to incline me to suppose that in the two passages quoted, the poet had his eye on the swallow.

In the first place the epithet garrula suits the swallow well, who is a great songster; and not the martin, which is rather a mute bird; and when it sings is so inward as scarce to be heard. Besides, if tignum in that place signifies a rafter rather than a beam, as it seems to me to do, then I think it must be the swallow that is alluded to, and not the martin; since the former does frequently build within the roof against the rafters; while the latter always, as far as I have been able to observe, builds without the roof against eaves and cornices.

As to the simile, too much stress must not be laid on it;

1 Sir Asion Lever's Museum, since disperser, see p. 8, note.-ED. 
yet the epithet nigra speaks plainly in favour of the swallow, whose back and wings are very black; while the rump of the martin is milk-white, its loack and wings blue, and all its under part white as snow. Nor can the clumsy motions (comparatively clumsy) of the martin well represent the sudden and artful evolutions and quick turns which Juturna gave to her brother's chariot, so as to elude the eager pursuit of the enraged Eneas. The verb sonat also seems to imply a bird that is somewhat loquacious. ${ }^{1}$

We have had a very wet autumn and winter, so as to raise the springs to a pitch beyond any thing since 1764; which was a remarkable year for floods and high waters. The land springs, which we call lavants, break out much on the downs of Sussex, Hampshire, and Wiltshire. The country people say, when the lavants rise, corn will always be dear; meaning that when the earth is so glutted with water as to send forth springs on the downs and uplands, that the corn vales must be drowned; and so it has proved for these ten or eleven years past. For land springs have never obtained more since the memory of man than during that period; nor has there been known a greater scarcity of all sorts of grain, considering the great improvements of modern husbandry. Such a run of wet seasons a century or two ago, would, I am pcrsuaded, have occasioned a famine. Therefore pamphlets and newspaper letters, that talk of combinations, tend to inflame and mislead; since we must not expect plenty till Providence sends us more favourable seasons.

The wheat of last year, all round this district, and in the county of Rutland, and elsewhere, yields remarkably bad: and our wheat on the ground, by the continual late sudden vicissitudes from fierce frost to pouring rains, looks poorly; and the turnips rot very fast.

1 "Nigra velut magnas domini cum divitis æodcs Pervolat, et pennis alta atria lustrat hirundo, Pabula parra legens, nidisque loquacibus escas: Et nunc porticibus vacuis, nunc humida circum Stagna sonat."

G. IV. 


\section{IETTER XX.}

\section{TO THE HONOURABLE DAINES BARRINGTON.}

Selborne, Feb. 26, 1774.

20rone $\mathrm{HE}$ sand martin, or bank martin, is by

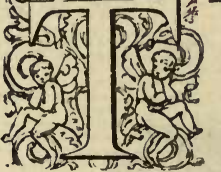
much the least of any of the British Hirundines; and as far as we have ever seen, the smallest known Hirundo: though Brisson asserts that there is one much smaller, and that is the Hirundo csculenti.

But it is much to be regretted that it is scarce possible for any observer to be so full and exact as he could wish in reciting the circumstances attending the life and conversation of this little bird, since it is feră naturâ, at least in this part of the kingdom, disclaiming all domestic attachments, and haunting wild heaths and commons where there are large lakes; while the other species, especially the swallow and house martin, are remarkably gentle and domesticated, and nover seem to think themselves safe but under the protection of man.

Here are in this parish, in the sand pits and banks of the lakes of Wolmer Forest, several colonics of these birds ; and yet they are never seen in the village; nor do they at all frequent the cottages that are scattered about in that wild district. The only instance I ever remember where this species haunts any building is at the town of Bishop's Walthain, in this county, where many sand martins nestle and breed in the scaffold holes of the back wall of William of Wykeham's stables: but then this wall stands in a very sequestered and retired enclosure, and faces upon a large and beautiful lake. And indeed this species seems so to delight in large waters, that no instance occurs of their 
abounding, but near vast pools or rivers; and in particular it has been remarked that they swarm in the banks of the Thames in some places below London bridge.

It is curious to observe with what different degrees of architectonic skill Providence has endowed birds of the same genus, and so nearly correspondent in their general mode of life! for while the swallow and the house martin discover the greatest address in raising and securely fixing crusts or shells of loam as cunabula for their young, the bank martin terebrates a round and regular hole in the sand or earth, which is serpentine, horizontal, and about two feet deep.

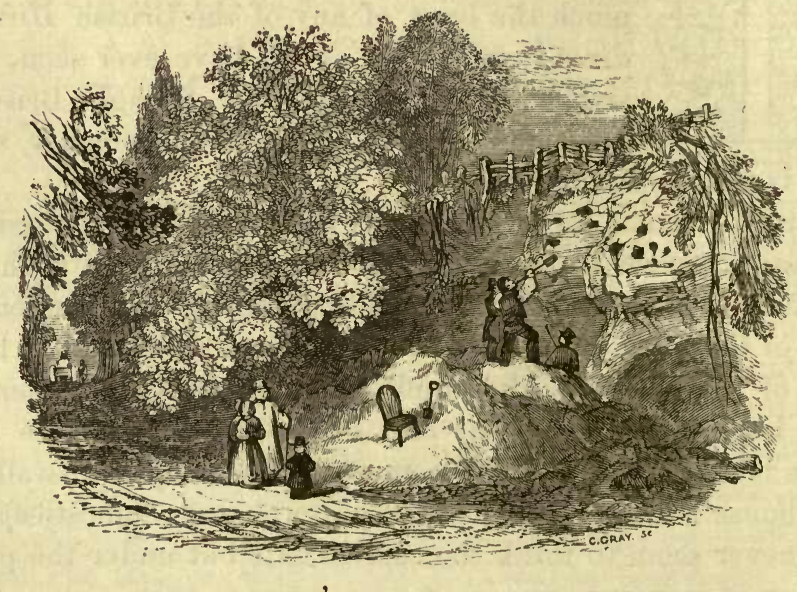

SAND MARTINS' COLONY AT OAKHANGER.

At the inner end of this burrow does this bird deposit, in a good degree of safety, her rude nest, consisting of fine grasses and feathers, usually goose feathers, very inartificially laid together.

Perseverance will accomplish any thing: though at first one would be disinclined to believe that this weak bird, with her soft and tender bill and claws, should ever be able to bore the stubborn sand bank without entirely disabling herself; yet with these feeble instruments have I seen a pair of them make great dispatch; and could remark how much they had scooped that day by the fresh sand which ran down 
the bank, and was of a different colour from that which lay loose and bleached in the sun.

In what space of time these little artists are able to mine and finish these cavities I have never been able to discover, for reasons given above; but it would be a matter worthy of observation, where it falls in the way of any naturalist to make his remarks. This I have often taken notice of, that several holes of different depths are left unfinished at the end of summer. To imagine that these beginnings were intentionally made in order to be in the greater forwardness for next spring, is allowing perhaps too much foresight and rerum prudentia to a simple bird. May not the cause of these latebroe being left unfinished arise from their

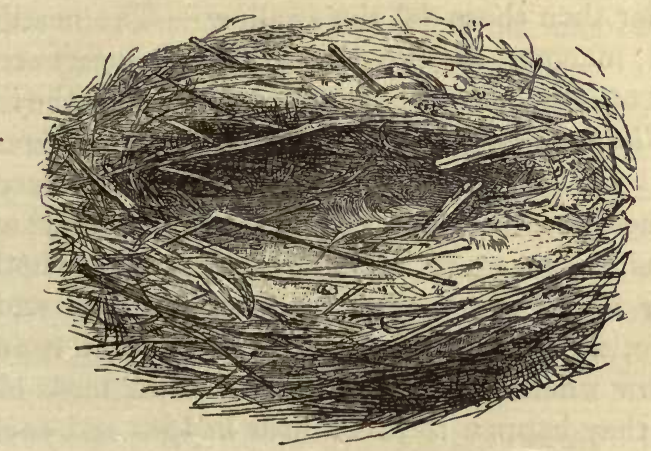

SAND MARTIN'S NEST.

meeting in those places with strata too harsh, hard, and solid, for their purpose, which they relinquish, and go to a fresh spot that works more freely? Or may they not in other places fall in with a soil as much too loose and mouldering, liable to founder, and threatening to overwhelm them and their labours?

One thing is remarkable - that, after some years, the old holes are forsaken and new ones bored; perhaps because the old habitations grow foul and fetid from long use, or because they may so abound with fleas as to become untenantable. This species of swallow moreover is strangely annoyed with fleas: and we have seen fleas, bed fleas (Pulex 
irritans $^{1}$ ), swarming at the mouths of these holes, like bees on the stools of their hives.

The following circumstance should by no means be omitted-that these birds do not make use of their caverns by way of hybernacula, as might be expected ; since banks so perforated have been dug out with care in the winter, when nothing was found but empty nests.

The sand martin arrives much about the same time with the swallow, and lays, as she does, from four to six white eggs. But as this species is cryptogame, carrying on the business of nidification, incubation, and the support of its young in the dark, it would not be so easy to ascertain the time of breeding, were it not for the coming forth of the broods, which appear much about the time, or rather somewhat earlier than those of the swallow The nestlings are supported, in common like those of their congeners, with gnats and other small insects; and sometimes they are fed with Libelluloe (dragon-flies) almost as long as themselves. In the last week in June we have seen a row of these sitting on a rail near a great pool as perchers, and so young and helpless as easily to be taken by hand; but whether tho dams ever feed them on the wing, as swallows and house martins do, we have never yet been able to determine; nor do we know whether they pursue and attack birds of prey.

When they happen to breed near hedges and enclosures, they are dispossessed of their breeding holes by the house sparrow, which is on the same account a fell adversary to house martins.

These Hirundines are no songsters, but rather mute, making only a little harsh noise when a person approaches their nests. They seem not to be of a sociable turn, never with us congregating with their congeners in the autumn. Undoubtedly they breed a second time, like the house martin and swallow; and withdraw about Michaelmas.

1 The flea of the sand martin, although so similar to the bed flea as to be scarcely distinguishable from it, is really distinct. It appears even to be distinct from the flea of the swallow, Pulex hirundinis (Stephens), and has been described as P. bifasciatus (Curtis).-ED. 
Though in some particular districts they may happen to abound, yet in the whole, in the south of England at least, is this much the rarest species. For there are few towns or large villages but what abound with house martins; few churches, towers, or steeples but what are hauntcd by some swifts; scarce a hamlet or single cottage chimney that has not its swallow; while the bank martins, scattered here and there, live a sequestcred life among some abrupt sand hills, and in the banks of sorne few rivers.

These birds have a peculiar manner of flying; flitting about with odd jerks and vacillations, not unlike the motions of a butterfly. Doubtless the flight of all Hirundines is influenced by and adapted to the peculiar sort of insects which furnish their food. Hence, it would be worth inquiry to examine what particular genus of insects affords the principal food of each respective species of swallow.

Notwithstanding what has been advanced above, some few sand martins, I see, haunt the skirts of London, frequenting the dirty pools in St. George's Fields, and about Whitechapel. The question is where these build, since there are no banks or bold shores in that neighbourhood: perhaps they nestle in the scaffold-holes of some old or new deserted building. They dip and wash as they fly sometimes, like the house martin and swallow.

Sand martins differ from their congeners in the diminutiveness of their size and in thoir colour, which is what is usually called a mouse colour. Near Valencia, in Spain, they are taken, says Willughby, and sold in the markets for the table; and are called by the country people, probably from their desultory jerking manner of flight, Papilion di montagna. ${ }^{1}$

1 Mr. Howard Saunders, in his "List of the Birds of Southern Spain" ("Iluis," 1871, p. 205), says:- "To my surprise I found this species nesting in the banks of the Guadalquivir in May. I had imagined it was a more nos thern breeder."-Ev 


\section{LETTER XXI.}

TO THE HONOURABLE DAINES BARRINGTON.

Serborne, Sept. 28, 1774.

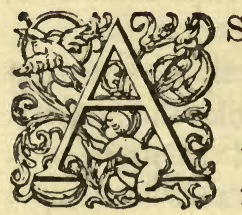

$\mathrm{S}$ the swift or black martin is the largest of the British Hirundines, so is it undoubtedly the latest comer. For I remember but one instance of its appearing before the last week in April; and in some of our late frosty, harsh springs, it has not been seen till the beginning of May. This species usually arrives in pairs.

The swift, like the sand martin, is very defective in architecture, making no crust or shell for its nest; but forming it of dry grasses and feathers, very rudely and inartificially put together. With all my attention to these birds, I have never been able once to discover one in the act of collecting or carrying in materials; so that I have suspected (since their nests are exactly the same) that they sometimes usurp upon the house-sparrows, and expel them, as sparrows do the house and sand martin, well remembering that I have seen them squabbling together at the entrance of their holes, and the sparrows up in arms, and much disconcerted at these intruders. And yet I am assured by a nice observer in such matters, that they do collect feathers for their nests in Andalusia; and that he has shot them with such materials in their mouths.

Swifts, like sand martins, carry on the business of nidification quite in the dark, in crannics of castles, and towers, and steeples, and upon the tops of the walls of churches under the roof; and therefore cannot be so narrowly watched as those species that build more openly; but, from what I could ever observe, they begin nesting about the middle of May; and I have romarkcd, from eggs taken, that they have sat hard by the 9th of June. In general they haunt tall buildings, churches, and steeples, and breed only in such : yet 
in this village some pairs frequent the lowest and meanest cottages, and educate their young under those thatched roofs. We remember but one instance where they breed out of buildings; and that is in the sides of a deep chalk-pit near the town of Odiham, in this county, where we have seen many pairs entering the crevices, and skimming and squeaking round the precipices.

As I have regarded these amusive birds with no small attention, if I should advance something new and peculiar with respect to them, and different from all other birds, I might perhaps be credited, especially as my assertion is the result of many years' exact observation. The fact that I would advance is, that swifts pair on the wing; and I would wish any nice observer, that is startled at this supposition, to use his own eyes, and I think he will soon be convinced. In another class of animals, viz. the insect, nothing is so common as to seo the different species of many genera pairing as they fly. The swift is almost continually on the wing; and as it never settles on the ground, on trees, or roofs, would seldom find opportunity for pairing, except in the air. If any person would watch these birds of a fine morning in May, as they are sailing round at a great hoight from the ground, he would see, every now and then, two meet, and both of them sink down together for many fathoms with a loud piercing shriok.

As the swift eats, diinks, collects materials for its nest, and, as it seems, propagates on the wing, it appears to live more in the air than any other bird, and to perform all functions there save those of sleeping and incubation.

This Hirundo differs widely from its congeners in laying invariably but two eggs at a time, ${ }^{1}$ which are milk-white, long, and peaked at the small end; whereas the other species lay at each brood from four to six. It is a most alert bird, rising very early, and retiring to roost very late, and is on the wing in the height of surnmer at least sixteen hours. In the longest days it does not withdraw to rest till

1 We have occasionally found three eggs in a nest, and these werc taken from under the eaves of some old cottages in W'est Sussex.-ED. 
a quarter before nine in the evening, being the latest of all day birds. Just before they retire, whole groups of them assemble high in the air, and squeak, and shoot about with wonderful rapidity. But this bird is never so much alive as in sultry thundry weather, when it expresses great alacrity, and calls forth all its powers. In hot mornings, several, getting together in little parties, dash round the steeples and churches, squeaking as they go in a very clamorous manner: these, by nice observers, are supposed to be males serenading their sitting hens; and not without reason, since they seldom squeak till they come close to the walls or eaves, and since those within utter at the same time a little inward note of complacency.

When the hen has sat hard all day, she rushes forth just as it is almost dark, and stretches and relieves her weary limbs, and snatches a scanty meal for a few minutes, and then returns to her duty of incubation. Swifts, when wantonly and cruelly shot while they have young, discover a little lump of insects in their mouths, which they pouch and hold under their tongue. In general they feed in a much higher district than the other species: a proof that gnats and other insects do also abound to a considerable height in the air : they also range to vast distances; since locomotion is no labour to them, who are endowed with such wonderful powers of wing. Their powers secm to be in proportion to their levers; and their wings are longer in proportion than those of almost any other bird. When they mute, or ease themselves in flight, they raise their wings, and make them meet over their backs.

At some certain times in the summer I had remarked that swifts were hawking very low for hours together over pools and streams; and could not help inquiring into the oljject of their pursuit that induced them to descend so inuch below their usual range. After some trouble, I found that they were taking Phryganea, Ephemerce, and Libelluloe (cadew-flies, may-flies, and dragon-flies), that were just emerged out of their aurelia state. I then no longer wondered that they should be so willing to stoop for a prey that afforded them such plentiful and succulent nourishment. 
They bring out their young about the middle or latter end of July: but as these never become perchers, nor, that ever I could discern, are fed on the wing by their dams, the coming forth of the young is not so notorious as in the other species.

On the 30th of last June I untiled the eaves of a house where many pairs build, and found in each nest only two squab, naked pulli: on the 8th of July I repeated the same inquiry, and found they had made very little progress towards a fledged state, but were still naked and helpless. From whence we may conclude that birds whose way of life keeps them perpetually on the wing, would not be able to quit their nest till the end of the month. Swallows and martins, that have numerous families, are continually feeding them every two or three minutes; while swifts, that have but two young to maintain, are much at their leisure, and do not attend on their nests for hours together.

Sometimes they pursue and strike at hawks that come in their way; but not with that vehemence and fury that swallows express on the same occasion. They are out all day long in wet days, feeding about, and disregarding still rain: from whence two things may be gathered; first, that many insects abide high in the air, even in rain; and next, that the feathers of these birds must be well preened to resist so much wet. Windy, and particularly windy weather with heavy showers, they dislike; and on such days withdraw, and are scarce ever seen.

There is a circumstance respecting the colour of swifts, which seems not to be unworthy our attention. When they arrive in the spring they are all over of a glossy, dark soot colour, except thcir clins, which are white; but by being all day long in the sum and air, they become quite weatherbeaten and bleached before they depart, ${ }^{1}$ and yet they return glossy again in the spring. Now, if they pursue the sun

1 Yarrell has remarked, that our swift departs before its moult, and when its plumage is at the worst from wear and tear. Our summer visitors generally complete their moult before they leave us, but not the Hirundinida. See also foot-note, p. 172.-ED. 
into lower latitudes, as some suppose, in order to enjoy a perpetual summer, why do they not return bleached? Do thcy not rather, porhaps, retire to rest for a season, and at that juncture moult and change their feathers, since all other birds are known to moult soon after the season of breeding.

Swifts are very anomalous in many particulars, dissenting from all their congeners not only in the number of their young, but in breeding but once in a summer; whereas all the other British Hivundines breed invariably twice. It is past all doubt that swifts can breed but once, since they withdraw in a short time after the flight of their young, and some time before their congeners bring out their second broods. We may here remark, that, as swifts breed but once in a summer, and only two at a time, and the other Hirundines twice, the latter, who lay from four to six eggs, increase at an avcrage five times as fast as the former.

But in nothing are swifts more singular than in their early retreat. They retire, as to the main body of them, by the 10th of August, and sometimes a few days sooner: and every straggler invariably withdraws by the 20 th, while their congeners, all of them, stay till the beginning of October; many of them all through that month, and some occasionally to the beginning of November. This early retreat is mysterious and wonderful, since that time is often the sweetest season in the year. But, what is more extraordinary, they begin to retire still earlier in the most southerly parts of Andalusia, where they can be no ways influenced by any defect of heat; or, as one might suppose, defect of food. Are they regulated in their motions with us by a failure of food, or by a propensity to moulting, or by a disposition to rest after so rapid a life, or by what? This is one of those incidents in natural history that not only baffles our researches, but almost eludes our guesses!

These Hirundines never perch on trees or roofs, and so never congregate with their congeners. They are fearless while haunting their nesting places, and are not to be scared with $a$ gun, and are often beaten down with poles and cudgels as they stoop to go under the eaves. Swifts are 
much infested with those pests to the genus called Hippoboscoe hirundinis; and often wriggle and scratch themselves, in their flight, to get rid of that clinging annoyance.

Swifts are no songsters, and have only one harsh screaming note: yet there are ears to which it is not displeasing, from an agreeable association of idcas, since that note never occurs but in the most lovely summer weather.

They never settle on the ground but through accident; and when down can hardly rise, on account of the shortness of their legs and the length of their wings: neither can they walk, but only crawl; but they have a strong grasp with their feet, by which they cling to walls. Their bodies being flat they can enter a very narrow crevice; and where they cannot pass on their bellies they will turn up edgewise.

The particular formation of the foot discriminates the swift from all the British Hirundines; and indeed from all other known birds, the Hirundo melba, or great whitebellied swift of Gibraltar, excepted; for it is so disposed as to carry "omnes quatuor digitos anticos," all its four toes forward; besides, the least toe, which should be the back toe, consists of one bone alone, and the other three only of two apiece : a construction most rare and peculiar, but nicely adapted to the purposes in which their feet are employed. This, and some peculiarities attending the nostrils and under mandible, have induced a discerning naturalist ${ }^{1}$ to suppose that this species might constitute a genus per se. ${ }^{2}$

In London a party of swifts frequents the Tower, playing

1 John Antony Scopoli, of Carniola, M.D.-G. W.

2 The genus suggested by Scopoli has bcen adopted by modern zoologists, and has been made to include all the species of swifts: but the name which he gave to it has been superseded by that of Cypseius, applied to it by Illiger and adopted from Aristotle, which is considered as indicating the habit of hiding their nests in holes.

The great white-bellied swift above referred to, an inhabitant of Central and Southern Europe, Western Asia, and Africa, is an occasional straggler to our shores. Since the days of Gilbert White a score of instances have been recorded of its occurrence in the British Islands. See the "Handbook of British Birds," p. 125.-Ev. 
and feeding over the river just below the bridge: others haunt some of the churches of the Borough next the fields; but do not venture, like the house martin, into the close crowded part of the town.

The Swedes have bestowed a very pertinent name on this swallow, calling it ring-swala, from the perpetual rings or circles that it takes round the scene of its nidification.

Swifts feed on Coleoptera, or small beetles with hard cases over their wings, as well as on the softer insects; but it does not appear how they can procure gravel $^{1}$ to grind their food, as swallows do, since they nover settle on the ground. Young ones, overrun with Hippoboscce, are sometimes found, under their nests, fallen to the ground; the number of vermin rendering their abode insupportable any longer. They frequent in this village sevcral abject cottages; yet a succession still haunts the same unlikely roofs: a good proof this that the same birds return to the same spots. As they must stoop very low to get up under these humble eaves, cats lie in wait, and somctimes catch them on the wing.

On the 5th of July, 1775, I again untiled part of a roof over the nest of a swift. The dam sat in the nest; but so strongly was she affected by natural $\sigma \tau$ rop $\eta^{\prime}$ for her brood, which she supposed to be in danger, that, regardless of her own safety, she would not stir, but lay sullenly by them, permitting herself to be taken in hand. The squal young we brought down and placed on the grass-plot, where they tumbled about, and were as helpless as a nowborn child. While we contemplated their naked bodies, their unwieldy disproportioned abdomina, and their heads, too heavy for their necks to support, we could not but wonder when we reflected that these shiftless beings in a little more than a fortnight would be able to dash through the air almost with the inconceivable swiftness of a meteor;

1 Very few of the soft-billed birds eat gravel, and we are inclined to think that the particles of grit found in the stomachs of swallows have found their way there accidentally whilst the birds have been collecting mud for their nests.-ED. 
and, perhaps, in their emigration, must traverse vast cont:nents and oceans as distant as the equator. So soon does Nature advance small birds to their $\eta^{i} \lambda เ x_{i}^{i} \alpha$, or state of perfection; while the progressive growth of men and large quadrupeds is slow and tedious!

\section{LETTER XXII.}

\section{TO TIE HONOURABLE DAINES BARRINGTON.}

Selborne, Sept. 13, 1774.

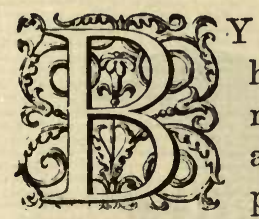
$Y$ means of a straight cottage chimney I had an opportunity this summer of re. marking, at my leisure, how swallows ascend and descend through the shaft: but my pleasure in contemplating the address with which this feat was performed to a considerable depth in the chimney, was somewhat interrupted by apprehensions lest my eyes might undergo the same fate with those of Tobit. ${ }^{1}$

Perhaps it may be some amusement to you to hear at what times the different species of Hirundines arrived this spring in three very distant counties of this kingdom. With us the swallow was seen first on April the 4th, the swift on April the 24th, the bank martin on April the 12th, and the house martin not till April the 30th. At South Zele, Devonshire, swallows did not arrive till April the 25th; swifts in plenty, on May the 1st; and house martins not till the middle of May. At Blackburne, in Lancashire, swifts were seen April the 28th; swallows, April the 29th; house martins, May the 1 st. Do these different dates in such distant districts, prove anything for or against migration ?"

1 Tobit, ii. 10.

2 See the "Field Calendar of Ornithology;" General Report for 1872 ; published in "The Field" of May 31 and June 7, 1873, and subsequently reprinted.-ED. 
A farmer, near Weyhill, fallows his land with two teams of asses; one of which works till noon, and the other in the afternoon. When these animals have done their work, they are penned all night, like sheep, on the fallow. In the winter they are confined and foddered in a yard, and make plenty of dung.

Linnæus says, that hawks "paciscuntur inducias cum avibus, quamdiu cuculus cuculat:" but it appears to me that, during that period, many little birds are taken and destroyed by birds of prey, as may be seen by their feathers left in lanes and under hedges.

The missel-thrush ${ }^{1}$ is, while breeding, fierce and pugna-

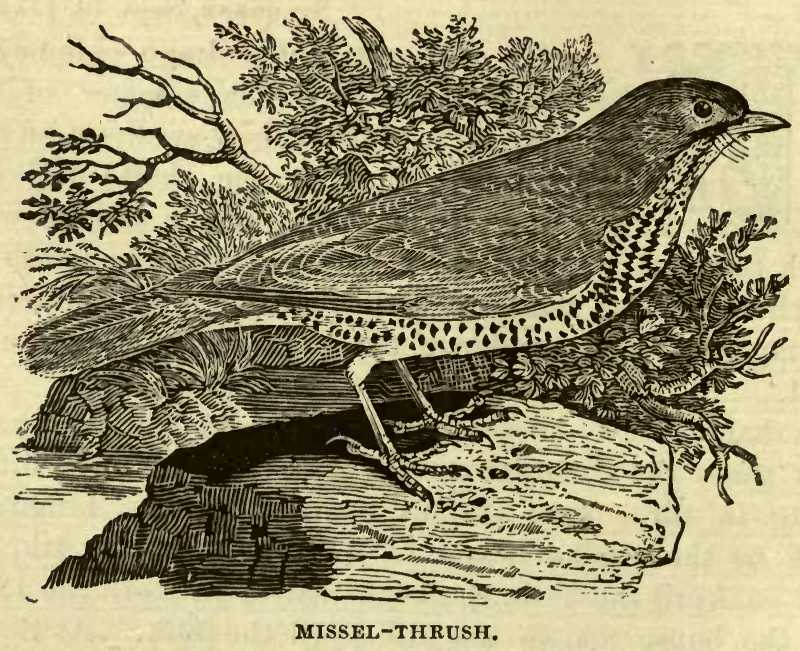

cious, driving such birds as approach its nest, with great fury, to a distance. The Welsh call it pen $y$ llwyn, the head or master of the coppice. He suffers no magpie, jay, or blackbird, to enter the garden where he haunts; and is, for the time, a good guard to the now sown legumens. In general he is very successful in the defence of his family: but once I observed in my garden, that several magpies

1 As to the proper mode of spelling the name of this bird, see Professor Newton's edition of Yarrell's "History of British Birds," vol. i. p. 260, note.-ED. 
came determined to storm the nest of a missel-thrush : the dams defended their mansion with great vigour, and fought resolutely pro aris et focis; but numbers at last prevailed, they tore the nest to pieces, and swallowed the young alive.

In the season of nidification the wildest birds are comparatively tame. Thus the ring-dove breeds in my fields, though they are continually frequented; and the misselthrush, though most shy and wild in the autumn and winter, builds in my garden close to a walk where peoplo are passing all day long.

Wall fruit abounds with me this year; but my grapes, that used to be forward and good, are at present backward beyond all precedent: and this is not the worst of the story; for the same ungenial weather, the same black cold solstice, has injured the more necessary fruits of the earth, and discoloured and blighted our wheat. The crop of hops promises to be very large.

Frequent returns of deafness incommode me sadly, and half disqualify me for a naturalist; for when those fits are upon me I lose all the pleasing notices and little intimations arising from rural sounds; and May is to me as silent and mute with respect to the notes of birds, \&c., as August. My eyesight is, thank God, quick and good; but with respect to the other sense, I am, at times, disabled:

"And Wisdom at one entrance quite shut out."

\section{I.ETTER XXIII.}

\section{TO THE HONOURABLE DAINES BARRINGTON.}

Serborne, June 8, 1775.

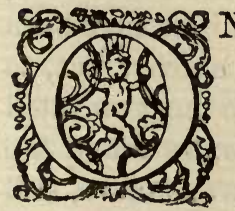

$N$ Soptember the 21 st, 1741 , being then on a visit, and intent on field diversions, I rose before daybreak: when I came into the enclosures, I found the stubbles and clovergrounds matted all over with a thick coat of obweb, in the meshes of which a copious and heavy dew 
hung so plentifully that the whole face of the country seemed, as it were, covered with two or three setting-nets drawn one over another. When the dogs attempted to hunt, their eyes were so blinded and hoodwinked that they could not proceed, but were obliged to lie down and scrapo the incumbrances from their faces with their fore feet, so that, finding my sport interrupted, I returned home musing in my mind on the oddness of the occurrence.

As the morning advanced the sun became bright and warm, and the day turned out one of those most lovely ones which no season but the autumn produces; cloudless, calm, sorene, and worthy of the south of France itself.

About nine an appearance very unusual began to demand our attention, a shower of cobwebs falling from very elevated regions, and continuing without any interruption till the close of the day. These webs were not single filmy threads, floating in the air in all directions, but perfect flakes or rags; some near an inch broad, and five or six long, which fell with a degree of velocity, that showed they were considerably heavier than the atmosphere.

On every side as the observer turned his eyes might he behold a continual succession of fresh flakes falling into his sight, and twinkling like stars as they turned their sides towards the sun.

How far this wonderful shower extended would be diffcult to say; but we know that it reached Bradley, Selborne, and Alresford, three places which lie in a sort of a triangle, the shortest of whose sides is about eight miles in extent.

At the second of those places there was a gentleman (for whose veracity and intelligent turn we have the greatest veneration) who observed it the moment he got abroad; but concluded that, as soon as he came upon the hill above his house, where he took his morning rides, he should be higher than this meteor, which he imagined might have been blown like thistle-down from the common above; but, to his great astonishment, when he rode to the most elevated part of the down, 300 feet above his fields, he found the webs in appearance still as much above him as before, still descending into sight in a constant succession, and twink- 
ling in the sun, so as to draw the attention of the most incurious.

Neither before nor after was any such fall observed; but on this day the flakes hung in the trees and hedges so thick, that a diligent person sent out might have gathered baskets full.

The remark that I shall make on these cobweblike appearances, called gossamer, is that, strange and superstitious as the notions about them were formerly, nobody in these days donbts but that they are the real production of small spiders, which swarm in the fields in fine weather in autumn, and have a power of shooting out webs from their tails, so as to render themselves buoyant and lighter than air. But why these apterous insects should that day take such a wonderful aërial excursion, and why their webs should at once become so gross and material as to be considerably more weighty than air, and to descend with precipitation, is a matter beyond my skill. If I might be allowed to hazard a supposition, I should imagine that those filmy threads, when first shot, might be entangled in the rising dew, and so drawn up, spiders and all, by a brisk evaporation into the regions where clouds are formed; and if the spiders have a power of coiling and thickening their webs in the air, as Dr. Lister says they have [see his Letters to Mr. Ray], then, when they were become heavier than the air, they must fall.

Every day in fine weather, in autumn chiefly, do I see those spiders shooting out their webs and mounting aloft: they will go off from your finger if you will take them into your hand. Last summer one alighted on my book as I was reading in the parlour; and, running to the top of the page, and shooting out a web, took its departure from thence. But what I most wondered at was, that it went off with considerable velocity in a place where no air was stirring; and I am sure that I did not assist it with my breath: so that these little crawlers seem to have, while mounting, some locomotive power without the use of wings, and to move in the air faster than the air itself. 


\section{LETTER XXIV.}

\section{TO THE HONOURABLE DAINES BARRINGTON.}

Selborne, Aug. 15, 1775.

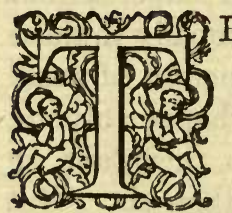
HERE is a wonderful spirit of sociality in the brute creation, independent of sexual attachment: the congregating of gregarious birds in the winter is a remarkable instance.

Many horses, though quiet with company, will not stay one minute in a field by themselves : the strongest fences cannot restrain them. My neighbour's horse will not only not stay by himself abroad, but he will not bear: to be left alone in a strange stable without discovering the utmost impatience, and endeavouring to break the rack and manger with his fore feet: he has been known to leap out at a stable window, through which dung was thrown, after company; and yet in other respects is remarkably quiet. Oxen and cows will not fatten by themselves; but will neglect the finest pasture that is not recommended by society. It would be needless to instance sheep, which constantly flock together.

But this propensity seems not to be confined to animals of the same species; for we know a doe, still alive, that was brought up from a little fawn with a dairy of cows; with them it goes afield, and with them it returns to the yard. The dogs of the house take no notice of this deer, being used to her; but, if strange dogs come by, a chase ensues; while the master smiles to see his favourite securely leading her pursuers over hedge, or gate, or stile, till she returns to the cows, who, with fierce lowings and

1 Barrington has inserted this Letter in his "Miscellanies," p. 251 ; prefacing it thus :- "I shall here, on this head, subjoin part of a letter which I have received from my often-mentioned correspondent, the Rev. Mr. White, of Selborne, in Hampshire."-Ev. 
menacing horns, drive the assailants quite out of the pasture.

Even great disparity of kind and size does not always prevent social advances and mutual fellowship. For a very intelligent and observant person has assured me that, in the former part of his life, keeping but one horse, he happened also on a time to have but one solitary hen. These two incongruous animals spent much of their time together in a lonely orchard, where they saw no creature but each other. By degrees an apparent regard began to tako place between these two sequestered individuals. The fowl would approach the quadruped with notes of complacency, rubbing herself gently against his legs; while the horse would look down with satisfaction, and move with the greatest caution and circumspection, lest he should trample on his diminutive companion. Thus, by mutual good offices, each seemed to console the vacant hours of the other: so that Milton, when he puts the following sentiment in the mouth of Adam, seems to be somewhat mistaken :

"Much less can bird with beast, or fish with fowl, So well converse; nor with the ox the ape."

\section{I.ETTER XXV.}

\section{TO THE HONOURABLE DAINES BARRINGTON}

Selborne, Oct. 2, 1775.

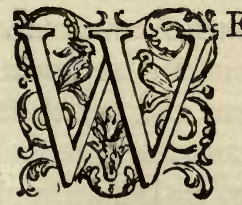

have two gangs or hordes of gipsies which infest the south and west of England, and come round in their circuit two or three times in the year. One of these tribes calls itself by the noble name of Stanley, of which I have nothing particular to say; but the other is distinguished by an appellative somewhat remarkable. As far as their harsh gibberish can be understood, they seem to say that the name of their clan is Curleople: now the 
termination of this word is apparently Grecian : and as Mezeray and the gravest historians all agree that these vagrants did certainly migrate from Egypt and the East, two or three centuries ago, and so spread by degrees over Europe, may not this family-name, a little corrupted, be the very name they brought with them from tho Levant? It would be matter of some curiosity, could one meet with an intelligent person among them, to inquire whether, in their jargon, they still retain any Greek words: the Greck radicals will appear in hand, foot, hcad, water, earth, \&c. It is possible that amidst their cant and corrupted dialect many mutilated remains of their native language might still be discovered.

With regard to those peculiar people, the gipsics, one thing is very remarkable, and especially as they came from warmer climates; and that is, that while other beggars lodge in barns, stables, and cow-houses, these sturdy savages seem to pride themselves in braving the scverities of winter, and in living sub dio the whole year round. Last September was as wet a month as ever was known; and yet during those deluges did a young gipsy girl lie-in in the midst of one of our hop gardens, on the cold ground, with nothing over her but a piece of a blanket extended on a few hazel rods bent hoop fashion, and stuck into the earth at cach end, in circumstances too trying for a cow in the same condition: yet within this garden there was a large hop-kiln, into the chambers of which she might have retired, had she thought shelter an object worthy her attention.

Europe itself, it scems, cannot set bounds to the rovings of these vagabonds: for Mr. Bell, in his return from Pekin, met a gang of these people on the confines of Tartary, who were endeavouring to penetrate those deserts and try their fortune in China. ${ }^{1}$

Gipsies are called in French, Bohomicns, in Italian and modern Greek, Zingari.

1 See Bell's Travels in China.-G. W. 


\section{LETTER XXVI.}

TO THE HONOURABLE DAINES BARRINGTON.

Selborne, Nov. $1,1775$.

" Hîc — tædæ pingues, hic plurimus ignis

Semper, et assiduâ postes fuligine nigri."

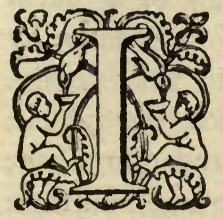

SHALL make no apology for troubling you with the detail of a very simple piece of domestic economy, being satisfied that you think nothing beneath your attention that tends to utility : the matter alluded to is the use of rushes instead of candles, which I am well aware prevails in many districts besides this; but as I know there are countries also where it docs not obtain, and as I have considered the subject with some degree of exactness, I shall proceed in my humble story, and leave you to judge of the expediency.

The proper species of rush for this purpose seems to be the Juncus conglomeratus, or common soft rush, which is to be found in most moist pastures, by the sides of streams, and under hedges. These rushes are in best condition in the height of summer; but may be gathered so as to serve the purpose well, quite on to autumn. It would be needless to add that the largest and longest are best. Decayed labourers, women, and children, make it their business to procure and prepare them. As soon as they are cut they must be flung into water, and kept there; for otherwise they will dry and shrink, and the peel will not run. At first a person would find it no easy matter to divest a rush of its peel or rind, so as to leave one regular, narrow, even rib from top to bottom that may support the pith : but this, like other feats, soon becomes familiar even to children; and we have seen an old woman, stone-blind, performing this business with great dispatch, and seldom failing to 
strip them with the nicest regularity. When these Junci are thus far prepared, they must lie out on the grass to be bleached, and take the dew for some nights, and afterwards be dried in the sun.

Some address is required in dipping these rushes in the scalding fat or grease; but this knack also is to be attained by practice. The careful wife of an industrious Hampshire labourer obtains all her fat for nothing; for she saves the scummings of her bacon pot for this use; and if the grease abounds with salt, she causes the salt to precipitate to the bottom, by setting the scummings in a warm oven. Where hogs are not much in use, and especially by the seaside, the coarser animal oils will come very cheap. A pound of common grease may be procured for four pence; and about six pounds of grease will dip a pound of rushes; and one pound of rushes may be bought for one shilling: so that a pound of rushes, medicated and ready for use, will cost three shillings. If men that keep bees will mix a little wax with the grease, it would give it a consistency, and render it more cleanly, and make the rushes burn longer: mutton suct would have the same effect.

A good rush, which measured in length two feet four inches and a half, bcing minuted, burned only three minutes short of an hour: and a rush of still greater length has been known to burn one hour and a quarter.

These rushes give a good clear light. Watch-lights (coated with tallow), it is true, shed a dismal one, "darkness visible;" but then the wick of those has two ribs of the rind, or peel, to support the pith, while the wick of the dipped rush has but one. The two ribs are intended to impede the progress of the flame and make the candle last.

In a pound of dry rushes, avoirdupois, which I caused to be weighed and numbered, we found upwards of 1,600 individuals. Now, suppose each of these burns, one with another, only half an hour, then a poor man will purchase 800 hours of light, a time exceeding thirty-three entire days, for three shillings. According to this account each rush, before dipping, costs one-thirty-third of a farthing, and one-eleventh afterwards. Thus a poor family will 
enjoy five hours and a half of comfortable light for a farthing. An experionced old housekeeper assures me that one pound and a half of rushes completely supplies his family the year round; since working people burn no candle in the long days, because they rise and go to bed by daylight.

Little farmers use rushes much in the short days, both morning and evening, in the dairy and kitchen; but the very poor, who are always the worst economists, and therefore must continue very poor, buy a halfpenny candle every evening, which, in their blowing, open rooms, does not burn much more than two hours. Thus have they only two hours' light for their money instead of eleven.

While on the subject of rural economy, it may not bo improper to mention a pretty implement of housewifery that we have seen no where else; that is, little neat besoms which our foresters make from the stalks of the Polytrichum cominune, or great golden maiden-hair, which they call silkwood, and find plenty in the bogs. When this moss is well combed and dressed, and divested of its outer skin, it becomes of a beautiful bright chestnut colour; and, being soft and pliant, is very proper for the dusting of beds, curtains, carpets, hangings, \&c. If these besoms were known to the brush-makers in town, it is probable they might come much in use for the purpose above mentioned. ${ }^{1}$

1 A besom of this sort is to be seen in Sir Ashton Lever's Mruseum.-G. IV.

This Museum, to which allusion has been already made, was disposed of by auction in 1806 . See p. 8 , foctnote.-F.D. 


\section{LETTER XXVII.}

\section{TO THE HONOURABLE DAINES BARRINGTON.}

Selborne, Dec. 12, 1775.

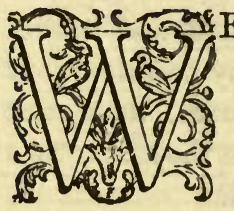

$\mathrm{E}$ had in this village, more than twenty years ago, an idiot boy, whom I well remember, who, from a child, showed a strong propensity to becs; they wcre his food, his amusement, his sole object: and as pcople of this cast have seldom more than ono point in view, so this lad exerted all his few faculties on this ono pursuit. In tho winter he dozed away his time, witlin his father's house, by the fircside, in a kind of torpid state, seldom departing from the chimney-corncr; but in the summer he was all alort, and in quest of his game in the fields, and on sunny banks. Honey bees, humble bees, and wasps, were his prey wherever he found thom: he had no apprehensions from their stings, but would scize them nudis manibus, and at once disarm them of their weapons, and suck their bodies for the sake of their honey-bags. Sometimes ho would fill his bosom between his shirt and his skin with a number of these captives: and sometimes would confine them in bottles. He was a very Merops apiaster, or beebird; and very injurious to men that kept bees; for he would slide into their bee-gardens, and, sitting down before the stools, would rap with his finger on the hives, and so take the bees as they came out. He has been known to overturn hives for the sake of honey, of which he was passionately fond. Where metheglin was making he would linger round the tubs and vessels, begging a draught of what he called bee-wine. As he ran about he used to make a humming noise with his lips, resembling the buzzing of bces. This lad was lean and sallow, and of a cadaverous complexion; and, except in his favourite pursuit, in which he was wonderfully adroit, discovered no manner of under. 
standing. Had his capacity been better, and directed to the same object, he had perhaps abated much of our wonder at the feats of a more modern exhibitor of bees; and we may justly say of him now,

"Thou,

Had thy presiding star propitious shone,

Shouldst Wildman be."

When a tall youth, he was removed from hence to a distant village, where he died, as I understand, before he arrived at manhood.

\section{LETTER XXVIII.}

\section{TO THE HONOURABLE DAINES BARRINGTON.}

SeLboRne, Jan. 8, 1776.

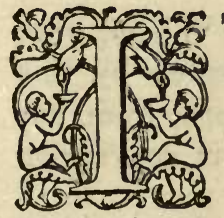

$\mathrm{T}$ is the hardest thing in the world to shake off superstitious prejudices: they are sucked in, as it were, with our mother's milk, and, growing up with us at a time when they take the fastest hold, and make the most lasting impressions, become so interwoven into our very constitutions, that the strongest good sense is required to disengage ourselves from them. No wonder, therefore, that the lower people retain them their whole lives through, since their minds are not invigorated by a liberal education, and therefore not enabled to make any efforts adequate to the occasion.

Such a preamble seems to be necessary before we enter on the superstitions of this district, lest we should be suspected of exaggeration in a recital of practices too gross for this enlightened age.

But the people of Tring, in Hertfordshire, would do well to remember that no longer ago than the year 1751, and within twenty miles of the capital, they seized on two superannuated wretches, crazed with age, and overwhelmed with 
infirmities, on a suspicion of witchcraft, and, by trying experiments, drowned them in a horse-pond.

In a farm-yard near the middle of this village stands at this day, a row of pollard-ashes, which, by the seams and long cicatrices down their sides, manifestly show that in former times they have been cleft asunder. These trees, when young and flexible, were severed and held open by wedges, while ruptured children, stripped naked, were pushed through the apertures, under a persuasion that, by such a process, the poor babes would be cured of their infirmity. As soon as the operation was over, the tree, in the suffering part, was plastered with loam, and carefully swathed up. If the parts coalesced and soldered together, as usually fell out, where the feat was performed with any adroitness at all, the party was cured; but where the cleft continued to gape, the operation, it was supposed, would prove ineffectual. Having occasion to enlarge my garden not long since, I cut down two or three such trees, one of which did not grow together.

We have several persons now living in the village, who, in their childhood, were supposed to be healed by this superstitious ceremony, derived down, perhaps, from our Saxon ancestors, who practised it before their conversion to Christianity. ${ }^{1}$

1 "Much nearer to the metropolis than Selborne," says Mr. Bennett, in a note to this passage, "and in days later than those alluded to by White, the ceremony described by him has been practised. The ash resorted to for the charm, in the instance referred to, is in the hedge of an orchard belonging to a house near Enfield, in which some of my earlier years were spent. A man living in the neighbourhood, and at the time when I was best acquainted with it (1810) about sixty years of age, was indicated as the individual on whose behalf recourse had been had to the observance. The tree had healed, and the cure had, of course, been performed."

He adds :- "Is it worth the remark that, as ashes secm seldom to fail to grow together after having been split, so also does it rarely happen that infants affected with umbilical hernia fail to be relieved from it at a very early age; and that, consequently, the charm-tree would, almost beyond the probability of an exception, accord in its healing with that of the infant whose fate was thus supposed to have been mysteriously connected with it?"-ED. 
At the south corner of the Plestor, or area near the church, there stood, about twenty years ago, a very old grotesque hollow pollard-ash, which for ages had been looked on with no small veneration as a shrew-ash. Now a shrew-ash is an ash whose twigs or branches, when gently applied to the limbs of cattle, will immediately relieve the pains which a beast suffers from the running of a shrewmouse over the part affected; for it is supposed that a shrew-mouse is of so baneful and deleterious a nature that wherever it creeps over a beast, be it horse, cow, or sheep, the suffering animal is afflicted with cruel anguish, and threatened with the loss of the use of the limb. Against this accident, to which they were continually liable, our provident forefathers always kept a shrew-ash at hand, which, when once medicated, would maintain its virtue for ever. A shrew-ash was made thus: ${ }^{1}$ - Into the body of the tree a deep hole was bored with an auger, and a poor devoted shrew-mouse was thrust in alive, and plugged in, no doubt with several quaint incantations long since forgotten. As the ceremonies necessary for such a consecration are no longer understood, all succession is at an end, and no such tree is known to subsist in the manor or hundred.

1 For a similar practice, see Plot's Staffordshire $-G$. W.

Dr. Plot relates that two workmen, on sawing the trunk of a solid oak, cut through the body of "a Hardishrew or Nursrow (as they here call them), i.e., a field-mouse," and that "the case remains an inexplicable riddle to all those about to this very day. But methinks, to any one that considers the superstitious custom they have in this country of making Nursrow-trees for the cure of unaccountable swellings in their cattle, the thing should not seem strange. For to make any tree, whether oak, ash, or elm, it being indifferent which, a Nursrow-tree, they catch one or more of these mice (which they fancy bite their cattle, and make them swell), and having bured a hole to the centre in the body of the tree, they put the mice in, and then drive a peg in after them of the same wood, where they, starving at last, communicate forsooth such a virtue to the tree that the cattle thus swoln, being whipped with the boughs of it, presently recover; of which trees they have not so many, thongh so easily made, but that at some places they go eight or ten miles to procure this remedy." - ED. 
As to that on the Plestor,

"The late vicar stubb'd and burn'd it,"

when he was way-warden, regardless of the remonstrances of the bystanders, who interceded in vain for its preservation, urging its power and efficacy, and alleging that it had been

"Religione patrum multos servata per annos." "

\section{LETTER XXIX.}

\section{TO THE HONOURABLE DAINES BARRINGTON.}

\section{Selborne, Feb. 7. 1776.}

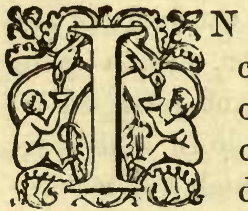

heary fogs, on elevated situations, especially, trees are perfect alembics; and no one that has not attended to such matters can imagine how much water one tree will distil in a night's time, by condensing the vapour which trickles down the twigs and boughs, so as to make the ground below quite in a float. In Newton Lane, in October, 1775, on a misty day, a particular oak in leaf dropped so fast that the cartway stood in puddles, and the ruts ran with water, though the ground in general was dusty.

In some of our smaller islands in the West Indies, if I mistake not, there are no springs or rivers; but the people are supplied with that necessary element, water, merely by the dripping of some large tall trees, which, standing in the bosom of a mountain, keep their heads constantly enveloped with fogs and clouds, from which thcy dispense their kindly never-ceasing moisture; and so render those districts habitable by condensation alone.

Trees in leaf have such a vast proportion more of surface than those that are naked that, in theory, their condensations should greatly exceed those that are stripped of their leaves; but as the former imbibe also a great quantity of moisture, it is difficult to say which drip most: but this I 
know, that deciduous trees that are entwined with much ivy seem to distil the greatest quantity. Ivy leaves are smooth, and thick, and cold, and, therefore, condense very fast; and, besides, evergreens imbibe very little. These facts may furnish the intelligent with hints concerning what sorts of trees they shonld plant round small ponds that they would wish to be perennial, and show them how advantageous some trees are in preference to others.

Trees perspire profusely, condense largely, and check evaporation so much that woods are always moist: no wonder therefore that they contribute much to pools and streams.

That trees are great promoters of lakes and rivers, appears from a well-known fact in North America; for, since the woods and forests have been grubbed and cleared, all bodies of water are much diminished; so that some streams that were very considerable a century ago, will not now drive a common mill. ${ }^{1}$ Besides, most woodlands, forests, and chases, with us, abound with pools and morasses, no doubt for the reason given above.

To a thinking mind, few phenomena are moro strange than the state of little ponds on the summits of chalk-hills, many of which are never dry in the most trying droughts of summer. On chalk-hills I say, because in many rocky and gravelly soils, springs usually break out pretty high on the sides of elevated grounds and mountains; but no person acquainted with chalky districts will allow that they ever saw springs in such a soil, but in valleys and bottoms, since the waters of so pervious a stratum as chalk all lie on one dead level, as well-diggers have assured me again and again.

Now, we have many such little round ponds in this district; and one in particular on our sheep-down, 300 feet above my house, which though never above three feet deep in the middle, and not more than thirty feet in diameter, and containing perhaps not more than two or three hundred hogsheads of water, yet never is known to fail, though it

1 Vide Kalm's "Travels to North America."-G. W. 
affords drink for three hundred or four hundred shcep, and for at least twenty head of large cattle beside. This pond, it is true, is overhung with two moderate beeches, that, doubtless, at times, afford it much supply; but then we have others as small, that, without the aid of trees, and in spite of evaporation from sun and wind, and perpetual consumption by cattle, yet constantly maintain a moderate share of water, without overflowing in the wettest scasons, as they would do if supplied by springs. By my journal of May, 1775, it appears that " the small and even considerable ponds in the vales are now dried up, while the small ponds on the very tops of hills are but littlo affected." Can this difference be accounted for from evaporation alone, which certainly is more prevalent in bottoms? or rather, have not thoss elevated pools some unnoticed recruits, which in the night-time counterbalance the waste of the day, without which, the cattle alone must soon exhaust them? And hero it will be necessary to enter more minutely into the cause. Dr. Hales, in his "Vegetable Statics," advances, from experiment, that "the moister the earth is, the more dew falls on it in a night; and more than a double quantity of dew falls on a surface of watr $r$ than there does on an equal surface of moist earth." Hence we see that water, by its coolness, is enabled to assimilate to itself a large quantity of moisture nightly, by condensation, and that the air, when loaded with fogs and vapours, and oven with copious dews, can alone advance a considerable and neverfailing resource. Persons that aro much abroad, and travel early and late, such as shepherds, fi.shermen, \&c., can tell what prodigious fogs prevail in the night on elevated downs, oven in the hottest parts of summer, and how much the surfaces of things are drenched by those swimming vapours, though, to the senses, all the while, little moisture seems to fall. 


\section{LETTER XXX.}

\section{TO THE HONOURABLE DAINES BARRINGTON.}

Selborne, April 3, 1776.

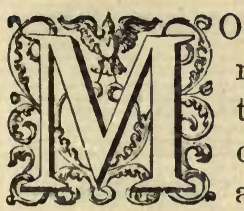
ONSIEUR HERISSANT, a French anatomist, seems persuadcd that he has discovered the reason why cuckoos do not hatch thcir own eggs: the impediment, he supposes, arises from the intcrnal structure of their parts, which incapacitates them for incubation. According to this gentleman, the crop, or craw, of a euckoo does not lic before the sternum at the bottom of the neck, as in poultry (Gallinoc), pigeons (Columbo), \&c., but immediately behind it, on and over the bowels, so as to make a large protuberance in the belly. ${ }^{1}$

Induced by this assertion, we procured a cuckoo, and cutting open the breast-bone and exposing the intestines to sight, found the crop lying as mentioned above. This stomach was large and round, and stuffed hard, like a pincushion, with food, which, upon nice examination, we found to consist of various insects, such as small scarabs, spiders, and dragon-flies; the last of which, as they were just emerging out of the aurelia state, we have secn cuckoos catching on the wing. A mong this farrago a'so were to be secn maggots, and many sacds, which belonged either to gooseberries, currants, cranberries, or some such fruit; so that these birds apparcntly subsist on insects and fruits: nor was there the least appearance of bones, feathers, or fur, to support the idle notion of their being birds of prey.

The sternum in this bird seemed to us to be remarkably short, between which and the anus lay the crop, or craw, and immodiately behind that, the bowcls against the backbone.

It must be allowed, as this anatomist observes, that the

I "Ilistoire de l'Académie Royale," 1752.-G. W. 
crop placed just upon the bowels must, especially when full, be in a very uneasy situation during the business of incubation; yet the test will be to examine whether birds that are actually known to sit for certain are not formed in a similar manner. This inquiry I proposed to myself to make with a fern-owl, or goat-sucker, as soon as opportunity offered; because, if their formation proves the same, the reason for incapacity in the cuckoo will be allowed to have been taken up somewhat hastily.

Not long after a fern-owl was procured, which, from its abit and shape, we suspected might resemble the cuckoo in its internal construction. Nor were our suspicions illgrounded; for upon the dissection, the crop, or craw, also lay behind the sternum, immediately on the viscera, between them and the skin of the belly. It was bulky, and stuffed hard with large Phalcence of several sorts, and their eggs, which, no doubt, had been forced out of those insects by the action of swallowing.

Now, as it appears that this bird, which is so well known to practise incubation, is formed in a similar manner with cuckoos, Monsieur Herissant's conjecture-that cuckoos are incapable of incubation from the disposition of their intestines-seems to fall to the ground; and we are still at a loss for the cause of that strange and singular peculiarity in the instance of the Cuculus canorus. ${ }^{1}$

We found the case to be the same with the ring-tail hawk ${ }^{2}$ in respect to formation; and, as far as I can recollect, with the swift; and probably it is so with many more sorts of birds that are not granivorous.

1 The cuckoo has no true crop, and the position of its proventriculus does not differ from that of other scansorial birds; the œsophagus descends along the posterior or dorsal part of the thorax, inclining to the left side, and, when opposite to the lower margin of the left lung, it begins to expand into the glandular cavity or proventriculus. The gizzard, which is neither large nor strong, is in immediate contact with the abdorninal parietes, and not separated from them by an intervening stratum of intestines; but this position cannot be supposed to interfere with the power of incubation, since it occurs also in other birds that do incubate. - ED.

2 'This is a provincial name for the female Hen harrier, Circus cyaneus - Ev. 


\section{LETTEP XXXY.}

\section{TO TIIE HONOURABLE DAINES BARRINGTON.}

\section{Selmorne, April 29, 1776.}

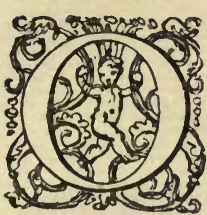

N August the 4th, 1775, we surprised a large viper, which seemed very heavy and bloated, as it lay in the grass basking in the sun. When we came to cut it up, we found that the abdomen was crowdcd with young, fifteen in number $;^{1}$ the shortest of which measured full seven inches, and were about the size of full grown earthworms. This little fry issued into the world with the true viper spirit about them, showing great alertness as soon as disengaged from the belly of the dam; they twisted and wriggled about, and set themselves up, and gaped very wide when touched with a stick, showing manifest tokens of menace and defiance, though as yet they had no manner of fangs that wo could find, even with the help of our glasses.

To a thinking mind nothing is more wonderful than that early instinct which impresses young animals with the notion of the situation of their natural weapons, and of using them properly in their own defence, even before those weapons subsist or aro formed. Thus, a young cock will spar at his adversary before his spurs are grown; and a calf or lamb will push with its head before its horns are sprouted. In the same manner did these young adders attempt to bite before their fangs were in being. The dam, however, was furnished with very formidable ones, which we lifted up (for they fold down when not used), and cut then off with the point of our scissars.

1 Bearing in mind the much vexed question, whether vipers, in time of danger, swallow their young, it may be here observed, that the expression "abdomen," as used by Gilbert White, must not be regarded as synonymous with the true stomach, but only as implying that larger cavity in which both stomach and uterus are contained. 'The young, of coursc, were in the latter and most natural receptacle.-ED. 
Thero was littlo room to suppose that this brood had ever been in the open air before; and that they were taken in for refuge, at the mouth of the dam, when she perceived that danger was approaching, because then probably we should have found them somewhere in the neck, and not in tho abdomen.

\section{LETTER XXXII.}

\section{TO THE HONOURABLE DAINES BARRINGTON.}

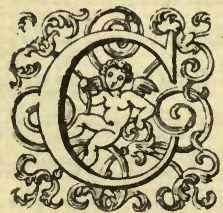

ASTRATION has a strange effect; it emasculates both man, beast, and bird, and brings them to a near resemblance of the other sex. Thus, eunuchs have smooth unmuscular arms, thighs, and legs, and broad hips, and beardliss chins, and squeaking voices. Gelt stags and bucks have hornless heads, like hinds and does. Thus wethers have small horns, like ewes; and oxen large bent horns, and hoarse voices when they low, like cows: for bulls have short straight horns; and though they mutter and grumble in a deep tremendous tone, yet they low in a shrill high key. Capons have small combs and gills, and look pallid about the hoad, like pullets ; they also walk without any parade, and hover chickens like hens. ${ }^{1}$ Barrow-hogs have also small tusks like sows.

Thus far it is plain that it puts a stop to the growth of those appendages that are looked upon as its insignia. But the ingenious Mr. Lisle, in his book on husbandry, carries it much farther ; for he says that the loss of those insignia alone has sometimes a strange effect: he had a boar so fierco and amorous, that, to prevent mischicf, orders were given

' Réaumur trained capons to nurse the chickens which j.e hatched by artificial heat. 'They clucked exactly like a hen, and proved as good nurses as a real mother could have been.-ED. 
for his tusks to be broken off. No sooner had the beast suffered this injury than his powers forsook him, and he neglected those females to whom before he was passionately attached, and from whom no fences could restrain him.

\section{LETTER XXXIII.}

TO THE HONOURABLE DAINES BARRINGTON.

OHe natural term of a hog's life is little known, e्रि (6) Dis lont animal to the full extent of its time; (d) ( who had no occasion to study every little advantage to a nicety, kept a half-bred Bantam sow, who was as thick as

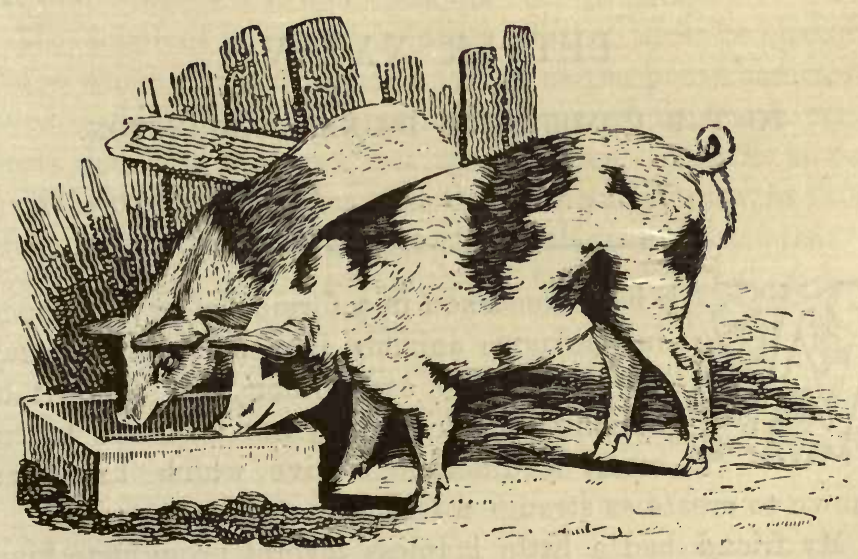

HOG.

she was long, and whose belly swept on the ground, till she was advanced to her seventeenth year, at which period sho showed some tokens of age, by the decay of her teeth and the decline of her fertility. 
For about ten years this prolific mother produced two litters in the year, of about ten at a time, and once above twenty at a litter; but, as there were near double the number of pigs to that of teats, many died. From long experience in the world, this female was grown very sagacious and artful; when she found occasion to converse with a boar, she used to open all the intervening gates, and march by herself up to a distant farm whore one was kept; and when her purpose was served, would return by the same means. At the age of about fifteen, her litters began to be reduced to four or five; and such a litter she exhibitcd when in her fatting pen. She proved when fat, good bacon, juicy, and tender; the rind, or sward, was remarkably thin. At a moderate computation, she was allowed to have been the fruitful parent of 300 pigs - a prodigious instance of fecundity in so large a quadruped! She was killed in spring, 1775.

\section{LETTER XXXIV.}

TO TIIE IIONOURABLE DAINES BARRINGTON.

Selborne, May 9, 1776.

"—__ admôrunt ubera tigres."

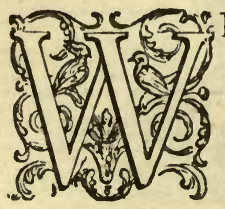

E have remarked in a former letter how much incongruous animals, in a lonely state, may be attached to each other from a spirit of sociality; in this it may not be amiss to recount a difforent motive which has been known to create as strange a fonducss.

My friend had a little helpless leveret brought to him, which the servants fed with milk in a spoon, and about the same time his cat kittened, and the young were dispatched and buried. The hare was soon lost, and supposed to be gone the way of most fondlings, - to be killed by some dog or cat. However, in about a fortnight, as the master was 
sitting in his garden in the dusk of the evening, he observed his cat, with tail erect, trotting towards him, and calling with little short inward notes of complacency, such as they use towards their kittens, and something gamboling after, which proved to be the leveret that the cat had supported with her milk, and continued to support with great affection.

Thus was a graminivorous animal nurtured by a carnivorous and predaceous one! ${ }^{1}$

Why so cruel and sanguinary a beast as a cat, of the ferocious genus of Felis, the murium len, as Linnous calls it, should be affected with any tenderness towards an animal which is its natural prey, is not so easy to determine.

This strange affection probably was occasioned by that desiderium, those tender maternal feelings which the loss of her kittens had awakened in her breast; and by the complacency and ease she derived to herself from the procuring her teats to be drawn, which were too much distended with milk, till, from habit, she became as much delighted with this foundling as if it had been her real offspring.

This incident is no bad solution of that strange circumstance which grave historians as woll as the pocts assert, of exposed children being sometimes nurtured by fomale wild beasts that probably had lost their young. For it is not one whit more marvellous that Romulus and Remus, in their infant state, should be nursed by a she-wolf, than that a poor little sucking leveret should be fostered and cherished by a blood-thirsty grimalkin.

\footnotetext{
“

viridi fotam Marortis in antro

Procubuisse lupam : geminos huic ubera circum

Ludere pendentes pueros, et lambere matrem

Impavidos : illam tereti cervice reflexam

Mulcere alternos, et corpora fingere linguâ."
}

1 An additional instance, in the case of a cat and squirrels, will be found mentioned later in the "Observations on Quadrupeds."-Ev. 


\section{LETTER XXXV.}

\section{TO THE HONOURABLE DAINES BARRINGTON.}

Selborne, May 20, 1777.

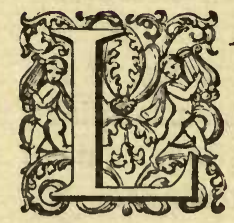

ANDS that are subject to frequent inundations are always poor; and probably the reason may be because the worms are drowned. The mostinsignificant insects and reptiles are of much more consequence and have much more influence in the economy of Nature than theincurious are aware of; and are mightyin their effect, from their minuteness, which renders them less an object of attention; and from their numbers and fecundity. Earthworms, though in appearance a small and despicable link in the chain of Nature, yet, if lost, would make a lamentable chasm. For, to say nothing of half the birds, and some quadrupeds which are almost entirely supported by them, worms seem to be great promoters of vegetation, which would proceed but lamely without them, by boring, perforating, and loosening the soil, and rendering it pervious to rains and the fibres of plants; by drawing straws and stalks of leaves and twigs into it; and, most of all, by throwing up such infinite numbers of lumps of earth called worm casts, which, being their excrement, is a fine manure for grain and grass. Worms probably provide new soil for hills and slopes where the rain washes the earth away; and they affect slopes probably to avoid being flooded. Gardeners and farmers express their detestation of worms ; the former because they render their walks unsightly, and make them much work; and the latter because, as they think, worms eat their green corn. But these men would find that the earth without worms would soon become cold, hard-bound, and void of fermentation, and consequently sterile; and besides, in favour of worms, it should be hinted that green corn, plants, and flowers, are not so much injured by them as by many species of Coleoptera (scarabs) 
and Tipulae (long-legs), in their larva, or grub state; and by unnoticed myriads of small shell-less snails, called slugs, which silently and imperceptibly make amazing havock in the field and garden. Farmer Young, of Norton Farm, says that this spring (1777) about four acres of his wheat in one field was entirely destroyed by slugs, which swarmed on the blades of corn, and devoured it as fast as it sprang.

These hints we think proper to throw out, in order to set the inquisitive and discerning to work.

A good monography of worms would afford much entertainment and information at the same time, and would open a large and new field in natural history. Worms work most in the spring; but by no means lie torpid in the dead months-are out every mild night in the winter, as any person may be convinced that will take the pains to examine his grassplots with a candle; are hermaphrodites, and very prolific.

\section{LETTER XXXVI.}

\section{TO TIIE HONOURABLE DAINES BARRINGTON.}

Seliorne, Nov. 22, 1777.

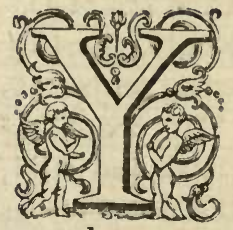
OU cannot but remember that the 26th and 27 th of last March were very hot days; so sultry that everybody complained, and wero restless under those sensations to which they had not been reconciled by gradual approaches.

This sudden summer-like heat was attended by many summer coincidences; for on those two days the thermometer rose to $66^{\circ}$ in the shade; many species of insects

1 This letter was first printed in "Barrington's Miscellanies" (1781), p. 225. "I shall here," he says, "subjoin a letter which I have received from that ingenious and observant naturalist, the Rev. Mr. White, of Selborne, Hampshirc."-Ev. 
revived and came forth; some bees swarmed in this neighbourhood; the old tortoise near Lewes, in Sussex, awakened and came forth out of its dormitory; and, what is most to my present purpose, many house swallows appeared, and were very alert in many places, and particularly at Cobham, in Surrey.

But as that short warm period was succeeded, as well as preceded, by harsh severe weather, with frequent frosts and ice, and cutting winds, the insects withdrew, the tortoise retired again into the ground, and the swallows were seen no more until the 10th of April, when, the rigour of the spring abating, a softer season began to prevail.

Again : it appears by my journals for many years past, that house martins retire, to a bird, about the beginning of October; so that a person not very observant of such matters would conclude that they had taken their last farewell; but then it may be seen in my diaries also, that considerable flocks have discovered themselves-again in the first week of November, and often on the fourth day of that month only for one day; and that not as if they were in actual migration, but playing about at their leisure and feeding calmly, as if no enterprise of moment at all agitated their spirits. And this was the case in the beginning of this very month; for, on the 4th of November, more than twenty house martins, which in appearance had all departed about the 7 th of October, were seen again, for that one morning only, sporting between my fields and the Hanger, and feasting on insects which swarmed in that sheltered district. The preceding day was wet and blustering, but the 4th was dark and mild, and soft, the wind at south-west, and the thermometer at $58 \frac{1}{2}^{\circ}$; a pitch not common at that season of the year. Moreover, it may not be amiss to add in this place, that whenever the thermometer is above $50^{\circ}$, the bat comes flitting out in every autumnal and winter month.

From all these circumstances laid together, it is obvious that torp.d insects, reptiles, and quadrupeds, are awakened from their profoundest slumbers by a little untimely warmth; and therefore that nothing so much promotes this death-like stupor as a defect of heat. And farther, it is reasonable to 
suppose that two whole spccies, or at least many individuals of those two species of British Hirundines do never leave this island at all, but partake of the same benumbed state; for we cannot suppose that, after a month's absence, house martins can return from southern regions to appear for one morning in November, or that house swallows should leave the districts of Africa to enjoy, in March, the transient summer of a couple of days. ${ }^{1}$

\section{LETTER XXXVII.}

\section{TO THE HONOURABLE DAINES BARRINGTON.}

Serborne, Jan. 8, 1778.

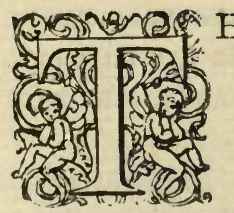

HERE was in this village, several years ago, a miserable pauper, who, from his birth, was afflicted with a leprosy, as far as we are aware, of a singular kind, since it affected only the palms of his hands and the soles of his feet. This scaly eruption usually broke out twice in the year, at the spring and fall; and, by peeling away, left the skin so thin and tender, that ncither his hands nor feet were able to perform their functions; so that the poor object was half his time on crutches, incapable of employ, and languishing in a tiresome stato of indolence and inactivity. His habit was lean, lank, and cadaverous. In this sad plight he dragged on a miscrable existence, a burthen to himself and his parish, which was obliged to support him till he was relieved by death, at more than thirty years of age.

The good women, who love to accout for every defect in children by the doctrine of longing, said that his mother felt a violent propensity for oysters, which she was unable to gratify; and that the black rough scurf on his hands and

1 A more obvious explanation of the appearance of swallows in November is that they are late broods from the north; and those seen in March are early arrivals on their way northwards.-WD. 
feet were the shells of that fish. We knew his parents, neither of which were lepers; his father, in particular, lived to be far advanced in years.

In all ages the leprosy has made dreadful havoc among mankind. The Israelites seem to have been greatly afflicted with it from the most remote times; as appears from the peculiar and repeated injunctions given them in the Levitical law. $\quad$ Nor was the rancour of this foul disorder much abated in the last period of their commonwealth, as may be seen in many passages of the New Testament.

Some centuries ago, this horrible distemper prevailed all Europe over; and our forefathers were by no means exempt, as appears by the large provision made for objects labouring under this calamity. There was an hospital for female lepers in the dioccse of Lincoln, a noble one near Durham, three in London and Southwark, and perhaps many more in or near our great lowns and cities. Moreover, some crowned heads, and other wealthy and charitable personages, bequeathed large legacies to such poor people as languishea under this hopeless infirmity.

It inust, therefore, in these days be, to a humane, and thinking person, a matter of equal wonder and satisfaction. when he contemplates how nearly this pest is cradicated, and observes that a leper now is a rare sight. He will, moreover, when engaged in such a train of thought, naturally inquire for the reason. This happy cliange perhaps may have originated and been continued from the much smaller quantity of salted meat and fish now eatcn in these kingdoms; from the use of linen next the skin; from the plenty of better bread; and from the profusion of fruits, roots, legumes, and greens, so common in overy family. Three or four centuries ago, before there were any enclosures, sown-grasses, field-turnips, or field-carrots, or hay, all the cattle which had grown fat in summer, and were not killed for winter use, were turned out soon after Michaclmas to shift as they could through the dead months; so that no fresh meat could be had in winter or spring. Hence the

I Sec Leviticus, chap. xiii. and xiv. 
marvellous account of the vast stores of salted flesh found in the larder of the eldest Spencer ${ }^{1}$ in the days of Edward the Second, even so late in the spring as the 3rd of May. It was from magazines like these that the turbulent barons supported in idleness their riotous swarms of retainers, ready for any disorder or mischief. But agriculture is now arrived at such a pitch of perfection, that our best and fattest meats are killed in the winter; and no man nceds eat salted flesh, unlcss he prefors it, that has money to buy fresh.

One cause of this distemper might be, no doubt, the quantity of wretched fresh and salt fish consumed by the commonalty at all seasons as well as in Lent, which our poor now would hardly be persuaded to touch.

The use of linen changes, shirts or shifts, in the room of sordid and filthy woollen, long worn next the skin, is a matter of neatness comparatively modern; but must prove a great means of preventing cutaneous ails. At this very time, woollen instead of linen prevails among the poorer Welsh, who are subject to foul eruptions.

The plenty of good wheaten bread that now is found among all ranks of people in the south, instead of that miserable sort which used in old days to be made of barley or beans, may contribute not a little to the sweetening their blood and correcting their juices; for the inhabitants of mountainous districts to this day are still liable to tho itch and other cutaneous disorders, from a wretchedness and poverty of diet.

As to the produce of a garden, erery middle-aged person of observation may perceive, within his own memory, both in town and country, how vastly the consumption of vegetables is increased. Grecn-stalls in cities now support multitudes in a comfortable state, while gardeners get fortunes. Every decent labourer also has his garden, which is lialf his support, as well as his delight; and common farmers provide plenty of beans, peas, and greens, for their linds to eat with their bacon; and those few that do not are

1 Viz. 600 bacons, cighty carcases of becf, and 600 muttons.- - i. W. 
despised for their sordid parsimony, and looked upon as regardless of the welfare of their dependents. Potatoes have prevailed in this little district, by means of premiums, within these twenty years only; and are much esteemed here now by the poor, who would scarce have ventured to taste them in the last reign.

Our Saxon ancestors certainly had some sort of cabbage, because they call the month of February sproutcale ${ }^{1}$ but long after their days, the cultivation of gardens was little attended to. The religious, being men of leisure, and keeping up a constant correspondence with Italy, were the first: people among us that had gardens and fruit-trees in anv perfection within the walls of their abbeys and priories. ${ }^{2}$ The barons neglected every pursuit that did not lead to war or tend to the pleasure of the chase.

It was not till gentlemen took up the study of horticulture themselves that the knowledge of gardening made such hasty advances. Lord Cobham, Lord Ila, and Mr. Waller of Beaconsfield, were some of the first people of rank that promoted the elegant science of ornamenting, without despising, the superintendence of the kitchen quarters and fruit walls.

A remark made by the excellent Mr. Ray, in his Tour of Europe, at once surprises us, and corroborates what has been advanced above; for we find him observing, so late as his days, that "the Italians use several herbs for sallets, which are not yet or have not been but lately used in England, viz. selleri (celery), which is nothing else but the sweet smallage; the young shoots whereof, with a little of the head of the root cut off, they eat raw with oil and

1 The Saxon names of many other montlss were equally significant; e.g. March, stormy month; May, Thrimilchi, the cows then being milked three times a day; June, dig and weed month; September, barley month, \&c.-Ev.

2 "In monasteries, the lamp of knowledge continued to burn, however dimly. In them, men of business were formed for the state: the art of writing was cultivated by the monks; they were the only proficients in mechanics, gardening, and architecture." See Dalrymple's "Annals of Scotland."-G. W. 
pepper." And farther, he adds, "curled endive blanched is much used beyond seas; and, for a raw sallet, seemed to excel lettuce itself." Now, this journey was undertaken no longer ago than in the year 1663.

\section{LETTER XXXVIII.}

\section{TO THE HONOURABLE DAINES BARRINGTON.}

" Fortè puer, comitum seductus ab agmine fido, Dixerat, ecquis adest? et, adest, responderat ccho. Hic stupet; utque aciem partes divisit in omnes, Voce, veni, clamat magnâ. Vocat illa vocantem."

Selborne, Feb. 12, 1778.

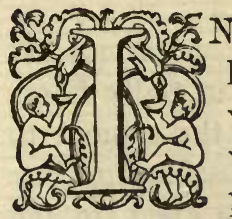

a district so diversified as this, so full of hollow vales and hanging woods, it is no wonder that echoes should abound. Many we have discovered that return the cry of a pack of dogs, the notes of a hunting horn, a tunable ring of bells, or the melody of birds, very agreeably; but we were still at a loss for a polysyllabical, articulate echo, till a young gentleman, who had parted from his company in a summer evening walk, and was calling after them, stumbled upon a very curious one in a spot where it might least be expected. At first he was much surprised, and could not be persuaded but that he was mocked by $\operatorname{som} \theta$ boy; but, repeating his trials in several languages, and finding his respondent to be a very adroit polyglot, he then discerned the deception.

This echo, in an evening, before rural noises cease, would repeat ten syllables most articulately and distinctly, especially if quick dactyls were chosen. The last syllables of

"Tityre, tu patulæ recubans_-

were as audibly and intelligibly returned as the first; and there is no doubt, could trial have been made, but that at 
midnight, when the air is very elastic, and a dead stillness prevails, one or two syllables more might have been obtained; but the distance rendered so late an experiment very inconvenient.

Quick dactyls we observed succeeded best; for when we came to try its powers in slow, heary, embarrassed spondees of the same number of syllables,

"Monstrum horrendum, informe, ingens_-

we could perceive a return but of four or five.

All echoes have some one place to which they are returned stronger and more distinct than to any other; and that is always the place that lies at right angles with the object of repercussion, and is not too near, nor too far off. Buildings or naked rocks re-echo much more articulately than hanging woods or vales; because in the latter the voice is, as it were, entangled and embarrassed in the covert, and weakened in the rebound.

The true object of this echo, as we found by various experiments, is the stone-built, tiled hop-kiln in Gally Lane, which measures in front forty feet, and from the ground to the eaves twelve feet. The true centrum phonicum, or just distance, is one particular spot in the King's Field, in the path to Nore Hill, on the very brink of the steep balk above the hollow cart-way. In this case there is no choice of distance; but the path, by mere contingency, happens to be the lucky, the identical spot, because the ground rises or falls so immediately, if the speaker either retires or advances, that his mouth would at once be above or below the object.

We measured this polysyllabical echo with great exactness, and found the distance to fall very short of Dr. Plot's rule for distinct articulation; for the Doctor, in his "History of Oxfordshire," allows 120 feet for the return of each syllable distinctly; hence this echo, which gives ten distinct syllables, ought to measure 400 yards, or 120 feet to each syllable; whereas our distance is only 258 yards, or near seventy-five feet to each syllable. Thus our measure falls short of the Doctor's, as five to eight; but then it must be acknowiedged that this candid philosopher was convinced 
afterwards that some latitude must be admitted of in the distance of echoes according to time and place. ${ }^{1}$

When experiments of this sort are making, it should always be remembered that weather and the time of day have a vast influence on an echo; for a dull, heavy, moist air deadens and clogs the sound; and hot sunshine renders the air thin and weak, and deprives it of all its springiness; and a ruffling wind quite defeats the whole. In a still, clear, dewy evening, the air is most elastic; and perhaps the later the hour the more so.

Echo has always been so amusing to the imagination, that the poets have personified her; and in their hands she has been the occasion of many a beautiful fiction. Nor need the gravest man be ashamed to appear taken with such a phenomenon, since it may become the subject of philosophical or mathematical inquiries.

One should have imagined that echoes, if not entertaining, must at least have been harmless and inoffensive; yet Virgil advances a strange notion, that they are injurious to bees. After enumerating some probable and reasonable annoyances, such as prudent owners would wish far removed from their bee-gardens, he adds,

$$
\text { "— aut ubi concava pulsu }
$$

Saxa sonant, vocisque offensa resultat imago."

This wild and fanciful assertion will hardly be admitted by the philosophers of these days; especially as they all now seem agreed that insects are not furnished with any organs of hearing at all. ${ }^{2}$ But, if it should be urged, that

${ }^{1}$ It is evident too, as Mr. Bennett has observed, from the previous statement of the different number of syllables returned by the echo, according to whether they were quick dactyls or heavy spondees, that some allowance must be made on this account also.-ED.

2 This was the opinion of Linnæus and Bonnet, naturalists of the highest authority. But, as Mr. Bennett has remarked, " repeated observations and experiments have since shown that many insects possess the sense of hearing. Without the aid of experiment it might, indeed, almost be regarded as established, that in those cases in which the faculty of producing sound is possessed by one sex of an animal, that of hearing it should belong to the other sex; and it would seem rather 
though they cannot hear, yet perhaps they may feel the repercussion of sounds, I grant it is possible they may. Yet that these impressions are distasteful or hurtful, I deny; bccause bees, in good summers, thrive well in my outlet, where the echoes are very strong: for this village is another Anathoth, a place of responses or echoes. Besides, it does not appear from experiment that bees are in any way capable of being affected by sounds: ${ }^{1}$ for I have often tried my own with a large speaking-trumpet held close to their hives, and with such an exertion of voice as would have hailed a ship at the distance of a mile, and still these insects pursued their various employments undisturbed, and without showing the least sensibility or resentment.

preposterous to grant the existence of a sense in one sex of an insect, and deny it to the other. Gilbert White, in his Letter respecting the field cricket (XLVI.), although in the earlier part of it he seems to guard himself from admitting that these insects hear by assuming that they feel ' a person's footsteps as he adrances,' must be regarded as insinuating the possession of that sense when he subsequently remarks that ' the males only make that shrilling noise, perhaps out of rivalry and emulation'-a rivalry and emulation which could not be excited in others by a sound unheard by them.

"But reasoning and conjecture are both equally unnecessary in a case in which direct cbservation may be adduced in proof. Brunelli's experiments seem on this point altogether satisfactory, and to prove that both the males and the females possess the sense of hearing. He kept several males of the large green grasshopper in a closet, where they were very merry and continued singing all the day; but a tap at the door would immediately silence them. In this instance they might, perhaps, have been affected by the concussion of the air ; and the result might rather have been owing to acuteness of touch than to hearing. But his subsequent experiments were not open to such an objection. He learned to imitate the chirping of these grasshoppers: and when he did this at the door of the closet in which they were kept, they soon began to answer him; at first by the gentle chirpings of a few, and then by a full chorus of the whole of them. He afterwards enclosed a male grasshopper in a box, and placed it in one part of his garden, leaving a female at liberty in a distant part of it: as soon as the male began to sing, the female immediately hopped away towards him. This latter experiment was frequently repeated, and in every case the female, as soon as the male began to chirp, hastened to join him."

1 'This statement has recently received some confirmation from the experiments of Sir John Lubbock, "Journ. Linn. Soc." 1874.-ED. 
Some time since its discovery, this echo is become totaliy silent, though the object or hop-kiln remains: nor is there any mystery in this defect; for the field between is planted as a hop-garden, and the voice of the speaker is totally absorbed and lost among the poles and entangled foliage, of the hops. And when the poles are removed in autumn, the disappointment is the same, because a tall quickset hedge, nurtured up for the purpose of shelter to the hopground, entirely interrupts the impulse and repercussion of the voice: so that, till those obstructions are removed, no more of its garrulity can be expected.

Should any gentleman of fortune think an echo in his park, or outlet, a pleasing incident, he might build one at little or no expense. For whenever he had occasion for a new barn, stable, dog-kennel, or the like structure, it would be only needful to erect this building on the gentle declivity of a hill, with a like rising opposite to it, at a few hundred yards' distance; and perhaps success might be the easier ensured, could some canal, lake, or stream intervene. From a seat at the centrum phonicum, he and his friends might amuse themselves sometimes of an evening with the prattle of this loquacious nymph; of whose complacency and decent reserve more may be said than can with truth of every individual of her sex; since she is

“

Nec prior ipsa loqui didicit resonabilis echo."

P. S.-The classic reader will, I trust, pardon the following lovely quotation, so finely describing echoes, and so poetically accounting for their causes from popular superstition:

"Quæ benè quom videas, rationem reddere possis

Tute tibi atque aliis, quo pacto per loca sola

Saxa pareis formas verborum ex ordine reddant,

Palanteis comites quom monteis inter opacos

Quærimus, et magnâ dispersos voce ciemus.

Sex etiam, aut septem loca vidi reddere voces

Unam quom jaceres: ita colles collibus ipsis

Verba repulsantes iterabant dicta referre.

Hæc loca capripedes Satyros, Nymphasque tenere

Finitimi fingunt, et Faunos esse loquuntur;

Quorum noctivago strepitu, ludoque jocanti 
Adfirmant volgo taciturna silentia rumpi,

Chordarumque sonos fieri, dulceisque querelas,

Tibia quas fundit digitis pulsata canentum:

Et genus agricolûm latè sentiscere, quom Pan

Pinea semiferi capitis velamina quassans,

Unco sæpe labro calamos percurrit hianteis,

Fistula silvestrem ne cesset fundere musam."

Lucretius, lib. iv. 1. 576.

\section{LETTER XXXIX.}

\section{TO THE HONOURABLE DAINES BARRINGTON.}

\section{Selborne, May 13, 1778.}

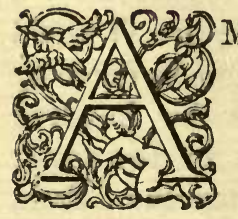

MONG the many singularities attending those amusing birds, the swifts, I am now confirmed in the opinion that we have every year the same number of pairs invariably; at least, the result of my inquiry has been exactly the same for a long time past. ${ }^{1}$ The swallows and martins are so numerous, and so widely distributed over the village, that it is hardly possible to recount them; while the swifts, though they do not all build in the church, yet so frequently haunt it, and play and rendezvous round it, that they are easily enumerated. The number that I constantly find are eight pairs ; about half of which reside in the church, and the rest build in some of the lowest and meanest thatched cottages. Now, as these eight pairs, allowance being made for accidents, breed yearly eight pairs more, what becomes annually of this increase; and, what determines every spring which pairs shall visit us, and reoccupy their ancient haunts?

1 It has been proved by experiment that swallows and swifts return to haunts where in previous years they have successfully reared their young. The birds have been caught upon their nests, and after being marked by having particular claws cut, or by having a little bit of ribbon or silver wire fastened round the foot, have been again liberated. 'The following year the marked birds have been recaptured in the same locality.--ED. 
Ever since I have attended to the subject of ornithology, I have always supposed that that sudden reverse of affection,

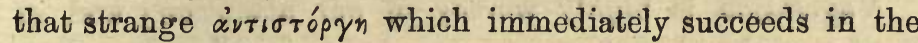
feathered kind to the most passionate fondness, is the occasion of an equal dispersion of birds over the face of the earth. Without this provision, one favourite district would be crowded with inhabitants, while others would be destitute and forsaken. But the parent birds seem to maintain a jealous superiority, and to oblige the young to seek for new abodes; and the rivalry of the males in many kinds prevents their crowding the one on the other.

Whether the swallows and house martins return in the same exact number annually is not easy to say, for reasons given above; but it is apparent, as I have remarked before in my Monographies, that the numbers returning bear no manner of proportion to the numbers retiring.

\section{LETTER XI.}

\section{TO TIE HONOURABLE DAINES BARRINGTON.}

Seldorive, June 2, 1778.

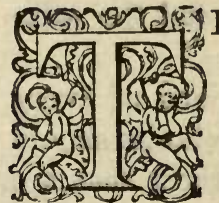

HE standing objection to botany has always been, that it is a pursuit that amuses the fancy and exercises the memory, without improving the mind, or advancing any real knowledge ; and, where the science is carried no farther than a mere systematic classification, the charge is but too true. But the botanist that is desirons of wiping off this aspersion, should be by no means content with a list of names; he should study plants philosophically, should investrgate the laws of vegetation, should examine the powers and virtues of efficacious herbs, should promote their cultivation; and graft the gardener, the planter, and the husbandman on the phytologist. Not that system is by any means to be thrown aside-without system the field of 
Nature would be a pathless wilderness; but system should be subservient to, not the main object of, pursuit.

Vegetation is highly worthy of our attention; and in itself is of the utmost consequence to mankind, and productive of many of the greatest comforts and elegancies of life. To plants we owe timber, bread, beer, honey, wine, oil, linen, cotton, \&c., what not only strengthens our hearts and exhilarates our spirits, but what secures us from inclemencies of weather, and adorns our persons. Man, in his true state of nature, seems to be subsisted by spontaneous vegetation; in middle climes, where grasses prevail, he mixes some animal food with the produce of the field and garden; and it is towards the polar extremes only that, like his kindred bears and wolves, he gorges himself with flesh alone, and is driven, to what hunger has never been known to compel the very beasts, to prey on his own species. ${ }^{1}$

The productions of vegetation have had a vast influence on the commerce of nations, and have been the great promoters of navigation, as may be seen in the articles of sugar, tea, tobacco, opium, ginseng, betel, paper, \&c. As every climate has its peculiar produce, our natural wants bring on a mutual intercouise; so that by means of trade each distant part is supplied with the growth of every latitude. But without the knowledge of plants and their culture, we must have been content with our hips and haws, without enjoying the delicate fruits of India, and the salutiferous drugs of Peru.

Instead of examining the minute distinctions of every various species of each obscure genus, the botanist should endeavour to make himself acquainted with those that are useful. You shall see a man readily ascertain every herb of the field, yet hardly know wheat from barley, or at least one sort of wheat or barley from another.

But of all sorts of vegetation the grasses seem to be most neglected; neither the farmer nor the grazier seem to distinguish the annual from the perennial, the hardy from the tender, nor the succulent and nutritive from the dry and juiceless.

1 See the late voyages to the South Seas.-G. W. 
The study of grasses would be of great consequence to a northerly and grazing kingdom. The botanist that could improve the sward of the district where he lived, would be a useful member of society - to raise a thick turf on a naked soil would be worth volumes of systematic knowledge; and he would be the best commonwealth's man that could occasion the growth of "two blades of grass where one alone was seen before."

\section{LETTER XLI.}

\section{TO THE HONOURABLE DAINES BARRINGTON.}

Seliorne, July 3, 1778.

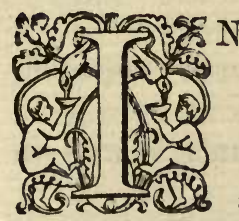

$\mathrm{N}$ a district so diversified with such a variety of hill and dale, aspects and soils, it is no wonder that great choice of plants should be found. Chalks, clays, sands, sheep-walks and downs, bogs, heaths, woodlands, and champaign fields, cannot but furnish an ample Flora. The deep rocky lanes abound with Filices, ${ }^{1}$ and the pastures and moist woods with Fungi. If in any branch of botany we may seem to be wanting, it must be in the large aquatic plants, which are not to be expected on a spot far removed from rivers, and lying up amidst the hill country at the spring heads. To enumerate all the plants that have been discovered within our limits would be a needless work; but a short list of the more rare, and the spots where they are to be found, may be neither unacceptable nor unentertaining:-

Helleborus foetidus, stinking hellebore, bear's foot, or setterwort, - all over the High Wood and Coney Croft Hanger; this continues a great branching plant the winter through, blossoming about January, and is very ornamental in shady

1 The ferns, though abundant in this district, belong comparatively to few species.-ED. 
walks and shrubberies. The good women give the leaves powdered to children troubled with worms; but it is a violent remedy, and ought to be administered with caution.

Helleborus viridis, green hellebore, -in the deep stony lane on the left hand just before the turning to Norton Farm, and at the top of Middlo Dorton under the hedge: this plant dies down to the ground early in autumn, and springs again about February, flowering almost as soon as it appears above ground.

Vaccinium oxycoccos, creeping bilberries, or cranberries, -in the bogs of Bin's Pond;

Vaccinium myrtillus, whortle, or bleaberries,-on the dry hillocks of Wolmer Forest;

Drosera rotundifolia, round-leaved sundew,-in the bogs of Bin's Pond;

Drosera longifolia, long-leaved sundew,-in the bogs of Bin's Pond;

Comarum palustre, purple comarum, or marsh cinquefoil, -in the bogs of Bin's Pond;

Hypericum androsoemum, Tutsan St. John's Wort,-in the stony, hollow lanes;

Vinca minor, lesser periwinkle,-in Selborne Hanger and Shrub Wood;

Monotropa hypopithys, yellow monotropa, or bird's nest, -in Selborne Hanger under the shady beeches, to whose roots it seems to be parasitical-at the north-west end of the Hanger;

Chlora perfoliata, Blackstonia perfoliata, Hudsoni, perfoliated yellow wort, - on the banks in the King's Field;

Paris quadrifolia, herb Paris, true love, or one berry,in the Church Litten Coppice;

Chrysosplenium oppositifolium, opposite golden saxifrage, -in the dark and rocky hollow lanes;

Gentiana amarella, autumnal gentian, or fellwort,-on the Zigzag and Hanger;

Lathroea squamaria, toothwort,-in the Church Litten Coppice under some hazels near the foot bridge in Trimming's garden hedge, and on the dry wall opposite Grange Yard; 
Dipsacus pilosus, small teasel,-in the Short and Long Lith;

Lathyrus sylvestris, narrow-leaved, or wild lathyrus,in the bushes at the foot of the Short Lith, near the path ; Ophrys spiralis, ${ }^{1}$ ladies' traces,-in the Long Lith, and towards the south corner of the common;

Ophrys nidus avis, ${ }^{2}$ bird's nest ophrys,-in the Long Lith under the shady beeches among the dead leaves, in Great Dorton among the bushes, and on the Hanger plentifully;

Serapias latifolia, ${ }^{3}$ helleborine,-in the High Wood under the shady beeches;

Daphne laureola, spurge laurel,-in Selborne Hanger and the High Wood;

Daphne mezereum, the mezereon,-in, Selborne Hanger among the shrubs at the south-east end above the cottages; Lycoperdon tuber, ${ }^{4}$ truffles, - in the Hanger and High Wood;

Sambucus ebulus, dwarf elder, wallwort, or danewort, -among the rubbish and ruined foundations of the Priory. ${ }^{5}$

1 Spiranthes autumnalis, Rich.

3 Epipactis latifolia, All.

2 Neottia nidus-avis, Rich.

4 Tuber astivum, Vitt.

5 From this letter and the previous one it would appear that Gilbert White paid comparatively but slight attention to the vegetable productions of the neighbourhood in which he resided. His strictures on "mere systematic classification" were perhaps not uncalled-for at the period when they were written, for the science of botany was then in a very unsatisfactory state in this country, little else being attempted beyond an arrangement of our indigenous plants according to the sexual system of Linnæus. It is to be regretted, however, that our author thought it "needless work" to. enumerate the plants found about Selborne, for the possession of such a catalogue at the present day would be of considerable interest and utility to those who are occupied with an investigation of the laws affecting plant distribution.

In regard to the botany of Selborne, Dr. Trimen informs us that Gilbert White's scanty observations on the subject have been supplemented by the late Dr. Bell Salter, who published in the "Phytologist" (vol. i. p. 1132) a list of the flowering plants observed by him at Selborne during three days' botanizing in the month of September, 1844, and subsequently in the same periodical (vol. ii. pp. 97 and 131) he gave an elaborate account of the Brambles (Rubi). Many notices of 
Of all the propensities of plants none seem more strange than their different periods of blossoming. Some produce their flowers in the winter, or very first dawnings of spring; many when the spring is established; some at midsummer; and some not till autumn. When we see the Helleborus foetidus and Helleborus niger blowing at Christmas, the Helleborus hyemalis ${ }^{1}$ in January, and the Helleborus viridis as soon as ever it emerges out of the ground, we do not wonder, because they are kindred plants that we expect should keep pace the one with the other. But other congenerous vegetables differ so widely in their time of flowering, that we cannot but admire. I shall only instance at present in the Crocus sativus, the vernal, and the autumnal crocus, which have such an affinity, that the best botanists only make them varieties of the same genus, of which there is only one species; not being able to discern any difference in the corolla, or in the internal structure. Yet the vernal crocus expands its flowers by the beginning of March at farthest, and often in very rigorous weather ; and cannot be retarded but by some violence offered:- while the autumnal (the Saffron) defies the influence of the spring and summer, and will not blow till most plants begin to fade and run to seed. This circumstance is one of the wonders of the creation, little noticed, because a common occurrence; yet ought not to be overlooked on account of its being familiar, since it would be as difficult to

Selborne as a locality will be found scattered thronghout Dr. Bromfield's Catalogue of Hampshire Plants (op. cit. vols. iii. iv.)

Dr. Trimen adds: "The singular parasitic Toothwort, Lathrae squamaria, and the pretty Marsh Cinquefoil, Comarum palustre, do not seem to have been recorded since Gilbert White's day for this part of Hampshire. The Mezereon above noticed may have been planted in the Hanger (see 'Phytologist,' vol. iii. p. 794). As an indication of the advance which has been made in the knowledge of plants since White's observations were penned, it may be mentioned that upon the lowest computation the species of Crocus now known to botanists amount to forty-seren. The three mentioned by White, Crocus sativus, $C$. vernus, and $C$. nudiflorus, are now universally considered to be distinct and well-defined species."-ED.

1 Eranthis hyemalis of recent authors. 
be explained as the most stupendous phenomenon in nature.

"Say, what impels, amidst surrounding snow

Congeal'd, the crocus' flamy bud to glow ?

Say, what retards, amidst the summer's blaze,

Th' autumnal bulb, till pale, declining days?

The God of Seasons; whose pervading power

Controls the sun, or sheds the fleecy shower:

He bids each flower his quickening word obey ;

Or to each lingering bloom enjoins delay."

\section{LETTER XLII.}

\section{TO THE HONOURABLE DAINES BARRINGTON.}

"Omnibus animalibus reliquis certus et uniusmodi et in suo cuique genere incessus est : aves solæ vario meatu feruntur et in terrâ et in aëre."-Purn. Nat. Hist. lib. x. cap. 38.

Selborne, Aug. 7, 1778.

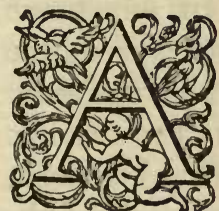

GOOD ornithologist should be able to distinguish birds by their air as well as by their colours and shape; on the ground as well as on the wing, and in the bush as well as in the hand. For, though it must not be said that every species of birds has a manner peculiar to itself, yet there is somewhat in most genera at least, that at first sight discriminates them, and enables a judicious observer to pronounce upon them with some certainty. Put a bird in motion

$$
\text { “__ et vera incessu patuit ___." }
$$

Thus kites and buzzards sail round in circles with wings expanded and motionless; and it is from their gliding manner that the former are still called in the north of England gleads, from the Saxon verb glidan, to glide. The kestril, or wind-hover, has a peculiar mode of hanging in the air in one place, his wings all the while being briskly agitated. Hen harriers fly low over heaths or fields of corn, and beat the ground regularly like a pointer or setting- 
dog. Owls move in a buoyant manner, as if lighter than the air; they scem to want ballast. There is a peculiarity belonging to ravens that must draw the attention even of the most incurious-they spend all their leisure time in striking and cuffing each other on the wing in a kind of playful skirmish; and when they move from one place to another, frequently turn on their backs with a loud croak, and seem to be falling to the ground. When this odd gesture betides them, they are scratching themselves with one foot, and thus lose the centre of gravity. Rooks sometimes dive and tumble in a frolicsome manner; crows and daws swagger in their walk; woodpeckers fly volatu undoso, opening and closing their wings at every stroke, and so are always rising or falling in curves. All of this genus use their tails, which incline downward, as a support while they run up trees. Parrots, like all other hookedclawed birds, walk awkwardly, and make use of their bill as a third foot, climbing and descending with ridiculous caution. All the Gallino parade and walk gracefully, and run nimbly; but fly with difficulty, with an impetuous whirring, and in a straight line. Magpies and jays flutter with powerless wings, and make no dispatch; herons seem encumbered with too much sail for their light bodies; but these vast hollow wings are necessary in carrying burthens, such as large fishes, and the like; pigeons, and particularly the sort called smiters, have a way of clashing their wings the one against the other over their backs with a loud snap; another variety called tumblers turn themselves over in the air. Some birds have movements peculiar to the season of pairing: thus ring-doves, though strong and rapid at other times, yet in the spring hang about on the wing in a toying and playful manner; thus the cock-snipe, while breeding, forgetting his former flight, fans the air like the wind-hover; and the greenfinch in particular exhibits such languishing and faltering gestures as to appear like a wounded and dying bird; the kingfisher darts along like an arrow ; fernowls, or goat-suckers, glance in the dusk over the tops of trees like a meteor; starlings, as it were, swim along, while missel-thrushes use a wild and desultory flight; swallows 
sweep over the surface of the ground and water, and distinguish themselves by rapid turns and quick evolutions; swifts dash round in circles, and the bank martin moves with frequent vacillations like a butterfly. Most of the small birds fly by jerks, rising and falling as they advance. Most small birds hop, but wagtails and larks walk, moving their legs alternately. Skylarks rise and fall perpendicularly as they sing; woodlarks hang poised in the air; and titlarks rise and fall in large curves, singing in their descent. The whitethroat uses odd jerks and gesticulations over the tops of hedges and bushes. All the duck kind waddle; divers and auks walk as if fettered, and stand erect on their tails: these are the compedes of Linnæus. ${ }^{1}$ Geese and cranes, and most wild fowls, move in figured flights, often changing their position. The secondary remiges of Tringa, wild ducks, and some others, are very long, and give their wings, when in motion, a hooked appearance. $^{2}$ Dabchicks, moorhens, and coots, fly erect, with their legs hanging down, and hardly make any dispatch; the reason is plain, their wings are placed too forward out of the true centre of gravity, as the legs of auks and divers are situated too backward.

\section{LETTER XLIII.}

\section{TO THE HONOURABLE DAINES BARRINGTON.}

Selborne, Sept. 9, 1778.

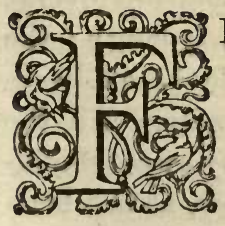

$\mathrm{BOM}$ the motion of birds, the transition is natural enough to their notes and language, of which I shall say something. Not that I would pretend to understand their language like the vizier, who, by the recital of a con-

1 "Pedes compedes," Genus Colymbus, "Syst. Nat." i. p. 220.-Ev.

2 These are not the secondaries, howerer, but the tertials. The secondaries are always short.-Eo. 
versation which passed between two owls, reclaimed a sultan, before delighting in conquest and devastation ; ${ }^{1}$ but I would be thought only to mean that many of the winged tribes have various sounds and voices adapted to express their various passions, wants, and feelings; such as anger, fear, love, hatred, hunger, and the like. All species are not equally eloquent; some are copious and fluent, as it were, in their utterance, while others are confined to a fow important sounds : no bird, like the fish kind, is quite mute, though some are rather silent. The language of birds is very ancient, and, like other ancient modes of speech, very elliptical; little is said, but much is meant and understood.

The notes of the eagle kind are shrill and piercing; and about the season of nidification much diversified, as I have been often assured by a curious observer of Nature who long resided at Gibraltar, where eagles abound. The notes of our hawks much resemble those of the king of birds. Owls have very expressive notes; they hoot in a fine vocal sound, much resembling the vox humana, and reducible by a pitchpipe to a musical key. ${ }^{2}$ This note seems to express complacency and rivalry among the males : they use also a quick call and a horrible scream; and can snore and hiss when they mean to menace. Ravens, beside their loud croak, can exert a deep and solemn note that makes the woods to echo; the amorous sound of a crow is strange and ridiculous ; rooks, in the breeding season, attempt sometimes, in the gaiety of their hearts, to sing, but with no great success; the parrot kind have many modulations of voice, as appears by their aptitude to learn human sounds; doves coo in an amorous and mournful manner, and are emblems of despairing lovers; the woodpecker sets up a sort of loud and hearty laugh; the fern-owl or goat-sucker, from the dusk till daybreak, serenades his mate with the clattering of castanets. All the tuneful Passeres express their complacency by sweet modulations, and a variety of melody. The swallow, as has been

1 See "Spectator," vol. vii. No. 512.-G. W.

2 The brown owl hoots; the white owl screams.-G. W.

But see p. 177, note 2.-ED. 
observed in a former letter, by a shrill alarm, bespcaks the attention of the other Hirundines, and bids them be aware that the hawk is at hand. Aquatic and gregarious birds, especially the nocturnal, that shift their quartors in the dark, are very noisy and loquacious, as cranes, wild geese, wild ducks, and the like; their perpetual clamour prevents them from dispersing and losing their companions.

In so extensive a subject, sketches and outlines are as much as can be expected, for it would be endless to instance in all the infinite variety of the feathered nation. We shall therefore confine the remainder of this letter to the few domestic fowls of our yards, which are most known and therefore best understood. And first the peacock, with his gorgeous train, demands our attention; but, like most of the gaudy birds, his notes are grating and shocking to the ear: the yelling of cats, and the braying of an ass, are not more disgustful. The voice of the goose is trumpet-like, and clanking; and once saved the Capitol at Rome, as grave historians assert: the hiss also of the gander is formidable and full of menace, and "protective of his young." Among ducks the sexual distinction of voice is remarkable; for while the quack of the female is loud and sonorous, the voice of the drake is inward and harsh, and feeble, and scarce discernible. The cock turkey struts and gobbles to his mistress in a most uncouth manner; he hath also a pert and petulant note when he attacks his adversary. When a hen turkey leads forth her young brood she keeps a watchful eye; and if a bird of prey appear, though ever so high in the air, the careful mother announces the enemy with a little inward moan, and watches him with a steady and attentive look; but, if he approach, her note becomes earnest and alarming, and her outcries are redoubled.

No inhabitants of a yard seem possessed of such a variety of expression and so copious a language as common poultry. Take a chicken of four or five days old, and hold it up to a window where there are flies, and it will immediately seize its prey, with little twitterings of complacency; but if you tender it a wasp or a bee, at once its note becomes harsh and expressive of disapprobation and a sense of danger. 
When a pullet is ready to lay, she intimates the event by a joyous and easy soft note. Of all the occurrences of their life that of laying seems to be the most important; for no sooner has a hen disburthened herself, than she rushes forth with a clamorous kind of joy, which the cock and the rest of his mistresses immediately adopt. The tumult is not confined to the family concerned, but catches from yard to yard, and spreads to every homestead within hearing, till at last the whole village is in an uproar. As soon as a hen becomes a mother, her new relation demands a new language; she then runs clucking and screaming about, and seems agitated as if possessed. The father of the flock has also a considerable vocabulary : if he finds food, he calls a favourite concubine to partake; and if a bird of prey passes over, with a warning voice he bids his family beware. The gallant chanticleer has, at command, his amorous phrases and his terms of defiance. But the sound by which he is best known is his crowing; by this he has been distinguished in all ages as the countryman's clock or larum, as the watchman that proclaims the divisions of the night. Thus the poet elegantly styles him

" _ the crested cock, whose clarion sounds

The silent hours."

A neighbouring gentleman one summer had lost most of his chickens by a sparrow-hawk, that came gliding down between a faggot pile and the end of his house to the place where the coops stood. The owner, inwardly vexed to see his flock thus diminishing, hung a setting net adroitly between the pile and the house, into which the caitiff dashed, and was entangled. Resentment suggested the law of retaliation: he therefore clipped the hawk's wings, cut off his talons, and fixing a cork on his bill, threw him down among the brood-hens. Imagination cannot paint the scene that ensued; the expressions that fear, rage, and revenge inspired were new, or at least such as had been unnoticed before : the exasperated matrons upbraided, they execrated, they insulted, they triumphed. In a word, they never desisted from buffeting their adversary till they had torn him in a hundred picces. 


\section{LETTER XLIV.}

\section{TO THE HONOURABLE DAINES BARRINGTON.}

SELtborse:

“

Quid tantum Oceano properent se tingere soles Hyberni ; vel quæ tardis mora noctibus obstet."

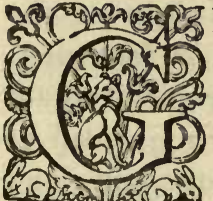

ENTLEMEN who have outlets might contrive to make ornament subservient to utility:a pleasing eyetrap might also contribute to promote science: an obelisk in a garden or park might be both an embellishment and a heliotrope.

Any person that is curious, and enjoys the advantage of a good horizon, might, with little trouble, make two heliotropes; the one for the winter, the other for the summer solstice: and these two erections might be constructed with very little expense, for two pieces of timber framework, about ten or twelve feet high, and four feet broad at the base, and close lined with plank, would answer the purpose.

The erection for the former should, if possible, be placed within sight of some window in the common sitting parlour, because men, at that dead season of the year, are usually within doors at the close of the day; while that for the latter might be fixed for any given spot in the garden or outlet, whence the owner might contemplate, in a fine summer's evening, the utmost extent that the sun makes to the northward at the season of the longest days. Now nothing would be necessary but to place these two objects with so much exactness that the westerly limb of the sun, at setting, might but just clear the winter heliotrope to the west of it on the shortest day, and that the whole disc of the sun, at the longest day, might exactly at setting alsn clear the summer heliotrope to the north of it. 
By this simple expedient it would soon appear that there is no such thing, strictly speaking, as a solstice : for, from the shortest day, the owner would, every clear evening, see the disc advancing, at its setting, to the westward of the object; and, from the longest day, observe the sun retiring backwards every evening at its setting towards the object westward, till, in a few nights, it would set quite behind it, and so by degrees to the west of it: for when the sun comes near the summer solstice, the whole disc of it would at first set behind the object. After a time, the northern limb would first appear, and so every night gradually more, till at length the whole diameter would set northward of it for about three nights; but on the middle night of the three, sensibly more remote than the former or following. When beginning its recess from the summer tropic, it would continue more and more to be hidden every night, till at length it would descend quite behind the object again; and so nightly more and more to the westward.

\section{LETTER XLV.}

TO THE HONOURABLE DAINES BARRINGTON.

SELBORNe.

“..... Mugire videbis

Sub pedibus terram, et descendere montibus ornos."

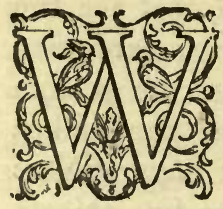

HEN I was a boy, I used to read, with astonishment and implicit assent, accounts in Baker's Chronicle of walking hills and travelling mountains. John Philips, in his "Cider," alludes to the credit that was given to such stories with a delicate but quaint vein of humour peculiar to the author of the " Splendid Shilling."

"I nor advise, nor reprehend, the choice

Of Marcley Hill ; the apple nowhere finds

A kinder mould: yet 'tis unsafe to trust

Deccitful ground: who knows but that, once more, 
This mount may journey, and, his present site Forsaking, to thy neighbour's bounds transfer The goodly plants, affording matter strange For law debates!"

But, when I came to consider better, I began to suspect that though our hills may never have journeyed far, yet that the ends of many of them have slipped and fallen away at distant periods, leaving the cliffs bare and abrupt. This seems to have been the case with Nore and Whetham Hills, and especially with the ridge between Harteley Park and Word-le-ham, where the ground has slid into vast swellings and furrows, and lies still in such romantic confusion as cannot be accounted for from any other cause. A strange event, that happened not long since, justifies our suspicions, which, though it befell not within the limits of this parish, yet, as it was within the hundred of Selborne, and as the circumstances were singular, may fairly claim a place in a work of this nature.

The months of January and February, in the year 1774, were remarkable for great melting snows and vast gluts of rain; so that, by the end of the latter month, the landsprings, or lavants, began to prevail, and to be near as high as in the memorable winter of 1764. The beginning of March also went on in the same tenor, when, in the night between the 8 th and 9 th of that month, a considerable part of the great woody hanger at Hawkley was torn from its place, and fell down, leaving a high free-stone cliff naked and bare, and resembling the steep side of a chalk-pit. It appears that this huge fragment, being perhaps sapped and undermined by waters, foundered, and was ingulfed, going down in a perpendicular direction; for a gate which stood in the field, on the top of the hill, after sinking with its posts for thirty or forty feet, remained in so true and upright a position as to open and shut with great exactness, just as in its first situation. Several oaks also are still standing, and in a state of vegetation, after taking the same desperate leap. That great part of this prodigious mass was ahsorbed in some gulf below is plain also from the inclining ground at the bottom of the hill, which is free and 
unencumbered, but would have been buried in heaps of rubbish, had the fragment parted and fallen forward. ${ }^{1}$

About a hundred yards from the foot of this hanging coppice stood a cottage by the side of a lane; and two hundred yards lower, on the other side of the lane, was a iarm-house, in which lived a labourer and his family; and just by, a stout new barn. The cottage was inhabited by an old woman and her son, and his wife. These people, in the evening, which was very dark and tempestuous, observed that the brick floors of their kitchens began to heave and part, and that the walls seemed to open, and the roofs to crack; but they all agreed that no tremor of the ground, indicating an earthquake, was ever felt, only that the wind continued to make a most tremendous roaring in the woods and hangers. The miserable inhabitants, not daring to go to bed, remained in the utmost solicitude and confusion, expecting every moment to be buried under the ruins of their shattered edifices. When daylight came they were at leisure to contemplate the devastations of the night. They then

${ }^{1}$ In a note to this passage Mr. Bennett expresses the opinion that it is not necessary to assume the existence of a gulf into which the mass was absorbed. The geological relations of the strata, he says, point to a much easier, as well as a more correct, explanation of the occurrence. Here, as elsewhere throughout the district, the malm rock or freestone of the upper greensand formation rests upon the gault or blue clay : a rock upon a yielding base. An adequate weight, placed upon so unfirm a soil as the lower of these formations, must of necessity sink into it. So prodigious a mass as that which, on the occasion described in the text, was separated from its adhesion to its native rock, and left to be supported by the soft clay alone, was more than its pulpy nature could support, and it gave way accordingly; receiving into its yielding substance, and burying almost entirely beneath its surface the detached face of the cliff, which subsided into it so easily and so perpendicularly as not to disturb the adjustment of a gate upon the sunken mass, once on the top, and now at the foot of the escarpment.

In other situations, and particularly on the southern coast of the Isle of Wight, slips similar to that of Hawkley have taken place, and from the same cause: either the separation of a portion of the freestone rock of the upper greensand formation and its subsidence into the gault; or the loosening of the gault, and the subsequent separation and subsidence of a portion of the freestone, which conld no longer be supported when its natural foundation had thus given way.-En. 
found that a deep rift or chasm had opened under their houses, and torn them, as it were, in two; and that one end of the barn had suffered in a similar manner; that a pond near the cottage had undergone a strange reverse, becoming deep at the shallow end, and so vice versâ ; that many large oaks were removed out of their perpendicular, some thrown down, and some fallen into the heads of neighbouring trees; and that a gate was thrust forward, with its hedge, full six

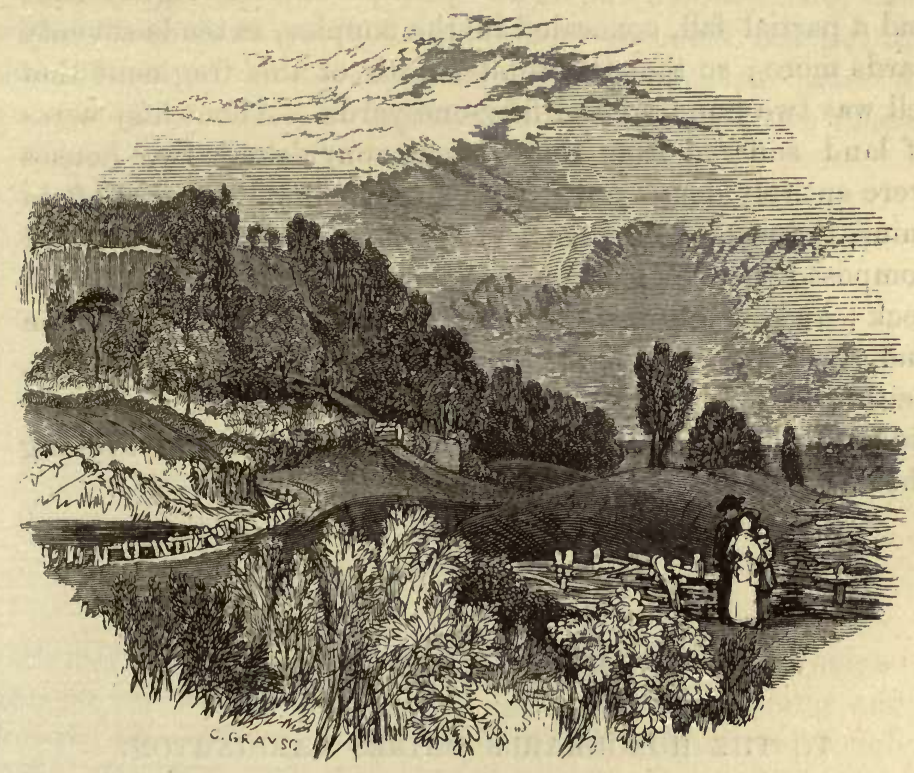

HAWKLEY SLIP.

fcet, so as to require a new track to be made to it. From the foot of the cliff, the general course of the ground, which is pasture, inclines in a moderate descent for half a mile, and is interspersed with some hillocks, which were rifted in every direction, as well towards the great woody hanger as from it. In the first pasture the deep clefts began; and running across the lane, and under the buildings, made such vast shelves that the road was impassable for some time; and so over to an arable field on the other side, which was strangely torn and disordered. The second pasture field, 
being more soft and springy, was protruded forward without many fissures in the turf, which was raised in long ridges resembling graves, lying at right angles to the motion. At the bottom of this enclosure, the soil and turf rose many feet against the bodies of some oaks that obstructed their farther course, and terminated this awful commotion.

The perpendicular height of the precipice, in general, is uwenty-three yards : the length of the lapse, or slip, as seen from the fields below, one hundred and eighty-one; and a partial fall, concealed in the coppice, extends seventy yards more; so that the total length of this fragment that fell was two hundred and fifty-one yards. About fifty acres of land suffered from this violent convulsion: two houses were entirely destroyed; one end of a new barn was left in ruins, the walls being cracked through the very stones that composed them; a hanging coppice was changed to a naked rock; and some grass grounds and an arable field so broken and rifted by the chasms as to be rendered, for a time, neither fit for the plough nor safe for pasturage, till considerable labour and expense had been bcstowed in levelling the surface and filling in the gaping fissures.

\section{LETTER XIVI.}

TO TIE HONOURABLE DAINES BARRINGTON.

SeliborNe.

66 resonant arbusta $"$

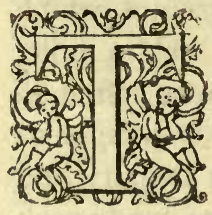

HERE is a steep abrupt pasture field interspersed with furze close to the back of this village, well known by the name of the Short Lithe, consisting of a rocky dry soil, and inclining to the afternoon sun. This spot abounds with the Gryllus campestris, or field cricket, which, though frequent in these parts, is by no means a common insect in many other counties. 
As their cheerful summer cry cannot but draw the attention of a naturalist, I have often gone down to examine the economy of these grylli, and study their mode of life; but they are so shy and cautious that it is no easy matter to get a sight of them; for, feeling a person's footsteps as he advances, they stop short in the midst of their song, and retire backward nimbly into their burrows, where they lurk till all suspicion of danger is over.

At first we attempted to dig them out with a spade, but without any great success : for either we could not get to the bottom of the hole, which often terminated under a great stone; or else, in breaking up the ground, we inad-

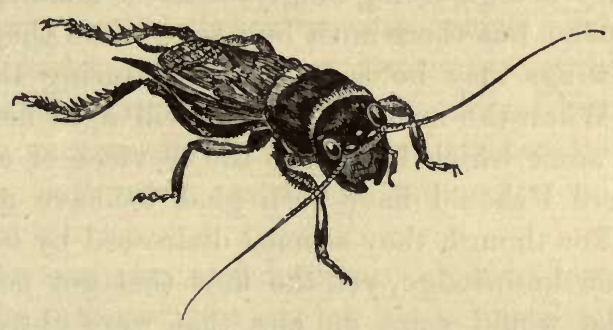

FIELD) CRICKET.

vertently squeezed the poor insect to death. Out of one so bruised we took a multitude of eggs, which were long and narrow, of a yellow colour, and covered with a very tough skin. By this accident we learned to distinguish the male from the female: the former of which is shining black, with a golden stripe across his shoulders; the latter is more dusky, more capacious about the abdomen, and carries a long sword-shaped weapon at her tail, which probably is the instrument with which she deposits her eggs in crannies and safe receptacles.

Where violent methods will not avail, more gentle means will often succeed; and so it proved in the present case : for though a spade be too boisterous and rough an implement, a pliant stalk of grass, gently insinuated into the caverns, will probe their windings to the bottom, and quickly 
bring out the inhabitant; and thus the liumane inquirer may gratify his curiosity without injuring the object of it. It is remarkable that, though these insects are furnished with long legs behind, and brawny thighs for leaping, like grasshoppers, yet when driven from their holes they show no activity, but crawl along in a shiftless manner, so as easily to be taken; and again, though provided with a curious apparatus of wings, yet they never exert them when there seems to be the greatest occasion. The males only make that shrilling noise, perhaps out of rivalry and emulation, as is the case with many animals which exert some sprightly note during their breeding time : it is raised by a brisk friction of one wing against the other. They are solitary beings, living singly, male or female, each as it may happen; but there must be a time when they pair, and then the wings may be useful, perhaps during the hours of night. When the males meet they will fight fiercely, as I found by some which I put into the crevices of a dry stone wall, where I should have been glad to have mado them settle. For though they seemed distressed by being taken out of their knowledge, yet the first that got possession of the chinks would seize on any that were obtruded upon them with a vast row of serrated fangs. With their strong jaws, toothed like the shears of a lobster's claws, they perforate and round their curious regular cells, having no fore-claws to dig like the mole cricket. When taken in hand, I could not but wonder that they never offered to defend themselves, though armed with such formidable weapons. Of such herbs as grow before the mouths of their burrows they eat indiscriminately; and on a little platform, which they make just by, they drop their dung; and never, in the daytime, seem to stir more than two or three inches from home. Sitting in the entrance of their caverns, they chirp all night as well as day from the middle of the month of May to the middle of July; and in hot weather, when they are most vigorous, they make the hills echo; and, in the stiller hours of darkness, may be heard to a considerable distance. In the beginning of the season their notes are more faint and inward; but become 
louder as the summer advances, and so die away again by degrees.

Sounds do not always give us pleasure according to their sweetness and melody, nor do harsh sounds always displease. We are more apt to be captivated or disgusted with the associations which they promote, than with the notes themselves. Thus the shrilling of the field-cricket, though sharp and stridulous, yet marvellously delights some hearers, filling their minds with a train of summer ideas of everything that is rural, verdurous, and joyous.

About the 10th of March the crickets appear at the mouths of their cells, which they then open and bore, and shape very elegantly. All that I ever have seen at that season were in their pupa state, and had only the rudiments of wings lying under a skin or coat, which must be cast before the insect can arrive at its perfect state ${ }^{1}$ from whence I should suppose that the old ones of last year do not always survive the winter. In August. their holes begin to be obliterated, and the insects are seen no more till spring.

Not many summers ago I endeavoured to transplant a solony to the terrace in my garden, by boring deep holes in the sloping turf. The new inhabitants stayed some time, and fed and sung, but wandered away by degrees, and were heard at a farther distance every morning; so that it appears that on this emergency they made use of their wings in attempting to return to the spot from which they were taken.

One of these crickets, when confined in a paper cage and set in the sun, and supplied with plants moistened with water, will feed and thrive, and become so merry and loud as to be irksome in the same room where a person is sitting: if the plants are not wetted it will die.

1 We have observed that they cast these skins in April, which are then seen lying at the mouths of their holes.-G. W. 


\section{LETTER XLVII.}

TO THE HONOURABLE DAINES BARRINGTON.

Selborne.

"Far firom all resort of mirth, Save the cricket on the hearth."

MrLton's Il Penseroso.

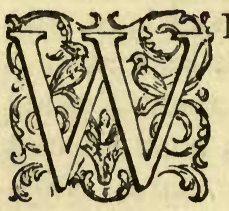

HILE many other insects must be sought after in fields, and woods, and waters, tho Gryllus domesticus, or house-cricket, resides altogether within our dwellings, intruding itself upon our notice, whether we will or no. This species delights in new-built houses, being, like the spider, pleased with the moisture of the walls ; and besides, the softness of the mortar enables them to burrow and mine between the joints of the bricks or stones, and to open communications from one room to another. They are particularly fond of kitchens and bakers' ovens, on account of their perpetual warmth.

Tender insects that live abroad either enjoy only tho short period of one summer, or else doze away the cold uncomfortable months in profound slumbers; but these, residing as it were in a torrid zone, are always alert and merry: a good Christmas fire is to them like the heats of the dog-days. Though they are frequently heard by day, yet is their natural time of motion only in the night. As soon as it grows dusk, the chirping increases, and they come running forth, and are from the size of a flea to that of their full stature. As one should suppose, from the burning atmosphere which they inhabit, they are a thirsty race, and show a great propensity for liquids, being found frequently drowned in pans of water, milk, broth, or the like. Whatever is moist they affect; and, therefore, often gnaw holes in wet woollen stockings and aprons that are hung to the fire: they are the housewife's barometer, foretelling her 
when it will rain, and are prognostic sometimes, she thinks, of ill or good luck; of the death of a near relation, or the approach of an absent lover. By being the constant companions of her solitary hours, they naturally become the objects of her superstition. These crickets are not only very thirsty, but very voracious; for they will eat the scummings of pots, and yeast, salt, and crumbs of bread, and any kitchen offal or sweepings. In the summer we have observed them to fly, when it became dusk, out of the windows, and over the neighbouring roofs. This feat of activity accounts for the sudden manner in which they often leave their haunts, as it does for the method by which they come to houses where they were not known before. It is remarkable that many sorts of insects seem never to use their wings but when they have a mind to shift their quar-

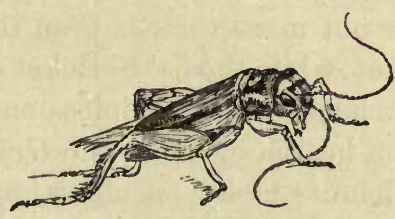

HOUSE CRICKET.

ters and settle new colonies. When in the air they move volatu undoso, in waves or curves, like wooùpeckers, opening and shutting their wings at every stroke, and so are always rising or sinking.

When they increase to a great degree, as they did once in the house where I am now writing, they become noisome pests, flying into the candles and dashing into people's faces, but may be blasted and destroyed by gunpowder discharged into thcir crevices and crannies. In families, at such times, they are, like Pharaoh's plague of frogs, "in their bed-chambers and upon their beds, and in their ovens, and in their kneading-troughs." I Their shrilling noise is occasioned by a brisk attrition of their wings. Cats catch hearth-crickets, and, playing with them as they do with 
mice, devour them. Crickets may be destroyed, like wasps, by phials half filled with beer, or any liquid, and set in their haunts; for, being always eager to drink, they will crowd in till the bottles are full. ${ }^{1}$

\section{LETTER XLVIII.}

\section{TO THE HONOURABLE DAINES BARRINGTON.}

Selborne.

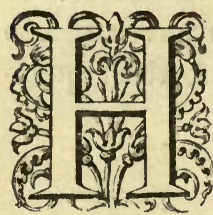

OW diversified are the modes of life not only of incongruous but even of congenerous animals; and yet their specific distinctions are not more various than their propensities. Thus, while the field-cricket delights in sunny dry banks, and the house-cricket rejoices amidst the glowing heat of the kitchen hearth or oven, the Gryllus gryllotalpa, or mole cricket, haunts moist meadows, and frequents the sides of ponds and banks of streams, performing all its functions in a swampy wet soil. With a pair of fore-feet, curiously adapted to the purpose, it burrows and works under ground like the mole, raising a ridge as it proceeds, but seldom throwing up hillocks.

As mole-crickets often infest gardens by the sides of canals, they are unwelcome guests to the gardener, raising up ridges in their subterraneous progress, and rendering the walks unsightly. If they take to the kitchen quarters, they occasion great damage among the plants and roots, by destroying whole beds of cabbages, young legumes, and flowers. When dug out they seem very slow and helpless, and make no use of their wings by day, but at night they come abroad and make long excursions, as I have been con-

1 Some additional particulars respecting the house-cricket will be found hereafter in the Observations on Insects.-ED.

${ }^{2}$ Gryllotalpa vulgaris, Latr.-ED. 
vinced by finding stragglers in a morning in improbabie places. In fine weather, about the middle of April, and just at the close of day, they begin to solace themselves with a low, dull, jarring note, continued for a long time without interruption, and not unlike the chattering of the fern-owl or goat-sucker, but more inward.

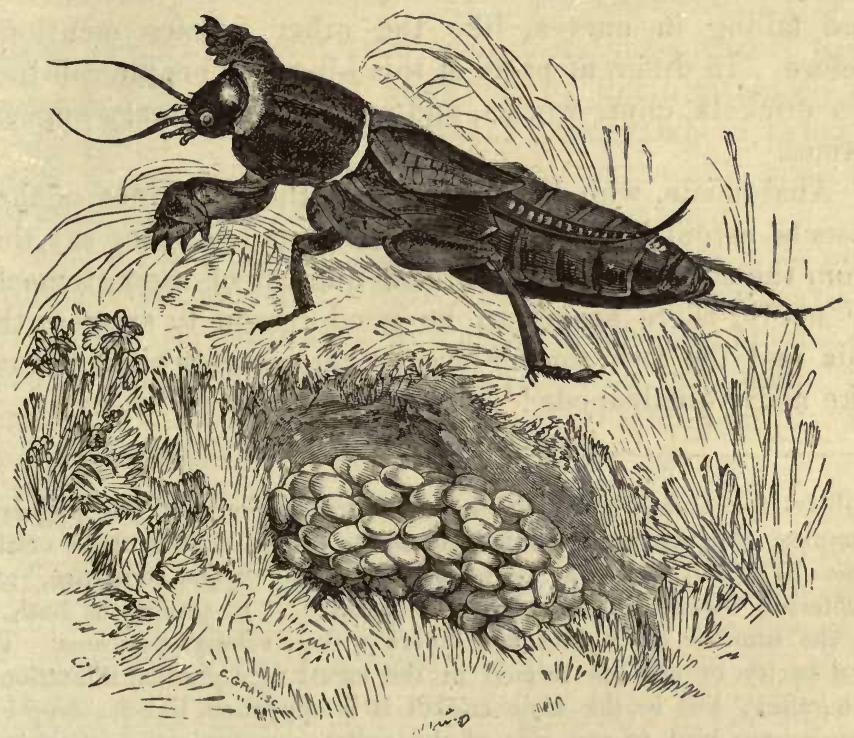

MOLE CRICKET AND NEST.

About the beginning of May they lay their eggs, as I was once an eye-witness; for a gardener, at a house where I was on a visit, happening to be mowing, on the 6 th of that month, by the side of a canal, his scythe struck too deep, pared off a large piece of turf, and laid open to view a curious scene of domestic economy: "6 ingentem lato dedit ore fenestram :

Apparet doinus intùs, et atria longa patescunt :

Apparent penetralia."

There were many caverns and winding passages leading to a kind of chamber, neatly smoothed and rounded, and about the size of a moderate snuff-box. Within this secret 
nursery were deposited near a hundred eggs of a dirty yellow colour, and enveloped in a tough skin, but too lately excluded to contain any rudiments of young, being full of a viscous substance. The eggs lay but shallow, and within the influence of the sun, just under a little heap of fresh moved mould, like that which is raised by ants.

When mole crickets fly, they move cursu undoso, rising and falling in curves, like the other species mentioned before. In different parts of this kingdom people call them fen crickets, churr worms, and eve churrs, all very apposite names.

Anatomists, who have examined the intestines of these insects, astonish me with their accounts ; for they say that, from the structure, position, and number of their stomachs, or maws, there seems to be good reason to suppose that this and the two former species ruminate or chew the cud like many quadrupeds !'

1 In the Hunterian Collection are preparations of the singularly complex stomach here alluded to as it exists in the mole cricket (No. 611) and in the locust (Nos. 474, 610). "The structure," says Professor Owen, in a note to this passage, "is similar in both, as to the number of cavities, but diflers in their relative positions. The first cavity, or crop, is formed in the locust by a gradual dilatation of the gullet; but in the mole cricket it is appended, like the crop of a granivorous bird, to one side of the gullet, communicating with it by a lateral opening. The canal which interrenes between the crop and gizzard is relatively longer in the mole cricket than in the locust. Its gizzard is small, but armed internally with longitudinal rows of complex teeth. Two large lateral pouches open into the lower part, or termination, of the gizzard. The analogy between this digestive apparatus and that of the ruminants is vague, and does not extend beyond the number of cavities. It is more like that of the bird; and since the comminuting or masticating organs are situated, as in the feathered class, in the stomach, it cannot be supposed that the fond is again returned to the mouth, where it has already received all the division which the oral instruments can effect." - ED. 


\section{LETTER XLIX.}

\section{TO THE HONOURABLE DAINES BARRINGTON.}

Selborne, May 7, 1779.

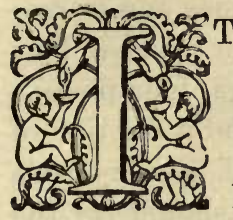

$T$ is now more than forty years that $I$ have paid some attention to the ornithology of this district, without being able to exhaust the subject: new occurrences still arise as long as any inquiries are kept alive.

In the last week of last month five of those most rare birds, too uncommon to have obtained an English name, but known to naturalists by the terms of Himantopus, or Loripes, and Charadrius Himantopus, ${ }^{1}$ were shot upon the verge of Frinsham Pond, a large lake belonging to the Bishop of Winchester, and lying between Wolmer Forest and the town of Farnham, in the county of Surrey. The pond-keeper says there were three brace in the flock; but that, after he had satisfied his curiosity, he suffered the sixth to remain unmolested. One of these specimens I procured, and found the length of the legs to be so extraordinary, that, at first sight, one might have supposed the shanks had been fastened on to impose on the credulity of the beholder: they were legs in caricatura; and had we seen such proportions on a Chinese or Japan screen we should have made large allowances for the fancy of the draughtsman. These birds are of the plover family, and might with propriety be called the stilt plovers. Brisson, under that idea, gives them the apposite name of L'Echasse. My specimen, when drawn and stuffed with pepper, weighed only four ounces and a quarter; though the naked part of the thigh measured three inches and a half, and the legs

1 Himantopus candidus, Bonnaterre ; $H$. melanopterus, Temminck. In the first edition of the present work, which appeared in quarto in 1789, amongst other illustrations is a full-page one of this singular-looking bird.-ED. 
four inches and a half. Hence we may safely assert that these birds exhibit, weight for inches, incomparably the greatest length of legs of any known bird. The flamingo, for instance, is one of the most long-legged birds, and yet it bears no manner of proportion to the Himantopus; for a cock flamingo weighs, at an average, about four pounds avoirdupois; and his legs and thighs measure usually about twenty inches. But four pounds are fifteen times and a fraction more than four ounces and one quarter; and if four ounces and a quarter have eight inches of legs, four pounds must have one hundred and twenty inches and a fraction of legs; viz. somewhat more than ten feet; such a monstrous proportion as the world never saw!. If you should try the experiment in still larger birds, the disparity would still increase. It must be matter of great curiosity to see the stilt plover move; to observe how it can wield such a length of lever with such feeble muscles as the thighs seem to be furnished with. At best one should expect it to be but a bad walker: but what adds to the wonder is, that it has no back toe. Now without that steady prop to support its steps it must be liable, in speculation, to perpetual vacillations, and seldom able to preserve the true centre of gravity.

The old name of Himantopus is taken from Pliny; and, by an awkward metaphor, implies that the legs are as slender and pliant as if cut out of a thong of leather. Neither Willughby nor Ray, in all their curious researches, either at home or abroad, ever saw this bird. Mr. Pennant never met with it in all Great Britain, but observed it often in the cabinets of the curious at Paris. Hasselquist says that it migrates to Egypt in the autumn : and a most accurate observer of nature has assured me that he has found it on the banks of the streams in Andalusia.

Our writers record it to have been found only twice in Great Britain. ${ }^{1} \quad$ From all these relations it plainly appears

1 The two specimens here referred to are doubtless those recorded by Sibbald and Pennant as having been procured near Dumfries (cf. Sibbald, "Hist. Scot." lib. iii. p. 18; and Pennant, "Caledonian 
that these long-legged plovers are birds of South Europe, and rarely visit our island; and when they do, are wanderers and stragglers, and impelled to make so distant and northern an excursion from motives or accidents for which we are not able to account. One thing may fairly be

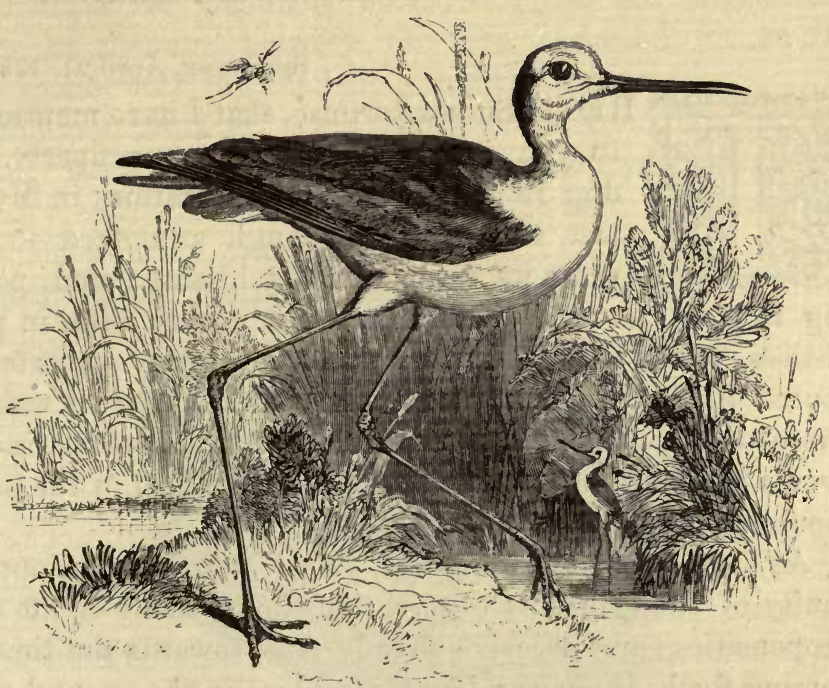

BLACK-WINGED STILT.

deduced, that these birds come over to us from the continent, since nobody can suppose that a species not noticed once in an age, and of such a remarkable make, can constantly breed unobserved in this kingdom.

Zoology," p. 35, pl.4). Gilbert White's notice of this species was the next in order of date, and since that time some thirty additional instances of its occurrence have been placed on record ( $c f$. "Handbook of British Birds," pp. 135, 136). One of these relates to the occurrence of a specimen in 1832 at the very pond where some fifty years previously it had been noticed by White. The author of "Ornithological Rambles in Sussex" has given a very pleasing account of the habits of this singular bird, as observed on its occurrence in Sussex, in the "Ibis" for 1859 (p. 395), to which account the reader would do well to refer.-ED. 


\section{LETTER L. \\ TO THE HONOURABLE DAINES BARRINGTON.}

Selborne, April 21, 1780.

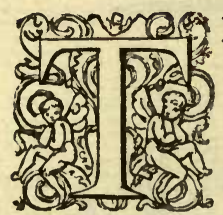

HE old Sussex tortoise, that I have mentioned to you so often, is become my property. I dug it out of its winter dormitory in March last, when it was enough awakened to express its resentment by hissing; and, packing it in a box with earth, carried it eighty miles in post chaises. The rattle and hurry of the journey so perfectly roused it, that, when I turned it out on a border, it walked twice down to the bottom of my garden: however, in the evening, the weather being cold, it buried itself in the looso mould, and continues still concealed.

As it will be under my eye, I shall now have an opportunity of enlarging my observations on its mode of life and propensities; and perceive already that, towards the time of coming forth, it opens a breathing place in the ground near its head, requiring, I conclude, a freer respiration as it becomes more alive. This creature not only goes under the earth from the middle of November to the middle of April, but sleeps great part of the summer; for it goes to bed in the longest days at four in the afternoon, and often does not stir in the morning till late. Besides, it retires to rest for every shower; and does not move at all in wet days.

When one reflects on the state of this strange being, it is a mattor of wonder to find that Providence should bestow such a profusion of days, such a seeming waste of longevity, on a reptile that appears to relish it so little as to squander more than two-thirds of its existence in a joyless stupor, and be lost to all sensation for months together in the profoundest of slumbers.

While I was writing this letter, a moist and warm after- 
noon, with the thermometer at $50^{\circ}$, brought forth troops of shell-snails; and, at the same juncture, the tortoise heaved up the mould and put out its head; and the next morning same forth, as it were raised from the dead; and walked about till four in the afternoon. This was a curious coincidence! a very amusing occurrence! to see such a similarity of feelings between the two espésкus! for so the Greeks call both the shell-snail and the tortoise.

Summer birds are, this cold and backward spring, unusually late: I have seen but one swallow yet. This conformity with the weather convinces me more and more that they sleep in the winter. ${ }^{1}$

More particulars respecting the old family tortoise.

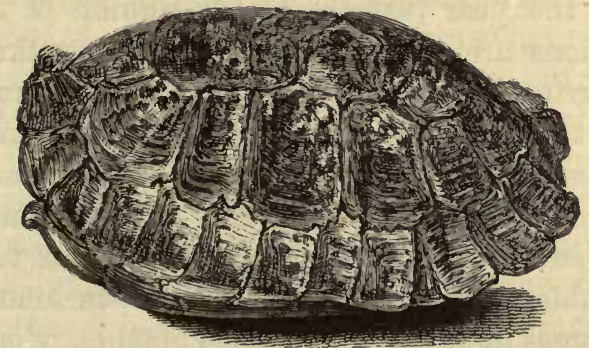

THE SHELL OF GILBERT WHITE'S TORTOISE.

Because we call this creature an abject reptile, we are too apt to undervalue his abilities, and depreciate his powers of instinct. Yet he is, as Mr. Pope says of his lord,

"Much too wise to walk into a well:"

and has so much discernment as not to fall down a haha; but to stop and withdraw from the brink with the readiest precaution.

Though he loves warm weather, he avoids the hot sun; because his thick shell, when once heated, would, as the poet says of solid armour - "scald with safety." He therefore spends the more sultry hours under the umbrella

1 In the original 4 to. this letter ends here, and the "particulars" which follow are given by way of supplement at the end of the Antiquities. It seems more appropriate, however, to reprint them here.-En. 
of a large cabbage leaf, or amidst the waving forests of an asparagus bed.

But as he avoids heat in the summer, so, in the decline of the year, he improves the faint autumnal beams, by getting within the reflection of a fruit-wall: and, though he never has read that planes inclining to the horizon receive a greater share of warmth, ${ }^{1}$ he inclines his shell, by tilting it against the wall, to collect and admit every feeble ray.

Pitiable seems the condition of this poor embarrassed reptile; to be cased in a suit of ponderous armour, which he cannot lay aside; to be imprisoned, as it were, within his own shell, must preclude, we should suppose, all activity and disposition for enterprise. Yet there is a season of the year.(usually the beginning of June) when his exertions are remarkable. He then walks on tiptoe, and is stirring by five in the morning; and, traversing the garden, examines every wicket and interstice in the fences, through which he will escape if possible; and often has eluded the care of the gardener, and wandered to some distant field. The motives that impel him to undertake these rambles seem to be of the amorous kind: his fancy then becomes intent on sexual attachments, which transport him beyond his usual gravity, and induce him to forget for a time his ordinary solemn deportment. ${ }^{2}$

1 Several years ago a book was written entitled "Fruit-walls improved by inclining them to the Horizon:" in which the author has shown, by calculation, that a much greater number of the rays of the sun will fall on such walls than on those which are perpendicular. G. TV.

2 This tortoise survived its master about a year, dying, it is believed, in the spring of 1794, after an existence in England of about fifty-four years, the last fourteen of which were spent at Selborne. Its shell, which is still preserved at Selborne, in the residence of the former owner, is considered by Mr. Bell to be that of Testudo marginata, the largest of the three European tortoises; but Mr. Bennett, for reasons stated by him in a note to this passage in his edition of the present work, was of opinion that it should be referred to a distinct species, and he proposed for it the specific name Whitei, in compliment to our author.-ED. 


\section{LETTER LI.}

\section{TO THE HONOURABLE DAINES BARRINGTON.}

Selborne, Sept. 3, 1781.

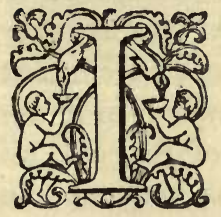

HAVE now read your Miscellanies through with much care and satisfaction; and am to return you my best thanks for the honourable mention made in them of me as a naturalist, which I wish I may deserve.

In some former letters I expressed my suspicions that many of the house martins do not depart in the winter far from this village. I therefore determined to make some search about the south-east end of the hill, where I imagined they might slumber out the uncomfortable months of winter. But supposing that the examination would be made to the best advantage in the spring, and observing that no martins had appeared by the 11th of April last; on that day I employed some men to explore the shrubs and cavities of the suspected spot. The persons took pains, but without any success; however, a remarkable incident occurred in the midst of our pursuit-while the labourers were at work, a house martin, the first that had been seen this year, came down the village in the sight of several people, and went at once into a nest, where it stayed a short time, and then flew over the houses; for some days after no martins were observed, not till the 16th of April, and then only a pair. Martins in general were remarkably late this year. 


\section{LETTER LII.}

TO THE HONOURABLE DAINES BARRINGTON.

Selborne, Sept. 9, 1781.

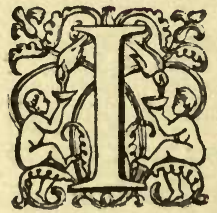

HAVE just met with a circumstance respect. ing swifts, which furnishes an exception to the whole tenor of my observations ever since I have bestowed any attention on that species of Hirundines. Our swifts, in general, withdrew this year about the first day of August, all save one pair, which in two or three days was reduced to a single bird. The perseverance of this individual made me suspect that the strongest of motives, that of an attachment to her young, could alone occasion so late a stay. I watched therefore till the 24th of August, and then discovered that, under the eaves of the church, she attended upon two young, which were fledged, and now put out their white chins from a crevice. These remained till the 27 th, looking more alert every day, and seeming to long to be on the wing. After this day they were missing at once; nor could I ever observe them with their dain coursing round the church in the act of learning to fly, as the first broods evidently do. On the 31 st I caused the eaves to be searched, but we found in the nest only two callow, dead, stinking swifts, on which a second nest had been formed. This double nest was full of the black shining cases of the Hippobosca hirundinis.

The following remarks on this unusual incident are obvious. The first is, that though it may be disagreeable to swifts to remain beyond the beginning of August, yet that they can subsist longer is undeniable. The second is, that this uncommon event, as it was owing to the loss of the first brood, so it corroborates my former remark, that swifts breed regularly but once; since, was the contrary the case, the occurrence above could neither be new nor rare.

P.S. One swift was seen at Lyndon, in the county of Rutland, in 1782, so late as the 3rd of September. 


\section{LETTER LIII.}

TO THE HONOURABLE DAINES BARRINGTON.

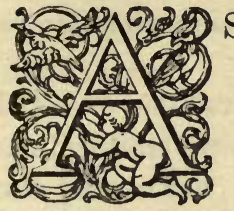

S I have sometimes known you make inquiries about several kinds of insects, I shall here send you an account of one sort which I little expected to have found in this kingdom. I had often observed that one particular part of a vine growing on the walls of my house was covered in the autumn with a black, dustlike appearance, on which the flies fed eagerly; and that the shoots and leaves thus affected did not thrive; nor did the fruit ripen. To this substance I applied my glasses; but could not discover that it had anything to do with animal life, as I at first expected: but, upon a closer examination behind the larger boughs, we were surprised to find that they were coated over with husky shells, from whose sides proceeded a cotton-like substance, surrounding a multitude of eggs. This curious and uncommon production put me upon recollecting what I have heard and read concerning the Coccus vitis viniferce of Linnæus, which, in the south of Europe, infests many vines, and is a horrid and loathsome pest. As soon as I had turned to the accounts given of this insect, I saw at once that it swarmed on my vine; and did not appear to have been at all checked by the preceding winter, which had been uncommonly severe.

Not being then at all aware that it had anything to do with England, I was much inclined to think that it came from Gibraltar among the many boxes and packages of plants and birds which I had formerly received from thence; and especially as the vine infested grew immediately under my study-window, where I usually kept my specimens. True it is that I had received nothing from thence for some years: but as insects, we know, are conveyed from one country to another in a very unex- 
pected manner, and have a wonderful power of maintaining their existence till they fall into a nidus proper for their support and increase, I cannot but suspect still that these Cocci came to me originally from Andalusia. Yet, all the while, candour obliges me to confess that Mr. Lightfoot has written me word, that he once, and but once, saw these insects on a vine at Weymouth in Dorsetshire; which, it is here to be observed, is a seaport town to which the Coccus might be conveyed by shipping.

As many of my readers may possibly never have heard of this strange and unusual insect, I shall here transcribe a passage from a natural history of Gibraltar, written by the Reverend John White, late vicar of Blackburn in Lancashire, but not yet published:-

"In the year 1770 a vine which grew on the east side of my house, and which had produced the finest crops of grapes for years past, was suddenly overspread on all the woody branches with large lumps of a white fibrous substance resembling spiders' webs, or rather raw cotton. It was of a very clammy quality, sticking fast to every thing that touched it, and capable of being spun into long threads. At first I suspected it to be the product of spiders, but could find none. Nothing was to be seen connected with it but many brown oval husky shells, which by no means looked like insects, but rather resembled bits of the dry bark of the vine. The tree had a plentiful crop of grapes set, when this pest appeared upon it; but the fruit was manifestly injured by this foul incumbrance. It remained all the summer, still increasing, and loaded the woody and bearing branches to a vast degree. I often pulled off great quantities by handfuls; but it was so slimy and tenacious that it could by no means be cleared. The grapes never filled to their natural perfection, but turned watery and vapid. Upon perusing the works afterwards of M. de Réaumur, I found this matter perfectly described and accounted for. Those husky shells, which I had observed, were no other than the female Coccus, from whose sides this cotton-like substance exudes, and serves as a covering and security for their eggs." 
To this account I think proper to add, that, although the female Cocci are stationary, and seldom remove from the place to which they stick, yet the male is a winged insect; and that the black dust which I saw was undoubtedly the excrement of the females, which is eaten by ants as well as flies. Though the utmost severity of our winter did not destroy these insects, yet the attention of the gardener in a summer or two has entirely relieved my vine from this filthy annoyance. ${ }^{1}$

As we have remarked above, that insects are often conveyed from one country to another in a very unaccountable manner, I shall here mention an emigration of small Aphides, which was observed in the village of Selborne no longer ago than August the 1st, 1785.

At about three o'clock in the afternoon of that day, which was very hot, the people of this village were surprised by a shower of Aphides, or smother-flies, which fell in these parts. Those that were walking in the street at that juncture found themselves covered with these insects, which settled also on the hedges and gardens, blackening all the vegetables where they alighted. My annuals were discoloured with them, and the stalks of a bed of onions were quite coated over for six days after. These armies were then, no doubt, in a state of emigration, and shifting their quarters; and might have come, as far as we know, from the great hop-plantations of Kent or Sussex, the wind being all that day in the easterly quarter. They were observed at the same time in great clouds about Farnham, and all along the vale from Farnham to Alton. ${ }^{2}$

1 It is not usual, as Mr. Bennett has remarked, for the Coccus of the vine to remain attached for several years in succession to a tree in the open air in England, for the severity of the winter generally destroys it at an early period. But to plants in greenhouses it often proves a serious evil. It can scarcely be regarded as an indigenous insect, and has probably been introduced into this country, from time to time, with cxotic plants.-En.

2 For various methods by which several insects shift their quarters, sec Derham's Physico-Theology.-G. W. 


\section{LETTER LIV.}

\section{TO THE HONOURABLE DAINES BARRINGTON.}

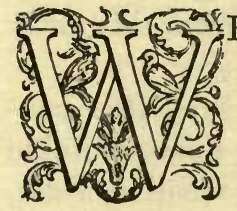

HEN I happen to visit a family where gold and silver fishes are kept in a glass bowl, I am always pleased with the occurrence, because it offers me an opportunity of observing the actions and propensities of those beings with whom we can be little acquainted in their natural state. Not long since I spent a fortnight at the house of a friend where there was such a vivary, to which I paid no small attention, taking every occasion to remark what passed within its narrow limits. It was here that I first observed the manner in which fishes die. As soon as the creature sickens, the head sinks lower and lower, and it stands, as it were, on its head, till, getting weaker, and losing all poise, the tail turns over, and at last it floats on the surface of the water with its belly uppermost. The reason why fishes, when dead, swim in that manner is very obvious, because, when the body is no longer balanced by the fins of the belly, the broad muscular back preponderates by its own gravity, and turns the belly uppermost, as lighter from its being a cavity, and because it contains the swimming-bladders, which contribute to render it buoyant. Some that delight in gold and silver fishes have adopted a notion that they need no aliment. True it is that they will subsist for a long time without any apparent food but what they can collect from pure water frequently changed; yet they must draw some support from animalcula and other nourishment supplied by the water, because, though they seem to eat nothing, yet the consequences of eating often

1 This letter was first published in the "Gentleman's Magazine" for 1786 (vol. lvi. p. 488), with the date of June 12th, and under the signature of V.-ED. 
drop from them. That they are best pleased with such jejune diet may easily be confuted, since, if you toss them crumbs they will seize them with great readiness, not to say greediness: however, bread should be given sparingly, lest, turning sour, it corrupt the water. They will also feed on the water-plant called Lemna (duck's meat), and also on small fry.

When they want to move a little, they gently protrude themselves with their pinnoe pectorales; but it is with their strong muscular tails only that they and all fishes shoot along with such inconceivable rapidity. It has been said that the eyes of fishes are immoveable; but these apparently turn them forward or backward in their sockets as their occasions require. They take little notice of a lighted candle, though applied close to their heads, but flounce and seem much frightened by a sudden stroke of the hand against the support whereon the bowl is hung, especially when they have been motionless, and are perhaps asleep. As fishes have no eyelids, it is not easy to discern when they are sleeping or not, because their eyes are always open.

Nothing can be more amusing than a glass bowl containing such fishes: the double refractions of the glass and water represent them, when moving, in a shifting and changeable variety of dimensions, shades, and colours; while the two mediums, assisted by the concavo-convex shape of the vessel, magnify and distort them vastly; not to mention that the introduction of another element and its inhabitants into our parlours engages the fancy in a very agreeable manner.

Gold and silver fishes, though originally natives of China and Japan, yet are become so well reconciled to our climate as to thrive and multiply very fast in our ponds and stews. Linnæus ranks this species of fish under the genus of Cyprinus, or carp, and calls it Cyprinus auratus.

Some people exhibit this sort of fish in a very fanciful way, for they cause a glass bowl to be blown with a large hollow space within, that does not communicate with it. In this cavity they put a bird occasionally; so that you may 
see a goldfinch or a linnet hopping, as it were, in the midst of the water, and the fishes swimming in a circle round it.

- The simple exhibition of the fishes is agreeable and pleasant, but in so complicated a way becomes whimsical and unnatural, and liable to the objection due to him,

"Qui variare cupit rem prodigialitèr unam."

\section{LETTER LV.}

TO THE HONOURABLE DAINES BARRINGTON.

October 10, 1781. :

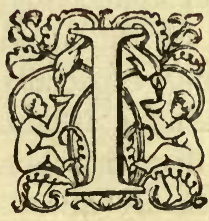

THINK I have observed before that much the most considerable part of the house martins withdraw from hence about the first week in October; but that some, the latter broods, I am now convinced, linger on till towards the middle of that month; and that at times, once perhaps in two or three years, a flight, for one day only, has shown itself in the first week in November.

Having taken notice, in October, 1780, that the last flight was numerous, amounting perhaps to one hundred and fifty, and that the season was soft and still, I was resolved to pay uncommon attention to these late birds, to find, if possible, where they roosted, and to determine the precise time of their retreat. The mode of life of these latter Hirundines is very favourable to such a design, for they spend the whole day in the sheltered districts, between me and the Hanger, sailing about in a placid, easy manner, and feasting on those insects which love to haunt a spot so secure from ruffling winds. As my principal object was to discover the place of their roosting, I took care to wait on them before they retired to rest, and was much pleased to find that, for several evenings together, just at a quarter past five in the afternoon, they all scudded away in great haste towards the south-east, and darted down among the 
low shrubs above the cottages at the end of the hill. This spot in many respects seems to be well calculated for their winter residence: for in many parts it is as steep as the roof of any house, and, therefore, secure from the annoyances of water; and it is, moreover, clothed with beechen shrubs, which, being stunted and bitten by sheep, make the thickest covert imaginable, and are so entangled as to be impervious to the smallest spaniel: besides, it is the nature of underwood beech never to cast its leaf all the winter, so that, with the leaves on the ground, and those on the twigs, no shelter can be more complete. I watched them on to the 13 th and 14th of October, and found their evening retreat was exact and uniform; but after this they made no regular appearance. Now and then a straggler was seen; and, on the 22nd of October, I observed two, in the morning, over the village, and with them my remarks for the season' ended.

From all these circumstances put together, it is more than probable that this lingering flight, at so late a season of the year, never departed from the island.' Had they indulged me that autumn with a November visit, as I much desired, I presume that, with proper assistants, I should have settled the matter past all doubt; but though the 3rd of November was a sweet day, and in appearance exactly suited to my wishes, yet not a martin was to be seen, and so I was forced, reluctantly, to give up the pursuit.

I have only to add, that were the bushes, which cover some acres, and are not my own property, to be grubbed and carefully examined, probably those late broods, and perhaps the whole aggregate body of the house martins of

1 Upon this passage the Rev. Mr. Herbert remarks that the author appears to have a strong bias to believe that martins, \&c., remain dormant in this country, having "taken up a very erroneous notion of the difficulty of the passage," and "drawing from circumstances probabilities which are not justified by his statements." It is scarcely necessary at the present day, either to follow or support Mr. Herbert in his arguments against hybernation, and in favour of migration, since all well. informed naturalists are now agreed that the theory advanced by Gilbert White is untenable. Were any proof of migration required, much stronger evidence than that adduced by Mr. Herbert could readily be supplied.-ED. 
this district, might be found there, in different secret dor. mitories; and that, so far from withdrawing into warmer climes, it would appear that they never depart 300 yards from the village.

\section{LETTER LVI.}

\section{TO THE HONOURABLE DAINES BARRINGTON.}

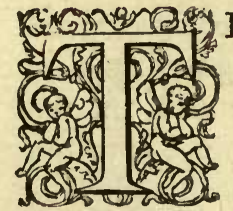

HEY who write on natural history cannot too frequently advert to instinct, that wonderful limited faculty, which, in some instances, raises the brute creation as it were above reason, and in others leaves them so far below it. Philosophers have defined instinct to be that secret influence by which every species is impelled naturally to pursue, at all times, the same way or track, without any teaching or example; whereas reason, without instruction, would often vary and do that by many methods which instinct effects by one alone. Now this maxim must be taken in a qualified sense; for there are instances in which instinct does vary and conform to the circumstances of place and convenience.

It has been remarked that every species of bird has a mode of nidification peculiar to itself; so that a schoolboy would at once pronounce on the sort of nest before him. This is the case among fields and woods and wilds; but in the villages round London, where mosses and gossamer, and cotton from vegetables, are hardly to be found, the nest of the chaffinch has not that elegant, finished appearance, nor is it so beautifully studded with lichens, as in a more rural district; and the wren is obliged to construct its house with straws and dry grasses, which do not give it that rotundity and compactness so remarkable in the edifices of that little architect. ${ }^{1}$ Again, the regular nest of the house

I May not the use of bright and fresh materials in the country, and 
martin is hemispheric ; but where a rafter, or a joist, or a cornice may happen to stand in the way, the nest is so contrived as to conform to the obstruction, and becomes flat or oval or compressed.

In the following instances instinct is perfectly uniform and consistent. There are three creatures, the squirrel, the field-mouse, and the bird called the nuthatch (Sitta europcea), ${ }^{1}$ which live much on hazel-nuts; and yet they open them each in a different way. The first, after rasping off the small end, splits the shell in two with his long fore teeth, as a man does with his knife; the second nibbles a hole with his teeth, so regular as if drilled with a wimble, and yet so small that one would wonder how the kernel can be extracted through it; while the last picks an irregular ragged hole with its bill: but as this artist has no paws to hold the nut firm while he pierces it, like an adroit workman, he fixes it, as it were, in a vice, in some cleft of a tree, or in some crevice; when, standing over it, he perforates the stubborn shell. We have often placed nuts in the chink of a gate-post where nuthatches havo been known to haunt, and have always found that those birds have readily penetrated them. While at work they make a rapping noise that may be heard at a considerable distance.

You that understand both the theory and practical part of music may best inform us why harmony or melody should so strangely affect some men, as it were by recollection, for days after a concert is over. What I mean the following passage will most readily explain:

"Præhabebat porrò vocibus humanis instrumentisque harmonicis musicam illam avium : non quod aliâ quioque non delectaretur; sed quod ex musicâ humanâ relinquerctur in

of those of a more sombre description in the neighbourhood of London be intended to answer the same purpose, namely, to render the nests secure from observation?-ED

1 The Scandinavian nuthatch, described by Linnæus ("Syst. Nat." i. p. 177,) as Sitta europaa, differs from that found in Grcat Britain, ancl the latter, therefore, should be distinguished as Sitta casia, that being the oldest name applied by Meyer ("Taschenb. Deutsch. Vögel," i. p. 128) to the eame bird as observed in Germany.-En. 
animo continens quædam, attentionemque et somnum con : turbans, agitatio; dum ascensus, exscensus, tenores, ac mutationes illæ sonorum et consonanticurum euntque redeuntque per phantasiam :-cum nihil tale relinqui possit ex modulationibus avium, quæ, quod non sunt perinde a nobis imitabiles, non possunt perinde internam facultatem commovere." - Gassendus in Vitâ Peireskii.

This curious quotation strikes me much by so well represonting my own case, and describing what I have so often felt, but never could so well express. When I hear fine music I am haunted with passages therefrom night and day; and especially at first waking, which, by their importunity, give me more uneasiness than pleasure : elegant lessons still tease my imagination, and recur irresistibly to my recollection at seasons, and even when I am desirous of thinking of more serious matters.

\section{LETTER LVII.}

TO TIIE HONOURABLE DAINES BARRINGTON.

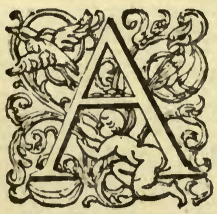

RARE, and I think a new, little bird frequents my garden, which I have great reason to think is the pettychaps: it is common in some parts of the kingdom; and I have received formerly several dead specimens from Gibraltar. This bird much resembles the white-throat, but has a more white or rather silvery breast and belly; is restless and active, like the willow-wrens, and hops from bough to bough, examining every part for food; it also runs up the stems of the crown-imperials, and, putting its head into the bells of those flowers, sips the liquor which stands in the nectarium of each petal. Sometimes it feeds on the ground like the hedge sparrow, by hopping about on the grass-plots and mown walks. ${ }^{1}$

1 This could not be the pettychaps, or garden warbler, as Gilbert 
One of my neighbours, an intelligent and observing man, informs me that, in the beginning of May, and about ten minutes before eight o'clock in the evening, he discovered a great cluster of house-swallows, thirty at least, he supposes, perching on a willow that hung over the verge of James Knight's upper pond. His attention was first drawn by the twittering of these birds, which sat motionless in a row on the bough, with their heads all one way, and, by their weight, pressing down the twig so that it nearly touched the water. In this situation he watched them till he could see no longer. Repeated accounts of this sort, spring and fall, induce us greatly to suspect that house swallows have some strong attachment to water, independent of the matter of food; and, though they may not retire into that element, yet they may conceal themselves in the banks of pools and rivers during the uncomfortable months of winter. ${ }^{1}$

One of the lieepers of Wolmer Forest sent me a peregrine falcon, which he shot on the verge of that district as it was devouring a wood-pigeon. The F'alco peregrinus, or haggard falcon, is a noble species of hawk seldom seen in the southern counties. ${ }^{2}$ In winter, 1767 , one was killed in the neighbouring parish of Faringdon, and sent by me to Mr. Pennant into North Wales. ${ }^{3}$ Since that time I have met with none till now. The specimen mentioned above was in fine preservation, and not injured by the shot; it

White supposed. His description of its appearance and habits points to the lesser whitethroat.-Ev.

1 This attachment of swallows to the neighbourhood of water at roosting-time may be easily accounted for by the circumstance that the willow branches not only afford them most convenient perches, but enable the birds to crowd close together and so secure greater warmth to individuals than they could possibly enjoy if each roosted upon a separate twig in trees or shrnbs of different growth. The noisy fluttering which ensues in a struggle for inside places must frequently have attracted the notice of attentive observers.-ED.

2 The peregrine breeds in the sea-cliffs of Sussex, Dorset, and the Isle of Wight, and doubtless did so in the days of Gilbert White, although the fact was unknown to him.-ED.

${ }^{3}$ See my tenth and elcventh [and twelfth] Letters to that gentleman. - G. W. 
measured forty-two inches from wing to wing, and twenty-one from beak to tail, and weighed two pounds and a half standing weight. This species is very robust, and wonderfully formed for rapine: its breast was plump and muscular; its thighs long, thick, and brawny; and its legs remarkably short and well set : the feet were armed with most formidable, sharp, long talons: the eyelids and cere of the bill were yellow, but the irides of the eyes dusky; the beak was thick and hooked, and of a dark colour, and had a jagged process near

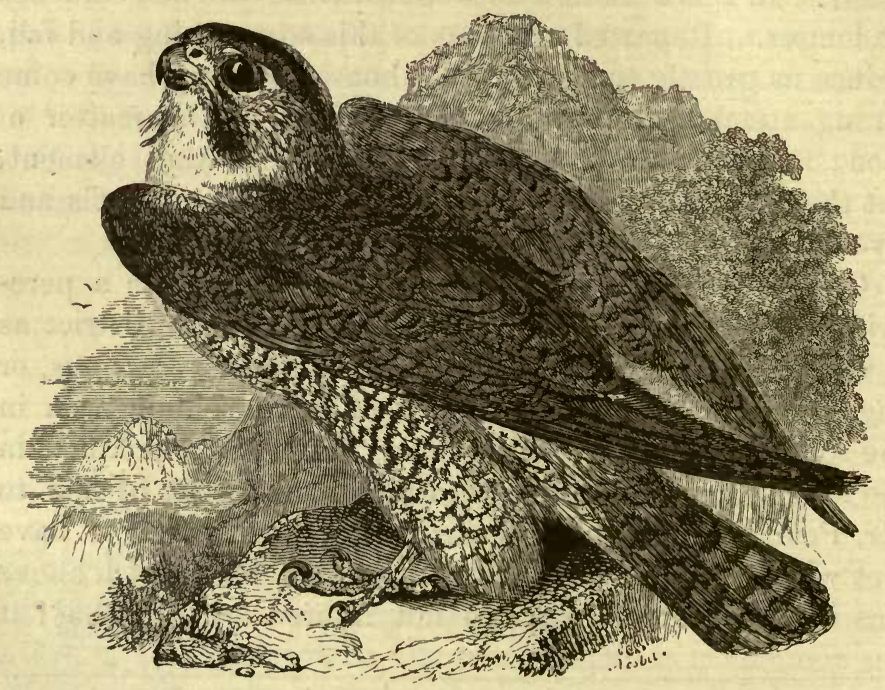

PEREGRINE FALCON.

the end of the upper mandible on each side: its tail, or train, was short in proportion to the bulk of its body: yet the wings, when closed, did not extend to the end of the train. From its large and fair proportions it might be supposed to have been a female; but I was not permitted to cut open the specimen. For one of the birds of prey, which are usually lean, this was in high case: in its craw were many barleycorus, which probably came from the crop of the wood pigeon, on which it was feeding when shot: for voracious birds do not eat grain; but, when devouring their quarry, with undistinguishing vehemence swallow bones 
and feathers, and all matters, indiscriminately. This falcon was probably driven from the mountains of North Wales or Scotland, where they are known to breed, by rigorous weather and deep snows that had lately fallen. ${ }^{1}$

\section{LETTER LVIII.}

\section{TO THE HONOURABLE DAINES BARRINGTON.}

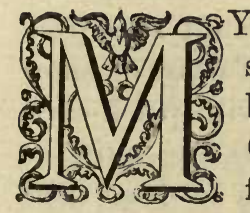

$Y$ near neighbour, a young gentleman in the service of the East India Company, has brought home a dog and a bitch of the Chinese breed from Canton; such as are fattened in that country for the purpose of boing eatcn : they are about the size of a moderate spaniel; of a pale yellow colour, with coarse bristling hairs on their bucks; sharp upright cars, and peaked heads, which give them a very fox-like appearance. Their hind legs are unusually straight, without any bend at the hock or ham, to such a degree as to give them an awkward gait when they trot. When they are in motion their tails are curved high over their backs like those of some hounds, and have a bare place each on the outside, from the tip midway, that does not seem to be matter of accident, but somewhat singular. Their eyes are jet black, small, and piercing: the insides of thcir lips and mouths of the same colour, and their tongues blue. The bitch has a dew-claw on each hind-leg; the dog has none. When taken out into a field the bitch showed some disposition for hunting, and dwelt on the scent of a covey of partridges till she sprung them, giving her tongue all the time. The dogs in South America are dumb; but these bark much in a short thick manner, like foxes; and

1 Although it is possible that this bird may have been migrating from the north, it is not unlikely to have been a wanderer from the Sussex or Dorsetshire sea-cliffs. See page 291, note 2.-ED. 
have a surly, savage demeanour like their ancestors, which are not domesticated, but bred up in sties, where they arc fed for the table with rice-meal and other farinaceous food. These dogs, having been taken on board as soon as weaned, could not learn much from their dam; yet they did not relish flesh when they came to England. In the islands of the Pacific Ocean the dogs are bred up on vegetables, and would not eat flesh when offered them by our circumnavigators.

We believe that all dogs, in a state of nature, have sharp, upright, fox-like ears; and that hanging ears, which are esteemed so graceful, are the effect of choice breeding and cultivation. Thus, in the "Travels of Ysbrandt Ides from Muscovy to China," the dogs which draw the Tartars on snow sledges near the river Oby are engraved with prick-ears, like those from Canton. The Kamtschatdales also train the same sort of sharp-eared, peaked-nosed dogs to draw their sledges; as may be seen in an elegant print engraved for Captain Cook's last voyage round the world.

Now we are upon the subject of dogs, it may not be impertinent to add, that spaniels, as all sportsmen know, though they hunt partridges and pheasants as it were by instinct, and with much delight and alacrity, yet will hardly touch their bones when offered as food; nor will a mongrel dog of my own, though he is remarkable for finding that sort of game. But, when we came to offer the bones of partridges to the two Chinese dogs, they devoured them with much greediness, and licked the platter clcan.

No sporting dogs will flush woodcocks till inured to the scent and trained to the sport, which they then pursue with vehemence and transport; but then they will not touch their bones, but turn from them with abhorrence, even when they are hungry.

Now that dogs should not be fond of the bones of such birds as they are not disposed to hunt is no wonder; but why they reject and do not care to eat their natural game is not so easily accounted for, since the end of hunting seems to be, that the chase pursued should be eaten. Dogs again will not devour the more rancid water-fowls, nor indeed the 
bones of any wild-fowls; nor will they touch the fotid bodies of birds that feed on offal and garbage: and indeed there may be somewhat of providential instinct in this circumstance of dislike; for vultures, ${ }^{1}$ and kites, and ravens, and crows, \&c. were intended to be messmates with $\operatorname{dogs}^{2}$ over their carrion; and seem to be appointed by Nature as fellowscavengers to remove all cadaverous nuisances from the face of the earth.

\section{LETTER LIX.}

\section{TO THE HONOURABLE DAINES BARRINGTON.}

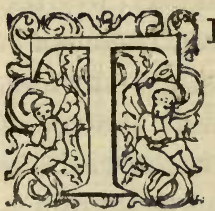

HE fossil wood buried in the bogs of Wolmer Forest is not yet all exhausted; for the peat cutters now and then stumble upon a log. ${ }^{3}$ I have just seen a piece which was sent by a village ; this was the but-end of a small oak, about five feet long, and about five inches in diameter. It had apparently been severed from the ground by an axe, was very ponderous, and as black as ebony. Upon asking the carpenter for what purpose he had procured it, he told me that it was to be sent to his brother, a joiner at Farnham, who was to make use of it in cabinet work, by inlaying it along with whiter woods.

Those that are much abroad on evenings after it is dark, in spring and summer, frequently hear a nocturnal bird passing by on the wing, and repeating often a short quick note. This bird I have remarked myself, but never could

1 Hasselquist, in his "Travels to the Levant," observes that the dogs and vultures at Grand Cairo maintain such a friendly intercourse as to bring up their young together in the same place.-G. W.

2 The Chinese word for a dog to a European ear sounds like quihloh.-G. W.

3 See Letter VI. to Pennant, p. 19, note 1-ED. 
make out till lately. I am assurod now that it is the stonecurlew (Charadrius odicncmus). ${ }^{1} \quad$ Some of them pass over or near my house almost every evening after it is dark, from the uplands of the hill and North Field, away down towards Dorton, where, among the streams and meadows, they find a greater plenty of food. Birds that fly by night are obliged to be noisy; their notes often repouted become signals or watch-words to keep them together, that they may not stray or lose each the other in the dark.

The evening proceedings and manœuvres of the rooks are curious and amusing in the autumn. Just before dusk they return in long strings from the foraging of the day, and rendezvous by thousands over Selborne Down, where they wheel round in the air, and sport and dive in a playful manner, all the while exerting their voices, and making a loud cawing, which, being blended and softened by the distance that we at the village are below them, becomes a confused noise or chiding; or rather a pleasing murmur, very engaging to the imagination, and not unlike the cry of a pack of hounds in hollow, echoing woods, or the rushing of the wind in tall trees, or the tumbling of the tide upon a pebbly shore. When this ceremony is over, with the last gleam of day, they retire for the night to the deep berenen woods of Tisted and Ropley. We romember a little girl who, as she was going to bed, used to remark on such an occurrence, in the true spirit of physico-theology, that the rooks were saying their prayers; and yet this child was much too young to be aware that the Scriptures have said of the Deity - that " he feedeth the ravens who call upon Him."

- Edicnemus crepitans, Temminck.-ED. 


\section{LETTER LX.}

\section{TO THE HONOURABLE DAINES BARRINGTON.}

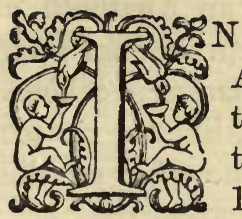

reading Dr. Huxham's "Observationes de Ä̈re," \&c. written at Plymouth, I find by those curious and accurate remarks, which contain an account of the weather from the year 1727 to the year 1748 inclusive, that though there is frequent rain in that district of Devonshire, yet tho quantity falling is not great: and that some years it has bcen very small; for in 1731 the rain measured only $17 \cdot 266$ inches; and in 174.1, 20.354; and again in 1743, only 20.908. Places near the sea have frequent scuds, that keep the atmosphere moist, yet do not reach far up into, the country; making thus the maritime situations appear wet; when the rain is not considerable. In the wettest years at Plymouth the doctor measured only once 36 ; and again once, viz. 1734, 37.114: a quantity of rain that has twice been exceeded at Selborne in the short period of my observations. Dr. Huxham remarks, that frequent small rains keep the air moist; while heavy ones render it more dry, by beating down the vapours. $\mathrm{He}$ is also of opinion that the dingy, smoky appearance in the sky, in very dry seasons, arises from the want of moisture sufficient to let the light through, and render the atmosphere transparent; because he had observed several bodies more diaphanous when wet than dry; and did never recollect that the air had that look in rainy seasons.

My friend, who lives just beyond the top of the down, brought his three swivel guns to try them in my outlet, with their muzzles towards the Hanger, supposing that the report would have had a great effect; but the experiment did not answer his expectation. He then removed them to the Alcove on the Hanger; when the sound, rushing along the Lythe and Comb Wood, was very grand; but it was at the Hermitage that the echoes and repercussions delighted the 
hearers; not only filling the Lythe with the roar, as if all the beeches were tearing up by the roots; but turning to the left, they pervaded the vale above Comb Wood Ponds; and after a pause seemed to take up the crash again, and to extend round Harteley Hangers, and to die away at last among the coppices and coverts of Ward-le-ham. It has been remarked before that this district is an Anathoth, a place of responses or echoes, and therefore proper for such experiments : we may farther add, that tho pauses in echoes, when they cease and yet are taken up again, like the pauses in music, surprise the hearers, and have a fine effect on the imagination.

The gentleman above mentioned has just fixed a barometer in his parlour at Newton Valence. The tube was first filled here (at Selborne) twice with care, when the mercury agreed and stood exactly with my own; but being filled again twice at Newton, the mercury stood, on account of the great elevation of that house, three-tenths of an inch lower than the barometers at this village, and so continucs to do, be the weight of the atmosphere what it may. The plate of the barometer at Newton is figured as low as $27^{\circ}$; because in stormy weather the mercury there will sometimes descend below $28^{\circ}$. We have supposed Newton House to stand 200 feet higher than this house: but if the rule holds good, which says that mercury in a barometer sinks one-tenth of an inch for every 100 feet elevation, then the Newton barometer, by standing three tenths lower than that of Selborne, proves that Newton House must be 300 feet higher than that in which I am writing, instead of 200 .

It may not be impertinent to add, that the barometers at Selborne stand three-tenths of an inch lower than the barometers of South Lambeth: whence we may conclude that the former place is about 300 feet higher than the latter; and with good reason, because the streams that rise with us run into the Thames at Weybridge, and so to London. Of course, therefore, there must be lower ground all the way from Selborne to South Lambeth; the distance between which, all the windings and indentings of the streams considered, cannot be less than 100 miles. 


\section{LETTER LXI.}

TO TIIE HONOURABLE DAINES BARRINGTON.

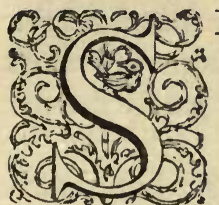

INCE the weather of a district is undoubtedly part of its natural history, I shall make no further apology for the four following letters, which will contain many particulars concerning some of the great frosts and a fow respecting some very hot summers, that have distinguished themselves from the rest during the course of my observations.

As the frost in January, 1768, was, for the small tine it lasted, the most severe that we had then known for many years, and was remarkably injurious to evergreens, some account of its rigour, and reason of its ravages, may be useful, and not unacceptable to persons that delight in planting and ornamenting; and may particularly become a work that professes never to lose sight of utility.

For the last two or three days of the former year there were considerable falls of snow, which lay deep and unifurm on the ground, without any drifting, wrapping up the more humble vegetation in perfect security. From the first day to the fifth of the new year more snow succeeded; but from that day the air became entirely clear; and the heat of the sun about noon had a considerable influence in sheltered situations.

It was in such an aspect that the snow on the author's evergreens was melted every day, and frozen intensely every night; so that the laurustines, bays, laurels, and arbutuses looked, in three or four days, as if they had been burned in the fire; while a neighbour's plantation of the same kind, in a high cold situation, where the snow was never melted at all, remained urinjured.

From hence I would infer, that it is the repeated melting and freezing of the snow that is so fatal to vegetation, 
rather than the severity of the cold. Therefore it highly behoves every planter, who wishes to escape the cruel mortification of losing in a few days the labour and hopes of years, to bestir himself on such emergencies; and, if his plantations are small, to avail himself of mats, cloths, peasohaum, straw, reeds, or any such covering for a short time; or if his shrubberies are extensive, to see that his people go about with prongs and forks, and carefully dislodge the snow from the boughs: since the naked foliage will shift much better for itself, than where the snow is partly melted and frozen again.

It may perhaps appear at first like a paradox; but doubtless the more tender trees and shrubs should never be planted in hot aspects; not only for the reason assigned above, but also, because thus circumstanced, they are disposed to shoot earlier in the spring, and to grow on later in the autumn than they would otherwise do, and so are sufferers by lagging or early frosts. For this reason also plants from Siberia will hardly endure our climate: because, on the very first advances of spring, they shoot away, and so are cut off by the severe nights of March or April.

Dr. Fothergill and otliers have experienced the same inconvenience with respect to the more tender shrubs from North America; which they therefore plant under north walls. There should also perhaps be a wall to the east to defend them from the piercing blasts from that quarter.

This observation might without any impropriety be carried into animal life; for discerning bee-masters now find that their hives should not in the winter be exposed to the hot sun, because such unseasonable warmth awakens the inhabitants too early from their slumbers; and, by putting their juices into motion too soon, subjects them afterwards to inconveniences when rigorous weather returns.

The coincidents attending this short but intense frost were, that the horses fell sick with an epidemic distemper, which injured the winds of many, and killed some; that colds and coughs were general among the human species; that it froze under people's beds for several nights; that neat was so hard frozen that it could not be spitted, and 
could not be secured but in cellars; that several redwings and thrushes were killed by the frost; and that the large titmouse continued to pull straws lengthwise from the eaves of thatched houses and barns in a most adroit manner, for a purpose that has been explained already. ${ }^{1}$

On the 3rd of January, Benjamin Martin's thormometer within doors, in a close parlour where there was no fire, fell in the night to $20^{\circ}$, and on the 4th to $18^{\circ}$, and on the 7th to $17 \frac{1}{2}^{\circ}$, a degree of cold which the owner never since saw in the same situation; and he regrets much that he was not able at that juncture to attend his instrument abroad. All this time the wind continued north and north-east; and yet on the 8th roost-cocks, which had been silent, began to sound their clarions, and crows to clamour, as prognostic of milder weather; and, moreover, moles began to heavo and work, and a manifest thaw took place. From the latter circumstance we may conclude that thaws often originate under ground from warm vapours which arise, else how should subterraneous animals receive such early intimations of their approach? Moreover, we have often observed that cold seems to descend from above; for, when a thermometer hangs abroad in a frosty night, the intervention of a cloud shall immediately raise the mercury $10^{\circ}$; and a cloar sky shall again compel it to descend to its former gage.

And here it may bo proper to observe, on what has been said above, that though frosts advance to their utmost severity by somewhat of a regular gradation, yet thaws do not usually come on by as regular a declension of cold, but often take place immediately from intense freezing, as men in sickness often mend at once from a paroxysm.

To the great credit of Portugal laurels and American junipers, be it remembcred that they remained untouched amidst the general havoc; hence men should learn to ornament chiefly with such trees as are able to withstand accidental screrities, and not subject themselves to the vexation of a luss which may befall them once perhaps in ten years, yet may hardly be recovered through the whole course of their lives.

1 See Letter XLI. to Pennant [p. 127].-G. W. 
As it appeared afterwards the ilexes wore much injured, the cypresses were half destroyed, the arbutuses lingered on, but never recovered; and the bays, laurustines, and laurels were killed to the ground, and the very wild hollies, in hot aspects, were so much affected that they cast all their leaves.

By the 14th of January the snow was entirely gone; the turnips emerged not damaged at all, save in sunny places, the wheat looked delicately, and the garden plants were well preserved; for snow is the most kindly mantle that infant vegetation can be wrapped in: were it not for that friendly meteor, no vegetable life could exist at all in northerly regions. Yet in Sweden the earth in April is not divested of snow for moro than a fortnight before the face of the country is covered with flowers.

\section{LETTER LXII.}

\section{TO THE HONOURABLE DAINES BARRINGTON.}

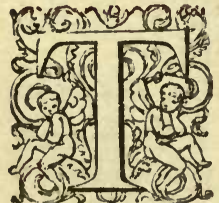

HERE were some circumstances attending the remarkable frost in January, 1776, so singular and striking, that a short detail of them may not be unacceptable.

The most certain way to be exact will be to copy the passages from my journal, which were taken from time to time as things occurred. But it may be proper previously to remark, that the first week in January was uncommonly wet, and drowned with vast rains from every quarter; from whence may be inferred, as there is great reason to believe is the case, that intense frosts seldom take place till the earth is perfectly glutted and chilled with water, ${ }^{1}$ and hence dry autumns are seldom followed by rigorous winters.

1 The autumn preceding January, 1768, was very wet, and particularly the month of September, during which there fell at Lyndon in the 
January 7 th.-Snow driving all the day, which was followed by frost, sleet, and some snow, till the 12 th, when a prodigious mass overwhelmed all the works of men, drifting over the tops of the gates and filling the hollow lanes.

On the 14th the writer was obliged to be much abroad, and thinks he never before or since has encountered such rugged Siberian weather. Many of the narrow roads were now filled above the tops of the hedges, through which the snow was driven into most romantic and grotesque shapes, so striking to the imagination as not to be seen without wonder and pleasure. The poultry dared not to stir out of their roostingplaces-for cocks and hens are so dazzled and confounded by the glare of snow that they would soon perish without assistance. The hares also lay sullenly in their seats, and would not move till compelled by hunger, being conscious, poor animals, that the drifts and heaps treacherously betray their footsteps, and prove fatal to numbers of them.

From the 14th the snow continued to increase, and began to stop the road waggons and coaches, which could no longer keep on their regular stages, and especially on the western roads, where the fall appears to have been deeper than in the south. The company at Bath, that wanted to attend the Queen's birthday, were strangely incommoded; many carriages of persons who got in their way to town, from Bath, as far as Marlborough, after strange embarrassments, here met with a ne plus ultra. The ladies fretted, and offered large rewards to labourers if they would shovel them a track to London, but the relentless heaps of snow were too bulky to be removed; and so the 18 th passed over, leaving the company in very uncomfortable circumstances at the Castle and other inns.

On the 20 th the sun shone out for the first time since the frost began-a circumstance that has been remarked before much in favour of vegetation. All this time the cold was not very intense, for the thermometer stood at $29^{\circ}, 28^{\circ}, 25^{\circ}$,

cornty of Rutland, six inches and a half of rain. And the terrible iong frost in 1739-40 set in after a rainy season, and when the springs were very high.-G. W. 
and thereabouts; but on the 21 st it descended to $20^{\circ}$. The birds now began to be in a very pitiable and starving condition. Tamed by the season, skylarks settled in the streets of towns, because they saw the ground was bare; rooks frequented dunghills close to houses, and crows watched horscs as they passed, and greedily devoured what dropped from them; hares now came into men's gardens, and scraping away the snow, devoured such plants as they could find.

On the 22nd the author had occasion to go to London, through a sort of Laplandian scene, very wild and grotesque indeed. But the metropolis itself exhibited a still more singular appearance than the country; for being imbedded deep in snow, the pavement of the streets could not be touched by the wheels or the horses' feet, so that the carriages ran about without the least noise. Such an exemption from din and clatter was strange, but not pleasant; it seemed to convey an uncomfortable idea of desolation:

"— ipsa silentia terrer.t."

On the 27th much snow fell all day, and in the evening the frost became very intense. At South Lambeth, for the four following nights, the thermometer fell to $11^{\circ}, 7^{\circ}, 6^{\circ}, 6^{\circ}$; and at Selborne to $7^{\circ}, 6^{\circ}, 10^{\circ}$; and on the 31st of January, just before sunrise, with rime on the trees and on the tubes of the glass, the quicksilver sunk exactly to zero, being $32^{\circ}$ below the freezing point; but by eleven in the morning, though in the shade, it sprung up to $16 \frac{1}{2}^{1}-$ a most unusual degree of cold this for the south of England! During these four nights the cold was so penetrating that it occasioned ice in warm chambers and under beds; and in the day the wind was so keen that pcrsons of robust constitution could scarcely endure to face it. The Thames was at once so frozen over, both above and below bridge that crowds ran

1 At Selborne the cold was greater than at any other place that the author could hear of with certainty; though some reported at the time that at a village in Kent the thermometer fell $2^{\circ}$ below zcro, viz., $34^{\circ}$ below the freezing point.

The thermometer uscd at Sclborne was graduated by Benjamin Martin.-G. IV. 
about on the ice. The streets were now strangely incumbered with snow, which crumbled and trod dusty, and, turning gray, resembled bay-salt: what had fallen on the roofs was so perfectly dry, that, from first to last, it lay twenty-six days on the houses in the city-a longer time than had been remembered by the oldest housekeepers living. According to all appearances we might now have expected the continuance of this rigorous weather for weeks to come, since every night increased in severity; but behold, without any apparent cause, on the 1st of February a thaw took place, and some rain followed before night-making good the observation above, that frosts often go off as it were at once, without any gradual declension of cold. On the 2nd of February the thaw persisted, and on the 3rd swarms of little insects were frisking and sporting in a court-yard at South Lambeth, as if they had felt no frost. Why the juices in the small bodies and smaller limbs of such minute beings are not frozen, is a matter of curious inquiry.

Severe frosts seems to be partial, or to run in currents; for at the same juncture, as the author was informed by accurate correspondents, at Lyndon, in the county of Rutland, the thermometer stood at $19^{\circ}$ : at Blackburn, in Lancashire, at $19^{\circ}$ : and at Manchester at $21^{\circ}, 20^{\circ}$, and $18^{\circ}$. Thus does some unknown circumstance strangely overbalance latitude, and render the cold sometimes much greater in the southern than in the northern parts of this kingdom.

The consequences of this severity were, that in Hampshire, at the melting of the snow, the wheat looked well, and the turnips came forth little injured. The laurels and laurustines were somewhat damaged, but only in hot aspects. No evergreens were quite destroyed; and not half the damage sustained that befell in January, 1768. Those laurels that were a little scorched on the south sides were perfectly untouched on their north sides. The care taken to shake the snow day by day from the branches seemed greatly to avail the author's evergreens. A neighbour's laurel-hedge, in a high situation, and facing to the north, was perfectly green and vigorous; and the Portugal laurels remained unhurt. 
As to the birds, the thrushes and blackbirds were mostly destroyed; and the partridges, by the weather and poachers, were so thinned that few remained to breed the following year.

\section{LETTER LXIII.}

TO THE HONOURABLE DAINES BARRINGTON.

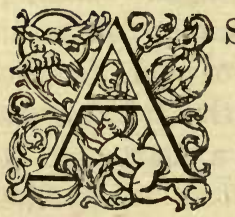

$\mathrm{S}$ the frost in December, 1784, was very extraordinary, you, I trust, will not be displeased to hear the particulars; and especially when I promise to say no more about the severities of winter after I have finished this letter.

The first week in December was very wet, with the barometer very low. On the 7 th, with the barometer at $28^{\circ}$ - five tenths, came on a vast snow, which continued all that day and the next, and most part of the following night; so that by the morning of the 9 th the works of men were quite overwhelmed, the lanes filled so as to be impassable, and the ground covered twelve or fifteen inches without any drifting. In the evening of the 9 th the air began to be so very sharp that we thought it would be curious to attend to the motions of a thermometer: we therefore hung out two; one made by Martin and one by Dollond, which soon began to show us what we were to expect; for, by ten o'clock, they fell to $21^{\circ}$, and at eleven to $4^{\circ}$, when we went to bed. On the 10th, in the morning, the quicksilver of Dollond's glass was down to half a degree below zero; and that of Martin's, which was absurdly graduated only to four degrees above zero, sunk quite into the brass guard of the ball; so that when the weather became most interesting, this was useless. On the 10th, at eleven at night, though the air was perfectly still, Dollond's glass went down to one degree below zero! This strange severity of the weather made me very desirous to know what degree of cold there might be in such an exalted and near situation as Newton. We 
had, therefore, on the morning of the 10th, written to Mr. - , and entreated him to hang out his thermometer, made by Adams; and to pay some attention to it morning and evening; expecting wonderful phenomena, in so elevated a region, at two hundred feet or more above my house. But, behold! on the 10th, at eleven at night, it was down only to $17^{\circ}$, and the next morning at $22^{\circ}$, when mine was at $10^{\circ}$ ! We were so disturbed at this unexpected reverse of comparative local cold, that we sent one of my glasses up, thinking that of Mr. - must, somehow, be wrongly constructed. But, when the instruments came to be confronted, they went exactly together; so that, for one night at least, the cold at Newton was $18^{\circ}$ less than at Selborne; and, through the whole frost, $10^{\circ}$ or $12^{\circ}$; and, indeed, when we came to observe consequences, we could readily credit this; for all my laurustines, bays, ilexes, arbutuses, cypresses, and even my Portugal laurels ${ }^{1}$, and (which occasions more regret) my fine sloping laurel hedge, were scorched up; while, at Newton, the same trees have not lost a leaf!

We had steady frost on to the 25th, when the thermometer in the morning was down to $10^{\circ}$ with us, and at Newton only to $21^{\circ}$. Strong frost continued till the 31st, when some tendency to thaw was observed; and, by January the $3 \mathrm{rd}, 1785$, the thaw was confirmed, and some rain fell.

A circumstance that I must not omit, because it was new to us, is, that on Friday, December the 10th, being bright sunshine, the air was full of icy spiculor, floating in all directions, like atoms in a sunbeam let into a dark room. We thought them at first particles of the rime falling from my tall hedges; but were soon convinced to the contrary, by making our observations in open places where no rime could

1 Mr. Miller, in his Gardener's Dictionary, says positively that the Portugal laurels remained untouched in the remarkable frost of 1739-40. So that either that accurate observer was much mistaken, or else the frost of December, 1784, was much more severe and destructive than that in the year above mentioned.-G. W. 
reach us. Were they watery particles of the air frozen ae they floated; or were they evaporations from the snow frozen as they mounted?

We were much obliged to the thermometers for the early information they gave us; and hurried our apples, pears, onions, potatoes, \&c. into the cellar, and warm closets; while those who had not, or neglected, such warnings, lost all their stores of roots and fruits, and had their very bread and cheese frozen.

I must not omit to tell you that, during those two Siberian days, my parlour cat was so electric, that had a person stroked her, and been properly insulated, the shock might have been given to a whole circle of people.

I forgot to mention before, that, during the two severe days, two men, who were tracing hares in the snow, had their feet frozen; and two men, who were much better employed, had their fingers so affected by the frost, while they were thrashing in a barn, that a mortification followed, from which they did not recover for many weeks.

This frost killed all the furze and most of the ivy, and in many places stripped the hollies of all their leaves. It came at a very early time of the year, before old November ended; and yet may be allowed from its effects to have exceeded any since 1739-40.

\section{LETTER LXIV.}

TO THE HONOURABLE DAINES BARRINGTON.

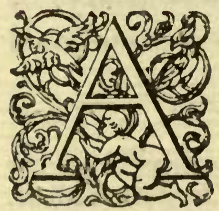

$S$ the effects of heat are seldom very remarkable in the northerly climate of England, where the summers are often so defective in warmth and sunshine as not to ripen the fruits of the earth so well as might be wished, I shall be more concise in my account of the severity of a summer season, and so make a little amends 
for the prolix account of the degrees of cold, and the inconveniences that we suffered from some late rigorous winters.

The summers of 1781 and 1783 were unusually hot and dry; to them therefore I shall turn back in my journals, without recurring to any more distant period. In the former of these years my peach and nectarine trees suffered so much from the heat that the rind on the bodies was scalded and came off; since which the trees have been in a decaying state. This may prove a hint to assiduous gardeners to fence and shelter their wall-trees with mats or boards, as they may easily do, because such annoyance is seldom of long continuance. During that summer also, I observed that my apples were coddled, as it were, on the trees; so that they had no quickness of flavour, and would not keep in the winter. This circumstance put me in mind of what I have heard travellers assert, that they never ate a good apple or apricot in the south of Europe, where the heats were so great as to render the juices vapid and insipid.

The great pests of a garden are wasps, which destroy all the finer fruits just as they are coming into perfection. In 1781 we had none: in 1783 there were myriads, which would have devoured all the produce of my garden, had wo not set the boys to take the nests, and caught thousands with hazel twigs tipped with birdlime: we have since employed the boys to take and destroy the large breeding wasps in the spring. Such expedients have a great effect on these marauders, and will keep them under. Though wasps do not abound but in hot summers, yet they do not prevail in every hot summer, as I have instanced in the two years above mentioned.

In the sultry season of 1783 honeydews were so frequent as to deface and destroy the beauties of my garden. $\mathrm{My}$ honeysuckles, which were one week the most sweet and lovely objects that the eye could behold, became the next the most loathsome; being enveloped in a viscous substance, and loaded with black aphides, or smother-flies. The occasion of this clammy appearance seems to be this, that 
in hot weather the effluvia of flowers in fields and meadows and gardens are drawn up in the day by a brisk evaporation, and then in the night fall down again with the dews, in which they are entangled; that the air is strongly scented, and therefore impregnated with the particles of flowers in summer weather, our senses will inform us; and that this clammy sweet substance is of the vegetable kind we may learn from bees, to whom it is very grateful: and we may be assured that it falls in the night, because it is always first seen in warm still mornings. ${ }^{1}$

On chalky and sandy soils, and in the hot villages about London, the thermometer has been often observed to mount as high as $83^{\circ}$ or $84^{\circ}$; but with us, in this hilly and woody district, I have hardly ever seen it exceed $80^{\circ}$, nor does it often arrive at that pitch. The reason, I conclude, is, that our dense clayey soil, so much shaded by trees, is not so easily heated through as those abovementioned: and, besides, our mountains cause currents of air and breezes; and the vast effluvia from our woodlands temper and moderate our heats.

\section{LETTER LXV.}

\section{TO THE HONOURABLE DAINES BARRINGTON.}

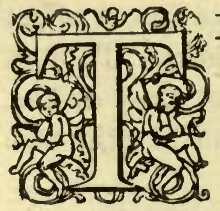

HE summer of the year 1783 was an amazing and portentous one, and full of horrible phenomena; for, besides the alarming meteors and tremendous thunder-storms that affrighted and distressed the different counties of this kingdom, the peculiar haze or smoky fog that

1 The conjecture here hazarded concerning the origin of honeydew is erroneous. Mr. Curtis has shown (Trans. Linn. Soc., vol. vi.) that this substance is the excrement of the Aphides. In order to convince a friend who was sceptical as to this fact, Mr. Rennie placed a sheet of writing paper under a branch where some Aphides were feeding, and 
prevailed for many weeks in this island, and in every part of Europe, and even beyond its limits, was a most extraordinary appearance, unlike any thing known within the memory of man. By my journal I find that I had noticed this strange occurrence from June 23 to July 20 inclusive, during which period the wind varied to every quarter without making any alteration in the air. The sun, at noon, looked as blank as a clouded moon, and shed a rustcoloured ferruginous light on the ground, and floors of rooms; but was particularly lurid and blood-coloured at rising and setting. All the time the heat was so intense that butchers' meat could hardly be eaten on the day after it was killed; and the flies swarmed so in the lanes and hedges that they rendered the horses half frantic, and riding irksome. The country people began to look with a superstitious awe, at the red, louring aspect of the sun; and indeed there was reason for the most enlightened person to be apprehensive; for, all the while, Calabria and part of the isle of Sicily were torn and convulsed with earthquakes; and about that juncture a volcano sprung out of the sea on the coast of Norway. On this occasion Milton's noble simile of the sun, in his first book of Paradise Lost, frequently occurred to my mind ; and it is indeed particularly applicable, because, towards the end, it alludes to a superstitious kind of dread, with which the minds of men are always impressed by such strange and unusual phenomena.

'

Looks through the horizontal misty air

Shorn of his beams; or from behind the moon,

In dim eclipse disastrous twilight sheds

On half the nations, and with fear of change

Perplexes monarchs."

over the leaves below them, which he previously cleaned from honeydew. The result, as he anticipated, was, that the paper was soon covered with honeydew, while the leaves below it were free.-En. 


\section{LETTER LXVI.}

TO THE HONOURABLE DAINES BARRINGTON.

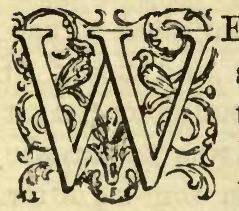

$\mathrm{E}$ are very seldom annoyed with thunderstorms; and it is no less remarkable than true, that those which arise in the south have hardly been known to reach this village; for before they get over us, they take a direction to the east or to the west, or sometimes divide into two, and go in part to one of those quarters, and in part to the other, as was truly the case in the summer of 1783, when though the country round was continually harassed with tempests, and often from the south, yet we escaped them all; as appears by my journal of that summer. ${ }^{1}$ The only way that I can at all account for this fact-for such it is-is that, on that quarter, between us and the sea, there are continual mountains, hill behind hill, such as Nore Hill, the Barnet, Butser Hill, and Portsdown, which somehow divert the storms, and give them a different direction. High promontories and elevated grounds have always been observed to attract clouds, and disarm them of their mischievous contents, which are discharged into the trees and summits as soon as they come in contact with those turbulent meteors; while the humble vales escape, because they are so far beneath them.

But, when I say I do not remember a thunderstorm from the south, I do not mean that we never have suffered from thunderstorms at all; for on June 5th, 1784, the thermometer in the morning being at $64^{\circ}$, and at noon at $70^{\circ}$, the barometer at $29^{\circ}$ - six tenths one-half, and the wind north, I observed a blue mist, smelling strongly of sulphur, hanging along our sloping woods, and seeming to

1 To this awful summer of 1783 , Cowper also alludes, in his Task, book ii. p. 41.-ED. 
indicate that thunder was at hand. I was called in about two in the afternoon, and so missed seeing the gathering of the clouds in the north, which they who were abroad assured me had something uncommon in its appearance. At about a quarter after two the storm began in the parish of Hartley, moving slowly from north to south; and from thence it came over Norton Farm, and so to Grange Farm, both in this parish. It began with vast drops of rain, which were soon succeeded by round hail, and then by convex pieces of ice, which measured three inches in girth. Had it been as extensive as it was violent, and of any continuance (for it was very short), it must have ravaged all the neighbourhood. In the parish of Hartley it did some damage to one farm; but Norton, which lay in the centre of the storm, was greatly injured; as was Grange, which lay next to it. It did but just reach to the middle of the village, where the hail broke my north windows, and all garden-lights and hand-glasses, and many of my neighbours' windows. The extent of the storm was about two miles in length and one in breadth. We were just sitting down to dinner; but were soon diverted from our repast by the clattering of tiles and the jingling of glass. There fell at the same time prodigious torrents of rain on the farms above mentioned, which occasioned a flood as violent as it was sudden; doing great damage to the meadows and fallows, by deluging the one and washing away the soil of the other. The hollow lane towards Alton was so torn and disordered as not to be passable till mended, rocks being removed that weighed two hundred-weight. Those that saw the effect which the great hail had on ponds and pools say that the dashing of the water made an extraordinary appearance, the froth and spray standing up in the air three feet above the surface. The rushing and roaring of the hail, as it approached, was truly tremendous.

Though the clouds at South Lambeth, near London, were at that juncture thin and light, and no storm was in sight, nor within hearing, yet the air was strongly electric; for the bells of an electric machine at that place rang repeatedly, and fierce sparks were discharged. 
When I first took the present work in hand, I proposed to have added an Annus Historico-Naturalis, or the Natural History of the Twelve Months of the Year; which would have comprised many incidents and occurrences that have not fallen into my way to be mentioned in my series of letters ; - but as Mr. Aikin, of Warrington, has lately published somewhat of this sort, and as the length of my correspondence has sufficiently put your patience to the test, I shall here take a respectful leave of you and natural history together; and am,

With all due deference and regard,

Your most obliged,

And most humble servant,

GiL. Whirz.

Selborxe, June $25,1787$.

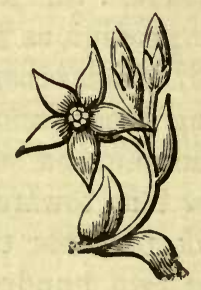




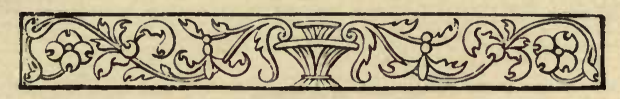

\title{
OBSERVATIONS
}

\author{
ON \\ VARIOUS PARTS OF NATURE, \\ FROM MR. WHITE'S MSS.
}

WITII REMARKS, BY MR. MARKWICK AND OTHFRS.

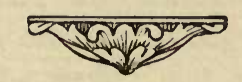




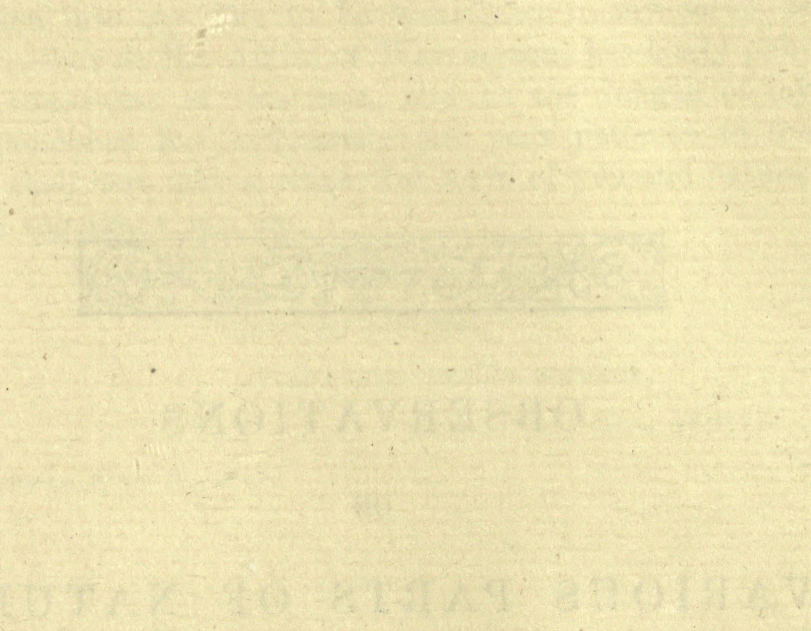




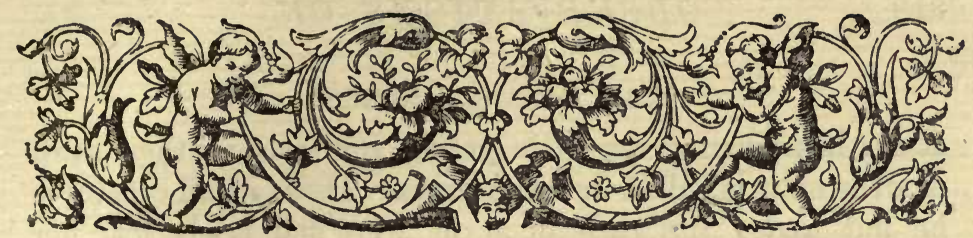

\section{OBSERVATIONS ON QUADRUPEDS.}

\section{SHEEP.}

(3) c1 (80) 1 in the shepherds say they tear their fleeces Tris with their own mouths and horns, and that (0) winters, being teased and tickled with a kind of lice.

After ewes and lambs are shorn, there is great confusion and bleating, neither the dams nor the young being able to distinguish one another as before. This embarrassment seems not so much to arise from the loss of the fleece, which may occasion an alteration in their appearance, as from the defect of that notus odor, discriminating each individual personally; which also is confounded by the strong scent of the pitch and tar wherewith they are newly marked; for the brute creation recognise each other more from the smell than the sight; and in matters of identity and diversity appeal much more to their noses than to their eyes. After sheep have been washed there is the same confusion, from the reason given above.

\section{RABBITS.}

RABBITS make incomparably the finest turf; for they not only bite closer than larger quadrupeds, but they allow no bents to rise: hence warrens produce much the most delicate turf for gardens. Sheep never touch the stalks of grasses. 


\section{CAT AND SQUIRRELS.}

A вог has taken three little young squirrels in their nest, or drey as it is called in these parts. These small creatures he put under the care of a cat who had lately lost her kittens, and finds that she nurses and suckles them with the same assiduity and affection as if they were her own offspring. This circumstance corroborates my suspicion, that the mention of exposed and deserted children being nurtured by female beasts of prey who had lost their young, may not be so improbable an incident as many have sup-

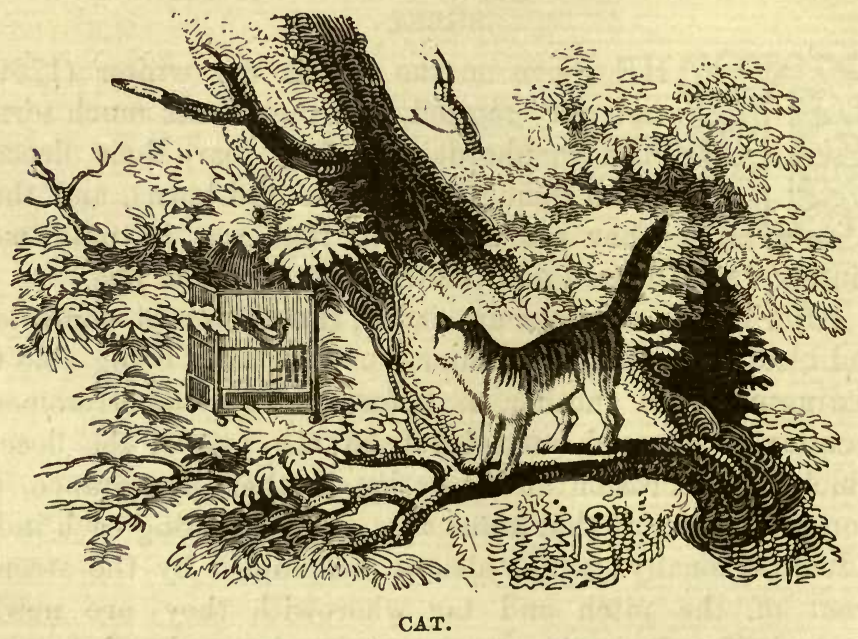

posed; and therefore may be a justification of those authors who have gravely mentioned what some have deemed to be a wild and improbable story.

So many people went to see the little squirrels suckled by a cat, that the foster mother became jealous of her charge, and in pain for their safety; and therefore hid them over the ceiling, where one died. This circumstance shows her affection for these foundlings, and that she supposes the squirrels to be her own young. Thus hens, when they have hatched ducklings, are equally attached to them as if they were their own chickens. 
HORSE.

As old hunting mare, which ran on the common, being taken very ill, ran down into the village, as it were to implore the help of men, and died the night following in the street.

\section{HOUNDS.}

The king's stag hounds came down to Alton, attended by a huntsman and six yeoman prickers, with horns, to try for the stag that has haunted Harteley Wood and its environs for so long a time. Many hundreds of people, horse and foot, attended the dogs to see the deer unharboured; but though the huntsman drew Harteley Wood, and Long Coppice, and Shrubwood, and Temple Hangers ; and in their way back Harteley and Ward-le-ham Hangers, yet no stag could be found.

The royal pack, accustomed to have the deer turned out before them, never drew the coverts with any address and spirit, as many people that were present observed: and this remark the event has proved to be a true one. For as a person was lately pursuing a pheasant that was wing-broken, in Harteley Wood, he stumbled upon the stag by accident, and ran in upon him as he lay concealed amidst a thick brake of brambles and bushes.

\section{OBSERVATIONS ON BIRDS.}

\section{BIRDS IN GENERAL.}

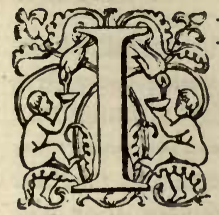

$\mathrm{N}$ severe weather, fieldfares, redwings, skylarks, and titlarks, resort to watered meadows for food: the latter wades up to its belly in pursuit of the pupæ of insects, and runs along upon the floating grass and weeds. Many gnats are on the snow near the water; these support the birds in part. 
Birds are much influenced in their choice of food by colour, for though white currants are a much sweeter fruit than red, yet they seldom touch the former till they have devoured every bunch of the latter.

Redstarts, flycatchers, and blackcaps arrive early in April. If these little delicate beings are birds of passage (as we have reason to suppose they are, because they are never seen in winter) how could they, feeble as they seem, bear up against such storms of snow and rain, and make their way through such meteorous turbulences, as one should suppose would embarrass and retard the most hardy and resolute of the winged nation? Yet they keep their appointed times and seasons; and in spite of frost and winds return to their stations periodically, as if they had met with nothing to obstruct them. The withdrawing and appearance of the short-winged summer birds is a very puzzling circumstance in natural history $!^{1}$

When the boys bring me wasps' nests, my bantam fowls fare deliciously, and when the combs are pulled to pieces, devour the young wasps in their maggot state with the highest glee and delight. Any insect-eating bird would do the same; and therefore I have often wondered that the accurate Mr. Ray should call one species of buzzard Buteo apivorous sive vespivorous, the honey buzzard, because some combs of wasps happened to be found in one of their nests. The combs were conveyed thither doubtless for the sake of the maggots or nymphs, and not for their honey: since none is to be found in the combs of wasps. Birds of prey occasionally feed on insects: thus have I seen a tame kite picking up the female ants full of eggs with much satisfaction.

1 That redstarts, flycatchers, blackcaps, and other slender-billed insectivorous small birds, particularly the swallow tribe, make their first appearance very early in the spring, is a well-known fact; though the flycatcher is the latest of them all in its visit (as this accurate naturalist observes in another place), for it is never seen before the month of May. If these delicate creatures come to us from a distant country, they will probably be exposed in their passage, as White justly remarks, to much greater difficulties from storms and tempests than their feeble powers 
ROOKS.

Rooks are continually fighting and pulling each other's nests to pieces : these proceedings are inconsistent with living in such close community. And yet if a pair offer to build on a single tree, the nest is plundered and demolished at once. Some rooks roost on their nest trees. The twigs which the rouks drop in building supply the poor with brushwood to light their fires. Some unhappy pairs are not permitted to finish any nests till the rest have completed their building. As soon as they get a few sticks together, a party comes and demolishes the whole. As soon as rooks have finished their nests, and before they lay, the cocks begin to feed the hens, who receive their bounty with a fondling tremulous voice, and fluttering wings, and all the little blandishments that are expressed by the young, while in a helpless state. This gallant deportment of the male is continued through the whole season of incubation. These birds do not pair on trees, nor in their nests, but on the ground in the open fields. ${ }^{1}$

appear to be able to surmount: on the other hand, if we suppose them to pass the winter in a dormant state in this country, concealed in carerus or other hiding places sufficiently guarded from the extreme cold of our winter to preserve their life, and that at the approach of spring they revive from their torpid state and reassume their usual powers of action, it will entirely remove the first difficulty, arising from the storms and tempests they are liable to meet with in their passage; but how are we to get over the still greater difficulty of their revivification from their torpid state? What degree of warmth in the temperature of the air is necessary to produce that effect, and how it operates on the functions of animal life, are questions not easily answered.

How could White suppose that Ray named this species the honey buzzard because it fed on honey, when he not only named it in Latin Buteo apivorus sive vespivorus, but expressly says that "it feeds on insects, and brings up its young with the maggots or nymphs of wasps ?"

That birds of prey, when in want of their proper food, flesh, sometimes feed on insects I have little doubt, and think I have observed the common buzzard to settle on the ground and pick up insects of some kind or other.-MARKwICK.

1 After the first brood of rooks are sufficiently fledged, they all leave their nest trees in the daytime, and resort to some distant place in search 


\section{THRUSHES.}

Thrushes during long droughts are of great service in hunting out shell snails, which they pull in pieces for their young, and are thereby very serviceable in gardens. Missel thrushes do not destroy the fruit in gardens like the other species of Turdi, but feed on the berries of misletoe, and in the spring on ivy berries, which then begin to ripen. In the summer, when their young become fledged; they leave neighbourhoods, and retire to sheep-walks and wild commons.

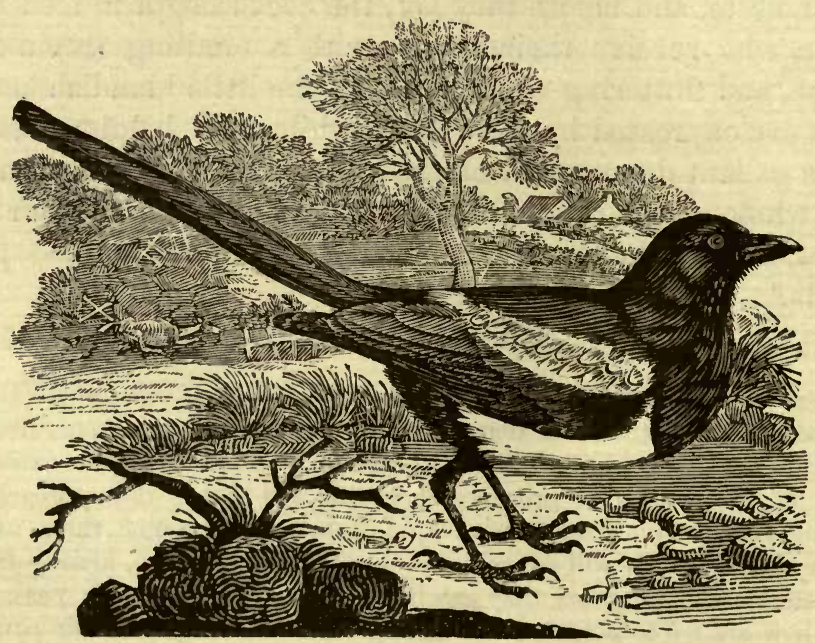

MAGPIE.

The magpies, when they have young, destroy the broods of missel thrushes; though the dams are fierce birds, and fight boldly in defence of their nests. It is probably to avoid such insults, that this species of thrush, though wild

of food, but return regularly every evening, in vast flights, to their nest trees, where, after flying round several times with much noise and clamour, till they are all assembled together, they take up their abode for the night.-MARK wick.

See Letter LIX. to Daines Barrington, p. 296.-ED. 
at other times, delights to build near houses, and in frequented walks and gardens. ${ }^{1}$

\section{POULTRY.}

MaNy creatures are endowed with a ready discernment to - see what will turn to their own advantage and emolument; and often discover more sagacity than could be expected. 'Thus my neighbour's poultry watch for waggons loaded

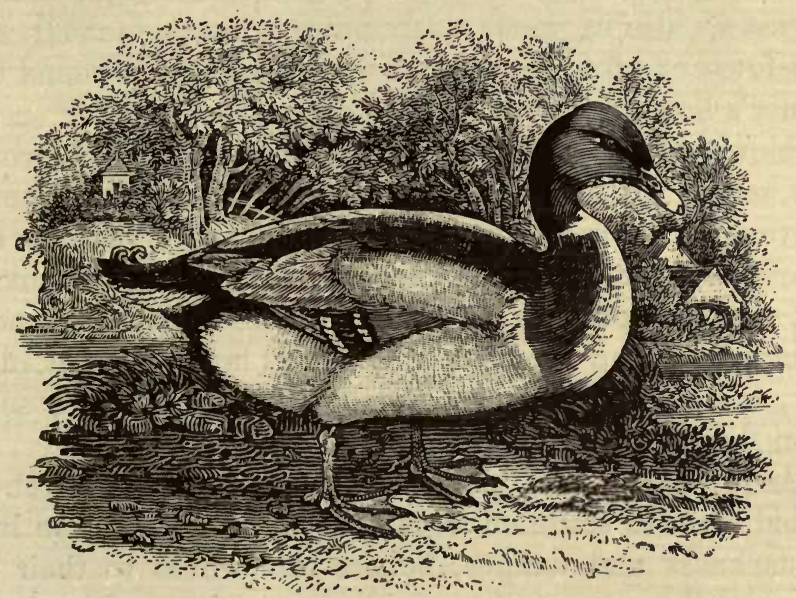

MALLARD.

with wheat, and running after them pick up a number of grains that are shaken from the sheaves by the agitation of the carriages. Thus, when my brother used to take down

1 Of the truth of the first of these observations I have been an eyewitness, having seen the common thrush feeding on the shell snail.

In the very early part of this spring (1797) a bird of this species used to sit every morning on the top of some high elms close by my windows, and delight me with its charming song, attracted thither, probably, by some ripe ivy berries that grew near the place.

I have remarked something like the latter fact, for I remember, many years ago, seeing a pair of these birds fly up repeatedly and attack some larger bird, which I suppose disturbed their nest in my orchard, uttering at the same time violent shrieks. Since writing the above, I have seen more than once a pair of these birds attack some magpies, that had disturbed their nest, with great violence and loud shrieks.-MARKwick. 
his gun to shoot sparrows, his cats would run out before him, to be ready to catch up the birds as they fell.

The earnest and early propensity of the Gallince to roost on high is very observable; and discovers a strong dread impressed on their spirits respecting vermin that may annoy them on the ground during the hours of darkness. Hence poultry, if left to themselves and not housed, will perch the winter through on yew trees and fir trees; and turkeys and guinea-fowls, heavy as they are, get up into apple trees: pheasants also in woods sleep on trees to avoid foxes; while pea-fowls climb to the tops of the highest trees round their owner's house for security, let the weather be ever so cold or blowing. Partridges, it is true, roost on the ground, not having the faculty of perching; but then the same fear prevails in their minds; for, through apprehensions from pole-cats and stoats, they never trust themselves to coverts, but nestle together in the midst of large fields, far removed from hedges and coppices, which they love to haunt in the day, and where at that season they can skulk more secure from the ravages of rapacious birds.

As to ducks and geese, their awkward splay web-feet forbid them to settle on trees; they therefore, in the hours of darkness and danger, betake themselves to their own element, the water, where amidst large lakes and pools, like ships riding at anchor, they float the whole night long in peace and security. ${ }^{1}$

1 Guinea fowls not.only roost on high, but in hard wcather resort, even in the daytime, to the very tops of the highest trees.

Last winter, when the ground was covered with snow, I discovered all my guinea fowls, in the middle of the day, sitting on the highest boughs of some very tall elms, chattering and making a great clamour: I ordered them to be driven down, lest they should be frozen to death in so elevated a situation, but this was not effected without much difficulty, they being very unwilling to quit their lofty abode, notwithstanding one of them had its feet so much frozen that we were obliged to kill it. I know not how to account for this, unless it was occasioned by their aversion to the snow on the ground, they being birds that come originally from a hot climate. [As to the effect of the glare of snow on poultry, see Letter LXII. to Daines Barrington, p. 303.-ED.]

Notwithstanding the awkward splay web-feet (as Mr. White calls them) of the duck genus, some of the foreign species have the power of 


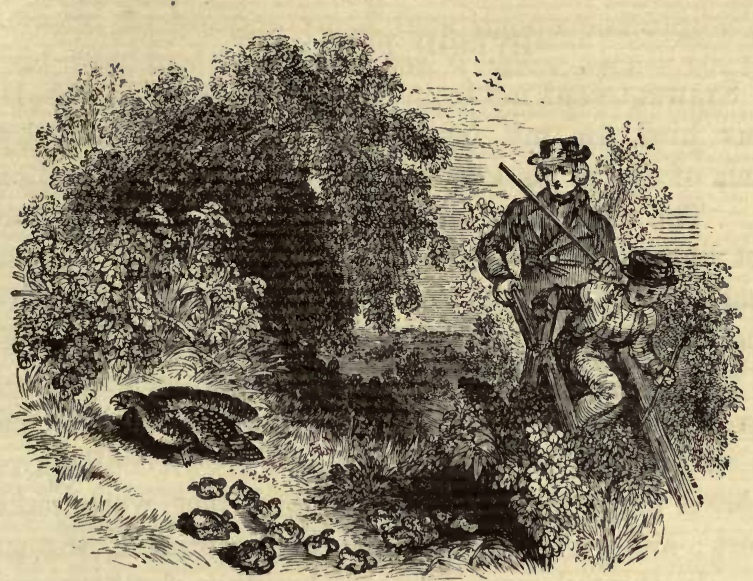

HEN PARTRIDGE.

A HEN partridge came out of a ditch, and ran along shivering with her wings, and crying out as if wounded and unable to get from us. While the dam acted this distress, the boy who attended me saw her brood, that was small and unable to fly, run for shelter into an old fox-earth under the bank. So wonderful a power is instinct. ${ }^{1}$

settling on the boughs of trees apparently with great ease ; an instance of which I have seen in the Earl of Ashburnham's menagerie, where the summer duck (Anas sponsa) flew up and settled on the branch of an oak tree in my presence; but whether any of them roost on trees in the night, we are not informed by any author that I am acquainted with. I suppose not, but that, like the rest of the genus, they sleep on the water, where the birds of this genus are not always perfectly secure, as will appear from the following circumstance which happened in this neighbourhood a few years since, as I was credibly informed. A female fox was found in the morning drowned in the same pond in which were several geese, and it was supposed that in the night the fox swam into the pond to devour the geese, but was attacked by the gander, which, being the most powerful in its own element, buffeted the fox with its wings about the head till it was drowned.-MARKwick.

1 It is not uncommon to see an old partridge feign itself wounded and run along on the ground fluttering and crying before either dog or man, to draw them away from its helpless unfledged young ones. I have seen it often, and once in particular I saw a remarkable instance of the old bird's solicitude to save its brood. As I was hunting a young pointer, the dog ran on a brood of very small partridges ; the old bird cried, flut- 


\section{HYBRID PHEASANT.}

Lord Stawell sent me from the great lodge in the Holt a curious bird for my inspection. It was found by the spaniels of one of his keepers in a coppice, and shot on the wing. The shape, and air, and habit of the bird, and the scarlet ring round the eyes, agreed well with the appearance of a cock pheasant: but then the head and neck, and breast and belly, were of a glossy black: and though it weighed three pounds three ounces and a half, ${ }^{1}$ the weight of a large full-grown cock pheasant, yet there were no signs of any spurs on the legs, as is usual with all grown cock pheasants, who have long ones. The legs and feet were naked of feathers; and therefore it could be nothing of the grouse kind. In the tail were no long bending feathers, such as cock pheasants usually have, and are characteristic of the sex. The tail was much shorter than the tail of a hen pheasant, and blunt and square at the end. The back, wing-feathers, and tail, were all of a pale russet, curiously streaked, somewhat like the upper parts of a hen partridge. I returned it with my verdict, that it was probably a spurious or hybrid hen bird, bred between a cock pheasant and some domestic fowl. When I came to talk with the keeper who brought it, he told me that some pea-hens had been known last summer to haunt the coppices and coverts where this mule was found.

Mr. Elmer, of Farnham, the famous game painter, was employed to take an exact copy of this curious bird. ${ }^{2}$

tered, and ran tumbling along just before the dog's nose till she had drawn him to a considerable distance, when she took wing and flew still farther off, but not out of the field: on this the dog returned to me, near which place the young ones lay concealed in the grass, which the old bird no sooner perceived than she flew back again to us, settled just before the dog's nose again, and by rolling and tumbling about drew off his attention from her young, and thus preserved her brood a second time. I have also seen, when a kite has been hovering over a covey of young partridges, the old birds fly up at the bird of prey, screaming and fighting with all their might to preserve their brood.-MARKwick.

1 Hen pheasants usually weigh only two pounds ten ounces.-G. W.

2 The picture was subsequently presented to Gilbert White by Lord Stawell. See Jesse's "Gleanings," second series, p. 159.-ED. 
[It ought to be mentioned that some good judges have imagined this bird to have been a stray grouse or black cock ; it is, however, to be observed, that Mr. W. remarks, that its legs and feet were naked, whereas those of the grouse are feathered to the toes.-J. A. $]^{1}$

1 Dr. Latham observes, that " pea-hens, after they have done laying, sometimes assume the plumage of the male bird," and has given a figure of the male-feathered pea-hen now to be seen in the Leverian Museum; and M. Salerne remarks, that "the hen pheasant, when she has done laying and sitting, will get the plumage of the male." May not this hybrid pheasant (as Mr. White calls it) be a bird of this kind? that is, an old hen pheasant which had just begun to assume the plumage of the cock. - Ma RKwICK.

Concerning the hybrid pheasant, John Hunter, in the "Philosophical Transactions," Art. xxx. 1760, says, "The subject of the account is a hen pheasant with the feathers of the cock. The author concludes, that it is most probable that all those hen pheasants, which are found wild, and have the feathers of the cock, were formerly perfect hens, but that now they are changed with age, and perhaps by certain constitutional circumstances." We may add that the assumption of male plumage by the hen is not confined to the pheasant.

The Hon. and Rev. W. Herbert, referring to the identical specimen described by Gilbert White, says :- "I saw this curious bird stuffed, in the collection of the Earl of Egremont at Petworth, in the year 1804, and $I$ have not the slightest hesitation in pronouncing that it was a mule between the black cock and the common pheasant. I was informed at the time by Lord Egremont that it was Mr. White's bird, and I examined it with the most minute attention, compared it with the description in the 'Naturalist's Calendar,' and wrote at the moment marginal memoranda on my copy of that book. In Mr. White's description of the bird, where he says that the back, wing-feathers, and tail, were somewhat like the upper parts of a hen partridge, I scratched out, at the time, the words 'somewhat like', and wrote in the margin ' much browner than,' and with that alteration I believe Mr. White's description to be quite correct; but I noted down that the plate was exceedingly ill coloured, which indeed may be perceived by comparing it with the description. I did not then, nor do I now, entertain the slightest doubt of its being a mule between the black game and the pheasant. I understand that some doubt exists at present whether it was Mr. White's identical specimen, though I am quite positive from my notes that it was at the time (now above thirty years ago) stated to me to have been so; and I am persuaded that it was his: but if there was any misunderstanding on that point, and it could have been a second specimen killed in the same line of country, there is not the slightest doubt that it was of like origin and appearance, for I had no excep- 


\section{LAND-RAIL.}

A MaN brought me a land-rail or daker-hen, a bird so rare in this district that we seldom see more than one or two in a season, and those only in autumn. ${ }^{1}$ This is deemed a bird of passage by all the writers; yet from its formation seems to be poorly qualified for migration; for its wings are short, and placed so forward, and out of the centre of gravity, that it flies in a very heavy and embarrassed manner, with its legs hanging down; and can hardly be sprung a second time, as it runs very fast, and seems to depend more on the swiftness of its feet than on its flying.

When we came to draw it, we found the entrails so soft and tender, that in appearance they might have been dressed like the ropes of a woodcock. The craw or crop was small

tions to take of White's description, except that the black was much browner than that of a partridge instead of somewhat like, which is not in fact contradictory. The whole of Lord Egremont's collection was afterwards destroyed by maggots, and the specimen has long ceased to exist. As I understand it has been surmised that the hybrid bird described by White might have been a young black cock in moult, I wish to state, in the most positive manner, that I am certain it was not. I had, at the period when I examined it, been in the annual habit of shooting young black game, and was perfectly well acquainted with all their variations of plumage; and had also been accustomed to see them reared in confinement. It is a point on which I could not be deceived. The bird had neither the legs and feet, nor the plumage, of a black cock in any stage of its growth."-ED.

1 The scarcity of the land-rail in the neighbourhood of Selborne in Gilbert White's day is not a little remarkable. Considering that the bird migrates to this country in spring from the south of Europe, one would suppose that in Hants and Sussex of all counties it would be found in tolerable plenty. It is by no means scarce there at the present day. In September, 1863, the writer, while shooting in company with a friend within ten miles of Selborne, killed three brace of land-rails in one day. This was on the 4th September, and the birds were all shot out of clover. If the species were not really overlooked by Gilbert White, owing to its skulking habits, the increase in its numbers at the present day in the district of which he wrote must be attributed to the alteration which has taken place in the mode of cultivating the surrounding farms, and the greater attraction which is now afforced to the bird in the way of food and shelter.-ED. 
and lank, containing a mucus; the gizzard thick and strong, and filled with small shell snails, some whole, and many ground to pieces through the attrition which is occasioned by the muscular force and motion of that intestine. We saw no gravel among the food: perhaps the shell snails might perform the functions of gravels or pebbles, and might grind one another.

Land-rails used to abound formerly, I remember, in the low wet bean fields of Christian Malford in North Wilts, and in the meadows near Paradise Gardens at Oxford, where I have often heard them cry crex, crex.

The bird mentioned above weighed seven ounces and a half, was fat and tender, and in flavour like the flesh of a woodcock. The liver was very large and delicate. ${ }^{1}$

\section{FOOD OF THE RING-DOVE.}

ONE of my neighbours shot a ring-dove on an evening as it was returning from feed and going to roost. When his wife had picked and drawn it, she found its craw stuffed with the most nice and tender tops of turnips. These she washed and boiled, and so sat down to a choice and deli-

1 Land-rails are more plentiful with us [at Catsfield, near Battle.ED.] than in the neighbourhood of Selborne. I have found four brace in an afternoon, and a friend of mine lately shot nine in two adjoining fields; but I never saw them in any other season than the autumn.

That it is a bird of passage there can be little doubt, though Mr. White thinks it poorly qualified for migration, on account of the wings being short, and not placed in the exact centre of gravity: how that may be I cannot say, but I know that its heavy sluggish flight is not owing to its inability of flying faster, for I have seen it fly very swiftly, although in general its actions are sluggish. Its unwillingness to rise proceeds, I imagine, from its sluggish disposition, and its great timidity, for it will sometimes squat so close to the ground as to suffer itself to be taken up by the hand, rather than rise; and yet it will at times run very fast.

What Mr. White remarks respecting the small shell snails found in its gizzard, confirms my opinion, that it frequents corn fields, seed clover, and brakes or fern, more for the sake of snails, slugs, and other insects [a lapsus calami-ED.] which abound in such places, than for the grain $\mathrm{cr}$ seeds; and that it is entirely an insectivorous bird.-MARKwick. 
cate plate of greens, culled and provided in this extraordinary manner.

Hence we may see that granivorous birds, when grain fails, can subsist on the leaves of vegetables. There is reason to suppose that they would not long be healthy without; for turkeys, though corn-fed, delight in a variety of plants, such as cabbage, lettuce, endive, \&c., and poultry pick much grass; while geese live for months together on commons by grazing alone. ${ }^{1}$

"Nought is useless made:

On the barren heath

The shepherd tends his flock that daily crop

Their verdant dinner from the mossy turf

Sufficient: after them the cackling goose,

Close grazer, finds wherewith to ease her want."

Phinips's Cider.

\section{HEN HARRIER.}

Mr. White, of Newton, sprung a pheasant in a wheat stubble, and shot at it; when, notwithstanding the report of the gun, it was immediately pursued by the blue hawk, known by the name of the hen harrier, but escaped into some covert. He then sprung a second, and third, in the same field, that got away in the same manner; the hawk hovering round him all the while that he was beating the field, conscious no doubt of the game that lurked in the stubble. Hence we may conclude that this bird of prey was rendered very bold and daring by hunger, and that hawks cannot always seize their game when they please. We may further observe, that they cannot pounce their

1 That many granivorous birds feed also on the herbage or leaves of plants, there can be no doubt: partridges and larks frequently feed on the green leaves of turnips, which gives a peculiar flavour to their flesh, that is, to me, very palatable: the flavour also of wild ducks and geese greatly depends on the nature of their food; and their flesh frequently contracts a rank unpleasant taste, from their having lately fed on strong marshy aquatic plants, as I suppose.

That the leaves of vegetables are wholesome and conducive to the health of birds, seems probable, for many people fat their ducks and turkeys with the leaves of lettuce chopped small.-MARKwick. 
quarry on the ground, where it might be able to make a stout resistance, since so large a fowl as a pheasant could not but be visible to the piercing eye of a hawk, when hovering over the field. Hence that propensity of cowering and squatting till they are almost trod on, which no doubt was intended as a mode of security: though long rendered destructive to the whole race of Gallina by the invention of nets and guns. ${ }^{1}$

\section{GREAT NORTHERN DIVER, OR LOON.}

As one of my neighbours was traversing Wolmer Forest from Bramshot across the moors, he found a large uncommon bird fluttering in the heath, but not wounded,

1 Of the great boldness and rapacity of birds of prey, when urged on by hunger, I have seen several instances; particularly when shooting in the winter in company with two friends, a woodcock flew across us closely pursued by a small hawk; we all three fired at the woodcock instead of the hawk, which, notwithstanding the report of three guns close by it, continued its pursuit of the woodcock, struck it down, and carried it off, as we afterwards discovered.

At another time, when partridge shooting with a friend, we saw a ring-tail hawk [the female hen-harrier.-ED.] rise out of a pit with some large bird in its claws; though at a great distance, we both fired and obliged it to drop its prey, which proved to be one of the partridges which we were in pursuit of. And lastly, in an evening, I shot at and plainly saw that $I$ had wounded a partridge, but it being late was obliged to go home without finding it again. The next morning I walked round my land without any gun, but a favourite old spaniel followed my heels. When I came near the field where I wounded the bird the evening before, I heard the partridges call, and seeming to be much disturbed. On my approaching the bar-way they all rose, some on my right, and some on my left hand; and just before and over my head I perceived (though indistinctly, from the extreme velocity of their motion) two birds fly directly against each other, when instantly, to my great astonishment, down dropped a partridge at my feet; the dog immediately seized it, and on examination I found the blood flow very fast from a fresh wound in the head, but there was some dry clotted blood on its wings and side; whence I concluded that a hawk had singled out my wounded bird as the object of his prey, and had struck it down the instant that my approach had obliged the birds to rise on the wing: but the space between the hedges was so small, and the motion of the birds so instantaneous and quick, that I could not distinctly observe the operation.-Markwick. 
which he brought home alive. On examination, it proved to be Colymbus glacialis, LrNN., the great speckled diver or loon, which is most excellently described in Willughby's Ornithology.

Erery part and proportion of this bird is so incomparably rdapted to its mode of life, that in no instance do we see the wisdom of God in the creation to more advantage. The head is sharp and smaller than the part of the neck adjoining, in order that it may pierce the water; the wings are placed forward and out of the centre of gravity, for a purpose which shall be noticed hereafter; the thighs quite. at the podex, in order to facilitate diving; and the legs are flat, and as sharp backwards almost as the edge of a knife, that in striking they may easily cut the water; while the feet are palmated, and broad for swimming, yet so folded up when advanced forward to take a fresh stroke, as to be full as narrow as the shank. The two exterior toes of the feet are longest; the nails flat and broad, resembling the human, which give strength and increase the power of swimming. The foot, when expanded, is not at right angles to the leg or body of the bird; but the exterior part inclining towards the head forms an acute angle with the body; the intention being not to give motion in the line of the legs themselves, but, by the combined impulse of both, in an intermediate line, the line of the body.

Most people know, that have observed at all, that the swimming of birds is nothing more than a walking in the water, where one foot succeeds the other as on the land; yet no one, as far as I am aware, has remarked that diving fowls, while under water, impel and row themselves forward by a motion of their wings, as well as by the impulse of their feet; but such is really the case, as any person may easily be convinced, who will observe ducks when hunted by dogs in a clear pond. Nor do I know that any one has given a reason why the wings of diving fowls are placed so forward: doubtless, not for the purpose of promoting their speed in flying, since that position certainly impedes it; but probably for the increase of their motion under water, by the use of four oars instead of two; yet were the wings and 
feet nearer together, as in land birds, they would, when in action, rather hinder than assist one another.

This Colymbus was of considerable bulk, weighing only three drachms short of three pounds avoirdupois. It measured in length from the bill to the tail (which was very short) two feet; and to the extremities of the toes four inches more; and the breadth of the wings expanded was forty-two inches. A person attempted to eat the body, but found it very strong and rancid, as is the flesh of all birds living on fish. Divers or loons, though bred in the most northerly parts of Europe, yet are seen with us in very severe winters; and on the Thames are called sprat loons, because they prey much on that sort of fish.

The legs of the Colymbi and Mergi are placed so very backward, and so out of all centre of gravity, that these birds cannot walk at all. They are called by Linnæus compedes, because they move on the ground as if shackled or fettered. ${ }^{1}$

1 These accurate and ingenious observations, tending to set forth in a proper light the wonderful works of God in the creation, and to point out His wisdom in adapting the singular form and position of the limbs of this bird to the particular mode in which it is destined to pass the greatest part of its life in an element much denser than the air, do $\mathrm{Mr}$. White credit, not only as a naturalist, but as a man and as a philosopher, in the truest sense of the word, in my opinion; for were we enabled to trace the works of nature minutely and accurately, we should find, not only that every bird, but every creature, was equally well adapted to the purpose for which it was intended; though this fitness and propriety of form is more striking in such animals as are destined to any uncommon mode of life.

I have had in my possession two birds, which, though of a different genus, bear a great resemblance to Mr. White's Colymbus, in their manner of life, which is spent chiefly in the water, where they swim and dive with astonishing rapidity, for which purpose their fin-toed feet, placed far behind, and very short wings, are particularly well adapted, and show the wisdom of God in the creation as conspicuously as the bird before mentioned. These birds were the greater and lesser crested grebe, Podiceps cristatus et auritus. What surprised me most was, that the first of these birds was found alive on dry ground, about seven miles from the sea, to which place there was no communication by water. How did it get so far from the sea? its wings and legs being so ill adapted either to flying or walking. The lesser crested grebe was also found in a fresh water pond which had no communication with other water, at some miles distance from the sca.-MARKwick. 


\section{STONE CURLEW.}

ON the 27th of February, 1788, stone curlews were heard to pipe; and on March 1st, after it was dark, some were passing over the village, as might be perceived by their quick short note, which they use in their nocturnal excursions by way of watch-word, that they may not stray and lose their companions.

Thus, we see, that retire whithersoever they may in the winter, they return again early in the spring, and are, as it now appears, the first summer birds that come back. Perhaps the mildness of the season may have quickened the emigration of the curlews this year.

They spend the day in high elevated fields and sheepwalks; but seem to descend in the night to streams anci meadows, perhaps for water, which their upland haunts do not afford them. ${ }^{1}$

\section{CHIFF CHAFF.}

The smallest uncrested willow-wren, or chiff-chaff, is the next early summer bird which we have remarked; it utters two sharp piercing notes, so loud in hollow woods as to occasion an echo, and is usually first heard about the 20th of March.

\section{FERN-OWL, OR GOAT-SUCKER.}

The country people have a notion that the fern-owl, or churn-owl, or eve-jarr, which they also call a puckeridge, is very injurious to weanling calves, by inflicting, as it strikes at them, the fatal distemper known to cow-leeches by the name of puckeridge. Thus does this harmless illfated bird fall under a double imputation which it by no means deserves-in Italy, of sucking the teats of goats,

I On the 31st of January, 1792, I received a bird of this species, which had been recently killed by a neighbouring farmer, who said that he had frequently seen it in his fields during the former part of the winter: this perhaps was an occasional straggler, which, by some accident, was prevented from accompanying its companions in their migration.-MARKWick. 
whence it is called Caprimulgus, and with us, of communicating a deadly disorder to cattle. But the truth of the matter is, the malady above-mentioned is occasioned by the Estrus bovis, a dipterous insect, which lays its eggs along the chines of kine, where the maggots, when hatched, eat their way through the hide of the beast into the flesh, and grow to a very large size. I have just talked with a man, who says he has more than once stripped calves who have died of the puckeridge ; that the ail or complaint lay along the chine, where the flesh was much swelled, and filled with purulent matter. Once I myself saw a large rough maggot of this sort squeezed out of the back of a cow.

These maggots in Essex are called wormils.

The least observation and attention would convince men, that these birds neither injure the goatherd nor the grazier, but are perfectly harmless, and subsist alone, being night birds, on night insects, such as Scaraboi, and Phaloeno; and through the month of July mostly on the Scaraboeus solstitialis, which in many districts abounds at that season. Those that we have opened have always had their craws stuffed with large night moths and their eggs, and pieces of chafers: nor does it anywise appear how they can, weak and unarmed as they seem, inflict any harm upon kine, unless they possess the powers of animal magnetism, and can affect them by fluttering over them.

A fern-owl, this evening (August 27), showed off in a very unusual and entertaining manner, by hawking round and round the circumference of my great spreading oak for twenty times following, keeping mostly close to the grass, but occasionally glancing up amidst the boughs of the tree. This amusing bird was then in pursuit of a brood of some particular Phaloena belonging to the oak, of which there are several sorts; and exhibited on the occasion a command of wing superior, I think, to that of the swallow itself.

When a person approaches the haunt of fern-owls in an evening, they continue flying round the head of the obtruder; and by striking their wings together above their backs, in the manner that the pigeons called smiters are known to 
do, make a smart snap; perhaps at that time they are jealous for their young, and this noise and gesture are intended by way of menace.

Fern-owls have attachment to oaks, no doubt on account of food; for the next evening we saw one again several times among the boughs of the same tree; but it did not skim round its stem over the grass, as on the evening before. In May these birds find the Scarabous melolontha on the oak; and the Scarabous solstitialis at midsummer. These peculiar birds can only be watched and observed for two hours in the twenty-four; and then in a dubious twilight an hour after sunset and an hour before sunrise.

On this day (July 14, 1789) a woman brought me two eggs of a fern-owl, or eve-jarr, which she found on the verge of the Hanger, to the left of the hermitage, under a beechen shrub. This person, who lives just at the foot of the Hanger, seems well acquainted with these nocturnal swallows, and says she has often found their eggs near that place, and that they lay only two at a time, on the bare ground. The eggs were oblong, dusky, and streaked somewhat in the manner of the plumage of the parent bird, and were equal in size at each end. The dam was sitting on the eggs when found, which contained the rudiments of young, and would have been hatched perhaps in a week. From hence we may see the time of their breeding, which corresponds pretty well with that of the swift, as does also the period of their arrival. Each species is usually seen about the beginning of May. Each breeds but once in a summer; each lays only two eggs.

July 4, 1790. The woman who brought me two fernowl's eggrs last year on July 14, on this day produced me two more, one of which had been laid this morning, as appears plainly, because there was only one in the nest the evening before. They were found, as last July, on the verge of the down above the hermitage, under a beechen shrub, on the naked ground. Last year those eggs were full of young, and just ready to be hatched.

These circumstances point out the exact time when these curious nocturnal migratory birds lay their eggs and 
hatch their young. Fern-owls, like snipes, stono curlews and some other birds, make no nest. Birds that build on the ground do not make much of nests. ${ }^{1}$

\section{SAND MARTINS.}

Marci 23, 1788. A gentleman, who was this week on a visit at Waverley, took the opportunity of examining some of the holes in the sand banks with which that district abounds. As these are undoubtedly bored by bank martins, and are the places where they avowedly breed, he was in hopes they might have slept there also, and that he might have surprised them just as they wore awaking from their winter slumbers. When he had dug for some time, he found the holes were horizontal and serpentine, as I had observed before, and that the nests were deposited at the inner end, and had been occupied by broods in former summers; but no torpid birds were to be found. He opened and examined about a dozen holes. Another gentleman made the same search many years ago, with as little success.

These holes were in depth about two feet.

March 21, 1790. A single bank or sand martin was seen hovering and playing round the sand pit at Short Heath, where in the summer they abound.

April 9, 1793. A sober hind assures us that this day, on Wish-hanger common, between Hedleigh and Frinsham, he saw several bank martins playing in and out, and hanging beforo some nest-holes in a sand hill, where these birds usually nestle.

This incident confirms my suspicions that this species of

1 No author that I am acquainted with has giren so accurate and pleasing an account of the manners and habits of the goat-sucker as Mr. White, taken entirely from his own observations. Its being a nocturnal bird, has prevented my having many opportunities of observing it. I suspect that it passes the day in concealment amidst the dark and shady gloom of deep-wooded dells, or as they are called here gills; having more than once seen it roused from such solitary places by my dogs, when shooting in the daytime. I have also sometimes seen it in an evening, but not long enongh to take notice of its habits and manners. I have never seen it but in the summer, between the months of May and September.-MAR K wick. 
Hirundo is to be scen first of any, and gives great reason to suppose that they do not leave their wild haunts at all, but are secreted amidst the clefts and caverns of those abrupt cliffs where they usually spend their summers.

The late severe veather considered, it is not very probable that these birds should have migrated so early from a tropical region, through all these cutting winds and pinching frosts; but it is easy to suppose that they may, like bats and flies, have been awakened by the influence of tho sun, amidst their secret latebro, where they have spent the uncomfortable foodless months in a torpid state, and the profoundest of slumbers.

There is a large pond at Wish-hanger, which induces these sand martins to frequent that district. For I have ever remarked that they haunt near great waters, either rivers or lakes. ${ }^{1}$

SWALLOWS CONGREGATING AND DISAPPEARING.

During the severe winds that often prevail late in the

${ }^{1}$ Here, and in many other passages of his writings, this very ingenious naturalist favours the opinion that part at least of the swallow tribe pass their winter in a torpid state, in the same manner as bats and flies, and revive again on the approach of spring.

I have frequently taken notice of all those circumstances which induced Mr. White to suppose that some of the Hirundines lie torpid during winter. I have seen, so late as November, on a finer day than usual at that season of the year, two or three swallows flying backwards and forwards under a warm hedge, or on the sunny side of some old building; nay, I once saw, on the 8th of December, two martins flying about very briskly, the weather being mild. I had not seen any considerable number either of swallows or martins for a considerable time before; from whence then could these few birls come, if not from some hole or cavern where they had laid themselves up for the winter? Surely it will not be asserted that these bircls migrate back ag:in from some distant tropical region, merely on the appearance of a fine day or two at this late scason of the ycar. Again, very early in the spring, and sometines immediately after very cold severe weather, on its growing a little warmer, a few of these birds suddenly make their appearance, long before the generality of them are seen. These appearances certainly favour the opinion of their passing the winter in a torpid state, but do not absolutely prove the fact; for who ever saw them reviving of their own accord from their torpid state, without being first brought to the fire, and, as it were, forced into life again; soun after which revivification they constantly die.-Mankwick. 
spring, it is not easy to say how the Hirundines subsist; for they withdraw themselves, and are hardly ever seen, nor do any insects appear for their support. That they can retire to rest, and sleep away theso uncomfortable periods as the bats do, is a matter rather to be suspected than proved: or do they not rather spend their time in deep and sheltered vales near waters, where insects are more likely to be found? Certain it is that hardly any individuals of this genus have at such times been seen for several days together.

September 13, 1791. The congregating flocks of Hirundines on the church and tower are very beautiful and amusing! When they fly off all together from the roof, on any alarm, they quite swarm in the air. But they soon settle in heaps, and preening their feathers, and lifting up their wings to admit the sun, seem highly to enjoy the warm situation. Thus they spend the heat of the day, preparing for their emigration, and, as it were, consulting when and where they are to go. The flight about the church seems to consist chiefly of house martins, about four hundred in number; but there are other places of rendezvous about tho village frequented at the same time.

It is remarkable that though most of them sit on the battlements and roof, yet many hang or cling for some time by their claws against the surface of the walls, in a manner not practised by them at any other time of their remaining with us.

The swallows scem to delight more in holding their assemblies on trees.

November 3, 1789. Two swallows were seen this morning at Newton vicarage-house, hovering and settling on the roofs and out-buildings. None have been observed at Sclborne since October 11 . It is very remarkables that after the Hirundines have disappeared for some weeks, a fow are occasionally seen again, sometimes in the first week in November, and that only for one day. Do they not withdraw and slumber in some hiding-place during the interval ? for we cannot suppose they had migrated to warmer climes, and so returned again for one day. Is it not more probable that they are awakened from sleep, and, like the bats, are come forth to collect a little food? Bats appear at all 
seasons through the autumn and spring months, when the thermometer is at $50^{\circ}$, because then moths, Phalcenoe, are stirring.

These swallows looked like young ones. ${ }^{1}$

WAGTAIIS.

WHILE the cows are feeding in moist low pastures, broods of wagtails, white and gray, ${ }^{2}$ =un round them close up to their noses, and under their very bellies, availing themselves of the flies that settlo on their legs, and probably finding worms and larve that are roused by the trampling of their feet. Nature is such an oconomist, that the most incongruous animals can avail themselves of each other! Interest makes strange friendships. ${ }^{3}$

\section{WRYNECK.}

THESE birds appear on the grassplots and walks: they walk a little as well as hop, and thrust their bills into the turf, in

1 Of their migration the proofs are such as will scarcely admit of a doubt. Sir Charles Wager and Captain Wright saw vast flocks of them at sea, when on their passage from one country to another. Our author, Mr. White, saw what he deemed the actual migration of these birds, and which he has described in his History of Selborne, [see Letter XXIII. to Pennant, p. 78.-Ev.] and of their congregating together on the roofs of churches and other buildings, and on trees, previous to their departure, many instances occur; particularly I once observed a large flock of house martins on the roof of the church here at Catsfield, which acted exactly in the manner here described by Mr. White, sometimes preening their feathers and spreading their wings to the sun, and then flying off all together, but soon returning to their former situation. The greatest part of these birds seemed to be young ones.-MARKwick.

2 This is the bird previously called the yellow wagtail in Letter XIII. to Pennant. See page 47, note 4.-ED.

3 Birds continually avail themselves of partic:lar and unusual circumstances to procure their food; thus wagtails keep playing about the noses and legs of eattle as they feed, in quest of thies and other insects which abound near those animals, and great numbers of them will follow close to the plough to devour the worms, \&c., that are turned up by that instrument. The redbreast attends the gardener when digging his borders, and will, with great familiarity and tameness, pick out the worms alinost close to his spade, as I have frequently seen. Starlings and magpies very often sit on the backs of sheep and deer to pick out their ticks.-Markwick. 
quest, I conclude, of ants, which are their food. While they hold their bills in the grass, they draw out their prey with their tongues, which are so long as to be coiled round their heads.

\section{IIA TVFINCH OR GROSBEAK.}

Mr. B. shot a cock grosbeak, which he had observed to haunt his garden for more than a fortnight. I began to accuse this bird of making sad havoc among the buds of the cherries, gooseberries, and wall-fruit of all the neighbouring orchards. Upon opening its crop or craw, no buds were to be seen, but a mass of kernels of the stones of fruits. Mr. B. observed that this bird frequentcd the spot where plum trees grow, and that he had seen it with somewhat hard in its mouth, which it broke with difficulty: these were the stones of damsons. The Latin ornithologists call this bird Coccothraustes, i.e. berry-breaker, becauss with its large horny beak it cracks and breaks the shells of stone fruits for the sake of the seed or kernel. Birds of this sort are rarely secn in England, and only in winter. ${ }^{1}$

\section{OBSERVATIONS ON INSECTS AND VERMES.}

\section{INSECTS IN GENERAL.}

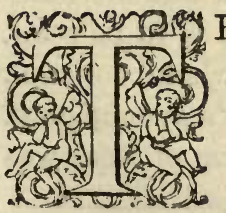

HE day and night insects occupy the annuals alternately: the Papilios, Muscoe, and Apes are succeeded at the close of the day by Phalcono, earwigs, woodlice, \&c. In the buz, partridges begin to call; theso two circumstances are buz, partridges begin to call; these two circumstances are exactly coincident.

1 I have never seen this rare bird but during the severest cold of the hardest winters, at which season of the year I have had in my possession two or three that were killed in this neighbourhood in different years.MaRKWICK.

Of late years this species has become much commoner in Englund, 
Ivy is the last flower that supports the hymenopterous and dipterous insects. On sunny days, quite on to November, they swarm on trees covered with this plant; and when they disappear, probably retire under the shelter of its leaves, concealing themselves between its fibres and the trees which it entwines. ${ }^{1}$

Spiders, woodlice, Lepismce in cupboards and among sugar, some Empides, gnats, flies of several species, some Plialcence in hedges, earthworms, \&c., are stirring at all times, when winters are mild; and are of great service to those soft-billed birds that never leave us.

On every sunny day the winter through, clouds of iusects, usually called gnats (I suppose Tipulce and Empides) appear sporting and dancing over the tops of the evergreen trees in the shrubbery, and frisking about as if the business of generation was still going on. Hence it appears that these Diptera (which by their sizes appear to be of different species) are not subject to a torpid state in the winter as most winged insects are. At night, and in frosty weather, and when it rains and blows, they seem to retire into those trees. They often are out in a fog. ${ }^{2}$

\section{IIUMMING IN THE AIR.}

ThERe is a natural occurrence to be met with upon the highest part of our down in hot summer days, which always amuses me much, without giving me any satisfaction with respect to the cause of it; and that is a loud audible humming of bees in the air, though not one insect is to be seen. This sound is to be heard distinctly the whole common through, from the Money-dells, to Mr. White's avenue gate. Any person would suppose that a large swarm of bees was

nesting now in many counties where formerly it was chiefly observed as a winter visitant. $C f$. "Handbook of British Birds," p. 29.-ED.

1 This I bave often observed, having seen bees and other winged insects swarming about the flowers of the ivy very late in the autumn. -MaRKwick.

2 This I have also seen, and have firequently observed swarms of little winged insects playing up and down in the air in the mirldle of winter, even when the ground has been covered with snow.-MA RK wick. 
in motion, and playing about over his head. This noise was heard last week, on June 28th.

"Resounds the living surface of the ground,

Nor undelightful is the ceaseless hum

To him who muses___ at noon."

"Thick in yon stream of light a thousand ways,

Upward and downward, thwarting and convolved,

The quivering nations sport."

THомson's Seasons.

\section{CHAFERS.}

CockCHAFERS seldom abound oftener than once in three or four years; when they swarm they deface the trees and hedges. Whole woods of oaks are stripped bare by them.

Chafers are eaten by the turkey, the rook, and the house sparrow.

The Scarabous solstitialis first appears about June 26; they are very punctual in their coming out every year. They are a small species, about half the size of the May chafer, and are known in some parts by the name of the fern chafer. $^{1}$

\section{PTINUS PECTINICORNIS.}

Those maggots that make worm holes in tables, chairs, bedposts, \&c., and destroy wooden furniture, especially where there is any sap, are the larvæ of the Ptinus pectinicornis. This insect, it is probable, deposits its eggs on the surface, and the worms eat their way in.

In their holes they turn into their pupa state, and so come forth winged in July; eating their way through the valances or curtains of a bed, or any other furniture that happens to obstruct their passage.

1 A singular circumstance relative to the cockchafer, or, as it is called here, the May-bug, Scarabcus melolontha, happened this year (1800):My gardener in digging some ground found, about six inches under the surface, two of these insects alive and perfectly formed so early as the 24th of March. When he brought them to me, they appeared to be as perfect and as much alive as in the midst of summer, crawling abont as briskly as ever : yet I saw no more of this insect till the 22ud of May, when it began to make its appearance. How comes it, that though it was perfectly formed so early as the 24th of March, it did not show itself above ground till nearly two months afterwards?-MAR K wick 
They seem to be most inclined to breed in bech; henco beech will not make lasting utensils, or furniture. If their eggs are deposited on the surface, frequent rubbings will preserve wooden furniture. ${ }^{1}$

\section{BLATTA ORIENTALIS-COCKROACH.}

A NEIGHBOUR complained to me that her house was overrun with a kind of black beetle, or, as she expressed herself, with a kind of black bob, which swarmed in her kitchen when they get up in a morning before daybreak.

Soon after this account, I observed an unusual insect in one of my dark chimney closets, and find since, that in the night they swarm also in my kitchen. On examination, I soon ascertained the species to be the Blatta orientalis of Linnæus, and the Blatta molendinaria of Mouffet. The male is winged; the female is not, but shows somewhat like the rudiments of wings, as if in the pupa state.

These insects belonged originally to the warmer parts of America, and were conveyed from thence by shipping to the East Indies; and by means of commerce begin to prevail in the more northern parts of Europe, as Russia, Sweden, \&c. How long they have abounded in England I cannot say; but have never observed them in my house till lately.

They love warmth, and haunt chimney closets, and the backs of ovens. Poda says that these and house crickets will not associate together; but he is mistaken in that assertion, as Linnæus suspected he was. They are altogether night insects (lucifugo), never coming forth till the rooms are dark and still, and escaping away nimbly at the approach of a candle. Their antennoe are remarkably long, slender, and flexile.

October, 1790. After the servants are gone to bed, the litchen hearth swarms with young crickets, and young

1 The-Plinus pectinicornis is not the only insect that is destructive to furniture. Various species of Anobium also perforate it in all directions. Linnæus's chairs were bored through and destroyed by A. pertinax; and the Rev. Mr. Kirby had his chairs, his pictureframes, and the floor of his chamber eaten in every direction by $A$. striatum. - ED. 
Bluttoe molendinarioe of all sizes, from the most minute growth to their full proportions. They seem to live in a friendly manner together, and not to prey the one on the other.

August, 1792. After the destruction of many thousands of Blattoe molendinarioe, we find that at intervals a frosh detachment of old ones arrives; and particularly during this hot season: for the windows being left open in the evenings, the males come flying in at the casements from the neighbouring houses, which swarm with them. How the females, that seem to have no perfect wings that they can use, can contrive to get from house to house, does not so readily appear. These, like many insects, when they find their present abodes overstocked, have powers of migrating to fresh quarters. Since the Blattoe have been so much kept under, the crickets have greatly increased in number.

\section{GRYLLUS DOMESTICUS - HOUSE CRICKET.}

Norember. After the servants are gone to bed, the kitchen hearth swarms with minute crickets not so large as fleas, which must have been lately hatched. So that these domestic insects, cherished by the influence of a constant large fire, regard not the season of their year, but produce their young at a time when their congeners are either dead, or laid up for the winter, to pass away the uncomfortable months in the profoundest slumbers, and a state of torpidity. When house crickets are out, and running about in a room in the night, if surprised by a candle, they give two or three shrill notes, as it were for a signal to their fellows, that they may escape to their crannies and lurking holes, to avoid danger.

\section{CIMEX LINEARIS.}

August 12, 1775. Cimices lineares ${ }^{1}$ are now eagerly pairing on ponds and pools. The females, who vastly exceed the males in bulk, dart and shoot along on the surface of the water with the males on their backs. When a female chooses to be disengaged, she rears, and jumps, and plunges, 
like an unruly colt; the lover thus dismounted, soon finds a new mate. The females afterwards retire to another part of the lake, perhaps to deposit their fretus in quiet; hence the sexes are found separate, except in the pairing season.

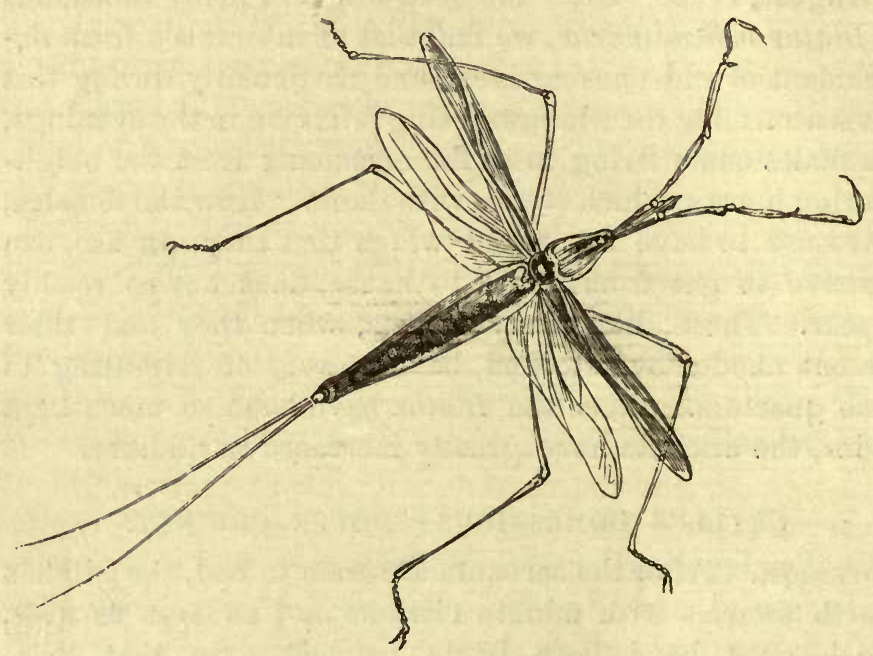

RANATRA LINEARIS.

From the multitude of minute young of all gradations of sizes, these insects seem without doubt to be viviparous. ${ }^{1}$

\section{PHALANA QUERCUS.}

Miss of our oaks are naked of leaves, and evtn the Holt in general, having been ravaged by the caterpillars of a small Plialona which is of a pale yellow colour. These insects, though a feeble race, yet, from their infinite numbers, are of wonderful effect, being able to destroy the foliage of

1 The egg of the long water-bug has been long known to entomologists. It is armed at one end by two bristles, and is inserted into the stem of an aquatic plant, generally of a club rush, in which it is so deeply imbedded by the lengthened ovipositor of the insect, as to be entirely hidden from view; the bristles alone projecting from the place of concealment. These bristles by preventing the edges of the plant stem from uniting, secure an exit for the larva as soon as it is latched. -Ev. 
whole forests and districts. At this season they leave their aurelia, and issue forth in their fly state, swarming and covering the trees and hedges.

In a ficld at Greatham, I saw a flight of swifts busied in catching their prey near the ground; and found they were hawking after these Phalcena. The aurelia of this moth is shining and black as jet; and lies wrapped up in a leaf of the tree, which is rolled round it, and secured at the ends by a web, to prevent the maggot from falling out.'

\section{EPHEMERA CAUDA TRIESTA-MAY FLY.}

Jone 10, 1771. Myriads of May flies appear for the first time on the Alresford stream. The air was crowded with them, and the surface of the water covered. Large trouts sucked them in as they lay struggling on the surface of the stream, unable to rise till their wings were dried.

This appearance reconciled me in some measure to the wonderful account that Scopoli gives of the quantities emerging from the rivers of Carniola. Their motions are very peculiar, up and down for many yards almost in a perpendicular line. ${ }^{2}$

\section{SPHINX OCELLATA.}

A VAST insect appears after it is dusk, flying with a humming noise, and inserting its tongue into the bloom of the honey-

1 I suspect that the insect here meant is not the Phulana quercus, but the Phalana viridata, concerning which, I find the following note in my "Naturalist's Calendar" for the year 1785 :-

About this time, and for a few days last past, I observed the leaves of almost all the oak trees in Denn Copse to be eaten and destroyed, and, on examining more narrowly, saw an infinite number of small beautiful pale green moths flying about the trees; the leaves of which that were not quite destroyed were curled up, and withinside were the exuvia or remains of the chrysalis, from whence I suppose the moths had issued, and whose caterpillar had eaten the leares.-MARKwick.

${ }^{2}$ I once saw a swarm of these insects playing up and down over the surface of a pond in Denn Park, exactly in the manner described by this accurate naturalist. It was late in the evening of a warm summcr's day when I observed them.-Markwick. 
suckle; it scarcely settles upon the plants, but feeds on the wing in the manner of humming birds. ${ }^{2}$

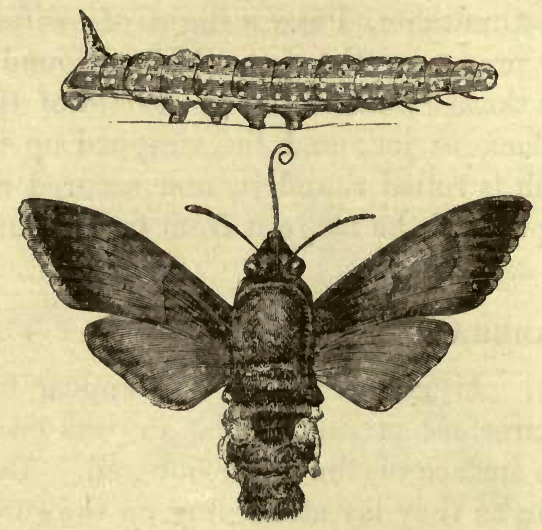

SPHINX STELLATARUM.

WILD BEE.

THERE is a sort of wild bee frequenting the garden-campion for the sake of its tomentum, which probably it turns to some purpose in the business of nidification. It is very pleasant to see with what address it strips off the pubes, running from the top to the bottom of a branch, and shaving it bare with all the dexterity of a hoop shaver. When it has got a vast bunnle almost as large as itself, it flies away, holding it secure between its chin and its fore legs.

There is a remarkable hill on the downs near Lewes in Sussex, known by the name of Mount Carburn, which overlooks that town, and affords a most engaging prospect of all the country round, besides several views of the sea. On the very summit of this exalted promontory, and amidst the trenches of its Danish camp, there haunts a species of wild bee, making its nest in the chalky soil. ${ }^{2}$ When people

1 I have frequently seen the large bee moth (Sphinx stellatarum) inserting its long tongue or proboscis into the centre of flowers, and feeding on their nectar, without settling on them, but keeping constantly on the wing.-MARKwick.

2 This was probably Bombus lapidarius.-ED. 
approach the place, these insects begin to be alarmed, and with a sharp and hostile sound, dash and strike round the heads and faces of intruders. I have been often interrupted myself while contemplating the grandeur of the scenery around mo, and have thought myself in danger of being stung.

\section{WASPS.}

Wasps abound in woody wild districts far from neighbourhoods; they feed on flowers, and catch flies and caterpillars to carry to their young. Wasps make their nests with the raspings of sound timber; hornets, with what they gnaw from decayed : these particles of wood are kneaded up with a mixture of saliva from their bodies and moulded into combs.

When there is no fruit in the gardens, wasps eat flies, and suck the honey from flowers, from ivy blossoms, and umbellated plants : they carry off also flesh from butchers' shambles. ${ }^{1}$

\section{ESTRUS CURVICAUDA.}

THIs insect lays its nits or eggs on horses' legs, flanks, \&c., each on a single hair. The maggots when hatched do not enter the horses' skins, but fall to the ground. It seems to abound most in moist moorish places, though sometimes seen in the uplands. ${ }^{2}$

\section{NOSE FLY.}

Aвout the beginning of July, a species of fly (Musca) obtains, which proves very tormenting to horses, trying still to enter thoir nostrils and ears, and actually laying their eggs in the latter of those organs, or perhaps in both. When these abound, horses in woodland districts become

1 In the ycar 1775 wasps abounded so prodigiously in this neighbourhood, that, in the month of August, no less than seven or eight nests were ploughed up in one field: of which there were several instances, as I was informed.

In the spring, about the beginning of April, a single wasp is sometimes seen, which is of a larger size than usual; this I imagine is the queen or feinale wasp, the mother of the future swarm.-MARKwICK.

2 See Letter XXXIV. to Pennant, page 107, note 2.-ED. 
very impatient at their work, continually tossing their heads, and rubbing their noses on each other, regardless of the driver, so that accidents often ensue. In the heat of the day, men are often obliged to desist from ploughing. Saddle horses are also very troublesome at such seasons. Country people call this insect the nose fly. ${ }^{1}$

\section{ICHNEUMON FLY.}

I sAw lately a small ichneumon fly attack a spider much larger than itself on a grass walk. When the spider made any resistance, the ichneumon applied her tail to him, and stung him with great vehemence, so that he soon became dead and motionless. The ichneumon then running backward, drew her prey very nimbly over the walk into the standing grass. This spider would be deposited in some hole where the ichneumon would lay some eggs; and as soon as the eggs were hatched, tho carcass would afford ready. food for the maggots.

Perhaps some eggs might be injected into the body of the spider, in the act of stinging. Some ichneumons deposit their eggs in the aurelia of moths and butte flies. ${ }^{2}$

1 Is not this insect the CEstrus nasalis of Linnæus, so well described by $\mathrm{Mr}$. Clark in the third volume of the Linnean Transactions, under the name of $Q$ Estrus veterinus.-Markwick.

2 In my "Naturalist's Calendar" for 1795, July 21st, I find the following note :-

It is not uncommon for some of the species of ichneumon flies to deposit their eggs in the chrysalis of a butterfly: some time ago I put two of the chrysalis of a butterfly into a box, and covered it with gauze, to discover what species of butterfly they would produce; but instead of a butterfly, one of them produced a number of small ichneumon flies.

There are many instances of the great service these little insects are to mankind in reducing the number of noxious insects, by depositing their eggs in the soft bodies of their larva; but none more remarkable than that of the Ichneumon tipula, which pierces the tender body and reposits its eggs in the larva of the Tipula tritici, [Cecidomyia tritici, Kirby-ED.] an insect which, when it abounds greatly, is very prejudicial to the grains of wheat. This operation I have frequently seen it perform with wonder and delight.-MARK WICK. 


\section{BOMBYLIUS MEDIUS.}

The Bombylius medius is much about in March and the beginning of April, and soon seems to retire. It is a hairy insect, like an humblebee, but with only two wings, and a long straight beak, with which it sucks the early flowers. The female seems to lay its eggs as it poises on its wings, by striking its tail on the ground, and against the grass that stands in its way, in a quick manner, for several times together. ${ }^{1}$

\section{MUSC $A$ - FLIES.}

Is the decline of the year, when the mornings and evenings become chilly, many species of flies (Muscce) retire into houses, and swarm in the windows.

At first they are very brisk and alert; but as they grow more torpid, one cannot help observing that they move with difficulty, and are scarce able to lift their legs, which seem as if glued to the glass; and by degrees many do actually stick on till they die in the place.

It has been observed that divers flies, besides their sharp hooked nails, have also skinny palms, or flaps to their feet, whereby they are enabled to stick on glass and other smooth bodies, and to walk on ceilings with their backs downward, by means of the pressure of the atmosphere on those flaps: the weight of which they easily overcome in warm weather when they are brisk and alert. But in the decline of the year, this resistance becomes too mighty for their diminished strength; and we see flies labouring along, and lugging their feet in windows, as if they stuck fast to the glass, and it is with the utmost difficulty they can draw one foot after another, and disengage their hollow caps from the slippery surface.

Upon the same principle that flies stick and support

1 I have often seen this inscct fly with great velocity, stop on a sudden, hang in the air in a stationary position for some time, and then fly off again; but do not recollect having ever seen it strike its tail against the ground, or any other substance.--MARKWICK. 
themselves, do boys, by way of play, carry heavy weights by only a piece of wet leather at the end of a string clapped close on the surface of a stone.

\section{TIPULA, OR EMPIDES.}

Mar. Millions of Empides, or Tipulce, come forth at the close of day, and swarm to such a degree as to fill the air. At this juncture they sport and copulate; as it grows more dark they retire. All day they hide in the hedges. As they rise in a cloud they appcar like smoke.

I do not ever remember to have seen such swarms, except in the fens of the Isle of Ely. They appear most over grass grounds.

\section{ANTS.}

August 23. Every ant hill about this time is in a strange hurry and confusion; and all the winged ants, agitated by some violent impulse, are leaving their homes, and, bent on emigration, swarm by myriads in the air, to the great emolument of the Hirundines, which fare luxuriously. Those that cscape the swallows return no more to their nests, but, looking out for fresh settlements, lay a foundation for future colonies. All the females at this time are pregnant: the males that escape being eaten wander away and die.

October 2. Flying ants, male and female, usually swarm and migrate on hot sunny days in August and September; but this day a vast emigration took place in my garden, and myriads came forth, in appearance, from the drain which goes under the fruit wall; filling the air and the adjoining trees and shrubs with their numbers. The females were full of eggs. This late swarming is probably owing to the backward, wet season. The day following, not one flying ant was to be seen.

Horse ants travel home to their nests laden with flies, which they have caught, and the aureliæ of smaller ants, which they scize by violence."

I In my "Naturalist's Calendar" for the year 1777, on September 6th, I find the following note to the article Flying Ants:- 


\section{GLOW-WORMS.}

Br observing two glow-worms which were brought from the field to the bank in the garden, it appeared to us, that these little creatures put out their lamps between eleven and twelve, and shine no more for the rest of the night.

Male glow-worms, attracted by the light of the candles, come into the parlour.

\section{EARTHWORMS.}

EARTHWORMS make their casts most in mild weather about. March and April; they do not lie torpid in winter, but come forth when there is no frost; they travel about in rainy nights, as appears from their sinuous tracks on the soft muddy soil, perhaps in search of food.

When earthworms lie out a nights on the turf, though they extend their bodies a great way, they do not quite leave their holes, but keep the ends of their tails fixed therein, so that on the least alarm they can retire with precipitation under the earth. Whatever food falls within their reach when thus extended, they seem to be content with, such as blades of grass, straws, fallen leaves, the ends of which they often draw into their holes; even when pairing their hinder parts never quit their holes, so that no two, except they lie within reach of each other's bodies, can pair; but as every individual is an hermaphrodite, there is no difficulty in meeting with a mate, as would be the case were they of different sexes.

I saw a prodigious swarm of these ants flying about the top of some tall elm trees close by my house; some were continually dropping to the ground as if from the trees, and others rising up from the ground: many of them were pairing; and I imagine thei life is but short. for as soon as produced from the egg by the heat of the sun, they propagate their species, and soon after perisb. They were black, somewhat like the small black ant, and had four wings. I saw also, at another place, a large sort which were yellowish. On the 8 th of September, 1785, I again observed the same circumstance uf a vast number of these insects flying near the tops of the elms and dropping to the ground.

On the 2nd of March, 1777, I saw great numbers of ants corne out of the ground.-MARKWICK. 


\section{SNAILS AND SLUGS.}

THE shell-less snails called slugs are in motion all the winter in mild weather, and commit great depredations on garden plants, and much injure the green wheat, the loss of which is imputed to earthworms; while the shelled snail, the фвp śorxos, does not come forth at all till about April 10th, and not only lays itself up pretty early in autumn, in places secure from frost, but also throws out round the mouth of its shell a thick operculum formed from its own saliva; so that it is perfectly secured, and corked up, as it were, from all inclemencies. The cause why the slugs are able to endure the cold so much better than shell snails is, that their bodies are covered with slime as whales are with blubber.

Snails pair about Midsummer; and soon after deposit their eggs in the mould by running their heads and bodies underground. Hence the way to be rid of them is to kill as many as possible before they begin to breed.

Large, gray, shell-less cellar snails lay themselves up about the same time with those that live abroad; hence it is plain that a defect of warmth is not the only cause that influences their retreat.

\section{SNAKES' SLOUGH.}

"There the snake throws her enamell'd skin." Shakspeare, "Mids. Night's Dream." Act ii. sc. 1.

Aвоuт the middle of this month (September) we found in \& field near a hedge the slough of a large snake, which seemed to have been newly cast. From circumstances it appeared as if turned wrong side outward, and as drawn off backward, like a stocking or woman's glove. Not only the whole skin, but scales from the very eyes, are peeled off, and appear in the head of the slough like a pair of spectacles. The reptile, at the time of changing his coat, had entangled himself intricately in the grass and weeds, so that the friction of the stalks and blades might promote this curious shifting of his exuviæ.

"- Lubrica serpens

Exuit in spinis vestem." Iucretius. 
It would be a most entertaining sight could a person be an eye-witness to such a feat, and see the snake in the act of changing his garment. As the convexity of the scales of the eyes in the slough is now inward, that circumstance alone is a proof that the skin has been turned: not to mention that now the present inside is much darker than the outer. If you look through the scales of the snake's eyes from the concave side, viz. as the reptile used them, they lessen objects much. Thus it appears from what has been said, that snakes crawl out of the mouth of their own sloughs, and quit the tail part last, just as eels are skinned by a cook maid. While the scales of the eyes are growing loose, and a new skin is forming, the creature, in appearance, must be blind, and feel itself in an awkward uneasy situation. ${ }^{1}$

\section{OBSERVATIONS ON VEGETABLES.}

TREES, ORDER OF LOSING THEIR LEAVES.

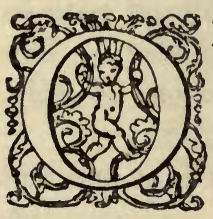

$\mathrm{NE}$ of the first trees that becomes naked is the walnut: the mulberry, the ash, especially if it bears many keys, and the horse-chestnut, come next. All lopped trees, while their heads are young, carry their leaves a long while. Apple-trees and peaches remain green till very late, often till the end of November; young beeches never cast their leaves till spring, till the new leaves sprout

1 I have seen many sloughs or skins of snakes entire, after they have cast them off; and once in particular I remember to have found one of these sloughs so intricately interwoven amongst some brakes that it was with difficulty removed without being broken; this undoubtedly was done by the creature to assist in getting rid of its incumbrance.

I have great reason to suppose that the eft or common lizard also casts its skin or slough, but not entire like the snake; for on the 30th of March, 1777, I saw one with something ragged hanging to it, which appeared to be part of its old skin.-MArkwrck. 
and push them off: in the autumn the beechen leaves turn of a deep chestnut colour. Tall beeches cast their leaves about the end of October.

\section{SIZE AND GROWTH.}

Mr. Marsham, of Stratton, near Norwich, informs me by letter thus:- "I became a planter early; so that an oak which I planted in 1720 is become now, at one foot from the earth, twelve feet six inches in circumference, and at fourteen feet (the half of the timber length) is eight feet two inches. So if the bark was to be measured as timber, the tree gives one hundred and sixteen and a half feet, buyer's measure. Perhaps you never keard of a larger oak while the planter was living. I flatter myself that I increased the growth by washing the stem, and digging a circle as far as I supposed the roots to extend, and by spreading sawdust, \&c., as related in the 'Philosophical Transactions.' I wish I had begun with beeches, (my favourite trees as well as yours), I might then have seen very large trees of my own raising. But I did not begin with beech till 1741, and then by seed; so that my largest is now, at five feet from the ground, six feet three inches in girth, and with its head spreads a circle of twenty yards diameter. This tree was also dug round, washed, \&c." Stratton, 24 July, $1790 .^{1}$

The circumference of trees planted by myself, at one foot from the ground (1790).

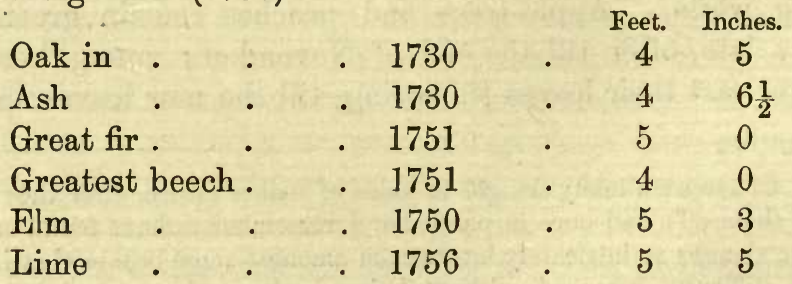

The great oak in the Holt, which is deemed by Mr.

1 It was at the hospitable seat of his " very worthy and ingenious friend, Robert Marsham," that Stillingfleet prepared his "Calendar of Flora for 1755," which has been already referred to. See p. 44.-ED. 
Marsham to be the biggest in this island, at seven feet from the ground, measures in circumference thirty-four feet. It has in old times lost several of its boughs, and is tending to decay. Mr. Marsham computes, that at four-

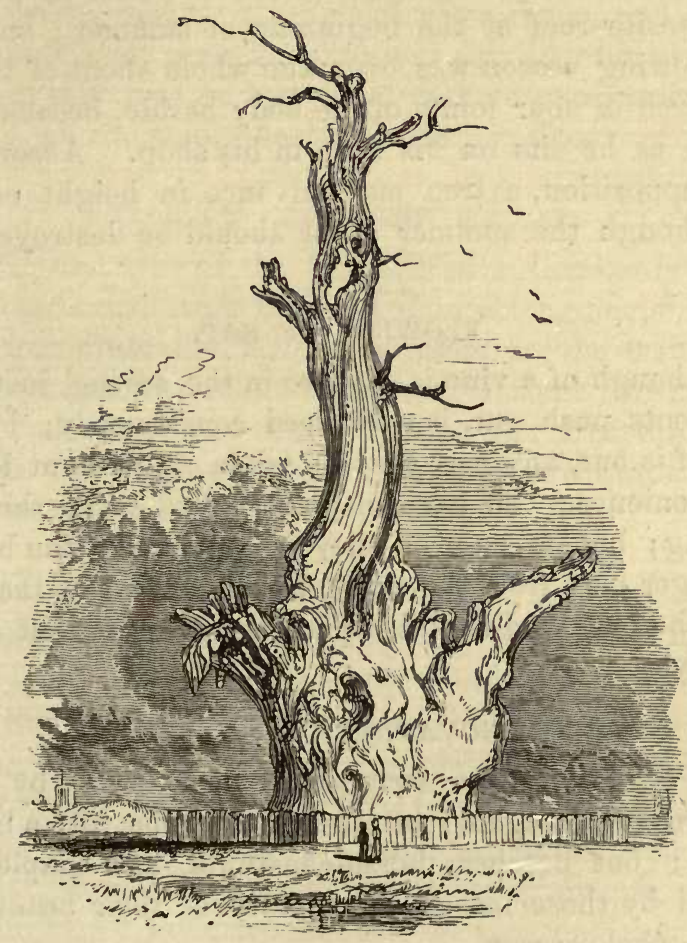

'IHE GRINDSTONE OAK, IN THE FOLT FOREST.

teen feet length this oak contains one thousand feet of timber. ${ }^{1}$

It has been the received opinion that trees grow in

$1 \mathrm{Mr}$. Bennett, in a note to this passage, says :- "There are in the Holt two great oaks; one known as the Grindstone, and the other as the Buck's Horn. The former, I apprehend, is the one measured by Mr. Marsham. At about five feet from the ground its circumference is fully thirty-six feet. It is now a ruin merely, and destitute altogether of life : a massive ruin, however, which will resist, through generations yet to come, the utmost force of the elements."-FD. 
height only by their annual upper shoot. But my neighbour over the way, whose occupation confines him to one spot, assures me that trees are expanded and raised in the lower parts also. The reason that he gives is this: the point of one of my firs began for the first time to peer over an opposite roof at the beginning of summer; but before the growing season was over, the whole shoot of the year, and three or four joints of the body beside, became visible to him as he sits on his form in his shop. According to this supposition, a tree may advance in height considerably, though the summer shoot should be destroyed every year.

\section{FLOWING OF SAP.}

If the bough of a vine is cut late in the spring, just before the shoots push out, it will bleed considerably; but after the leaf is out, any part may be taken off without the least inconvenience. So oaks may be barked while the leaf is budding; but as soon as they are expanded, the bark will no longer part from the wood, because the sap that lubricates the bark and makes it part, is evaporated off through the leaves.

\section{RENOVATION OF LEAVES.}

WHEN oaks are quite stripped of their leaves by chafers, they are clothed again soon after Midsummer with a beautiful foliage; but beeches, horse-chestnuts, and maples, once defaced by those insects, never recover their beauty again for the whole season.

\section{ASH-TREES.}

MANY ash-trees bear loads of keys every year, others never seem to bear any at all. The prolific ones are naked of leaves and unsightly; those that are sterile abound in foliage, and carry their verdure a long while, and are pleasing objects.

\section{BEECH.}

BeEches love to grow in crowded situations, and will insinuate themselves through the thickest covert, so as to 
surmount it all: are therefore proper to mend thin places in tall hedges.

\section{SYCAMORE.}

MAY 12. The sycamore, or great maple, is in bloom, and at this season makes a beautiful appearance, and affords much pabulum for bees, smelling strongly like honey. The foliage of this tree is very fine, and very ornamental to outlets. All the maples have saccharine juices.

\section{GALLS OF LOMBARDY POPLAR.}

THe stalks and ribs of the leaves of the Lombardy poplar are embossed with large tumours of an oblong shape, which, by incurious observers, have been taken for the fruit of the tree. These galls are full of small insects, some of which are winged, and some not. The parent insect is of the genus of Cynips. Some poplars in the garden are quite loaded with these excrescences.

\section{CHESTNUT TIMBER.}

JoHn CARPENTER brings home some old chestnut-trees which are very long; in several places the wood-peckers had begun to bore them. The timber and bark of these trees are so very like oak, as might easily deceive an indifferent observer, but the wood is very shaky, and towards the heart cup-shaky (that is to say, apt to separate in round pieces like cups), so that the inward parts are of no use. They were bought for the purpose of cooperage, but must make but ordinary barrels, buckets, \&c. Chestnut sells for half the price of oak; but has sometimes been sent into the king's docks, and passed off instead of oak.

\section{LIME BLOSSOMS.}

Dr. Chander tells, that in the south of France, an infusion of the blossoms of the lime-tree (Tilia) is in much esteem as a remedy for coughs, hoarsenesses, fevers, \&c., and that at Nismes, he saw an avenue of limes that was quite ravaged and torn in pieces by people greedily gathering the bloom, which they dried and kept for these purposos. 
Upon the strength of this information we made some tea of lime blossoms, and found it a very soft, well flavoured, pleasant, saccharine julep, in taste much resembling the juice of liquorice.

\section{BLACKTHORN.}

THIs tree usually blossoms while cold north-east winds blow; so that the harsh rugged weather obtaining at this season is called by the country people, blackthorn winter.

\section{IVY BERRIES.}

Ivy berries afford a noble and providential supply for birds in winter and spring; for the first severe frost freezes and spoils all the haws, sometimes by the middle of November; ivy berries do not seem to freeze.

\section{HOPS.}

The culture of Virgil's vines corresponded very exactly with the modern management of hops. I might instance in the perpetual diggings and hoeings, in the tying to the stakes and poles, in pruning the superfluous shoots, \&c.; but lately I have observed a new circumstance, which was, a neighbouring farmer's harrowing between the rows of hops with a small triangular harrow, drawn by one horse, and guided by two handles. This occurrence brought to my mind the following passage :-

"

ipsa

Flectere luctantes inter vineta juvencos."

Georgic. II.

Hops are dicocious plants; hence perhaps it might be proper, though not practised, to leave purposely some male plants in every garden, that their farina might impregnate the blossoms. The female plants without their male attendants are not in their natural state: hence we may suppose the frequent failure of crop so incident to hop-grounds; no other growth, cultivated by man, has such frequent and general failures as hops.

Two hop-gardens much injured by a hailstorm, June 5, show now (September 2) a prodigious crop, and larger and 
fairer hops than any in the parish. The owners seem now to be convinced that the hail, by beating off the tops of the binds, has increased the side shoots, and improved the crop. Query therefore, should not the tops of hops be pinched off when the binds are very gross and strong?

\section{SEED LYING DORMANT.}

THe naked part of the Hanger is now covered with thistles of various kinds. The seeds of these thistles may have lain probably under the thick shade of the beeches for many years, but could not vegetate till the sun and air were admitted. When old beech-trees are cleared away, the naked ground in a year or two becomes covered with strawberry plants, the seeds of which must have lain in the ground for an age at least. One of the slidders or trenches down the middle of the Hanger, close covered over with lofty beeches near a century old, is still called Strawberry Slidder, though no strawberries have grown there in the memory of man. That sort of fruit, did once, no doubt, abound there, and will again when the obstruction is removed.

\section{BEANS SOWN BY BIRDS.}

MANY horsebeans sprang up in my field-walks in the autumn, and are now grown to a considerable height. As the Evel was in beans last summer, it is most likely that these seeds came from thence; but then the distance is too considerable for them to have been conveyed by mice. It is most probable therefore that they were brought by birds, and in particular by jays and pies, who seem to have hid them among the grass and moss, and then to have forgotten where they had stowed them. Some pease are also growing in the same situation, and probably under the same circumstances.

\section{CUCUMBERS SET BY BEES.}

IF bees, who are much the best setters of cucumbers, do not happen to take kindly to the frames, the best way is to tempt them by a little honey put on the male and female 
bloom. When they are once induced to haunt the frames, they set all the fruit, and will hover with impatience round the lights in a morning, till the glasses are opened. Probatum est.

WHEAT.

A notron has always obtained, that in England hot summers are productive of fine crops of wheat; yet in the years 1780 and 1781, though the heat was intense, the wheat was much mildewed, and the crop light. Does not severe heat, while the straw is milky, occasion its juices to exude, which being extravasated, occasion spots, discolour the stems and blades, and injure the health of the plants?

\section{TRUFFLES.}

Acgust. A truffle-hunter called on us, having in his pocket several large truffles found in this neighbourhood. He says these roots are not to be found in deep woods, but in narrow hedge-rows and the skirts of coppices. Some truffles, he informed us, lie two feet within the earth, and some quite on the surface; the latter, he added, have little or no smell, and are not so easily discovered by the dogs as those that lie deeper. Half-a-crown a pound was the price which he asked for this commodity.

Truffles never abound in wet winters and springs. They are in season, in different situations, at least nine months in the year.

\section{TREMELLA NOSTOC.}

THобян the weather may have been ever so dry and burning, yet after two or three wet days, this jellylike substance abounds on the walks.

\section{FAIRY RINGS.}

THE cause, occasion, call it what you will, of fairy rings, subsists in the turf, and is conveyable with it; for the turf of my garden-walks, brought from the down above, abounds with those appearances, which vary their shape, and shift situation continually, discovering themselves now in circles, 
now in segments, and sometimes in irregular patches and spots. Wherever they obtain, puffballs abound; the seeds of which were doubtless brought in the turf.

\section{METEOROLOGICAL OBSERVATIONS.}

BAROMETER.

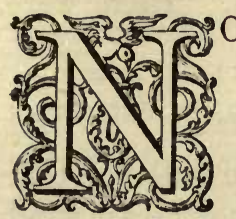
OVEMBER 22, 1768. A remarkable fall of the barometer all over the kingdom. At Selborne we had no wind, and not much rain; only vast, swagging, rocklike clouds appeared at a distance.

\section{PARTIAL FROST.}

THE country people, who are abroad in winter mornings long before sunrise, talk much of hard frost in some spots, and none in others. The reason of these partial frosts is obvious, for there are at such times partial fogs about; where the fog obtains, little or no frost appears, but where the air is clear, there it freezes hard. So the frost takes place either on hill or in dale, wherever the air happens to be clearest and freest from vapour.

\section{THAW.}

ThAWs are sometimes surprisingly quick, considering the small quantity of rain. Does not the warmth at such times come from below? The cold in still, severe seasons seems to come down from above, for the coming over of a cloud in severe nights raises the thermometer abroad at once full ten degrees. The first notices of thaws often seem to appear in vaults, cellars, \&c.

If a frost happens, even when the ground is considerably dry, as soon as a thaw takes place, the paths and fields are all in a batter. Country people say that the frost draws moisture. But the true philosophy is, that the steam and vapours continually ascending from the earth, are bound in by the frost, and not suffered to escape till released by the 
thaw. No wonder then that the surface is all in a float; since the quantity of moisture by evaporation that arises daily from every acre of ground is astonishing.

\section{FROZEN SLEET.}

JANUARY 20. Mr. H.'s man says, that he caught this day, in a lane near Hackwood Park, many rooks, which, attempting to fly, fell from the trees with their wings frozen together by the sleet, that froze as it fell. There were, he affirms, many dozen so disabled.

\section{MIST, CALLED LONDON SMOKE.}

THIs is a blue mist which has somewhat the smell of coalsmoke, and as it always comes to us with a north-east wind, is supposed to come from London. It has a strong smell, and is supposed to occasion blights. When such mists appear they are usually followed by dry weather.

\section{REFLECTION OF FOG.}

When peoplewalk in a deep white fog by nightwith a lanthorn, if they will turn their backs to the light, they will see their shades impressed on the fog in rude gigantic proportions. This phenomenon seems not to have been attended to, but implies the great density of the meteor at that juncture.

\section{HONEYDEW.}

June 4, 1783. Vast honeydews this week. The reason of these seems to be, that in hot days the effluvia of flowers are drawn up by a brisk evaporation, and then in the night fall down with the dews with which they are entangled. ${ }^{1}$

This clammy substance is very grateful to bees, who gather it with great assiduity, but it is injurious to the trees on which it happens to fall, by stopping the pores of the leaves. The greatest quantity falls in still close weather;

1 The nature of honeydew has been already referred to in Letter LXIV. to Daines Barrington, and the above explanation shown to be erroneous. See p. 310 and note.-ED. 
because winds disperse it, and copious dews dilute it, and prevent its ill effects. It falls mostly in hazy warm weather.

\section{MORNING CLOUDS.}

AFTER a bright night and vast dew, the sky usually becomes cloudy by eleven or twelve o'clock in the forenoon, and clear again towards the decline of the day. The reason seems to be, that the dew, drawn up by evaporation, occasions the clouds; which, towards evening, being no longer rendered buoyant by the warmth of the sun, melt away, and fall down again in dews. If clouds are watched in a still warm evening, they will be seen to melt away, and disappear.

\section{DRIIPING WEATHER AFTER DROUGHT.}

No one that has not attended to such matters, and takcn down remarks, can be aware how much ten days' dripping weather will influence the growth of grass or corn after a severe dry season. This present summer, 1776, yielded a remarkable instance; for till the 30 th of May the fields were burnt up and naked, and the barley not half out of the ground; but now, June 10, there is an agreeable prospect of plenty.

\section{AURORA BOREALIS.}

November 1, 1787. The Northern Aurora made a particular appearance, forming itself into a broad, red, fiery belt, which extended from $\mathrm{E}$. to W. across the welkin; but the moon rising at about ten o'clock, in unclouded majesty in the E., put an end to this grand, but awful meteorous phenomenon.

\section{BLACK SPRING, 1771.}

DR. JoHnson says, that " in 1771 the season was so severe in the island of Skye, that it is remembered by the name of the Black Spring. The snow, which seldom lies at all, covered the ground for eight weeks, many cattle died, and those that survived weie so emaciated that they did not 
366 METEOROLOGIOAL OBSERVATIONS.

require the male at the usual season." The case was just the same with us here in the south; never were so many barren cows known as in the spring following that dreadful period. Whole dairies missed being in calf together.

At the end of March the face of the earth was naked to a surprising degree. Wheat hardly to be seen, and no signs of any grass; turnips all gone, and sheep in a starving way. All provisions rising in price. Farmers cannot sow for want of rain.

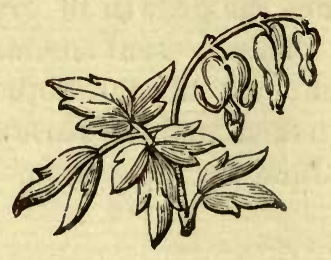




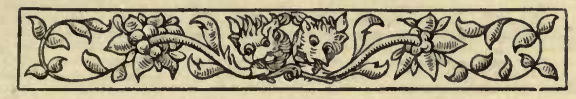

SUMMARY OF THE WEATHER.

MMin 


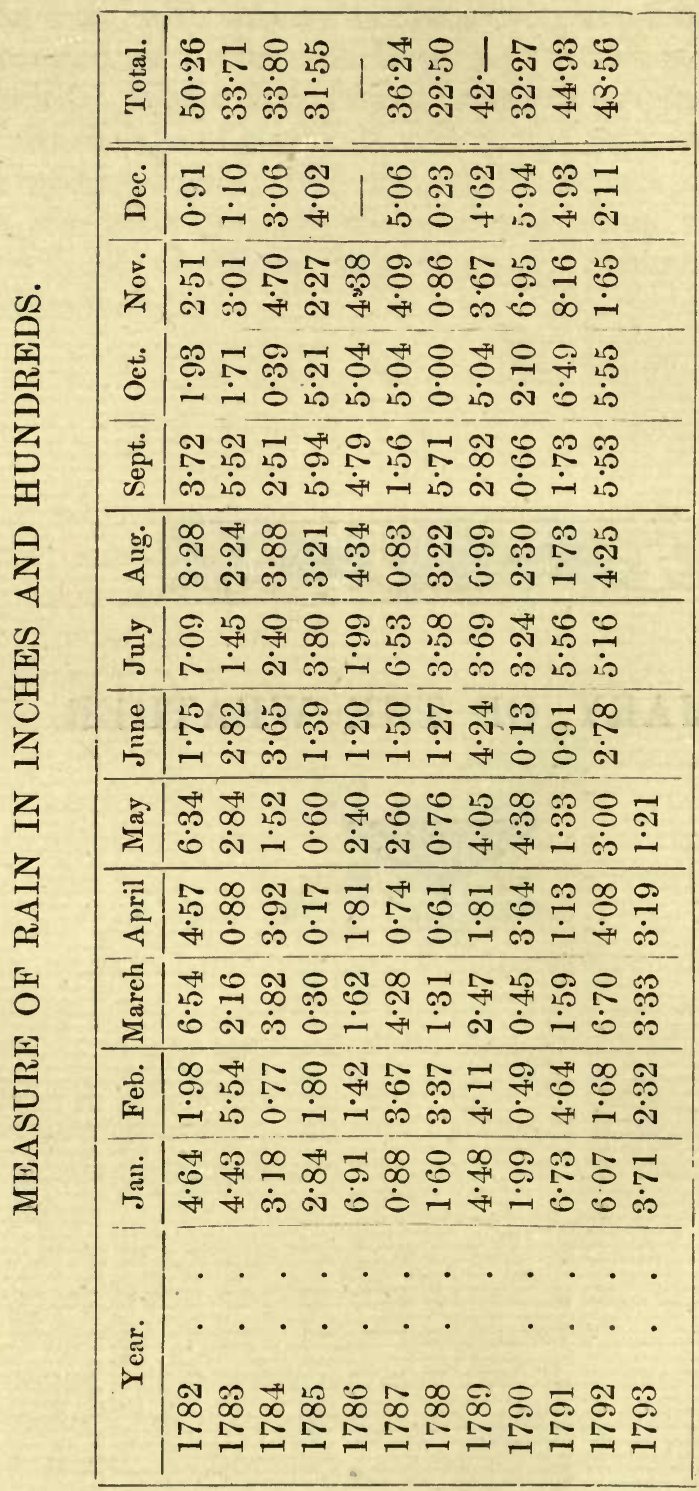

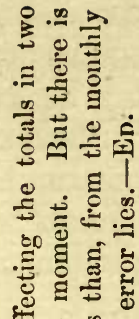

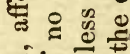
जٓ융

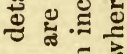
४⿻ ह 此 코 ฮี प्र

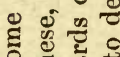
品 。 ๘

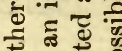
๑藏 द 1080.5 स ता उั๐ ○. ๘ 를. . 式方 ปै 范 00

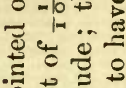

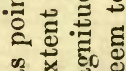
है ثِ ఏ थी की

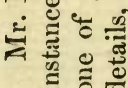




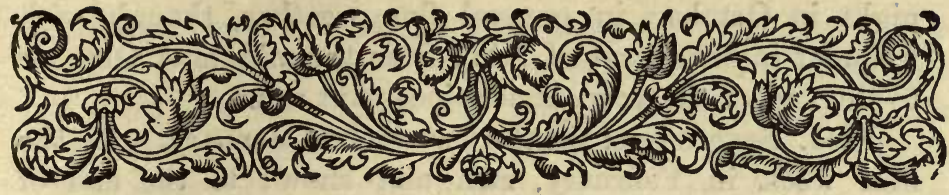

\section{SUMMARY OF THE WEATHER.}

1768.

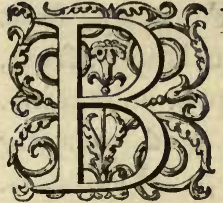

EGINS with a fortnight's frost and snow. Rainy during February. Cold and wet spring. Wet season from the beginning of June to the end of harvest. Latter end of September foggy, without rain. All October and the first part of November rainy; and thence to the end of the year alternate rains and frosts.

1769. January and February, frosty and rainy, with gleams of fine weather in the intervals. To the middle of March, wind and rain : to the end of March, dry and windy. To the middle of April, stormy with rain. To the end of June, fine weather, with rain. To the beginning of August, warm, dry weather. To the end of September, rainy, with short intervals of fine weather. To the latter end of October, frosty mornings, with fine days. The next fortnight rainy; thence to the end of November dry and frosty. December, windy, with rain and intervals of frost, and the first fortnight very foggy.

1770. Frost for the first fortnight: during the 14th and 15th all the snow melted. To the end of February, mild, hazy weather. The whole of March frosty, with bright weather. April cloudy, with rain and snow. May began with summer showers, and ended with dark cold raius. June, rainy, chequered with gleams of sunshine. The first fortnight in July, dark and sultry; the latter part of the month, heary rain. . August, September, and the first fort- 
night in October, in general fine weather, though with frequent interruptions of rain; from the middle of October to the end of the year, almost incessant rains.

1771. Severe frost till the last week in January. To the first week in February, rain and snow; to the end of February, spring weather. To the end of the third week in April, frosty weather. To the end of the first fortnight in May, spring weather, with copious showers. To the end of June, dry, warm weather. The first fortnight in July, warm, rainy weather. To the end of September, warm weather, but in general cloudy, with showers. October, rainy. November, frost, with intervals of fog and rain. December, in general bright, mild weather, with hoar frosts.

1772. To the end of the first week in Fubruary, frost and snow. To the end of the first fortnight in March, frost, sleet; rain, and snow. To the middle of April, cold rains. To the middle of May, dry weather, with cold piercing winds. To the end of the first week in June, cool showers. To the middle of August, hot, dry summer weather. To the end of September, rain, with storms and thunder. To December 22, rain, with mild weather. December 23, the first ice. To the end of the month, cold, foggy weather.

1773. The first week in January, frost; thence to the end of the month, dark rainy weather. The first fortnight in February, hard frost. To the end of the first week in March, misty, showery weather; bright spring days to the close of the month. Frequent showers to the latter end of April. To the end of June, warm showers, with intervals of sunshine. To the end of August, dry weather, with a few days of rain. To the end of the first fortnight in November, rainy. The next four weeks, frost; and thence to the end of the year, rainy.

1774. Frost and rain to the end of the first fortnight in March; thence to the end of the month, dry weather. To the 15th of April, showers; thence to the end of April, fine spring days. During May, showers and sunshine in about an equal proportion. Dark, rainy weather to the end of the third week in July; thence to the 24th of August, sultry, with thunder and occasional showers. To the end of the 
third wock in November, rain, with frequent intervals of sunny weather. To the end of December, dark, dripping fogs.

1775. To the end of the first fortnight in March, rain almost every day. To the first week in April, cold winds with showers of rain and snow. To the end of June, warm, bright weather, with frequent showers. The first fortnight in July, almost incessant rains. To the 26th of August, sultry weather, with frequent showers. To the end of the third week in September, rain, with a few intervals of fine weather. To the end of the year, rain, with intervals of hoar-frost and sunshine.

1776. To January 24, dark, frosty weather, with much snow. March 24, to the end of the month, foggy, with hoar-frost. To the 30th of May, dry, dark, harsh weather, with cold winds. To the end of the first fortnight in July, warm, with much rain. To the end of the first week in August hot and dry, with intervals of thunder showers. To the end of October, in general fine seasonable weather, with a considerable proportion of rain. To the end of the year, dry frosty weather, with some days of hard rain.

1777. To the 10th of January, hard frost: to the 20th of January, foggy, with frequent showers. To the 18th of February, hard, dry frost, with snow. To the end of May, heavy showers, with intervals of warm, dry, spring days. To the 8th of July, dark, with heary rain: to the 18th of July, dry, warm weather: to the end of July, very heavy rains. To the 12 th of October, remarkably fine, warm weather. To the end of the year, gray, mild weather, with but little rain, and still less frost.

1778. To the 13th of January, frost, with a little snow: to the 24th of January, rain : to the 30 th, hard frost. To the 23rd of February, dark, harsh, foggy weather, with rain: to the end of the month, hard frost with snow. To the end of the first fortnight in March, dark, harsh weather. From the 1st, to the end of the first fortnight in April, spring weather: to the end of the month, snow and ice. To the 11th of June, cool, with heavy showers. To the 19th of July, hot, sultry, parching weather: to the end of the month, heavy showers. To the end of Sep- 
tember, dry warm weather. To the end of the year, wet, with considerable intervals of sunshine.

1779. Frost and showers to the end of January. To the 21st of April, warm, dry weather. To the 8th of May, rainy. To the 7 th of June, dry and warm. To the 6th of July, hot weather, with frequent rain: to the 18 th of July, dry, hot weather. To August 8, hot weather, with frequent rains: to the end of August, fine dry harvest weather. To the end of November, fine autumnal weather, with intervals of rain. To the end of the year, rain, with frost and snow.

1780. To the end of January, frost. To the end of February, dark, harsh weather, with frequent intervals of frost. To the end of March, warm, showery, spring weather. To the end of April, dark, harsh weather, with rain and frost. To the end of the first fortnight in May, mild, with rain. To the end of August, rain, and fair weather in pretty equal proportions. To the end of October, fine autumnal weather, with intervals of rain. To the 24th of November, frost. To December 16, mild, dry, foggy weather. To the end of the year, frost and snow.

1781. To January 25, frost and snow. To the end of February, harsh and windy, with rain and snow. To April 5, cold, drying winds. To the end of May, mild, spring weather, with a few light showers. June began with heavy rain, but thence to the end of October, dry weather, with a few flying showers. To the end of the year, open weather, with frequent rains.

1782. To February 4, open, mild weather : to February 22, hard frost. To the end of March, cold, blowing weather, with frost and snow and rain. To May 7, cold, dark rains; to the end of May, mild, with incessant rains. To the end of June, warm and dry. To the end of August, warm, with almost perpetual rains. The first fortnight in September, mild and dry ; thence to the end of the month, rain. To the end of October, mild, with frequent showers. November began with hard frost, and continued throughout with alternate frost and thaw. The first part of December frosty: the latter part nild. 
1783. To January 16, rainy, with heavy winds: to the 24th, hard frost. To the end of the first fortnight in February, blowing, with much rain. To the end of February, stormy, dripping weather. To the 9 th of May, cold, harsh winds (thick ice on the 5th of May). To the end of August, hot weather with frequent showers. To the 23rd of September, mild, with heavy driving rains. To November 12, dry, mild weather. To the 18th of December, gray, soft weather, with a few showers. To the end of the year, hard frost.

1784. To February 19, hard frost, with two thaws; one, the 14th of January, the other, the 5th of February: to February 28, mild, wet fogs. To the 3rd of March, frost, with ice: to March 10, sleet and snow. To April 2, snow and hard frost : to April 27, mild weather, with much rain. To May 12, cold, drying winds: to May 20, hot, cloudless weather. To June 27, warm, with frequent showers. To July 18, hot and dry. To the end of A ugust, warm with heavy rains. To November 6, clear, mild, autumnal weather, except a few days of rain at the latter end of September. To the end of the year, fog, rain, and hard frost (on December 10, the therm. 1 deg. below 0.)

1785. A thaw began on the 2nd of January, and rainy weather with wind continued to January 28. To the 15th of March, very hard frost: to the 21st of March, mild, with sprinkling showers. To April 7, hard frost. To May 17 , mild, windy weather, without a drop of rain: to the end of May, cold, with a few showers. To June 9, mild weather, with frequent soft showers. To July 13, hot, dry weather, with a few showery intervals: to July 22, heavy rain. To the end of September, warm, with frequent showers. To the end of October, frequent rain. To the 18th of November, dry, mild weather. (Haymaking finished November 9 , and the wheat harvest November 14.) To December 23, rain. To the end of the year hard frost.

1786. To the 7th of January, frost and snow; to January 13, mild, with much rain: to the 21st of January, deep snow. To February 11, mild, with frequent rains; to the 21st of February, dry, with high winds. To the 10th of 
March, hard frost. To the 13 th of April, wet with intervals of frost; to the end of April, dry, mild weather. On the 1st and 2nd of May, thick ice; to the 10th of May, heavy rain. To June 14, fine, warm, dry weather. From the 8th to the 11th of July heavy showers. To October 13, warm, with frequent showers; to October 19, ice; to October 24, mild, pleasant weather. To November 3, frost. To December 16, rain, with a few detached days of frost. To the end of the year, frost and snow.

1787. To January 24, dark, moist, mild weathor : to January 28, frost and snow. To February 16, mild, showery weather; to February 28, dry, cool weather. To March 10, stormy, with driving rain; to March 24, bright, frosty weather. To the end of April, mild, with frequent rain. To May 22, fine bright weather. To the end of June, mostly warm, with frequent showers (on June 7, ice as thick as a crown piece). To the end of July, hot and sultry, with copious rain. To the end of September, hot dry weather, with occasional showers. To November 23, mild, with light frosts and rain; to the end of November, hard frost. To December 21, still and mild, with rain. To the end of the year, frost.

1788. To January 13, mild and wet; to January 18, frost; to the end of the month, dry, windy weather. To the end of February, frosty, with frequent showers. To March 14, hard frost; to the end of March, dark, harsh weather, with frequent showers. To April 4, windy, with showers. To the end of May, bright, dry, warm weather, with a few occasional showers. From June 28 to July 17, heary rains. To August 12, hot, dry weather. To the end of September, alternate showers and sunshine. To November 22, dry, cool weather. To the end of the year, hard frost.

1789. To January 13, hard frost ; to the end of the month, mild, with showers. To the end of February, frequent rain, with snow showers and heary gales of wind. To the 13th of March, hard frost, with snow. To April 18, heavy rain, with frost and snow and sleet; to the end of April, dark, cold woather, with frequent rains. To June 9, warm, spring 
weather, with brisk winds and frequent showers; from June 4 to the end of July, warm, with much rain. To August 29 , hot, dry, sultry weather. To September 11, mild, with frequent showers; to the end of September, fine autumnal weather, with occasional showers. To November 17, heavy rain, with violent gales of wind. To December 18, mild, dry weather, with a few showers. To the end of the year rain and wind.

1790. To January 16, mild, foggy weather, with occasional rains; to January 21, frost; to January 28, dark, with driving rains. To February 14, mild, dry weather; to February 22, hard frost. To April 5, bright, cold weather, with a few showers; to April 15, dark and harsh, with a deep snow ; to April 21, cold, cloudy weather, with ice. To June 6, mild spring weather, with much rain. From July 3 to July 14, cool, with heavy rain; to the end of July, warm, dry weather. To August 6, cold, with wind and rain: to August 24, fine harvest weather. To September 5, strong gales, with driving showers. To November 26, mild autumnal weather, with frequent showers. To December 1, hard frost and snow. To the end of the year, rain and snow, and a few days of frost.

1791. To the end of January, mild, with heavy rains. To the end of February, windy, with much rain and snow. From March to the end of June, mostly dry, especially June; (March and April, rather cold and frosty, May and June hot). July, rainy. Fine harvest weather, and pretty dry, to the end of September. Wet October, and cold towards the end. Very wet and stormy in November. Much frost in December.

1792. Some hard frost in January, but mostly wet and mild. February, some hard frost and a little snow. March, wet and cold. April, great storms on the 13th, then some very warm weather. May and June, cold and dry. July, wet and cool; indifferent harvest, rather late and wet. September, windy and wet. October, showery and mild. November, dry and fine. December, mild. 


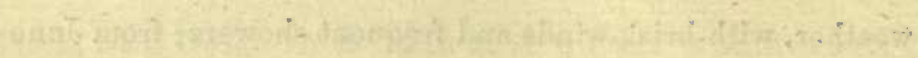

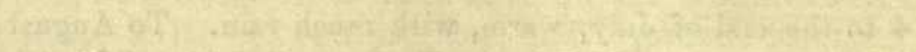

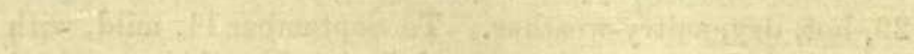

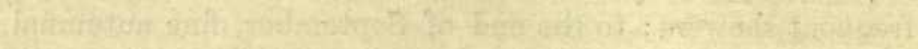

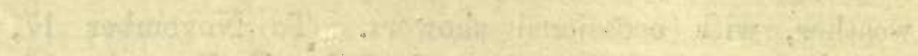

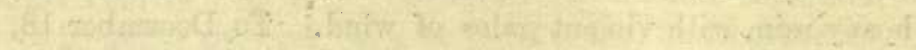

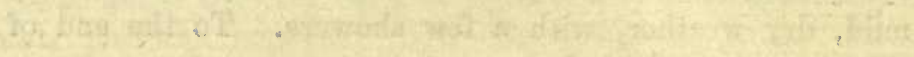

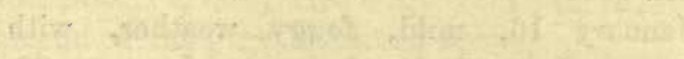

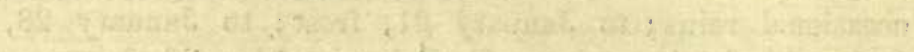

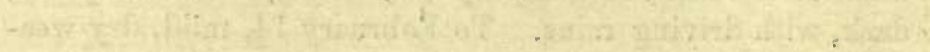

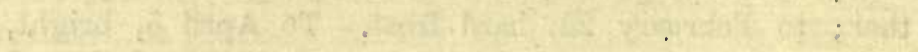

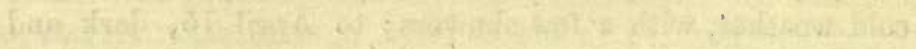

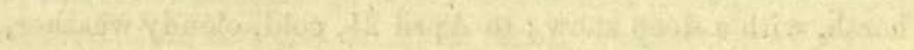

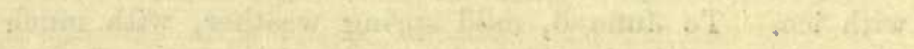

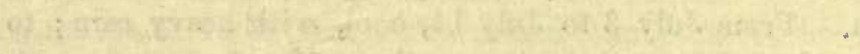

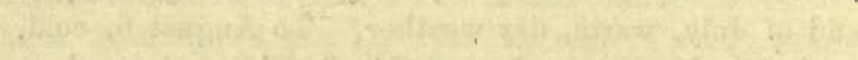

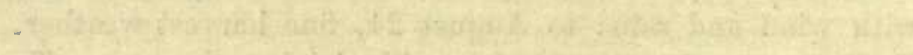

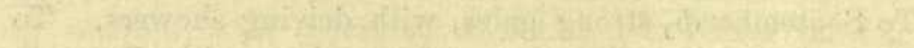

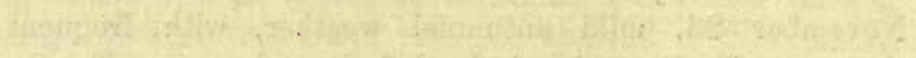

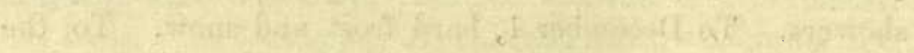

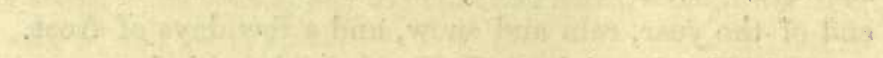

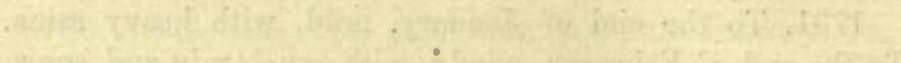
- .

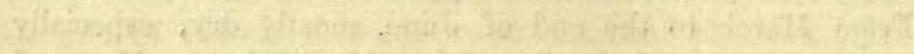
7.

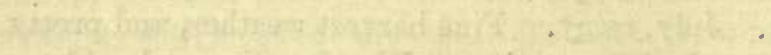

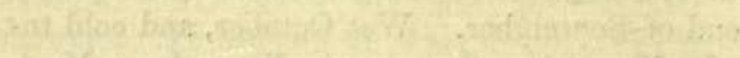

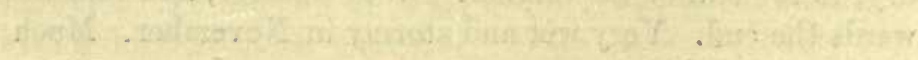

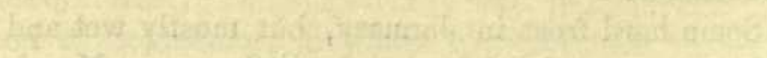

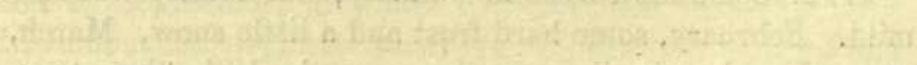

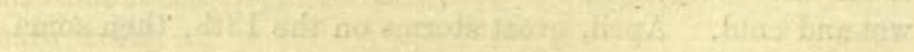

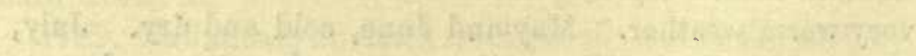

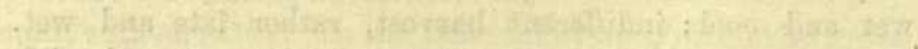

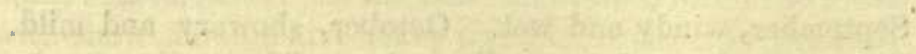

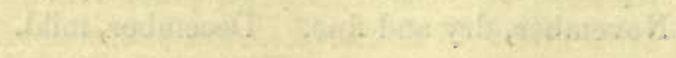




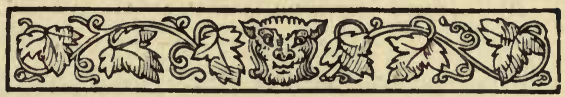

\section{A NATURALIST'S CALENDAR:}

WITH OBSERVATIONS IN VARIOUS BRANCHES OF NATURAL HISTORY.

EXTRACTED FROM THE PAPERS OF THE REV. GILBERT WHITE;

B Y JOHN A IKIN, M.D.

WITH REMARKS BY MR. MARKWICK AND OTHERS.

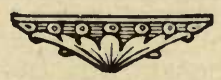





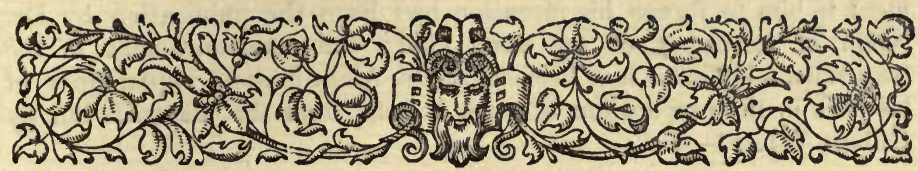

\section{DR. AIKIN'S ADVERTISEMENT.}

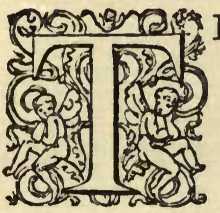

HE Rev. Mr. White, so agreeably known to the public by his Natural History of Selborne, left behind him a series of yearly books, containing his diurnal observations on the occurrences in the various walks of rural nature, from the year 1768 to the time of his death in 1793. From these annals he had already extracted all the matter comprised in the work abovementioned, down to the middle of 1787 ; but several curious facts in the preceding numbers had not been thus employed; and all the subsequent ones remained untouched. It was thought a mark of respect due to his memory, and to the reputation he had acquired as a faithful and elegant observer, not to consign these relics to neglect. The manuscripts were accordingly put into my hands for the purpose of selecting from them what might seem worthy of laying before the public. The present small publication is the fruit of my research. With no small pains I collected the materials of it, dispersed through the records of so many years, and gave them such an arrangement as $I$ thought would present them in the most agreeable and useful manner to the lovers of natural knowledge. ${ }^{1}$

J. AIKIN.

LoNdoN, Jan. 1, 1795.

1 The "Natural History of Selborne" and the "Naturalist's Calendar" are singularly connected. In the last paragraph of the former work, Gilbert White announces that he had proposed to have added a Natural IIistory of the Twelve Months of the Year, and that a main induce. 
ment to him to forego his intention had been the publication by Dr. Aikin of somewhat of the same kind: the commencement of the Naturalist's Calendar is a Preface by Dr. Aikin himself, explanatory of his part in the preparation of such a work from the materials left by Gilbert White!-ED.

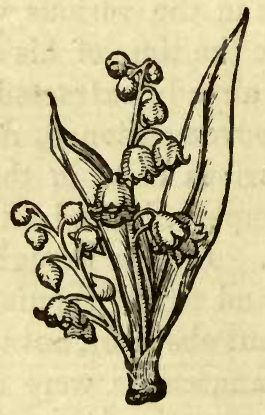




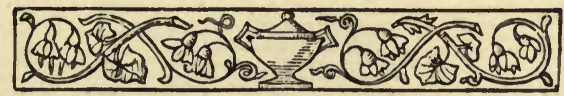

\section{THE NATURALIST'S CALENDAR,}

AS KEPT AT SELBORNE, IN HAMPSHIRE,

FROM THE YEAR 1768 TO THE YEAR 1793.

BY THE REV. GILBERT WHITE, M.A.

TO WHICH ARE APPENDFD, PARALLEL OBSERVATIONS MADE AT CATSFIELD, NEAR BATTLE, IN SUSSEX.

BY WILLIAM MARKWICK, ESQ. F.L.S.

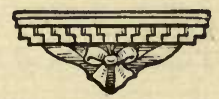




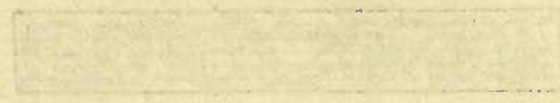

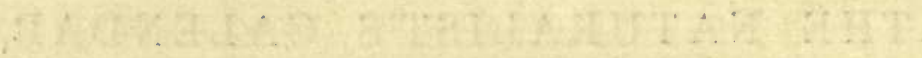

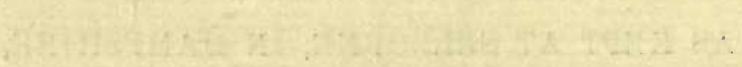

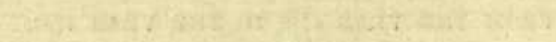

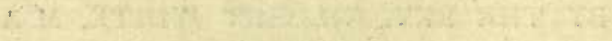




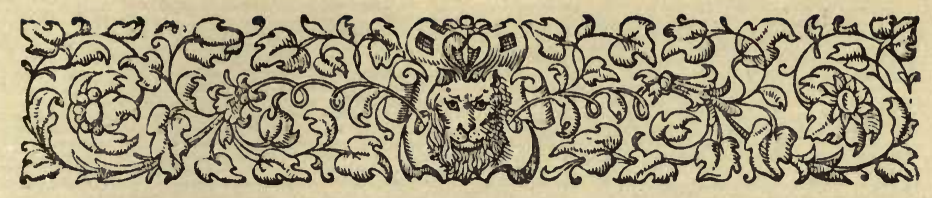

\section{PREFACE TO THE NATURALIST'S CAIENDAR.}

HE mode in which the following rural Calendar
out from the Journals all the circumstances earliest and latest of those dates; so that the Calendar exhibits the extreme range of variation in the first occurrence of all the phenomena mentioned. To many of them only one date is annexed, only one observation having been entered. This is particularly the case with respect to the flowering of plants, with which the book of 1768 alone was copiously filled; and it is to be noted that this was rather a backward year.-[J. A.]

[In the preface to the edition of the Natural History published in 1802 it is stated that

A very valuable addition to the Calendar and Observations has been obtained from the kindness of William Markwick, Esq., F.L.S., well known as an accurate observer of nature; whose parallel calendar, kept in the county of Sussex, is given upon the opposite columns.]

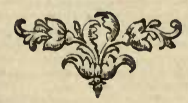




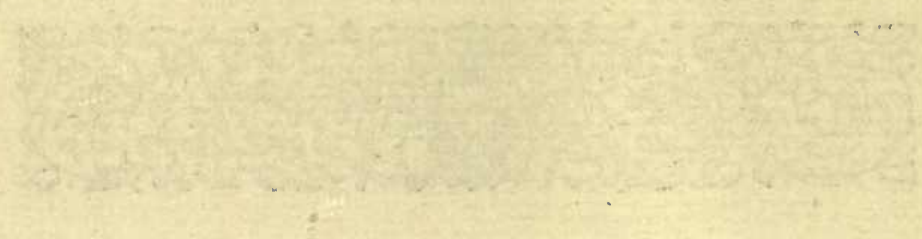

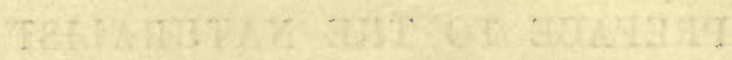

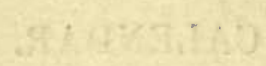

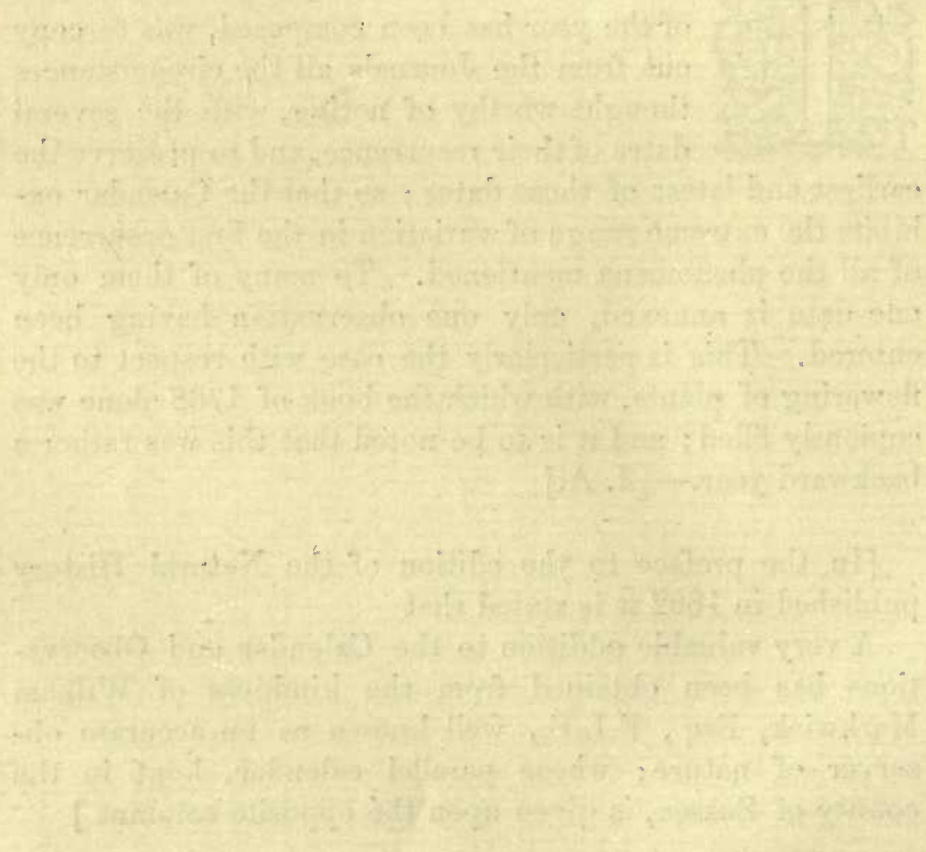




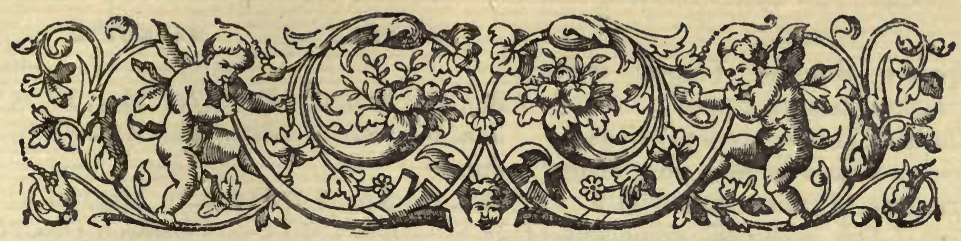

A

COMPARATIVE VIEW

OF

\section{WHITE'S AND MARKWICK'S CALENDARS.}

Of the abbreviations used, $f$. signifies flowering; l. leafing; and $a p$. the first appearance.

REDBREAST (Sylvia rubecula) whistles

Larks (Alauda arvensis) congregate

Nuthatch (Sitta casia) chatters

Winter aconite (Helleborus hiemalis) fl.

Shelless snail or slug (Limax) ap.

Gray wagtaii (Motacilla boarula) ap.

White wagtail (Motacillaalba) ap. $\}$

Missel thrush (Turdus viscivorus) sings

Bearsfoot (Helleborus fotidus) fl.

Polyanthus (Primula polyantha) fl.

Double daisy (Bellis perennis plena) fl.

Mezereon (Daphne mezereum) $\mathrm{fl}$.

Pansy (Viola tricolor) fl.

Red dead-nettle (Lamium purpureum) $\mathrm{fl}$.

Groundsel (Senecio vulgaris) fi.

Hazel (Corylus avellana) catkins open

Hepatica (Anemone hepatica) $\mathrm{fl}$.

Hedge sparrow (Sylvia modularis) whistles

Common flies (Musca domestica) seen in windows

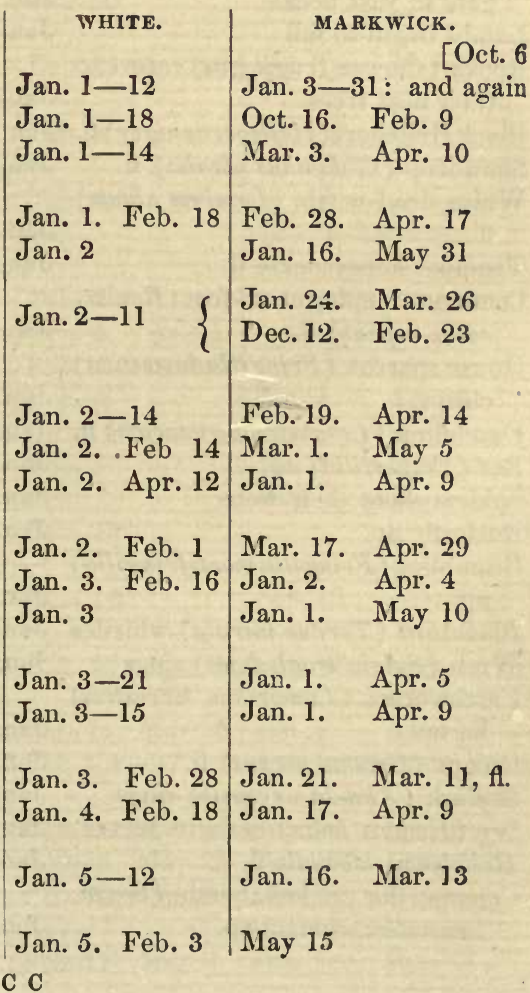


Greater titmouse (Parus major) makes its spring note

Thrush (Turdus musicus) sings

Insects swarm under sunny hedges

Primrose (Primula vulgaris) $\mathrm{fl}$.

Bees (Apis mellifica) come out of their hives

Gnats play about

Hen chaffinches (Fringilla calebs) Jan. 6-.11 flock

Furze or gorse (Ulex europaus) fl. Jan. 8. Feb. 1 Wall-flower (Cheiranthus cheiri; seu fruticulosus of Smith) $\mathrm{fl}$.

Stock (Cheiranthus incanus) fl.

Snow Bunting (Emberiza nivalis)

in great flocks
Linnets (Fringilla linota) congregate in rast flocks

Lambs begin to fall

Rooks (Corvus frugilegus) resort to their nest trees

Black Hellebore(Helleborusniger) fl.

Snowdrop (Galanthus nivalis) fl.

White dead-nettle (Lamium album) fl.

Trumpet honeysuckle fl.

Common creeping crow-foot (Ranunculus repens) fl.

Jan. 9

House sparrow (Fringilla domestica) chirps

Dandelion (Leontodon taraxacum) ff.

Bat (Vespertilio) ap.

Spiders shoot their webs

Butterfly ap.

Brambling (Fringilla montifringilla) ap.

Blackbird (Turdus merula) whistles

Wren (Sylvia troglodytes) sings

Earthworms (Lumbricus terrestris) lie out

Crocus (Crocus vernus) fl.

Skylark (Alauda arvensis) sings

Ivy (Hedera helix) casts its leaves Helleborus hiemalis $\mathrm{fl}$.

Common dor or clock beetle (Scara baus stercorarius) ap.
Jan. 8. Apr. 1

Jan. 8-12

Jan. 9

Jan. 9-11

Jan. 10. Feb. 11

Jan. 10

Jan. 10. Feb. 5

Jan. 13

Jan. 13

Jan. 13

MARKWICK.

Feb. 17. Mar. 17

Jan. 15. Apr. 4

Jan. 3. Mar. 22

[seen Dec. 30

Jan. 31. Apr. 11: last

Dec. 2. Feb. 3, male and female seen in equal numbers

Jan. 1. Mar. 27

Feb. 21. May 9

Feb. 1. June 3

Jan. 11

Jan. 6. Feb. 21

Jan. 23

Apr. 27

Jan. 18. Mar. 1

Mar. 23. May 10

Apr. 10. May 12

Jan. 14

Jan. 16. Mar. 11

Jan. 16. Mar. 24

Jan. 16

Jan. 16

Jan. 16

Jan. 17

Jan. 17

Jan. 18. Feb. 8

Jan. 18. Mar. 18

Jan. 21

Jan. 22

Jan. 22-24

Jan. 23
Feb. 17. May 9

Feb. 1. Apr. 17

Feb. 6. June 1 : last [seen Nov, 20

Feb. 21. May 8: last [seen Dec. 22

Jan. 10-31

Feb. 15. May 13

Feb. 7. June 12

Jan. 20. Mar. 19

Jan. 12. Feb. 27 : sings

[till Nov. 13

Feb. 28. Apr. 17

Feb. 12. Apr. 19: last [seen Nov. 24 
Peziza acetabulum ap.

Helleborus viridis $\mathrm{fl}$.

Hazel (Corylus avellana) shows its female blossoms

Woodlark (Alauda arborea) sings

Chaffinch (Fringilla cœlebs) sings

Jackdaw (Corvus monedula) begins to come to churches

Yellow wagtail (Motacilla fava) ap.

Honeysuckle (Lonicera periclymenum) 1.

Field or procumbent speedwell ( $V e$ ronica agrestis) $\mathrm{fl}$.

Small tortoise-shell butterfly (Papilio urtica) ap.

White wagtail (Motacilla alba) sings

Wood snail (Helix nemoralis) ap.

Earthworms (Lumbricus terrestris)

engender
Barren strawberry (Fragaria ste. rilis) $\mathrm{fl}$.

Tomtit (Parus ccruleus) makes its spring note

Brown wood owl (Strix aluco) hoots

Hen sits

Marsh titmouse (Parus palustris) begins his two harsh sharp notes

Gossamer floats

Musca tenax ap.

Laurustine (Viburnum tinus) fl.

Butcher's broom (Ruscus aculeatus) fi.

Fox (Canis vulpes) smells rank

Turkey cock struts and gobbles

Yellowhammer (Emberiza citrinella) sings

Brimstone butterfly (Papilio rhamni) ap.

Green woodpecker (Picus viridis) laughs

Raven (Corvus corax) builds

Male yew tree (Taxus baccata) sheds its farina

Coltsfoot (Tussilago farfara) $\mathrm{fl}$.

Rooks (Corvus frugilegus) build Partridges (Perdix cinerea) pair

Peas (Pisum sativum) sown

\begin{tabular}{|l|} 
wHITE. \\
Jan. 23 \\
Jan. 23. Mar. 5 \\
Jan. 23. Feb. 1 \\
Jan. 24. Feb. 21 \\
Jan. 24. Feb. 15 \\
Jan. 25. Mar. 4 \\
Jan. 25. Apr. 14 \\
Jan. 25 \\
Jan. 27. Mar. 15 \\
Jan. 27. Apr. 2 \\
Jan. 28 \\
Jan. 28. Feb. 24 \\
Jan. 30 \\
Teb. 1.
\end{tabular}

Feb. 1. Mar. 26

Feb. 1

Feb. 2

Feb. 3

Feb. 3

Feb. 4. Apr. 1

Feb. 4. Apr. 8

Feb. 5

Feb. 5

Feb. 7

Feb. 10

Feb. 12

Feb. 13. Apr. 2

Feb. 13. Mar. 23

Feb. $14-17$

Feb. 14. Mar. 27

Feb. 15. Mar. 23

Feb. 16. Mar.6

Feb. 17

Feb. 17. Mar. 8 Feb. 8. Mar. 31
MARKWICK.

Jan. 27. Mar. 11, fl.

Jan. 28. June 5

Jan. 21. Feb. 26

Apr. 13. July 3 : last [seen Sept. 8

Jan. 1. Apr. 9

Feb. 12. Mar. 29

[seen June 6

Mar. 5. Apr. 24: last

Mar. 16

Apr. 2. June 11

Jan. 13. Mar. 26

Apr. 27

Mar. 8, hatches

Jan. 1. Apr. 5

Jan. 1. May 10

May 19: young brought

[forth

Feb. 18. Apr. 28

Feb. 13. Mar. 8 : last [seen Dec. 24

Jan. 1. Apr. 17

Apr. 1: has young ones

[June 1

Feb. 2. Apr. 11, fl.

Feb. 18. Apr. 13

Feb. 28. Mar. 5

Feb. 16. Mar. 20 
House pigeon (Columba domestica) builds

Field crickets (Gryllus campestris) open their holes

Common flea (Pulex irritans) ap.

Pilewort (Ficaria verna) fl.

Goldfinch (Fringilla carduelis) sings

Viper (Coluber berus) ap.

Woodlouse (Oniscus asellus) ap.

Missel thrushes (Turdus viscivorus) pair

Daffodil (Narcissus pseudonarcissus) fl.

Willow (Salix alba) fl.

Frogs (Rana temiporaria) croak

Sweet violet (Viola odorata) fl.

Phalsena tinea vestianella ap.

Stone curlew (OEdicnemus crepitans) clamours

Filbert (Corylus sativus) fl.

Ring-dove (Columba palumbus) coos Apricot tree (Prunus armeniaca) fl.

Toad (Rana bufo) ap.

Frogs (Rana temporaria) spawn

Ivy-leaved speedwell (Veronica hederifolia) fl.

Peach (Amygdalus persica) fl.

Frog (Rana temporaria) ap.

Shepherd's purse (Thlaspi bursa pastoris) $\mathrm{fl}$.

Pheasant (Phasianus colchicus) crows

Land tortoise comes forth

Lungwort (Pulmonaria officinalis) $\mathrm{fl}$.

Podura fimetaria ap.

Aranea scenica saliens ap.

Sicolopendra forficata ap.

Wryneck (Yunx torquilla) returns

Goose lays

Duck lays

Dog violet (Viola canina) fl.

Peacock butterfly (Papilio Io) ap.

Trout (Salmo fario) begin to rise

Beans (Vicia faba) planted

Bloodworms appear in the water

Crow (Corvus corone) builds

Oats (Avena sativa) sown
W HITE.

Feb. 18

Feb. 20. Mar. 30

Feb. 21-26

Feb. 21. Apr. 13

Feb. 21. Apr. 5

Feb. 22. Mar. 26

Feb. 23. Apr. 1

Feb. 24

Feb. 24. Apr. 7

Feb. 24. Apr. 2

Feb. 25

Feb.26. Mar. 31

Feb. 26

Feb.27. Apr. 24

Feb. 27

Feb. 27. Apr. 5

Feb.

Feb. 28. Mar. 24

Feb. 28. Mar. 22

Mar. 1. Apr. 2

Mar. 2. Apr. 17

Mar. 2. Apr. 6

Mar. 3

Mar. 3-29

Mar.4. May 8

Mar. 4. Apr. 16

Mar. 4

Mar. 4

Mar. 5-16

Mar. 5. Apr. 25

Mar. 5

Mar. 5

Mar. 6. Apr. 18

Mar. 6

Mar. 7-14

Mar. 8

Mar. 8

Mar. 10

Mar. 10-18
MARKWICK.

Feb. 8, has young ones

Jan. 25. Mar. 26

Feb. 28. May 5

Feb. 23. May 6: last [seen Oct. 28

Apr. 27. June 17

Feb. 26. Apr. 18

Feb. 27. Apr. 11

Mar. 9. Apr. 20

Feb. 7. Apr. 5

June 17

Jan. 25. Mar. 26

Mar. 2. Aug. 10

Feb. 28. Apr. 5

Mar. 15. July 1

Feb. 9. Apr. 10: tad-

[poles Mar. 19

Feb. 16. Apr. 10

Mar.4. Apr. 29

Mar. 9

Jan. 2. Apr. 16

Mar. 1. May 22

Mar.2. May 19

[seen Sept. 14

Mar. 26. Apr. 23: last

Mar. 21

Mar. 28

Feb. 28. Apr. 22

Feb. 13. Apr.20: last [seen Dec. 25

Apr. 29 emerge

July 1, has young ones

Mar.16. Apr. 13 
Golden crested wren (Regulus cristatus) sings

Aspen (Populus trenıula) fl.

Common elder (Sambucus nigra) 1.

Laurel (Prunus laurocerasus) fl.

Chrysomela gottingensis ap.

Black ant (Formica nigra) ap.

Ephemera biseta ap.

Gooseberry (Ribes grossularia) 1.

Common stitchwort (Stellaria holostea) fl.

Wood anemone (Anemone nemorosa) fl.

Blackbird (Turdus merula) sits

Raven (Corvus corax) sits

Wheatear (Sylvia ænanthe) returns

Muskwood crowfoot (Adoxa moschatellina) $\mathrm{fl}$.

Small uncrested willow wren ap.

Fumaria bulbosa fl.

Elm (Ulmus campestris) fl.

Turkey (Meleagris gallopavo) lays

House pigeon (Columba domestica) sits

Marsh marigold (Caltha palustris) fl.

Buzz-fly (Bombylius medius) ap.

Sand martin (Hirundo riparia) ap.

Snake (Coluber natrix) ap.

Horse ant (Formica herculanea) ap.

Greenfinch (Loxia chloris) sings

Ivy (Hedera helix) berries ripe

Periwinkle (Vinca minor) $\mathrm{fl}$.

Spurge laurel (Daphne laureola) fl.

Swallow (Hirundo rustica) ap.

Blackcap (Sylvia atricapilla) whistles

Ducks hatched

Golden saxifrage (Chrysosplenium oppositifolium) fl.
WHITE.

Mar. 12. Apr.30

Mar. 12

Mar. 13-20

Mar. 15. May 21

Mar. 15

Mar. 15. Apr. 22

Mar. 16

Mar. 17. Apr. 11

Mar. 17. May 19

Mar. 17. Apr.22

Mar. 17

Mar. 17

Mar. $18-30$

Mar. 18. Apr. 13

Mar. 19. Apr. 13

Mar. 19

Mar. 19. Apr. 4

Mar. 19. Apr. 7

Mar. 20

Mar. 20. Apr. 14

Mar.21. Apr. 28

Mar. 21. Apr. 12

Mar. 22-30

Mar.22. Apr. 18

Mar. 22. Apr.22

Mar.23. Apr. 14

Mar. 25

Mar. 25. Apr. 1

Mar. 26. Apr. 20

Mar.26. May 4

Mar. 27

Mar.27. Apr.9
MARKWICK.

[Dec. 23. Jan. 26 Apr. 15. May 22, seen Feb. 26. Mar. 28 Jan. 24. Apr. 22

Apr. 2. May 27

Mar. 2. May 18

Feb. 26. Apr. 9

Mar. 8. May 7

Feb. 27. Apr. 10

Apr. 14, lays : young

[ones May 19

Apr. 1, builds

Mar. 13. May 23: last [seen Oct. 26

Feb. 23. Apr. 28

Willow wren (Sylvia trochilus) Mar. 30. May 16: sits May 27: last seen Oct. 23

Feb. 17. Apr. 25

Mar. 18-25: sits Apr.

[4: young ones Apr.30

Mar. 20: younghatched

Mar. 22. May 8

Mar. 15. Apr. 30

Apr.8. May 16: last [seen Sept. 8

Mar. 3. Apr.29: last [seen Oct. 2

Feb. 4. Mar. 26: last [seen Nov. 12

Mar. 6. Apr. 26

Feb. 16. May 19

Feb. 6. May 7

Apr. 12-22

Apr. 7-27: last seen

[Nov. 16

Apr. 14. May 18: seen Apr.14. May 20: last seen Sept. 19

Apr. 6. May 16

Feb. 7. Mar. 7 
House martin (Hirundo urbica) ap.

Chimney swallow (Hirundo rustica) ap.

Double hyacinth (Hyacinthus orien talis) fl.

Young geese

Wood sorrel (Oxalis acetosella) fl. Ring ouzel (Turdus torquatus) ap. Barley (Hordeum sativum) sown Nightingale (Sylvia luscinia) sings

Ash (Fraxinus excelsior) fl.

Spiders' webs on the surface of the ground

Chequered daffodil (Fritillaria meleagris) $\mathrm{fl}$.

Julus terrestris ap.

Cowslip (Primula veris) fl.

Ground ivy (Glechoma hederacea) fl.

Snipe (Scolopax gallinago) pipes

Box tree (Buxus sempervirens) ff.

Elm (Ulmus campestris) l.

Gooseberry (Ribes grossularia) fl.

Currant (Ribes hortensis) fl.

Pear tree (Pyrus communis) fl.

Newt or eft (Lacerta vulgaris) ap.

Dogs' mercury (Mercurialis perennis) $\mathrm{fl}$.

Wych elm (Ulmus glabra seu montana of Smith) fl.

Ladies smock (Cardamine pratensis) fl.

Cuckoo (Cuculus canorus) heard

Blackthorn (Prunus spinosa) fl.

Deathwatch (Termes pulsatorius) beats

Gudgeon (Gobio fluviatilis) spawns

Redstart (Ruticilla phœenicura) ap.

Crown imperial (Fritillaria imperialis) $\mathrm{fl}$.

Titlark (Alauda pratensis) sings

Beech (Fagus sylvatica) 1.

Wood snail (Helix nemoralis) comes out in troops

Middle yellow wren ap.

\section{WHITE.}

Mar.28. May 1

Mar. 28. Apr. 13

Mar. 29. Apr. 22

Mar. 29

Mar.30. Apr.22

Mar.30. Apr. 17

Mar. 31. Apr.30

Apr. 1. May 1

Apr. 1. May 4

Apr. 1

Apr. 2-24

Apr. 2

Apr. 3-24

Apr. 3-15

Apr. 3

Apr. 3

Apr. 3

Apr. 3-14

Apr. 3-5

Apr. 3. May 21

Apr. 4

Apr. 5-19

Apr. 5

Apr. 6-20

Apr. $7-26$

Apr.7. May 10

Apr. 7

Apr. 7

Apr. 8-28

Apr. 8-24

Apr. 9-19

Apr. 10. May 8

Apr. 11. May 9

Apr. 11
MARKWICK.

Apr. 14. May 8: last [seen Dec. 8

Mar. 23. Apr. 24

Mar. 29. Apr. 19

Feb. 26 . Apr. 26

Oct. 11

Apr. 12. May 20

Apr. 5. July 4: last [seen Aug. 29

Mar. 16. May 8

Apr. 15. May 1

Mar. 3. May 17

Mar. 2. Apr. 16

Mar. 27. May 8

Apr. 2. May 19

Mar. 21. May 1

Mar. 24. Apr. 28

Mar. 30. Apr. 30

Feb. 17. Apr. 15: last [seen Oct. 9

Jan. 20. Apr. 16

Apr. 19. May 10, 1 .

Feb. 21. Apr. 26

Apr. 15. May 3: last [heard June 28

Mar. 16. May 8

Mar. 28. May 28

Apr. 5: sings Apr. 25 :

[last seen Sept. 30

Apr. 1. May 13

Apr. 14-29: sits June

[16-27

Apr. 24. May 25

May 17. June 11 ap. 
Swift (Cypselus apus) ap.

Stinging fly (Conops calcitrans) ap. Whitlow grass (Draba verna) fl. Larch tree (Pinus larix rubra) 1. Whitethroat (Sylvia cinerea) ap.

Red ant (Formica rubra) ap.

Mole cricket (Gryllus gryllotalpa) churs

Second willow or laughing wren ap.

Red rattle (Pedicularis sylvatica) fl.

Common flesh-fly (Musca carnaria) ap.

Ladybird (Coccinella bipunctata) ap.

Grasshopper lark (Salicaria locustella) ap.

Large shivering willow wren

Middle willow wren ap.

Wild cherry (Prunus cerasus) fl.

Garden cherry (Prunus cerasus) fl.

Plum (Prunus domestica) fl.

Harebell (Hyacinthus non-scriptus seu Scilla nutans of Smith) fl.

Turtle (Columba turtur) coos

Hawthorn (Cratagus seu Mespilus Oxyacantha of Smith) $\mathrm{fl}$.

Male fool's orchis (Orchis mascula) fl. Blue flesh-fly (Musca vomitoria) ap. Black slug (Limax ater) abounds Apple tree (Pyrus malus sativus) fl. Large bat ap.

Strawberry, wild wood (Fragaria vesca) $\mathrm{fl}$.

Sauce alone (Erysimum alliaria) ft.

Wild or bird cherry (Prunus avium) fl.

Apis hypnorum ap.

Musca meridiana ap.

Wolf fly (Asilus) ap.

Cabbage butterfly (Papilio brassica) ap.

Dragon-fly (Libellula) ap.

Sycamore (Acer pseudoplatanus) fl.
WHITE. Apr. 13. May 7 Apr. 28. May 19 Apr. 14. May 17 Apr. 14 Apr. 14

Apr. 14. May 14

Apr. 14

Apr. 14. May 27

Apr.14-19-23

Apr. 15-19

Apr. 15

Apr. 16

Apr. 16-30

Apr. 17. May 7

Apr. 17-27

Apr. 18. May 12

Apr. 18. May 11

Apr. 18. May 5

Apr. 19-25

Apr. 20-27

Apr. 20. June 11

Apr. 21

Apr.21. May 23

Apr.22

Apr. 22. May 25

Apr.22. June11

Apr. 23-29

Apr. 23

Apr. 24

Apr. 24

Apr.24. May 28

Apr. 25

Apr. 28. May 20 Apr. 30. May 21

Apr. 29. June 15

Apr.30. June 6 Apr. 20. June 4
Apr. 18. May 13: last [seen Nov. 10

Jan. 15. Mar. 24

Apr. 1. May 9

Apr. 14. May 5: sings

May 3-10: last seen

Sept. 23

Apr. 9. June 26

Apr. 10. June 4

Willow wren, its shivering note heard Apr. 28. May 14

Mar. 30. May 10

Mar. 25. May 6

Mar. 24. May 6

Mar. 27. May 8

May 14. Aug. 10: seen

Apr. 19. May 26

Mar. 29. May 13

Feb. 1. Oct. 24, ap.

Apr. 11. May 26

Apr. 8-9

Mar. 31. May 8

Mar. 30. May 10 
Bombylius minor ap.

Glowworm (Lampyris noctiluca) shines

Fern-owl or goatsucker (Caprimulgus europaus) returns

Common bugle (Ajuga reptans) fl.

Field crickets (Gryllus campestris) trill

Chafer or May-bug (Scarabaus melolontha) ap.

Honeysuckle (Lonicera periclymenum) fl.

Toothwort (Luthraa squamaria) ff.

Wood snails (Helix nemoralis) pair Sedge warbler (Salicaria phragmitis) sings

Mealy tree (Viburnum lantana) fl.

Flycatcher (Muscicapa grisola) ap.

Apis longicornis ap.

Reed warbler (Salicaria strepera) ap.

Oak (Quercus robur) in male bloom

Admiral buttertly (Papilio atalanta) ap.

Orange tip butterfly (Papilio cardamines) ap.

Beech (Fagus sylvatica) fl.

Common maple (Acer campestris) fl.

Barberry tree (Berberis vulgaris) fl.

Wood Argus butterfly (Papilio ageria) ap.

Orange lily (Lilium bulbiferum) fl.

Burnet moth (Sphinx filipendula) ap.

Walnut (Juglans regia) 1 .

Laburnum (Cytisus laburnum) $\mathrm{fl}$.

Forest fly (Hippobosca equina) ap.

Saintfoin (Hedysarum onobrychis) fl.

Peony (Paonia officinalis) fl.

Horse chestnut (AEsculus hippocastanum) fl.

Lilac (Syringa vulgaris) fl.

Columbine (Aquilegia vulgaris) fl.

Medlar (Mespilus germanica) fl.

Tormentil (Tormentilla reptans) fl.

Lily of the valley (Convallaria majalis) $\mathrm{fl}$.

Bees (Apis mellifica) swarm

Woodroof (Asperula odorata) fl.

\begin{tabular}{|c|c|c|}
\hline $\begin{array}{l}\text { WHITE. } \\
\text { ay } 1\end{array}$ & & ICK. \\
\hline 1. J & June 19. & Sept. 2 \\
\hline Lay $1-26$ & $\begin{array}{l}\text { May } 16 . \\
\text { Mar. } 27 .\end{array}$ & $\begin{array}{l}\text { Sept. } 14 \\
\text { May } 10\end{array}$ \\
\hline ay $2-24$ & & \\
\hline ay $2-26$ & May 2. & July 7 \\
\hline $\begin{array}{l}-30 \\
-12 \\
-J u n e ~ 17\end{array}$ & Apr. 24. & June 21 \\
\hline $\begin{array}{l}\text { Iay } 4 \\
\text { Iay } 5-17 \\
\text { May } 10-30 \\
\text { May 10. June } 9\end{array}$ & $\begin{array}{l}\text { June 2-3 } \\
\text { Apr. } 25 . \\
\text { Apr. } 29 .\end{array}$ & $\begin{array}{l}30 \\
\text { May } 22 \\
\text { May } 21\end{array}$ \\
\hline $\begin{array}{l}\text { Lay } 11-13 \\
\text { [ay } 13-15\end{array}$ & $\begin{array}{l}\text { Aug. } 2 \\
\text { fl. Apr. } 29\end{array}$ & 9. Jun \\
\hline ay 1 & & \\
\hline $\begin{array}{l}-26 \\
-26\end{array}$ & $\begin{array}{l}\text { Mar. } 30 . \\
\text { Apr. } 23 . \\
\text { Apr. } 24 . \\
\text { Apr. } 28 .\end{array}$ & $\begin{array}{l}\text { May } 19 \\
\text { May } 28 \\
\text { May } 27 \\
\text { June 4 }\end{array}$ \\
\hline & & \\
\hline & Ju & \\
\hline Iay & May & \\
\hline 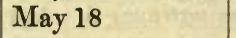 & Apr. & \\
\hline Tav 18. June 5 & May & Jur \\
\hline 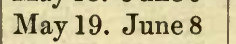 & & \\
\hline Lay 2 & Ap & May 2 \\
\hline & & \\
\hline & & \\
\hline-2 & $\mathrm{M}$ & \\
\hline . June 20 & Apr. 8. & June 19 \\
\hline ת & Apr. 17. & June 1 \\
\hline & & \\
\hline 22 & May 12. & \\
\hline
\end{tabular}


Wasp, female (Vespa vulgaris) ap.

Mountain ash (Sorbus seu Pyrus aucuparia of Smith) $\mathrm{fl}$.

Bird's-nest orchis (Ophrys nidus avis) $\mathrm{fl}$.

White-beam tree (Cratcgus) seu Pyrus aria of Smith) 1.

Milkwort (Polygala vulgaris) fl.

Dwarf cistus (Cistus helianthemum) fl.

Guelder rose (Viburnum opulus) $\mathrm{fl}$. Common elder (Sambucus nigra) $\mathrm{fl}$.

Cantharis noctiluca ap.

Apis longicornis bores holes in walks

Mulberry tree (Morus nigra) 1.

Wild service tree (Cratagus seu Pyrus torminalis of Smith) fl.

Sanicle (Sanicula europaa) $\mathbf{f l}$.

Avens (Geum urbanum) fl.

Female fool's orchis (Orchis morio) fl.

Ragged Robin (Lychnis flos cuculi) f.

Burnet (Poterium sanguisorba) fl.

Foxglove (Digitalis purpurea) $\mathrm{fl}$.

Corn flag (Gladiolus communis) fl.

Serapias longifolia $\mathrm{ft}$.

Raspberry (Rubus idrus) fl.

Herb Robert (Geranium robertianum) fl.

Figwort (Scrophularia nodosa) fl.

Gromwell (Lithospermum officinale) fl.

Wood spurge (Euphorbia amygdaloides) $\mathrm{fl}$.

Ramsons (Allium ursinum) fl.

Mouse-ear scorpion grass (Myosotis scorpioides) fl.

Grasshopper (Gryllus grossus) ap.

Kose (Rosa hortensis) fl.

Mouse-ear hawkweed (Hieracium pilosella) $\mathrm{tl}$.

Buckbean (Menyanthes trifoliata) $\mathrm{fl}$.

Rose chafer (Scarabaus auratus) ap.

Sheep shorn

Water flag (Iris pseudacorus) fl.

Cultivated rye (Secale cereale) $\mathrm{fl}$.
WHITE.

May 23

May 23. June 8

May 24. June 11

May 24. June 4

May 24. June 7

May 25

May 26

May 26. June 25

May 26

May 27. June 9

May 27. June 13

May 27

May 27, June 13

May 28

May 28

May 29. June 1

May 29

May 30. June 22

May 30. June 20

May 30. June 13

May 30. June 21

May 30

May 31

May 31

June 1

June 1

June 1

June 1-14

June 1-21

June 1. July 16

June 1

June $2-8$

June 2-23

June 2

June 2
MARK WICK.

Apr. 2. June 4 : last

[seen Nov. 2

Apr. 20. June 8

May 18. June 12

May 3

Apr. 13. June 2

May 4. Aug. 8

May 10. June 8

May 6. June 17

May 20. June 11

May 13. June 19

Apr. 23. June 4

May $9 . \quad$ June 11

Apr. 17. May 20

May 12. June 8

Apr. 30. Aug. 7

May 23. June 15

June 9. July 8

May 10. June 16

Mar. 7. May 16

May 12. June 20

May $10-24$

Mar. 23. May 13

Apr. 21. June 4

Apr. 11. June 1

Mar. 25. July 6: last [seen Nov. 3

June 7. July 1

Apr. 19. June 12.

A pr. 20. June 8

Apr. 18. Aug. 4

May 23. June 17

May 8. June 9

May 27 
Hound's tongue (Cynoglossum officinale) fl.

Helleborine (Serapias latifolia) fl.

Green gold fly (Musca casar) ap.

Argus butterfly (Papilio moera) ap.

Spearwort (Ranunculus fammula) $\mathrm{fl}$.

Birdsfoot trefoil (Lotus corniculatus) fl.

Fraxinella or white dittany (Dictamnus albus) fl.

Phryganea nigra ap.

Angler's may-fly (Ephemera vulgata) ap.

Ladies' fingers (Anthyllis vulneraria) fl.

Bee orchis (Ophrys apifera) fl.

Pink (Dianthus deltoides) $\mathrm{fl}$.

Syringa (Philadelphus coronarius) fl.

Libellula virgo ap.

Vine (Vitis vinifera) ft.

Portugal laurel (Prunus lusitanicus) fl.

Purple spotted martagon (Lilium martagon) $\mathrm{fl}$.

Meadow crane's-bill (Geranium pratense) $\mathrm{fl}$.

Black bryony (Tamus communis) ft.

Field pea (Pisum sativum arvense) ff.

Bladder campion (Cucubalus behen seu Silene influta of Smith) $\mathrm{fl}$.

Bryony (Bryonia alba) fl.

Hedge nettle (Stachys sylvatica) fl.

Bittersweet (Solanum dulcamara) fl.

Walnut (Juglans regia) fl.

Phallus impudicus ap.

Rosebay willow-herb (Epilobium angustifolium) $\mathrm{Al}$.

Wheat (Triticum hybernum) fi.

Comfrey (Symphytum officinale) $\mathrm{fl}$.

Yellow pimpernel (Lysimachia nemorum) fl.

Tremella nostoc ap.

Buckthorn (Rhamnus catharticus) fl. Cuckow-spit insect (Cicadaspumaria) ap.

Dog-rose (Rosa canina) fl.

Large puff-ball (Lycoperdon bovista) ap.
WHITE.

June 2

June 2 Aug. 6

June 2

June 2

June 3

June 3

June 3-11

June 3

June 3-14

June 4

June 4 July 4

June 5-19

June 5

June 5-20

June 7. July 30

June 8. July 1

June 8-25

June 8. Ang. 1

June 8

June 9

June 9

June 9

June 10

June 11

June 12

June 12. July 23

June 12

June 13. July 22

June 13

June 13-30

June 15. Aug.24

June 16

June 16

June 17, 18

June 17 Sept. 3
MA RK WICK.

May 11. June 7

July $2 \cdot 2$. Sept. 6

Apr. 25. June 13

Apr. 10. June 3

June 9. July 24

June 1. Aug. 16

May 26. July 6

May 16. June 23

June 18. July 29

June 3. July 16

June 18. July 19

May 15. June 21

May 15. June 21

May 4. July 13

May 13. Aug. 17

May 28. June 24

May 15. June 20

Apr. 18. June 1

June 4. July 28

June 4-30

May 4. June 23

Apr. 10. June 12

May 25

June 2-21

May 24. June 21

May 6. Ang. 19 
I white.

Mullein (Verbascum thapsus) tl. June 18

Viper's bugloss (Echium vulgare) fl. June 19

Meadow hay cut

Stag beetle (Lucanus cervus) ap.

Borage (Borago officinalis) fl.

Spindle tree (Enonymus europæeus) fl.

Musk thistle (Carduus nutans) fl.

Dogwood (Cornus sanguinea) fl.

Field scabious (Scabiosa arvensis) fl.

Marsh thistle (Carduus palustris) fl.

Dropwort (Spirca filipendula) fl.

Great wild valerian (Valeriana officinalis) $\mathrm{fl}$.

Quail (Perdix coturnix) calls

Mountain willow herb (Epilobium montanum) fl.

Thistleupon thistle(Carduus crispus) fl.

Cow parsnep (Heracleum sphondylium) $\mathrm{fl}$.

Earth-nut (Bunium bulbocastanum seu flexuosum of Smith) fl.

Young frogs (Rana temporaria) migrate

Estrus curvicauda ap.

Vervain (Verbena officinalis) fl.

Corn poppy (Papaver rhceas) fl.

Self-heal (Prunella vulgaris) $\mathrm{fl}$.

Agrimony (Agrimonia eupatoria) fl.

Great horse-fly (Tabanus bovinus) ap.

Greater knapweed (Centaurea scabiosa) $\mathrm{fl}$.

IIushrooin (Agaricus campestris) ap. June 26. Aug. 30

Common mallow (Malva sylvestris) fl. June 26

Dwarf mallow (Malva rotundifolia) fl.

St. John's Wort(Hypericum perforatum) fl.

Broom rape (Orobanche major) $\mathrm{fl}$.

Henbane (Hyoscyamus niger) $\mathrm{fl}$.

Goat's-beard (Tragopogon pratensis) fl.

Deadly nightshade (Atropa belladonna) fl.

Truffles (Lycoperdon tuber) begin to be found

Young partridges (Perdix cinerea) fly
June 19. July 20

June 19

June 20

June 20

June 20. July 4

June 21

June 21

June 21-27

June 22. July 9

June 22. July 7

June 22. July 4

June 22

June 23-29

June 23

June 23

June 23. Aug. 2

June 24

June 24

June 24

June 24

June 24-29

June 24. Aug. 2

June 25

June 26

June 26

June 27. July 4

June 27

June 27

June 27

June 28. July 29

June 28. July 31 July $8-28$
MARK WICK.

June 10. July 22

May 27. July 3

June 13. July 7

June 14-21

Apr. 22. July 26

May 11. June 25

June 4. July 25

May 28. June 2T

June 16. Aug. 14

May 15. June 19

May 8. Sept. 3

May 22. Jüly 21

July 23 : seen Sept 1

June $5-21$

May 22. July 22

May 27. July 12

May 4--31

June 10. July 17

Apr. 30. July 15

June 7-23

June 7. July 9

June 7. Aug. 14

Apr. 16. Aug. 16

May 27. July 13

May 12. July 30

June 15. July 12

May 9. July 25

May 13. June 19

June $5-14$

May 22. Aug. 14 
Jime tree (Tilia europaa) fl. Spear thistle (Carduus lanceolatus) fl.

Meadow sweet (Spirca ulmaria) fl.

Greenweed (Genista tinctoria) $\mathrm{fl}$.

Wild thyme (Thymus serpyllum) fl. Stachys germanica $\mathrm{fl}$.

Day lily (Hemerocallis flava) $\mathrm{Al}$.

Jasmine (Jasminum officinale) $\mathrm{fl}$.

Holyoak (Alcea rosea) $\mathrm{fl}$.

Monotropa hypopitys $\mathrm{fl}$.

Ladies' bedstraw (Galium verum) fl. Galium palustre $\mathrm{fl}$.

Nipplewort (Lapsana communis) ft. Welted thistle (Carduus acanthoides) fl.

Sneezewort (Achillea ptarmica) fl. Mnsk mallow (Malva moschata) fl. Pimpernel (Anagallis arvensis) fl.

Hoary beetle (Scarabaus solsticialis) ap.

Common thistle (Serratula arvensis seu Carduus arvensis of Smith) $\mathrm{fl}$.

Pheasant's eye (Adonis annua seu autumnalis of Smith) fl.

Red eyebright (Euphrasia seu Bartsia odontites of Smith) $\mathrm{fl}$.

Thorough wax (Bupleurum rotundifolium) $\mathrm{fl}$.

Cockle (Agrostemma githago) $\mathrm{fl}$.

Ivy-leaved wild lettuce (Prenanthes muralis) $\mathrm{fl}$.

Feverfew (Matricaria seu Pyrethrum parthenium of Smith) $\mathrm{fl}$.

Stonecrop (Sedum acre) $\mathrm{fl}$.

Privet (Ligustrum vulgare) $\mathrm{fl}$.

Common toadflax (Antirrhinum lınaria) fl.

Perennial wild flax (Linum perenne) fl.

Whortle-berries (Vaccinium myrtil$l u s$ ) ripe

Yellow base rocket (Reseda lutea) fl. Blue-bottle (Centaurea cyanus) $\mathrm{fl}$.

Dwarf carline thistle (Carduus acaulis) $\mathrm{fl}$.

Bull-rush or cat's-tail (Typha latifolia) $\mathrm{fl}$
wHITE.

June28. July 31 June 12. July 30

June 28. July 12 June 27. July 18

June 28

June 28

June 28

June 29. July 20

June 29. July 4

June 29. July 30

June 29. Aug. 4

June 29. July 23

June 29

June 29

June 29

June 29

June 30

June 30

June 30

June 30. July 17

July 1

July 1

July 2

July 2

July 2

July 2

July 2

July 3

July 3

July 3

July 4

July 4-24

July 5

July 5

July 5-12

July 6
June 16. July 24

June 4. July 24

June 6. July 19

June 27. July 2]

July $4 . \quad$ Sept. 7

June 22. Ang. 3

May 30. July 24

June 22. Aug. 3

June 9. July 14

May 4. June 22

June 15. July 15

April 11. July 15

June 20. Aug. 10

May 14. July 25

June 2. July 25

June 19. July 24

June 8. July 12

June 3. July 13

June 21. Aug. 3

Apr. 21. July 6

July 19

May 15. Oct. 14

June 30. Aug. 4

June 29. July 21
May 29. June 9 
Spiked willow-herb (Lythrum salicaria) fl.

Black mullein (Verbascum nigrum) ft.

Chrysanthemum coronarium, fl.

Marigolds (Calendula officinalis) fl.

Little field madder (Sherardia arvensis) $\mathrm{fl}$.

Field calamint (Melissa seu Thymus nepeta of Smith) fl.

Black horehound (Ballota nigra) $\mathrm{fl}$.

Wood betony (Betonica officinalis) fl.

Round-leaved bell-flower (Campanula rotundifolia) $\mathrm{fl}$.

All-good (Chenopodium bonus Henricus) $\mathrm{fl}$.

Wild carrot (Daucus carota) fi.

Indian cress (Tropaolum najus) fl.

Cat-mint (Nepeta cataria) fl.

Cow-wheat (Melampyrum sylvaticum seu pratense of Smith) $\mathrm{fl}$.

Crosswort (Valantia cruciata seu Galium cruciatum of Smith) fl.

Cranberries (Vaccinium oxycoccus) ripe

Tufted vetch (Vicia cracca) fl.

Wood vetch (Vicia sylvatica) fl.

Little throat-wort (Campanula glomerata) $\mathrm{fl}$.

Sheep's scabious (Jasione montana)fl.

Wild parsnep (Pastinaca sylvestris)fl.

White lily (Lilium candidum) fl.

Hemlock (Conium maculatum) fi.

Hedge parsley (Caucalis anthriscus) fl.

Flying ants ap.

Moneywort (Lysimachia nummularia) fl.

Scarlet martagon (Lilium chalcedonicum) fl.

Lesser stitchwort (Stellaria graminea) $\mathrm{fl}$.

Fool's parsley ( REthusa cynapium) $\mathrm{fl}$.

Dwarf elder (Sambucus ebulus) fl.

Young martins and swallows begin to congregate

Potatoe (Solanum tuberosum) fi.

Wood angelica (Angelica sylvestris) fl.

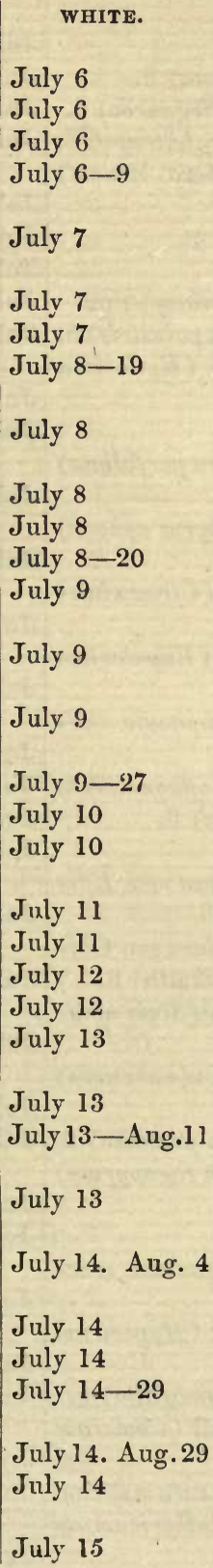

MARKWICK.

June 24. Aug. 17

May 28. July 28

A pr. 20. July 16

Jan. 11. June 6

Thymus Calamintha

June 16. Sept. 12

June 10. July 15

June 12. July 29

Apr. 21. June 15

June 7. July 14

June 11. July 25

May 2. June 22

Apr. 10. May 28

May 31. July 8

July 28. Ang. 18

June 10. July 25

June 21. July 22

June 4. July 20

Aug. 20. Sept. 19

June 14. Aug. 16

June 21. Aug. 6

May 8. June 23

June 9. Aug. 9

Aug. 12. Sept. 8

June 3. July 12 
Digitalis ferruginen $\mathrm{fl}$.

Ragwort (Senecio jacobaa) fl.

Golden rod (Solidago virgaurea) fl.

Star thistle (Centaurea calcitrapa) fl.

Tree primrose (Enothera biennis) fl.

Peas (Pisum sativum) cut

Galega officinalis $\mathrm{fl}$.

Apricots (Prunus armeniaca) ripe

Clown's allheal (Stachys palustris) fl.

Branching willow-herb (Epilobium ramosum) fl.

Rye harvest begins

Yellow centaury (Chlora perfoliata) fl.

Yellow vetchling (Lathyrus aphaca) fl.

Enchanter's nightshade (Circca lutetiana) $\mathrm{fl}$.

Water hemp agrimony (Eupatorium cannabinum) fl.

Giant throatwort (Campanula latifolia) $\mathrm{fl}$.

Eyebright (Euphrasia officinalis) fl.

Hops (Humulus lupulus) fl.

Poultry moult

Dodder (Cuscuta europaa seu Epithymum of Smith) fl.

Lesser centaury (Gentiana seu Chironia centaurium of Smith) fl.

Creeping water parsnep (Sium nodiflorum) fl.

Common spurrey (Spergula arvensis) fl.

Wild clover (Trifolium pratense) fl. Buckwheat (Polygonum fagopyrum) fl.

Wheat harvest begins

Great bur-reed (Spargunium erectum) fl.

Marsh St. John's-wort (Hypericum elodes) $\mathrm{fl}$.

Sun-dew (Drosera roindifolia) fi.

Purple marsh cinquefoil (1 iomarum palustre) $\mathrm{fl}$.

Wild cherries (Prunus cera ius) ripe

Lancashire asphodel (Anther icum ossifrngum) fl.
WHITE.

July $15-25$

July 15

July 15

July 16

July 16

July 17. Aug. 14 July 17

July 17. Aug. 21

July 17

July 17

July 17. Aug. 7

July 18. Aug. 15

July 18

July 18

July 18

July 19

July 19

July 19, Aug. 10

July 19

July 20

July 20

July 20

July 21

July 21

Julv 21

July 21. Aug. 23

July 22

July $22-31$

Tuly 22

July 22

July 22

July 22
MARKWICK.

June 22. July 13

July 7. Ang. 29

July 16. Aug. 16

June 12. July 18

July 13. Aug. 15

July 5. Aug. 16

June 12. July 14

June 15. Aug. 13

June 20. July 27

July 4. Aug. 6

[13. Aug. 14

Camp.Trachelium.July

May 28. July 19

July 20. Aug. 17

July 9. Aug. 7

June 3. July 19

July 10. Sept. 11

Apr. 10. July 16

May 2. June 7

June 27. July 10

July 11. Ang. 26

June 10. July 23

June 16. Aug. 10

Aug. 1

May 27. July 12

June 21. July 29 
Hooded willow-herb (Scutellaria galericulata) $\mathrm{fl}$.

Water dropwort (Enanthe fistulosa) fl.

Horehound (Marrubium valgare) $\mathrm{fl}$. Seseli caruifolium $\mathrm{fl}$.

Water plantain (Alisma plantago) $\mathrm{fl}$. Alopecurus myosuroides $\mathrm{fl}$.

Virgin's bower (Clematis vitalba) $\mathrm{fl}$. Bees kill the drones

Teasel (Dipsacus sylvestris) fl.

Wild marjoram (Origanum vulgare) fl.

Swifts (Cypselus apus) begin to depart

Small wild teasel (Dipsacus pilosus) fl.

Wood sage (Teucrium scorodonia)fl.

Everlasting pea (Lathyrus latifolius) fi.

Trailing St. John's wort (Hypericum humifusum) $\mathrm{fl}$.

White hellebore (Veratrum album) fi.

Camomile (Anthemis nobilis) $\mathrm{fl}$.

Lesser field scabious (Scabiosa columbaria) fl.

Sunflower (Helianthus multiflorus) ff. Yellow loosestrife (Lysimachia vulgaris) $\mathrm{fl}$.

Swift (Cypselus apus) last seen

Oats (Avena sativa) cut

Barley (Hordeum sativum) cut

Lesser hooded willow-herb (Scutellaria minor) $\mathrm{fl}$.

Middle fleabane (Inula dysenterica) fl.

Apis manicata ap.

Swallow-tailed butterfly (Papilio machaon) ap.

Whame or burrel fly (CFstrus equi) lays eggs on horses

Sow thistle (Sonchus arvensis) $\mathrm{fl}$.

Plantain fritillary (Papilio cinxia) ap.

Yellow succory (Picris hieracioides) fl.

Musca mystacea ap.

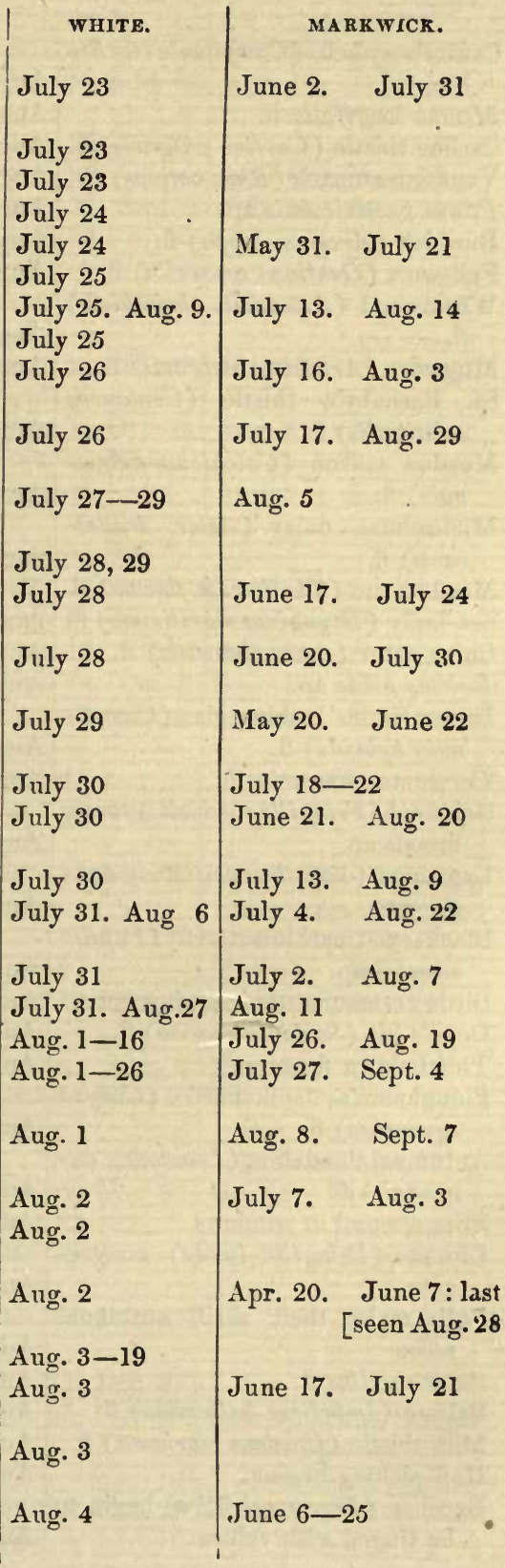


Canterbury bells (Campanula trachelium) $\mathrm{fl}$.

Mentha longifolia $\mathrm{fl}$.

Carline thistle (Carlina vulgaris) ff.

Venetian sumach (Rhus cotinus) $\mathrm{fl}$.

Ptinus pectinicornis ap.

Burdock (Arctium lappa) fl.

Fell-wort (Gentiana amarella) fl.

Wormwood (Artemisia absinthium) fl.

Mugwort (Artemisia vulgaris) fl.

St. Barnaby's thistle (Centaurea solstitialis) fl.

Meadow saffron (Colchicum autumnale) fl.

Michaelmas daisy (Aster tradescanti) $\mathrm{fl}$.

Meadow rue (Thalictrum flavum) fl.

Sea holly (Eryngium maritimum) fl.

China aster (Aster chinensis) fl.

Boletus albus ap.

Lesser Venus' looking-glass (Campanula hybrida) fl.

Carthamus tinctorius $\mathrm{fl}$.

Goldfinch (Fringilla carduelis) young broods ap.

Lapwings (Vanellus cristatus) congregate

Black-eyed marble butterfly (Papilio semele) ap.

Birds re-assume their spring notes

Devil's bit (Scabiosa succisa) fl.

Thistledown floats

Ploughman's spikenard (Conyza squarrosa) ff.

Autumnal dandelion (Leontodon autumnale) fil.

Flies abound in windows

Linnets (Fringilla linota) congregate

Bulls make their shrill autumnal noise

Aster amellus fi.

Balsam (Impatiens balsamina) fl.

Milk thistle (Carduus marianus) ff.

Hop-picking begins.

Beeches (Fagus sylvatica) begin to be tinged with yellow
MARKWICK.

Aug. 5

Aug. 5

Aug. 7

Aug. 7

Aug. 7

Aug. 8

Aug. 8. Sept. 3

Aug. 8

Aug. 8

Aug. 10

Aug. 10 Sept. 13

Ang. 15. Sept. 29

Aug. 12. Sept. 27

Aug. 14

Ang. 14

Aug. 14. Sept. 28

Aug. 14

Aug. 15

Aug. 15

Aug. 15

Aug. 15. Sept. 12

Ang. 11. Oct. 8

July 22. Aug. 21

July 9. Aug. 10.

Aug. 6. Oct. 2

May 10

May 14

June 15

Sept. 25 Feb. 4

Aug. 15

Aug. 16

Aug. 17

Aug. 17. Sept. 10

Aug. 18

Ang. 18

Aug. 18

Aug. 18. Nov. 1 Aug. 22. Nov. 8

Aug. 20

Aug. 22

Aug. 23

Aug. 24

Aug. 24. Sept. 17

May 22. July 26

Apr. 21. July 18

Sept. 1-15

Aug. 24. Sept. 22 Sept. 5-29 
Soapwort (Saponaria officinalis) fl.

Ladies' traces (Ophrys spiralis) fl.

Small golden black-spotted butterfly

$$
\text { (Papilio phlaas) ap. }
$$

Swallow (Hirundo rustica) sings

Althce frutex (Hibiscus syriacus) $\mathrm{fl}$

Great fritillary (Papilio paphia) ap.

Willow red under-wing moth (Pha. lana pacta) ap.

Stone curlew (Otis odicnemus) clamours

Phalana rissula ap.

Grapes ripen

Wood owls (Strix aluco) hoot

Saffron butterfly (Papilio hyale) ap.

Ring ouzel (Turdus torquatus) appears on its autumnal visit

Flycatcher (Muscicapagrisola) withdraws

Beans (Vicia faba) cut

Ivy (Hedera helix) fl.

Stares (Sturnus vulgaris) congregate

Wild honeysuckles (Lonicera periclymenum) fl. a second time

Woodlark (Alauda arborea) sings

Woodcock (Scolopax rusticola) comes

Strawberry tree (Arbutus unedo) fl. Wheat sown

Swallows last seen. (N.B. The house martin the latest.)

Redwing (Turdus iliacus) comes

Fieldfare (Turdus pilaris) comes

Gossamer fills the air

Chinese holyoak (Alcea rosea) $\mathrm{fl}$.

Hen chaffinches (Fringilla colebs) congregate

Wood pigeons (Columba palumbus) come

Royston crow (Corvus cornix) comes

Snipes (Scolopax gallinago) come up into the meadows

\begin{tabular}{|l|}
\multicolumn{1}{|c|}{ whit E. } \\
Aug. 25 \\
Aug. 27. Sept. 12 \\
Aug. 29 \\
Aug. 29 \\
Aug. 30 . Sept. 2
\end{tabular}

MARKWICK. July 19. Ang. 23 Aug. 18. Sept. 18

Apr. 11. Aug. 20

Aug. 30

Aug. 31

Sept. 1. Nov. 7 June 17

Sept. 1

Sept. 4. Oct. 24 Aug. 31. Nov. 4

Sept. 4. Nov. 9

Sept. 4

Sept. $4-30$

Sept. $6-29$

Sept. 11

Sept. 12. Oct. 2

Sept. 12. Nov. 1

Sept. 25

Sept. 28. Oct. 24

Sept.29. Nov.11

Oct. 1. Nov. 1: young ones Apr. 28: last seen Apr. 11

Oct. 1 May 21. Dec. 10

Oct. 3. Nov. 9 Sept. 23. Oct. 19

Oct. 4. Nov. 5 Nov. 16

Oct. 10. Nov. 10 Oct. 1. Dec. 18: sings Feb. 10. Mar. 21

last seen Apr. 13

Oct. 12. Nov. 23 Oct. 13. Nov. 18: last

Oct. $15-27$

Oct. 19

[seen May 1

July 7. Aug. 21

Oct. 20. Dec. 31

Oct. 23. Dec. 27

Oct. 23. Nov. 29

Oct. 13. Nov. 17: last seen Apr. 15

[seen Apr. 14

Oct. 25. Nov. 20 Sept. 29. Nov. 11 : last D D 
Tortoise begins to bury himself

Rooks (Corvus frugilegus) visit their nest trees

Bucks grunt

Primrose (Primula vulgaris) fl.

Green whistling plover (Charadrius pluvialis) ap.

Helvella mitra ap.

Greenfinches (Fringilla chloris) fock

Hepatica fl.

Furze (Ulex europaus) fl.

Polyanthus (Primula polyantha) fl.

Young lambs dropped

Moles work in throwing up hillocks

Helleborus fotidus $\mathrm{fl}$.

Daisy (Bellis perennis) $\mathrm{fl}$.

Wallflower (Cheiranthus cheiri seu fruticulosus of Smith) $\mathrm{fl}$.

Mezereon (Daphne mezereum) fl.

Snowdrop (Galanthus nivalis) fl.
WHITE.

Oct. 27 . Nov. 26

Oct. 31. Dec. 25

Nov. 1

Nor. 10 Oct. 7. Dec. 30

Nov. 13,14

Nov. 16

Nov. 27

Nov. 30. Dec. 29

Dec. 4-21

Dec. 7-16

Dec. $11-27$

Dec. 12-23

Dec. 14-30

Dec. 15

Dec. 15

Dec. 15

Dec. 29.
MARKWICK.

June 29. Oct. 20

Feb. 19

Dec. $16-31$

Dec. 31

Dec. 12. Feb. 21

Dec. 26 - 31

Nov. 5. 
THE

ANTIQÜITIES

\author{
OF \\ SELBOR N E, \\ IN
}

THE COUNTY OF SOUTHAMPTON

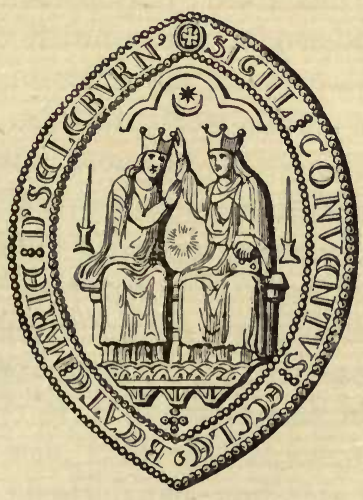

..... Juvat ire . . .

Desertosque videre locos ..... TIRGIL. 


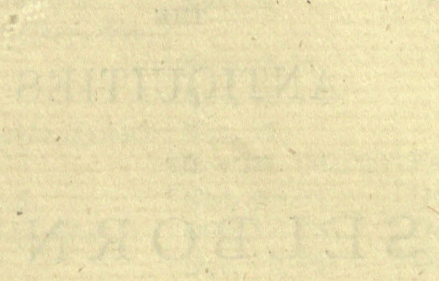

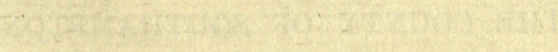

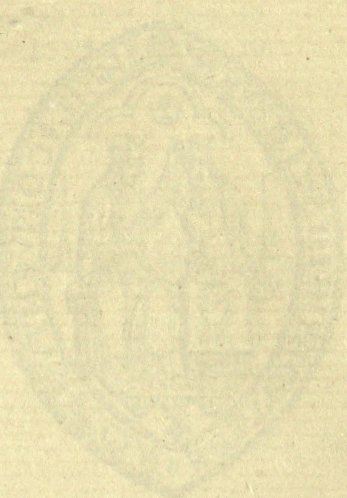




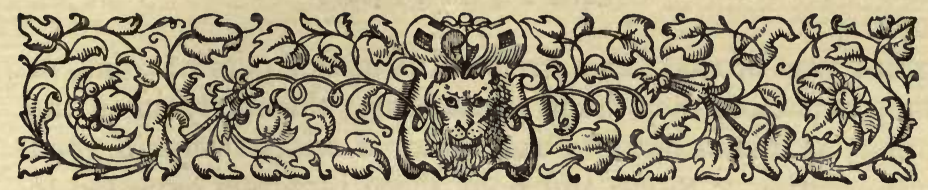

\section{THE ANTIQUITIES OF SELBORNE.}

\section{LETTER I.}

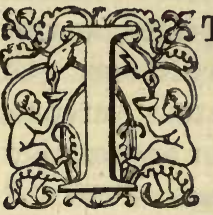

$\mathrm{T}$ is reasonable to suppose that in remote ages this woody and mountainous district was inhabited only by bears and wolves. Whether the Britons ever thought it worthy their attention, is not in our power to determine : ${ }^{1}$ but we may safely conclude, from circumstances, that it was not unknown to the Romans. Old people remember to have heard their fathers and grandfathers say that, in dry summers and in windy weather, pieces of money were sometimes found round the verge of Wolmer Pond; and tradition had inspired the foresters with a notion that the bottom of that lake contained great stores of treasure. During the spring and summer of 1740 there was little rain; and the following summer also, 1741, was so uncommonly dry, that many springs and ponds failed, and this lake in particular, whose bed became as dusty as the surrounding heaths and wastes. This favourable juncture induced some of the forest cottagers to begin a search, which was attended with such success, that all the labourers in the neighbourhood flocked to the spot, and with spades and hoes turned up

1 Several ancient "barrows" in Wolmer Forest, which have been opened from time to time, have been found to contain fragments of human bones and pottery, and in at least one instance an urn of unburnt clay containing fragments of bones, tending to prove that the barrows in question were of British origin in Roman times.-ED. 
great part of that large area. Instead of pots of coins, as they expected, they found great heaps, the one lying on the other, as if shot out of a bag, many of which were in good preservation. Silver and gold these inquirers expected to find ; but their discoveries consisted solely of many hundreds of Roman copper coins, and some medallions, all of the lower empire. There was not much virtu stirring at that time in this neighlourhood; however, some of the gentry and clergy around bought what pleased them best, and some dozens fell to the share of the author.

The owners at first held their commodity at a high price; but finding that they were not likely to meet with dealers at such a rate, they soon lowered their terms, and sold the fairest as t'iey could. The coins that were rejected became current, and passed for farthings at the petty shops. Of those that we saw, the greater part were of Marcus Aurelius, and the Empress Faustina, his wife, the father and mother of Commodus. Some of Faustina were in high relief, and exhibited a very agreeable set of features, which probably resembled that lady, who was more celebrated for her beauty than for her virtues. The medallions in general were of a paler colour than the coins. To pretend to account for the means of their coming to this place would be spending time in conjecture. The spot, I think, could not be a Roman camp, because it is commanded by hills on two sides; nor does it show the least traces of intrenchments; nor can I suppose that it was a Roman town, because I have too good an opinion of the taste and judgment of those polished conquerors to imagine that they would settle on so barren and dreary a waste. 


\section{LETTER II.}

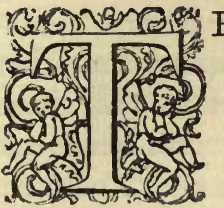

HAT Selborne was a place of some distinction and note in the time of the Saxons, we can give most undoubted proofs. But, as there are few, if any, accounts of villages before Domesday, it will be best to begin with that venerable record. "Ipse rex tenet Selesburne. Eddid regina tenuit, et nunquam geldavit. De isto manerio dono dedit rex Radfredo presbytero dimidiam hidam cum ecclesia. Tempore regis Edwardi et post, valuit duodecim solidos et sex denarios; modo octo solidos et quatuor denarios." Here we see that Selborne was a royal manor; and that Editha, the queen of Edward the Confessor, had been lady of that manor ; and was succeeded in it by the Conqueror; and that it had a church. Beside these, many circumstances concur to prove it to have been a Saxon village; such as the name of the place itself, ${ }^{1}$ the names of many fields, and some families, ${ }^{2}$ with a variety of words in husbandry and common life, still subsisting amiong the country people.

What probably first drew the attention of the Saxons to

1 Selesburne, Seleburne, Selburn, Selbourn, Selborne, and Selborn, as it has been variously spelt at different periods, is of Saxon derivation; for $\mathrm{Sel}$ signifies great, and burn torrens, a brook or rivulet: so that the name seems to be derived from the great perennial stream that breaks out at the upper end of the village. Sel also signifies "bonus, item, focundus, fertilis. Sel-zærr-zun, focunda graminis clausura; fertile pascuum. Abiit tamen apud nonnullos in nomen proprium. Inde pratum quoddam apud Godelming in agro Surriensi hodie vocatur Sal-gars-ton." Lye's Saxon Dictionary, in the Supplement, by Mr. Manning.-G. W.

2 Thus the name of Aldred signifies all-reverend, and that of Kemp means a soldier. Thus we have a church-litton, or enclosure for dead bodies, and not a church-yard: there is also a Culver-croft near the Grange-farm, being the enclosure where the priory pigeon-house stood, from culver, a pigeon Again there are three steep pastures in this parish called the Lithe, from Hlithe, clivus. The wicker-work that binds 
this spot was the beautiful spring or fountain called Wellhead, ${ }^{1}$ which induced them to build by the banks of that perennial current; for ancient settlers loved to reside by brooks and rivulets, where they could dip for their water without the trouble and expense of digging wells and of drawing.

It remains still unsettled among the antiquaries at what time tracts of land were first appropriated to the chase alone for the amusement of the sovereign. Whether our Saxon monarchs had any royal forests does not, I believe, appear on record; but the Constitutiones de Foresta of Canute, the Dane, are come down to us. We shall not therefore pretend to say whether Wolmer Forest existed as a royal domain before the Conquest. If it did not, we may suppose it was laid out by some of our earliest Norman kings, who were exceedingly attached to the pleasures of the chase, and resided much at Winchester, which lies at a moderate distance from this district. The Plantagenet princes seem to have been pleased with Wolmer; for tradition says that King John resided just upon the verge, at Ward-le-ham, on a regular and remarkable mount, still called King John's Hill, and Lodge Hill; and Edward III.

and fastens down a hedge on the top is called ether, from ether a hedge. When the good women call their hogs they cry sic, sic, ${ }^{*}$ not knowing that sic is Saxon, or rather Celtic, for a hog. Coppice or brushwood our countrymen call rise, from hris, frondes; and talk of a load of rise. Within the author's memory the Saxon plurals, housen and peason, were in common use. But it would be endless to instance in every circumstance: he that wishes for more specimens must frequent a farmer's kitchen. I have therefore selected some words to show how familiar the Saxon dialect was to this district, since in more than seven hundred years it is far from being obliterated.-G. W.

I Well-head signifies spring-head, and not a deep pit from whence we draw water.-For particulars about which see Letter I. to Mr. Pennant.-G. W.

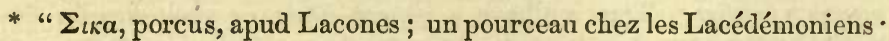
ce mot a sans doute esté pris des Celtes, qui disoient sic, pour marquer un pourceau. Encore aujourd'huy quand les Bretons chassent ces animaux, ils ne disent point autrement, que sic, sic."-Pezron, Antiquité de la Nation et de la Langue des Celtes. 
had a chapel in his park, or enclosure, at Kingsley.' Humphrey, Duke of Gloucester, and Richard, Duke of York, say my evidences, were both, in their turns, wardens of Wolmer Forest; which seems to have served for an appointment for the younger princes of the royal family, as it may again.

I have intentionally montioned Edward III. and the Dukes Humphrey and Richard, before King Edward II. because I have reserved, for the entertainment of my readers, a pleasant anecdote respecting that prince, with which I shall close this letter.

As Edward II. was hunting in Wolmer Forest, Morris Ken, of the kitchen, fell from his horse several times; at which accidents the king laughed immoderately: and, when the chase was over, ordered him twenty shillings; ${ }^{2}$ an enormous sum for those days! Proper allowances ought to be made for the youth of this monarch, whose spirits also, we may suppose, were much exhilarated by the sport of the day; but, at the same time, it is reasonable to remark that, whatever might be the occasion of Ken's first fall, the subsequent ones seem to have been designed. The scullion appears to have been an artful fellow, and to have seen the king's foible; which furnishes an early specimen of that his easy softness and facility of temper, of which the infamous Gaveston took such advantages, as brought innumerable calamities on the nation, and involved the prince at last in misfortunes and sufferings too deplorable to be mentioned without horror and amazement.

1 The parish of Kingsley lies between, and divides Wolmer Forest from Ayles Holt Forest.-See Letter IX. to Mr. Pennant.-G. W.

The church at Kingsley is a very humble structure, with a tower not unlike a dovecot. Indeed the whole edifice strikingly bears out the assertion of Gilbert White, that some of the Hampshire places of worship make little better appearances than dovecots.-ED.

2 "Item, paid at the lodge at Wolmer, when the king was stag-hunting there, to Morris Ken, of the kitchen, because he rode before the king and often fell from his horse, at which the king laughed exceedingly - a gift, by command, of twenty shillings."-A MS. in possession of Thomas Astle, Esq., containing the private expenses of Edward II.-G. W. 


\section{LETTER III.}

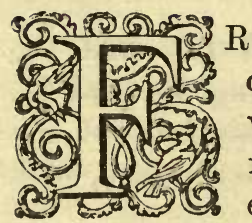

ROM the silence of Domesday respecting churches, it has been supposed that few villages had any at the time when that record was taken; but Selborne, we sec, enjoyed the benefit of one: hence we may conclude that this place was in no abject state, even at that very distant period. How many fabrics have succeeded each other since the days of Radfredrus the presbyter, we cannot pretend to say; our business leads us to a description of the present edifice, in which we shall be circumstantial.

Our church, which was dedicated to the Virgin Mary, consists of three aisles, and measures fifty-four feet in length by forty-seven in breadth, being almost as broad as it is long. The present building has no pretensions to antiquity; and is, as I suppose, of no earlier date than the beginning of the reign of Henry VII. It is perfectly plain and unadorned, without painted glass, carved work, sculpture, or tracery. But when I say it has no claim to antiquity, I would mean to be understood of the fabric in general; for the pillars which support the roof are undoubtedly old, being of that low, squat, thick order, usually called Saxon. These, I should imagine, upheld the roof of a former church, which, falling into decay, was rebuilt on those massy props, because their strength had preserved them from the injuries of time. ${ }^{1}$ Upon these rest blunt Gothic arches, such as prevailed in the reign above-men-

1 In the same manner, to compare great things with small, did Wykeham, when he new built the cathedral at Winchester, from the tower westward, apply to his purpose the old piers or pillars of Bishop Walkelin's church, by blending Saxon and Gothic architecture together.-Sce Lowth's "Life of Wykeham."-G. W. 
tioned, and by which, as a criterion, we would prove the date of the building. ${ }^{1}$

At the bottom of the south aisle, between the west and south doors, stands the font, which is deep and capacious, and consists of three massy round stones, piled one on another, without the least ornament or sculpture : the cavity at the top is lined with lead, and has a pipe at bottom to convey off the water after the sacred ceremony is performed.

The east end of the south aisle is called the South Chancel,

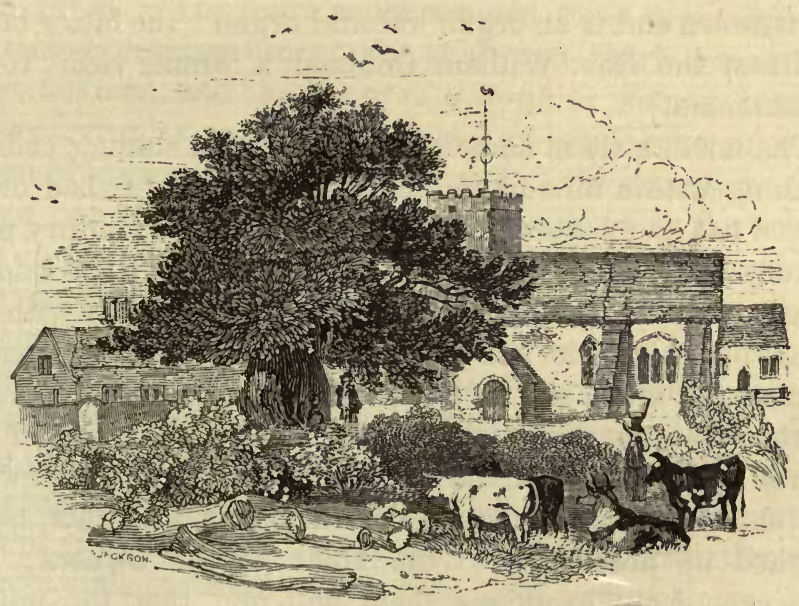

SOUTH VIEW OF SELBORNE CHURCH.

and, till within these thirty years, was divided off by an old carved Gothic frame work of timber, [the line of which may still be traced in a beam of partition between the pews,] having been a private chantry. In this opinion we are more confirmed by observing two Gothic niches within the space, the one in the east wall and the other in the south, near which there probably stood images and altars: [but

1 The churches in some of the adjoining parishes are of very ancient date, and well worth the attention of the antiquary. Those of Fmpshot and Hartley in particular are very old structures, and probably referable to a period anterior to the Norman Conquest.-ED. 
these niches are in a different style of arch, and were probably not formed at the same time.]

In the middle aisle there is nothing remarkable; but I remember when its beams were hung with garlands in honour of young women of the parish, reputed to have died virgins, ${ }^{1}$ and recollect to have seen the clerk's wife cutting, in white paper, the resemblances of gloves, and ribbons to be twisted into knots and roses, to decorate these memorials of chastity. In the church of Faringdon, which is the next parish, many garlands of this sort still remain. [The pulpit is placed at the eastern end of the middle aisle. At the western end is an organ loft and organ : the latter being a gift of the Rev. William Cobbold, a former vicar, to his parishioners.]

The north aisle is narrow and low, with a sloping ceiling, reaching within nine or ten feet of the floor. It had originally a flat roof covered with lead, till, within a century past, a churchwarden stripping off the lead, in order, as he said, to have it mended, sold it to a plumber, and ran away with the money. This aisle has no door, for an obvious reason; because the north side of the churchyard, being surrounded by the vicarage garden, affords no path to that side of the church. Nothing can be more irregular than the pews of this church, which are of all dimensions and heights, being patched up according to the fancy. of the owners; but whoever nicely examines them will find that the middle aisle had, on each side, a regular row of benches of solid oak, all alike, with a low back-board to each. These we should not hesitate to say are coeval with the present church; and especially as it is to be observed that, at their ends, they are ornamented with carved blunt Gothic niches, exactly correspondent to the arches of the church, and to a niche in the south wall. The south aisle also has a row of

1 Virgin garlands were originally formed of real flowers, and garlands so made are often alluded to by our old dramatists. We believe that the custom referred to still prevails amongst the peasantry in some parts of Yorkshire and Westmoreland.-ED. 
these benches; but some are decayed through age, and the rest much disguised by modern alterations. ${ }^{1}$

At the upper end of this aisle and running out to the north stands a transept, known by the name of the North Chancel, measuring twenty-one feet from south to north, and nineteen feet from east to west: this was intended, no doubt, as a private chantry; and was also, till of late, divided off by a Gothic frame work of timber. In its north wall, under a very blunt Gothic arch, lies perhaps the founder of this edifice, which, from the shape of its arch, may be deemed no older than the latter end of the reign of Henry VII. The tomb was examined some years ago, but contained nothing except the skull and thigh bones of a large tall man, and the bones of a youth or woman, lying in a very irregular manner, without any escutcheon or other token to ascertain the names or rank of the deceased. The grave was very shallow, and lined with stone at the bottom and on the sides. ${ }^{2}$

From the east wall project four stone brackets, which I conclude supported images and crucifixes. In the great thick pilaster, jutting out between this transept and the chancel, there is a very sharp Gothic niche, of older date than the present chantry or church. But the chief pieces of antiquity are two narrow stone coffin lids, which compose part of the floor, and lie from west to east, with the very narrow ends eastward: these belong to remote times; and, if originally placed here, which I doubt, must have been part of the pavement of an older transept. At present there are no coffins under them, whence I conclude they have been removed to this place from some part of a former church. One of these lids is so eaten by time, that no sculpture can be discovered upon it; or, perhaps, it may be the wrong side uppermost: but on the other, which seems

1 Since this description was peuned, considerable alterations have naturally been effected in the interior of the church.-Ev.

2 There is no longer any vestige of a tomb in the north wall of the north chancel.-Ev. 
to be of stone of a closer and harder texture, is to be discerned a discus, with a cross on it, at the end of a staff or rod, the well known symbol of a Knight Templar. ${ }^{1}$

This order was distinguished by a red cross on the left shoulder of their cloak, and by this attribute in their hand. Now, if these stones belonged to Knights Templars, they must have lain here many centuries; for this order came into England early in the reign of King Stephen, in 1113; and was dissolved in the time of Edward II. in 1312, having subsisted only 199 years. Why I should suppose that Knights Templars were occasionally buried at this church, will appear in some future letter, when we come to treat more particularly concerning the property they possessed here, and the intercourse that subsisted between them and the priors of Selborne.

We must now proceed to the chancel, properly so called, which seems to be coeval with the church, and is in the same plain unadorned style, though neatly kept. This room measures thirty-one feet in length, and sixteen feet and a half in breadth, and is wainscoted all round, as high as to the bottom of the windows. [It is raised one step above the body of the church.] The space for the communion table is raised two steps above the rest of the floor, and railed in with oaken balusters. [Over the communion table is a painting in Lluree compartments of the Offering of the Wise Men, presented by Benjamin White, Esq. It is attributed to John de Maubeuge.]

Here I shall say somewhat of the windows of the chancel in particular, and of the whole fabric in general. They are mostly of that simple and unadorned sort called Lancet, some single, some double, and some in triplets. At the east end of the chancel are two of a moderate size, near each other; and in the north wall two very distant small ones, unequal in length and height: and in the south wall are two, one on each side of the chancel door, that are broad and squat, and of a different order. At the east end of the

1 See Dugdale, "Monasticon Anglicanum," vol. ii. where there is a fine engraving of a Knight-'Templar, by Hollar.-G. W 
south aisle of the church there is a large lancet window in a triplet; and a very small, narrow, single one in the south wall, and two broad squat windows beside, and a double lancet one in the west end; so that the appearance is very irregular. In the north aisle are two windows, made shorter when the roof was sloped; and in the north transept a large triple window, shortened at the time of a repair in 1721 ; when over it was opened a round one of considerable size, which affords an agreeable light, and renders that chantry the most cheerful part of the edifice. ${ }^{1}$

The church and chancels have all coved roofs, ceiled about the year 1683; before which they were open to the tiles and shingles, showing the naked rafters, and threatening the congregation with the fall of a spar, or a blow from a piece of loose mortar.

On the north wall of the chancel is fixed a large oval white marble monument, with the following inscription; and at the foot of the wall, over the deceased, and inscribed with his name, age, arms, and time of death, lies a large slab of black marble:

Prope hunc Parietem Sepelitur

GILBERTUS WHITE, SAMSONIS WHITE, de

Oxon. Militis Filius tertius, Collegii Magdale-nensis ibidem Alumnus, \& Socius. Tandem faven-te Collegio ad hanc Ecclesiam promotus ; ubi primæ-vâ Morum Simplicitate, et diffusâ erga Omnes Bene-volentiâ feliciter Consenuit.

Pastor Fidelis, Comis, Affabilis, Maritus, et Pater Amantissimus, A Conjuge invicem, et Liberis, atque

A Parochianis, impensè dilectus.

Pauperibus ita Beneficus ut Decimam partem Censûs Moribundus

Piis usibus Consecravit.

Meritis demum juxta et Annis plenus ex hac Vitâ migravit Feb. 13\%.

Anno Salutis $172 \frac{7}{8}$

1 The "lancet" windows are evidently insertions in the place of Perpendicular ones. Indeed, in some of them the work of the original windows may be distinctly traced. The "round window" may afford " an agreeable light," but it is by no means an object for admiration. -Ep. 
Etatis Suæ 77.

Hoc Posuit Rebecca

Conjux illius mæstissima, mox Secutura.

On the same wall is newly fixed a small square table monument of white marble, inscribed in the following manner :-

Sacred to the Memory

of the Revid. ANDREW ETTY, B. D.

23 Years Vicar of this Parish :

In whose Character

The Conjugal, the Parental, and the Sacerdotal Virtues

were so happily combined

as to deserve the Imitation of Mankind.

And if in any particular he followed more invariably

The steps of his blessed Master,

It was in his Humility.

His Parishioners,

Especially the Sick and Necessitous,

as long as any 'Traces of his Memory shall remain,

Must lament his Death.

To perpetuate such an example, this Stone is erected;

As while Living he was a Preacher of Righteousness,

So, by it, he being Dead yet Speaketh.

He died April $8^{\text {th }} .1784$. Aged 66 years.

[But the most interesting monument to the visitant of Selborne, that its church can ever contain, is one affixed to the south wall. A square tablet of white marble, surrounded by black and having a lightly ornamented margin and a label below bearing the arms of the family, is tbus inscribed:

In the fifth Grave from this Wall are interred the Remains of The Rev ${ }^{d}$. GILBERT WHITE, M. A.

Fifty Years Fellow of Oriel College in Oxford, and Historian of this, his native Parish.

He was the eldest Son of John White, Esquire, Barrister at Law, and Anne, his Wife, only Child of

Thomas Holt, Rector of Streatham, in Surrey, which said John White was the only Son of Gilbert White, formerly Vicar of this Parish.

He was Kind and Beneficent To His Relations, Benevolent to the Poor,

and deservedly respected by all his Friends and Neighbours.

He was born July 18, 1720, O. S. and died June 20, 1793.

Nec bono quicquam mali evenire potest, nec vivo, nec mortuo.] 


\section{LETTER IV.}

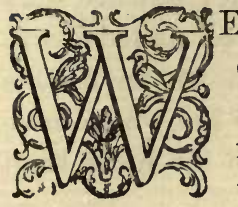

have now taken leave of the inside of the church, and shall pass by a door at the west end of the middle aisle into the belfry. This room is part of a handsome square embattled tower of forty-five feet in height, and of much more modern date than the church; but old enough to have needed a thorough repair in 1781, when it was neatly stuccoed at a considerable expense, by a set of workmen who were employed on it for the greatest part of the summer. The old bells, three in number, loud and out of tune, were taken down in 1735 , and cast into four; to which Sir Simeon Stuart, the grandfather of the present baronet, added a fifth at his own expense; and, bestowing it in the name of his favourite daughter Mrs. Mary Stuart, caused it to be cast with the following motto round it:

"Clara puella dedit, dixitque mihi esto Maria:

Illius et laudes nomen ad astra sono."

The day of the arrival of this tuneable peal was observed as a high festival by the village, and rendered more joyous, by an order from the donor, that the treble bell should be fixed bottom upward in the ground, and filled with punch, of which all present were permitted to partake.

The porch of the church, to the south, is modern, and would not be worthy attention did it not shelter a fine sharp Gothic door-way. This is undoubtedly much older than the present fabric; and, being found in good preservation, was worked into the wall, and is the grand entrance into the church; nor are the folding doors to be passed over in silence, since, from their thick and clumsy structure, and the rude flourished work of their hinges, they may possibly be as ancient as the door-way itself.

The whole roof of the south aisle, and the south side of the roof of the middle aisle, is covered with oaken shingles 
instead of tiles, on account of their lightness, which favours the ancient and crazy timber frame. And indeed, the consideration of accidents by fire excepted, this sort of roofing is much more eligible than tiles. For shingles well seasoned, and cleft from quartered timber, never warp, nor let in drifting snow; nor do they shiver with frost; nor are they liable to be blown off, like tiles; but, when well nailed down, last for a long period, as experience has shown us in this place, where those that face to the north are known to have endured, untouched, by undoubted tradition for more than a century.

Considering the size of the church, and the extent of the parish, the churchyard is very scanty; and especially as all wish to be buried on the south side, which is become such a mass of mortality that no person can be there interred without disturbing or displacing the bones of his ancestors. There is reason to suppose that it once was larger, and extended to what is now the vicarage court and garden; because many human bones have been dug up in those parts several yards without the present limits. At the east end are a few graves; yet none till very lately on the north side; but, as two or three families of best repute have begun to bury in that quarter, prejudice may wear out by degrees, and their example be followed by the rest of the neighbourhood. ${ }^{1}$

In speaking of the church, I have all along talked of the east and west end, as if the chancel stood exactly true to those points of the compass; but this is by no means the case, for the fabric bears so much to the north of the east that the four corners of the tower, and not the four sides, stand to the four cardinal points. The best method of accounting for this deviation seems to be, that the workmen, who probably were employed in the longest days, endeavoured to set the chancels to the rising of the sun.

Close by the church, at the west end, stands the vicarage

I This prejudice seems to have died out. But the objection to bury behind the church is apparently not confined to a Hampshire village. We believe that in many towns of the north of England, the same scruple exists.-ED. 
house; an old, but roomy and convenient edifice. It faces very agreeably to the morning sun, and is divided from the village by a neat and cheerful court. According to the manner of old times, the hall was open to the roof; and so continued, probably, till the vicars became family-men, and began to want more conveniences; when they flung a floor

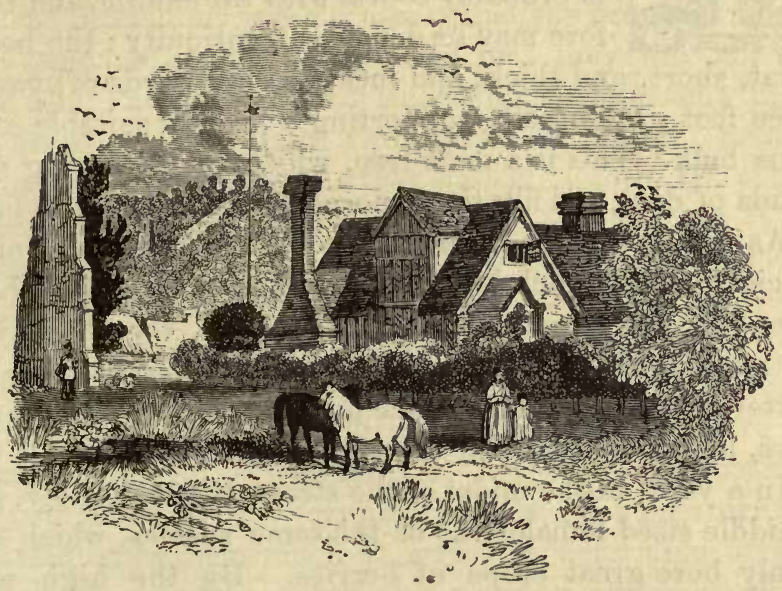

THE VICARAGE HOUSE.

across, and, by partitions, divided the space into chambers. In this hall we remember a date, some time in the reign of Elizabeth; it was over the door that leads to the stairs.

Behind the house is a garden of an irregular shape, but well laid out, whose terrace commands so romantic and picturesque a prospect, that the first master in landscape might contemplate it with pleasure, and deem it an object well worthy of his pencil. 


\section{LETTER V.}

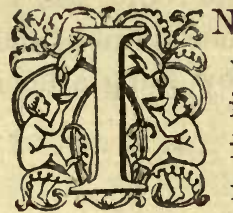

$\mathrm{N}$ the churchyard of this village is a yerw-tree, whose aspect bespeaks it to be of a great age ; it seems to have seen several centuries, and is probably coeval with the church, and therefore may be deemed an antiquity : the body is squat, short, and thick, and measures [upwards of] twentythree feet in the girth, supporting a head of suitable extent to its bulk. This is a male tree, which in the spring sheds clouds of dust, and fills the atmosphere around with its farina.

As far as we have been able to observe, the males of this species become much larger than the females; and it has so fallen out that most of the yew-trees in the churchyards of this neighbourhood are males; but this must have been matter of mere accident, since men, when they first planted yews, little dreamed that there were sexes in trees.

In a yard, in the midst of the street, till very lately, grew a middle sized female tree of the same species, which commonly bore great crops of berries. By the high winds usually prevailing about the autumnal equinox, these berries, then ripe, were blown down into the road, where the hogs ate them. And it was very remarkable, that, though barrow-hogs and young sows found no inconvenience from this food, yet milch-sows often died after such a repast: a circumstance that can be accounted for only by supposing that the latter, being much exhausted and hungry, devoured a larger quantity.

While mention is making of the bad effects of yewberries, it may be proper to remind the unwary, that the twigs and leaves of yew, though eaten in a very small quantity, are certain death to horses and cows, and that in a few minutes. A horse tied to a yew hedge, or to a faggot stack of dead yew, shall be found dead before the owner can be aware that any danger is at hand, and the writer has been several times a sorrowful witness to losses of this kind among his friends; and in the island of Ely had once 
the mortification to see nine young steers or bullocks of his own all lying dead in a heap from browzing a little on a hedge of yew in an old garden into which they had broken in snowy weather. Even the clippings of a yew hedge have destroyed a whole dairy of cows when thrown inadvertently into a yard. And yet sheep and turkeys, and, as parkkeepers say, deer, will crop these trees with impunity.

Some intelligent persons assert that the branches of yew, while green, are not noxious; and that they will kill only when dead and withered, by lacerating the stomach; but to this assertion we cannot by any means assent, because, among the number of cattle that we have known fall victims to this deadly food, not one has been found, when it was opened, but had a lump of green yew in its paunch. True it is, that yew trees stand for twenty years or more in a field, and no bad consequences ensue; but at some time or other cattle, either from wantonness when full, or from hunger when empty (from both which circumstances we have seen them perish), will be meddling, to their certain destruction; the yew seems to be a very improper tree for a pasture field.

Antiquaries seem much at a loss to determine at what period this tree first obtained a place in churchyards. A statute passed A.D. 1307 and 35 Edward I. the title of which is "Ne rector arbores in cemeterio prosternat." Now if it is recollected that we seldom see any other very large or ancient tree in a churchyard, but yews, this statute must have principally related to this species of tree; and consequently their being planted in churchyards is of much more ancient date than the year 1307.

As to the use of these trees, possibly the more respectable parishioners were buried under their shade before the improper custom was introduced of burying within the body of the church, where the living are to assemble. Deborah, Rebekah's nurse, ${ }^{1}$ was buried under an oak; the most honourable place of interment probably next to the cave of Machpelah, ${ }^{2}$ which seems to have been appropriated to the remains of the patriarchal family alone.

1 Gen. xxxv. 8.

2 Gen. xxiii. 9 . 
The farther use of yew trees might be as a screen to churches, by their thick foliage, from the violence of winds; perhaps also for the purpose of archery, the best long bows being made of that material; and we do not hear that they are planted in the churchyards of other parts of Europe, where long bows were not so much in use. They might also be placed as a shelter to the congregation assembling before the church doors were opened, and as an emblem of mortality by their funereal appearance. ${ }^{1}$ In the south of England every churchyard almost has its tree, and some two; but in the north, we understand, few are to be found. ${ }^{2}$

The idea of R. C. that the yew tree afforded its branches instead of palms for the processions on Palm Sunday, is a good one, and deserves attention.-See Gent. Mag. vol. i. p. 128 .

\section{LET'TER VI.}

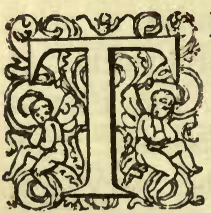

HE living of Selborne was a very small vicarage; but, being in the patronage of Magdalen College, in the university of Oxford, that society endowed it with the great tithes of Selborne, more than a century ago, and since the year 1758 again with the great tithes of Oakhanger, called Bene's Parsonage: so that, together, it is become a respectable piece of preferment, to which one of the fellows is always presented. The vicar holds the great tithes, by lease, under the college. The great disadvantage of this living is, that it has not one foot of glebe near home. ${ }^{3}$

1 Or perhaps of immortality by their evergreen foliage: whence, probably, the derivation of the name yew, q. d. ewig, everlasting.-- ED.

2 In the northern churchyards the place of the yew is supplied by the ash, lime, and horse-chestnut. Yew trees, however, and some of them of large size, are frequently to be met with in the courtyards and gardens of ancient mansions in the north of England.-ED.

'At Bene's, or Bin's parsonage there is a house and stout barn, and 
ITS PAYMENTS ARE,

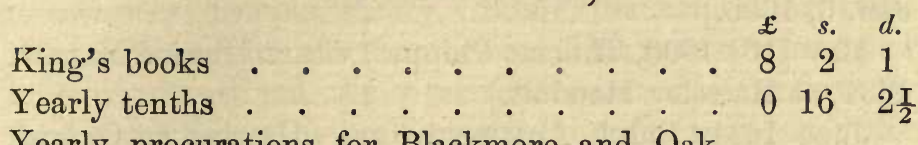

Yearly procurations for Blackmore and Oak-

hanger Chap : with acquit: . . . . 0717

Selborne procurations and acquit: . . . 090

I am unable to give a complete list of the vicars of this parish till towards the end of the reign of Queen Elizabeth; from which period the registers furnish a regular series.

In Domesday we find thus-" De isto manerio dono dedit Rex Radfredo presbytero dimidiam hidam cum ecclesia." So that before Domesday, which was compiled between the years 1081 and 1086, here was an officiating minister at this place.

After this, among my documents, I find occasionil mention of a vicar here and there: the first is

Roger, instituted in 1254.

In 1410 John Lynne was vicar of Selborne.

In 1411 Hugo Tybbe was vicar.

The presentations to the vicarage of Selborne generally ran in the name of the prior and the convent; but Tybbe was presented by prior John Wynechestre only.

June 29, 1528, William Fisher, vicar of Selborne, resigned to Miles Peyrson.

1594, William White appears to have been vicar to this time. Of this person there is nothing remarkable, but that he hath made a regular entry twice in the register of Selborne of the funeral of Thomas Cowper, Bishop of Winchester, as if he had been buried at Selborne; yet this learned prelate, who died 1594, was buried at Winchester, in the cathedral, near the episcopal throne. ${ }^{1}$

1595, Richard Boughton, vicar.

seven acres of glebe. Bene's parsonage is three miles from the church. -G. W.

'See Godwin “de Præsulibus Angliæ," folio, Cant. 1743, page 239. -G. W. 
[Sept. 6] 1596, William Inkforbye, vicar. [Buried Jan. 6, 1606.]

May [16] 1606, Thomas Phippes, vicar. [Buried May 27, 1631, at Harteley Mauduit.]

June 1631, Ralph Austine, vicar. [Buried at Oxford, March 24, 1631.]

July 1632, John Longworth. This unfortunate gentleman, living in the time of Cromwell's usurpation, was deprived of his preferment for many years, probably because he would not take the league and covenant: for I observe that his father-in-law, the Reverend Jethro Beal, rector of Faringdon, which is the next parish, enjoyed his benefice during the whole of that unhappy period. Longworth, after he was dispossessed, retired to a little tenement about one hundred and fifty yards from the church, where he earned a small pittance by the practice of physic. During those dismal times it was not uncommon for the deposed clergy to take up a medical character; as was the case in particular, I know, with the Reverend Mr. Yalden, rector of Compton, near Guildford, in the county of Surrey. Vicar Longworth used frequently to mention to his sons, who told it to my relations, that, the Sunday after his deprivation, his puritanical successor stepped into the pulpit with no small petulance and exultation: and began his sermon from Psalm xx. 8: "They are brought down and fallen; but we are risen and stand upright." This person lived to be restored in 1660, and continued vicar for eighteen years; but was so impoverished by his misfortunes, that he left the vicarage house and premises in a very abject and dilapidated state.

July 1678. Richard Byfield, [B.D.] who left eighty pounds by will, the interest to be applied to apprentice out poor children : but this money, lent on private security, was in danger of being lost, and the bequest remained in an unsettled state for near twenty years, till 1700 ; so that little or no advantage was derived from it. About the year 1759 it was again in the utmost danger by the failure of a borrower; but, by prudent management, has since been raised to one hundred pounds stock in the three per 
cents. reduced. The trustees are the vicar and the renters or owners of Temple, Priory, Grange, Blackmore, and Oakhanger House, for the time being. This gentleman seemed inclined to have put the vicarial premises in a comfortable state; and began, by building a solid stone wall round the front court, and another in the lower yard, between that and the neighbouring garden; but was interrupted by death from fulfilling his laudable intentions. [He lies buried in the chancel of his church; and a black slab, within the rails of the communion table and near the north wall, commemorates him.]

April [7], 1680, Barnabas Long became vicar. [Dr. Long appears to have resigned the vicarage in consequence of obtaining other preferment. We learn from Wood that on the 6th of February, 1681, he was installed prebend of Botesant in the church of York; and, on the 24th of May, 1682, of Stillington also. From the same authority it may be added that he died in 1685 .]

June [23], 1681. This living was now in such low estimation in Magdalen College, that it descended to a junior fellow, Gilbert White, M.A., who was instituted to it in the thirty-first year of his age. At his first coming he ceiled the chancel, and also floored and wainscoted the parlour and hall, which before were paved with stone and had naked walls; he enlarged the kitchen and brewhouse, and dug a cellar and well: he also built a large new barn in the lower yard, removed the hovels in the front court, which he laid out in walks and borders; and entirely planned the back garden, before a rude field with a stone-pit in the midst of it. By his will he gave and bequeathed "the sum of forty pounds to be laid out in the most necessary repairs of the church: that is, in strengthening and securing such parts as seem decaying and dangerous." With this sum two large buttresses were erected to support the east end of the south wall of the church; and the gable end wall of the west end of the south aisle was new built from the ground.

By his will also he gave "One hundred pounds to be laid out on lands; the yearly rents whereof shall be em- 
ployed in teaching the poor children of Selbourne parish to read and write, and say their prayers and catechism, and to sew and knit:- and be under the direction of his executrix. as long as she lives; and, after her, under the direction of such of his children and their issue, as shall live in or within five miles of the said parish : and on failure of any such, then under the direction of the vicar of Selbourn for the time being; but still to the uses above-named." With this sum were purchased, of Thomas Turville, of Hawkely, in the county of Southampton, yeoman, and Hannah his wife, two closes of freehold land, commonly called Collier's, containing, by estimation, eleven acres, lying in Hawkeley aforesaid. These closes are let at this time, 1785, on lease, at the rate of three pounds by the year. ${ }^{1}$

This vicar also gave by will two hundred pounds towards the repairs of the highways ${ }^{2}$ in the parish of Selborne. That sum was carefully and judiciously laid out in the summer of the year 1730 , by his son John White, who made a solid and firm causey from Rood Green, all down Honey Lane, to a farm called Oak Woods, where the sandy soil begins. This miry and gulfy lane was chosen as worthy of repair, because it leads to the forest, and thence through the Holt to the town of Farnham in Surrey, the only market in those days for men who had wheat to sell in this neighbourhood. This causey was so deeply bedded with stone, so properly raised above the level of the soil, and so well drained, that it has, in some degree, withstood fifty-four years of neglect and abuse; and might, with moderate attention, be rendered a solid and comfortable road. The space from Rood Green to Oak Woods measures about three quarters of a mile.

In 1727, William Henry Cane, B.D., became vicar; and,

1 The fac-simile of the author's autograph, subjoined to the original advertisement prefixed to the present volume, is taken from his signature to the lease here referred to.-ED.

2 "Such legacies were very common in former times, before any effectual laws were made for the repairs of highways."-Sir John Cullum's "Hawsted," p. 15.-G. W. 
among several alterations and repairs, new built the back front of the vicarage house.

On February 1, 1740, Duncombe Bristowe, D.D., was instituted to this living. What benefactions this vicar bestowed on the parish will be best explained by the following passages from his will:- "Item, I hereby give and bequeath to the minister and churchwardens of the parish of Selbourn, in the county of Southampton, a mahogany table, which I have ordered to be made for the celebration of the Holy Communion; and also the sum of thirty pounds, in trust, to be applied in manner following; that is, ten pounds towards the charge of erecting a gallery at the west end of the church; and ten pounds to be laid out for clothing, and such like necessaries, among the poor (and especially among the ancient and infirm) of the said parish : and the remaining ten pounds to be distributed in bread, at twenty shillings a week, at the discretion of John White, Esq., or any of his family, who shall be resident in the said parish."

On November 12, 1758, Andrew Etty, B.D., became vicar. Among many useful repairs he new roofed the body of the vicarage house; and wainscoted, up to the bottom of the windows, the whole of the chancel, to the neatness and decency of which he always paid the miost exact attention.

On September 25, 1784, Christopher Taylor, B.D., was inducted into the vicarage of Selborne. 


\section{LETTER VII.}

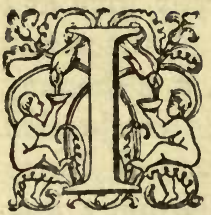

SHALL now proceed to the Priory, which is undoubtedly the most interesting part of our history.

The Priory of Selborne was founded by accomplished foreigners that resorted to the court of King John, where they were usually caressed, and met with a more favourable reception than ought, in prudence, to have been shown by any monarch to strangers. This adventurer was a Poictevin by birth, had been bred to arms in his youth, and distinguished by knighthood. Historians all agree not to speak very favourably of this remarkable man; they allow that he was possessed of courage and fine abilities, but then they charge him with arbitrary principles and violent conduct. By his insinuating manners he soon rose high in the favour of John; and in 1205, early in the reign of that prince, was appointed Bishop of Winchester. In 1214 he became Lord Chief Justiciary of England, the first magistrate in the state, and a kind of viceroy, on whom depended all the civil affairs in the kingdom. After the death of John, and during the minority of his son Henry, this prelate took upon him the entire management of the realm, and was soon appointed protector of the king and kingdom.

The barons saw with indignation a stranger possessed of all the power and influence, to part of which they thought they had a claim; they therefore entered into an association against him, and determined to wrest some of that authority from him which he had so unreasonably usurped. The bishop discerned the storm at a distance; and, prudently G. W.

See Godwin "de Præsulibus Angliæ," folio, Cant. 1743, p. 217.- 
resolving to give way to that torrent of envy which he knew not how to withstand, withdrew quietly to the Holy Land, where he resided some time.

At this juncture a very small part of Palestine remained in the hands of the Christians: they had been by Saladine dispossessed of Jerusalem, and all the internal parts, near forty years before; and with difficulty maintained some maritime towns and garrisons: yet the busy and enterprising spirit of de Rupibus could not be at rest; he distinguished himself by the splendour and magnificence of his expenses, and amused his mind by strengthening fortresses and castles, and by removing and endowing of churches. Before his expedition to the east he had signalized himself as a founder of convents, and as a benefactor to hospitals and monasteries.

In the year 1231 he returned again to England; and the very next year, in 1232, began to build and endow the Priory of Selborne. As this great work followed so close upon his return, it is not improbable that it was the result of a vow made during his voyage; and especially as it was dedicated to the Virgin Mary. Why the bishop made choice of Selborne for the scene of his munificence can never be determined now: it can only be said that the parish was in his diocese, and lay almost midway between Winchester and Farnham, or South Waltham and Farnham; from either of which places he could without much trouble overlook his workmen, and observe what progress they made; and that the situation was retired, with a stream running by it, and sequestered from the world, amidst woods and meadows, and so far proper for the site of a religious house. ${ }^{1}$

I The institution at Selborne was a priory of Black Canons of the order of St. Augustine, called also Canons Regular. Regular Canons were such as lived in a conventual manner, under one roof, had a common refectory and dormitory, and were bound by vows to observe the rules and statutes of their order; in fine, they were a kind of religious, whose discipline was less rigid than the monks'. The chief rule of these canons was that of St. Augustine, who was constituted Bishop of Hippo, A.D. 395 ; but they were not brought into England 
The first person with whom the founder treated about the purchase of land was Jacobus de Achangre, or Ochangre, a gentleman of property who resided at that hamlet; and, as appears, at the house now called Oakhanger House. With him he agreed for a croft, or little close of land, known by the name of La Liega, or La Lyge, which was to be the immediate site of the Priory.

De Achangre also accommodated the bishop at the same instant with three more adjoining crofts, which for a time was all the footing that this institution obtained in the parish. The seller in the conveyance says, "Warantizabimus, defendemus, et acquietabimus contra omnes gentes;" viz. "We will warrant the thing sold against all claims from any quarter." In modern conveyancing this would be termed a covenant for further assurance. Afterwards is added-"Pro hac autem donacione, \&c. dedit mihi pred. Episcopus sexdecem marcas argenti in Gersumam:" i.e. "the bishop gave me sixteen silver marks as a consideration for the thing purchased."

As the grant from Jac. de Achangre was without date, ${ }^{1}$ and the next is circumstanced in the same manner, we cannot say exactly what interval there was between the two purchases; but we find that Jacobus de Nortun, a neighbouring gentleman, also soon sold to the Bishop of Winchester some adjoining grounds, through which our stream passes, that the priory might be accommodated with a mill, which was a common necessary appendage to every manor: he also allowed access to these lands by a road for carts and waggons.- "Jacobus de Nortun concedit Petro Winton episcopo totum cursum aque que descendit de Molendino

till after the conquest; and seem not to have obtained the appellation of Augustine Canons till some years after. Their habit was a long black cassock, with a white rocket over it ; and over that a black cloak and hood. The monks were always shaved: but these canons wore their hair and beards, and caps on their heads. There were of these canons, and women of the same order called Canonesses, about one hundred and seventy-five houses.-G. W.

1 The custom of affixing dates to deeds was not become general in the reign of Henry III.-G. W. 
de Durton, usq; ad boscum Will. Mauduit, et croftam terre vocat: Edriche croft, cum extensione ejusdem et abuttamentis; ad fundandam domum religiosam de ordine Sti. Augustini. Concedit etiam viam ad carros, et caretas," \&c. This vale, down which runs the brook, is now called the Long Lithe, or Lythe. Bating the following particular expression, this grant runs much in the style of the former; "Dedit mihi episcopus predictus triginta quinque marcas argenti ad me acquietandum versus Judoeos." - That is, " the bishop advanced me thirty-five marks of silver to pay my debts to the Jews," who were then the only lenders of money.

Finding himself still straitened for room, the founder applied to his royal master, Henry, who was graciously pleased to bestow certain lands in the manor at Selborne on the new priory of his favourite minister. These grounds had been the property of Stephen de Lucy; and, abutting upon the narrow limits of the convent, became a very commodious and agreeable acquisition. This grant, I find, was made on March the 9th, in the eighteenth year of Henry, viz., 1234, being two years after the foundation of the monastery. The royal donor bestowed his favour with a good grace, by adding to it almost every immunity and privilege that could have been specified in the law language of the times.-"Quare volumus prior, \&c., habeant totam terram, \&c., cum omnibus libertatibus in bosco et plano, in viis et semitis, pratis et pascuis; aquis et piscariis ; intra burgum, et extra burgum, cum soka et saca, Thol et Them, Infangenethef et Utfangenethef, et hamsocne et blodwite, et pecunia que dari solet pro murdro et forstal, et flemenestrick, et cum quietancia de omni scotto et geldo, et de omnibus auxiliis regum, vicecomitum, et omn : ministralium suorum; et hidagio et exercitibus, et scutagiis, et tallagiis, et shiris et hundredis, et placitis et querelis, et warda et wardpeny, et opibus castellorum et pontium, et clausuris parcorum, et omni carcio et sumagio, et domor: regal: edificatione, et omnimola reparatione, et cum omnibus aliis libertatibus." This grant was made out by Richard, Bishop of Chichester, then chancellor, at the town of Northampton, 
before the lord chief justiciary, who was the founder him self.

The charter of foundation of the Priory, dated 1233, comes next in order to be considered; but being of some length, I shall not interrupt my narrative by placing it here. ${ }^{1}$ My copy, taken from the original, I have compared

1 Carta Petri et conventus ecclesie Winton. pro fundatione prioratus de Seleburne, \&rc. dat. 1233.

Omnibus Christi fidelibus ad quos presens scriptum pervenerit. P. divina miseracione Wintōn ecclesie minister humilis salutem in Domino: Ex officio pastorali tenemur viros religiosos, qui pauperes spiritu esse pro Christo neglectis lucris temporalibus elegerunt; spirituali affectu diligere, fovere pariter et creare, eorumq; quieti sollicite providere; ut tanto uberiores fructus de continua in lege Dei meditatione percipiant, quanto a conturbationibus malignorum amplius fuerint ex patroni provisione et ecclesiastica defensione securi. Hinc est quod universitati vestre notificamus, nos divine caritatis instinctu, de assensu conventus ecclesie nostre Wintōn, fundasse domum religiosam, ordinis magni patris Augustini, in honore Dei et gloriose semper virginis ejusdem Dei genetricis Marie, apud Seleburne; ibidemque canonicos regulares instituisse : ad quorum sustentationem et hospitum et pauperum susceptionem, dedimus, concessimus, et presenti carta nostra confirmavimus eisdem canonicis, totam terram quam habuimus de dono Jacobi de Acangre : et totam terram, cursum aque, boscum et pratum que habuimus de dono Jacobi de Nortone; et totam terram boscum et redditum que habuimus de dono domini Henrici regis Anglie; cum omnibus predictarum possessionum pertinentiis. Dedimus etiam et concessimus in proprios usus eisdem canonicis ecclesiam predicte ville de Seleburne, et ecclesias de Basing, et de Basingestok, cum omnibus earundem ecclesiarum capellis, libertatibus, et aliis pertinenciis; salva honesta et sufficienti sustentatione vicariorum in predictis ecclesiis ministrantium; quorum presentatio ad priorem predicte domus religiose de Seleburne et canonicos ejusdem loci in perpetuum pertinebit. Preterea possessiones et redditus, ecclesias sive decimas, quas in episcopatu nostro adempti sunt, vel in posterum, Deo dante, justis modis poterunt adipisci, sub nostra et Wintōn ecclesie protectione suscepimus, et episcopalis auctoritate officii confirmavimus; eadem auctoritate firmiter inhibentes, ne quis locum, in quo divino sunt officio mancipati, seu alias eorum possessiones, invadere vi vel fraude vel ingenio malo occupare audeat, vel etiam retinere, aut fratres conversos, servientes, vel homines eorum aliqua violentia perturbare, sive fugientes ad eos causa salutis sue conservande a septis domus sue violenter presumat extraere. Precipimus autem ut in eadem domo religiosa de Seleburne ordo canonicus, et regularis conversatio, secundum regulam magni patris Augustini, quam primi inhabitatores professi sunt, in perpetuum observetur; et ipsa domus religiosa a cujuslibet 
with Dugdale's copy, and find that they perfectly agree; except that in the latter the preamble and the names of the witnesses are omitted. Yet I think it proper to quote a passage from this charter-"Et ipsa domus religiosa $a$ cujuslibet alterius domîs religiosa subjectione libera permaneat, et in omnibus absoluta" - to show how much Dugdale was mistaken when he inserted Selborne among the alien priories; forgetting that this disposition of the convent contradicted the grant that he had published. In the Monasticon Anglicanum, in English, p. 119, is part of his catalogue of alien priories, suppressed 2 Henry V. viz. 1414, where may be seen as follows:-

$\mathrm{S}$.

Sele, Sussex.

SELEBURN.

Shirburn.

This appeared to me from the first to have been an oversight, before I had seen my authentic evidences. For priories alien, a few conventual ones excepted, were little better than granges to foreign abbeys; and their priors little more than bailiffs, removable at will: whereas the priory of Selborne possessed the valuable estates and manors of Selborne, Achangre, Norton, Brompden, Bas. singes, Basingstoke, and Natele; and the prior challenged

alterius domus religiose subjectione libera permaneat, et in omnibus absoluta; salva in omnibus episcopali auctoritate, et Wintōn ecclesie dignitate. Quod ut in posterum ratum permaneat et inconcussum, presenti scripto et sigilli nostri patrocinis duximus confirmandum. His testibus domino Waltero abbate de Hyda. Domino Walters Priore de sancto Swithuno, domino Stephano priore de Motesfonte, magistro Alano de Stoke; magistro Willo de sancte Marie ecclesia, tunc officiali nostro; Luca archidiacon' de sur'. magistro Humfrido de Millers, Henrico \& Hugone capellanis, Roberto de Clinchäp, et Petro Rossinol clericis, et multis aliis. Datum apud Wlnes* per manum P. de cancellis. In die sanctorum martirum Fabiani et Sebastiani. Anno Domi milesimo ducentesimo tricesimo tercio.

Seal, two saints and a bishop praying:

Legend: SVI. M. SIT $€$. BONI. P€TR' PAVL' $€$ PATRONI.

* Probably Wolvesey-house near Winchester.-G. W. 
the right of Pillory, Thurcet, and Furcas, and every manorial privilege.

I find next a grant from Jo. de Venur, or Venuz, to the prior of Selborne-"de tota mora [a moor or bog] ubi Bene oritur, usque ad campum vivarii, et de prato voc. Sydenmeade cum abutt: et de cursu aque molendini." And also a grant in reversion " unius virgate terre" [a yard land] in Achangre at the death of Richard Actedene his sister's husband, who had no child. He was to present a pair of gloves of one penny value to the prior and canons, to be given annually by the said Richard; and to quit all claim to the said lands in reversion, provided the prior and canons would engage annually to pay to the king, through the hands of his bailiffs of Aulton, ten shillings at four quarterly payments, "pro omnibus serviciis, consuetudinibus, exactionibus, et demandis."

This Jo. de Venur was a man of property at Oakhanger, and lived probably at the spot now called Chapel Farm. The grant bears date the seventeenth year of the reign of Henry III. [viz. 1233].

It would be tedious to enumerate every little grant for lands or tenements that might be produced from my vouchers. I shall, therefore, pass over all such for the present, and conclude this letter with a remark that must strike every thinking person with some degree of wonder. No sooner had a monastic institution got a footing, but the neighbourhood began to be touched with a secret and religious awe. Every person round was desirous to promote so good a work; and either by sale, by grant, or by gift in reversion, was ambitious of appearing a benefactor. They who had not lands to spare gave roads to accommodate the infant foundation. The religious were not backward in keeping up this pious propensity, which they observed so readily influenced the breasts of men. Thus did the more opulent monasteries add house to house, and field to field; and, by degrees, manor to manor, till at last "there was no place left ;" but every district around became appropriated to the purposes of their founders, and every precinct was drawn into the vortex. 


\section{LETTER VIII.}

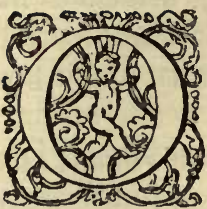

UR forefathers in this village were no doubt as busy and bustling, and as important, as ourselves: yet have their names and transactions been forgotten from century to century, and have sunk into oblivion; nor has this happened only to the vulgar, but even to men remarkable and famous in their generation. I was led into this train of thinking by finding in my vouchers that Sir Adam Gurdon was an inhabitant of Selborne, and a man of the first rank and property in the parish. By Sir Adam Gurdon I would be understood to mean that leading and accomplished malecontent in the Mountfort faction, who distinguished himself by his daring conduct in the reign of Henry III. The first that we hear of this person in my papers is, that with two others he was bailiff of Alton before the sixteenth of Henry III. viz. about 1231, and then not knighted. Who Gurdon was, and whence he came, does not appear: yet there is reason to suspect that he was originally a mere soldier of fortune, who had raised himself by marrying women of property. The name of Gurdon does not seem to be known in the south; but there is a name so like it in an adjoining kingdom, and which belongs to two or three noble families, that it is probable this remarkable person was a North Briton; and the more so, since the Christian name of Adam is a distinguished one to this day among the family of the Gordons. But, be this as it may, Sir Adam Gurdon has been noticed by all the writers of English history for his bold disposition and disaffected spirit, in that he not only figured during the successful rebellion of Leicester, but kept up the war after the defeat and death of that baron, intrenching himself in the woods of Hampshire, towards the town of Farnham. After the battle of Evesham, in which Mountfort fell, in the year 1265, Gurdon might not think it safe to return to his house for 
fear of a surprise; but cautiously fortified himself amidst the forests and woodlands with which he was so well acquainted. Prince Edward, desirous of putting an end to the troubles which had so long harassed the kingdom, pursued the arch-rebel into his fastnesses; attacked his camp; leaped over the intrenchments; and, singling out Gurdon, ran him down, wounded him, and took him prisoner. ${ }^{1}$

There is not perhaps in all history a more remarkable instance of command of temper, and magnanimity, than this before us: that a young prince, in the moment of victory, when he had the fell adversary of the crown and royal family at his mercy, should be able to withhold his hand from that vengeance which the vanquished so well deserved. A cowardly disposition would have been blinded by resentment: but this gallant heir-apparent saw at once a method of converting a most desperate foe into a lasting friend. He raised the fallen veteran from the ground, he pardoned him, he admitted him into his confidence, and introduced him to the queen, then lying at Guildford, that very evening. This unmerited and unexpected lenity melted the heart of the rugged Gurdon at once; he became in an instant a loyal.and useful subject, trusted and employed in matters of moment by Edward when king, and confided in till the day of his death.

\section{LETTER IX.}

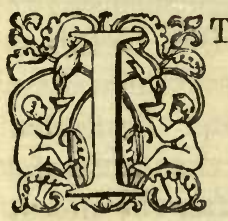

has been hinted in a former letter that Sir Adam Gurdon had availed himself by marrying women of property. By my evidences it appears that he had three wives, and probably in the following order: Constantia, Ameria, and Agnes. The first of these ladies, who was the companion of his middle life, seems to have been a person

1 M. Paris, p. 675, and Triveti Annales.-G. W. 
of considerable fortune, which she inherited from Thomas Makerel, a gentleman of Selborne, who was either her father or uncle. The second, Ameria, calls herself the quondam wife of Sir Adam, "quæ fui uxor," \&c., and talks of her sons under age. Now Gurdon had no son : and beside Agnes in another document says, "Ego Agnes quondam uxor Domini Adæ Gurdon in pura et ligea viduitate mea:" but Gurdon could not leave two widows; and therefore it seems probable that he had been divorced from Ameria, who afterwards married and had sons. By Agnes Sir Adam had a daughter Johanna, who was his heiress, to whom Agnes in her lifetime surrendered part of her jointure:-he had also a bastard son.

Sir Adam seems to have inhabited the house now called Temple, lying about two miles east of the church, which had been the property of Thomas Makerel.

In the year 1262 he petitioned the prior of Sellborne in his own name, and that of his wife Constantia only, for leave to build him an oratory in his manor house, "in curia sua." Licenses of this sort were frequently obtained by men of fortune and rank from the bishop of the diocese, the archbishop, and sometimes, as I have seen instances, from the pope; not only for convenience sake, and on account of distance, and the badness of the roads, but as a matter of state and distinction. Why the owner should apply to the prior, in preference to the bishop of the diocese, and how the former became competent to such a grant, I cannot say; but that the priors of Selborne did take that privilege is plain, because some years afterward, in 1280, Prior Richard granted to Henry Waterford and his wife Nichola a license to build an oratory in their court house, "curia sua de Waterford," in which they might celebrate divine service, saving the rights of the mother shurch of Basynges. Yet all the while the prior of Selborne grants with such reserve and caution, as if in doubt of his power, and leaves Gurdon and his lady answerable in future to the bishop, or his ordinary, or to the vicar for the time being, in case they should infringe the rights of the mother church of Selborne. 
The manor house called Temple is at present a single building, running in length from south to north, and has been occupied as a common farm house from time immemorial. The south end is modern, and consists of a brewhouse, and then a kitchen. The middle part is a hall twenty-seven feet in length and nineteen feet in breadth; and has been formerly open to the top; but there is now a floor above it, and also a chimney in the western wall. The roofing consists of strong massive rafter-work ornamented with carved roses. I have often looked for the lamb and

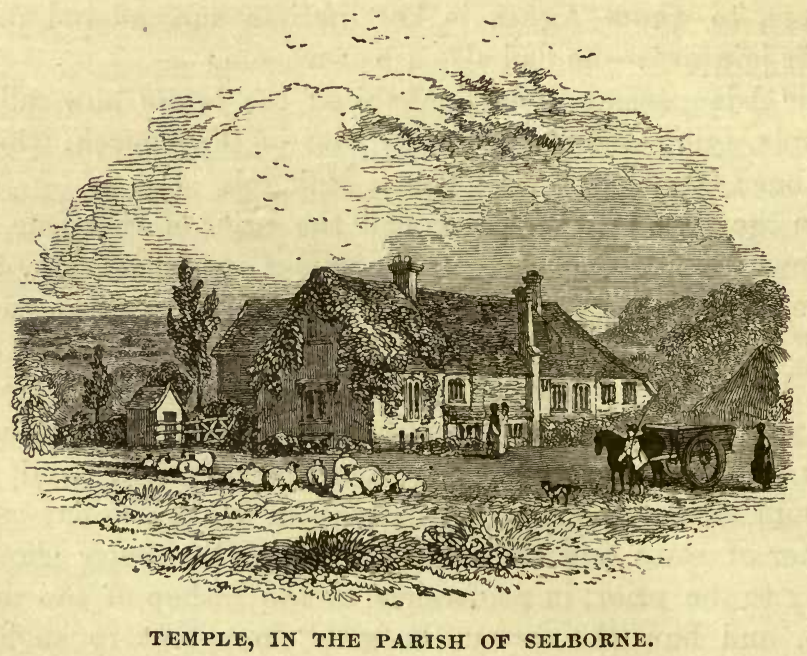

flag, the arms of the Knights Templars, without success; but in one corner found a fox with a goose on his back, so coarsely executed that it required some attention to make out the device.

Beyond the hall to the north is a small parlour with a vast heary stone chimney-piece; and, at the end of all, the chapel or oratory, whose massive thick walls and narrow windows at once bespeak great antiquity. This room is only sixteen feet by sixteen feet eight inches ; and full seventeen feet nine inches in height. The ceiling is formed of vast joists, placed only five or six inches apart. Modern delicacy 
would not much approve of such a place of worship ; for it has at present much more the appearance of a dungeon than of a room fit for the reception of people of condition. The field on which this oratory abuts is still called Chapel Field. The situation of this house is very particular, for it stands upon the immediate verge of a steep abrupt hill.

Not many years since, this place was used for a hop-kiln, and was divided into two stories by a loft, part of which remains at present, and makes it convenient for peat and turf, with which it is stowed. ${ }^{1}$

\section{LETTER $\mathrm{X}$.}

Qunaren HE Priory at times was much obliged to Gur-

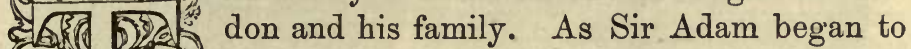
(10) 13 advance in years he found his mind influenced rid by the prevailing opinion of the reasonable(a) ness and efficacy of prayers for the dead; and therefore, in conjunction with his wife Constantia, in the year 1271, granted to the prior and convent of Selborne all his right and claim to a certain place, placea, called La Pleystow, in the village aforesaid, "in liberam, puram, et perpetuam elemosinam." This Pleystow, locus ludorum, or play-place, is a level area near the church of about fortyfour yards by thirty-six, and is known now by the name of the Plestor. ${ }^{3}$

1 There is not a vestige now remaining of the house described by Gilbert White. But the modern residence, in its whitened walls, slated roof, and squared form (the very reverse of the irregular and picturesque building represented on the opposite page), occupies nearly the same position with its predecessor, and commands the same extensive view over the forest,- $-\mathrm{ED}$.

2 In Saxon Plezejrop, or Plezrrop; viz. Plegestow, or Plegstow. -G. W.

3 At this juncture probably the vast oak, mentioned p. 5, was planted by the prior, as an ornament to his new acquired market-place. According to this supposition the oak was aged four hundred and thirty-two years when blown down.-G. W. 
It continues still, as it was in old times, to be the scene of recreation for the youths and children of the neighbourhood; and impresses an idea on the mind that this village, even in Saxon times, could not be the most abject of places, when the inhabitants thought proper to assign so spacious a spot for the sports and amusements of its young people. ${ }^{1}$

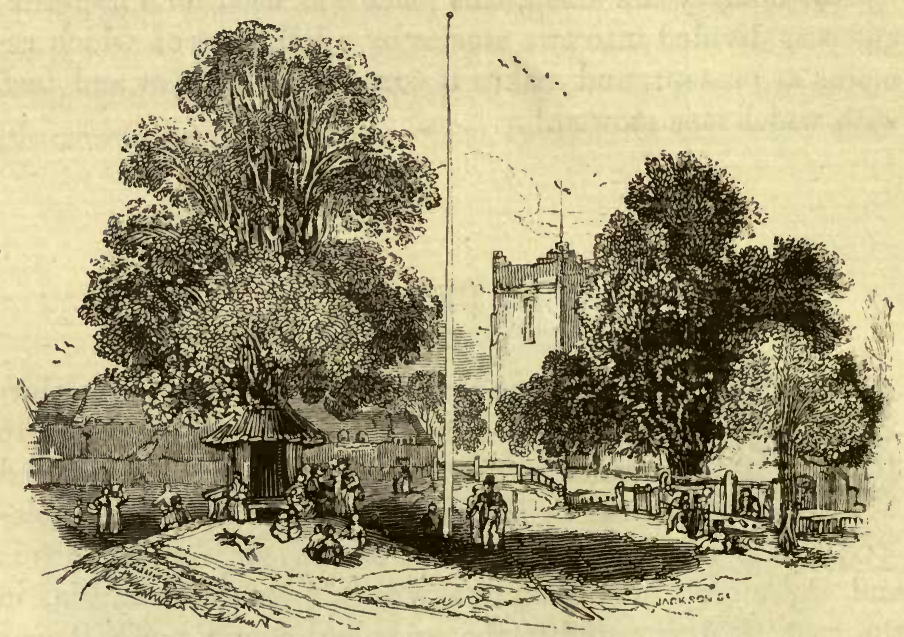

THE PLESTOR.

As soon as the prior became possessed of this piece of ground, he procured a charter for a market ${ }^{2}$ from King Henry III., and began to erect houses and stalls, "seldas," around it. From this period Selborne became a market town, but how long it enjoyed that privilege does not

1 For more circumstances respecting the Plestor, see I.etter II. to Mr. Pennant.-G. W.

2 Bishop Tanner, in his Notitia Monastica, has made a mistake respecting the market and fair at Selborne ; for, in his references to Dodsworth, cart. 54 Hen. III. m. 3. he says, "De mercatu, et feria de Sele. burn." But this reference is wrong; for, instead of Seleburn, it proves that the place there meant was Lekeborne or Legeborn, in the county of Iincoln. This error was copied from the index of the Cat. MSS. Angl. It does not appear that there ever was a chartered fair at Selborne. For several particulars respecting the present fair at Selborne see Letter XXVI. of these Antiquities.-G. W. 
appear. At the same time Gurdon reserved to himself and his heirs a way through the said Plestor to a tenement and some crofts at the upper end, abutting on the south corner of the churchyard. This was, in old days, the manorial house of the street manor, though now a poor cottage; and is known at present by the modern name of Elliot's. Sir Adam also did, for the health of his own soul, and that of his wife Constantia, their predecessors and successors, grant to the prior and canons quiet possession of all the tenements and gardens, "curtillagia," which they had built and laid out on the lands in Selborne, on which he and his vassals, "homines," had undoubted right of common; and moreover did grant to the convent the full privilege of that right of common; and empowered the religious to build tenements and make gardens along the king's highway in the village of Selborne.

From circumstances put together, it appears that the above were the first grants obtained by the Priory in the village of Selborne, after it had subsisted about thirty-nine years: moreover they explain the nature of the mixed manor still remaining in and about the village, where one field or tenement shall belong to Magdalen College in the university of Oxford, and the next to Norton Powlet, Esq., of Rotherfield House; and so down the whole street. The case was, that the whole was once the property of Gurdon, till he made his grants to the convent; since which some belongs to the successors of Gurdon in the manor, and some to the college; and this is the occasion of the strange jumble of property. It is remarkable that the tenement and crofts which Sir Adam reserved at the time of granting the Plestor should still remain a part of the Gurdon manor, though so desirable an addition to the vicarage that is not as yet possessed of one inch of glebe at home: but of late, viz. in January, 1785, Magdalen College purchased that little estate, which is lifeholding, in reversion, for the generous purpose of bestowing it and its lands, being twelve acres (three of which abut on the churchyard and vicarage garden) as an improvement hereafter to the living, and an eligible advantage to future incumbents. 
The year after Gurdon had bestowed the Plestor on the Priory, viz. in 1272, Henry III. King of England died, and was succeeded by his son Edward. This magnanimous prince continued his regard for Sir Adam, whom he esteemed as a brave man, and made him warden, "custos," of the forest of Wolmer. ${ }^{1}$ Though little emolument might hang to this appointment, yet are there reasons why it might be

1 Since the letters respecting Wolmer Forest and Ayles Holt, from pp. 17 to 33, were printed, the author has been favoured with the following extracts :

In the "Act of Resumption, 1 Hen. VII." it was provided, that it be not prejudicial to "Harry at Lode, ranger of our forest of Wolmere, to him by oure letters patents before tyme gevyn."-Rolls of Parl. vol. vi. p. 370 .

In the 11 Hen. VII. 1495. - Warlham [Ward-le-ham] and the office of forest [forester] of Wolmere" were held by Edmund, Duke of Suffolk.-Rolls, ib. 474.

Act of general pardon, 14 Hen. VIII. 1523, not to extend to "Rich. Bp. of Wynton [Bishop Fox] for any seizure or forfeiture of liberties, \&c. within the forest of Wolmer, Alysholt, and Newe Forest; nor to any person for waste, \&c. within the manor of Wardlam, or parish of Wardlam [Ward-le-ham;] nor to abusing, \&c. of any office or fee, within the said forests of Wolmer or Alysholt, or the said park of Wardlam."-County Suth't.—-Rolls prefixed to first Vol. of Journals of the Lords, p. xciii. b.

To these may be added some other particulars, taken from a book lately published, entitled "An Account of all the Manors, Messuages, Lands, \&c. in the different Counties of England and Wales, held by Lease from the Crown; as contained in the Report of the Commissioners appointed to inquire into the State and Condition of the Royal Forests," \&c.-London, 1787.

\section{"Southampton."}

P. 64. "A fee-farm rent of £3ı $2 s$. 11d. out of the manors of East and West Wardleham; and also the office of lieutenant or keeper of the forest or chase of Aliceholt and Wolmer, with all offices, fees, commodities, and privileges thereto belonging.

"Names of lessees, William, Earl of Dartmouth and others (in trust).

"Date of the last lease, March 23, 1780; granted for such term as would fill up the subsisting term to thirty-one years.

"Expiration March 23, 1811."

"Appendix, No. III."

"Southampton."

"Hundreds-Selborne and Finchdeanc."

"Honours and manors," \&c.

"Aliceholt Forest, three parks there. 
highly acceptable; and, in a few reigns after, it was given to princes of the blood. ${ }^{1}$ In old days gentry resided more at home on their estates, and, having fewer resources of elegant in-door amusement, spent most of their leisure hours in the field and the pleasures of the chase. A large domain, therefore, at a little more than a mile distance, and well-stocked with game, must have been a very eligible acquisition, affording him influence as well as entertainment; and especially as the manorial house of Temple, by its exalted situation, could command a view of near two-thirds of the forest.

That Gurdon, who had lived some years the life of an outlaw, and, at the head of an army of insurgents, was for a considerable time in high rebellion against his sovereign, should have been guilty of some outrages, and should have committed some depredations, is by no means matter of wonder. Accordingly we find a distringas against him, ordering him to restore to the Bishop of Winchester some of the temporalities of that see, which he had taken by violence and detained, viz., some lands in Hocheleye, and a mill. ${ }^{2}$ By a breve, or writ, from the king, he is also enjoined to readmit the Bishop of Winchester, and his tenants of the parish and town of Farnham, to pasture their horses, and other larger cattle, "averia," in the Forest of Wolmer, as had been the usage from time immemorial. This writ is dated in the tenth year of the reign of Edward, viz., 1282.

All the king's writs directed to Gurdon are addressed in the following manner: "Edwardus, Dei gratia, \&c. dilecto et fideli suo Ade Gurdon salutem;" and again, "Custodi foreste sue de Wolvemere." 3

In the year 1293 a quarrel between the crews of an

"Bensted and Kingsley; a petition of the parishioners concerning the three parks in Aliceholt Forest."

William, first Earl of Dartmouth, and paternal grandfather to the present Lord Stawel, was a lessee of the forests of Aliceholt and Wolmer, before Brigadier-General Emanuel Scroope Howe.-G. W.

1 See Letter II. of these Antiquities.-G. W.

2 Hocheleye, now spelt Hawkley, is in the hundred of Selborne, and has a mill at this day.-G. W.

3 See p. 27, note 4.-Ev. 
English and a Norman ship, about some trifle, brought on by degrees such serious consequences, that in 1295 a war broke out between the two nations. The French king, Philip the Hardy, gained some advantages in Gascony ; and, not content with those, threatened England with an invasion, and, by a sudden attempt, took and burnt Dover.

Upon this emergency Edward sent a writ to Gurdon, ordering him and four others to enlist three thousand soldiers in the counties of Surrey, Dorset, and Wiltshire, ablebodied men, "tam saggitare quam balistare potentes:" and to see that they were marched, by the feast of All Saints, to Winchelsea, there to be embarked aboard the king's transports.

The occasion of this armament appears also from a summons to the Bishop of Winchester to parliament, part of which I shall transcribe on account of the insolent menace which is said therein to have been denounced against the English language:- "qualiter rex Franciæ de terra nostra Gascon nos fraudulenter et cautelose decepit, eam nobis nequiter detinendo... vero predictis fraude et nequitia non contentus, ad expugnationem regni nostri classe maxima et bellatorum copiosa multitudine congregatis, cum quibus regnum nostrum et regni ejusdem incolas hostiliter jam invasurus, linguam Anglicam, si concepte iniquitatis proposito detestabili potestas correspondeat, quod Deus avertat, omnino de terra delere proponit." Dated 30th September, in the year of King Edward's reign xxiii. ${ }^{1}$

The above are the last traces that I can discover of Gurdon's appearing and acting in public. The first notice that my evidences give of him is, that, in 1232, being the sixteenth of Henry III., he was the king's bailiff, with others, for the town of Alton. Now, from 1232 to 1295 is a space of sixty-three years; a long period for one man to be employed in active life! Should any one doubt whether all these particulars can relate to one and the same person, I should wish him to attend to the following reasons why

1 Reg. Wynton, Stratford, but query Stratford; for Stratford was not Bishop of Winton till 1323, near thirty years afterwards.-G. IV. 
they might. In the first place, the documents from the Priory mention but one Sir Adam Gurdon, who had no son lawfully begotten; and in the next, we are to recollect that he must have probably been a man of uncommon vigour both of mind and body; since no one, unsupported by such accomplishments, could have engaged in such adventures, or could have borne up against the difficulties which he sometimes must have encountered; and, moreover, we have modern instances of persons that have maintained their abilities for near that period.

Were we to suppose Gurdon to be only twenty years of age in 1232, in 1295 he would be eighty-three; after which advanced period it could not be expected that he should live long. From the silence, therefore, of my evidences it seems probable that this extraordinary person finished his life in peace, not long after, at his mansion of Temple. Gurdon's seal had for its device-a man with a helmet on his head, drawing a cross-bow; the legend, "Sigillum Ade de Gurdon ;" his arms were, "Goulis et iii floures argent issant de testes de leopards." 1

If the stout and unsubmitting spirit of Gurdon could be so much influenced by the belief and superstition of the times, much more might the hearts of his ladies and daughter. And accordingly we find that Ameria, by the consent and advice of her sons, though said to be all under age, makes a grant for ever of some lands down by the stream at Durton; and also of her right of the common of Durton itself. ${ }^{2}$ Johanna, the daughter and heiress of Sir Adam, was married, I find, to Richard Achard; she also grants to the prior and convent lands and tenements in the village of Selborne, which hèr father obtained from Thomas Makerel; and all also her goods and chattels in Selborne for the consideration of two hundred pounds sterling. This last business was transacted in the first year of Edward II.

1 From the collection of Thomas Martin, Esq., in the Antiquarian Repertory, vol. iii. p. 109, No. XXXI.-G. W.

2 Durton, now called Dorton, is still a common for the copyholders of Selborne manor.-G. W. 
viz. 1307. It has been observed before that Gurdon had a natural son: this person was called by the name of John Dastard, alias Wastard, but more probably Bastard; since bastardy in those days was not deemed any disgrace, though dastardy was esteemed the greatest. He was married to Gunnorie Duncun; and had a tenement and some land granted him in Selborne by his sister Johanna.

\section{LETTER XI.}

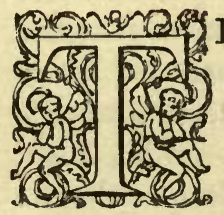

HE Knights Templars, ${ }^{1}$ who have been mentioned in a former letter, had considerable property in Selborne; and also a preceptory at Sudington, now called Southington, a lage. Bishop Tanner mentions only two such houses of

\section{The Military Orders of the Religious.}

The Knights Hospitalars of St. John of Jerusalem, afterwards called Knights of Rhodes, now of Malta, came into England about the year 1100,1 Hen. I.

The Knights Templars came into England pretty early in Stephen's reign, which commenced 1135 . The order was dissolved in 1312, and their estates given by act of Parliament to the Hospitalars in 1323, (all in Edw. II.) though many of their estates were never actually enjoyed by the said Hospitalars. - Vid. Tanner, p. xxiv. x.

The commandries of the Hospitalars, and preceptories of Templars, were each subordinate to the principal house of their respective religion in London. Although these are the different denominations, which Tanner at p. xxviii. assigns to the cells of these different orders, yet throughout the work very frequent instances occur of preceptories attributed to the Hospitalars; and if in some passages of Notitia Monast. commandries are attributed to the Templars, it is only where the place afterwards became the property of the Hospitalars, and so is there indifferently styled preceptory or commandry ; see pp. 243, 263, 276, 577,678 . But, to account for the first observed inaccuracy, it is probable the preceptories of the Templars, when given to the Hospitalars, were still vulgarly, however, called by their old name of preceptories; whereas in propriety the societies of the Hospitalars were indeed (as has been said) commandries. And such deviation from the strictness of 
the Templars in all the county of Southampton, viz. Godesfield, founded by Henry de Blois, Bishop of Winchester, and South Badeisley, a preceptory of the Knights Templars, and afterwards of St. John of Jerusalem, valued at $£ 11816 s .7 d$. per annum. Here then was a preceptory unnoticed by antiquaries, between the village and Temple. Whatever the edifice of the preceptory might have been, it has long since been dilapidated; and the whole hamlet contains now only one mean farm-house, though there were two in the memory of man.

It has been usual for the religious of different orders to fall into great dissensions, and especially when they were near neighbours. Instances of this sort we have heard of between the monks of Cauterbury; and again between the old abbey of St. Swythun, and the comparatively new

expression in this case might occasion those societies of Hospitalars also to be indifferently called preceptories, which had originally been vested in them, having never belonged to the Templars at all.-See in Archer, p. 609. Tanner, p. 300 , col. 1. 720 , note $e$.

It is observable that the very statute for the dissolution of the Hospitalars holds the same language; for there, in the enumeration of particulars, occur "commandries, preceptories." Codex, p. 1190. Now this intercommunity of names, and that in an act of parliament too, made some of our ablest antiquaries look upon a preceptory and commandry as strictly synonymous; accordingly we find Camden, in his Britannia, explaining praceptoria in the text by a commandry in the margin, pp. $356,510$.

Commandry, a manor or chief messuage with lands, \&c., belonging to the priory of St. John of Jerusalem; and he who had the government of such house was called the commander, who could not dispose of it but to the use of the priory, only taking thence his own sustenance, according to his degree, who was usually a brother of the same priory. Cowell. He adds (confounding these with preceptories) they are in many places termed Temples, as Temple Bruere in Lincolnshire, \&c. Preceptories were possessed by the more eminent sort of Templars, whom the chicf master created and called Praceptores Templi. Cowell, who refers to Stephens de Jurisd. lib. 4. c. 10. num. 27.

Placita de juratis et assis coram Salom. de Roff et sociis suis justic. Itiner. apud Wynton, \&c. anno regni R. Edwardi fil. Reg. Hen. octavo.- " et Magr. Milicie Templi in Angl. ht emendassē panis, \& suis [cerevisiæ] in Sodington, \& nescint $q^{\circ}$. war. et-et magist. Milicie Templi nōn vēn iō distr.-Chapter House, Westminster.-G. W. 
minster of Hyde in the city of Winchester. ${ }^{1} \quad$ These feuds arose probably from different orders being crowded within the narrow limits of a city, or garrison-town, where every inch of ground was precious, and an object of contention. But with us, as far as my evidences extend, and while Robert Saunford was master, ${ }^{2}$ and Richard Carpenter was preceptor, the Templars and the Priors lived in an intercourse of mutual good offices.

My papers mention three transactions, the exact time of which cannot be ascertained, because they fell out before dates were usually inserted; though probably they happened about the middle of the thirteenth century, not long after Saunford became master. The first of these is that the Templars shall pay to the priory of Selborne, annually, the sum of ten shillings at two half yearly payments from their chamber, "camera," at Sudington, "per manum preceptoris,

1 Notitia Monastica, p. 155.

"Winchester, Newminster. King Alfred founded here first only a house and chapel for the learned monk Grimbald, whom he had brought out of Flanders : but afterwards projected, and by his will ordered, a noble church or religious house to be built in the cemetery on the north side of the old minster or cathedral ; and designed that Grimbald should preside over it. This was begun A.D. 901, and finished to the honour vi the Holy Trinity, Virgin Mary, and St. Peter, by his son, King Edward, who placed therein secular canons : but A.D. 963, they were expelled, and an abbot and monks put in possession by Bishop Ethelwold.

"Now the churches and habitations of these two societies being so very near together, the differences which were occasioned by their singing, bells, and other matters, arose to so great a height, that the religious of the new monastery thought fit, about A.D. 1119, to remove to a better and more quiet situation without the walls, on the north part of the city called HYDE, where King Henry I. at the instance of Will. Gifford, Bishop of Winton, founded a stately abbey for them. St. Peter was generally accounted patron; though it is sometimes called the monastery of St. Grimbald, and sometimes of St. Barnabas," \&c.

Note. A few years since a county bridewell, or house of correction, has been built on the immediate site of Hyde Abbey. In digging up the old foundations the workmen found the head of a crozier in good preservation.-G. W.

2 Robert Saunforde was master of the Temple in 1241; Guido de Foresta was the next in 1292. The former is fifth in a list of the masters in a MS. Bib. Cotton. Nero. F. VI.-G. W. 
vel ballivi nostri, qui pro tempore fuerit ibidem," till they can provide the prior and canons with an equivalent in lands or rents within four or five miles of the said convent. It is also further agreed, if the Templars shall be in arrears for one year, that then the prior shall be empowered to distrain upon their live stock in Bradeseth. The next matter was a grant from Robert de Saunford to the priory for ever, of a good and sufficient road, "cheminum," capable of admitting carriages, and proper for the drift of their larger cattle, from the way which extends from Sudington towards Blakemere, on to the lands which the convent possesses in Bradeseth.

The third transaction (though for want of dates we cannot say which happened first and which last) was a grant from Robert Saunford to the priory of a tenement and its appurtenances in the village of Selborne, given to the Templars by Americus de Vasci. ${ }^{1}$ This property, by the manner of describing it,- " totum tenementum cum omnibus pertinentiis suis, scilicet in terris, \& hominibus, in pratis \& pascuis, \& nemoribus," \&c., seems to have been no inconsiderable purchase, and was sold for two hundred marks sterling, to be applied for the buying of more land for the support of the holy war.

Prior John is mentioned as the person to whom Vasci's land is conveyed. But in Willis's list there is no Prior John till 1339, several years after the dissolution of the order of the Templars in 1312; so that unless Willis is wrong, and has omitted a Prior John since 1262 (that being the date of his first prior), these transactions must have fallen out before that date.

I find not the least traces of any concerns between Gurdon and the Knights Templars; but probably after his death his daughter Johanna might have, and might bestow,

1 Americus Vasci, by his name, must have been an Italian, and had bcen probably a soldier of fortune, and one of Gurdon's captains. Americus Vespucio, the person who gave name to the new world, was a Florentine.-G. W. 
Temple on that order in support of the holy land; and, moreover, she seems to have been moving from Selborne when she sold her goods and chattels to the priory, as mentioned above.

Temple no doubt did belong to the knights, as may be asserted, not only from its name, but also from another corroborating circumstance of its being still a manor tithefree; "for, by virtue of their order," says Dr. Blackstone, " the lands of the Knights Templars were privileged by the pope with a discharge from tithes."

Antiquaries have been much puzzled about the terms preceptores and preceptorium, not being able to determine what officer or edifice was meant. But perhaps all the while the passage quoted above from one of my papers "ser manum preceptoris vel ballivi nostri, qui pro tempore fuerit ibidem," may help to explain the difficulty. For if it be allowed here that preceptor and ballivus are synonymous words, then the brother who took on him that office resided in the house of the Templars at Sudington, a preceptory; where he was their preceptor, superintended their affairs, received their money; and, as in the instance there mentioned, paid from their chamber, "camera," as directed: so that, according to this explanation, a preceptor was no other than a steward, and a preceptorium was his residence. I am well aware that, according to strict Latin, the vel should have been seu or sive, and the order of the words "preceptoris nostri, vel ballivi, qui" -et "ibidem" should have been $i b i$; ibidem necessarily having reference to two or more persons : but it will hardly be thought fair to apply the niceties of classic rules to the Latinity of the thirteenth century, the writers of which seem to have aimed at nothing farther than to render themselves intelligible.

There is another remark that we have made, which, I think, corroborates what has been advanced; and that is, that Richard Carpenter, preceptor of Sudington, at the time of the transactions between the Templars and Selborne Priory, did always sign last as a witness in the three deeds: he calls himself frater, it is true, among many other brothers, 
but subscribes with a kind of deference, as if, for the time being, his office rendered him an inferior in the community. ${ }^{1}$

\section{LET'TER XII.}

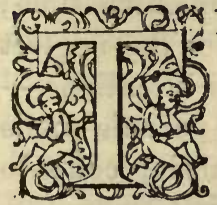

HE ladies and daughter of Sir Adam Gurdon were not the only benefactresses to the Priory of Selborne; for, in the year 1281, Ela Longspee obtained masses to be performed for her engagement that one of the convent should every day say a special mass for ever for the said benefactress, whether living or dead. She also engaged within five years to pay to the said convent one hundred marks of silver for the support of a chantry and chantry-chaplain, who should perform his masses daily in the parish church of Selborne. ${ }^{2}$ In the east end of the south aisle there are two sharp-pointed Gothic niches; one of these probably was the place under

1 In two or three ancient records relating to St. Oswald's hospital in the city of Worcester, printed by Dr. Nash, pp. 227 and 228 of his "Collections for the History of Worcestershire," the words preceptorium and preceptoria signify the mastership of the said hospital: "ad preceptorium sive magisterium presentavit-preceptorii sive magisterii patronus. Vacavit dicta preceptoria seu magisterium-ad preceptoriam et regimen dicti hospitalis - Te preceptorem sive magistrum prefecimus."

Where preceptorium denotes a building or apartment it may probably mean the master's lodgings, or at least the preceptor's apartment, whatsoever may have been the office or employment of the said preceptor.

A preceptor is mentioned in Thoresby's "Ducatus Leodiensis, or IIistory of Leeds," p. 225, and a deed witnessed by the preceptor and chaplain before dates were inserted.-Du Fresne's "Supplement:" "Pre. ceptoria, prædia preceptoribus assignata."-Cowell, in his "Law Dictionary," enumerates sixteen preceptoria, or preceptories, in England; but Sudington is not among them.-It is remarkable that Gurtlerus, in his "Ilistoria Templariorum," Amstel. 1691, never once mentions the words preceptor or preceptorium.-G. W.

2 A chantry was a chapel joined to some cathedral or parish church, and endowed with annual revenues for the maintenance of one or more priests to sing mass daily for the soul of the founder, and others.-G. IV. 
which these masses were performed; and there is the more reason to suppose as inuch, because, till within these thirty years, this space was fenced off with Gothic wooden railing, and was known by the name of the south chancel. ${ }^{1}$

The solicitude expressed by the donor plainly shows her piety and firm persuasion of the efficacy of prayers for the dead; for she seems to have made every provision for the payment of the sum stipulated within the appointed time; and to have felt much anxiety lest her death, or the neglect of her executors or assigns, might frustrate her intentions."Et si contingat me in solucione predicte pecunie annis predictis in parte aut in toto deficere, quod absit; concedo et obligo pro me et assignatis meis, quod Vice-Comes ... Oxon. et ... qui pro tempore fuerint, per omnes terras et tenementa, et omnia bona mea mobilia et immobilia ubicunque in balliva sua fuerint inventa ad solucionem predictam faciendam possent nos compellere." And again"Et si contingat dictos religiosos labores seu expensas facere circa predictam pecuniam, seu circa partem dicte pecunio; volo quod dictorum religiosorum impense et labores levantur ita quod predicto priori vel uni canonicorum suorum super hiis simplici verbo credatur sine alterius honere probacionis ; et quod utrique predictorum virorum in unam marcam argenti pro cujuslibet distrincione super me facienda tenear.-Dat. apud Wareborn die sabati proxima ante festum St. Marci evangeliste, anno regni regis Edwardi tertio decimo."2

But the reader perhaps would wish to be better informcd respccting this benefactress, of whom as yet he has heard no particulars.

The Ela Longspee therefore above-mentioned was a lady

1 For what is said more respecting this chantry see Letter III. of these "Antiquities."-Mention is made of a Nicholas Langrish, capellanus de Selborne, in the time of Henry VIII. Was he chantry-chaplain to Ela Longspee, whose masses were probably continued to the time of the Reformation? More will be said of this person hereafter.-G. W.

2 Ancient deeds are often dated on a Sunday, having been executed in churches and churchyards for the sake of notoriety, and for the convenicncy of procuring several witnesses to attest.-G. W. 
of high birth and rank, and became countess to Thomas de Newburgh, the sixth Earl of Warwick: she was the second danghter of the famous Ela Longspee, Countess of Salisbury, by William Longspee, natural son of King Henry II. by Rosamond.

Our lady, following the steps of her illustrious mother,' "was a great benefactress to the university of Oxford, to the canons of Oseney, the nuns of Godstow, and other religious houses in Oxfordshire. She died very aged in the year $1300,{ }^{2}$ and was buried before the high altar in the abbey church of Oseney, at the head of the tomb of Henry D'Oily, under a flat marble, on which was inlaid her portraiture, in the habit of a vowess, engraved on a copper-plate." -Edmonson's "History and Genealogical Account of the Grevilles," p. 23.

\section{LETTER XIII.}

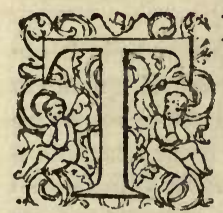

HE reader is hero presented with five forms respecting the choosing of a prior, but as they are of some length thry must be reserved for the Appendix ; ${ }^{3}$ their titles are No. 108, "Charta petens licentiam eligendi prelatum a Domino episcopo Wintoniensi :"-" Forma licentie con-

1 Ela Lonsgpee, Countess of Salisbury, in 1232, founded a monastery at Lacock, in the county of Wilts, and also another at Hendon, in the caunty of Somerset, in her widowhood, to the honour of the Blessed Virgin and St. Bernard. (CAMden.)-G. W.

2 Thus she survived the foundation of her chantry at Selborne fifteen years. A bout this lady and her mother consult Dugilale's "Baronage," i. 72, 175, 177.-Dugdale's "Warwickshire," i. 383.-Leland's "Itin." ii. $45 .-$ G. W.

3

(Appendix, No. 108.)

Carta petens licentiam cligendi prelatum a Domino Episcopo Wintonicnsi. Defuncto prelato forma petendi licentiam eligendi.

"Domino et patri in Christo reverendo domino \& P. Dei gratia Wintoniensi episcopo, devoti sui filii supprior monasterii de S. Wintoniensis 
cesse:"-_ Forma decreti post electionem conficiendi:" "Modus procedendi ad electionem per formam scrutinii : :et "Forma ricte presentandi electum." Such evidences are rare and curious, and throw great light upon the general

dioceseos salutem cum subjectione humili, reverentiam, et honorem. Monasterio nostro de S. in quo sub protectione vestra vivimus, sub habitu regulari, Prioris solacio destituto per mortem bone memorie, \&c. quondam Prioris nostri, qui tali hora in aurora diem clausit extremum, vestre paternitati reverende et dominationi precipue istum nostrum et nostri monasterii casum flebilem cum merore nunciamus; ad vestre paternitatis refugium fratres nostros A. et C. canonicos destinantes, rogando et petendo devote quatenus nobis dignemini licenciam tribuere, ut monasterio predicto, Prioris regimine destituto, providere possimus, invocata Spiritus sancti gratia, per electionem canonicam de Priore. Actum in monasterio predicto 5 kalend. \&c. anno Domini, \&c. Valeat reverenda paternitas véstra semper in Domino."

\section{Forma licencie concesse.}

" $P$. Dei gratia Wintoniensis episcopus dilectis in Christo filiis suppriori et conventui talis loci salutem, gratiam, et benedictionem. Viduitatem monasterii vestri vacantis per mortem quondam $R$. Prioris vestri, cujus anime propicietur altissimus, paterno compacientes affectu, petitam a nobis eligendi licenciam vobis concedimus, ut patronus. Datum apud, \&c. 3 kalend. Jul. anno consecrationis nostre tertio."

\section{Forma decreti post electionem conficiendi.}

"In nomine Domini nostri Jhesu Christi, Ainen. Monasterio beate Marie talis loci Winton. dioc. solacio destituto per mortem R. quondam Prioris ipsius; ac corpore ejus, prout moris est, ecclesiastice sepulture commendato ; petita cum devocione licentia per fratres $K$. et . canonicos a ven: in Christo patre et domino domino P. Dei gratia Wintoniensi episcopo ejusdem monasterii patrono, eligendi priorem, et optenta; die dato, a toto capitulo ad eligendum vocati fuere evocandi, qui debuerunt. volucrunt, et potuerunt comode electioni prioris in monasterio predicto interesse; omnes canonici in capitulo ejusdem ecclesie convenerunt tali die, anno Dom. \&c. ad tractandum de electione sui prioris facienda; qui, invocata Spiritus Sancti gratia, ad procedendum per formam scrutinii concencientes."

(N. 108.) Modus procedendi ad electionem per formam scrutinii.

"Omnibus in capitulo congregatis qui debent volunt et possunt comode interesse electioni eligendi sunt tres de capitulo* non nostro obediencias ores, + qui erunt scrutatores, et sedebunt in angulo capituli; et primo requirent vota sua propria, videlicet, duo requirent tertium et duo

* Fratres canonicos. See Forma decreti, \&c.-G. W.

+ Obedientiores, sc. mure regular. In virtute obedientiæ occurs in Not. Visit.-G. W. 
monastico-ecclesiastical history of this kingdom, not yet sufficiently understood.

In the year 1324 there was an election for a prior at Selborne; when some difficulties occurring, aud a devolution

alterum, \&c. dicendo sic, 'Frater $\mathbf{P}$. in quem concentis ad eligendum in prelatum nostrum?' quibus examinatis, et dictis eorum per vicem ex ipsis in scriptura redactis, vocabunt ad se omnes fratres singillatim, primo suppriorem, \&c. Et unus de tribus examinatoribus scribet dictum cujuslibet. Celebrato scrutinio, publicare db coram omnibus. Facta ptmodū concensum collectione apparebit in quem pars major capituli et sanior concentit; quo viso, major pars dicet minori, ' Cum major pars et sanior capituli nostri concenciat in fratrem $R$. ipse est eligendus, unde, si placet, ipsum communiter eligamus;' si vero omnes acquieverint, tunc ille qui majorem vocem habet in capitulo surgens dicet, 'Ego frater R. pro toto capitulo eligo fratrem R. nobis in pastorem;' et omnes dicent; 'Placet nobis.' Et incipient, 'Te Deum laudamus.' Si vero in unum concordare nequiverint, tunc hiis, qui majorem vocem habet inter illos qui majorem et saniorem partem capituli constituerint, dicet, 'Ego pro me et illis qui mecum concenciunt in fratrem $\mathbf{R}$. eligo ipsum in,' \&c. Et illi dicent, 'Placet nobis,' \&c."

\section{Forma ricte presentandi electum.}

"Reverendo in Christo patri et domino domino P. Dei gratia Winton. episcopo devoti sui filii frater $R$. supprior couventualis beate Marie de tali loco, et ejusdem loci Conventus, cum subjectione humili, omnem obedienciam, reverenciam, et honorem. Cum conventualis ecclesia beate Marie talis loci, in qua sub protectione vestra vivimus sub habitu regulari, per mortem felicis recordationis $\mathrm{R}$. quondam prioris nostri destitrita ecclesia priore, qui $6^{\text {to }} \mathrm{kalend}$. Jul. in aurora anno Dom. \&c. diem clausit extremum; de corpore ejus, prout moris est, ecclesiastice tradito sepulture; petita a vobis, tanquam a Domino, et vero ejusdem ecclesie patrono et pastore, licencia eligendi priorem et optenta; convenientibus omnibus canonicis predicte ecclesie in capitulo nostro, qui voluerunt debuerunt et potuerunt comode electioni nostre interesse, tali die anno Dom. supradicto, invocata Spiritus Sancti gratia, fratrem R. de C. ejusdem ecclesie canonicum unanimi assensu et voluntate in priorem nostrum, ex puris votis singulorum, unanimiter eligimus. Quem reverende paternitati vestre et dominacioni precipue Priorem vero patrono nostro et pastore confirmandum, si placet, tenore presentium presentamus; dignitatem vestram humiliter et devote rogantes, quatenus, dicte elcctioni felicem prebere volentes assensum, eidem $R$. electo nostro nunc confirmabitis, et quod vestrum est pastorali solicitudine impendere dignemini. In cujus rei testimonium presentes litteras sigillo capituli nostri signatas paternitati vestre transmittimus. Valeat reverenda paternitas vestre sempcr in Domino. Datum tali loco die et anno supradictis. Omnes et singuli, per iratres A. B. et C. ejusdem ecclesie 
taking place, application was made to Stratford, who was Bishop of Winchester at that time, and of course the visitor and patron of the convent at the spot above-mentioned. ${ }^{1}$

AN EXTRACT FROM REG. STRATFORI. WINTON.

P. 4. "Commissio facta sub-priori de Selebourne" by the bishop, enjoining him to preserve the discipline of the order in the convent during the vacancy made by the late death of the prior, ("nuper pastoris solatio destituta,") dated $4^{\text {to }}$. kal. Maii. ann. $2^{\text {do }}$ sc. of his consecration. [sc. 1324.]

P. 6. "Custodia Prioratus de Seleburne vacantis," committed by the bishop to Nicholas de la . . ., a layman, it belonging to the bishop " ratione vacationis ejusdem," in July, 1324. Ibid. "Negotium electionis de Selebourne. Acta coram Johanne Episcopo, \&c. 1324 in negotio electionis de fratre Waltero de Insula concanonico prioratus de Selebourne," lately elected by the sub-prior and convent, by way of scrutiny; that it appeared to the bishop, by certificate from the Dean of Alton, that solemn citation and

canonicos de voluntate tocius conventus ad inquirenda vota singulorum constitutos, secreto et singillatim requisiti; tandem publicato scrutinio et facta votorum colectione inventum est, majorem et saniorem partem tocius capituli dicte ecclesie in fratrem $\mathrm{S}$. de B. dicte ecclesie canonicum unanimiter et concorditer concencisse; vel sic, quando inventum omnes canonicos dicte ecclesie preter duos in fratrem, A. D. quibus statim majori parti eligendum adquiescenter: frater $\mathrm{k}$. supprior ecclesie memorate, juxta potestatem sibi a toto conventu traditam, vice consociorum suorum et sua ac tocius conventus, dictum fratrem S. de B. in priorem ejusdem ecclesie elegit, sub hac forma; 'Ego frater supprior conventualis ecclesie beate Marie talis loci, potestate et auctoritate mihi a toto conventu dicte ecclesie tradita et commissa, quando, puplicato scrutinio et omnibus circa hoc rite peractis, inveni majorem et partem saniorem tocius capituli nostri in fratrem $\mathrm{S}$. de $\mathrm{B}$. virum providum unanimiter concencisse, ipsum nobis et ecclesie nostre, vice tocius conventus, in priorem eligendum; et eidem electioni subscribo; cui electioni omnes canonici nostri concencerunt, et subscripserunt.'- 'Ego frater de C. presenti electioni concencio, et subscribo.' Et sic de singulis electoribus; in cujus rei testimonium sigillum capituli nostri apponi fecimus ad presentes."-G. W.

1 Stratford was Bishop of Winchester from 1323 to 1333, when ho was translated to Canterbury.-G. W. 
proclamation had been made in the church of the convent where the election was held, that any who opposed the said election or elected should appear. Some difficulties were started, which the bishop overruled, and confirmed the election, and admitted the now prior sub hac forma:

"In Dei nomine Amen. Ego Johannes permissione divina, \&c. te Walterum de Insula ecclesie de Selebourne nostre dioceseos nostrique patronatus vacantis, canonicum et cantorem, virum utique providum, et discretum, literarum scientia preditum, vita moribus et conversatione merito commendatum, in ordine sacerdotali et etate legitima constitutum, de legitimo matrimonio procreatum, in ordine et religione Sancti Augustini de Selebourne expresse professum, in spiritualibus et temporalibus circumspectum, jure nobis hac vice devoluto in hac parte, in dicte ecclesio de Selebourne prefectum priorem; curam et administrationem ejusdem tibi in spiritualibus et temporalibus committentes. Dat. apud Selebourne XIII kalend. Augusti anno supradicto."

There follows an order to the sub-prior and convent pro obedientia:

A mandate to Nicholas above-named to release the Priory to the new prior:

A mandate for the induction of the now prior.

\section{LETTER XIV.}

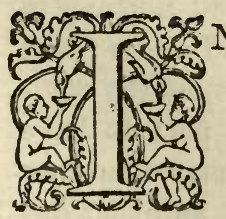

N the year 1373 Wykeham, Bishop of Winchester, hold a visitation of his whole diocese; not only of the secular clergy through tho several deaneries', but also of the monasteries, and religious houses of all sorts, which he visited in person. The next year he sent his commissioners with power to correct and reform the several irregularities and abuses which he had discovered in the course of his visitation. 
"Some years afterward, the bishop having visited three several times all the religious houses throughout his diocese, and being well informed of the state and condition of each, and of the particular abuses which required correction and reformation, besides the orders which he had already given, and the remedies which he had occasionally applied by his commissioners, now issued his injunctions to each of them. They were accommodated to their several exigencies, and intended to correct the abuses introduced, and to recall them all to a strict observation of the rules of their respective orders. Many of these injunctions are still extant, and are evident monuments of the care and attention with which he discharged this part of his episcopal duty." 1

Some of these injunctions I shall here produce; and they are such as will not fail, I think, to give satisfaction to the antiquary, both as never having been published before, and as they are a curious picture of monastic irregularities at that time.

The documents that I allude to are contained in the Notabilis Visitatio de Seleburne, held at the Priory of that place, by Wykeham in person, in the year 1387.

This evidence, in the original, is written on two skins of parchment; the one large, and the other smaller, and consists of a preamble, thirty-six items, and a conclusion, which altogether evince the patient investigation of the visitor, for which he had always been so remarkable in all matters of moment, and how much he had at heart the regularity of those institutions, of whose efficacy in their prayers for the dead he was so firmly persuaded. As the bishop was so much in earnest, we may be assured that he had nothing in view but to correct and reform what he found amiss; and was undur no bias to blacken or misrepresent, as the commissioners of Thomas Lord Cromwell seem in part to have done at the time of the reformation. ${ }^{2}$ We may therelore with reason suppose that the bishop gives us an exact de-

1 See "Lowth's Life of Wykeham."-G. W.

2 Letters of this sort from Dr. Layton to Thomas Lord Cromwell, are still extant. $-\mathrm{G}$. W. 
lineation of the morals and manners of the canons of Selborne at that juncture: and that what he found they had omitted he enjoins them; and for what they have done amiss, and contrary to their rules and statutes, he reproves them; and threatens them with punishment suitable to their irregularities.

This visitatio is of considerable length, and cannot be introduced into the body of this work; ${ }^{1}$ we shall therefore take some notice, and make some remarks, on tho most singular items as they occur.

In the preamble the visitor says-"Considering the charge lying upon us, that your blood may not be required at our hands, we came down to visit your Priory, as our office required : and every time we repeated our visitation we found something still not only contrary to regular rules but also repugnant to religion and good reputation."

In the first article after the preamble-" he commands them on their obedience, and on pain of the greater excommunication, to see that the canonical hours by night and by day be sung in their choir, and the masses of the Blessed Mary, and other accustomed masses, be celebrated at the proper hours with devotion, and at moderate pauses; and that it be not allowed to any to absent themselves from the hours and masses, or to withdraw before they are finished."

Item $2 \mathrm{~d}$. He enjoins them to observe that silence to which they are so strictly bound by the rule of St. Augustine at stated times, and wholly to abstain from frivolous conversation.

[Item 3rd. That whercas, although in health, they have many times neglected the celebration of masses, and have thereby defrauded the souls of the founders and other benefactors; he enjoins them to confess frequently, and devoutly to celebrate mass, as well for the living as the

1 It was printed entire in an Appendix to the first edition: but as the principal items have been abstracted in the text by Gilbert Whitc. and as the heads of the remaining items are now given [between brackets] by the editor, it has been judged unnecessary to reprint here, verbatim, an article of such considerable length.-ED. 
dead, as often as may be. If any impediment occur to prevent the celebration, they are to report it within three days to the prior; who is also required to search diligently every month into breaches of this rule, and to punish the delinquents.]

Item 4th. "Not to permit such frequent passing of secular people of both sexes through their convent, as if a thoroughfure, from whence many disorders may and have arisen."

Item 5th. "To take care that the doors of their church and Priory be so attended to that no suspected and disorderly females, 'suspectæ et aliæ inhonestæ,' pass through their choir and cloister in the dark;" and to see that the doors of their church between the nave and the choir, and the gates of their cloister opening into the fields, be constantly kept shut until their first choir-service is over in the morning, at dinner time, and when they meet at their evening collation. ${ }^{1}$

Item 6 th mentions that several of the canons are found to be very ignorant and illiterate, and enjoins the prior to see that they be better instructed by a proper master.

[Item 7th. The decretals concerning their order are not read, on which account they, in consequence of their ignorance of them, to the peril of their souls act in a manner therein expressly forbidden. Wherefore they are required to have these decretals written in a volume, and read twice a year in the chapter for the information of the seniors ; and to have them explained, in the vulgar, to the novices, so that they may know them as it were by heart. This charge is laid upon the prior, under pain of suspension.]

Item 8th. The canons are here accused of refusing to accept of their statutable clothing year by year, and of demanding a certain specificd sum of money, as if it were their annual rent and due. This the bishop forbids, and orders that the canons shall be clothed out of the revenue of the Priory, and the old garments be laid by in a chamber

1 A cullation was a meal or repast on a fast day, in lieu of a supper -G. W. 
and given to the poor, according to the rule of St. Au. gustine.

In Item 9th is a complaint that some of the canons are given to wander out of the precincts of the convent without leave; and that others ride to their manors and farms, under pretence of inspecting the concerns of the society, when they please, and stay as long as they please. But they are enjoined never to stir either about their own private concerns or the business of the convent without leave from the prior; and no canon is to go alone, but to have a grave brother to accompany him.

The injunction in Item 10th, at this distance of time, appears rather ludicrous; but the visitor seems to be rery serious on the occasion, and says that it has been evidently proved to him that some of the canons, living dissolutely after the flesh, and not after the spirit, sleep naked in their beds without their breeches and shirts, " absque femoralibus et camisiis." ${ }^{1} \mathrm{He}$ enjoins that these culprits shall be punished by severe fasting, especially if they shall be found to be faulty a third time; and threatens the prior and subprior with suspension if they do not correct this enormity.

In Item 11 th the good bishop is very wroth with some of the canons, whom he finds to be professed hunters and sportsmen, keeping hounds, and publicly attending huntingmatches. These pursuits, he says, occasion much dissipation, danger to the soul and body, and frequent expense; he, therefore, wishing to extirpate this vico wholly from the convent, "radicibus extirpare," does absolutely enjoin the canons never intentionally to be present at any public noisy tumultuous huntings; or to keep any hounds, by themselves or by others, openly or by stealth, within the convent, or without. $^{2}$

1 The rule alluded to in Item 10th, of not sleeping naked, was enjoined the Knights Templars, who also were subject to the rules of St. Augustine.-See Gurtleri Hist. Templariorum.-G. W.

2 Considering the strong propensity in human nature towards the pleasures of the chase, it is not to be wondered that the canons of Sclborne shouid languish after hunting, when, from their situation so near the precincts of Wolmer Forest, the king's hounds must have becn often 
In Item 12 th he forbids the canons in office to make their business a plea for not attending the service of the choir; since by these means either divine worship is neglected, or their brother canons are overburdened.

[Item 13th directs that two of the canons shall twice in every year personally visit the manors, and report in writing their condition and the live and dead stock at each; that in case of the death of any officer, the convent may not be left in ignorance as to the state of his charge; neglect to be severely punished, according to the bishop's discretion.]

By Item 14th we are informed that the original number of cannns at the Priory of Selborne was fourteen; but that at this visitation they were found to be let down to oleven. The visitor therefore strongly and earnestly enjoins them that, with all due speed and diligence, they should proceed to the election of proper persons to fill up the vacancies, under pain of the greater excommunication.

[Item 15th is especially addressed to the prior, who has neglected to make inquisition as to proprietary canons, "whence it has resulted that the old enemy, taking advantage of the continued sloth of the shepherd, has seduced the wretched and erring sheep by means of the snare of property into the thirst of avarice," to the serious peril of their souls. $\mathrm{He}$ is required, twice a year at least, to make inquisition and to punish offenders. In neglect of this duty he is ipso facto suspended.

[Item 16th refers to the constitutions as requiring that abbots and priors, and other officers, should twice at least in each year, in the presence of the whole convent, or of a certain number deputed by the chapter, render a full account of their administration; and avers that this has not been attended to in the Priory of Selborne. Requires that it be observed in future, under pain of suspension.]

In Item $17 \mathrm{th}$, the prior and canons are accused of suffer-

in hearing, and sometimes in sight from their windows. If the bishop was so offended at these sporting canons, what would he have said to our modern fox-hunting divines?-G. W. 
ing, through neglect, notorious dilapidations to take place among their manorial houses and tenements, and in the walls and enclosures of the convent itself, [sumptuously erected by the industry of their predecessors, ] to the shame and scandal of the institution : they are therefore enjoined, under pain of suspension, to repair all defects within the space of six months.

T+em 18th. Charges them with grievously burdening the said Priory by means of sales, and grants of liveries, ${ }^{1}$ and corrodies. ${ }^{2}$

The bishop, in item 19th, accuses the canons of neglect and omission with respect to their perpetual chantryservices.

Item 20th. Thn visitor here conjures the prior and canons not to withhold their original alms, "eleemosynas;" nor those that they were enjoined to distribute for the good of the souls of founders and benefactors; he also strictly orders that the fragments and broken victuals, both from the hall of their prior and their common refectory, should be carefully collected together by their eleemosynarius, and given to the poor without any diminution; the officer to be suspended for neglect or omission.

[Item 21st. It could scarcely be anticipated that it should have been necessary to enjoin that the brethren should be supplied, when sick, with suitable food and drink, and with fitting medicines, out of the common stock, "sicut antiquitus fieri consueverat;" and have also the use of the rooms of the infirmary: yet such is the tenor of this item. Tt appears as though some one had claimed for himself a property in the infirmary, to the exclusion of the others.]

1 "Liberationes, or liberatura, allowances of corn, \&c., to servants, -nlivered at certain times, and in certain quantities, as clothes were, mong the allowances from religious houses to their dependants.-See the corrodies granted by Croyland abbey._- "Hist. of Croyland," Appendix, No. XXXIV.

"It is not improbable that the word in after ages came to be confined to the uniform of the retainers or servants of the great, who were hence called livery servants."-Sir John Cullum's "Hist. of Hawsted."-G.W.

2 A corrody is an allowance to a servant living in an abbey or priory. -G. W. 
[Item 22nd. Since negligence or remissness towards offenders is in itself detestable, and since facility of pardon operates as an incentive to delinquency; orders that, without exception of persons, correction shall be used according to the amount of the delinquency; and that the regular observances shall be duly kept.]

Item 23d. He bids them distribute their pittances, "pitancias," regularly on obits, anniversaries, festivals, \&c. -

[Item 24th. Prohibits the sale of wood, the farming out of manors or of churches, or the transaction of any other important business, without consultation and consent of the whole convent, or of the larger and discreeter portion of it: otherwise there is no validity in the proceeding. "Illa quoque que omnes tangunt ab omnibus merito debeant approbari."]

Item 25th. All and every one of the canons are hereby inhibited from standing godfather to any boy for the future, "ne comlatres alicujus puevi de cetero fieri presumatis," unless by express license from the bishop obtained; because from such relationship favour and affection, nepotism, and undue influence, arise, to the injury and detriment of religious institutions. $^{2}$

Item 26th. The visitor herein severely reprimands the canons for appearing publicly in what would be called in the universities an unstatutable manner, and for wearing of

1 "Pituncia, an allowance of bread and beer, or other provision to any pious use, especially to the religious in a monastery, \&c., for augmentation of their commons."- "Gloss. to Kennet's Par. Antiq."-G. W.

2 "The relationship between sponsors and their god-children, who were called spiritual sons and daughters, was formerly esteemed much more sacred than at present. The presents at christenings were sometimes very considerable: the connexion lasted through life, and was closed with a legacy. This last mark of attention seems to hare been thought almost indispensable: for, in a will, from whence no exuracts have been given, the testator left every one of his god-children a bushel of barley." -Sir John Cullum's " Hist. of Hawsted."-G. W.

"D. Margaretæ filiæ Regis primogrenitæ, quam filiolam, quia ejus in baptismo compater fuit, appellat, cyphum aureum et quadraginta libras, legavit."-Archbishop Parker "de Antiquitate Eccles. Brit." speaking of Archbishop Morton.-G. IV 
boots, "caligæ de Burneto, et sotilarium-in ocrearum loco, ad modum sotularium."1

It is remarkable that the bishop expresses more warmth against this than any other irregularity; and strictly enjoins them, under pain of ecclesiastical censures, and even imprisonment if necessary (a threat not made use of before) for the future to wear boots, "ocreis seu botis," according to the regular usage of their ancient order.

[Item 27th. Requires that, according to the constitutions, three or at the least two parts of the convent should daily eat together in the refectory; and forbids all dining in private places, with certain exceptions. One of the privileged places is the "aula prioris :" but the prior is desired to use due diligence that, without exception of persons, he invite sometimes one and sometimes another of those whom he knows to be most in need.]

[Item 28th. That as the lives of the younger members of the community are watched over by the seniors, so also the seniors are required by the constitutions to have witnesses of their proceedings. Enjoins that the prior should annually change his chaplain; both with the view of securing greater efficiency in the discharge of the duties, and in order that he might have ready an unsuspected witness respecting him, in the event of any scandal or imputation being cast upon him by malice.]

Item 29th. He here again, but with less earnestness, forbids them foppish ornaments, and the affectation of appearing like beaux with garments edged with costly furs, with fringed gloves, and silken girdles trimmed with gold

$1 \mathrm{Du}$ Fresne is copious on caliga of sereral sorts. "Hoc item de Clericis, presertim beneficiatis : caligis scacatis (chequered) rubies, et viridibus publice utentibus dicimus esse censendum."-Statut. Eccles. Tutel. The chequered boots seem to be the Highland plaid stockings. "Burnetum, i. e. Brunetum, pannus non ex lanâ nativi coloris confectus."- "Sotularium, i. e. subtalaris, quia sub talo est. Peculium genus, quibus maxime Monachi nocte utebantur in æstate; in hyeme vero Soccis."

This writer gives many quotations concerning Sotularia, which were not to be too shapely; nor were the caliga to be laced on too nicely. -G. W. 
and silver. It is remarkable that no punishment is annexed to this injunction.

[Item 30th. The bishop appears to have believed in the vulgar adage that what is every body's business is nobody's business; and probably attributed to this cause much of the disorder that prevailed. He here remarks that as each office ought to be committed to a special officer, he requires that to be done for the future: such officers to be elected according to the custom of the Priory. The penalty for disobedience in this case is no less than excommunication.]

Item 31st. He here singly and severally forbids each canon not admitted to a cure of souls to administer extreme unction, or the sacrament, to clergy or laity, or to perform the service of matrimony, till he has taken out the licence of the parish pricst.

Item 32nd. The bishop says in this item that he had observed and found, in his several visitations, that the sacramental plate and cloths of the altar, surplices, \&c. were sometimes left in such an uncleanly and disgusting condition as to make the beholders shudder with horror;- "quod aliquibus sunt horrori $;^{1 "}$ he therefore enjoins them for the future to see that the plate, cloths, and vestments be kept bright, clean, and in decent order; and, what must surprise the reader, adds-that he expects for the future that the sacrist should provide for the sacrament good wine, pure and unadulterated; and not, as had often been the practice, that which was sour, and tending to decay:- he says farther, that it seems quite preposterous to omit in sacred matters ithat attention to decent cleanliness, the neglect of which would disgrace a common convivial meeting.

". . . . ne turpe toral, ne sordida mappa

Corruget nares; ne non et cartharus, et lanx

Ostendat tibi tc

Item $33 \mathrm{~d}$ says that, though the relics of saints, the plate,

1 "Men abhorred the offering of the Lord."-1 Sam. chap. ii. v. 17. Strange as this account may appear to modern delicacy, the autior, when first in orders, twice met with similar circumstances attending the sacrament at two churches belonging to two obscure villages. In the first he found the inside of the chalice covered with birds' dung : and in 
holy vestments, and books of religious houses, are forbidden by canonical institutes to be pledged or lent out upon pawn; yet, as the visitor finds this to be the case in his several visitations, he therefore strictly enjoins the prior forthwith to recall those pledges, and to restore them to the convent; and orders that all the papers and title deeds thereto belonging should be safely deposited, and kept under three locks and keys.

[Item 34th. That as religious men ought continually to be advancing in holiness, he enjoins them when they have performed the observances of their order and regular discipline, to frequent the cloisters for the reading of the holy scriptures and for devout contemplation.]

[Item 35th. A special injunction to the prior, exemplifying the hospitality that prevailed in monastic establishments. That when any relation of any of the canons should come on a visit to him, his reception should be liberal according to his condition: suggesting, however, that the brethren should avoid being overburthensome to the Priory in such matters.]

[Item 36 th. It avails but little to make laws unless attention is paid to their execution. In order that they may by frequent hearing be impressed on the most treacherous memories, and that no one may pretend ignorance of them; enjoins and orders that these injunctions and the beforementioned decrees shall be written in a volume, and all and singular of them be read fully in the province of the whole convent twice in every year. Requires observance of all of them under penalties. Finally, reserves to himself the power of altering in any way either the injunctions or the penalties.]

In the course of the Visitatio Notabilis the constitutions of Legate Ottobonus are frequently referred to. Ottobonus was afterwards Pope Adrian V. and died in 1276. His

the other the communion-cloth soiled with cabbage and the greasy drippings of a gammon of bacon. The good dame at the great farmhouse, who was to furnish the cloth, being a notable woman, thought it best to save her clean linen, and so sent a foul cloth that had covered her own table for two or three Sundays before.-G. W 
constitutions are in Lyndewood's Provinciale, and were drawn up in the 52nd of Henry III.

In the Visitatio Notabilis the usual punishment is fasting. on bread and beer; and in cases of repeated delinquency on bread and water. On these occasions quarta feria, et sexta feria, are mentioned often, and are to be understood of the days of the week numerically on which such punishment is to be inflicted.

\section{LETTER XV.}

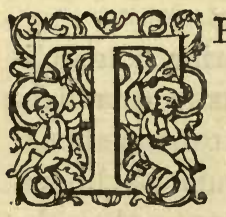

HOUGH Bishop Wykeham appears somewhat stern and rigid in his visitatorial character towards the Priory of Selborne, yet he was on the whole a liberal friend and benefactor to that convent, which, like every society or individual that fell in his way, partook of the generosity and benevolence of that munificent prelate.

In the year 1377, William of Wykeham, out of his mere good will and liberality, discharged the whole debts of the prior and convent of Selborne, to the amount of one hundred and ten marks eleven shillings and sixpence ${ }^{1}$ and, a few years before he died, he made a free gift of one hundred marks to the same priory: on which account the prior and convent voluntarily engaged for the celebration of two masses a day by two canons of the convent for ten years, for the bishop's welfare, if he should live so long; and for his soul if he should die before the expiration of this term. ${ }^{2}$

At this distance of time it seems matter of great wonder to us how these societies, so nobly endowed, and whose members were exempt by their very institution from every means of personal and family expense, could possibly run in debt without squandering their revenues in a manner incompatible with their function.

1 Yet in ten years' time we find, by the Notabilis Visitatio, that all their relics, plate, vestments, title deeds, \&c., were in pawn.-G. W.

" Lowth's "Life of Wykeham."-G. W. 
Religious houses might sometimes be distressed in their revenues by fires among their buildings, or large dilapidations from storms, \&c.; but no such accident appears to have befallen the Priory of Selborne. Those situate on public roads, or in great towns, where there were shrines of saints, were liable to be intruded on by travellers, devotees, and pilgrims; and were subject to the importunity of the poor, who swarmed at their gates to partake of doles and broken victuals. Of these disadvantages some convents used to complain, and especially those at Canterbury; but this priory, from its sequestered situation, could seldom be subject to either of these inconveniences, and therefore we must attribute its frequent debts and embarrassments, well endowed as it was, to the bad conduct of its members, and a general inattention to the interests of the institution.

\section{LETTER XVI.}

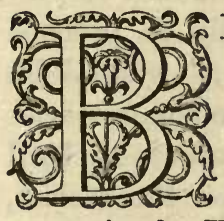

EAUFORT was Bishop of Winchester from 1405 to 1447; and yet, notwithstanding this long episcopate, only tom. i. of Beaufort's Register is to be found. This loss is much to be regretted, as it must unavoidably make a gap in the History of Selborne Priory, and perhaps in the list of its priors.

In 1410 there was an election for a prior, and again in 1411.

In vol. i. p. 24, of Beaufort's Register, is the instrument of the election of John Wynchestre to be prior-the substance as follows:-

Richard Elstede, senior canon, signifies to the bishop that brother Thomas Weston, the late prior, died October 18 th, 1410 , and was buried November 11th. That the bishop's license to elect having been obtained, he and the whole convent met in the chapter-house, on the same day, about the hour of vespers, to consider of the election:- that brother John Wynchestre, then sub-prior, with the general 
consent, appointed the 12th of November, ad horam ejusdem diei capitularem, for the business:- when they met in the chapter-house, post missam de sancto Spiritu, solemnly celebrated in the church;-to wit, Richard Elstede; Thomas Halyborne; John Lemyngton, sacrista; John Stepe, cantor; Walter Ffarnham; Richard Putworth, celerarius; Hugh London; Henry Brampton, alias Brompton; John Wynchestre, senior; John Wynchestre, junior; - then " proposito primitus verbo Dei," and then "ympno Veni Creator Spiritus" being solemnly sung, cum "versiculo et oratione," as usual, and his letter of license, with the appointment of the hour and place of election, being read, alta voce, in valvis of the chapter-house;-John Wynchestre, senior, the subprior, in his own behalf and that of all the canons, and by their mandate, "quasdam monicionem et protestacionem in scriptis redactas fecit, legit, et interposuit" - that all persons disqualified, or not having right to be present, should immediately withdraw; and protesting against their voting, \&c. - that then having read the constitution of the general council "Quia propter," and explained the modes of proceeding to election, they agreed unanimously to proceed "per viam seu formam simplicis compromissi;" when John Wynchestre, sub-prior, and all the others (the commissaries under-named excepted) named and chose brothers Richard Elstede, Thomas Halyborne, John Lemyngton the sacrist, John Stepe, chantor, and Richard Putworth, canons, to be commissaries, who were sworn each to nominate and elect a fit person to be prior; and empowered by letters patent under the common seal, to be in force only until the darkness of the night of the same day; - that they, or the greater part of them, should elect for the whole convent, within the limited time, from their own number, or from the rest of the convent; - that one of them should publish their consent in common before the clergy and people:- they then all promised to receive as prior the person these five canons should fix on. The commissaries seceded from the chapterhouse to the refectory of the Priory, and were shut in with master John Penkester, bachelor of laws; and John Couke and John Lynne, perpetual vicars of the parish churches 
of Newton and Selborne; and with Sampson Maycock, a public notary; where they treated of the election; when they unanimously agreed on John Wynchestre, and appointed Thomas Halyborne, to choose him in common for all, and to publish the election, as customary; and returned long before it was dark to the chapter-house, where Thomas Halyborne read publicly the instrument of election; when all the brothers, the new prior excepted, singing solemnly the hymu "Te Deum laudamus," fecerunt deportari novum electum, by some of the brothers, from the chapter-house to the high altar of the church $;^{1}$ and the hymn being sung, dictisque versiculo et oratione consuetis in liac parte, Thomas Halyborne, mox tunc ibidem, before the clergy and people of both sexes solemnly published the election in vulgari. Then Richard Elstede, and the whole convent by their proctors and nuncios appointed for the purpose, Thomas Halyborne and John Stepe, required several times the assent of the elected; "et tandem post diutinas interpellationes, et deliberationem providam penes se habitam, in hac parte divine nolens, ut asseruit, resistere voluntati," within the limited time he signified his acceptance in the usual written form of words. The bishop is then supplicated to confirm their election, and do the needful, under common seal, in the chapter-house. November 14, 1410.

The bishop, January 6, 1410, apud Esher in camera inferiori, declared the election duly made, and ordered the new prior to be inducted-for this the Archdeacon of Winchester was written to: "stallumque in choro, et locum in capitulo juxta morem preteriti temporis," to be assigned him; and every thing beside necessary to bo done.

BEAUFORT'S REGISTER, VOL. I.

P. 2. Taxatio spiritualis Decanatus de Aulton, Ecclesia

1 It seems here as if the canons used to chair their new elected prior frum the chapter-house to the high altar of their convent church. In Ictler XXI. on the same occasion, it is said- "et sic canentes dictum clectum ad majus altare ecclesie deduximus, ut apud nos moris est." G. W. 
de Selebourn, cum Capella,--xxx marc. decima x lib. iii sol. Vicaria de Selebourn non taxatur propter exilitatem.

P. 9. Taxatio bonorum temporalium religiosorum in Archidiac. Wynton.

Prior de Selebourn habet maneria de

Brondene taxat. ad . . . . $x x x$ s. ii d.

Apud Schete ad . . . . xvii s.

P. Selebourne ad . . . . . vi lib.

In civitate Wynton de reddit . . vi lib. viii ob.

Tannaria sua taxat. ad . . . . x lib. s.

Summa tax. xxxviii lib. xiiii d. ob. Inde decima vi lib. s. q. ob.

\section{LETTER XVII.}

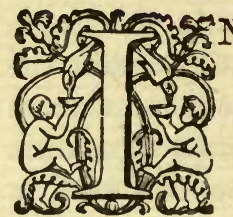

FFORMATION being sent to Rome respecting the havock and spoil that was carrying on among the revenues and lands of the Priory of Selborne, as we may suppose by the Bishop of Winchester, its visitor, Pope Martin, ${ }^{1}$ as soon as the news of these proceedings came before him, issued forth a bull, in which he enjoins his commissary immediately to revoke all the property that had been alienated.

In this instrument his holiness accuses the prior and canons of having granted away (they themselves and their predecessurs) to certain clerks and laymen their tithes, lands, rents, tenements, and possessions, to some of them for their lives, to others for an undue term of years, and to some again for a perpetuity, to the great and heavy detriment of the monastery; and these leases were granted, he continues to add, under their own hands, with the sanction

1 Pope Martin V. chosen about 1417. He attempted to reform the church, but died in 1431 , just as he had summoned the council of Basle. -G. W. 
of an oath and the renunciation of all rights and claims, and under penalties, if the right was not made good. But it will be best to give an abstract from the bull.

N. 298. Pope Martin's bull, touching the revoking of certain things alienated from the Priory of Seleburne. Pontif. sui ann. 1.

"Martinus Eps. servus servorum Dei. Dilecto filıo Priori de Suthvale ${ }^{1}$ Wyntonien. dioc. Salutem \& apostolicam ben. Ad audientiam nostram pervenit quam tam dilecti filii prior et conventus monasterii de Seleburn per Priorem soliti gubernari ordinis $\mathrm{S}^{\mathrm{ti}}$. Augustini Winton. dioc. quam de predecessores eorum decimas, terras, redditus, domos, possessiones, vineas, ${ }^{2}$ et quedam alia bona ad monasterium ipsum spectantia, datis super hoc litteris, interpositis juramentis, factis renuntiationibus, et penis adjectis, in gravem ipsius monasterii lesionem, nonnullis clericis et laicis, aliquibus eorum ad vitam, quibusdam vero ad non modicum tempus, \& aliis perpetuo ad firmam, vel sub censu annuo concesserunt; quorum aliqui dicunt super hiis a sede aplica in communi forma confirmationis litteras impetrasse. Quia vero nostri interest lesis monasteriis subvenire- $\left[\mathrm{He}_{\theta}\right.$ the Pope here commands] -ea ad jus et proprietatem monasterii studeas legitime revocare," \&c.

The conduct of the religious had now for some time been generally bad. Many of the monastic societies, being very opulent, were become voluptuous and licentious, and had deviated entirely from their original institutions. The laity saw with indignation the wealth and possessions of their pious ancestors perverted to the service of sensuality

1 Should have been no doubt Southwick, a priory under Portsdown -G. W.

2 Mr. Barrington is of opinion that anciently the English vinea was in almost every instance an orchard; not perhaps always of apples merely, but of other fruits ; as cherries, plums, and currants. We still say a plum or cherry-orchard.-See Vol. III. of Archæologia.

In the instance abore the pope's secretary might insert vineas merely because they were a species of cultivation familiar to him in Italy.G. W.

Orchard, says Mr. Bennett, is, properly speaking, merely a garden : q. d. wort-yard.-ED. 
and indulgence, and spent in gratifications highly unbecoming the purposes for which they were given. A total disregard to their respective rules and discipline drew on the monks and canons a heavy load of popular odium. Some good men there were who endeavoured to oppose the general delinquency; but their efforts were too feeble to stem the torrent of monastic luxury. As far back as the year 1381 Wickliffo's principles and doctrines had made some progress, were well received by men who wished for a reformation, and were defended and maintained by them as long as they dared; till the bishops and clergy began to be so greatly alarmed, that they procured an act to be passed by which the secular arm was empowered to support the corrupt doctrines of the church; but the first lollard was not burnt till the year 1401 .

The wits also of those times did not spare the gross morals of the clergy, but boldly ridiculed their ignorance and profligacy. The most remarkable of these were Chaucer, and his contemporary, Robert Langelande, better known by the name of Piers Plowman. The laughable tales of the former are familiar to almost every reader; while the visions of the latter are but in few hands. With a quotation from the Passus Decimus of this writer I shall conclude my letter; not only on account of the remarkable prediction therein contained, which carries with it somewhat of the air of a prophecy; but also as it seems to have been a striking picture of monastic insolence and dissipation: and a specimen of one of the keenest pieces of satire now perhaps subsisting in any language, ancient or modern.

"Now is religion a rider, a romer by streate;

A leader of leve-days, and a loud begger;

A pricker on a palfry from maner to maner,

A heape of hounds at his arse, as he a lord were.

And but if his knave kneel, that shall his cope bring,

He loureth at him, and asketh him who taught him curtesie.

Little had lords to done, to give lands from her heirs,

To religious that have no ruth if it rain on her altars.

In many places ther they persons be, by hemself at ease;

Of the poor have they no pity, and that is her charitie;

And they letten hem as lords, her lands lie so broad. 
And there shal come a king, ${ }^{1}$ and confess you religious;

And beate you, as the bible telleth, for breaking your rule,

And amend monials, and monks, and chanons,

And put hem to her penaunce ad pristinum statum ire."

\section{LETTER XVIII.}

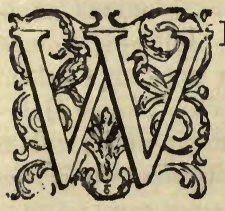

ILLIAM of Waynflete became Bishop of Winchester in the year 1447, and seems to have pursued the generous plan of Wykeham in endeavouring to reform the priory of Selborne.

When Waynflete came to the see he found prior Stype, alias Stepe, still living, who had been elected as long ago as the year 1411 .

Among my documents I find a curious paper of the things put into the custody of Peter Bernes the sacrist, and especially some relics : the title of this evidence is "No. 50. Indentura prioris de Selborne quorundam tradit. Petro Bernes sacristæ, ibidem, ann. Hen. VI. . . . una cum confiss. ejusdem Petri script." 2 The occasion of this cata-

1 F. 1. a. "This prediction, although a probable conclusion concerning a king who after a time would suppress the religious houses, is remarkable. I imagined it was foisted into the copies in the reign of king Heury VIII., but it is in MSS. of this poem, older than the year 1400."

"Again, fol. lxxxv. a. where he, Piers Plowman, alludes to the Knights Templars, lately suppressed, he says,

\section{". . . . . . . Men of holie kirk}

Shall turne as Templars did; the tyme approacheth nere."

"This, I suppose, was a favourite doctrine in Wickliffe's discourses." -Warton's Hist. of English Poetry, vol. i. p. 282.-G. W.

2 (Appendix No. 50.)

Indentura Prioris de Selborne quomindam tradit. Petro Barnes sacrista ibidem ann. Hen. 6. . . una cum confiss. ejusdem Petri script.

HEC indentura facta die lune proxime post ffestum natalium $\overline{\text { Dni }}$ anno regis Honrici sexti post conquestum anglie v...... inter frratrem 
logue, or list of effects, being drawn between the prior and sacrist does not appear, nor the date when; only that it happened in the reign of Hen. VI. This transaction probably took place when Bernes entercd on his office; and

Johannem Stepe priorem ecclesie beate Marie de Selborne \& Petrum Bernes sacrist. ibidem videlicet quod predictus prior deliveravit prefato Petro omnia subscripta. In primis XxIr amit xxxI aubes vid. v. sine parura pro quadragesima $\times$ xII manicui. Item $\mathbf{x} \times 1$ stole Item virr casule vid. II: albe pro quadragesima Item $x \mathbf{x}$ dalmatic. vid. I debit. Item $\mathbf{x v r}$ cape vid. Irr veteres Item unam amittam $\mathbf{I}$ albam cum paruris unum manipulum I stolam I casulam et duas dalmaticas de dono Johannis Combe capellani de Cicestria pro diebus principalibus Item 1 amittam I aubam cum paruris I manipulum I stolam I casulam de dono ffratris Thome Halybone canonicis Item I amittam I aubam cum paruris I manipulum I stolam I casulam pertinentem ad altare sancte Catherine virginis pro priore Item I amittam II aubas cum paruris Ir manipul Ir stolas et Ir casulas pertinentes ad altare sancti Petri de dono patris Ricardi holte. Item de dono ejusdem II tuella vid. I cum fruictello et I canvas pro eodem altare Item I tuellum pendentem ad terram pro quadragesima Item vi tuell cum ffruictibus $\mathbf{x v}$ tuell sine ffruictell. Item $\mathbf{I m} \overline{\text { tuell }}$ pro lavatore Item $\mathbf{v}$ corporas Item Ir ffruictell pro summo altare sine tuellis Item Ir coopertor pro le ceste Item II pallias de sericu debili Item I velum pro quadragesima Item I tapetum viridis coloris pro summo altare II ridell cum IIII ridellis parvis pertinent. ad dict. altare Item vII offretor vid. $\mathbf{v}$ debit. Item IIII vexilla Item IIII pelves III quessones vid. I de serico Item II super altaria Item quinq; calices vid. IIII de auro Item II cruettes de argento de dono dni Johannis Combe capellani de Cicestre Item viII eruettes de peuter Item I coupam argent. et deaur. Item II osculator argent. Item I osculatorium cum osse digiti auricular $S^{t i .}$ Johannis Baptiste Item I crux argent. et deaur. non radicat. Item turribulum argent et deaur. Item I anulum cum saphiro Item I aliud anulum I politum aureum Item I anulum argent. et deauratum $S^{t i .}$ Ellmundi. Item I concha cum pereo infixo Item I cistam argent. et deaur. Item I imaginem beate Marie argent. et deaurat. Item I parvam crucem cum $\checkmark$ reliquiis Item I junctorium $S^{t i .}$ Ricardi Item I tecam pro reliquiis imponend Item I calefactor $S^{t i .}$ Ricardi Item IIII candelabra vid. II de stagno et II de ferro Item I pecten $S^{t i .}$ Ricardi Item II viell de cristall In parte fract Item I pelvim de coper ad lavator Item II osculat. de coper Item I parvum turribulum de latyn Item I vas de coper pro frank et sence consecrand Item I pixidem de juery pro corpore Christi Item II vasa de plumbo pro oleo conservando Item I patellam eneam ferro ligat Item I tripodem ferr. Item I costrēll contum II lagen et I potrell. Item II babyngyres Item II botelles de corio vid. I de quarte et I de pynte Item III anul. arg. et I pixidem $\mathrm{S}^{\text {te }}$ Marie de Waddon Item ( 
there is the more reason to suppose that to be the case, because the list consists of vestments and implements, and relics, such as belonged to the church of the Priory, and fell under the care of the sacrist. I shall just mention the relics, although they are not all specified; and the state of the live stock of the monastery at that juncture.

"Item 2 osculator. argent.

"Item 1 osculatorium cum osse digiti auricular. $-\mathrm{S}^{\text {ti }}$. Johannis Baptistæ. ${ }^{1}$

"Item 1 parvam crucem cum V. reliquiis.

"Item 1 anulum argent. et deauratum St. Edcundi."

"Item 2 osculat. de coper.

"Item 1 junctorium St. Ricardi. ${ }^{3}$

"Item 1 pecten St. Ricardi." 4

The staurum, or live stock, is quite ridiculous, consisting only of " 2 vacce, 1 sus, 4 hoggett. et 4 porcell." viz. two cows, one sow, four porkers, and four pigs.

Instrumenta pro Sandyng Item I ledbynff Item I shasshobe Item I securim Item II scabell. de ferro pro cancell Item I plane Item I cistam sine cerura Item XIIII sonas Item XIX taperes ponder XIII tb et dimid. Item II torches ponder $\mathrm{xx}$ ib Item XII tb cere et dimid. Item de candelis de cera ponder vI fb Item I tb de frankincense Item I lagenam olei Item Ix pondera de plumbo

(Vide de stauro in tergo) et in tergo scribuntur hæc, "II vacce I sus III hoggett et III porcell."-G. W.

1 How the convent came by the bone of the little finger of St. John the Baptist does not appear; probably the founder, while in Palestine, purchased it among the Asiatics, who were at that time great traders in relics. We know from the best authority that as soon as Herod had cruelly beheaded that holy man, "his disciples came and took up the bu'y and buried it, and went and told Jesus."-Matt. xiv. 12.-Farther would be difficult to say.-G. W.

2 November 20, in the calendar, Edmund king and martyr, in the ninth century.-See also a Sanctus Edmundus in Godwin, among the archbishops of Canterbury, in the thirteenth century; his surname Rich, in 1234. -G. W.

3 April 3, ibid. Richard, Bishop of Chichester, in the thirteenth century; his surname De la Wich, in 1245.

Junctorium, perhaps a joint or limb of St. Richard; but what particular joint the religious were not such osteologists as to specify. This barbarous word was not to be found in any dictionary consulted by the anthor.-G. W.

4 "Pecten inter ministeria sacra recensetur, quo scil. sacerdotes as 


\section{LETTER XIX.}

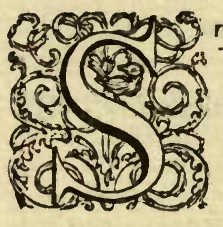

TEPE died towards the end of the year 1453 , as we may suppose pretty far advanced in life, having been prior forty-four years.

On the very day that the vacancy happened, viz. January 26, 1453-4, the sub-prior and convent petitioned the visitor- "vos unicum levamen nostrum et spem unanimiter rogamus, quatinus eligendum ex nobis unum confratrem de gremio nostro, in nostra religione probatum et expertum, licenciam vestram paternalem cum plena libertate nobis concedere dignemini graciose." - Reg. Waynflete, tom. i.

Instead of the license requested we find next a commission "custodie prioratus de Selebourne durante vacatione," addressed to brother Peter Berne, canon-regular of the Priory of Selebourne, and of the order of St. Augustine, appointing him keeper of the said Priory, and empowering him to collect and receive the profits and revenues, and "alia bona" of the said Priory; and to exercise in every respect the full power and authority of a prior; but to be responsible to the visitor finally, and to maintain this superiority during the bishop's pleasure only. This instrument is dated from the bishop's manor-house in Southwark, March 1, 1453-4, and the seventh of his consecration.

After this transaction it does not appear that the chapter of the Priory proceeded to any election : on the contrary, we find that at six months' end from the vacancy the visitor declared that a lapse had taken place; and that.therefore

clerici, antequam in ecclesiam procederent, crines pecterent. E quibus colligitur monachos, tunc temporis, non omnino tonsos fuissi."-Du Fresne.

The anthor remembers to have seen in great farm houses a family comb chained to a post for the use of the hinds when they came in to their meals.-G. W. 
he did confer the priorship on canon Peter Berne.- "Prioratum vacantem et ad nostram collationem seu provisionem, jure ad nos in hac parte per lapsum temporis legitime devoluto spectantem, tibi (sc. P. Berne) de legitimo matrimonio procreato, \&c.-conferimus," \&c. This deed bears date, July 28, 1454.-Reg. Waynflete, tom. i. p. 69.

On February 8, 1462, the visitor issued out a power of sequestration against the Priory of Selborne on account of notorious dilapidations which threatened manifest ruin to the roofs, walls, and edifices of the said convent; and appointing John Hammond, B.D., rector of the parish church of Hetleigh, John Hylling, vicar of the parish church of Newton Valence, and Walter Gorfin, inhabitant of the parish of Selborne, his sequestrators, to exact, collect, levy, and receive, all the profits and revenues of the said convent: he adds "ac ea sub arcto et tuto custodiatis, custodirive faciatis;" as they would answer it to the bishop at their peril.

In consequence of these proceedings prior Berne, on the last day of February, and the next year, produced a state of the revenues of the Priory, No. 381, called "A paper conteyning the value of the manors and lands pertayning to the Priorie of Selborne. 4 Edward III. with a note of charges yssuing out of it." 1

This is a curious document. From circumstances in this

1 (Appendix, No. 381.)

A Paper conteyning the value of the Manors and Lands pertayning to the Priorie of Selborne. iv. Edw. 3. With a note of charges yssuing out of $i t$.

SELEBORNE PRIORATUS.

Suмma totalis valoris maneriorum terrarum tenementorum et premissorum ejusdem Prioratus in ffesto $\mathbf{S}^{\text {ti }}$. Michaelis Archang. anno secundo Regis Edvardi $4^{\mathrm{t}}$. ut patet Rotul. de valoribus liberat.

$$
\text { III vi li. (i. e. Lxxxvi li.) x s. vi d. }
$$

Inde in redditibus resolutis domino pape domino Archiepiscopo et in diversis ffeodis certis personis concessis ac aliis annualibus reprisis in eisdem Rotul. de raloribus annotatis per annum XIII li. xIx s. $v$ d.

Et remanet de claro valore LXXI li $x \mathrm{~s}$. viII $d$. 
paper it is plain that the sequestration produced good effects; for in it are to be found bills of repairs to a considerable amount.

Quatuor canonicis et quatuor ffamulis deo et ecclesie ibid. servientibus pro eorum vadiis vestur. et. diet. ut patet per bill inde fact. per annum $x x x$ li.

Diversis creditoribus pro eorum debitis persolvendis ut patet per parcell inde fact. xv. li. $x v$ s. IIII d.

Reparacionibus Ecclesiarum domorum murorum et clausurarum ejusdem Prioratus per annum xv li, xv s. IrII d.

Annua pencione Domini Prioris et assignata per annum quousque remanet $\mathrm{x}$ li.

\section{SELEBORNE PRIORATUS.}

Modo sequitur de Reformatione premissorum.

Summa total. valorum. ibid. misis et desperatis inde deductis prout patet per declaracionem Dni. Petri Prioris de Seleborne ad man. Dni nostri Wynton apud Palacium suum de Wolsley presentat. per ipsum ultimo die ffebr. Ann. Domini Mccccluxir. et penes ipsum remanet.

LXXI li. x s. vIII d. unde per ipsum Dnum nostrum Wynton assignantur in fforma sequente videlicet.

( Pro quatuor canonicis et quatuor ffamulis deo et ecclesie ibid. servientibus pro eorum $\overline{\text { Diet. vadiis et vestur. ut patet }}$ per bill inde fact.

xxx. li. Pro annua pencione Prioris quousque
remanet.

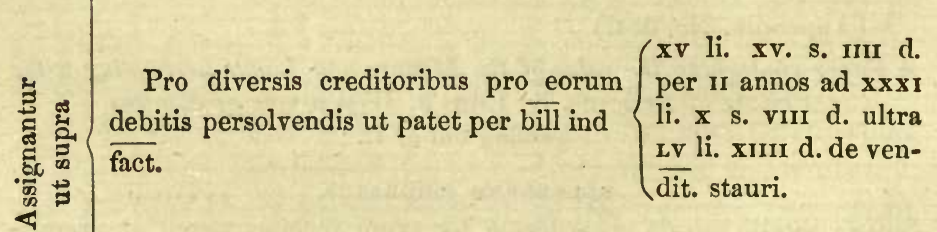

Pro diversis reparacionibus ecclesiarum dcmorum murorum et clausurarum ut patet per bill.

(xv. li. xv. s. IIII d. per II annos ad $\mathbf{x x x I}$ li. $x$ s. vili. d. Sum. ma total. valoris pro debitis et reparacioni. bus assignat. $\operatorname{cum} L \dot{\mathbf{V}}$ li. xuIn d. de vendit. Stauri ut supra cxvir li. II s. vi d. 
By this evidence also it appears that there were at that juncture only four canons at the Priory $;^{1}$ and that these, and their four household servants, during this sequestration, for their clothing, wages, and diet, were allowed per ann. $\mathrm{xxx}$ lib.; and that the annual pension of the lord prior, reside where he would, was to be $x$ lib.

In the year 1468 , prior Berne, probably wearied out by the dissensions and want of order that prevailed in the convent, resigned his priorship into the hands of the bishop.

\section{Reg. WaYNFLete, tom. i. pars $1^{\mathrm{ma}}$, fol. 157. \\ March 28, A.D. 1468.}

"In quadam alta camera juxta magnam portam manerii" of the Bishop of Wynton "de Waltham coram eodem

Debita que debentur ibid. per diversos tenentes et ffirmarios ad festum. $\mathrm{S}^{\text {ti }}$. Michaelis anno tertio Regis Edvardi $4^{\text {ti }}$. ridelicet. Abbas de Derford de feodffirme sua ad Ix li vI s. $\} \times x$ li. vir. s. xI d.
viII d. per annum a retro

Thomas Perkyns armig.ffirmarius Rectorie de Estworlam pro uno anno finiente ad ffestum $\mathrm{S}^{\mathrm{u}}$. Mich. $\}$ IX $\mathbf{s}$.
anno II. Regis Edvardi $4^{\mathrm{ti}}$.

Johannes Shalmere ball. de Selborne debet

Ricardus Cawry debet de eodem anno

LXxv s.

vi s.

Summa xxvirli.viri s.xId.

Thomas Perkyns armig. debet de ffirme sua predicta ad festum $\mathrm{S}^{\text {ti }}$. Mich ann. vir ultra feod. suum $\}$ vir li. vi s. virId. ad xxs. per annum Thomas lussher debet pro ffirme sua ad xu s. per
annum cum feod. suis ad xx s. per annum ann.

Hugo Pakenham debet de reddit. suo ad xx s. per $\}$ c s.

Abbas de Derford debet de ffeod firme sua ultra xx li. vil s. xI d. ut supra pro annis III. IIII. et v. $\}$ xxvin li.
Regis Edvardi

Walterus Berlond ffirmarius de Shene debet

Henr. Shafter firmarius ffeod de Basynstoke Henr.lode nuper ffirmarius manerii de Chede debet $\mathrm{xx}$ li.

Ix li. v s. II d. XII li. IIII d.

Summa Lxvi li: xII s. vi d.

\section{Total LXxxxiv li. xII d.}

1 If Bishop Wykeham was so disturbed (see Notab. Visitatio) to find the number of canons reduced from fourteen to eleven, what would he have said to have seen it diminished below one third of that number? -G. W. 
rev. patre ibidem tunc sedente," Peter Berne, prior of Selborne, "ipsum prioratum in sacras et venerabiles manus," of the bishop, "viva voce libere resignavit :" and his resig-" nation was admitted before two witnesses and a notary public. In consequence, March 29th, before the bishop, in "capella manerii sui ante dicti pro tribunali sedente, comparuerunt fratres" Peter Berne, Thomas London, William Wyndesor, and William Paynell, alias Stretford, canons regular of the Priory, "capitulum, et conventum ejusdem ecclesie facientes; ac jus et voces in electione futura prioris dicti prioratus solum et in solidum, ut asseruerunt, habentes;" and after the bishop had notified to them the vacancy of a prior, with his free license to elect, deliberated awhile, and then, by way of compromise, as they affirmed, unanimously transferred their right of election to the bishop before witnesses. In consequence of this the bishop, after full deliberation, proceeded, April 7th, " in capella manerii sui de Waltham," to the election of a prior; " et fratrem Johannem Morton, priorem ecclesie conventualis de Reygate dicti ordinis $\mathrm{S}^{\text {ti }}$. Augustini Wynton. dioc. in priorem vice et nomine omnium et singulorum canonicorum predictorum elegit, in ordine sacerdotali, et etate licita constitutum, \&c." And on the same day, in the same place, before the same witnesses, John Morton resigned to the bishop the priorship of Reygate viva voce. The bishop then required his consent to his own election; "qui licet in parte renitens tanti reverendi patris se confirmans," obeyed, and signified his consent oraculo vive vocis. Then was there a mandate citing any one who would gainsay the said election to appear before the bishop or his commissary in his chapel at Farnham on the 2nd day of May next. The dean of the deanery of Aulton then appeared before the chancellor, his commissary, and returned the citation or mandate dated April 22nd, 1468, with signification, in writing, of his having published it as required, dated Newton Valence, May 1st, 1468. This certificate being read, the four canors of Selborne appeared and required the election to be confirmed; et ex super abundanti appointed William Long their proctor to solicit in their name that he might be canonically confirmed. John Morton 
also appeared, and proclamation was made; and no one appearing against him, the commissary pronounced all absentees contumacious, and precluded them from objecting at any other time; and, at the instance of John Morton and the proctor, confirmed the election by his decree, and directed his mandate to the rector of Hedley and the vicar of Newton Valence to install him in the usual form.

Thus, for the first time, was a person, a stranger to the convent of Selborne, and never canon of that monastery, elected prior: though the style of the petitions in former elections used to run thus, - "Vos .... rogamus quatinus eligendum ex nobis unum confratrem de gremio nostro,licentiam vestram-nobis concedere dignemini."

\section{LETTER XX.}

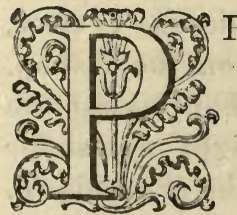

RIOR MORTON dying in 1471, two canons, by themselves, proceeded to election, and chose a prior; but two more (one of them Berne) complaining of not being summoned, objected to the proceedings as informal ; till at last the matter was compromised that the bishop should again, for that turn, nominate as he had before. But the circumstances of this election will be best explained by the following extract:

\section{REG. WAYNFLETE, tom. ii. pars $1^{\mathrm{ma}}$, fol. 7 .}

Memorandum. A.D. 1471. August 22.

William Wyndesor, a canon-regular of the Priory of Selborne, having been elected prior on the death of brother John, appeared in person before the bishop in his chapel at South Waltham. He was attended on this occasion by Thomas London and John Bromesgrove, canons, who had elected him. Peter Berne and William Stratfeld, canons, also presented themselves at the same time, complaining that in this business they had been overlooked, and not 
summoned; and that therefore the validity of the election might with reason be called in question, and quarrels and dissensions might probably arise between the newly chosen prior and the parties thus neglected.

After some altercation and dispute they all came to an agreement with the new prior, that what had been done should be rejected and annulled; and that they would again, for this turn, transfer to the bishop their power to elect, arder, and provide them another prior, whom they promised unanimously to admit.

The bishop accepted of this offer before witnesses; and on September 27, in an inner chamber near the chapel above-mentioned, after full deliberation, chose brother Thomas Fairwise, vicar of Somborne, a canon-regular of St. Augustine in the Priory of Bruscough, in the diocese of Coventry and Litchfield, to be prior of Selborne. The form is nearly as above in the last election. The canons are again enumerated; W. Wyndesor, sub-prior, P. Berne, T. London, W. Stratfeld, J. Bromesgrove, who had formed the chapter, and had requested and obtained license to elect, but had unanimously conferred their power on the bishop. In consequence of this proceeding, the bishop taking the business upon himself that the Priory might not suffer detriment for want of a governor, appoints the aforesaid $T$. Fairwise to be prior. A citation was ordered as above for gainsayers to appear October 4th, before the bishop or his commissaries at South Waltham; but none appearing, the commissaries admitted the said Thomas, ordered him to be installed, and sent the usual letter to the convent to render him due obedience.

Thus did the Bishop of Winchester a second time appoint a stranger to be prior of Selborne, instead of one chosen out of the chapter. For this seeming irregularity the visiter had no doubt good and sufficicnt reasons, as probably may appear hereaftcr. 


\section{OH SELBORNF.}

\section{LETTER XXI.}

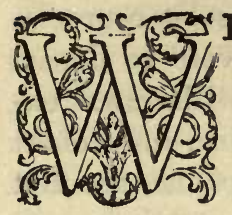

HATEVER might have been the abilities and disposition of prior Fairwise, it conld not have been in his power to have brought about any material reformation in the Priory of Selborne, because he departed this life in the month of August, 1472, before he had presided one twelvemonth.

As soon as their governor was buried, the chapter applied to their visiter for leave to choose a new prior, which being granted, after deliberating for a time, they proceeded to an election by a scrutiny. But as this mode of voting has not been described but by the mere form given in a note, an extract from the bishop's register, representing the manner more fully, may not be disagreeable to several readers.

ReG. WAYNFLETE, tom. ii. pars $1^{\mathrm{ma}}$, fol. 15 .

"Reverendo, \&c. ac nostro patrono graciocissimo vestri humiles, et devote obedientio filii," \&c.

To the right reverend Father in God, and our most gracious patron, we, your obedient and devoted sons, William Wyndesor, president of the chapter of the Priory of Selborne, and the convent of that place, do make known to your lordship, that our priorship being lately vacant by the death of Thomas Fairwise, our late prior, who died August 11th, 1472, having committed his body to decent sepulture, and having requested, according to custom, leave to elect another, and having obtained it under your seal, we William Wyndesor, president of the convent, on the 29th of August, in our chapter-house assembled, and making a chapter, taking to us in this business Richard ap Jenkyn, and Galfrid Bryan, chaplains, that our said Priory might not by means of this vacancy incur harm or loss, unanimously agreed on August the last for the day of election; on which day, having first celebrated mass, "De sancto spiritu," at the high altar, and having called a chapter by tolling a bell about ten o' the clock, we, William Wyndesor, president, Peter Berne, Thomas London, 
and William Stratfeld, canons, who alone had roices, being the only canons, about ten o' the clock, first sung "Veni Creator," the letters and license being read in the presence of many persons there. Then William Wyndesor, in his own name, and that of all the canons, made solemn proclamation, enjoining all who had no right to vote to depart out of the chapter-house. When all were withdrawn except Guyllery de Lacuna, in decretis Baccalarius, and Robert Peverell, notary-public, and also the two chaplains, the first was requested to stay, that he might direct and inform us in the mode of election; the other, that he might record and attest the transactions; and the two last that they might be witnesses to them.

Then, having read the constitution of the general council, "Quia propter," and the forms of elections contained in it being sufficiently explained to them by De Lacuna, as well in Latin as the vulgar tongue, and having deliberated in what mode to proceed in this election, they resolved on that of scrutiny. Three of the canons, Wyndesor, Berne, and London, were made scrutators: Berne, London, and Stratfeld, choosing Wyndesor; Wyndesor, London, and Stratfeld, choosing Berne; Wyndesor, Berno, and Stratfeld, choosing: London.

They were empowered to take each other's vote, and then that of Stratfeld: " et ad inferiorem partem angularem" of the chapter-house, "juxta ostium ejusdem declinentes," with the other persons (except Stratfeld, who stayed behind), proceeded to voting, two swearing, and taking the voice of the third, in succession, privately. Wyndesor voted first: "Ego credo Petrum Berne meliorem et utiliorem ad regimen istius ecclesie, et in ipsum consentio, ac eum nomino," \&c. Berne was next sworn, and in like manner nominated Wyndesor; London nominated Berne: Stratfeld was then called and sworn, and nominated Berne.

"Quibus in scriptis redactis," by the notary-public, they returned to the upper part of the chapter-house, where by Wyndesor "sic peracta fecerunt in communi," and then solemnly, in form written, declared the election of Berne: when all, " antedicto nostro electo excepto, approbantes et ratificantes, cepimus decantare solemniter 'Te Deum Lau- 
damns,' et sic canentes dictum electum ad majus altare ecclesie deduximus, ut apud nos est moris." Then "Wyndesor electionem clero et populo infra chorum dicte ecclesie congregatis publicavit, et personam electi publico et personaliter ostendit." We then roturned to the chapter-house, except our prior; and Wyndesor was appointed by the other two their proctor, to desire the assent of the elected, and to notify what had been done to the bishop; and to desire him to confirm the election, and do whatever else was necessary. Then their proctor, before the witnesses, required Berne's assent in the chapter-house: "qui quidem instanciis et precibus multiplicatis devictus," consented, " licet indignus electus," in writing. They therefore requested the bishop's confirmation of their election "sic canonice et solemniter celebrata," \&c. \&c. Sealed with their common seal, and subscribed and attested by the notary. Dat. in the chapter-house, September 5th, 1472.

In consequence, September 11th, 1472, in the bishop's chapel at Esher, and before the bishop's commissary, appeared W. Wyndesor, and exhibited the above instrument, and a mandate from the bishop for the appearance of gainsayers of the election there on that day:-and no one appearing, the absentees were declared contumacious; and the election confirmed; and the vicar of Aulton was directed to induct and install the prior in the usual manner.

Thus did canon Berne, though advanced in years, reassume his abdicated priorship for the second time, to the no small satisfaction, as it may seem, of the Bishop of Winchester, who professed, as will be shown not long hence, a high opinion of his abilities and integrity.

\section{LETTER XXII.}

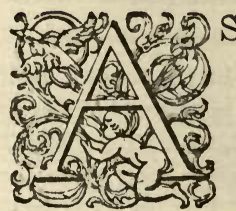

prior Berne, when chosen in 1454, held his priorship only to 1468 , and then made a voluntary resignation, wearied and disgusted, as we may conclude, by the disorder that prevailed in his convent; it is no matter of wonder that, when re-chosen in 1472 , he should not long. 
maintain his station; as old age was then coming fast upon him, and the increasing anarchy and misrule of that declining institution required unusual vigour and resolution to stem that torrent of profligacy which was hurrying it on to its dissolution. We find, accordingly, that in 1478 he resigned his dignity again into the hands of the bishop.

\section{REG. WAYNFLETE. FOL. 55.}

May 14, 1478. Peter Berne resigned the priorship. May 16, the bishop admitted his resignation " in manerio suo de Waltham," and declared the priorship void; "et priorat. solacio destitutum esse;" and granted his letters for proceeding to a new election: when all the religious, assembled in the chapter-house, did transfer their power under their seal to the bishop by the following public instrument.

"In Dei nomine Amen," \&c. A.D. 1478, Maii 19. In the chapter-house for the election of a prior for that day, on the free resignation of Peter Berne, having celebrated in the first place mass at the high altar "De spiritu sancto," and having called a chapter by tolling a bell, ut moris est; in the presence of a notary and witnesses appeared personally Peter Berne, Thomas Ashford, Stephen Clydgrove and John Ashton, presbyters, and Henry Canwood, ${ }^{1}$ in chapter assembled; and after singing the hymn "Veni Creator Spiritus," "cum versiculo et oratione 'Deus qui corda;' declarataque licentia Fundatoris et patroni futurum priorem eligendi concessa, et constitutione consilii generalis que incipit 'Quia propter' declaratis ; viisque per quas possent ad hanc electionem procedere," by the decretorum doctorem, whom the canons had taken to direct them-they all and every one "dixerunt et affirmarunt se nolle ad aliquam viam procedere:" - but, for this turn only, renounced their

1 Here we see that all the canons were changed in six years; and that there was quite a new chapter, Berne excepted, between 1472 and 1478; for, instead of Wyndesor, London, and Stratfeld, we find Ashford, Clydgrove, Ashton, and Canwood, all new men, who were soon gone in their turn off the stage, and are heard of no more. For, in six years after, there seem to have been no canons at all.-G. W. 
right, and unanimously transferred their power to the bishop, the ordinary of the place, promising to receive whom he should provide; and appointed a proctor to present the instrument to the bishop under their seal; and required their notary to draw it up in due form, \&c., subscribed by the notary.

After the visiter had fully deliberated on the matter, he proceeded to the choice of a prior, and elected, by the following instrument, John Sharp, alias Glastenbury.

\section{Fol. 56. Provisio Prioris per $\overline{\mathrm{Epm}}$.}

Willmus, \&c. to our beloved brother in CHRIST, John Sharp, alias Glastenbury, Ecclesie conventualis de Bruton, of the order of St. Austin, in the diocese of Bath and Wells, canon-regular, salutem, \&c. "De tue circumspectionis industria plurimum confidentes, te virum providum et discretum, literarum scientia, et moribus merito commendandum, \&c." - do appoint you prior - under our seal. " Dat. in manerio nostro de Suthwaltham, May 20,1478, et nostre Consec. 31."

Thus did the bishop, three times out of the four that he was at liberty to nominate, appoint a prior from a distance, a stranger to the place, to govern the convent of Selborne, hoping by this method to have broken the cabal, and to have interrupted that habit of mismanagement that had pervaded the society: but he acknowledges, in an evidence lying before us, that he never did succeed to his wishes with respect to those late governors, - "quos tamen male se habuisse, et inutiliter administrare, et administrasse usque ad presentia tempora post debitam investigationem, \&c. invenit." The only time that he appointed from among the canons, he made choice of Peter Berne, for whom he had conceived the greatest esteem and regard.

When prior Berne first relinquished his priorship, he returned again to his former condition of canon, in which he continued for some years; but when he was re-chosen, and had abdicated a second time, we finc him in a forlorn state, and in danger of being reduced to beggary, had not the Bishop of Winchester interposed in his favour, and with great humanity insisted on a provision for him for life 
The reason for this difference seems to have been, that, in the first case, though in years, he might have been hale and capable of taking his share in the duty of the convent; in the second, he was broken with age, and no longer equal to the functions of a canon.

Impressed with this idea the bishop very benevolently interceded in his favour, and laid his injunctions on the new elected prior in the following manner.

Fol. 56. "In Dei nomine Amen. Nos Willmus, \&c. considerantes Petrum Berne," late prior "in administratione spiritualium et temporalium prioratus laudabiliter vixisse et rexisse; ipsumque senio et corporis debilitate confractum; ne in opprobrium religionis mendicari cogatur;-eidem annuam pensionem a Domino Johanne Sharp, alias Glastonbury, priore moderno," and his successors, and, from the Priory or church, to be paid every year during his life, "de voluntate et ex consensu expressis" of the said John Sharp, "sub ea que sequitur forma verborum-assignamus:"

1st. That the said prior and his successors, for the time being, honeste exhibebunt of the fruits and profits of the priorship, "eidem esculenta et potulenta," while he remained in the Priory, "sub consimili portione eorundem prout convenienter priori," for the time being, ministrari contigerit; and in lile manner uni famulo, whom he should choose to wait on him, as to the servientibus of the prior.

Item. "Invenient seu exhibebunt eidem unam honestam cameram" in the Priory, "cum focalibus necessariis seu opportunis ad eundem."

Item. We will, ordain, \&c. to the said P. Berne an annual pension of ten marks, from the revenue of the Priory, to be paid by the hands of the prior quarterly.

The bishop decrees farther, that John Sharp, and hi successors, shall take an oath to observe this injunction, and that before their installation.

"Lecta et facta sunt hæc in quodam alto oratorio," belonging to the bishop at Suthwaltham, May 25, 1478, in the presence of John Sharp, who gave his assent, and then took the oath before witnesses, with the other oaths before the chancellor, who decreed he should be inducted and installed; as was done that same day. 
How John Sharp, alias Glastonbury, acquitted himself in his priorship, and in what manner he made a vacancy, whether by resignation, or death, or whether he was removed by the visiter, does not appear : we only find that some time in the year 1484 there was no prior, and that the bishop nominated canon Ashford to fill the vacancy.

\section{LETTER XXIII.}

Orenteras HIS Thomas Ashford was most undoubtedly

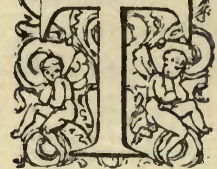
the last prior of Selborne; and therefore here will be the proper place to say something concerning a list of the priors, and to endeavour to improve that already given by others.

At the end of Bishop Tanner's Notitia Monastica, the folio edition, among Brown Willis's Principals of Religious Houses, occur the names of eleven of the priors of Selborne, with dates. But this list is imperfect, and particularly at the beginning; for though the Priory was founded in 1232, yet it commences with Nich. de Cantia, elected in 1262 ; so that for the first thirty years no prior is mentioned; yet there must have been one or more. We were in hopes that the register of Peter de Rupibus would have rectified this omission; but, when it was examined, no information of the sort was to be found. From the year 1410 the list is much corrected and improved; and the reader may depend on its being thenceforward very exact.

A List of the Priors of Selborne Priory, from Brown Willis's Principals of Religious Houses, with additions within [ ] by the Author.

[John —— was prior, sine dat. $\left.{ }^{1}\right]$

Nich. de Cantia. el. . • . • . . 1262.

1 See, in Letter XI. of these Antiquities, the reason why prior John - - who had transactions with the Knights Templars, is placed in the list before the year 1262.-G. W. 
[Peter - was prior in . . . . . 1 1271.]

[Richard — was prior in . . . . . 1280.]

Will. Basing was prior in . . . . . . 1299.

Walter de Insula el. in . . . . . . . 1324.

[Some difficulties, and a devolution; but the election confirmed by Bishop Stratford.]

John de Wintōn . • . . . . . . . 1339.

Thomas Weston . . . . . . . . . 1377.

John Winchester [Wynchestre] • . . . . 1410.

[Elected by Bishop Beaufort "per viam vel formam simplicis compromissi.']

[John Stype, alias Stepe, in . . . . . . 1411.]

Peter Bene [alias Berne or Bernes, appointed keeper, and, by lapse to Bishop Wayneflete, prior] in . . . . . . . . . 1454.

[He resigns in 1468.]

John Morton [Prior of Reygate] in . . . 1468.

[The canons by compromise transfer the power of election to the bishop.]

Will. Winsor [Wyndesor, prior for a few days] 1471.

[but removed on account of an irrogular election.]

Thomas Farwill [Fairwise, vicar of Somborne] 1471.

[by compromise again elected by the bishop.]

[Peter Berne, re-elected by scrutiny in . . . 1472.]

[resigns again in 1478.]

John Sharper [Sharp] alias Glastonbury

1478.

[Canon-reg. of Bruton, elected by the bishop by compromise.]

[Thomas Ashford, canon of Selborne, last prior elected by the Bishop of Winchester, some time in the year and deposed at the dissolution.]

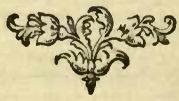




\section{LETTER XXIV.}

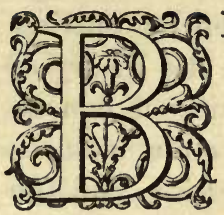

ISHOP WAYNFLETE'S efforts to continue the Priory still proved unsuccessful; and the convent, without any canons, and for some time without a prior, was tending swiftly to its dissolution.

When Sharp's, alias Glastonbury's, priorship ended does not appear. The bishop says that he had been obliged to remove some priors for mal-administration; but it is not well explained how that could be the case with any, unless with Sharp; because all the others, chosen during his episcopate, died in their office, viz. Morton and Fairwise; Bern $\theta$ only excepted, who relinquished twice voluntarily, and was moreover approved of by Waynflete as a person of integrity. But the way to show what ineffectual pains the bishop took, and what difficulties he met with, will be to quote the words of the libel of his proctor Radulphus Langley, who appeared for the bishop in the process of the impropriation of the Priory of Selborne. The extract is taken from an attested copy.

"Item-that the said bishop-dicto prioratui et personis ejusdem pie compatiens, sollicitudines pastorales, labores, et diligentias gravissimas quam plurimas, tam per se quam per suos, pro reformatione premissorum impendebat; et aliquando illius loci prioribus, propter malam et inutilem administrationem, et dispensationem bonorum predicti prioratus, suis demeritis exigentibus, amotis ; alios priores in quorum circumspectione et diligentia confidebat, prefecit; quos tamen male se habuisse ac inutiliter administrare, et administrasse, usque ad presentia tempora post debitam investigationem, \&c. invenit." So that he despaired, with all his care,- "statum ejusdem reparare vel restaurare; et considerata temporis malicia, et preteritis timendo, et conjecturando futura de aliqua bona et sancta religione ejusdem 
ordinis, \&c. juxta piam intentionem primevi fundatoris ibidem habend, desperatur."

William Wainfleet, Bishop of Winchester, founded his college of St. Mary Magdalen, in the university of Oxford, in or about the year 1459 ; but the revenues proving insufficient for so large and noble an establishment, the college supplicated the founder to augment its income by putting it in possession of the estates belonging to the Priory of Selborne, now become a deserted convent, without canons or prior. The president and fellows state the circumstances of their numerous institution and scanty provision, and the ruinous and perverted condition of the Priory. The bishop appoints commissaries to inquire into the state of the said monastery; and, if found expedient, to confirm the appropriation of it to the college, which soon after appoints attorneys to take possession, September 24, 1484. But the way to give the reader a thorough insight respecting this transaction will be to transcribe a farther proportion of the process of the impropriation from the beginning, which will lay open the manner of proceeding, and show the consent of the parties.

\section{IMPROPRIATIO SELBORNE, 1485.}

"Universis sancte matris ecclesie filiis, \&c. Ricardus Dei gratia prior ecclesie conventualis de Novo Loco, \&c. ${ }^{1}$ ad universitatem vestre notitie deducimus, \&c. quod coram nobis commissario predicto in ecclesia parochiali $\mathrm{S}^{\text {ti }}$. Georgii de Essher, dict. Winton. dioc. $3^{\circ}$. die Augusti, A.D. 1485, indictione tertia pontificat. Innocentii $8^{\mathrm{vi}}$. ann. $]^{\mathrm{mo}}$.judicialiter comparuit venerabilis vir Jacobus Preston, S. T. P.

1 Ecclesia Conventualis de Noro Loco was the monastery afterwards ealled the New Minster, or Abbey of Hyde, in the city of Winchester. Should any intelligent reader wonder to see that the prior of Hyde Abbey was commissary to the Bishop of Winton, and should conclude that there was a mistake in titles, and that the abbot must have been here meant; he will be pleased to recollect that this person was the second in rank; for, " next under the abbnt, in every abbey, was the prior."-Pref. to Notit. Monast., p. xxix. Besides, abbots were great personages, and too high in station to submit to any office under the bishop.-G. W. 
infrascriptus, et exhibuit literas commissionis - quas quidem per magistrum Thomam Somercotes notarium publicum, \&c. legi fecimus, tenorem sequentem in se continentes." The same as No. 103, but dated- "In manerio nostro de Essher, Augusti $1^{\mathrm{mo}}$. A.D. 1485, et nostre consec. anno 39." [No. 103 is repeated in a book containing the like process in the preceding year by the same commissary, in the parish church of St. Andrew the apostle, at Farnham, Sept. 6th, anno 1481.] "Post quarum literarum lecturam-dictus magister Jacobus Preston, quasdam procuratorias literas mag. Richardi Mayewe presidentis, ut asseruit, collegii beate Marie Magdalene, \&c. sigillo rotundo communi, \&c. in cera rubea impresso sigillatas realiter exhibuit, \&c. et pro eisdem $\overline{d n i s ~ s u i s, ~ \& c . ~ f e c i t ~ s e ~ p a r t e m, ~ a c ~ n o b i s ~ s u p p l i-~}$ cavit ut juxta formam in eisdem traditam procedere dignaremur, \&c." After these proclamations no contradictor or objector appearing - " ad instantem petitionem ipsius mag. Jac. Preston, procuratoris, \&c. procedendum fore decrevimus vocatis jure vocandis; nec non mag. Tho. Somercotes, \&c. in actorum nostrorum scribam nominavimus. Consequenter et ibidem tunc comparuit magister Michael Clyff, \&c. et exhibuit in ea parte procuratorium suum," for the prior and convent of the cathedral of Winton, "et fecit se partem pro eisdem.-Deinde comparuit coram nobis, \&.c. honestus vir Willmus Cowper," proctor for the bishop as patron of the Priory of Selborne, and exhibited his "procuratorium, \&c." After these were read in the presence of Clyff and Cowper, "Preston, viva voce," petitioned the commissary to annex and appropriate the Priory of Selborne to the college-" propter quod fructus, redditus, et proventus ejusdem coll. adẹo tenues sunt et exiles, quod ad sustentationem ejus, \&c. non sufficiunt."-The commissary, "ad libellandum et articulandum in scriptis"-adjourned the court to the 5th of August, then to be held again in the parish church of Essher.

W. Cowper being then absent, Radulphus Langley appeared for the bishop, and was admitted his proctor. Preston produced his libel or article "in scriptis" for the union, \&c. " et admitti petiit eundem cum effectu; cujus libelli tenor 
sequitur.-In Dei nomine, Amen. Coram nobis venerabil in Christo patre Richardo, priore, \&c. de Novo Loco, \&c. commissario, \&c." On the part of the college of Magd. dicit, allegat, and in his "scriptis proponit, \&c."

"Imprimis-that said college consists of a president and eighty scholars, besides sixteen choristers, thirteen servientes inibi altissimo famulantibus, et in scientiis plerisque liberalibus, presertim in sacra theologia studentibus, nedum ad ipsorum presidentis et scholarium pro presenti et imposterum, annuente deo, incorporandorum in eodem relevamen; verum etiam ad omnium et singulorum tam scholarium quam religiosorum cujuscunque ordinis undequaque illuc confluere pro salubri doctrina volentium utilitatem multiplicem, ad incrementa virtutis fideique catholice stabilimentum. Ita videlicet quod omnes et singuli absque personarum seu nationum delectu illuc accedere volentes, lecturas publicas et doctrinas tam in grammatica, loco ad collegium contiguo, ac philosophiis morali et naturali, quam in sacra theologia in eodem collegio perpetuis temporibus continuandas libere atque gratis audire valeant et possint, ad laudern gloriam et honorem Dei, \&c. extitit fundatum et stabilitum."

For the first item in this process see the beginning of this letter. Then follows item the second - "that the revenues of the college non sufficiunt his diebus." "Item - that the premisses are true, \&c. ut super eisdem laborarunt, et laborant publica vox et fama. Unde facta fide petit pars eorundem that the Priory be annexed to the college: ita quod dicto prioratu vacante liceat iis ex tunc to take possession, \&c." This libel, with the express consent of the other proctors, we, the commissary, admitted, and appointed the 6th of August for Preston to prove the premisses.

Preston produced witnesses, W. Gyfford, S. T. P., John Nele, A. M., John Chapman, chaplain, and Robert Baron, literatus, who were admitted and sworn, when the court was prorogued to the 6 th of August; and the witnesses, on the same 6th of August, were examined by the commissary, "in capella infra manerium de Essher situata, secrete et singillatim." Then follow the "literæ procuratoriæ:" first 
that of the college, appointing Preston and Langport their proctors, dated August 30th, 1484; then that of the prior and convent of the cathedral of Winton, appointing David Husband and Michael Cleve, dated September 4th, 1484; then that of the bishop, appointing W. Gyfford, Radulphus Langley, and Will. Cowper, dated September 3rd, 1484. Consec. $38^{\circ}$. - Quo die adveniente, in dicta ecclesia parochiali, appeared "coram nobis" James Preston to prove the contents of his libel, and exhibited some letters testimonial with the seal of the bishop, and these were admitted; and consequenter Preston produced two witnesses, viz. Dominum Thomam Ashforde nuper priorem dicti prioratus, et Willm. Rabbys literatum, who were admitted and sworn, and examined as the others, by the commissary; "tunc \& ibidem assistente scriba secrete \& singillatim;" and their depositions were read and made public, as follows:

Mr. W. Gyfford, S. T. P., aged 57, of the state of Magd. Coll. \&c. \&c. as before:

Mr. John Nele, aged 57, proves the articles also:

Robert Baron, aged 56 :

Johannes Chapman, aged 35, also affirmed all the five articles :

Dompnus Thomas Ashforde, aged 72 years-"dicit $2^{\text {dum }} 3^{\mathrm{um}} 4^{\mathrm{um}}$ articulos in eodem libello contentos, concernentes statum dicti prioratus de Selebourne, fuisse et esse veros."

W. Rabbys, ætat 40 ann. agrees with Gyfford, \&c.

Then follows the letter from the bishop, "in subsidium probationis," abovementioned- " Willmus, \&c. salutem, \&c. noverint universitas véstra, quod licet nos prioratui de Selebourne, \&c. pie compacientes sollicitudines pastorales, labores, diligentias quamplurimas per nos \& commissarios nostros pro reformatione status ejus impenderimus, justicia id poscente; nihilominus tamen," \&c. as in the article-to "desperatur," dated "in manerio nostro de Essher, Aug. 3d, 1485, \& consec. 39." Then, on the 6th of August, Preston, in the presence of the other proctors, required that they should be compelled to answer; when they all allowed 
the articles "fuisse \& esse vera ;" and the commissary, at the request of Preston, concluded the business, and appointed Monday, August 8th, for giving his decree in the same church of Essher; and it was that day read, and contains a recapitulation, with the sentence of union, \&c., witnessed and attested.

As soon as the president and fellows of Magdalen College had obtained the decision of the commissary in their favour, they proceeded to supplicate the pope, and to entreat his holiness that he would give his sanction to the sentence of union. Some difficulties were started at Rome; but they were surmounted by the college agent, as appears by his letters from that city. At length Pope Innocent VIII. by a bull ${ }^{1}$ bearing date the 8 th day of June, in the year of our Lord 1486, and in the second year of his pontificate, confirmed what had been done, and suppressed the convent.

Thus fell the considerable and well-endowed Priory of Selborne, after it had subsisted about two hundred and fifty-four years; about seventy-four years after the suppression of Priories alien by Henry V., and about fifty years before the general dissolution of monasteries by Henry VIII. The founder, it is probable, had fondly imagined that the sacredness of the institution, and the pious motives on which it was established, might have preserved it inviolate to the end of time-yet it fell,

"To teach us that God attributes to place

No sanctity, if none be thither brought

By men, who there frequent, or therein dwell."

Mruton's "Paradise Lost."

1 There is nothing remarkable in this bull of Pope Innocent except the statement of the annual revenue of the Priory of Selborne, which is therein estimated at 160 flor. auri; whereas Bishop Godwin sets it at $£ 337$ 15s. $6 \frac{1}{4} d$. Now a floren, so named, says Camden, because made by Florentines, was a gold coin of King Edward III. in value 6s., whereof 160 is not one-seventh part of $£ 33715$ s. $6 \frac{1}{8} d-G$. W. 


\section{LETTER XXV.}

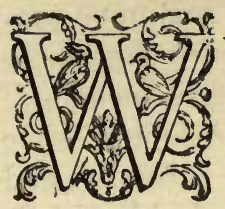

AINFLEET did not long enjoy the satisfaction arising from this new acquisition; but departed this life in a few months after he had effected the union of the Priory with his late founded college; and was succeeded in the see of Winchester by Peter Courtney, some time towards the end of the year 1486 .

In the beginning of the following year the new bishop released the president and fellows of Magdalen College from all actions respecting the Priory of Selborne; and the prior and convent of St. Swithun, as the chapter of Winchester cathedral, confirmed the release. ${ }^{1}$

N. 293. "Relaxatio Petri epi Wintōn Ricardo Mayow Presidenti, omnium actionum occasione indempnitatis sibi debite pro unione Prioratus de Selborne dicto collegio. Jan. 2. 1487. et translat. anno $1^{\circ}$."

N. 374. "Relaxatio prioris et conventus $\mathrm{S}^{\text {ti }}$. Swithini Wintōn confirmans relaxationem Petri ep. Winton." 1487. Jan. 13.

Ashforde, the deposed prior, who had appeared as an evidence for the impropriation of the Priory at the age of seventy-two years, that he might not be destitute of a maintenance, was pensioned by tho college to the day of his death; and was living on till 1490, as appears by his acquittances.

REG. A. ff. 46.

"Omnibus Christi fidelibus ad quos presens scriptum pervenerit, Richardus Mayew, presidens, \&c. et scolares, salutem in Domino."

"Noveritis nos prefatos presidentem et scolares dedisse,

1 The Bishops of Winchester were patrons of the Priory.-G. W. 
concessisse, et hoc presenti scripto confirmasse Thome Ashforde, capellano, quendam annualem redditum sex librarum tresdecim solidorum et quatuor denariorum bone et legalis monete Anglie-ad terminum vite prefati Thome" - to be paid from the possessions of the college in Basingstoke."In cujus rei testimonium sigillum nostrum commune presentibus apponimus. Dat. Oxon. in coll. nostro supradicto primo die mensis Junii anno regis Ricardi tertii secundo," viz. 1484. The college, in their grant to Ashforde, style him only capellanus; but the annuitant very naturally, and with a becoming dignity, asserts his late title in his acquittances, and identifies himself by the addition of nuper priorem, or late prior.

As, according to the persuasion of the times, the depriving the founder and benefactors of the Priory of their masses and services would have been deemed the most impious of frauds, Bishop Wainfleet, having by statute ordained four obits for himself to be celebrated in the chapel of Magdalen College, enjoined in one of them a special collect for the anniversary of Peter de Rupibus, with a particular prayer-"Deus Indulgentiarum."

The college also sent Nicholas Langrish, who had been a chantry priest at Selborne, to celebrate mass for the souls of all that had been benefactors to the said Priory and college, and for all the faithful who had departed this life.

N.356. Thomas Knowles, presidens, \&c._ "damus et concedimus Nicholao Langrish quandam capellaniam, vel salarium, sive alio quocunque nomine censeatur, in prioratu quondam de Selborne pro termino 40 annorum, si tam diu vixerit. Ubi dictus magr ${ }^{\mathrm{r}}$. Nicholaus celebrabit pro animabus omnium benefactorum dicti prioratus et coll. nostri, et omnium fidelium defunctorum, \&c. Insuper nos, \&c. concedimus eidem ibidem celebranti in sustentationem suam quandam annualem pensionem sive annuitatem octo librarum, \&c. - in dicta capella dicti prioratus-concedimus duas cameras contiguas ex parte boreali dicte capelle, cum una coquina, et cum uno stabulo conveniente pro tribus equis, cum pomerio eidem adjacente voc. le Orcheyard-Preterea 
26s. 8d. per ann. ad inveniendum unum clericum ad serviendum sibi ad altare, et aliis negotiis necessariis ejus."His wood to be granted him by the president on the progress.-He was not to absent himself beyond a certain time; and was to superintend the coppices, wood, and hedges.“Dat. $5^{\text {to }}$. die Julii. an ${ }^{\circ}$. Hen. VIII ${ }^{\text {vi }}$. 36"." [viz. 1546.]

Here we see the Priory in a new light, reduced as it were to the state of a chantry, without prior and without canons, and attended only by a priest, who was also a sort of bailiff or woodman, his assistant clerk, and his female cook. ${ }^{1}$ Owen Oglethorpe, president, and Magdalen College, in the fourth year of Edward VI., viz. 1551, granted an annuity of ten pounds a year for life to Nich. Langrish, who, from the preamble, appears then to have been fellow of that society: but, being now superannuated for business, this pension is granted him for thirty years, if he should live so long. It is said of him-"cum jam sit provectioris etatis quam ut," \&c.

Laurence Stubb, president of Magd. Coll. leased out the Priory lands to John Sharp, husbandman, for the term of twenty years, as early as the seventeenth year of Henry VIII.- viz. 1256: and it appears that Henry Newlyn had been in possession of a lease before, probably towards the end of the reign of Henry VII. Sharp's rent was vili . per ann.-Regist. B. p. 43.

By an abstract from a lease lying before me, it appears that Sharp found a house, two barns, a stable, and a dufhouse [dove-house], built, and standing on the south side of the old Priory, and late in the occupation of Newlyn. In this abstract also are to be seen the names of all the fields, many of which continue the same to this day. ${ }^{2}$ Of

1 This is a clerical error. The text (see last page) is "cum una coquina et cum uno stabulo," with a kitchen and stable.-ED.

2 It may not be amiss to mention here that various names of tithings, farms, fields, woods, \&c., which appear in the ancient deeds and evidences of several centuries' standing, are still preserved in common use with little or no variation:-as Norton, Southington, Durton, Achangre, Blackmore, Bradshot, Rood, Plestor, \&c., \&c. At the same time it should be acknowledged that other places have entirely lost their original 
some of them I shall take notice, where anything singular occurs.

And here first we meet with Paradyss [Paradise] Mede. Every convent had its Paradise; which probably was an enclosed orchard, pleasantly laid out, and planted with fruit trees. Tylehouse Grove, so distinguished from having a tiled house near it. ${ }^{1}$ Butt-wood Close; here the servants of the Priory and the village swains exercised themselves with their long bows, and shot at a mark against a butt, or bank. $^{2}$ Cundyth [conduit] Wood: the engrosser of the lease not understanding this name has made a strange barbarous word of it. Conduit Wood was and is a steep rough cow-pasture, lying above the Priory, at about a quarter of a mile to the south-west. In the side of this field there is a spring of water that never fails; at the head of which a cistern was built which communicated with leaden pipes that conveyed water to the monastery. When this reservoir was first constructed does not appear; we only know that it underwent a repair in the episcopate of Bishop Wainfleet, about the year 1462.3 Whether these pipes only conveyed

titles, as Le Buri and Trucstede in this village; and La Liega, or La Lyge, which was the name of the original site of the Priory, \&c.G. W.

1 Men at first heaped sods, or fern, or heath, on their roofs to keep off the inclemencies of weather; and then by degrees laid straw or haum. The first refinements in roofing were shingles, which are very ancient. Tiles are a very late and imperfect covering, and were not much in use till the beginning of the sixteenth century. The first tiled house at Nottingham was in 1503.-G. W.

Mr. Bennett has suggested that perhaps the tile house was the establishment at which the tiles used in the convent flooring were madc. The number of plain tiles which were used there appears to have been considerable: in the preparation of the ornamented ones much time must have been occupied. The manufacture of them on the spot would have been quite in accordance with the arrangements made by such establishments generally, and certainly by the Priory of Selborne, for carrying on trades within themselves, and thus rendering themselves self-dependent only. - ED.

3 There is also a Butt-close just at the back of the village.-G. W.

2 N. 381. "Clausure terre abbatie ecclesie parochiali de Seleburne, ixs. iiiid. Reparacionibus domorum predicti prioratus iiii lib. xi $s$. Aque eonduct. ibidem. xxiii $d .-\mathrm{G}$. W. 
the water to the Priory for common and culinary purposes, or contributed to any matters of ornament and elegance, we shall not pretend to say; nor when artists and mechanics first understood anything of hydraulics, and that water confined in tubes would rise to its original level. There is a person now living who had been employed formerly in digging for these pipes, and once discovered several yards, which they sold for old lead.

There was also a plot of ground called Tan House Garden: and "Tannaria sua," a tan-yard of their own, has been mentioned in Letter XVI. This circumstance I just take notice of, as an instance that monasteries had trades and occupations carried on within themselves. ${ }^{1}$

Registr. B. pag. 112. Here we find a lease of the parsonage of Selborne to Thomas Sylvester and Miles Arnold, husbandmen - of the tythes of all manner of corne pertaining to the parsonage-with the offerings at the chapel of Whaddon belonging to the said parsonage. Dat. June 1 . $27^{\text {th }}$. Hen. $8^{\text {th }}$. [viz. 1536.]

As the chapel of Whaddon has never been mentioned till now, and as it is not noticed by Bishop Tanner in his Notitia Monastica, some more particular account of it will be proper in this place. Whaddon was a chapel of ease to the mother church of Selborne, and was situated in the tithing of Oakhanger, at about two miles' distance from the village. The farm and field whereon it stood are still called Chapel Farm and Field $:^{2}$ but there are no remains or traces of the building itself, the very foundations having been destroyed before the memory of man. In a farm yard at Oakhanger we remember a large hollow stone of a close substance, which had been used as a hogtrough, but was then broken. This stone, tradition said, had been the baptismal font of Whaddon chapel. The chapel had been in a very ruinous state in old days; but

I There is still a wood near the Priory, called Tanner's Wood.G. W.

2 This is a manor-farm, at present the property of Lord Stawell; and belonged probably in ancient times to Jo. de Venur, or Venuz, one of the first benefactors to the Priory.-G. W. 
was new built at the instance of Bishop Wainfleet, about the year 1463, during the first priorship of Berne, in consequence of a sequestration issued forth by that visitor against the Priory on account of notorious and shameful dilapidations. ${ }^{1}$

The Selborne rivulet becomes of some breadth at Oakhanger, and, in very wet seasons, swells to a large flood. There is a bridge over the stream at this hamlet of considerable antiquity and peculiar shape, known by the name of Tunbridge: it consists of one single blunt Gothic arch, so high and sharp as to render the passage not very convenient or safe. ${ }^{2}$ Here was also, we find, a bridge in very early times; for Jacobus de Hochangre, the first benefactor to the Priory of Selborne, held his estate at Hochangre by the service of providing the king one foot soldier for forty days, and by building this bridge. "Jacobus de Hochangre tenet Hochangre in com. Southampton, per Serjantiam ${ }^{3}$ inveniendi unum valectum in exercitu Domini regis [scil. Henricii III ${ }^{\mathrm{tii}}$.] per 40 dies; et ad faciendum pontem de Hochangre: et valet per ann. C. s."-Blount's "Ancient Tenures," p. 84.

A dove-house was a constant appendant to a manorial dwelling : of this convenience more will be said hereafter.

A corn-mill was also esteemed a necessary appendage of every manor; and therefore was to be expected of course at the Priory of Selborne.

The prior had secta molendini, or ad molendinum : ${ }^{4}$ a power of compelling his vassals to bring their corn to be

1 See Letter XIX. of these Antiquities._" Summa total. solut. de novis edificationibus, et reparacionibus per idem tempus, ut patet per comput."

"Videlicet de nova edificat. Capelle Marie de Wadden. xiiii lih. vs. viii $d$.-Reparacionibus ecclesie Prioratus, cancellor. et capellar. ecclesiarum et capellarum de Selbornc, et Estworhlam."-\&c. \&c.

2 Inconvenient antiquity has, in this instance, given way to modern convenience. The little bridge is now low and easy of passage, and consists of three small arches instead of one.-ED.

3 Sargentia, a sort of tenure of doing something for the king.-G. W.

4 "Servitium, quo feudatorii grana sua ad Domini molendinum, ibi molenda perferre, ex consuetudine, astringuntur."-G. W. 
ground at his mill according to old custom. He had also, according to Bishop Tanner, secta molendini de Strete: but the purport of Strete, we must confess, we do not understand.' Strete, in old English, signifies a road or highway, as Watling Strete, \&c., therefore the prior might have some mill on a high road. The Priory had only one mill originally at Selborne; but, by grants of lands, it came possessed of one at Durton, and one at Oakhanger, and probably some on its other several manors. ${ }^{2}$ The mill at the Priory was in use within the memory of man, and the ruins of the mill-house were standing within these thirty years: the pond and dam, and miller's dwelling, still remain. ${ }^{3}$ As the stream was apt to fail in very dry summers, the tenants found their situation very distressing for want of water, and so were forced tc abandon the spot. This inconvenience was probably never felt in old times, when the whole district was nothing but woodlands : and yet several centuries ago there seem to have been two or three mills between Well-head and the Priory.

Occasional mention has been made of the many privileges and immunities enjoyed by the convent and its priors; but a more particular statement seems to be necessary. The author therefore thinks this the proper place, before he concludes these antiquities, to introduce all that has been collected by the judicious Bishop Tanner, respecting the Priory and its advantages, in his Notitia Monastica, a book now seldom seen, on account of the extravagance of its price; and being but in few hands cannot be easily con-

1 As there was another manor besides that of the Priory, in the Strete of Selborne, namely Sir Adam Gurdon's, possibly the privilege secta molendini de Strete enabled the prior to compel the vassals of that manor, equally with his own, to bring their corn to be ground at his mill.-ED.

2 Thomas Knowles, president, \&c. ann. Hen. 8vi. xxiii . [viz. 1532.] devised to J. Whitelie their mills, \&c. for twenty years. Rent xxiii $s$. iiii d.-Accepted Frewen, president, \&c. ann. Caroli xv. [viz. 1640.] demised to Jo. Hook and Elizabeth, his wife, the said mills. Rent as above.-G. W.

3 The miller's dwelling has long since disappeared; and the Millfield, now cultivated as a hop-ground, commemorates in name only the former use of the spot.-Ev. 
sulted. ${ }^{1}$ He also adds a few of its many privileges from other authorities:- the account is as follows.-Tanner, page 166 .

\section{SELEBURNE.}

A Priory of black canons, founded by the often-mentioned Peter de Rupibus, Bishop of Winchester, A.D. 1233, and dedicated to the Blessed Virgin Mary: but was suppressed-and granted to William Wainfleet, Bishop of Winchester, who made it part of the endowment of St. Mary Magdalene College in Oxford. The Bishops of Winchester were patrons of it. [Pat. 17. Ed. II.]-Vide in Mon. Angl. tom. ii. p. 343. "Cartam fundationis ex ipso autographo in archivis Coll. Magd. Oxōn. ubi etiam conservata sunt registra, cartæ, rentalia et alia munimenta ad hunc prioratum spectantia.

"Extracta quædam e registro MS. in Bibl. Bodl.Dodsworth, vol. 89. f. 140."

"Cart. antiq. N. N. n. 33. P. P. n. 48. et 71. Q. Q. n. 40. plac. coram justit. itin. [Southampton] $20 \mathrm{Hen}$. rot. 25. De eccl. de Basing, \& Basingstoke. Plac. de juratis apud Winton. 40 Hen. III. rot.-Pro secta molendini de Strete. Cart. 54. Hen. III. m. 3. [De nercatu, \& feria apud Seleborne, a mistake.]-Pat. 9. Edw. I. m.-Pat. 30. Edw. I. m.-Pat. 33. Edw. I. p. 1. m.-Pat. 35. Edw. I. m.-Pat.1. Edw. II. p. 1. m. 9.-Pat. 5. Edw. II. p. 1. m. 21. De terris in Achanger.-Pat. 6. Edw. II. p. 1. m. 7. De eisdem.-Brev. in Scacc. 6 Edw. II. Pasch. rot. 8.-Pat. 17. Edw. II. p. 1. m.-Cart. 10. Edw. III. n. 24.-Quod terræ suæ in Seleburn, Achangre, Norton, Basings, Basingstoke, and Nately, sint de afforestatæ, and pro aliis libertatibus.-Pat. 12. Edw. III. p. 3. m. 3.-Pat. 13. Edw. III. p. 1. m.-Cart. 18. Edw. III. n. 24."”

"N. N. 33. Rex concessit quod prior et canonici de Seleburn habeant per terras suas de Seleburne, Achangre,

1 A few days after this was written a new edition of this valuable work was announced in the month of April of the year 1787, as published by Mr. Nasmith.-G. W. 
Norton, Brompden, Basinges, Basingstoke, \& Nately, diversas libertates.

"P. P. 48. Quod prior de Seleburne habeat terras suas quietas de vasto et regardo."-Extracts from Ayloffe's "Calendars of Ancient Charters."

"Placita de juratis \& assis coram Salōm de Roff, \& sociis suis justic. itiner. apud Wynton in comitatu Sutht.-anno

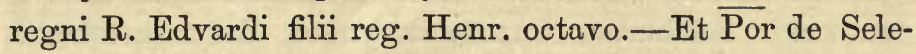
born ht. in Selebr. furc. thurset. pillory, emendasse panis, \& suis." [cerevisiæ.]-Chapter House, Westminster.

"Placita Foreste apud Wyntōn in com. Sutham.-Anno reg. Edwardi octavo coram Rog. de Clifford.-\&c. Justic. ad eadem placita audienda et tminand. assigtis.

"Carta Pror de Seleburn, H. Dei gra. rex. angl. \&c. Concessim. prior. sce. Mario de Seleburn. et canonicis ibidem Deo servient. . . . . q q $\overline{\text { ipi }}$ et $\overline{\text { oes }}$ hoies sui in $\overline{p d}$ cis terris suis et tenementis manentes sint in ppetum quieti de sectis Swanemotor. et omnium alior. placitor. for. et de espeltamentis canum. et de omnibus submonitoibz. placitis querelis et exaccoibus et occoibz. ad for. et for. et viridar. et eor. ministros ptinentibz."-Chapter House, Westminster.

"Plita Forestarum in com. Sutht. apud Suthamton..... anno regni regis Edwardi tcii post conquestum quarto coram $\overline{\mathrm{J} o h e}$ Mantvers. \&c. justic. itinand \&c.

"De hiis qui.clamant libtates intra Forestas in com. Sutht.

"Prior de Selebourne clamat esse quietus erga $\overline{\mathrm{dnm}}$ regem de omnibus finibus et amerciamentis $p$ tnsgr. et omnibus exaccoibz ad Dom. regem vel hered. suos ptinent. pret. plita corone reg.

"Item clamat $q^{d}$ si aliquis hominum suorum de terris et ten. p. delicto suo vitam aut membrum debeat amittere, vel fugiat \& judico stare noluerit, vel aliud delictum fecit pro quo debeat catella sua amittere, ubicunq; justitia fieri dubeat omnia catella illa sint $\overline{p t c i}$ Prioris et successor. suor. 
Et liceat eidem priori et ballis suis ponere se in seisinam in hujusmodi catall. in casibus pdcis sine disturbacone ballivor. dni reg. quorumcunque.

"Item clam. quod licet aliqua libtatum $p \overline{\mathrm{dnm}}$ regem concessar. pcessu temporis quocunq; casu contingente usi non

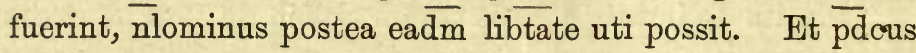
prior quesitus $p$ justic. quo warranto clamat omn. terr. et ten. sua in Seleburne, Norton, Basynges, Basyngestoke, \& Nattele, que prior domus pdte huit \& tenuit $\mathrm{X}^{\mathrm{mo}}$ die April anno regni dni Hen. reg. pavi dni reg. $\overline{\text { nue XVIII. immppm }}$ esse quieta de vasto et regardo, et visu forestarior. et viridarior. regardator. et omnium ministrorum foreste." \&c. \&c. - Chapter House, Westminster.

\section{LETTER XXVI.}

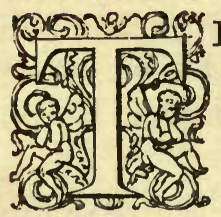

HOUGH the evidences and documents of the Priory and parish of Selborne are now at an end, yet, as the author has still several things to say respecting the present state of that convent and its Grange, and other matters, he does not see how he can acquit himself of the subject without trespassing again on the patience of the reader by adding one supplementary letter.

No sooner did the Priory (perhaps much out of repair at the time) become an appendage to the college, but it must at once have tended to swift decay. Magdalen College wanted now only two chambers for the chantry priest and his assistant; and therefore had no occasion for the hall, dormitory, and other spacious apartments belonging to so large a foundation. The roofs, neglected, would soon become the possession of daws and owls; and, being rotted and decayed by the weather, would fall in upon the floors; so that all parts must have hastened to speedy dilapidation and a scene of broken ruins. Three full centuries have 
now passed since the dissolution; a series of years that would craze the stoutest edifices. But, besides the slow hand of time, many circumstances have contributed to level this venerable structure with the ground; of which nothing now remains but one piece of a wall of about ten feet long, and as many feet high, which probably was part of an out-house. ${ }^{1}$ As early as the latter end of the reign of Hen. VII. we find that a farm-house and two barns were built to the south of the Priory, and undoubtedly out of its materials. Avarice, again, has much contributed to the overthrow of this stately pile, as long as the tenants could make money of its stones or timbers. Wantonness, no doubt, has had a share in the demolition; for boys love tc destroy what men venerate and admire. A remarkable instance of this propensity the writer can give from his own knowledge. When a schoolboy, more than fifty years ago, he was eyewitness, perhaps a party concerned, in the undermining a portion of that fine old ruin at the north end of Basingstoke town, well known by the name of Holy Ghost Chapel. Very providentially the vast fragment, which these thoughtless little engineers endeavoured to sap, did not give way so soon as might have been expected; but it fell the night following, and with such violence that it shook the very ground, and, awakening the inhabitants of the neighbouring cottages, made them start up in their beds as if they had felt an earthquake. The motive for this dangerous attempt does not so readily appear: perhaps the more danger the more honour, thought the boys; and the notion of doing some mischief gave a zest to the enterprise. As Dryden says upon another occasion,

"It look'd so like a sin it pleased the more."

Had the Priory been only levelled to the surface of the ground, the discerning eye of an antiquary might have ascertained its ichnography, and some judicious hand might have developed its dimensions. But, besides other ravages,

1 This wall has since shared the fate of other portions of the Priory, and the stones thereof have gone either to mend a barn or to repair a road-ED. 
the very foundations have been torn up for the repair of the highways; so that the site of this convent is now become a rough, rugged pasture-field, full of hillocks and pits, choked with nettles and dwarf-elder, and trampled by the feet of the ox and the heifer. ${ }^{1}$

As the tenant at the Priory was lately digging among the foundations, for materials to mend the highways, his labourers discovered two large stones, with which the farmer was so pleased that he ordered them to be taken out whole. One of these proved to be a large Doric capital, worked in good taste; and the other a base of a pillar; both formed out of the soft freestone of this district. These ornaments, from their dimensions, seem to have belonged to massive columns; and show that the church of this convent was a large and costly edifice. They were found in the space which has always been supposed to have contained the south transept of the Priory church. Some fragments of large pilasters were also found at the same time. The diameter of the capital was two feet three inches and a half; and of the column, where it had stood on the basse, eighteen inches and three quarters.

1 Mr. Bennett found in 1837 that the ground had been so effectually cleared as almost to have become a smooth homestead. A few heaps of stone derived, it was supposed, from the last remnants of the foundations, and piled ready for use as materials, were all that remained in the Priory field to evidence the former site of that important building. Among the heaps were some fashioned stones which would not be broken to pieces. Some fragments of columns and of a pediment, perhaps of a monument of superior pretensions, were preserved. These were placed, together with a stone coffin that had been dug up on the spot, in the garden of the adjoining farm. A considerable number of ornamented tiles were also found; some of which exhibited merely fancy devices, some bore eagles displayed and other apparently armorial emblems, and one bore a shield of three fleurs de luces, supported by two hawks. These tiles were used to form the pavement of a summer-house in the garden of the Priory Farm. Some fragments of stained glass were also found, together with portions of the ornamented leaden casement including them; affording additional proofs of an important building.

The complete clearance, however, which has since taken place, renders it improbable that any future discovery of interest will be made on the spot.-ED. 
Two years ago some labourers digging again among the ruins found a sort of rude thick vase or urn of soft stone, containing about two gallons in measure, on the verge of the brook, in the very spot which tradition has always pointed out as having been the site of the convent kitchen. This clumsy utensil, whether intended for holy water, or whatever purpose, we were going to procure, but found that the labourers had just broken it in pieces, and carried it out on the highways. ${ }^{1}$

The Priory of Selborne had possessed in this village a Grange, an usual appendage to manorial estates, where the fruits of their lands were stowed and laid up for use, at a time when men took the natural produce of their estates in kind. The mansion of this spot is still called the Grange, and is the manor-house of the convent possessions in this place. The author has conversed with very ancient people who remembered the old original Grange ; but it has long given place to a modern farm-house. Magdalen College holds a court-leet and court-baron ${ }^{2}$ in the great wheat-barn of the said Grange, annually, where the president usually superintends, attended by the bursar and steward of the college. ${ }^{3}$

The following uncommon presentment at the court is not unworthy of notice. There is on the south side of the king's field (a large common field so called) a considerable tumulus, or hillock, now covered with thorns and bushes, and known by the name of Kite's Hill, which is presented, year by year, in court as not ploughed. Why this injunction is still kept up respecting this spot, which is surrounded on all sides by arable land, may be a question

1 A judicious antiquary, who saw this vase, observed, that it possibly might have been a standard measure between the monastery and its tenants. The Priory we have mentioned claimed the assize of bread and beer in Selborne manor; and probably the adjustment of dry measures for grain, \&c.-G. W,

2 The time when this court is held is the mid-week between Easter and Whitsuntide.-G. W.

3 Owen Oglethorp, president, \&c. an. Edw. Sexti primo [viz. 1547] demised to Robert Arden, Selborne Grange, for twenty years. Rent $v^{i}{ }^{i}$.-Index of Leases.-G. W. 
not easily solved, since the usage has long survived the knowledge of the intention thereof. We can only suppose that as the prior, besides thurset and pillory, had also furcas, a power of life and death, that he might have reserved this little eminence as the place of execution for delinquents. And there is the more reason to suppose so, since a spot just by is called Gally (Gallows) Hill.

The lower part of the village next the Grange, in which is a pond and a stream, is well known by the name of

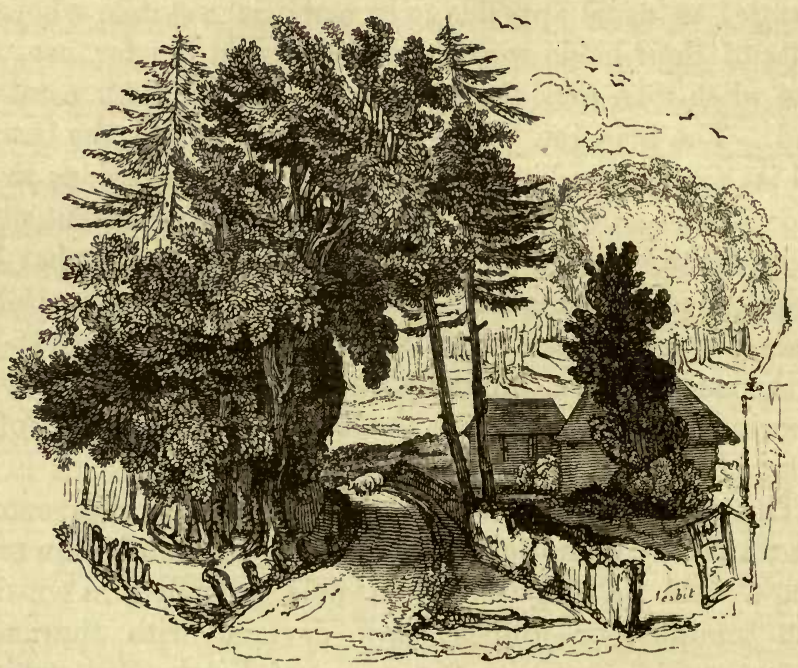

WAY LEADING TO GRACIOUS STREET.

Gracious Street, an appellation not at all understood. There is a lake in Surrey, near Chobham, called also Gracious Pond; and another, if we mistake not, near Hedleigh, in the county of Hants. This strange denomination we do not at all comprehend, and conclude that it may be a corruption from some Saxon word, itself perhaps forgotten.

It has been observed already, that Bishop Tanner was mistaken when he refers to an evidence of Dodsworth, " $D e$ mercatu et FERIA de Seleburne." Selborne never had a chartered fair ; the present fair was set up since the year 1681 , by a set of jovial fellows, who had found in an old 
almanack that there had been a fair here in former days on the 1st of August; and were desirous to revive so joyous a festival. Against this innovation the vicar set his face, and persisted in crying it down, as the probable occasion of much intemperance. However the fair prevailed; but was altered to the 29th of May, because the former day often interfered with wheat harvest. On that day it still continues to be held, and is become a useful mart for cows and calves. Most of the lower housekeepers brew beer against this holiday, which is dutied by the excisemen; and their becoming victuallers for the day without a license is overlooked.

Monasteries enjoyed all sorts of conveniences within themselves. Thus at the Priory, a low and moist situation, there were ponds and stews for their fish: at the same place also, and at the Grange in Culver Croft, ${ }^{1}$ there were dovehouses; and on the hill opposite to the Grange the prior had a warren, as the names of The Coney Crofts and Coney Croft Hanger plainly testify. ${ }^{2}$

Nothing has been said as yet respecting the tenure or holding of the Selborne estates. Temple and Norton are manor farms and freehold; as is the manor of Chapel near Oakhanger, and also the estate at Oakhanger House and Blackmoor. The Priory and Grange are leasehold under Magdalen College, for twenty-one years, renewable every seven: all the smaller estates in and round the village are copyhold of inheritance under the college, except the little remains of the Gurdon manor, which had been of old leased out upon lives, but have been freed of late by their present lord, as fast as those lives have dropped.

Selborne seems to have derived much of its prosperity from the near neighbourhood of the Priory. For monasteries were of considerable advantage to places where they had their sites and estates, by causing great resort, by procuring markets and fairs, by freeing them from the cruel oppression of forest laws and by letting their lands at easy

1 Culver, as has been observed before, is Saxon for a pigenn-G. W.

2 A warren was an usual appendage to a manor.--G. W. 
rates. But, as soon as the convent was suppressed, the town which it had occasioned began to decline, and the market was less frequented; the rough and sequestered situation gave a check to resort, and the neglected roads rendered it less and less accessible.

That it had been a considerable place for size formerly appears from the largeness of the church, which much exceeds those of the neighbouring villages ; by the ancient extent of the burying ground, which, from human bones occasionally dug up, is found to have been much encroached upon; by giving a name to the hundred; by the old foundations and ornamented stones, and tracery of windows that have been discovered on the north-east side of the village; and by the many vestiges of disused fish-ponds still to be seen around it. For ponds and stews were multiplied in the times of popery, that the affluent might enjoy some variety at their tables on fast days; therefore the more they abounded the better probably was the condition of the inha. bitants.

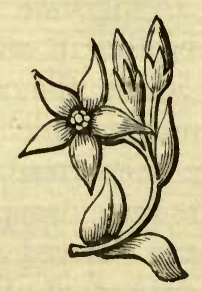




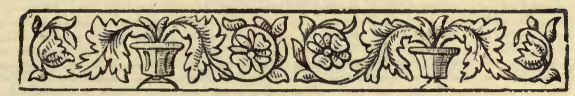

\section{POEMS,}

SEY,EC'TED FROM THE MSS. OF 'I'HE

REV. GILBERT WHITE.

wivin 


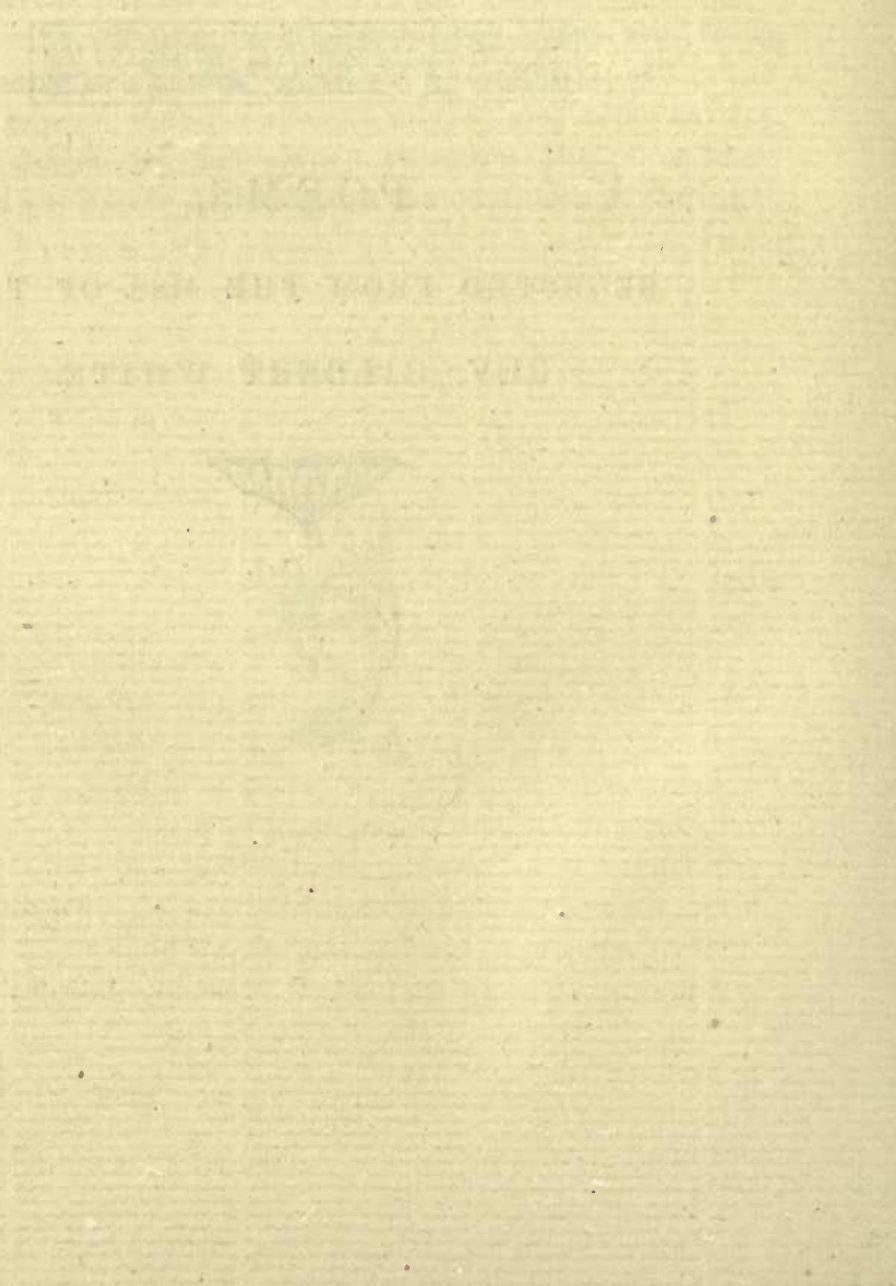




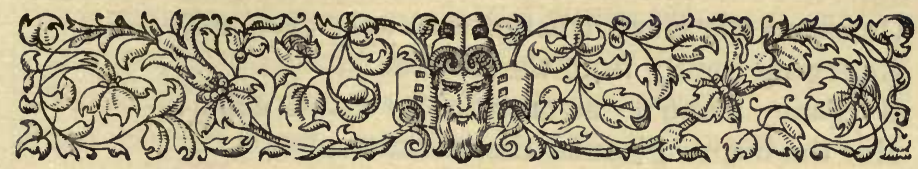

\section{POE M S.}

\section{THE INVITATION TO SELBORNE.}

The Selborne spreads her boldest beauties
Wildly majestic! what is all the pride
Arise, my stranger, to these wild scenes haste ;
The unfinish'd farm awaits your forming taste :
Plan the pavilion, airy, light, and true;
Through the high arch call in the length'ning view ;
Expand the forest sluping up the hill;
Swell to a lake the scant, penurious rill;
Extend the vista, raise the castle mound
In antique taste with turrets ivy-crown'd;
O'er the gay lawn the flowery shrub dispread,
Or with the blending garden mix the mead;
Bid China's pale, fantastic fence, delight;
Or with the mimic statue trap the sight.
Oft on some evening, sunny, soft, and still,
The muse shall lead thee to the beach-grown hill,
To spend in tea the cool, refreshing hour,
Where nods in air the pensile, nest-like bower ;

1 A kind of arbour on the side of a hill.- G. W. 
Or where the Hermit hangs the straw-clad cell,

Emerging gently from the leafy dell;

By Fancy plann'd; as once th' inventive maid

Met the hoar sage amid the secret shade;

Romantic spot! from whence in prospect lies

Whate'er of landscape charms our feasting eyes ;

The pointed spire, the hall, the pasture-plain,

The russet fallow, or the golden grain,

The breezy lake that sheds a gleaming light,

Till all the fading picture fail the sight.

Each to his task; all different ways retire;

Cull the dry stick; call forth the seeds of fire;

Deep fix the kettle's props, a forky row,

Or give with fanning hat the breeze to blow.

Whence is this taste, the furnish'd hall forgot,

To feast in gardens, or the unhandy grot?

Or novelty with some new charms surprises,

Or from our very shifts some joy arises.

Hark, while below the village-bells ring round,

Echo, sweet nymph, returns the soften'd sound;

But if gusts rise, the rushing forests roar,

Like the tide tumbling on the pebbly shore.

Adown the vale, in lone, sequester'd nook,

Where skirting woods imbrown the dimpling brook,

'The ruin'd Convent lies; here wont to dwell

The lazy canon midst his cloister'd cell ${ }^{2}$

While papal darkness brooded o'cr the land,

Ere Reformation made her glorious stand:

Still oft at eve belated shepherd-swains

See the cowl'd spectre skim the folded plains.

To the high Temple would my stranger go, ${ }^{3}$

1 A grotesque building, contrived by a young gentleman, who used on occasion to appear in the character of a hermit.-G. W.

2 The ruins of a priory, founded by Peter de Rupibus, Bishop of Winchester.-G. W.

3 The remains of a preceptory of the Knights Templars; at least it was a farm dependant upon some preceptory of that order. I find it was a preceptory, called the Preceptory of Sudington; now called Southington.-G. W. 
The mountain-brow commands the woods below;

In Jewry first this order found a name,

When madding Croisades set the world in flame;

When western climes, urged on by pope and priest,

l'our'd forth their millions o'er the deluged east:

Luxurious knights, ill suited to defy

To mortal fight Turcéstan chivalry.

Nor be the Parsonage by the muse forgot;

The partial bard admires his native spot;

Smit with its beanties, loved, as yet a child, (Unconscious why) its scapes grotesque, and wild. High on a mound th' exalted gardens stand, Beneath, deep valleys scoop'd by Nature's hand.

A Cobham here, exulting in his art, Might blend the General's with the Gardener's part; Might fortify with all the martial trade Of rampart, bastion, fosse, and palisade; Might plant the mortar with wide threatening bore, Or bid the mimic cannon seem to roar.

Now climb the steep, drop now your eye below, Where round the blooming village orchards grow; There, like a picture, lies my lowly seat, A rural, shelter'd, unobserved retreat.

Me far above the rest Selbornian scenes, The pendent forests, and the mountain greens Strike with delight; there spreads the distant view, That gradual fades till sunk in misty blue: Here Nature hangs her slopy woods to sight, Rills purl between, and dart a quivering light. 


\title{
SELBORNE HANGER.
}

\author{
A WINTER PIECE.
}

\section{TO THE MISS BATTIES.}

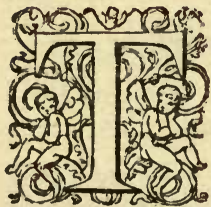

HE Bard, who sang so late in blithest strain Selbornian prospects, and the rural reign, Now suits his plaintive pipe to sadden'd tone, While the blank swains the changeful year bemoan.

How fallen the glories of these fading scenes! The dusky beech resigns his vernal greens, The yellow maple mourns in sickly hue, And russet woodlands crowd the dark'ning view.

Dim, clustering fogs involve the country round, The valley and the blended mountain-ground Sink in cenfusion; but with tempest-wing Should Boreas from his northern barrier spring; The rushing woods with deafening clamour roar, Like the sea tumbling on the pebbly shore. When spouting rains descend in torrent tides, See the torn Zigzag weep its channel'd sides: Winter exerts its rage; heavy and slow, From the keen east rolls on the treasured snow; Sunk with its weight the bending boughs are seen, And one bright deluge whelms the works of men. Amidst this savage landscape, bleak and bare, Hangs the chill Hermitage in middle air; Its haunts forsaken, and its feasts forgot, A leaf-strown, lonely, desolated cot!

Is this the scene that late with rapture rang, Where Delphy danced, and gentle Anna sang; With fairy-step where Harriet tripp'd so late, And on her stump reclined the musing Kitty sato? 
Return, dear Nymphs; prevent the purple spring, Ere the soft nightingale essays to sing; Ere the first swallow sweeps the freshening plain, Ere love-sick turtles breathe their amorous pain; Let festive glee th' enliven'd village raise, Pan's blameless reign, and patriarchal days;

With pastoral dance the smitten swain surprise, And bring all Arcady before our eyes.

Return, blithe maidens; with you bring along Free, native humour, all the charms of song, The feeling heart, and unaffected ease, Each nameless grace, and every power to please.

Nov. 1, 1763.

\section{ON THE RAINBOW.}

"Luok upon the rainbow, and praise him that made it: very beautiful is it in the brightness thereof."-Eecles. xliii. 11 .

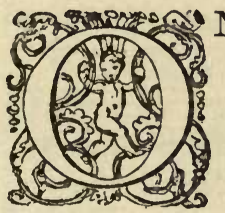

$\mathrm{N}$ morning or on evening cloud impress'd, Bent in vast curve, the watery meteor shines Delightfully, to the levell'd sun opposed: Lovely refraction! while the vivid brede In listed colours glows, th' unconscious swain With vacant eye gazes on the divine Phenomenon, gleaming o'er the illumined fields, Or runs to catch the treasures which it sheds.

Not so the sage, inspired with pious awe;

He hails the federal arch ${ }^{1}$ and looking up

Adores that God, whose fingers form'd this bow Magnificent, compassing heaven about

With a resplendent verge, "Thou madest the cloud, Maker Omnipotent, and thou the bow ; And by that covenant graciously hast sworn

${ }^{1}$ Gen. ix. 12-17. 
Never to drown the world again $:^{1}$ henceforth, Till time shall be no more, in ceaseless round, Season shall follow season: day to night, Summer to winter, harvest to seed time, Heat shall to cold in regular array Succeed."-Heaven-taught, so sang the Hebrew bard."

\section{A HARVEST SCENE.}

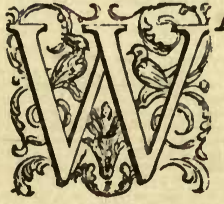

AKED by the gentle gleamings of the morn, Soon clad, the reaper, provident of want, Hies cheerful-hearted to the ripen'd field; Nor hastes alone; attendant by his side Bears on her breast the sleeping babe; behind, With steps unequal, trips her infant train: Thrice happy pair, in love and labour join'd ! All day they ply their task; with mutual chat, Beguiling each the sultry, tedious hours.

Around them falls in rows the sever'd corn, Or the shocks rise in regular array.

But when high noon invites to short repast, Beneath the shade of sheltering thorn they sit, Divide the simple meal, and drain the cask: The swinging cradle lulls the whimpering babe Meantime; while growling round, if at the tread Of hasty passengers alarm'd, as of their store Protective, stalks the cur with bristling back. To guard the scanty scrip and russet frock.

1 Gen. viii. 22.

2 Moses. 
DARK, STILL, DRY, WARM WEATHER,

OCCASIONALLY HAPPENING IN THE WINTER MONTHS.

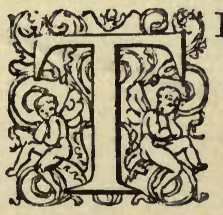

HE imprison'd winds slumber, within their caves

Fast bound: the fickle vane, emblem of change,

All Nature nodding seems composed: thick steams

From land, from flood updrawn, dimming the day,

"Like a dark ceiling stand:" slow through the air Gossamer floats, or stretch'd from blade to blade The wavy network whitens all the field.

Push'd by the weightier atmosphere, up springs The ponderous mercury, from scale to scale Mounting, amidst the Torricellian tube. ${ }^{1}$

While high in air, and poised upon his wings, Unseen, the soft, enamour'd woodlark runs Through all his maze of melody; the brake Loud with the blackbird's bolder note resounds. Sooth'd by the genial warmth, the cawing rook Anticipates the spring, selects her mate, Haunts her tall nest-trees, and with sedulous care Repairs her wicker eyrie, tempest torn.

The ploughman inly smiles to see upturn His mellow glebe, best pledge of future crop.

With glee the gardener eyes his smoking beds:

E'en pining sickness feels a short relief.

The happy schoolboy brings transported forth His long forgotten scourge, and giddy gig: 
O'er the white paths he whirls the rolling hoop, Or triumphs in the dusty fields of taw.

Not so the museful sage : abroad he walks Contemplative, if haply he may find What cause controls the tempest's rage, or whence Amidst the savage season winter smiles.

For days, for weeks, prevails the placid calm. At length some drops prelude a change: the sun With ray refracted bursts the parting gloom; When all the chequer'd sky is one bright glare. Mutters the wind at eve: the horizon round With angry aspect scowls: down rush the showers: And float the deluged paths, and miry fields.

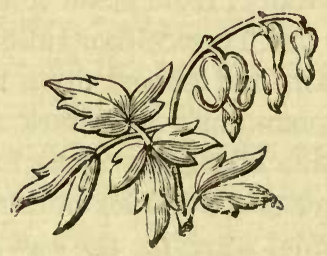




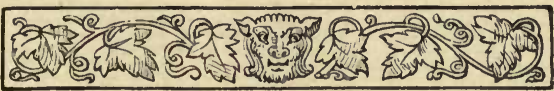

APPENDIX.

\author{
- \\ I E N L E T T ERS \\ FROM
}

THE REV. GILBERT WHITE, M.A。

TO

ROBERT MARSHAM, F.R.S.

1790-1793.

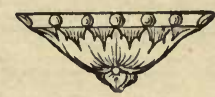





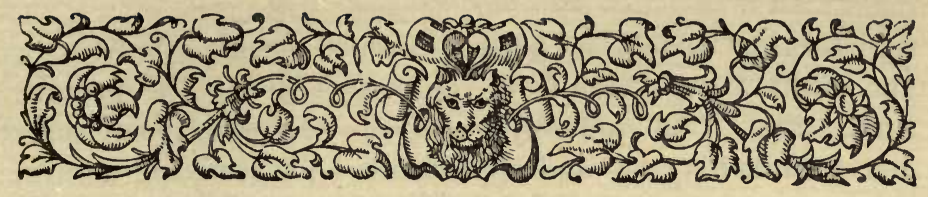

\section{EDITOR'S NOTE.}

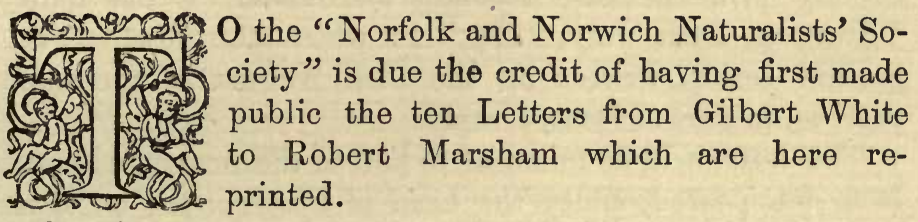

By singular good fortune these letters were discovered amongst other family records in the possession of the Rev. H. P. Marsham, of Rippon Hall, near Norwich, a great grandson of the gentleman to whom they were addressed, and with great liberality he placed them at the disposal of the Society in whose "Transactions" they have been recently published," together with the corresponding replies from Marsham to White, the originals of which are in the possession of Mr. Bell of Selborne.

Robert M irsham, of Stratton Strawless, Norfolk, to whom these letters were addressed, is already known to most readers of White's writings as a correspondent to whose opinions the latter often referred in terms of respect. His leisure hours were devoted chiefly to arboriculture, and he delighted in making experiments on the growth of forest trees, the results of which he communicated from time to time to the "Philosophical Transactions" of the Royal Society, of which learned body he was a Fellow. The "Indications of Spring," of which he left such a remarkable

1 "Transactions of the Norfolk and Norwich Naturalists' Society." 1876, vol. ii. pp. 133-195. 
register, and which has been continued by his family witk one slight interruption from the year 1736 to the present time, afforded an annually recurring topic for correspondence, while his taste and opportunities for studying nature, led him to make many observations on rural subjects, the extent and variety of which may be inferred from the comments which they evoked from White. He died in September, 1797.

By a curious coincidence, the only letter from Marsham to White hitherto published (that is, until the Norfolk Society printed those recently discovered) is one dated "Stratton, 24th July, 1790," to which the first of the present series, written on the 13th August of the same year, is, in part at least, a reply.

This letter will be found at p. 356 of the present volume. It first appeared, under the head of Observations on Vegetables, in White's "Calendar of Nature," which was published after his death by Aikin in 1795, and which has been since appended to almost every edition of the "Natural History of Selborne," although it formed no part of the original work.

The tenth letter of the new series is of especial interest, as having been penned only eleven days before White's death, which took place on the 26th June, 1793 ; and hence it may be regarded as the last of his agreeable essays on Natural History, which to English readers must ever remain as delightful in style as they are instructive in matter.

It only remains to add that the notes appended to the following letters are those which, at the request of the "Norfolk and Norwich Naturalists' Society," were written by me in the spring of the present year, for publication in the above-mentioned "Transactions."

J. E. Harting.

August, 1876. 


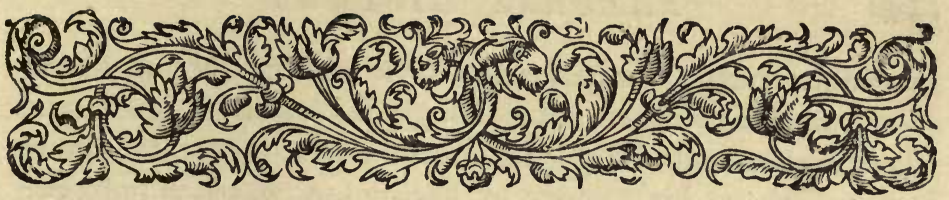

\section{LETTER I.}

\section{TO ROBERT MARSHAM, ESQUIRE.}

Selborne, near Alton, Hants, Aug. 13, 1790.

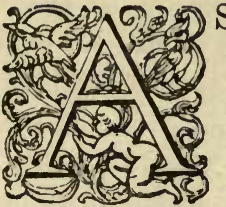

$\mathrm{S}$ an author I have derived much satisfaction from your kind and communicative letter; and am glad to hear that my book has found its way into Norfolk, and that it has fallen into the hands of so intelligent and candid a reader as yourself, whose good word may contribute to make it better known in those parts. I am glad that you happened to mention your most estimable friend the late Dr. Stephen Hales, ${ }^{1}$ because he was also my most

1 A memoir of Dr. Stephen Hales, extracted from Butler's "Memoirs of Bishop Hildersley," with an engraving from an original portrait, and a facsimile of his handwriting, will be found in the "Gentleman's Magazine" for Jan., 1799 (p. 9). Born in 1677, this celebrated philosopher and divine was the grandson of Sir Robert, and brother of Sir Thomas Hales, Bart., of Bekesbourne, in the county of Kent. Educated at Corpus Christi College, Cambridge, where he was admitted a Fellow in 1702, he was appointed first to the cure of Teddington, then to the rectory of Porlock, in Somersetshire, and ultimately, in 1722, to the rectory of Farringdon, near Alton, the arjoining parish to that in which Gilbert White resided. In addition to a treatise on "Vegetable Staticks," which was translated into French by Buffon, as well as into Italian, German, and Dutch, and a practical work on "Ventilators," he indited numerous sermons and tracts in the cause of temperance, and published several scientific papers in the "Philosophical Transactions" of the Royal Society, of which learned body he was elected a Fellow in 
valuable friend, and in former days near neighbour during the summer months. For though his usual abode was at Teddington, yet did he for many years reside for about two months at his rectory of Faringdon, which is only two miles from hence; and was well known to my grandfather and father, as well as to myself. If I might presume to say that what you see respecting the copulation of toads is, I think, a mistake, you will pardon my boldness; because the amours carried on in pools and wet ditches in the spring time are performed by frogs, which are more black and bloated at that season than afterwards. As to toads, they seem to be more reserved in their intrigues. ${ }^{1}$

With regard to the annual increase of swallows, and that those that return bear no manner of proportion to those that depart $;^{2}$ it is a subject so strange, that it will be best for me to say little. I suppose that nature, ever provident, intends the vast increase as a balance to some great devastations to which they may be liable either in their emigrations or winter retreats. Our swifts have been gone about a week ! but the other hirundines have sent forth their first broods in vast abundance; and are now busied in the rearing of a second family. Myself and visitors have often paid due attention to the oak in the Holt, which ought

1717. In the sixth letter of the present series it will be seen that allusion is made in some detail to the philosophical pursuits in which he was wont to engage. He died 4th Jan. 1761.

The family of Hales was originally seated at Hales Place, in Halden, Kent, whence they were usually called "at-Hale." Nicholas at-Hale, or Hales, lived there at the latter end of the reign of Edward III. See Hasted's " History of Kent," vol. ii. p. 576 (1782), and vol. iii. p. 716, (1790).-Ev.

${ }^{1}$ See Letter XVII. to Pennant, and the notes thereto, p. 61.-ED.

2 This observation occurs, nearly in the same words, in Letter XXXIX. to Daines Barrington, p. 247.-ED.

3 The early retreat of the swift, "so many weeks before its congeners," is a circumstance to which White has frequently alluded. See Letter XXVI. to Pennant, p. 90. Elsewhere he remarks, "they usually withdraw within the first week of August." See Letter XXXVII. to Pennant, p. 114.-ED. 
indeed to have been noticed in my book, and especially as it contains some account of that forest.' You have been an early planter indeed! and may safely say, I should think, that no man living can boast of so large an oak of his own planting ! $!^{2}$ As I had reason to suppose that actual measurement would give me the best idea of your tree, I first took the girth of my biggest oak, a single tree, age not known, in the midst of my meadow : when though it carries a head that measures twenty-four yards three ways in diameter; yet is the circumference of the stem only $10 \mathrm{ft} .6 \mathrm{in}$. I then measured an oak, standing singly in a gentleman's outlet at about two miles distance, and found it exactly the dimensions of yours. After such success you may well say with Virgil,

"Et dubitant homines serere, atque impendere curas?"

In an humble way I have been an early planter myself. The time of planting, and growth of my trees are as follows: -Oak, in 1731, 4 ft. 5 in.; ash, in 1731 , 4 ft. $6 \frac{\mathrm{I}}{2}$ in.; spruce fir, in 1751, $5 \mathrm{ft}$.; beech, in 1751, $4 \mathrm{ft}$; elm, in $1750,5 \mathrm{ft}$. 3 in.; lime, in $1756,5 \mathrm{ft} .5$ in. $^{3}$ Beeches with us, the most lovely of all forest trees, thrive wonderfully on steep, sloping grounds, whether they be chalk or freestone. I am in possession myself of a beechen steep grove on the freestone, that I am persuaded would please your judicious eye; in which there is a tree that measures fifty feet without bough or fork, and twenty-four feet beyond the fork; there are many as tall. I speak from long observation when I assert, that beechen groves to a warm aspect grow onethird faster than those that face to the N. and N.E., and

1 See Letter IX. to Pennant, pp. 29-32, and the "Observations on Vegetables," pp. 356-357.-Ev.

2 This oak of Marsham's will be found noticed in the "Observations on Vegetables," p. 356, where White has quoted a letter from Marsham on the subject, dated "Stratton, 24 July, 1790," to which it would seem the present letter is a reply.-ED.

3 These dates and measurements, with a slight discrepancy, have been published in the "Observations on Vegetables" p. 356, above referred to.-ED. 
the bark is much more clean and smooth. ${ }^{1} \quad$ About thirty or forty years ago the oaks in this neighbourhood were much admired, viz., in Hartley Wood, at Temple, and Blackmoor." At the last place, the owner, a very ancient yeoman, through a blameable partiality, let his trees stand till they were red-hearted and white-hearted three or four feet up the stem. We have some old edible chestnut trees in this neighbourhood; but they make vile timber, being always shakey, and sometimes cup-shakey. ${ }^{3}$

As you seem to know the Fern-owl, or Churn-owl, or Eve-jar, I shall send you, for your amusement, the following account of that curious, nocturnal, migratory bird. ${ }^{4}$ The country people here have a notion that the Fern-owl, which they also call Puckeridge, is very injurious to weanling calves by inflicting, as it strikes at them, the fatal distemper known to cow-leeches by the name of puckeridge. Thus does this harmless, ill-fated bird fall under a double imputation, which it by no means deserves;-in Italy of sucking the teats of goats, where it is called Caprimulgus; and with us, of communicating a deadly disorder to cattle. But the truth of the matter is, the malady above-mentioned is occasioned by a dipterous insect called the oestrus bovis, which lays its eggs along the backs of kine, where the maggots, when hatched, eat their way through the hide of

1 See the "Observations on Vegetables," p. 358.-ED.

2 "The oaks of Temple and Blackmoor stand high in the estimation of purveyors, and have furnished much naval timber; while the trees on the freestone grow large, but are what workmen call shaky, and so brittle as often to fall to pieces in sawing." Letter I. to Pennant, p. 4. -Ev.

3 This term is explained, in the "Observations on Vegetables" (p. 359), to mean that the wood is "apt to separate in round pieces like cups."-ED.

4 This account will be found already published in the "Observations on Birds," under the head of "Fern-Owl, or Goatsucker" (pp. 334-335), and as it is in the same words, it is probably extracted from the notes which White had collected for a history of this bird to be published in the Philosophical Transactions of the Royal Society. See the 4th letter in the present series, p. 542.-Ev. 
the beast into it's flesh, and grow to a large size. ${ }^{1} \quad$ I have just talked with a man, who says, he has been employed, more than once, in stripping calves that had dyed of the puckeridge : that the ail, or complaint, lay along the chine, where the flesh was much swelled, and filled with purulent matter. Once myself I saw a large, rough maggot of this sort squeezed out of the back of a cow. An intelligent friend informs me, that the disease along the chines of calves, or rather the maggots that cause them, are called by the graziers in Cheshire worry brees, and a single one worry bree. No doubt they mean a breese, or breeze, the name for the gad-fly, or cestrus, the parent of these maggots, which lays its eggs along the backs of kine.

But to return to the fern-owl. The least attention and observation would convince men that these poor birds neither injure the goat-herd, nor the grazier; but that they are perfectly harmless, and subsist alone on nightmoths, and beetles ; and through the month of July mostly on the scaraboeus solstitialis, the small tree-beetle, which in many districts flies and abounds at that season. Those that we have opened have always had their craws stuffed with large night moths, and pieces of chafers ; nor does it anywise appear, how they can, weak and unarmed $a^{\circ}$ they are, inflict any malady on kine, unless they possess the powers of animal magnetism, and can affect them by fluttering over them. Upon recollection it must have been at your house that the amiable Mr. Stillingfleet kept his "Calendar of Flora" in $1755 .^{2}$ Similar pursuits make intimate and

1 In letter XXXIV. to Pennant (p. 107 and note), as well as in the "Observations on Insects and Vermes," (p. 349,) this insect is noticed by White under the name CEstrus curvicauda. At the date of his former letter, March 30th, 1771, he seems to have been unaware that it had been described by Linnæus as $O$ Estrus bovis, but this impression was evidently altered before the date of the present letter to Marsham.-ED.

2 This was so. Stillingfleet refers to him as his "very worthy and ingenious friend Robert Marsham," and speaks in high terms of the hospitable treatment that he experienced at Stratton. See the fifth letter of the present series, p. 545. The "Calendar of Flora," made in 1755 
lasting friendship. As I do not take in the R. S. T. ${ }^{1}$ I will with pleasure accept of your present of a copy of your "Indications of Spring." Hoping that your benevolence will pardon the unreasonable length of this letter, on which I look back with some contrition; I remain, with true esteem,

$$
\begin{aligned}
& \text { Your most humble servant, } \\
& \text { GiL. White. }
\end{aligned}
$$

Any farther correspondence will be deemed an honour.

\section{LETTER II.}

TO ROBERT MARSHAM, ESQUIRE.

Selborne, Jan. 18th,'1791.

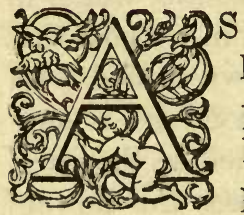

$S$ your long silence gave me some uneasiness lest it should have been occasioned by indisposition; so the sight of your last obliging letter afforded me much satisfaction in proportion.

I was not a little pleased to find that your friend Lord Suffield corroborated the account of the Cuckoo given by Mr. Jenner, whose relation of the proceedings of that peculiar bird is very curious, new, and extraordinary. ${ }^{2}$ It does not appear from your letter that you endeavoured to revive the Swallow, which fell down before your parlourwindow. I have not yet done with trees, and shall there-

and published in 1761 , will be found alluded to in Letter XII. to Pennant, p. 44.-Ev.

1 Royal Society's "Transactions," better known perhaps as the "Philosophical Transactions."-ED.

2 Dr. Jenner's "Observations on the Natural History of the Cuckoo" will be found in the "Philosophical Transactions" for 1778, pp. 219237. -En. 
fore add, that my tall seventy-four feet beech measures six feet in the girth at two feet above the ground. Beeches seem to me to thrive best on stoney, or chalkey cliffs, where there secms to be little or no soil. Thus about a mile and an half from me to the S.E. in an abrupt field, stand four noble beech-trees on the edge of a steep, rocky ravine, or water-gulley, the biggest of which measures $9 \mathrm{ft} .5$ in. at four feet from the ground. Their noble branching heads, and smooth rind show that they are in the highest vigour and preservation. Again the vast bloated, pollard, hollow beeches, mentioned before, stood on the bare, naked end of a chalky promontory, many of which measured from twenty to thirty feet in circumference! they were the admiration of all strangers. How has prevailed the notion that all old London was built with chestnut? It is with us now vile timber, porous, shakey, and fragile, and only fit for the meanest coopery purposes. Yet have I known it smuggled into Portsmouth dock as good ship building oak! ${ }^{1}$

The more I observe and take notice of the best oaks now remaining in this neighbonrhood, the more I am astonished at the oak which you planted yourself. For there is a most noble tree of that kind near Hartely house, which I caused to be measured last week; when behold, at four feet above the ground the girth proved to be only $14 \mathrm{ft}$., when yours measured $12 \mathrm{ft} .6$ in.! Why this fine shafted tree, with its majestic head, escaped the axe thirty years ago, when Sir Simeon Stuart felled all its contemporaries, I cannot pretend to say. If you ever happen to see the Hamadryad of your favourite oak, pray give my respects to her. She must be a fine venerable old lady. For a diverting story respecting an Hamadryad, see the "Spectator," vol. 8, p. 128.

Behind my house I have got an outlet of seven acres laid

1 In his "Observations on Vegetables" (p. 359), White has remarked, "The timber and bark of these trees are so very like oak, as might, easily deceive an indifferent observer. *** Chestnut sells for half the price of oak; but has sometimes been sent into the King's docks, and passed off instead of oak." - ED. 
out in walks by my father. As the soil is strong, the hedges, which are cut-up, are prodigious. The maples about thirty-five feet in height, and the hazels, and whitethorns twenty, which, when feathered to the ground, were beautiful : but they now, being fifty years old, have rather over-stood their time; and besides, the severity of December, 1784, has occasioned irreparable damages among the branches. Thus much for trees. Lord Stawell has lately sent me such a bird, sprung and shot in his coverts, as I never saw before, or shall again. I pronounced it to be a mule, bred between a cock pheasant and a pea-hen. ${ }^{1}$

You say woodcocks in their passage strike against lighthouses on your coast: a gentleman tells me, that at Penzance sea-fowls frequently dash in the night against windows where they see a light. My well is sixty-three feet in depth; yet in very dry seasons, as last autumn, it is nearly exhausted: yet you would be surprised to see how few inches of rain falling will replenish it again. ${ }^{2}$ How do rains insinuate themselves to such depths? The rains this winter have been prodigious! In November last seven inches; in December six inches. The whole rain at Selborne in 1790 was thirty-two inches. Sure such thunder, and lightning, and winds have never fallen out within your observation in one winter! Had I known you thirty years ago, I should have been much pleased; because I would have gone to have seen you; and perhaps you might have been prevailed on when all our timber was standing, to have returned the visit. In the year 1746 I lived for six months

1 This was a hybrid between the Blackcock and Pheasant. It is noticed in the "Observations on Birds," under the head of "Hybrid Pheasant" (p. 326), where the author states that Mr. Elmer, of Farnham, the famous game painter, was "employed to take an exact copy of this curious bird." The picture was subsequently presented to Gilbert White by Lord Stawell (see Jesse's "Gleanings," second series, p. 159), and was engraved for the second edition of his works, where it will be found in vol. ii. p. 173.-ED.

2 Sixty-three feet is stated to be the average depth of the wells at Selborne, which, when sunk to that depth, seldom fail. See Letter I. to Pennant (p. 4.)-ED. 
at Thorney in the Isle of Ely, to settle an executorship, and dispose of live stock; there I lost nine oxen by their eating yew, as mentioned in my book. ${ }^{1}$ I hope you will write not long hence. With the truest respect and esteem I remain,

Your most humble servant,

GiL. White.

The dark butterfly which you saw was the papilio urtica: it is often more early than the yellow papilio rhamni. At this moment the Barometer stands somewhat below 28 in. 5 tens! the rain this day has been very great from the S.E.

\section{LETTER III.}

\section{TO ROBERT MARSHAM, ESQUIRE.}

Sexborne, Feb. 25th, 1791.

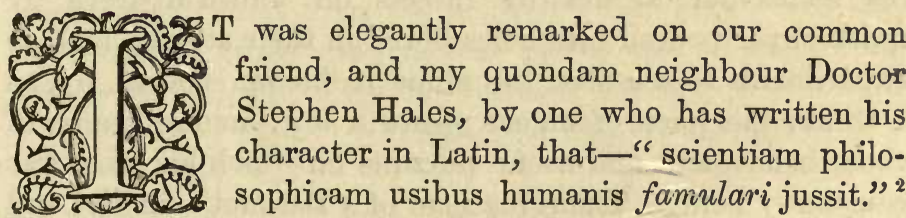
The observation was just, and the assertion no inconsiderable compliment: for undoubtedly speculative enquiries can bear no competition with practical ones, where the latter profess never to lose sight of utility.

1 See Letter V. on the Antiquities of Selborne, p. 420.-ED.

2 This line was written by Dr. John Burton, and will be found in his "Opuscula Miscellanea Metrico-Prosaica" (1771) p. 55. Dr Burton has himself been eulogized as " a man whose liberality of sentiment always induced him to pay public respect to those whom he esteemed deserving of it." See the "Gentleman's Magazine," April, 1780, p. 166.-Ev. 
As I perceive you loved the good old man, I do not know how I can amuse you better, than by sending you the following anecdotes respecting him, some of which may not have fallen within your observation. ${ }^{1}$ His attention to the inside of ladies' tea-kettles, to observe how far they were incrusted with stone (tophus lebetinus Linnæi) that from thence he might judge of the salubrity of the water of their wells :- his advising water to be showered down suspicious wells from the nozle of a garden watering-pot in order to discharge damps, before men ventured to descend;-his directing air-holes to be left in the out-walls of ground rooms, to prevent the rotting of floors and joists;-his earnest dissuasive to young people, not to drink their tea scalding hot; his advice to watermen at a ferry, how they might best preserve and keep sound the bottoms or floors of their boats;-his teaching the housewife to place an inverted tea-cup at the bottom of her pies and tarts to prevent the syrop from boiling over, and to preserve the juice; - his many though unsuccessful attempts to find an adequate succedaneum for yeast or barm, so difficult to be procured in severe winters, and in many lonely situations;his endeavour to destroy insects on wall-fruit-trees by quick-silver poured into holes bored in their stems; and his experiments to dissolve the stone in human bodies, by, as I think, the juice of onions;-are a few, among many, of those benevolent and useful pursuits on which his mind was constantly bent. Though a man of a Baronet's family, and of one of the best houses in Kent, ${ }^{2}$ yet was his humility so prevalent, that he did not disdain the lowest offices, provided they tended to the good of his fellow creatures. The last act of benerolence in which I saw him employed was, at his rectory of Faringdon, the next parish to this, where I found him in the street with his paint-pot before him, and

1 An extract from Hales's "Hæmastatics" (p. 360) will be found embodied by White in note to his Sixth Letter to Pennant (p. 18). -ED.

2 See note 1 to the first letter in the present series.-ED. 
much busied in painting white with his own hands the tops of the foot-path posts, that his neighbours might not be injured by running against them in the dark. His whole mind seemed replete with experiment, which of course gave a tincture, and turn to his conversation, often somewhat peculiar, but always interesting. He used to lament to my father, how tedious a task it was to convince men, that sweet air was better than foul, alluding to his ventilators; and once told him, with some degree of emotion, that the first time he went on board a ship in harbour at Portsmouth, the officers were rude to him; and that he verily believed he should never have prevailed to have seen his ventilators in use in the Royal Navy, had not Lord Sandwich, then First Lord of the Admiralty, abetted his pursuits in a liberal manner, and sent him down to the Commissioners of the dock with letters of recommendation. It should not be forgotten that ou. friend, under the patronage of Sir Joseph Jekyll, was instrumental in procuring the Gin Act, and stopping that profusion of spirituous liquors which threatened to ruin the morals and constitutions of our common people at once. ${ }^{1}$ He used to say, that the hogs of distillers were more brutal than the hogs of other men; and that, when drunk, they used to bite pieces out of each other's backs and sides! With due respects I remain,

Your most humble servant, GIL. White.

I did myself the honour of writing to you very lately about trees, and other matters. This winter continues wet and mild : wet springs are bad for Selborne. My crocuses make a fine show.

1 The name of Dr. Stejhen Hales, says his biographer, is to be remembered with respect as an early advocate of Temperance, in the cause of which, as before stated, he indited numerous sermons and tracts.-ED. 


\section{LETTER IV.}

\section{TO ROBERT MARSHAM, ESQLIRE.}

Selborne, near Alton, Dec. 19, 1791.

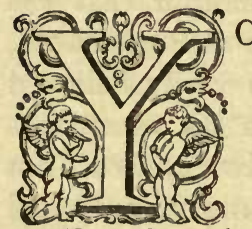

OUR letter, which met me so punctually in London, was so intelligent, and so entertaining, as to have merited a better treatment, and not to have been permitted to have lain so long unnoticed!

That there is no rule without an exception is an observation that holds good in Natural History: for though you and $I$ have often remarked that Swifts leave us in general by the first week in August : yet I see by my journal of this year, that a relation of mine had under the eaves of his dwelling house in a nest a young squab Swift, which the dam attended with great assiduity till September 6 th $;^{1}$ and on October 22nd, I discovered here at Selborne three young martins in a nest, which the dams fed and attended with great affection on to November 1st, a severe frosty day, when they disappeared, and one was found dead in a neighbour's garden. The middle of last September was a sweet season! during this lovely weather the congregating flocks of house martins on the church tower were very beautiful and amusing. When they flew off all together from the roof on any alarm they quite swarmed in the air. But they soon

1 The length of stay which the Swifts make with us in autumn must in some measure depend upon the locality which they frequent during the summer, for in the parish of Harting, Sussex (not a dozen miles from Selborne), I have remarked during the last ten years that these birds invariably remain until the end of the first week in September, or at least a month after the average date of their departure as observed by White at Selborne. See Letter XXXVII. to Pennant (p. 114). -ED. 
settled again in heaps on the shingles; where preening their feathers, and lifting up their wings to admit the rays of the sun, they seemed highly to enjoy the warm situation. Thus did they spend the heat of the day, preparing for their migration, and as it were consulting when and where they are to go! The flight about the church consisted chiefly of house martins, about 400 in number: but there were other places of rendezvous about the village frequented at the same time. The swallows seem to delight more in holding their assemblies on trees. Such sights as these fill me with enthusiasm, and make me cry out involuntarily,

"Amusive birds! say where your hid retreat,

When the frost rages, and the tempests beat!"

We have very great oaks here on absolute sand. For over Wolmer Forest, at Bramshot Place, where I visit, I measured last summer three great hollow oaks, which made a very grotesque appearance at the entrance of the avenue, and found the largest twenty-one feet in girth at five feet from the ground. The largest sycamore in my friend's court measures thirteen feet. His edible chestnuts grow amazingly, but make (for some have been felled) vile shaky, cup-shaky timber. ${ }^{2}$ I think the oak on sands is shaky, as it is also on our rocks, as I know by sad experience the last time I built. The indented oaken leaf which you gathered between Rome and Naples was the quercus cerris of Linnæus. ${ }^{3}$ The yellow oak which you saw in Sussex escaped my notice.

Richard Muliman Trench Chiswell, Esq., of Portland Place, and M.P., tells a friend of mine in town that he has an elm in Essex for which he has been bid $£ 100$. It is long enough, he says, to make a keel ungrafted for a manof-war of the largest dimensions. As he expressed a desire

1 These original lines occur in "The Naturalist's Summer Evening Walk," which White dedicated to Pennant, see p. 83.-Ev.

2 See note 3, to the first letter of the present series, p. 530.-ED.

3 This, the Turkish oak, was introduced into this country about a century ago, from the south of Europe, and is now much planted as an ornamental tree.-ED. 
of corresponding with me, I have written to him, and desired some particulars respecting this amazing tree.

You seem to wonder that Mr. Willughby should not be aware that the Fern-owl is a summer bird of passage. But you must remember that those excellent men, Willughby and Ray, wrote when the ornithology of England, and indeed the Natural History, was quite in its infancy. But their efforts were prodigious, and indeed they were the Fathers of that delightful study in this kingdom. I have thoughts of sending a paper to the R. S. respecting the fern-owl, and seem to think that I can advance some particulars concerning that peculiar, migratory, nocturnal bird, that have never been noticed before. The rain of October last was great, but of November still more. The former month produced 6 in. 49 hund., but the latter upwards of 8 in., $5 \frac{1}{2}$ of which fell in one week, viz., from Nov. 13th to the 19th, both inclusive! You will, I hope, pardon my neglect and write soon. O, that I had known you forty years ago!

I remain, with great esteem,

Your most humble servant,

GIL. White.

My tortoise was very backward this year in preparing his hybernaculum, and did not retire till towards the beginning of December. ${ }^{1}$ The late great snow hardly reached us, and was gone at once.

1 In previous years this "old Sussex tortoise began first to dig the ground, in order to the forming its hybernaculum, on Nov. 1st" (Letter XIII. to Daines Barrington, p. 172), and " retired under ground about the 20th of November." (Letter XVII. to Daines Barrington, p. 190.) It was not until April, 1780, that White was able to announce to his friend that the animal had become his property. (Letter L. to Daines Barrington, p. 276.)

This tortoise survived its master about a year, dying, it is believed, in the spring of 1794, after an existence in England of about fifty-four years, the last fourteen of which were spent at Selborne. Its shell, which is still preserved at Selborne, in the residence of the former owner, is considered by Mr. Bell to be that of Testudo marginatu. See antea, pp. 277-278._-Ev. 


\section{LETTER V.}

TO ROBER'T MARSHAM, ESQUIRE.

Selborne, March 20th, 1792.

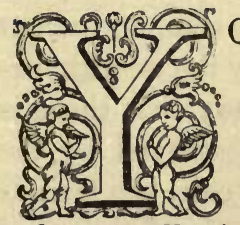

$\mathrm{OU}$, in a mild way, complain a little of Procrastination: but I, who have suffered all my life long by that evil power, call her the Domon of Procrastination, and wish that Fuseli, the grotesque painter in London, who excells in drawing witches, dæmons, incubus's, and incantations, was employed in delineating this ugly hag, which fascinates in some measure the most determined and resolute of men.

You do not, I find, seem to assent to my story respecting Mr. Chiswell's elm. There may probably be some misapprehension on my side. I will therefore allow $\mathrm{Mr}$. Chiswell that priviledge which every Englishman demands as his right, the liberty of speaking for himself. "In regard to my tree," says he, " it is a Wych Elm, perfectly strait, and fit for the keel of the largest man-of-war. The purveyor of the navy offered my late uncle $£ 50$ for it, although it would have cost as much more to have conveyed it to Portsmouth; and he would have run all risque of soundness. It grows about eleven miles from Saffron Walden, in a deep soil, and near thirty from Cambridge, the nearest place for water-carriage. I will measure it next summer." He adds, "I have been, and am a considerable planter, and have been honoured with three gold medals from the Society of Arts," \&c. Thus far Mr. Chiswell.

As I begin to look upon you as a Selborne man, at least as one somewhat interested in the concerns of this place, I wish that you could see "The sixth Report of the Commissioners appointed to enquire into the state and condition of the Woods, Forests, \&c. of the Crown," \&c. This Report 
was printed February, 1790 ; though never published, but distributed among the members of the House of Commons, from some of whom you may borrow it, as I have done. This curious survey will inform you, from the best authority, of all the circumstances respecting the advantages, usages, abuses, \&c. of our Forest of Alice Holt and Wolmer. Here you will see, that the Forest now consists of 8,694 acres, 107 of which are in ponds; that the present timber is estimated at $£ 60,000,{ }^{1}$ that it is almost all of a size, and about 100 years old ; that it is shamefully abused by the neighbouring poor, who lop it and top it as they please; that there is no succession because all the bushes are destroyed by the commoners around; ${ }^{2}$ that your old favourite oak, the Grindstone Oak, is estimated at twenty-seven loads of timber ; ${ }^{3}$ that the peat cut in Wolmer is prodigious; in the year 1788 in one walk 942 loads, and in another walk the same year 423 loads, besides heath and fern; and in the same year 935,000 turves; \&c. \&c. \&c. Lord Stawell is the Lieutenant or Grantee; whose lease expires in 1811, as I have said in my book. ${ }^{4}$ That nobleman did me the honour to call on me a morning or two ago, and sat with me two hours: he brought me a white woodcock, milk white all over except a few spots.

My friend at Bramshot Place, where I measured the great

1 This survey and valuation was made in 1787. Wolmer, with but two enclosures within its precincts, then extended over 5,949 acres; the royal forest of the Holt, with its enclosures, was found to comprehend 2,744 acres. The timber of the Holt was valued at $£ 61,000$. See Letter VIII. to Pennant, p. 27.-Ev.

2 The wrong-doers in this case were the poor of the parishes of Binstead and Frinsham, Bentley and Kingsley, who laid claim to "the lop and top" in opposition to Lord Stawell, the grantee. "Forty-five of these people his lordship served with actions." See Letter IX. to Pcnnant, p. 32,-ED.

3 See antea, p. 357.-ED.

4 Letter IX. to Pennant, p. 30. On the expiration of the grant to Lord Stawell, the Commissioners of Woods and Forests resumed possession of the Holt. All the lands held by him, and two-thirds of the former open forest were subsequently enclosed and planted.-ED. 
pollard oaks and sycamore last summer, has got a great range of chestnut-paling; I shall tell him what Mr. Kent says respecting timber of that sort. The rain with us in 1791 was 44 in. 93 hund., upwards of 8 inches of which fell in November! the rain of the present year has been considerable. Our indications of spring this year are thus: Jan. 19, Winter Aconite blows; Jan. 21, Hepaticas blow ; Jan. 29, Snowdrop blows; 31, Hazels; Feb. 4, Crocus blows; 13, Brimstone Butterfly ; 21, Yellow Wagtail appears ; 26, Humble Bee; March 16, Daffodil blows, and Apricot; 19, Peaches and Nectarines. I have read Boswell's "Johnson" with pleasure. As to Bishop Horne I knew him well for near forty years, he has often been at my house. Stillingfleet, I see, wrote his "Calendar of Flora," at your house; he speaks in high terms of the hospitable treatment that he experienced at Stratton.'

Wonderful is the regularity observed by nature! I have often remarked that the smallest willow wren (see my Book), called here the Chif-chaf, from its two loud sharp notes, is always the first spring bird of passage, and that it is heard usually on March $20,{ }^{2}$ when behold, as I was writing this very page, my servant looked in at the parlour door, and said that a neighbour had heard the Chif-chaf this morning!! These are incidents that must make the most indifferent look on the works of the Creation with wonder!

My old tortoise lies under my laurel hedge, and seems as yet to be sunk in profound slumbers. ${ }^{3}$ You surprise me, when you mention your age: your neat hand and accurate language would make one suppose you were not fifty. I remain, with true esteem,

Your most obliged servant,

GiL. White.

1. See the first letter of the present series, and note 2, p. 533.-ED.

2 The substance of this remark will be found already published in the "Observations on Birds" (p. 334), under the head of "Chiff-chaff:" -ED.

3 See p. 542, note 1.-ED. 
When Mr. Townsend avers that the Nightingales at Valez ${ }^{1}$ sing the winter through, I should conclude that he took up that notion on mere report, because I had a brother who lived eighteen years at Gibraltar, and who has written an accurate Natural History of that rock, and its environs. Now, he says that Nightingales leave Andalusia as regularly towards autumn as other summer birds of passage. A pair always breeds in the Governor's garden at the Convent. I'his history has never been published, and probably now never will, because the poor author has been dead some years. There is in his journals such ocular demonstration of swallow emigration to and from Barbary at Spring and Fall, as I know, would delight you much. There is an $\mathrm{Hi}$ rundo hiberna that comes to Gibraltar in October and departs in March, and abounds in and about the Garrison the winter through. ${ }^{2}$

\section{LETTER VI.}

TO ROBERT MARSHAM, ESQUIRE.

Selborne, August 7, 1792.

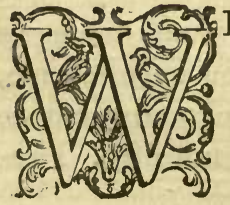
HILE all the young people of this neighbourhood are gone madding this morning to the great last day's review at Bagshot, I am sitting soberly down to write to my friend in Norfolk; almost forgetting, now I am old, the impulse that young men feel to run after new

1 Townsend ("Travels in Spain ") wrote "Velez," i.e. Velez Malaga, an older city than the present Malaga, on the old main road to Granada. -ED.

2 See Letter XXXII. to Pennant (p. 102), where White identifies his brother's bird, and correctly so, with the Hirundo rupestris of Scopoli. It is again mentioned by him in the seventh letter of the present series. -Fid. 
sights ; and that I myself, in the year 1756 , set off with a party at two o' the clock in the morning to see the Hessian troops reviewed on a down near Winchester. While I was writing the sentence above, my servant, and some neighbours came down from the hill, and told me that they could not only hear the discharges of the ordnance and small arms, and see the volumes of smoke from the guns, but that they could also, they thought, smell the scent of the gunpowder, the wind being N.E., and blowing directly from the scene of action at Wickham bushes, though they are in a direct line more than twenty miles from hence.

As I had written to you as long ago as March, I began to fear that our correspondence was interrupted by indisposition - when your agreeable letter of July 14th came in, and relieved me from my suspense. You do me much honour by calling one of your beeches after my name. Linnæus himself was complimented with the Linnoea borealis by one of his friends, a mean, trailing, humble plant, growing in the steril, mossy, shady wilds of Siberia, Sweden, and Russia; while I am dignified by the title of a stately Beech, the most beautiful and ornamental of all forest trees. ${ }^{1}$ The reason, I should suppose, why your trees havenot encreased in growth and girth this summer is the want of heat to expand them. I have not this year measured my firs in circumference; but they have, I see, many of them, made surprising leading shoots. My account of the Fern-owl, or Eve-jarr, was prevented by Madam Procrastination, who, a jade, lulled me in security all the spring, and told me I had time enough and to spare, till at last I found that the R. S. meetings were prorogued till the autumn ; against which I

1 The genus Linncea was characterized by Dr. Gronovius, and first published as a genus in 1737 in the first edition of Linnæus "Genera Plantarum." In the same year appeared the "Flora Lapponica," in which a good figure of the plant will be found, as well as in the "Flora Suecica," published in 1745. Only one species of the genus is known, the Linncea barealis, above mentioned.-ED.

2 The meetings of the Royal Society, for whose "Transactions" the account of the Fern-owl was intended. See p. 532, note 4.-ED. 
hope to be ready: and as I have got my materials, trust that when I do set about the business "verba haud invita sequentur." By all means get a sight of the sixth Report of the Commissioners, \&c. : it will entertain you, and furnish you with much matter, and many anecdotes respecting Selborne, of which I could have availed myself greatly had they been printed before I published my work. ${ }^{1}$ My book is gone to Madras, and several to France, and one to Switzerland, and one copy is going to Chinā with Lord Macartney, but whether some Mandareen will read it, I know not. We have a young gent. here now on a visit, the son of our late Vicar Etty, who assures me, that at Canton he has seen the Chinese reading English books; and has heard them converse sensibly on the manners and police of this kingdom. The Chif-Chaf of this village is the smallest willow wren of my History. ${ }^{2}$ Once I had a spaniel that was pupped in a rabbit burrow on the verge of Wolmer forest. Though I have long ceased to be a sportsman, yet I still love a dog; and am attended daily by a beautiful spaniel with long ears, and a spotted nose and legs, who amuses me in my walks by sometimes springing a pheasant, or partridge, and seldom by flushing a woodcock, of late become with us a very rare bird. Remember the story of Pylades and Orestes; and do not say that exalted friendship never existed among men. Chif-Chaf, the first bird of passage, was heard here March 20; Swallow was seen, March 26; Nightingale and Cuckoo, April 9; House Martins, April 12; Redstart, April 19; Swift, April 14; Fern-owl heard May 19 ; Fly-catcher, the latest summer bird, May 20. We have experienced a very black wet summer, and solstice; but none of those floods and devastations mentioned in the newspapers! Indeed we know no floods here, but frequent rains. Yet in warm summers we have as fine melons, and grapes, and wall-fruit as I have ever seen. July at an average produces the most rain of any English month.

1 This Report was printed in February, 1790. See p. 542.-Ev.

2 See Letter XVI. to Pennant, p. 56, note 2.-F. 
This last measured 5 in. and $15 \mathrm{~h}$. Pray, good Sir, procure better ink; yours is so pale, that it often renders your neat hand scarcely legible! I am now offering my intelligent young neighbours sixpence for every authentic anecdote that they can bring me respecting Fern-owls; and will give you the same sum for the same information. As I was coming over our down after sunset lately, a cock bird amused us much by flying round and settling often on the turf. As he passed us, he often gave a short squeak, or rather whistle. We were near his nest. These, like other birds of passage, frequent the same spots. ${ }^{1}$ There are always three pairs on our hill every year. Did you know Sir John Cullum of your part of the world? He was an agreeable, worthy man, and a good antiquary. I was also well acquainted with your late good Bishop Horne: he has often been at my house. I concur with you most heartily in your admiration of the harmony and beauty of the works of the creation! Physico-theology is a noble study, worthy the attention of the wisest man! Pray write. Our Swifts have behaved strangely this summer: for the most part there were but three round the church, except now and then of a fine evening, when there were thirteen. They seem to be all gone. House-martins leave Gibraltar by the end of July! I conclude with all due regard.

\section{Your humble servant}

Gil. White.

[On the back of this letter is endorsed in the handwriting of $\mathrm{Mr}$. Marsham the following description of a "Wall-creeper," which he obtained at Stratton, and which will be found referred to in Letters VIII. and IX. of the present series.- " Bird six inches from bill end to tail tip, and eleven inches from tip of wings. The bill very slender, and + an inch long (the sign + was often employed by Mr. Marsham to signify "more than"). Body cinereous. Wings near the body chiefly red and fading to near black. The quill feathers have two large spots, the outmost white, the lesser yellow. Stratton, Oct. 30, 1792."

1 That is, the spots which they have frequented in former years. This has been ascertained to be true of Nightingales, Swallows, Swifts, snd some other birds. - ED. 
Mr. Marsham, in narrating the circumstances of its capture. says :-

"My man has just now shot me a bird, which was flying about my house: I am confident I have never seen its likeness before. But on application to Willughby, I conclude it is the Wall-creeper, or Spidercatcher. I find he had not seen it in England. ${ }^{\text {T }}$ It is very beautifully coloured, though the chief is cinereous; but the shades of red on the wings, and the large spots of white and yellow, on the quill feathers, are uncommonly pleasing. You see Willughby does not mention them."?

\section{LETTER VII.}

\section{TO ROBERT MARSHAM, ESQUIRE.}

Selborne, November 3, 1792.

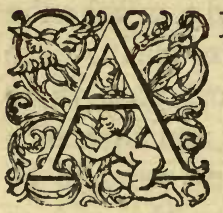

$\mathrm{N}$ extract from the Natural History of Gibraltar by the late Reverend John White: ${ }^{2}-$

"In the first year of my residence at Gibraltar, which was 1756 , it appeared extraordinary to me to see birds of the Swallow kind very frequent in the streets all the winter through. Upon enquiry I was told that they were Bank Martins : and having at that time been but little conversant in Natural History, they passed with me as such for some years without any farther regard. At length, when I had taken a more attentive survey of the physical productions of this climate, I soon discovered these hirds to be none of the common British species described by authors; and I farther found that they were never seen in Gibraltar through the whole course of the summer; but constantly and invariably

1 Willughby's words are :- "In Anglia nostra eam invenire aiunt, quamvis nobis nondum fuerit conspecta " ("Ornithologia," 1676, p. 99). -ED.

2 Another extract from this unpublished MS. was communicated to Daines Barrington, Letter LIII., p. 282.-Ev. 
made their first appearance about the 18th and 20th, and once as early as the 12 th of October, and remained in great abundance until the beginning of March.

"These phænomena awakened and alarmed my curiosity as events entirely new and unheard of among the body of Ornithologists, and induced me to be particularly exact and attentive in my observations on every part of their conduct. Early in the autumn vast multitudes of these martins congregate in all parts of the town of Castillar, which is situate on the summit of a precipice most singularly lofty and romantic, about twenty miles north of Gibraltar. Hence it may be inferred that they build and breed on the inland mountains of Andalusia and Grenada. But on the approach of winter, when their summer habitations become bleak and inhospitable (for all those mountains are then usually covered with snow), they retreat to these warm shores, and remain there till the snow is gone next spring. A few are always to be seen about our hill by the middle of October, shifting round to all sides of the rock at times to avoid the wind. November 2, 1771, I saw several, with some young ones among them sitting in groups, on the cliffs, where the old ones came and fed them."

Thus have I, for your amusement, acçording to promise, sent you an extract concerning this new, and unnoticed swallow, which my brother, with great propriety, in his work has called Hirundo hyemalis ; ${ }^{1}$ and has given several particulars concerning it, and a description of it, too long for the compass of a lettcr.

Permit me just to hint to you, that I wrote to you some time ago in answer to your last letter, which gave me much satisfaction.

I forgot to mention in the extract, that these winter swallows usually leave Gibraltar about the beginning of March, unless deep snows (as is sometimes the case, and

1 In his twenty-second letter to Pennant (p. 102), and in the fifth letter of the present series, the species is named hyberna. The above name hyemalis possibly is a lapsus memoria.-ED. 
was particularly so in 1770 and 1772) fall in Spain about that time; and then they linger there till the latter end of the month.

Surely, my dear Sir, we live in a very eventful time, that must cut-out much work for Historians and Biographers! but whether all these strange commotions will turn out to the benefit or disadvantage of old England, God only knows! We have experienced a sad spring, summer, and autumn; and now the fallows are so wet, and the landsprings break forth so frequently, that men cannot sow their wheat in any comfort. Our barley is much damaged; and malt will be bad.

Have you read Mr. Arthur Young's "Travels through France?" He says, p. 543, when speaking of the French clergy - One did not find among them poachers, or foxhunters, who having spent the morning in scampering after hounds, dedicate the evening to the bottle, and reel from inebriety to the pulpit." Now, pray, who is Mr. Young ; is he a man of fortune, or one that writes for a livelihood? He seems to reside in Suffolk, near Bury S. Edmund; so probably you can tell me somewhat about him.

Pray do wood-peckers ever damage and bore your timbertrees? Not those, I imagine, of your own planting, but only those that are tending to decay. I had a brood this year in my outlet hatched, I suspect, in the bodies of some old willows. My dissertation on the Caprimulgus is almost finished.

I remain, with all due respect, and esteem,

Your most obedient and obliged servant,

Gil. White. 


\section{LETTER VIII.}

TO ROBERT MARSHAM, ESQUIRE.

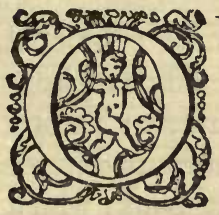

UR two last letters seem as if they had crossed each other on the road; but whether they conversed when they met, does not appear.

If you have got the Certhia muraria, or true Wall-creeper, you are in possession of a very rare and curious bird. For in all my researches here at home for fifty years past, and in all the vast collections that I have seen in London, I have never met with it. No wonder that the great Mr. Willughby is not very copious on the subject, for he acknowledges fairly that he had not seen it; though he supposes it may be found in this island. ${ }^{1}$ The best person I can refer you to is, Dr. John Antony Scopoli, a modern, elegant, foreign naturalist, born in the Tyrol, but late deceased in Pavia, where he was professor of Botany. This curious and accurate writer was in possession of one in his own museum, and gives the following description of his specimen in his "Annus primus historico-naturalis :"- "That its bill is somewhat longer than its shanks, slender, and somewhat bent; that the tongue is bifid, and the feet consisting of three toes forward and one behind." Again he adds, "that the upper part is cinereous, the throat whitish ; the abdomen, wings in part, tail and feet black; the wings at their base, and the quill feathers at their base on one side reddish." "It was taken in Carniola. It is the size of

1 Willughby's observation is as follows:- "They say it is found in England; but we have not had as yet the hap to meet with it." His description of the bird which he calls the Wall-creeper, or Spider-catcher, Picus murarius, Aldrov., is borrowed from Aldrovandus, and he places it after the Woodpeckers, and amongst the "Woodpeckers less properly so called." ("Ornithology," Book II. p. 143, tab. 23.)-ED. 
the common creeper, or Certhia familiaris: ${ }^{1}$ its nostrils oblong, tail cinereous at the point, the first four quill feathers distinguished on the inner side by two white spots." He concludes thus: "Migrat solitario sub finem autumni ; turres et muros ædium altiorum adit; araneas venatur; saltitando candit; volatu vago et incerto fertur volucris muta." You are sure, I trust, that your bird is not the Sitta Europoea. or Nut-hatch.

I have written so soon, that you may examine your bird well again, before the specimen decays. Your lady's turkeyhen is a most prolific dame; and must, I think, lay herself to death. You persist very laudably in your curious experiments on trees. Whenever you recommend my book, which begins to be better known, you lay me under fresh obligations. I am writing my account of the Fern-owl, and endeavouring to vindicate it from the foul imputation of being a Caprimulgus. My letter will make a fierce appearance with a quotation from Aristotle, and another from Pliny, but whether the R. S. will read it, or whether afterwards they will print it I know not. ${ }^{2}$

With all good wishes for your health and prosperity, I remain

Your obliged and humble servant,

GiL. White.

Selborne Nov. 20th, 1792.

1 Scopoli (op. cit. p. 51) says, "Statura sitte," that is, the size of the Nut-hatch.-ED.

2 The history of the Fern-owl, so long contemplated and so frequently alluded to, unfortunately it would seem was never completed, the author dying within six months after the date of this letter--ED. 


\section{LETTER IX.}

\section{TO ROBERT MARSHAM, ESQUIRE.}

Selborne, Jan. 2, 1793.

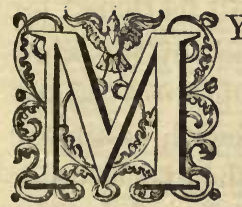

$Y$ best thanks are due for your kind letter of December 21, to which I shall pay proper attention presently. But I shall speak first of the margin of this, which contains the rain of last year, which was so remarkably wet, that you may be, perhaps, glad to see what proportion the fall of water bears to that of other uncomfortable, unkindly years. The rain in 1782 , as you see in my book, was 52 inches; in 1789, 42 inches; and in 1791, 44 inches: yet these wet seasons had not the bad influence of last year, which much injured our RAIN IN 1792.

\begin{tabular}{|c|c|}
\hline Jan. & $\begin{array}{l}\text { In. } \mathrm{Hun} \text {, } \\
6-7\end{array}$ \\
\hline Feb. & 1.68 \\
\hline Mar. & . $6-70$ \\
\hline Apr. & . $4-8$ \\
\hline May & . 3.0 \\
\hline June & . $2-78$ \\
\hline July & . $5-16$ \\
\hline Aug. & . 4-25 \\
\hline Sep. & $.5-53$ \\
\hline Oct. & . $5-55$ \\
\hline Nov. & . $1-65$ \\
\hline Dec. & . $2-11$ \\
\hline & $48-5$ \\
\hline
\end{tabular}
harvest, damaged our fallows, prevented the poor from getting in their peat and turf, which lies rotting in the Forest, washed and soaked my cleft beechen wood, so that it will not burn; it prevented our fruits from ripening. The truth is, we have had as wet years, but more intervals of warmth and sunshine.

I am now persuaded that your bird is a great curiosity, the very Certhia muralis, or Wall-creeper, which neither Willughby nor Ray ever saw; nor have I, in fifty years' attention to the winged creation, ever met with it either wild or among the vast collections that I have examined in London. It seems to be a South Europe bird, frequenting towns, and towers, and castles, but has been found but very seldom indeed in England. ${ }^{1}$ So that you will have the satis-

1 This statement, no doubt, is founded on Willughby's observation before quoted. See antea, p. 553, note 1.-En. 
faction of introducing \& new bird of which future ornithologists will say, "found at Stratton in Norfolk by that painful and accurate Naturalist, Robert Marsham, Esq." I You observe that Scopoli does not take notice that the hind claw is about double the length of the fore claws, but Linnæus corroborates your remark by saying, "Ungues validi, præsertim posticus." You seem a little to misunderstand Scopoli respecting the spots on the inner side of the quill feathers : by the inner side he does not mean the under side of the wing next the body, but only the inner or broader web of the quills, on which those remarkable spots are found, as appear by the drawing. I am much delighted wich the exact copies sent me in the frank, and so charmingly executed by the fair unknown, whose soft hand has directed her pencil in a most elegant manner, and given the specimens a truly delicate and feathery appearance. Had she condescended to have drawn the whole bird I should have been doubly gratified! It is natural to young ladies to wish to captivate men, but she will smile to find that her present conquest is a very old man.

My best thanks are due for all your good offices respecting my work, and in particular for your late recommendation to the Duke of Portland.

You did not in your last take any notice of my inquiries concerning woodpeckers, whether they ever pierce a sound tree, or only those that are tending to decay. ${ }^{2}$ I have observed that with us they love to bore the edible chestnuts; perhaps because the wood is softer than that of oak. They breed in my outlet, I think in old willows. You have not told me anything about Arthur Young. You cannot abhor the dangerous doctrines of levellers and republicans more than I do! I was born and bred a gentleman, and hope I

1 A prophecy singularly verified after an interval of more than eighty years.-ED.

2 The ability of the Green Woodpecker to pierce sound timber has been placed beyond duubt by the testimony of more recent observers. -Ev. 
shall be allowed to die such. The reason you having so many bad neighbours is your nearness to a great, factious manufacturing town. Our common people are more simpleminded and know nothing of Jacobin clubs.

I admire your fortitude and resolution, and wonder that you have the spirit to engage in new woods and plantations. Our winter, as yet, has been mild and open, and favourable to your pursuits. Pray present my respects to your lady, and desire her to accept of my best wishes, and all the compliments of the season, jointly with yourself. I have now squirrels in my outlet; but if the wicked boys should hear of them, they will worry them to death. There is too strong a propensity in human nature towards persecuting and destroying!

I remain, with much esteem, yours, \&c.,

Gil. White.

\section{LETTER X.}

TO ROBERT MARSHAM, ESQUIRE.

Selborne, June 15, 1793.

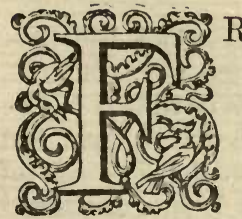

ROM my long silence you will conclude that procrastination has been at work, and perhaps not without reason. But that is not all the cause, for I have been annoyed this spring with a bad nervous cough, and a wandering gout, that have pulled me down very much, and rendered me very languid and indolent.

As you love trees and to hear about trees, you will not be displeased when you are told that your old friend the great oak in the Holt forest is at this very instant under particular circumstances. For a brother of mine, a man of virtù, who rents Lord Stawell's beautiful seat near the Holt, called Moreland, is at this very juncture employing a draughtsman, 
a French refugee, to take two or three views of this extraordinary tree on folio paper, with an intent to have them engraved. Of this artist I have seen some performances, and think him capable of doing justice to the subject. These views my brother proposes to have engraved, and will probably send a set to you, who deserve so well of all lovers of trees, as you have made them so much your study, and have taught men so much how to cultivate and improve them I have told you, I believe, before, that the great Holt Oak has long been known in these parts by the name of the Grindstone Oak, because an implement of that sort was in old days set up near it, while a great fall of timber was felled in its neighbourhood.

After a mild, wet winter we have experienced a very harsh backward spring with nothing but N. and N.E. winds. All the Hirundines except the sand-martins were very tardy, and do not seem even yet to make any advances towards breeding. As to the sand-martins they were seen playing in and out of their holes in a sand-cliff as early as April 9th. Hence I am confirmed in what I have long suspected, that they are the most early species. I did not write the letter in the "Gent. Mag." against the torpidity of swallows, nor would it be consistent with what I have sometimes asserted so to do. ${ }^{1}$ As to your recent

1 The letter here referred to is no doubt a letter which had then lately appeared in the "Gentleman's Magazine," dated Feb. 7th 1793, and probably the reason why Marsham attributed this to Gilbert White was that the writer had signed himself "A Parish Priest," and had stated that his house was "about thirty miles from the sen-coast of Hampshire." On the other hand it is evident that White disclaimed the authorship because the observations of the writer in regard to the supposed torpidity of Swallows were inconsistent with the views which he himself had expressed in his book. See Letters X. and XXXVIII., to Peanant (pp. 33, 115); and Letters IX. XII. and XVIII. to Daines Barrington (pp. 161, 171, 191).

Who then was the writer of this letter? Not Dr. Stephen Hales, for although at one time he resided about the same distance as White did from the sea-coast of Hampshire, he died in 1761, or more than thirty years before the letter in question was dated.

Apropos of letters in the "Gentleman's Magazine" attributed to 
proof of their torpidity in Yorkshire, I long to see it. But as much writing is sometimes irksome, cannot you call in occasionally some young person to be your amanuensis?

There has been no such summer as this, so cold and so dry, I can roundly assert, since the year 1765 . We have had no rain since the last week in April, and the two first days in May. Hence our grass is short, and our spring-corn languishes. Our wheat, which is not easily injured in strong ground by drought, looks well. The hop-planters begin to be solicitous about their plantations. Here I shall presume to correct (with all due deference) an expression of the great philosopher Dr. Derham. He says in his Physicotheology, "that all cold summers are wet:" whereas he should have said most.

Have you seen Arthur Young's "Example of France a Warning to England?" it is a spirited performance. The season with us is unhealthy.

With true esteem I remain,

Your obliged servant,

Gil. White.

[At the head of this letter is the following note in the handwriting of Mr. Marsham :- "This worthy man died this month."

His death took place on the 26 th of June, 1793, eleven days after the date of this letter.]

Gilbert White, it is perhaps not generally known that in the volume of that periodical for 1781 appeared a letter under the signature " $V$ " (since proved to have been penned by White), in which an interesting account is given of the writer's college acquaintance at Oxford with the poet Collins.

In the Memoir prefixed to the Aldine edition of that poet's works (p. xxxi.), the editor has reprinted this letter entire, prefacing it with the following remark :-

"It is here printed from the original manuscript, addressed 'For Mr. Urban. To the care of Mr. Newbery, at the corner of St. Paul's Churchyard, London.' The letter bears the 'Alton' postmark, and is from the pen of Collins's college acquaintance Gilbert White, thc celebrated author of the 'Nritural History of Selborne." - ED. 



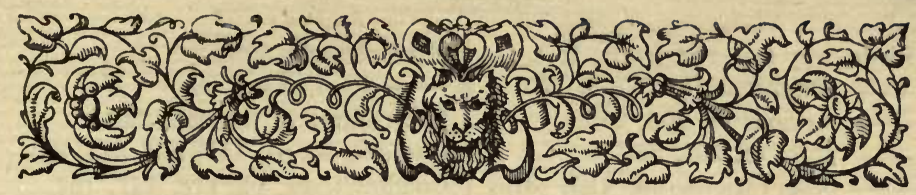

\section{INDEX.}

A.mminiss - 10

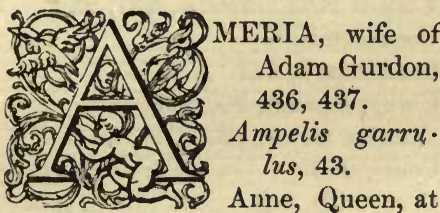

Wolmer Forest, 22.

Anguis fragilis, 64 .

Antiquities, 403, 405.

Ants, 352.

Aphides, shower of, 283.

Arum eaten by thrushes, 54 .

Ashford, Thomas, prior of Selborne, 491.

Ash-trees, 358.

Asses ploughing, 210.

Auk, Little, near Alresford, 119.

Aurora Borealis, 365 .

Ayles Holt, alias Alice Holt, the forest of, 29.

Barker, Thomas, some account of, 14, 78.

Barometer, 363.

remarkable fall of, 301,304 .

Barometers, Selborne and Newton, compared, 298, 307.

— South Lambeth, 298.

Barragon, 16.

Barrington, Daines, some account of, Intro.

Barrows, ancient, 405.

Bats, 40, 41, 84, 90, 112.
Bats, drink on the wing, 41 .

- the large sort, $90,112$. note on the species, 113.

Beans sown by birds, 361 .

Beaufort, Bp. of Winchester, 469.

Bee-bird, 162.

Beeches, 358. - 2. 3 .

Bees, wild, 348 .

Bells, church, 417.

Berne, alias Bernes, Peter, Prior of Selborne, 475, 487.

Besoms, 219.

Bin's, or Bean's-parsonage, 422.

- pond, 26.

Birds assuming male plumage, 327

- instinct of, 288, 289.

137.

of summer passage, 59,136 ,

98.

removing dung of nestlings,

$182,183$.

migrations of, $161,163$.

migratory, at Gibraltar, 103.

soft-billed, 137.

of winter passage, 138 .

in song before Midsummer,

141.

in song after Midsummer,

140.

singing at night, 139.

singing as they fly, 142 .

breeding most early, 142.

00 
Rirds, why fatter in frosts, 150 .

- congregating of, 158, 170.

- motions of, $253,255$.

notes of, $255,256$.

- observations on, 125,319 , 320.

Bird's-nest ophrys, 251.

Blackbird, 54, 121, 306.

Blackcap, 35, 40, 95, 124, 145, 149, 152.

Black cock, hybrid, 326.

Black game, 20.

Black spring of 1771,365 .

Blackthorn, 360.

Blatta orientalis, 344.

Blind-worm, 64 .

Bog-oak, 18, 19.

Bog-plants, 27.

Bombylius medius, 351.

Butany, 247, 248.

— of Selborne, 249, 253.

Bot-fly, 107, 108.

Brimstone-lodge, 26.

Brooks at Selborne, 3.

Buck's Horn Oak, 357.

Bug, harvest, 106.

Bull-head, 39.

Bullfinch turning black, 54, 118.

Bunting, 47.

- snow, $54,88$.

Bustards, 143, 156.

Butcher-bird, red backed, 70, 116.

- great grey, 116.

- woodchat, 86, 116.

Buzzard, honey, 130, 320.

Buzzards, 253.

Calculus from stomach of ox, 111 . Calendar, Naturalist's, 377, 402.

Canary birds, 44 .

Cancer, reputed cure for, 67 .

Cane, or Weasel, 53, 121.

Caprimulgus, 76, 78, 84, 113,114, $123,151,335$.

Carex cespitosa, 26.

Carp, 28.

Castration, 230.

Cat and leveret, 232.

Cat and squirrel, 318.
Cats, electric, 308. fond of fish, 96

Caterpillars of the oak, 346.

Chafers, 80, 81, 113, 123, 335, 343

Chaffinch, 46, 54, 118, 147, 157.

Chalk hills, 187, 225.

Chestnut timber, 359.

Chiff chaff, 54, 334.

Chough, 117, 156.

Church, Selborne, 410, 411.

Churn-owl, 84.

Cimex linearis, 345.

Clouds, morning, cause of, 365.

Cob-webs, 211, 213.

Coccus vitis vinifera, 281, 282.

Cockscomb, 8.

Cock-roach, 344.

Coins, Roman, 29, 406.

Coluber natrix, 65.

Coots, 255.

Corn-mills, 504.

Cornua Ammonis, 9.

Cranes, 255, 257.

Cricket, field, $84, \cdot 264,265,266$ : 267.

- house, 268, 269, 345. mole, 270, 271, 272.

Crocus, 252.

Crossbill, 39, 156, 189.

Crow, 117, 122, 130, 254. Royston or grey, 166.

Cuckoo, 83, 146, 147, 155, '227.

- note of, 167, 168.

Cucumbers set by bees, 361 .

Curlew, stone, 55, 72, 83, 86, 90 . 104, 105, 296, 334.

Cyprinus, 285.

Dabchick, or Little Grebe, 255.

Daker-hen, or Landrail, 14, 328.

Daws, 73, 74, 75, 171, 190, 254.

Deer, 21, 22, 23.

- - red, in Wolmer Forest, 21, 22.

fallow, in Holt Forest, 30, 31.

Deer-stealing, 23, 24.

Dipper, 99, 156. 
Divers 255, 331, 333.

- great northern, 331.

Dogs, 293, 294.

Chinese, 293.

Domesday book, 407,410 .

Dorr, 84.

Dove, ring, 132, 147, 211, 254, 256, 329.

- rock, 132, 133. stock, 73, 117, 132, 166.

Dovehonse, 504, 513.

Downs, Sussex, 2, 186, 187.

Dragon-flies, 156, 200.

Dripping weather, 365 .

Euck with silver collar, 163.

Ducks, 26, 28, 40, 255.

Eagles, 256.

Earth-worms, 234, 353.

Echoes, 24:, 245, 297.

Eels, 28, 39, 121.

Eft, $63,68$.

Elm, broad-leaved, 5 .

Empides, 352.

Ephemera, 83, 347.

Etty, Rev. Andrew, vicar of Selborne, 416 .

Fair at Selborne, 512.

Fairwise, prior of Selborne, 485 .

Fairy rings, 362 .

Falcon, peregrine, 36, 37, 41, 291, 292.

Fern-owl, 113, 114, 151, 228, 254, $256,334$.

Fieldfare, 87, 92, 158, 160, 166.

— nesting of, 159 .

Filices, 13.

Fishes in the forest ponds, 28.

— in Selborne streams, 39.

- gold and silver, 284, 285.

Fleas, 180, 200.

Flies, house, 351.

Flora of Selborne, 249, 253

Fly, bacon, 106.

bot, 107, 108.

- forest, 180 .

- horse, 180, 811 .
Fly, ichneumon, 350.

- May, 83, 347.

nose, 349 .

Flycatcher, 34, 40, 58, 95, 124, $152,175$.

Fog, 364 .

Fossils of Selborne, 8, 9.

Foxes, 27.

Freestone, 10.

Frog, $61,63$.

tree, 63.

Frost of January, 1768, 299.

- of January, 1776, 302.

— of December, 1784, 306.

- partial, 363.

$\zeta$

Garlands, 412.

Gasterosteus aculeatus, 39, 66.

- pungiti:s, 66.

Geese, wild, 88, 255, 257.

Geology of Selborne, 4, 10, 12.

German silk-tail, 43.

Gipsies, 215, 216.

Glow-worm, 84, 353.

Goatsucker, 76, 78, 84, 113, 123, $254,256,334$.

Goldfinch, 149.

Gorgonia, 8.

Gossamer, 211, 213.

Gracious Street, 512.

Grange, the, 511 .

Grasses, 249.

Grasshopper, 84, 264.

— W arbler, 58, 95, 121.

Gray hen, 21.

Greatham, the manor farm of, 24 .

Grebe, Little, or Dabchick, 255.

Greenfinch, 254.

Grindstone Oak, in the Holt Forest, 357.

Grosbeak, 38, 341.

Gryllus domesticus, 268, 269, 345.

Gurdon, Sir Adam, 435, 436, 439, $441,442,444$.

Hanger, the, 2, 10, 14, 20, 130, 520.

Hares, 13, 83, 303, 304, 308. 
IIares, Scotch and Irish, 88. white, 88.

Harvest scenc, 522.

Hawfinch, or Grosbeak, 38, 341.

Hawk, sparrow, 121, 130, 175.

Hawks, 162, 174, 210, 256.

Hawkley Hanger, 261, 263. Mill, 443.

Haws, 43.

Haze, 310.

Hazel, wych, 5

Heath cock, 20

Heath-fires, 18, 25.

Hedge-hog, 91 .

Heüge-sparrows, 121，126, 147, 150.

Heliotropes, summer and winter, 259.

Hen harrier, 121, 228, 253, 330.

Heron, 76, 254.

Heronry at Cressi Hall, 76.

Himantopus, 273, 274.

Hippobosca hirundinis, 180, 280.

Hirundines, 154, 162, 174, 179, $181,186,188,190,200,202,207$, 209, 237, 280, 286.

Hirundo rupestris at Gibraltar, 102.

Hogs, 231.

Hollow lanes, 12.

Holt, Ayles, a royal forest, 29.

Honey-dew, 309, 310, 364.

Hoopoe, 37, 38, 162.

Hops, 211, 360.

IIorse, 319.

Horse-fly, 107, 108.

Hounds, 319.

House-sparrow, 95, 122.

Howe, General, 32.

Humming in the air, 342.

IIuxham, Dr., 297.

Hybrid pheasant, 326.

Ichneumon fly, 350.

Ichthyology, 74.

Idiot, strange propensity of, 220.

Indian grass, 77.

Insects in frost, 305.

- observations on, 281, 341.

Instinct, 288, 289.
Invitation to Selborne, 517.

Ivy berries, 360 .

Jackdaw, 73, 74, 75, 171, 190.

Jay, 254.

Johanna, heiress of Sir Adam Gurdon, 445, 449.

Juniper, American, 301.

Kestrel, 121, 175, 253.

Kingfisher, 254.

Kites, 162, 253.

Knignts Templars at Selborne, $\mathbf{4 1 4}$ 446.

Kuckahn, 154.

Lacerta, 66 .

Lakes, 27.

Lampern, 39, 66 .

Land-rail, 14, 328.

Land-slips, 261.

Land springs, 196, 261.

Lanes, hollow, 12.

Langeland, Robert, 474.

Langrish, Nicholas, 500.

Lapwing, 119, 171.

Lark, 88, 255.

- grasshopper, 58, 95, 121.

- sky, 165, 255.

— wood, 84, 255. white, 54 .

Lavants, 196, 261.

Leaves, renovation of, 358 .

Lepers, 237, 239.

Leprosy, 237, 239.

Leveret suckled by a cat, 232 .

Leverian Museum, 8, 195, 219.

Libellula, 156, 200.

Lime blossoms, 359.

Linnets, 47.

Lizard, 66, 71. green, 75,78 .

Loaches from Ambresbury, 67.

Longspee, Ela, 451, 453.

Macroglossa stellatarum, 348.

Magpie, 210, 254, 322.

Mallard, 323.

Malm, black, 3 . 
Malm, white, 4.

Manors and lands of the Priory, 479.

Markwick, William, some account of, Intro.

Marsham, Robert, 356.

Martin, house, 33, 34, 40, 44, 74, $95,113,115,118,181,185,236$, 247, 279, 286.

- sand or bank, 197, 198, 199, 202, 255, 337.

May-bug, 343.

May-fly, 83, 347 .

Mazell, Peter, 66.

Melolontha fullo, 80, 81 . vulgaris, 80.

Mice, 40, 42, 50, 55, 122

Migration of birds, 161, 163.

- at Gibraltar, 163

Miller's thumb, 39.

Mills, water, 505.

Minnows, 66 .

Mirage, 364.

Miscellanies, 279.

Missel thrush, 44, 117, 210, 254.

Mist called London smoke, 364 .

Mole, 121.

Monuments, 415, 416.

Moorhen, 255.

Moose-deer, 93, 98.

Morton, John, prior of Selborne, 483.

Mouse, harvest, 42, 50, 55 .

— long-tailed field, 176, 289.

Musca, chamaleon, 109. putris, 107.

Music, effects of, 289, 290.

Mussels, 97.

Mytilus Crista Galli, 8.

Naturalist's Calendar, 377-402.

- Summer Evening Walk, 83.

Nautili, 10.

Nests, 288, 289.

Newt, or eft, water, 63,68 .

Nidification, 288.

Nightingale, 120, 164, 168.

Nightjar, 76, 78, 84, 113, 114, 123 , 228.
Nore Hill, 3.

Nose fly, 349.

Nuthatch, 60, 289.

Oak, on the Plestor, 5, 439.

Oakhanger ponds, 26.

Oaks of Temple and Blackmoor, 4.

of Losel's Wood, 6 . in the Holt, 357.

Obelisks, 259.

OEstrus curvicauda, 107, 108, 349.

Oropendola, 162.

Osprey, at Frinsham, 116.

Ostrea carinata, 9.

Otis tarda, 143, 156.

Otter, 97.

Owl, brown, 40, 179.

- white or barn, $40,83,96$, 177, 178, 194, 254.

- eagle, 88 .

Owls hooting in different keys, 167, 256.

Paradise of Selborne Priory, 502.

Parrots, 254, 256.

Partridge, 13, 19, 20, 96, 174, 306, 325.

- feigning lameness, 325.

Parus, 54. See Titmouse.

Peacocks, 110, 111, 257.

Pectines, 10.

Pennant, some account of, Intro.

Perch, 28.

Peregrine, 36, 37, 41, 291, 292.

Pettychaps, 290.

Phalona quercus, 346.

Pheasant, 13, 27.

- hybrid, 326.

Pigeons, 96, 254.

Plants, rare, of Selborne, 249, 253

Plestor, the, 5, 439, 440.

Plover, the stilt, 273, 275.

Poems, 515.

Polytrichum commune, 219.

Pond, Bin's or Bean's, 26.

Ponds, 26, 27, 28.

Poplar galls, 359 .

Porch, church, 417 . 
Portugal laurel, 301, 305.

Poultry, 257, 258, 3:3.

Preceptory at Selborne, 414, 450.

- Sudington, 446.

Priors of Selborne, 491.

— forms of choosing, 453, 457.

Priory of Selborne, 428, 429.

Ptinus pectinicornis, 343.

Puckeridge, 334.

Pulveratrices, 155.

Quail, 13, 48, 83.

Queen's bank, 22.

Rabbits, 317.

Rainbow, 521.

Rain-fall, 14.

Ranatra linearis, 346

Rat, water, 89.

Raven, 6, 7, 62, 174, 254, 256.

Redbreast, 122, 123, 127, 145, 147, 149.

Red-deer, 21.

Redstart, 40, 58, 121, 124, 152.

Redwing, 150, 159, 168, 301.

- nesting of, 159.

Reed Sparrow, 145, 150, 152, 157.

Reguli noncristati, 40, 58, 69 .

Relics of the Priory, 477.

Reptiles, 61, 71.

Ring-dove, 132, 147, 211, 254, 256, 329.

Ring-ousel, 44, 70, 76, 81, 85, 99, $114,115,116,117,156,166,189$. Rooks, 53, 122, 171, 190, 254, 256, 296, 321, 364 .

— white, 53. with frozen wings, 364 .

Ruperta, 30.

Rupibus, or Roche de la, Peter de, 428.

Rushes for candles, 217, 219.

Salads, 240, 241.

Sand martin, 197, 198, 199, 202, 337.

Sandpiper, 70.

Sap, observations on, 358

Saxon months, 240.
Scallops, 10.

Scarbaus fullo, 180. solstitialis, 343

Secta molendini, 504.

Sedge-bird, 82, 86, 120, 145.

Seeds lying dormant, 361 .

Selborne Hanger, 2, 10, 14, 20, $130,520$.

Sharp, John, prior of Selborne, 489, $490,491$.

Sheep, 25, 187, 317.

- Sussex, horned and hornless, 187.

Shelldrake, 73.

Shells, fossil, 8.

Shrew, 223.

— water, 89. ash, 223.

Shrike, great grey, 116 .

- red-backed, 70, 116.

woodchat, 86, 116.

Silicaria, 54, 81, 85, 88.

Sitta europcea, 60, 289. casia, 289.

Skylark, 165.

- in streets, 304.

Sleet, frozen, 364 .

Slugs, 235.

Snails and slugs, 235,354 .

Snakes, 65, 86.

Snake's slough, 354 .

Snipe, 26, 35, 40, 101, 254.

- food of, 146.

- humming of, 35, 60, 119.

Snow, effects of, 303,324 .

Snow-fleck, 54, 88.

Song of birds, 139, 140, 142, 255.

Sow, fecundity of, 231, 232.

Sparrow, hedge, 121, 126, 147, 150

- house, 95, 122.

reed, $145,150,152,157$.

Sparrowhawk, 121, 130, 175, 258

Sphinx ocellata, 347.

- stellatarum, 348.

Spring, black, 365.

Squirrels, 289, 318.

— suckled by a cat, 318

Starling, 171, 254.

Stepe, prior of Selborne, 47? 
Sticklebacks, 39.

Stilt, black-winged, 273, 275.

Stock-dove, 73, 117, 132, 166.

Stone, free, 4, 10.

rag, 11 .

- sand or forest, $4,12$.

yellow or rust colour, 11 .

Stonechat, 118, 128.

Stone curlew, 55, 72, 83, 86, 90, 104, 105, 296, 334.

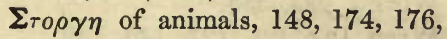
194, 247.

Storm-cock, 117.

Stratiomys chamaleon, 109.

Suborbital sinuses in deer, 51 .

Sudington, preceptory of, 446 .

Summers, sultry, 309, 310.

Superstitions, 221.

Swallow, 33, 34, 44, 49, 79, 83, 90, $95,113,118,120,149,151,152$, $161,171,180,190,193,195,209$, $236,247,254,256,291,338,339$.

- supposed hybernation of, 33 , 115, 161, 171, 191.

Swans, 121.

Swift, 33, 34, 40, 83, 90, 114, 118, $120,168,202,208,246,255$, 280. 207.

Sycamore, 359.

Tanner's wood, 503.

Teal, 26, 28, 40, 119, 176.

Templars, Knights, at Selborne, $414,446$.

Temple, manor-house, 438.

Tench, 28.

Thaws, 363.

Thrushes, 54, 121, 150, 301, 306, 322.

Thrush, missel, 44, 117, 210, 254.

Thunderstorms, 312.

'Tiles, ornamented, 502, 510.

Timber in the Holt Forest. 27.

- _ in Wolmer Forest, 27.

-_ fall of, 32.

__ value of, 2 ?.

Tipula, 352.
Titlark, 117, 145, 147, 155, 165, 319.

Titmouse, blue, 127, 128.

- coal, 127.

- great, 122, 127, 128, 301 .

- long-tailed, 127. marsh, 122, 127, 128.

Toads, 61, 67, 75 .

- venom of, 62 .

Tortoise, 152, 172, 190, 236, 276 . 278.

'Tower, church, 417.

Tree-frog, 63.

Trees, 14, 167, 224, 225, 355

- size and growth of, 356.

Tremella nostoc, 362.

Tringa, 70.

Trout, 39.

Truffles, 362.

Tun-briclge, 504.

Turkey, 257.

Turnip-flies, 107.

Vegetables, 355.

Vespertilio altivolans, 112.

Vicarage of Selborne, 419.

Vicars of Selborne, 423, 427.

Viper, 61, 64, 229.

- swallowing its young, 64,

65.

Virgin garlands, 412.

Visitatio notabilis de Seleburne, $458,468$.

Vole, water, $36,89$.

Wagtails, 47, 118, 121, 126, 145. $147,255,340$.

Waldon-lodge, 26.

Wall-fruit, 211.

Waltham blacks, 22, 23.

Warbler, grasshopper, 58, 95

- sedge, 82.

Wasps, 309, 320, 349.

Water, characteristics of hard and soft, 4.

Water-ouzel, 99, 156.

Water-rat, 36, 89.

Waxwing, 43. 
Waynflete, William of, 475,493 , 499.

Weasel, 53, 121.

Weather, 299. summary of the, 367,369 .

Weaver's Down, 12.

Well-head, 3, 408.

Wells, 4.

Whaddon chapel, 503.

Wheat, $196,362$.

Wheatear, 48, 118, 128, 188, 189.

Whinchat, 118, 128.

Whitethroat, 40, 95, 123, 124, 147, 149, 15:, 255.

- lesser, 124, note, 291 , note.

Widgenn, $28,40$.

Wild-boars, 32.

Wild-ducks, 26, 28, 176, 255, 257.

Wild-fowl, 20, 29, 40, 255.

Willow-wrens, 54, 56, 57, 58, 69, 81.

Winchester, Hoadley Bishop of, 23.

Witcheraft, 222.

Wolmer Forest, 17, 408. Pond, 28.

Wood, fossil, 18, 19, 295.

Wood, Losel's, 6.
Woodchat, 86.

Woodcock, 13, 100, 146, 158, 160, $163,164,169$.

- carrying its young, 100, 101

- food of, 146. nesting, 159, 161.

Woodlark, 84, 121, 149.

Woodpecker, 126, 254, 256.

Woodpigeon, 131, 166, 211, 291.

Wormils, 335 .

Worms, 234, 353.

Wren, 122, 126, 127, 145, 149.

- golden-crowned, $60,126,143$.

- willow, 35, 121, 175. wood, $34,35,95$.

Wryneck, 126, 340.

Wych-hazel, 5 .

Wykeham, William of, $457,468$.

Wynchestre, John, prior of Selborne, $469,470$.

Wyndesor, William, prior of Selborne, 483 .

Yellowhammer, 145, 149.

Ycoman-prickers, $2 \%$.

Yew-trees, 420. why planted in churchyards, 421, 422 . 



\section{DAY USE}

\section{RETURN TO DESK FROM WHICH BORROWED}

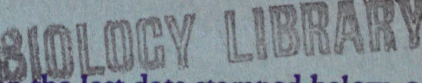

This book is due on the last date stamped below, or on the date to which renewed.

Renewed books are subject to immediate recall.

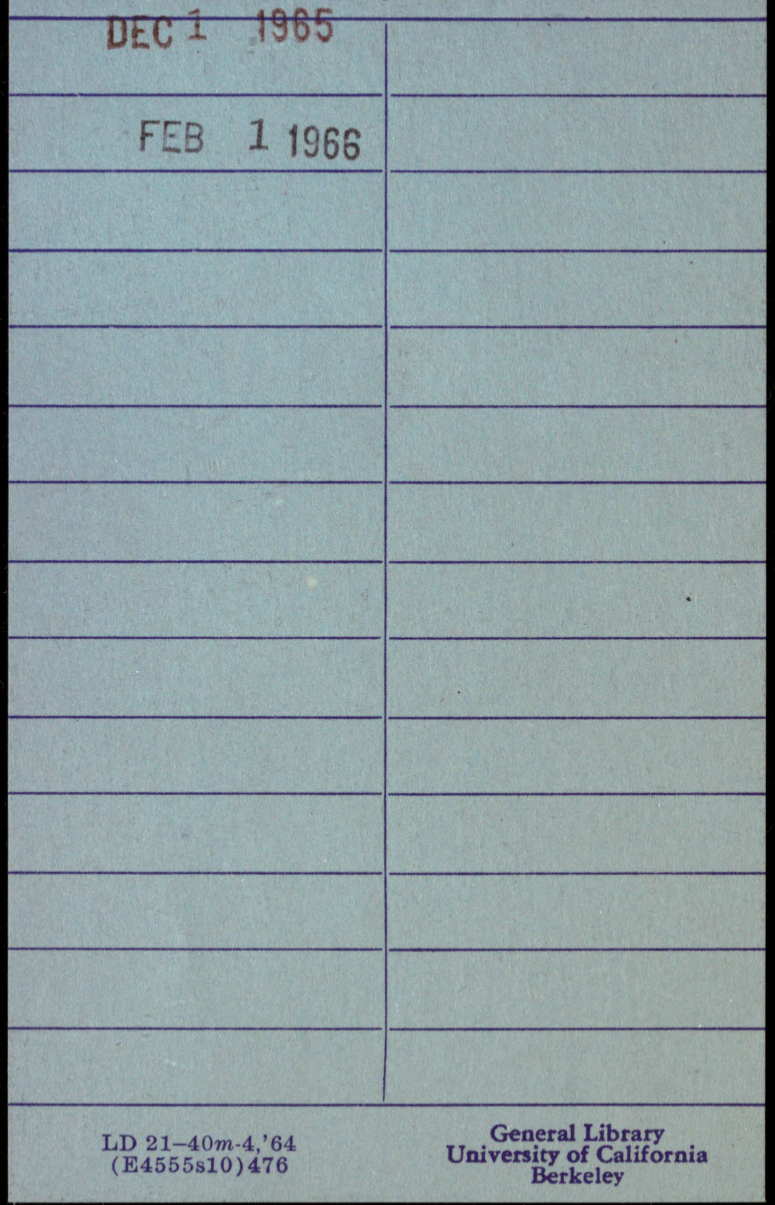


